UNIVERSIDADE DE SÃO PAULO

FACULDADE DE ARQUITETURA E URBANISMO

PROGRAMA DE PÓS-GRADUAÇÃO EM ARQUITETURA E URBANISMO

\title{
OS ESPAÇOS EXPERIMENTAIS DAS ESCOLAS PÚBLICAS DE ARQUITETURA DO BRASIL: REALIDADE OU UTOPIA?
}

Tese apresentada a Faculdade de Arquitetura e Urbanismo da Universidade de São Paulo para obtenção do título de Doutor em Ciências.

Área de Concentração: Tecnologia da Arquitetura

Doutoranda:

Albenise Laverde

Orientadora:

Profa. Dra. Cláudia Terezinha de Andrade Oliveira

Financiamento:

Fundação de Amparo à Pesquisa do Estado de São Paulo DFAPESP

"As opiniōes, hipóteses e conclusões ou recomendações expressas neste material são de responsabilidade da autora e não necessariamente refletem a visão da FAPESP e da CAPES".

EXEMPLAR REVISADO E ALTERADO EM RELAÇÃO À VERSÃO ORIGINAL, SOB RESPONSABILIDADE DA AUTORA E ANUÊNCIA DA ORIENTADORA.

A versão original, em formato digital, ficará arquivada na Biblioteca da Faculdade.

São Paulo, 23 de julho de 2017. 
Autorizo a reprodução e divulgação total ou parcial deste trabalho, por qualquer meio convencional ou eletrônico, para fins de estudo e pesquisa, desde que citada a fonte.

Catalogação na Publicação Serviço Técnico de Biblioteca

Faculdade de Arquitetura e Urbanismo da Universidade de São Paulo

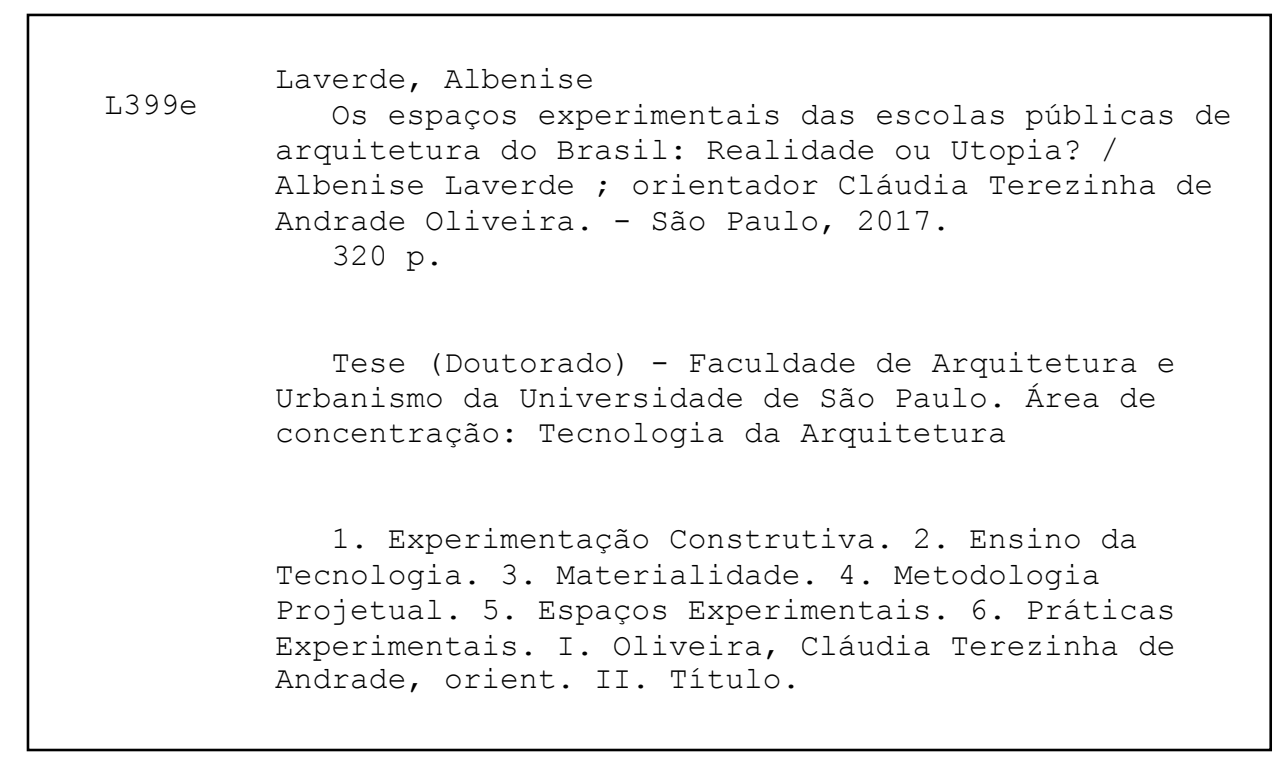


FOLHA DE JULGAMENTO 

Ao meu pai Antônio Laverde (in memoriam) 

"A utopia está lá no horizonte - disse Fernando Birri -. Me aproximo dois passos, ela se afasta dois passos. Caminho dez passos e o horizonte corre dez passos. Por mais que eu caminhe, jamais alcançarei. Para que serve a utopia? Serve para isso: para que eu não deixe de caminhar"

Eduardo Galeano 



\section{AGRADECIMENTOS}

A experiência do doutorado foi um período de amplas reflexões que levaram a construções e desconstruções em todos os sentidos.

E foi em meio a esta dinâmica que meu pai Antônio me deixou, meu maior incentivador. Mas, quando olho em retrospectiva, o doutorado não foi apenas momentos de tristeza e perdas, foi por meio dele que oportunidades se abriram, tanto na vida pessoal como profissional. Neste período conheci pessoas ótimas que, direta ou indiretamente, contribuíram para enriquecer este trabalho, tenho muita gratidão por todas elas.

Em especial à minha orientadora Cláudia, que tão bem conduziu este trabalho e, diante das adversidades surgidas me ajudou a enfrentá-las, apontando novos caminhos para serem trilhados. Obrigada pela confiança, amizade e conduta como orientadora.

Também agradeço ao programa FAPESP/CAPES - Processo n² 2013/22935-1, Fundação de Amparo à Pesquisa do Estado de São Paulo (FAPESP) - que forneceu o apoio financeiro necessário para o desenvolvimento do trabalho em diferentes regiões do país. Por meio das visitas técnicas pude contar com a colaboração de 67 pesquisadores pertencentes às seguintes instituições públicas: UFRGS, UFPel, UEL, UFPR, FAUUSP, UNICAMP, IAU-USP, UFRJ, UFF, UFMG, UFU, UFV, UFES, UFMS, UNB, UFBA, UFPE, UFPB, UFRN, UFC e UFPA e à entidades como ABEA e CAU. Agradeço as valiosas informações fornecidas por todos vocês, algo imprescindível para se chegar aos resultados desta pesquisa, espero ter atingido a expectativa de todos.

Quanto às amizades paulistanas - afloradas nos cantos mais inusitados - estas eu não esquecerei. Amigos que, como 'pássaros migradores' alegraram minha vida por uma estação e agora se vão, espero poder reencontrá-los sempre...

Agradeço muito aos familiares e amigos que ao longo destes 04 anos, mesmo com a distância, continuaram presentes em minha vida. As visitas, mensagens e telefonemas fizeram toda a diferença para superar a saudade.

E à Ti, Senhor, dedico o meu maior agradecimento, por permitir que eu alcançasse este patamar e enxergasse com mais clareza minha pequenez perante Sua sabedoria. 



\section{RESUMO}

\section{Os espaços experimentais das escolas públicas de arquitetura do Brasil: realidade ou utopia?}

Esta tese está inserida no debate sobre a utilização da experimentação construtiva ao longo da concepção da materialidade e seu papel como recurso pedagógico. Trata mais especificamente, dos espaços e práticas experimentais no contexto acadêmico nacional, objetivando compreender o processo de configuração dos espaços da área técnico-construtiva implantados nas escolas públicas de arquitetura de acordo com as particularidades advindas de diferentes contextos do país, das políticas educacionais e das ações dos atores envolvidos, com a identificação das condições essenciais para que estas práticas sejam implantadas e potencializadas no contexto acadêmico. $O$ trabalho foi desenvolvido a partir de pesquisas documentais e por meio de visitas técnicas realizadas em 21 escolas públicas de arquitetura localizadas em diferentes regiões do país, com entrevistas direcionadas aos principais atores que atualmente estão à frente da área da Tecnologia da Construção. O trabalho trouxe contribuições de ordem teórica a partir da sistematização de uma bibliografia abrangente sobre um tema pouco estudado no contexto nacional. Quanto às contribuições de ordem prática, os dados obtidos nas visitas técnicas possibilitaram contextualizar os desafios enfrentados no ensino da Tecnologia da Construção, que não se resumem ao arranjo físico laboratorial, mas a uma dimensão mais ampla, abrangendo aspectos político-educacionais, estruturais e sócio-econômicos e também, questões de fundo, como as relações interpessoais e burocráticas. Estes resultados permitiram identificar as condições consideradas como essenciais na (re)formulação de estratégias voltadas à área da Tecnologia da Construção e sua infraestrutura, de maneira que as experiências existentes possam ser potencializadas e novas implantações tenham maior respaldo técnico de acordo com as particularidades contextuais.

Palavras-chave: Experimentação Construtiva, Ensino da Tecnologia, Materialidade, Metodologia projetual, Espaços Experimentais, Práticas Experimentais. 

ABSTRACT

\section{The experimental workspaces in public schools of architecture in Brazil: reality or utopia?}

This thesis is inserted in the debate about the use of experimentation in building along with the conception of materiality and its role as pedagogical resource. It approaches, more specifically, the experimental workspaces and practices in the Brazilian academic context. It aims to understand the process of shaping the workspaces of the technology and construction fields established in public schools of architecture according to the singularities from different contexts of the country, educational policies and activities of the actors involved, identifying the essential conditions for those practices to be implemented and strengthened in the academic context. The work was developed based on documentary research and through technical visits in 21 public schools of architecture located in different regions of the country, with interviews directed to the main actors who are currently in charge of the field of Technology of Construction. In relation to the practical contributions, the data obtained in the technical visits made it possible to contextualize the challenges faced in the education of Technology of Construction. These challenges are not limited to the physical arrangement of the laboratory; they embrace a broader dimension, covering education politics, structural and socioeconomic aspects and, still, background issues such as interpersonal relations and bureaucracy. These results enabled the identification of conditions considered essential in the (re) formulation of strategies directed to the field of Technology of Construction and its infrastructure, so that the existing experiences can be strengthened and new applications can have a greater technical support according to the contextual singularities.

Keywords: Building experimentation, Technology Education, Materiality, Design Methodology, Experimental Workspaces, Experimental Practice. 



\section{LISTA DE QUADROS}

\section{CAPÍTULO INTRODUTÓRIO}

Quadro 01: Distribuição dos cursos por regiões e estados.

34

Quadro 02: Data de implantação dos cursos de Arquitetura e Urbanismo no país, com destaque às escolas a serem visitadas ao longo da pesquisa.

Quadro 03: Apresentação das escolas escolhidas de acordo com os aspectos regionais e históricos para serem 34 visitadas in loco.

\section{CAPÍTULO 01}

Quadro 04: Etapas de exploração do protótipo no escritório Renzo Piano Building Workshop.

Quadro 05: Etapas de inserção da pesquisa experimental nos projetos IRCAM (Institut de Recherche et Coordination Acoustique/Musique) em Paris e Citè Internationale em Lyon.

\section{CAPÍTULO 02}

Quadro 06: Alguns exemplos de atividades experimentais realizadas em escolas internacionais de arquitetura.

Quadro 07: Histórico de algumas atividades na área experimental construtiva por meio de protótipos em escala, realizadas em escolas brasileiras no período compreendido entre 1962- 2012.

\section{CAPÍTULO 03}

Quadro 08: Currículos Mínimos de 1962 e 1969.

Quadro 09: Síntese dos principais fatos históricos que contribuíram de alguma forma para reformas e melhorias para a área da Tecnologia da Construção.

Quadro 10: Cursos de arquitetura e urbanismo em instituições públicas no país, de acordo com os critérios explicitados no Capítulo Introdutório.

Quadro 11: Distribuição da Grade Curricular com a carga horária semestral - FAU UFRJ

132

Quadro 12: Distribuição da Grade Curricular com a carga horária semestral - FA UFBA

Quadro 13: Distribuição da Grade Curricular com a carga horária semestral FA UFRGS

Quadro 14: Distribuição da Grade Curricular com a carga horária semestral - EA UFMG

Quadro 15: Distribuição da Grade Curricular com a carga horária semestral - FAU UFPE

Quadro 16: Distribuição da Grade Curricular com a carga horária semestral - FAU USP

Quadro 17: Distribuição da Grade Curricular com a carga horária semestral - FAU UNB

Quadro 18: Distribuição da Grade Curricular com a carga horária semestral - CAU UFPR

Quadro 19: Distribuição da Grade Curricular com a carga horária semestral - FAU UFC

Quadro 20: Distribuição da Grade Curricular com a carga horária semestral - FAU UFPA

Quadro 21: Distribuição da Grade Curricular com a carga horária semestral - EAU UFF

Quadro 22: Distribuição da Grade Curricular com a carga horária semestral - FAURB UFPel

Quadro 23: Distribuição da Grade Curricular com a carga horária semestral - CAU UFRN

Quadro 24: Distribuição da Grade Curricular com a carga horária semestral - DAU UFPB

Quadro 25: Distribuição da Grade Curricular com a carga horária semestral - CAU UFES

Quadro 26: Distribuição da Grade Curricular com a carga horária semestral - CTU UEL

Quadro 27: Distribuição da Grade Curricular com a carga horária semestral - IAU USP

Quadro 28: Distribuição da Grade Curricular com a carga horária semestral - DAU UFV

Quadro 29: Distribuição da Grade Curricular com a carga horária semestral - FAUeD - UFU

Quadro 30: Distribuição da Grade Curricular com a carga horária semestral - CAU - UFMS

Quadro 31: Distribuição da Grade Curricular com a carga horária semestral - FEC - UNICAMP 


\section{LISTA DE FIGURAS}

\section{CAPÍTULO INTRODUTÓRIO}

Figura 01: Sequencia de imagens de experimentos utilizados na investigação de formas complexas desenvolvidos 26 por Antonì Gaudi (a), Felix Candela (b), Frei Otto (c) e Renzo Piano (d).

Figura 02: Sequencia de fotos de obras desenvolvidas a partir de experimentos investigativos com modelos em 27 pequena escala e protótipos em escalas próximas a real.

Figura 03: Sequencia de imagens de experiências realizadas em Les Grands Ateliers, em Grenoble - França. $\quad 28$

Figura 04: Mapa do Brasil com a localização das escolas públicas de Arquitetura e Urbanismo.

\section{CAPÍTULO 01}

Figura 05: Sequencia de fotos do processo de pesquisa da estrutura do Hangar para aeronaves, Orvieto, Itália, 1936.

Figura 06: Sequencia de fotos sobre o desenvolvimento projetual por meio de protótipos do Hipódromo de Madri, 1935

Figura 07: Sequencia de fotos Igreja de Atlandida - Uruguai

Figura 08: Sequencia de fotos galpão portuário em Montevidéu

Figura 09: Protótipos experimentais desenvolvidos por Felix Candela no México.

Figura 10: Sequencia de imagens do projeto Teatro Transportável, submetido no VI Congresso UIA. Tema do congresso 'Novas Técnicas e Novos Materiais na Construção', 1961.

Figura 11: Derivações de conexões nos estudos de Emilio Perez Piñero. a) e b) nó com 3 barras. c) e d) nó com quatro barras.

Figura 12: a, b e c) Sequencia de imagens de protótipos em escala real. d) Estudos por meio de protótipos da cúpula reticulada para o 'Festival da Espanha', 1966.

Figura 13: Experimentações por meio de modelos físicos desenvolvidos por Frei Otto. $\mathbf{5 4}$

Figura 14: Sequencia de imagens - Projeto Estádio Olímpico de Munique. $\quad \mathbf{5 4}$

Figura 15: Estudos com malhas de cabos $\quad \mathbf{5 5}$

Figura 16: Estudos relativos à interface entre biologia e engenharia. $\quad \mathbf{5 6}$

Figura 17: Atividades experimentais realizadas por Renzo Piano antes da criação do escritório Renzo Piano Building $\mathbf{5 8}$ Workshop

Figura 18: Uma parede do Ateliê em Vessima, onde modelos e protótipos em escala real são desenvolvidos para 60 estudos, RPBW.

Figura 19: Estudos para o projeto IBM Travelling Pavilion, 1982-84.

Figura 20: a) Maison du peuple em Clichy. 1935-1939. Fabricação da fachada-cortina por Jean Prouvé. Arquiteto: 62 Marcel Lods.

Figura 21: Sistemas modulares com Estruturas tipo 'Pórtico Central'.

Figura 22: Estudos sobre seções descontínuas $\quad 64$

Figura 23: Sequencia de fotos do Edifício IRCAM (Institut de Recherche et Coordination Acoustique/Musique) em 65 Paris.

Figura 24: Sequencia de fotos do City International em Lyon, França.

Figura 25 - Detalhes desenvolvidos por Frei Otto para Projeto do Estádio Olímpico de Munique - 72. 67

Figura 26: Pavilhão do Japão em Hannover. Oportunidade em que Shigeru Ban trabalhou com Frei Otto. 69

Figura 27: Casas de tubos de papelão

Figura 28: Sequencia de imagens com a execução de uma abóbada elaborada por Eladio Dieste, explicitando as particularidades do processo de otimização do trabalho operário.

Figura 29: Máquinas e equipamentos desenvolvidos por Eládio Dieste de acordo com as condicionantes contextuais.

Figura 30: Intervenções na resolução das questões de drenagem e saneamento por meio da pré-fabricação na cidade de Salvador.

Figura 31: Sequencia de imagens do processo de capacitação de mão de obra ocorrendo simultaneamente ao processo de construção de escolas rurais, no município de Abadiânia, GO.

\section{CAPÍTULO 02}

Figura 32: Lazlo Moholy-Nagy: Acessório luminoso (modulador luz-espaço), 1922-1930.

Figura 33: Exercícios desenvolvidos por Albers com o material papel, com estudos sobre a firmeza e construção sem 
recortes.

Figura 34: Estudos de Eduardo Torroja com modelos de escala reduzida. $\quad 91$

Figura 35: Estudos realizados por Luigi Nervi com modelos reduzidos.

Figura 36 : Jean Prouvè como professor do Conservatório Nacional de Artes e Ofícios - CNAN. 94

Figura 37: Instituto de Estruturas Leves de Stuttgart. $\quad 96$

Figura 38: Les Grands Ateliers - Módulos pedagógicos (para manipulação de diferentes materiais: concreto, 99 madeira, pedra, aço, alvenaria e terra) voltados às práticas construtivas.

Figura 39: Atividades de pesquisa no ETH/Zurich - ITA $\quad 99$

Figura 40: Atividades realizadas pelas equipes do Laboratório Buchy Lab. 100

Figura 41: Atividades realizadas em TU Stuttgart. $\quad 100$

Figura 42: Atividades realizadas em 2013 na Faculdade de Artes e Design da Universidade de Kioto: Práticas a partir 101 da exploração de métodos construtivos adotados pelo arquiteto Shigeru Ban.

Figura 43: Canteiro de obras de Brasília. $\quad 104$

Figura 44: Exemplo de trabalho realizado no Curso Integrado FAUUSP: produção de tijolo solo-cimento. 104

Figura 45: Práticas construtivas na Universidade Farias Brito. $\quad 105$

$\begin{array}{lr}\text { Figura 46: Atividades práticas de ensino e extensão } & 105\end{array}$

Figura 47: Exercícios na área de sistemas estruturais desenvolvidos na PUCCAMP. $\quad 105$

Figura 48: Práticas construtivas e testes com protótipos - ensino Sistemas Estruturais. Universidade São Judas 106 Tadeu.

Figura 49: Registro das primeiras experiências realizadas no canteiro experimental da FAUUSP em 1993.

Figura 50: Exercícios construtivos realizados na Unimep $\quad 106$

Figura 51: Exercícios práticos no Canteiro Experimental FAUUSP. 106

Figura 52: Atividades práticas realizadas na FAUUSP entre 2000/2001 - disciplina Tecnologia do Edifício IV - 107 Componentes Pré-moldados.

Figura 53: Curso de Projeto I - 10 ano do Curso de Arquitetura e Urbanismo, 2003-atual. 107

Figura 54: Curso 'Fundamentos da Construção' - PUC Minas. 107

Figura 55: Primeiras práticas experimentais realizadas na disciplina 'Introdução à Tecnologia da Construção' - 108 FAUeD-UFU.

\section{CAPÍTULO 03}

Figura 56: Sequencia de fotos externas e internas do edifício sede do curso de Arquitetura e Urbanismo da UFRJ.

Figura 57: Planta térrea da Faculdade de Arquitetura e Urbanismo da UFRJ.

Figura 58: Sequencia de imagens internas do Laboratório de Materiais da Construção - FAU UFRJ.

Figura 59: Sequencia de imagens das áreas de apoio ao Laboratório de Materiais de Construção:

Figura 60: Imagens do edifício da Faculdade de Arquitetura da UFBA

Figura 61: Sequencia de imagens do Laboratório de Estruturas (também de Construção) pertencente à Escola Politécnica, com maquinário implantado e em fase de implantação.

Figura 62: Implantação dos edifícios pertencentes ao curso de Arquitetura e da Escola Politécnica.

Figura 63: Vista principal do prédio sede do curso de Arquitetura e Urbanismo da UFRGS

Figura 64: Escola de Arquitetura da UFMG - a) e b) vistas externas do edifício e praça. c) e d) Vistas internas junto à entrada principal.

Figura 65: Máquina de ensaios alemã - Único equipamento deixado pelos militares no Laboratório de Materiais após ocupação por volta de 1964. Encontra-se sem uso e é mantida até hoje nas dependências da Escola.

Figura 66: Atual Laboratório de Materiais em fase de implantação - EA UFMG.

Figura 67: Imagens do Centro de Artes e Comunicação - CAC - dentre os cursos sediados neste edifício está o curso 158 de Arquitetura e Urbanismo.

Figura 68: Estrutura Pedagógica do CAU/UFPE: Fases anuais de formação e linhas de atuação.

Figura 69: Imagens de algumas áreas possíveis de uso para a realização de atividades práticas.

Figura 70: Imagens externas e interna FAUUSP.

Figura 71: Instalações do LAME - Edifício Vilanova Artigas

Figura 72: Planta do LAME no Edifício ANEXO. 
Figura 74: Sequencia de fotos das primeiras experiências realizadas no período de implantação do Canteiro Experimental.

Figura 75: Imagens do Canteiro Experimental da FAUUSP

Figura 76: Instalações físicas utilizadas pela FAUUNB no prédio do ICC - Instituto Central de Ciências 175

Figura 77: Imagens do início da implantação da UNB e do curso de Arquitetura e Urbanismo. 176

Figura 78: Laboratório de Modelos Reduzidos 177

Figura 79: Implantação de atividades de caráter experimental- CAU/UFPR. 182

Figura 80: Imagens das instalações físicas do curso de Arquitetura e Urbanismo - UFC 184

Figura 81: Edifícios sede do curso de Arquitetura e Urbanismo. 187

Figura 82: Edifício onde está instalado o curso de Arquitetura e Urbanismo da UFF. 191

Figura 83: Imagens internas do Laboratório de Materiais pertencente ao curso da Engenharia Civil. 193

Figura 84: Edifício sede do curso da Faculdade de Arquitetura e Urbanismo da UFPel. 194

Figura 85: Edifício pertencente ao curso de Arquitetura e Urbanismo da UFRN. 198

Figura 86: Área destinada ao atual Canteiro Experimental. 200

Figura 87: Vista da Coordenação do Curso de Arquitetura e Urbanismo a partir do pátio central - UFPB 203

Figura 88: Laboratório de Ensaio de Materiais e Estruturas - LABEME. 205

Figura 89: Centro de Artes - CAR. Imagens do complexo de edifícios utilizados pelo curso da Arquitetura e 207 Urbanismo.

Figura 90: Sequencia de fotos da área laboratorial ligada à Tecnologia da Construção e utilizada pelos alunos do 210 curso de Arquitetura e Urbanismo da UFES.

Figura 91: Sequencia de imagens do Laboratório de Maquetes/Marcenaria - CTU. 213

Figura 92: Sequencia de imagens do Laboratório de Materiais de Construção. 214

Figura 93: Imagens do espaço interno do Laboratório de Estruturas $\mathbf{2 1 4}$

Figura 94: Atividades experimentais na forma de diferentes protótipos. $\mathbf{2 1 5}$

Figura 95: Vista do edifício sede do curso do IAU USP. 217

Figura 96: Sequencia de imagens do interior do LCC - Laboratório de Construção Civil. 219

Figura 97: Parte do mapa geral da EESC-USP com a localização dos edifícios e laboratórios pertencentes ao IAU. 220

Figura 98: Espaço provisório/expositivo construído pelos próprios alunos para abrigar materiais, equipamentos e 220 sistemas construtivos.

Figura 99: Imagens do edifício pertencente ao Departamento de Arquitetura e Urbanismo 223

Figura 100: Laboratório de Materiais de Materiais de Construção Civil: 225

Figura 101: Laboratório do Ambiente Construído (FAUeD) e área externa. 230

Figura 102: Laboratório de Materiais e Técnicas de Construção Civil, pertencente à FECIV (Faculdade de Engenharia 230 Civil).

Figura 103: Mapa com a localização do edifício sede do curso de Arquitetura e Urbanismo, Canteiro Experimental e 233 também o edifício sede do curso de Engenharia Civil e o Laboratório de Materiais de Construção.

Figura 104: Edifícios pertencentes ao CAU UFMS.

Figura 105: Laboratório de Materiais de Construção Civil. a) e b) Imagens internas. c) e d) protótipos desenvolvidos no espaço externo.

Figura 106: Edifício de uso compartilhado entre o curso de Arquitetura e Urbanismo e Engenharia Civil.

Figura 107: Laboratório de Materiais de Construção - LMC. 238

Figura 108: Mapa esquemático com a localização do Laboratório de Materiais e Construção - LMC. 238

Figura 109: FEC - Faculdade de Engenharia Civil, Arquitetura e Urbanismo. Plano Diretor - Unicamp. Adaptado pela 239 autora.

\section{CAPÍTULO 04}

Figura 110: Sequencia de imagens indicando cronologicamente as implantações das escolas inseridas em instituições públicas pelo território nacional (visitadas e não visitadas). 


\section{LISTA DE GRÁFICOS}

\section{CAPÍTULO 04}

Gráfico 01: Porcentagem das escolas visitadas (inseridas em Instituições Públicas) de acordo com o histórico de implantação/origem.

Gráfico 02: Área ocupada pela Tecnologia da Arquitetura nas grades curriculares

Gráfico 03: Número de créditos destinados à Área da Tecnologia da Arquitetura

Gráfico 04: Área ocupada pela Tecnologia da Construção de acordo com as grades curriculares

Gráfico 05: Número de créditos destinados à área da Tecnologia da Construção

Gráfico 06: Modelo atual adotado pelas escolas - responsabilidade assumida para a área da Tecnologia da Construção - número de situações encontradas.

Gráfico 07: Representatividade da metodologia pedagógica utilizada na abordagem do conteúdo das disciplinas de Tecnologia da Construção - oferecida sistematicamente e não eventualmente.

Gráfico 08: Existência e caracterização da infraestrutura laboratorial na área da Tecnologia da Construção.

Gráfico 09: Representatividade das atividades de caráter laboratorial (quando existentes) - utilização de modelos/protótipos ou realização de ensaios para o ensino do conteúdo da área da Tecnologia da Construção.

Gráfico 10: Existência de cursos de Pós-Graduação nos cursos de Arquitetura e Urbanismo visitados. 


\section{SIGLAS}

ABEA - Associação Brasileira de Ensino em Arquitetura e Urbanismo CAU - Conselho de Arquitetura e Urbanismo

CEAU - Comissão de Especialistas em Arquitetura e Urbanismo CEPLAN - Centro de Planejamento Oscar Niemeyer

CFE - Conselho Federal de Educação

CM - Currículo Mínimo

CNAN - Conservatório Nacional de Artes e Ofícios

CREA - Conselho Regional de Engenharia e Agronomia

EESC - Escola de Engenharia de São Carlos

ETHZ - Eidgenössische Technische Hochschule Zürich (Instituto Federal de Tecnologia de Zurique)

FAPESP - Fundação de Amparo à Pesquisa do Estado de São Paulo GEEF - Gestão de Espaço Físico

IASS - International Association for Shell Structures

IBM - International Business Machines

IES - Instituições de Ensino Superior

IFES - Instituto Federal do Espírito Santo

IFF - Instituto Federal Fluminense

LDB - Lei de Diretrizes e Bases da Educação

ILEK - Institute of Lightweight Structures and Conceptual Design

IRCAM - Institut de Recherche et Coordination Acoustique/Musique

MEC - Ministério da Educação e Cultura

Pimeg-ARQ - Programa Integrado de Melhoria do Ensino de Graduação em Arquitetura

RPBW - Renzo Piano Building Workshop

PPP - Projeto Político Pedagógico

SESU - Secretaria de Ensino Superior

UCG - Universidade Católica de Goiás

UDESC - Universidade do Estado de Santa Catarina

UEG - Universidade Estadual de Goiás

UEL - Universidade Estadual de Londrina

UEM - Universidade Estadual de Maringá

UEMA - Universidade Estadual do Maranhão

UFAL - Universidade Federal de Alagoas

UFAM - Universidade Federal do Amazonas
UFAP - Universidade Federal do Amapá

UFBA - Universidade Federal da Bahia

UFC - Universidade Federal do Ceará

UFES - Universidade Federal do Espírito Santo

UFFS - Universidade Federal da Fronteira Sul

UFG - Universidade Federal de Goías

UFJF - Universidade Federal de Juiz de Fora

UFMG - Universidade Federal de Minas Gerais

UFMS - Universidade Federal de Mato Grosso do Sul

UFMT - Universidade Federal de Mato Grosso

UFOP - Universidade Federal de Ouro Preto

UFPA - Universidade Federal do Pará

UFPB - Universidade Federal da Paraíba

UFPE - Universidade Federal de Pernambuco

UFPI - Universidade Federal do Piauí

UFPR - Universidade Federal do Paraná

UFRGS - Universidade Federal do Rio Grande do Sul

UFRN - Universidade Federal do Rio Grande do Norte

UFRR - Universidade Federal de Roraima

UFRRJ - Universidade Federal Rural do Rio de Janeiro

UFS - Universidade Federal de Sergipe

UFSC - Universidade Federal de Santa Catarina

UFS - Universidade Federal de São João del Rey

UFSM - Universidade Federal de Santa Maria

UFT - Universidade Federal do Tocantins

UFU - Universidade Federal de Uberlândia

UFV - Universidade Federal de Viçosa

UIA - Union Internationale des Architectes

UnB - Universidade de Brasília

UNESP - Universidade Estadual Paulista

UNICAMP - Universidade Estadual de Campinas

UNILA - Universidade Federal da Integração Latino-

Americana

USP - Universidade de São Paulo

UTFPR - Universidade Federal Tecnológica do Paraná 


\section{SUMÁRIO}

INTRODUÇÃO

$\begin{array}{lr}\text { APRESENTAÇÃO DA PESQUISA } & 25\end{array}$

A DINÂMICA DE CONSTRUÇÃO DA PESQUISA 32

ESTRUTURAÇÃO DO TRABALHO

1. CAPÍTULO 01 - A CONCEPÇÃO ARQUITETÔNICA ORIENTADA PELA EXPERIMENTAÇÃO FÍSICA

1.1. CONSIDERAÇÕES SOBRE A DIMENSÃO DA EXPERIMENTAÇÃO NA ARQUITETURA 45

1.2. A PESQUISA EXPERIMENTAL ASSOCIADA AO PODER DE PRODUÇÃO DA INDÚSTRIA 61

1.3. A EXPERIMENTAÇÃO CONSTRUTIVA EM RESPOSTA A PROBLEMAS SOCIOECONÔMICOS E 68 AMBIENTAIS

1.4. Generalistas ou especialistas?

2. CAPÍTULO 02 - OS PROCESSOS EXPERIMENTAIS NO CONTEXTO ACADÊMICO: 079 DIÁLOGO ENTRE O PROJETO E A MATERIALIDADE

2.1. A EXPERIMENTAÇÃO COMO PRÁTICA PEDAGÓGICA 81

2.2. A RELAÇÃO ENTRE AS ATIVIDADES PROFISSIONAIS E ACADÊMICAS NO PROCESSO EXPERIMENTAL 90

2.3. CARACTERIZAÇÃO DOS ESPAÇOS EXPERIMENTAIS E ATIVIDADES ACADÊMICAS 97

2.4. ENTRE A INVENTIVIDADE E A REPRODUÇÃO 108

3. CAPÍTULO 03 - OS ESPAÇOS EXPERIMENTAIS E PRÁTICAS TÉCNICO-CONSTRUTIVAS DAS ESCOLAS PÚBLICAS DE ARQUITETURA

3.1. O OlHAR DE ENTIDADES NACIONAIS (MEC, ABEA, CAU E INSTITUIÇÕES DE ENSINO) SOBRE A ÁREA TECNOLÓGICA DOS CURSOS DE ARQUITETURA - ENTENDIMENTOS SOBRE A ÁREA EXPERIMENTAL

3.2. CARACTERIZAÇÃO DOS ESPAÇOS EXPERIMENTAIS E DAS PRÁtICAS tÉCNICO-CONSTRUTIVAS DAS ESCOLAS VISITADAS

3.2.1. Escolas Visitadas 134

3.2.1.1. Escolas implantadas antes da década de $1960 \quad 135$

3.2.1.2. Escolas implantadas na década de $1960 \quad 173$

3.2.1.3. Escolas implantadas na década de $1970 \quad 190$

3.2.1.4. Escolas implantadas na década de $1980 \quad 216$

3.2.1.5. Escolas implantadas na década de $1990 \quad 222$

$\begin{array}{ll}3.2 .2 \text { Quadro Síntese } & 240\end{array}$

4. ANALISANDO OS DADOS, COMPREENDENDO OS FATOS 243

4.1. O IMBRICAMENTO DAS PARTICULARIDADES HISTÓRICA, REGIONAL E ESTRUTURAL 245

4.2. CONFLUÊNCIA DE ENTENDIMENTOS SOBRE A ÁREA EXPERIMENTAL/CONSTRUTIVA ENTRE AS ESCOLAS VISITADAS

4.2.1. Estrutura Curricular e os conteúdos da área da Tecnologia da Construção 255

4.2.2. Infraestrutura física laboratorial e as práticas pedagógicas 264 
5. CONSIDERAÇÕES FINAIS 285

ANÁLISE NACIONAL A PARTIR DAS PARTICULARIDADES LEVANTADAS 287

$\begin{array}{ll}\text { REFERÊNCIAS BIBLIOGRÁFICAS } & 306\end{array}$

$\begin{array}{lr}\text { ANEXOS } & 319\end{array}$ 


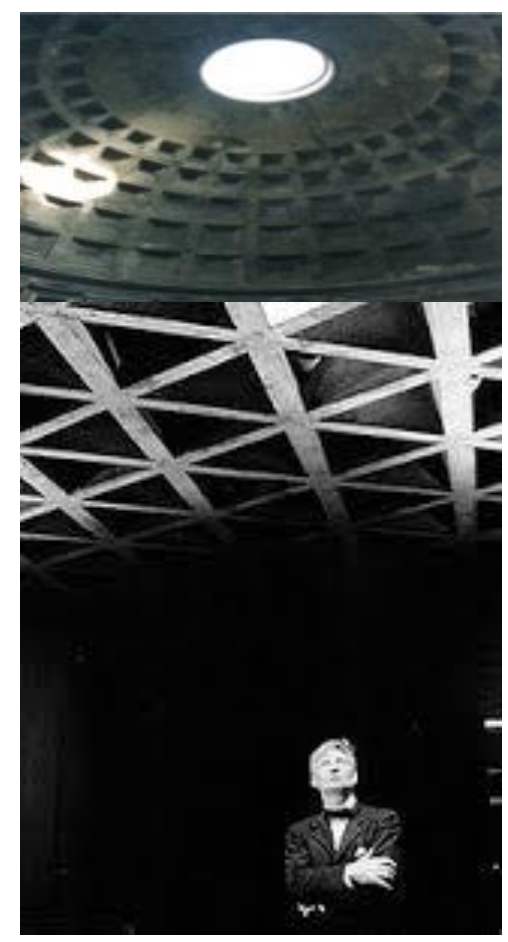

\section{CAPÍTULO INTRODUTÓRIO}

APRESENTAÇÃO

A DINÂMICA DE CONSTRUÇÃO DA PESQUISA ESTRUTURAÇÃO DO TRABALHO 


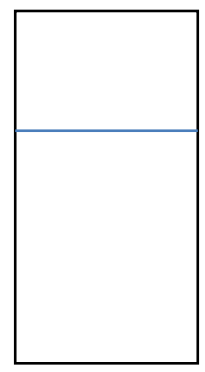

Imagem capa:

Cúpula do Panteon - Roma/ Arquiteto Louis I. Kahn sob a laje composta pelo entramado triangular em concreto da Galeria de Arte da Universidade Yale.

Fonte: Montagem realizada pela autora a partir de ADDIS, 2009/ PALERMO,2006. 


\section{APRESENTAÇÃO DA PESQUISA}

A utilização de processos experimentais para a concepção da materialidade teve, ao longo dos anos, um importante papel para a compreensão e resolução de diferentes questões que envolvem o projeto arquitetônico. Como prática pedagógica, estes processos permanecem ainda válidos e são intensamente explorados no contexto acadêmico, destacando-se a adoção de modelos e protótipos voltados a investigações na área técnico-construtiva, desenvolvidos geralmente em espaços experimentais específicos.

Inserido neste debate, o presente trabalho tem como principal objetivo compreender o processo de configuração dos espaços experimentais da área técnico-construtiva implantados nas escolas públicas de arquitetura de acordo com as particularidades advindas de diferentes contextos do país, das políticas educacionais e das ações dos atores envolvidos, com a sugestão de diretrizes que promovam implantações com respaldo técnico necessário e potencializem as práticas existentes.

A relevância deste trabalho dá-se sob ordens de contribuição tanto teórica quanto prática. Concorre inicialmente, para a sistematização de uma bibliografia abrangente sobre o processo experimental acadêmico, tema pouco estudado no contexto nacional. No campo prático, os dados obtidos nas visitas técnicas possibilitaram contextualizar os desafios enfrentados no ensino da Tecnologia da Construção que não se resumem ao arranjo físico laboratorial, mas a uma dimensão mais ampla. As informações levantadas possibilitaram identificar as condições consideradas como essenciais na (re)formulação de estratégias voltadas à área da Tecnologia da Construção e sua infraestrutura, de maneira que as experiências existentes possam ser potencializadas e novas implantações tenham maior respaldo técnico de acordo com as particularidades contextuais.

Sobre a adoção da pesquisa e da experimentação física ao longo do desenvolvimento projetual, diversos exemplos desenvolvidos no decorrer da história sustentam a importância da retomada deste assunto nos dias atuais e revelam a influência que a evolução tecnológica exerceu sobre a arquitetura. Segundo Addis (2009), embora tenha sido a partir da década de 1920 que os testes com maquetes em escala tenham sido desenvolvidos em centros de pesquisa, inclusive universidades, tornaram-se um método comprovado na comunidade de pesquisa da engenharia por volta da década de 1950, quando os projetistas deixaram de analisar os materiais como artesãos e passaram a fazê-los como cientistas. Diante desta disponibilidade de recursos, quando o problema construtivo não podia ser esclarecido com 
base na experiência, os projetistas recorriam à experimentação física juntamente com a análise teórica.

Embora alguns dos exemplos analisados neste trabalho já tenham sido exaustivamente estudados, permanecem como fontes passíveis de serem revisitadas diante da dimensão atemporal dos avanços alcançados, ficando evidente que a resolução construtiva foi para muitos profissionais um campo essencial à criação e porta obrigatória para a realização final do objeto previamente concebido. Estes projetistas, em circunstâncias diferentes, tiveram que ser confrontados com a materialização de suas obras, pois não bastava concebê-las, tiveram que construí-las e, na maior parte das vezes, como clientes de suas próprias criações. Esta imagem de "autoconstrutores" revela claramente até que ponto suas ideias estavam conectadas à realidade e as soluções sempre voltadas para a busca da simplicidade, na solução mais natural, econômica e eficiente. E, ao estudá-los sob a luz de seus entendimentos sobre a experimentação, é possível estabelecer correlações sobre o desenvolvimento tecnológico/inovativo e o formal/criativo.

A Figura 01 ilustra uma sequencia de imagens de experimentos com modelos em pequena escala e protótipos próximos à escala real, utilizados tanto por engenheiros como por arquitetos para o estudo de formas e processos inovadores.
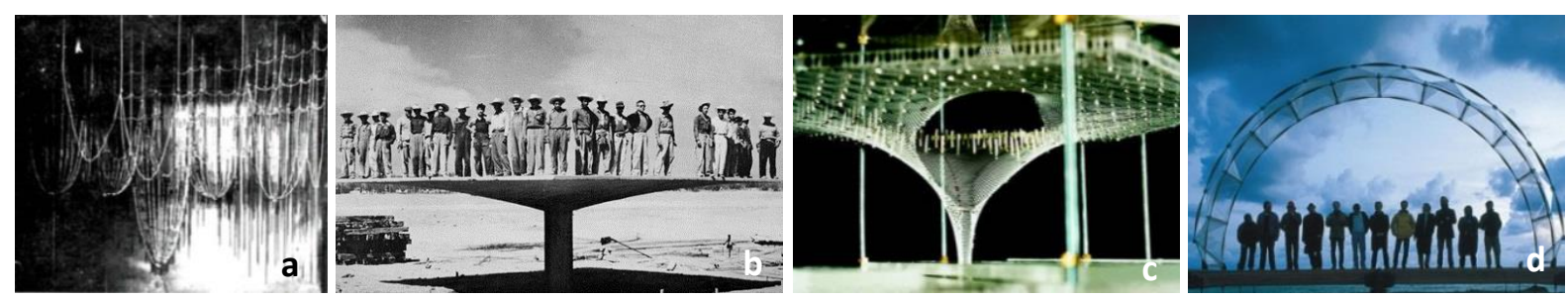

Figura 01- Sequencia de imagens de experimentos utilizados na investigação de formas complexas desenvolvidos por a) Antonì Gaudi, b) Felix Candela, c) Frei Otto e d) Renzo Piano.

Fontes: a) Addis,2009; b) http:www.chqs.net/archivos/informes/archivos_1_040310_la+estructura+veloz.pdf; c) Otto,1973; d) Buchanan, 2007.

Os modelos e protótipos apresentados na Figura 01 contribuíram para a compreensão e execução de obras emblemáticas em diferentes períodos como pode ser observado, sequencialmente, na Figura 02: a) Cripta Guell do arquiteto Antonì Gaudì, de 1917; b) High Life Textile Factory de Felix Candela, de 1955; c) Pavilhão de Munique de Frei Otto, de 1972 e o Pavilhão Itinerante da IMB de Renzo Piano, 1982. 

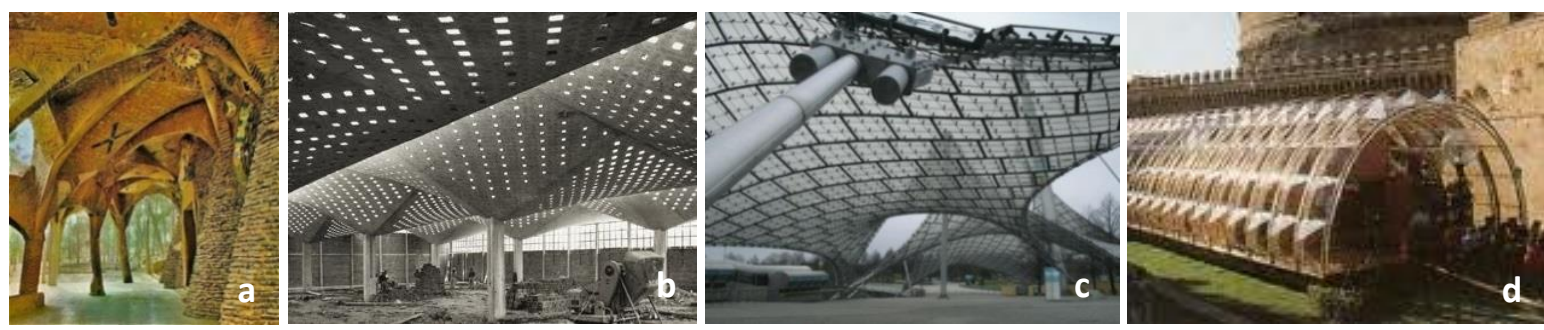

Figura 02 - Sequencia de fotos de obras desenvolvidas a partir de experimentos investigativos com modelos em pequena escala e protótipos em escalas próximas a real.

Fontes: a) Miracle, 2002; b) ttp:www.chqs.net/archivos/informes/archivos_1_040310_la+estructura+veloz.pdf; c) Otto, 1973; d) Buchanan, 2007.

O fato de diversos profissionais estudados terem feito do contexto acadêmico uma extensão do seu trabalho reflete o quanto acreditavam na valia do processo experimental como instrumento para a inovação construtiva e no avanço da ciência. Este período em contato com o ensino pode ser considerado como uma oportunidade para a sustentação dos princípios defendidos em suas carreiras e de aproximar a universidade do contexto real. Os dados levantados sobre esta questão permitem explicar: 'como e em que medida estes processos exploratórios, ao serem analisados e transferidos para a área acadêmica, podem contribuir para o estabelecimento de correlações segundo alguns aspectos: metodologia projetual em associação às questões relativas à materialidade, infraestrutura laboratorial necessária, parcerias com o setor industrial e a liberdade de criação e pesquisa no desenvolvimento de processos inovadores?'

Sobre o campo do ensino, observa-se que desde o Período Moderno a utilização de processos experimentais ao longo da concepção da materialidade teve um importante papel. Em Droste (2006) e, principalmente em Wick (1989), é realizada uma explanação sobre a forma de abordagem deste assunto na escola da Bauhaus, ao longo de importantes investigações sobre os materiais no que diz respeito tanto aos aspectos técnicos de processamento, como também, aos aspectos sensoriais que a materialidade poderia evocar.

Desde sua fundação, a Bauhaus tratou a questão da experimentação como algo crucial no curso, promovendo oficinas aos alunos na direção da síntese entre arte e técnica. Em seu livro, Rainer Wick chama à atenção sobre a atuação docente de Josef Albers ${ }^{1}$, por adotar um

\footnotetext{
${ }^{1}$ Josef Albers exerceu atividade docente no Curso Preliminar da Bauhaus entre 1923-1933. Destacou-se por promover uma metodologia embasada sobre dois alicerces: os "exercícios com a matéria" e os "exercícios com materiais". De acordo com Wick (1989), diversamente dos exercícios com a matéria, cujo objetivo era o reconhecimento sensorial das superfícies dos materiais, os exercícios com materiais voltavam-se a experimentação das características imanentes aos materiais, tais como estabilidade, resistência, consistência, capacidade, etc. Assim, por meio de uma observação exata e de uma nova visão os estudantes não apenas adquiriam indutivamente conhecimentos técnicos básicos, mas ao mesmo tempo cruzavam estes conhecimentos com princípios formais genéricos como harmonia, ritmo, proporção, medida, simetria, entre outros.
} 
princípio pedagógico que também concedia uma posição primordial a este aspecto, e que ele mesmo resumiu de maneira expressiva na frase: "Experimentar é melhor que estudar"².

Ao longo dos anos, os processos experimentais foram incorporando os avanços tecnológicos disponíveis em cada período para o estudo de diferentes questões que envolvem o ambiente construído, como os desenvolvidos na École Nationale Superieure d'Architecture de Grenoble - Studio Architecture et Cultures Constructives, cujas atividades podem ser observadas na Figura 03. Para um dos coordenadores do curso, Pascal Rollet ${ }^{3}$, as práticas realizadas dentro da universidade podem ser tidas como uma pedagogia que encoraja a descoberta do potencial de diferentes materiais, propiciando a aquisição de maior segurança sobre os princípios de desenho, uso dos materiais e análise estrutural. Esta aprendizagem pode oferecer aos estudantes a oportunidade de expressar a mudança de posição sobre as questões sociais, técnicas e ambientais de acordo com o seu tempo.
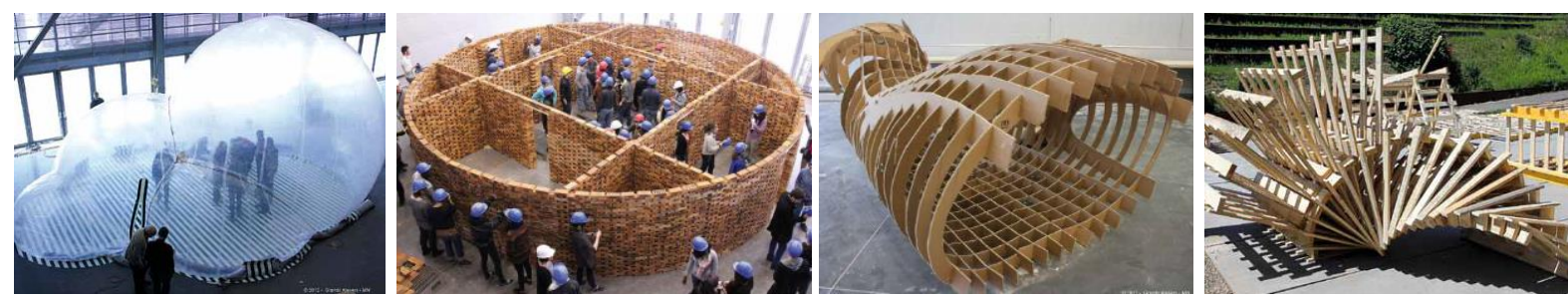

Figura 03- Sequencia de imagens de experiências realizadas em Les Grands Ateliers, em Grenoble - França. Fonte: Les Grands Ateliers. Activités 2011-2012.

Em relação às experiências acadêmicas desenvolvidas no contexto nacional, foi possível resgatar algumas iniciativas que influenciaram, de alguma forma, a conformação dos atuais espaços experimentais presentes em várias escolas de arquitetura, com destaque às divulgadas nos trabalhos de Lotufo (2014), Lopes (2014), Saramago (2011), Schlee (2010) e Leite (2005). Estes autores relatam várias práticas pedagógicas realizadas por pesquisadores na intenção de contribuir para a melhoria do ensino na área da Tecnologia da Construção dos cursos de Arquitetura e Urbanismo do país. Estes dados permitem responder a seguinte pergunta de pesquisa: 'A partir do incipiente desenvolvimento de atividades experimentais nas escolas brasileiras, estas seriam dispensáveis diante de um histórico que não tem por base este método pedagógico?'

As informações publicadas nos trabalhos dos autores supracitados dão indicativos de que a maior parte das iniciativas voltadas à exploração do processo experimental nos cursos de

\footnotetext{
${ }^{2}$ Wick (1989), p. 236.

${ }^{3}$ Disponível em: www.lesgrandsateliers.org. Acesso em 08 de agosto 2013.
} 
Arquitetura e Urbanismo no país teve, ao longo dos anos, maior evidência em escolas particulares, com poucas exceções. Esta situação revela a necessidade de resgatar o processo de desenvolvimento de atividades deste caráter também nas escolas públicas ${ }^{4}$, para que seja possível averiguar: 'se este cenário se deve apenas pela falta de divulgações sobre as experiências realizadas ou problemas de diferentes ordens conduziram a esta constatação. E, se as experiências nacionais que adotam predominantemente técnicas de trabalho-intensivas como instrumental pedagógico, podem contribuir para o desenvolvimento de processos mais racionalizados', sendo esta segunda parte da pergunta uma consideração de perspectiva de pesquisa sugerida em Saramago (2011).

Estes dados também se tornam importantes diante das mudanças vivenciadas nos últimos tempos com a inserção de novas ferramentas investigativas no processo projetual. Em Kowaltowski et. al. (2011), é possível verificar diferentes abordagens que envolvem o projeto arquitetônico e as metodologias e tecnologias associadas ao seu processo de desenvolvimento, com discussões recentes sobre esta sistemática, defendendo como postura teórica, a associação do fazer arquitetônico à atividade científica e, no que diz respeito à técnica, traz investigações acerca de técnicas e ferramentas disponíveis para a aplicação no processo de projeto, com exemplos de emprego de alguns experimentos em laboratório ${ }^{5}$.

A partir deste trabalho, é possível verificar em pesquisas atuais sobre tecnologias aplicadas no processo de projeto, a necessidade de expandir a discussão que aproxime a adoção de ferramentas físicas investigativas com a realidade material. O contato com a materialidade por meio de protótipos que avaliem aspectos inerentes aos materiais construtivos continua sendo um processo de experimentação mais passível de ser atingido em um espaço como o canteiro e laboratórios específicos. As novas ferramentas investigativas, como prototipagem e modelagem virtual, complementam os estudos, mas não substituem os dados obtidos por meio de processos próximos à escala real ${ }^{6}$. A deficiência advinda da falta de contato com a materialidade também tem provocado prejuízos em outras áreas do ensino como o desenho arquitetônico. Tamashiro (2010) associa esta deficiência à diminuição da vivência com

\footnotetext{
${ }^{4}$ Comprometidas com o tripé: Pesquisa, Ensino e Extensão.

${ }^{5} \mathrm{O}$ trabalho intitulado 'O processo de projeto em arquitetura: da teoria à tecnologia' foi desenvolvido entre 2006 e 2011 como projeto temático financiado pela FAPESP - Fundação de Amparo à Pesquisa de São Paulo. Foi publicado na forma de um livro em 2011 com a compilação de diferentes pesquisas com interface à temática.

${ }^{6}$ Independente da escala, os processos exploratórios são passíveis de absorção de tecnologias mais avançadas, possibilitando a otimização dos processos construtivos.
} 
experiências materiais e o baixo entendimento técnico-construtivo, resultando em desenhos inexpressivos ou representados de forma incoerente com a realidade material.

Já Pippard (1947) faz uma consideração pertinente e atemporal sobre a adoção de ferramentas físicas no âmbito acadêmico, salientando a importância da associação dos processos experimentais ao conteúdo teórico trabalhado em sala de aula, para que os dados fornecimentos por estas ferramentas sejam tratados e interpretados por quem as desenvolve. O processo de interpretação é fundamental para o amadurecimento das ideias e aperfeiçoamento do projeto, principalmente quando o desenho não fornece a dimensão real do problema a ser enfrentado. Devido a isso, os protótipos produzidos têm uma importância significativa nas etapas iniciais de desenvolvimento, porque elucidam a teoria. Embora, normalmente, exista a tendência de subestimar as potencialidades que estas ferramentas oferecem na simplificação e encurtamento do tempo de desenvolvimento de projeto e novos produtos.

Embora muitos dos trabalhos apresentados tenham sido desenvolvidos entre as décadas de 1940 e 1970, a partir deles é possível levantar preocupações e desafios comuns aos vivenciados atualmente, como a construção hipotética de um cenário mais favorável ao ensino do conteúdo tecnológico nos cursos de Arquitetura ${ }^{7}$, como o fazem Vianna (1989), Zanettini (2002) e Lima (2004) ao reforçar o discurso de uma formação profissional generalista. Proporcionando ao aluno ferramentas compatíveis com os desafios contemporâneos no que diz respeito às questões sociais, ambientais, tecnológicas e industriais, atuando como agentes responsáveis pela abertura de novos caminhos a partir da invenção e quebra de paradigmas.

Quanto às pesquisas nacionais sobre o tema, além da maior parte das publicações encontradas relatarem atividades experimentais em escolas particulares de Arquitetura como já sinalizado - destaca-se também outra questão, grande parte destas pesquisas foram desenvolvidas na região sudeste, em especial no Estado de São Paulo, este cenário fortalece ainda mais a necessidade de ampliar as discussões para o contexto nacional, na intenção de documentar a diversidade que atualmente existe na configuração dos espaços

\footnotetext{
${ }^{7}$ A formação multidisciplinar do arquiteto e o equilíbrio entre o conteúdo teórico e prático foram intensamente discutidos por diversos profissionais brasileiros na década de 1950 e revelam desafios comuns aos vivenciados atualmente no ensino de Arquitetura e Urbanismo, principalmente, no que se refere à dualidade entre arte e técnica, assunto que sempre suscitou opiniões divergentes, como visto no documento O Ensino de Arquitetura, de 1956, quando os professores Mário Wagner Vieira da Cunha, Luís Saia, João Batista Vilanova Artigas e Lina Bo Bardi participaram de um debate sobre as reestruturações necessárias ao curso.
} 
experimentais e práticas de ensino na área técnico-construtiva. A escassez de atividades voltadas à experimentação construtiva foi detectada pelo CEAU (Comissão de Especialistas em Arquitetura e Urbanismo) segundo Grazzia (1999), como uma das mais notáveis falhas na formação do arquiteto e urbanista. Segundo o mesmo documento, "a dinâmica do processo de ensino/aprendizagem requer a utilização de múltiplas formas de apropriação do conhecimento, e não se limita à oferta de disciplinas ministradas em sala de aula". Em 2008, este assunto foi retomado com maior força pela ABEA (Associação Brasileira de Ensino de Arquitetura e Urbanismo), quando algumas experiências foram apresentadas com resultados muito positivos, salientando a relevância destas atividades práticas/construtivas nos cursos de Arquitetura.

Em relação aos trabalhos já realizados e direcionados a retratar o cenário acadêmico nacional, alguns deles estiveram baseados na aplicação de questionários, com a obtenção e divulgação apenas de dados quantitativos, ficando ausente a análise qualitativa sobre as atividades desenvolvidas, algo somente possível a partir da visita in loco. A caracterização e análise em diferentes regiões do país permite a obtenção de um respaldo mais seguro para a análise do contexto nacional e suas particularidades. Além disso, a obtenção de informações junto a diferentes atores envolvidos com a temática conduz a outros pontos de vista, fomentando a resposta às seguintes questões: - De que forma estes espaços experimentais inseridos nos cursos de Arquitetura podem contribuir para a formação de um profissional mais sensível às questões relativas à materialidade e que participe no desenvolvimento técnico do setor construtivo? Quais os limites e potencialidades da parceria entre indústria e academia na formação do futuro profissional?

Além de dar maior respaldo à outra questão: Quais as condições mais favoráveis para que atividades de caráter experimental possam ser desenvolvidas nas escolas visitadas, permitindo o diálogo entre a dimensão expressiva e construtiva?

A partir da conjuntura de informações levantadas em diferentes fontes por meio da pesquisa documental foi proposta a seguinte hipótese para esta pesquisa: 'As atividades experimentais podem ser consideradas como uma prática pedagógica singular, que oferece ao aluno a possibilidade de conhecer diferentes aspectos envolvidos no projeto de arquitetura, tanto de caráter expressivo como também construtivo e de refletir sobre questões sociais, técnicas e ambientais. Embora essas atividades tragam contribuições já validadas ao ensino do conteúdo técnico nos cursos de arquitetura, são escassas as pesquisas que procuram analisar 
qualitativamente estas práticas no contexto nacional. Caracterizar e compreender a atual conformação dos espaços experimentais das escolas públicas de arquitetura do país daria subsídios para potencializar as atividades atualmente desenvolvidas e oferecer dados mais consistentes para a viabilização de novas implantações, considerando as particularidades de cada contexto'.

\section{A DINÂMICA DE CONSTRUÇÃO DA PESQUISA}

O termo Espaços Experimentais foi adotado neste trabalho pelo caráter genérico e por permitir abranger diferentes tipos de estruturações físicas e espaciais voltadas ao ensino da área da Tecnologia da Construção, diante da possibilidade de serem encontradas, ao longo da pesquisa, infraestruturas laboratoriais distintas das tradicionalmente utilizadas no âmbito acadêmico, como os Laboratórios de Materiais e Técnicas Construtivas e os Canteiros de Obras e/ou Experimentais.

Em relação à área da Tecnologia da Construção, foi considerada nesta pesquisa como pertencente à macro área da Tecnologia da Arquitetura (a qual abrange outras disciplinas de caráter técnico como: Conforto Ambiental, Sistemas Estruturais, Instalações Prediais, etc). Desta forma, a pesquisa refere-se extritamente às disciplinas de Materiais Construtivos e Técnicas Construtivas. Esta organização pré-estabelecida no trabalho foi necessária para aprofundar a pesquisa e viabilizar a identificação dos principais atores à frente das disciplinas da área de Materiais e Técnicas Construtivas e da coordenação dos espaços experimentais que dão suporte às mesmas. Contudo, esta delimitação não deixa de reconhecer a possibilidade de extrapolar, eventualmente, as investigações para outras áreas diante das interfaces existentes, como ocorre com a área de Sistemas Estruturais.

Em relação ao desenvolvimento do trabalho, ao longo da pesquisa foram realizadas algumas alterações que levaram a mudanças nas estratégias metodológicas para coleta de dados, de acordo com a disponibilidade de recursos financeiros e das políticas de fomento à pesquisa.

A primeira estratégia proposta no plano de trabalho foi delineada a partir da consulta preliminar aos trabalhos já desenvolvidos sobre a temática, notando-se que a ferramenta de aplicação de questionários direcionados aos cursos distantes da cidade sede da pesquisa pode fornecer dados equivocados e distorcidos, que nem sempre refletem a realidade vivenciada por estas escolas. Diante desta constatação, a análise in loco torna-se recomendável e se 
revela mais eficaz no processo de aproximação com a fonte primária a ser analisada, permitindo não apenas visualizar os espaços experimentais, como também, entrevistar os atuais agentes responsáveis pela área da Tecnologia da Construção em cada local visitado.

O procedimento de coleta de dados, inicialmente proposto, considera os recursos logísticos e financeiros para estabelecer critérios de seleção das escolas a serem visitadas, cuja escolha pudesse contextualizar as particularidades do cenário nacional. Para isso, foi realizado o levantamento das escolas públicas de arquitetura do país por meio da consulta aos dados fornecidos pelo $M E C^{8}$, os quais foram, posteriormente, organizados em um mapa com a distribuição das instituições pelo território nacional, de acordo com a Figura 04.

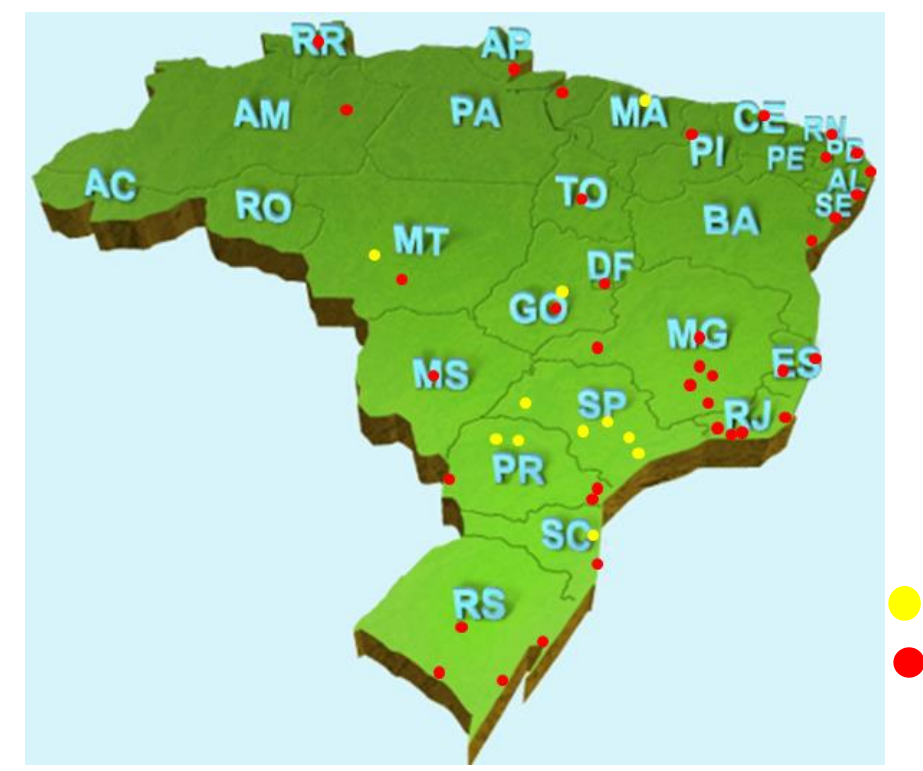

Escolas Públicas Estaduais

Escolas Públicas Federais

Figura 04 - Mapa do Brasil com a localização das escolas públicas de Arquitetura e Urbanismo.

Fonte: Adaptação realizada pela autora a partir de http://emec.mec.gov.br/. Ano de referência: 2013.

Devido ao crescimento expressivo de escolas particulares implantadas nos últimos anos, a atualização do número de escolas de arquitetura no país tem sido uma tarefa difícil. Com relação às escolas públicas, permanece um número mais estável com poucas alterações. No início desta pesquisa, em 2013, o Brasil contava com 280 escolas de Arquitetura e Urbanismo, deste total, 47 cursos inseridos em instituições públicas (11 estaduais e 36 federais), indicando um percentual aproximado de 17\%. Em relação à distribuição das escolas no território nacional (escolas públicas e privadas), 24\% das escolas apresentavam-se localizadas na Região Sul, $42 \%$ na Região Sudeste, 12\% na Região Centro-oeste, 15\% na Região Nordeste e 7\% na Região Norte, de acordo com o Quadro 01.

\footnotetext{
${ }^{8}$ Disponível em: http://emec.mec.gov.br/. Acesso realizado em 20/09/2013.
} 
Quadro 01 - Distribuição dos cursos por regiões e estados.

\begin{tabular}{|c|c|c|c|c|c|c|c|c|c|c|c|c|c|c|c|c|c|c|c|c|c|c|c|c|c|c|c|}
\hline Região & \multicolumn{3}{|c|}{ Sul } & \multicolumn{4}{|c|}{ Sudeste } & \multicolumn{5}{|c|}{ Centro-Oeste } & \multicolumn{9}{|c|}{ Nordeste } & \multicolumn{6}{|c|}{ Norte } \\
\hline Estados & RS & SC & PR & SP & MG & RJ & ES & MS & MT & GO & DF & TO & BA & SE & AL & PE & PB & RN & CE & PI & MA & PA & AP & AM & RO & RR & $A C$ \\
\hline $\mathrm{N}^{\circ}$ escolas Públic. & 04 & 02 & 05 & 05 & 06 & 04 & 02 & 01 & 02 & 02 & 01 & 01 & 01 & 01 & 01 & 01 & 02 & 01 & 01 & 01 & 01 & 01 & 01 & 01 & - & 01 & - \\
\hline $\mathrm{N}^{\circ}$ escolas Priv. & 18 & 23 & 16 & 56 & 22 & 13 & 09 & 04 & 04 & \begin{tabular}{|l|}
07 \\
\end{tabular} & 09 & 02 & 06 & 01 & 01 & 08 & 03 & 03 & 05 & 02 & 03 & 03 & 02 & 05 & 04 & - & 02 \\
\hline Total & 22 & 25 & 21 & 61 & 28 & 17 & 11 & 05 & 06 & 09 & 10 & 03 & 07 & 02 & 02 & 09 & 05 & 04 & 06 & 03 & 04 & 04 & 03 & 06 & 04 & 01 & 02 \\
\hline $\begin{array}{l}\mathrm{N}^{0} \text { total de escolas } \\
\text { de Arq./região }\end{array}$ & & 68 & & & & & & & & 33 & & & & & & & 42 & & & & & & & & & & \\
\hline
\end{tabular}

Fonte: Dados organizados pela autora, a partir da consulta das referencias publicadas pelo Ministério da Educação e Cultura - MEC, em setembro de 2013. Disponível em: http://emec.mec.gov.br/.

Dentre os critérios para a escolha das instituições públicas a serem visitadas destaca-se a data de implantação dos cursos, em que as escolas implantadas nos últimos 10 anos $^{9}$ não foram contempladas por este trabalho. Este recorte temporal deve-se ao fato de que a implantação dos espaços e o desenvolvimento das atividades de experimentação requerem um período de consolidação, envolvendo questões políticas, culturais e econômicas nas diversas instâncias, de acordo com cada instituição.

$\mathrm{Na}$ intenção de atender as condicionantes supracitadas, foi elaborado o Quadro 02 , com as datas de implantação dos cursos de Arquitetura e Urbanismo, implantados em instituições públicas nacionais. De acordo com o critério apontado, 07 escolas deveriam ser visitadas na região Sul, 12 na região Sudeste, 04 na região Centro Oeste, 09 na região Nordeste e 01 na região Norte, somando-se 33 escolas, que equivalem a 70\% das escolas públicas. O Quadro 02 leva em consideração apenas a data de implantação das escolas, mas não a proporção de escolas/região, o que levaria algumas regiões serem mais estudadas em relação a outras.

Quadro 02 - Data de implantação dos cursos de Arquitetura e Urbanismo no país, com destaque às escolas a serem visitadas ao longo da pesquisa.



\footnotetext{
${ }^{9}$ Em relação ao ano de início da pesquisa, 2013.
} 


\begin{tabular}{|c|c|c|c|c|c|c|c|c|c|c|}
\hline Região Nordeste & BA & SE & $\mathrm{AL}$ & PE & \multicolumn{2}{|c|}{ PB } & RN & CE & PI & MA \\
\hline $\begin{array}{c}\text { Instituições Públicas que } \\
\text { possuem curso de } \\
\text { Arquitetura }\end{array}$ & UFBA & UFS & UFAL & UFPE & UFCG & UFPB & UFRN & UFC & UFPI & UFMA \\
\hline Ano de criação do curso & 1880 & 2007 & 1973 & 1932 & 2002 & 1974 & 1973 & 1965 & 1993 & 1993 \\
\hline Região Norte & \multicolumn{2}{|c|}{ PA } & AP & & RO & \multicolumn{2}{|c|}{ AM } & $\mathbf{R R}$ & \multicolumn{2}{|r|}{ AC } \\
\hline $\begin{array}{c}\text { Instituições Públicas que } \\
\text { possuem curso de } \\
\text { Arquitetura }\end{array}$ & \multicolumn{2}{|c|}{ UFPA } & UFAP & & - & \multicolumn{2}{|c|}{ UFAM } & UFRR & & - \\
\hline Ano de criação do curso & \multicolumn{2}{|c|}{1964} & $2011 / 12$ & & - & \multicolumn{2}{|c|}{2010} & 2005 & & - \\
\hline
\end{tabular}

Fonte: Consulta aos dados disponibilizados nos sites institucionais de cada escola de Arquitetura.

Esta situação foi questionada e reavaliada ao longo da pesquisa, juntamente com a disponibilidade de recursos financeiros, sendo necessário o estabelecimento de outras estratégias e critérios para uma nova seleção, levando à redução do número de escolas a serem visitadas. $E$, na intenção de manter inalteradas algumas questões da proposta, optou-se pela reavaliação das estratégias de pesquisa, de maneira que o objetivo do trabalho fosse alcançado e as perguntas de pesquisa respondidas, utilizando-se um número menor de elementos (escolas analisadas) do que o inicialmente proposto (33 escolas).

Ao estudar alguns autores como Selltiz (1975), Richardson (1985) e Oliveira (2011), pôdese constatar que as alterações intencionadas para coleta de dados seriam viáveis, por se tratar de uma pesquisa exploratória e qualitativa, portanto, que não emprega instrumental estatístico como base do processo de análise dos objetivos propostos, pela sua natureza complexa e particular. Diante disso, continuava a ser indicada para coleta de dados a aplicação de técnicas como a observação e entrevistas, pela propriedade que os procedimentos possuem de penetrar na complexidade de um problema.

A partir das características enquadradas pelos autores supracitados como pesquisa exploratória, foi considerado neste trabalho o tipo de amostragem não-probabilística ${ }^{10}$, correspondente a uma técnica que não utiliza a seleção aleatória, mas confia no julgamento pessoal do próprio pesquisador. Este tipo de amostragem, de acordo com Selltiz (1975) e Mattar (1996), não tem como objetivo a generalização dos resultados obtidos, mas dá a chance de obter certa ideia da variedade de elementos existentes no conjunto pesquisado, neste caso, os espaços experimentais, pela intenção em considerar suas particularidades regionais e históricas de implantação e utilização, diante da diversidade de situações que seriam encontradas.

\footnotetext{
${ }^{10}$ De acordo com Mattar (1996, p. 133), para a escolha do processo de amostragem, o pesquisador deve levar em conta o tipo de pesquisa, a acessibilidade aos elementos da população, a disponibilidade ou não de ter os elementos da população, a representatividade desejada ou necessária, a oportunidade apresentada pela ocorrência de fatos ou eventos, a disponibilidade de tempo, recursos financeiros e humanos etc.
} 
Neste segundo momento, a delimitação da amostragem de escolas baseou-se no préestabelecimento de categorias bem definidas que se relacionam intencionalmente em direção à obtenção das respostas às perguntas do plano de pesquisa, tratando-se, portanto, da fusão entre amostragem não-probabilística intencional e por quotas ${ }^{11}$. Esta escolha também está apoiada na inexistência de dados analíticos sobre a totalidade dos espaços experimentais das escolas nacionais de arquitetura, assim como, na dificuldade de realização das visitas técnicas e entrevistas, processo este atrelado à disponibilidade de recursos e tempo demandado para sua realização.

A partir do recorte temporal quanto à data de implantação do curso inicialmente proposto (acima de 10 anos de acordo com o ano de início da pesquisa - 2013), as categorias de análise consideradas na segunda seleção seriam:

Regional - procurando abranger escolas de diferentes regiões do país e que tivessem representatividade regional;

Histórica - classificação das escolas (apresentadas inicialmente sem o recorte) baseando-se no momento político educacional em vigor no período de sua implantação:

- Cursos criados antes da década de 1960 - provenientes em sua maioria de dois modelos de ensino, Belas-Artes e Politécnico. Cursos criados neste período em instituições públicas: UFRJ (1826); UFBA (1880); UFRGS (1898/1936); UFMG (1930); UFPE (1932) e USP-SP (1948).

- Cursos implantados na década de 1960 - discussões de maior abrangência nacional sobre os rumos do ensino de arquitetura no país; implantação da ditadura militar. Cursos criados neste período em instituições públicas: UNB (1962); UFPR (1962/63); UFC (1964) e UFPA (1964);

- Cursos criados na década de 1970 - implementação de regulamentações no ensino a partir do Currículo Mínimo de 1969; criação dos CEAUs (Comissão de Especialistas em Arquitetura e Urbanismo) e fundação da ABEA (chamada inicialmente de Associação Brasileira de Escolas de Arquitetura). Cursos criados neste período em instituições públicas: UFF (1970); UFPel (1971); UFRN (1973); UFAL (1974); UFPB (1974); UFSC (1977); UEL (1978) e UFES (1978);

- Cursos criados na década de 1980 - fim da ditadura militar; pouca discussão e atuação das entidades ligadas ao ensino. Cursos criados neste período em instituições públicas: UNESP/Bauru (1984) e USP/São Carlos (1985);

\footnotetext{
${ }^{11}$ A amostragem não probabilística de acordo com diferentes autores pode ser classificada em: amostra acidental ou por conveniência; amostra intencional ou por julgamento e também amostra por quotas ou proporcionais. Neste trabalho foram adotados os tipos: intencional e por quotas. Em relação às características de cada uma delas, fica claro em Oliveira (2001) que a amostragem intencional é realizada de acordo com o julgamento do pesquisador, considerando que a amostra escolhida poderá oferecer as contribuições solicitadas. Este método também é muito utilizado para a escolha de uma localidade "representativa" por meio de um número reduzido de amostras. No caso da amostra por quotas constitui um tipo especial de amostra intencional em que o pesquisador procura obter uma amostra que seja similar à população sob algum aspecto, para efeito comparativo no tratamento dos dados.
} 
- Cursos implantados na década de 1990 - início de $2000^{12}$ - levantamento aprofundado realizado pela nova equipe do CEAU, com considerações mais detalhadas sobre a infraestrutura existente nos cursos de arquitetura e urbanismo. Foi o período mais fértil de discussão sobre a situação da área experimental encontrada nas escolas visitadas (rede pública e privada). Cursos criados neste período em instituições públicas: UFV (1992); UFJF (1992); UFSM (1993); UFPI (1993); UEMA (1993); UFMT (1995); UFU (1996); UNICAMP (1999); UEM (2000); UFRRJ (2000); UFMS (1999/2000); UFT (2000) e UFCG (2002).

Ao cruzar as informações sobre o momento histórico de implantação das escolas e sua distribuição no território nacional, foi realizada uma nova seleção de escolas para serem visitadas, apoiando-se também nas considerações sobre o método de amostragem não probabilística, na tentativa de formar um conjunto que apresentasse representatividade regional e também atendesse as considerações sobre os aspectos históricos. Desta forma, dentro do universo de 33 escolas de arquitetura e urbanismo inseridas em instituições públicas e implantadas até 2002, de acordo com o Quadro 02, 21 delas foram contempladas por esta pesquisa, conforme o Quadro 03:

Quadro 03. Apresentação das escolas escolhidas de acordo com os aspectos regionais e históricos para serem visitadas in loco:

\begin{tabular}{|c|c|c|c|c|c|c|c|c|c|c|c|c|c|c|c|c|}
\hline Região Sul & \multicolumn{6}{|c|}{ RS } & \multicolumn{3}{|c|}{ SC } & \multicolumn{7}{|c|}{ PR } \\
\hline $\begin{array}{l}\text { Instituições Públicas que } \\
\text { possuem curso de } \\
\text { Arquitetura }\end{array}$ & \multicolumn{2}{|c|}{ UFFS } & UFSM & \multicolumn{3}{|r|}{ UFRGS } & \multicolumn{2}{|c|}{ UDESC } & UFSC & \multicolumn{2}{|c|}{ UNILA } & \multicolumn{2}{|l|}{ UTFPR } & \multicolumn{2}{|l|}{ UEL } & UFPR \\
\hline Ano de criação do curso & 2010 & \multicolumn{2}{|c|}{1993} & 1971 & \multicolumn{2}{|c|}{$1898 / 36$} & \multicolumn{2}{|c|}{2008} & 1977 & \multicolumn{2}{|c|}{2010} & 2009 & 2000 & \multicolumn{2}{|c|}{ 1978/79 } & $1962 / 3$ \\
\hline Região Sudeste & \multicolumn{5}{|c|}{ SP } & \multicolumn{6}{|c|}{ MG } & \multicolumn{3}{|c|}{ RJ } & \multicolumn{2}{|r|}{ ES } \\
\hline $\begin{array}{l}\text { Instituições Públicas que } \\
\text { possuem curso de } \\
\text { Arquitetura }\end{array}$ & $\begin{array}{l}\text { Unesp } \\
\text { P.Prud. }\end{array}$ & Unicamp & $\begin{array}{l}\text { USP/ } \\
\text { SCar }\end{array}$ & $\begin{array}{l}\text { Unesp } \\
\text { Bauru }\end{array}$ & $\begin{array}{l}\text { USP/ } \\
\text { SP }\end{array}$ & UFSJ & UFOP & UFU & UFV & UFJF & UFMG & IFF & \begin{tabular}{|l|l|} 
UFRRJ & UFF \\
\end{tabular} & UFRJ & IFES & UFES \\
\hline Ano de criação do curso & 2003 & 1999 & 1985 & 1984 & 1948 & 2009 & 2008 & 1996 & 1992 & 1992 & 1946 & 2008 & $2000 \quad 1970 \mid$ & $\mid 1826$ & 2008 & \begin{tabular}{l|l|}
3 & 1978
\end{tabular} \\
\hline Região Centro-Oeste & \multicolumn{2}{|r|}{ MS } & \multicolumn{5}{|c|}{ MT } & \multicolumn{5}{|c|}{ GO } & \multicolumn{2}{|l|}{ DF } & \multicolumn{2}{|c|}{ TO } \\
\hline $\begin{array}{l}\text { Instituições Públicas que } \\
\text { possuem curso de } \\
\text { Arquitetura }\end{array}$ & \multicolumn{2}{|r|}{ UFMS } & \multirow{2}{*}{\multicolumn{3}{|c|}{ UEMT }} & UFI & & & UFG & & UEG & & UNB & & UF & FT \\
\hline Ano de criação do curso & & $99 / 2000$ & & & & 19 & & & 2009 & & 2008 & & 1962 & & 200 & 00 \\
\hline Região Nordeste & BA & & SE & & $\overline{A L}$ & $\mathrm{PE}$ & & & PB & & RN & $\mathbf{N}$ & CE & $\mathbf{P I}$ & & MA \\
\hline $\begin{array}{l}\text { Instituições Públicas que } \\
\text { possuem curso de } \\
\text { Arquitetura }\end{array}$ & UFB & & UFS & & FAL & UFF & & UFCG & & JFPB & UFR & RN & UFC & UFPI & & UEMA \\
\hline Ano de criação do curso & 188 & & 2007 & & 974 & 193 & & 2002 & & 1974 & & 73 & 1964 & 1993 & & 1993 \\
\hline Região Norte & & PA & & & $\mathbf{P P}$ & & RC & 0 & & AM & & & $\mathbf{R R}$ & & AC & \\
\hline $\begin{array}{l}\text { Instituições Públicas que } \\
\text { possuem curso de } \\
\text { Arquitetura }\end{array}$ & & UFPA & & & $=A P$ & & - & - & & UFAN & & & UFRR & & - & \\
\hline Ano de criação do curso & & 1964 & & 201 & $1 / 12$ & & - & 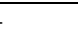 & & 2010 & & & 2005 & & - & \\
\hline
\end{tabular}

\footnotetext{
${ }^{12}$ As categorias criadas deixam de considerar as escolas criadas nos últimos 10 anos, de acordo com a regra de corte já explicitada ao longo do texto.
} 
Legenda de implantações de acordo com cada governo:

- Escolas implantadas antes de 1956 (sem considerar a data de federalização)

- Juscelino Kubitscheck (01/1956 a 01/1961)*

- Jânio Quadros (01/1961 a 08/1961)*

- Mazzili (08/1961 a 09/1961)*

- João Goulart (09/1961 a 04/1964)

- Humberto Castelo Branco (04/1964 a 03/1967)*

- Artur Costa e Silva (03/1967 a 08/1969)*

- Junta Governativa Provisória (08/1969 a 10/1969)*
- Emílio Médici (10/1969 a 03/1974)

- Ernesto Geisel (03/1974 a 03/1979)

- João Figueiredo (03/1979 a 03/1985)

- Sarney (03/1985 a 03/1990)*

- Fernando Collor (03/1990 - 12/92)

- Itamar (12/1992 a 01/1995)

- Fernando Henrique Cardoso (01/1995 a 01/2003)

*Obs.: Neste governo não houve implantação de cursos de arquitetura e urbanismo em instituições públicas de ensino superior.

A seleção das escolas a serem visitadas também deveria dar subsídios para analisar a hipótese levantada na pesquisa, permitindo caracterizar as particularidades advindas do contexto de inserção de cada escola e atingir uma escala considerável para compreender a variedade de entendimentos sobre a questão experimental nas escolas públicas em diferentes regiões do país. O fato de selecionar apenas um número representativo de escolas de cada região, mediante as categorias previamente estabelecidas, pode ser considerado aceitável para responder as perguntas de pesquisa, pois mais significativo que o número de escolas é a possibilidade da consulta dos dados em fonte primária (por meio das entrevistas, visitas técnicas e, quando possível, o acesso a documentos internos), promovendo maiores chances de compreensão sobre as variáveis que influenciam na identidade da escola.

Desta forma, as visitas in loco, além de possibilitar a observação direta do objeto de estudo, permitem a realização de entrevistas direcionadas aos professores que estão à frente das disciplinas voltadas à Tecnologia das Construções (arquitetos e/ou engenheiros) e, em alguns casos, nos cursos onde há a ausência de figuras representativas na área estudada, alguns coordenadores de curso foram consultados, na intenção de compreender e construir o cenário local. O método adotado foi a entrevista semi-estruturada, por meio de um roteiro de perguntas predeterminadas $^{13}$, mas com uma margem de liberdade para que a pesquisadora/entrevistadora pudesse desenvolver cada situação na direção que considerasse adequada.

As entrevistas direcionadas a diferentes profissionais espalhados pelo território brasileiro foi uma das estratégias para o desvencilhamento de pressupostos pessoais, muitas vezes consolidados a partir de escassas fontes bibliográficas sobre o tema, os quais podem vir a sustentar determinadas linhas de pensamento ligadas diretamente a estas fontes. Com isso, 0 trabalho traz à tona diferentes pontos de vista sobre o assunto dentro de uma comunidade

\footnotetext{
${ }^{13}$ Ver anexo 01 e 02 - Coleta de dados/Roteiro Entrevista e Termo de Consentimento, respectivamente.
} 
acadêmica mais ampla e que vivencia condições de trabalho semelhantes, como as instituições públicas.

Os dados coletados junto aos entrevistados e mediante o acesso a documentos de domínio público e em consulta a documentos internos relativos aos cursos, foram estruturados visando à obtenção das seguintes informações ${ }^{14}$ :

- Contextualização histórica do momento de implantação do curso;

- Modelo adotado pela escola visitada para a condução da área da tecnologia da construção;

- Estrutura Curricular e a identificação das estratégias adotadas na distribuição das disciplinas da Tecnologia;

- Perfil dos docentes que ministram as disciplinas da área da Tecnologia da Construção e que estão à frente da coordenação dos espaços experimentais, quando existentes;

- Disponibilidade de recursos humanos e materiais;

- Dados sobre a utilização da infraestrutura laboratorial, identificando quando de uso compartilhado ou não e qual a política de utilização por parte do curso de arquitetura;

- Caracterização da infraestrutura e das práticas laboratoriais quando existentes;

- Dados sobre as práticas realizadas, se possuem caráter instrucional ou incluem pesquisas experimentais;

- Informações sobre a pós-graduação quando existente na escola visitada e se há linhas de concentração na área da Tecnologia da Construção;

- Evidências de correlação entre as informações dos Projetos Político Pedagógico de curso (PPP) e o cenário atual - considerações realizadas sobre a área tecnológica;

- Diferenças entre escolas de um mesmo estado, de uma mesma região ou entre regiões;

- Correlações entre as atividades pedagógicas e o contexto socioeconômico local;

A classificação em categorias (Histórica e Regional) de acordo com a sequencia cronológica dos fatos históricos mais relevantes ao tema - a área experimental/construtiva dos cursos de arquitetura das escolas públicas nacionais - permitiu que durante as visitas e também ao longo do tratamento dos dados, fossem criados parâmetros para facilitar a compreensão de uma série de fenômenos (históricos/culturais/políticos/econômicos), que influenciaram a

\footnotetext{
${ }^{14}$ Deve ser destacado que as informações aqui descritas referem-se à data de visita às escolas, fato que ocorreu no intervalo entre 11/2013 e 11/2016. Sendo assim, há a possibilidade de várias escolas terem realizado eventuais intervenções, promovendo modificações e benfeitorias em relação ao exposto neste trabalho.
} 
configuração dos espaços experimentais visitados e também a forma de condução das atividades na área da Tecnologia da Construção. Estas categorias de análise permitiram criar uma lógica para a realização das visitas, com a possibilidade de averiguar a influência que escolas mais antigas exerceram sobre outras, ao exportar quadros docentes, experiências e discussões já amadurecidas sobre o ensino.

\section{ESTRUTURAÇÃO DO TRABALHO}

Para a construção desta pesquisa foram consideradas como unidades de análise: 1) A adoção da experimentação no contexto profissional, a partir do estudo de metodologias projetuais que tiveram como apoio o uso de modelos e protótipos. 2) o processo experimental no contexto acadêmico, identificando possibilidades exploratórias deste recurso no campo do ensino. 3) Os espaços e práticas experimentais no contexto acadêmico nacional, procurando compreender a estruturação da área da Tecnologia da Construção de acordo com as particularidades advindas de diferentes regiões do país, das políticas educacionais e das ações dos atores envolvidos. Estas unidades de análise, correlacionadas, permitiram ampliar a visão reflexiva sobre o processo experimental utilizado ao longo do desenvolvimento projetual e a real vocação dos espaços laboratoriais acadêmicos, com a identificação das condições essenciais para que estas práticas possam ser trabalhadas e potencializadas no ensino.

O trabalho inicia com o Capítulo Introdutório, desenvolvido na intenção de delimitar o objeto de estudo e expor as intenções do trabalho. A 'Introdução' traz as perguntas de pesquisa entremeadas à justificativa da proposta, assim como o objetivo e a hipótese de pesquisa. A metodologia adotada encontra-se no subitem 'A Dinâmica de Construção da Pesquisa', que explicita as reformulações das estratégias adotadas para a condução do trabalho.

O Capítulo 01 apresenta parte do referencial teórico, com a análise de determinados processos metodológicos que se apoiaram na experimentação como auxílio ao enfrentamento de desafios técnicos inerentes ao projeto, explicitando o caráter atemporal deste recurso quando analisados profissionais que atuaram em diferentes momentos históricos, consequentemente, com diferentes disponibilidades de tecnologias. A pesquisa explicita a estreita relação que estes profissionais mantinham com o setor industrial e o envolvimento de alguns deles com temáticas vinculadas a problemas socioeconômicos e ambientais. Os dados 
levantados neste capítulo fomentaram a discussão final sobre a importância da formação generalista e especialista nos dias atuais.

O Capítulo 02 tem seu referencial teórico direcionado à área do ensino, com a análise de práticas pedagógicas voltadas à experimentação construtiva. O conteúdo inicia a partir da análise histórica sobre a experiência da Bauhaus, perpassando posteriormente por diversos períodos, na busca de informações que permitissem ampliar a compreensão sobre as particularidades do contexto acadêmico diante dos novos desafios a serem enfrentados atualmente no processo de formação. Alguns profissionais analisados no Capítulo 01 foram retomados, identificando aqueles que tiveram a oportunidade de estender seu trabalho para o contexto acadêmico, procurando detectar, quando possível, o processo de transferência dos conceitos profissionais para o ensino. Este capítulo também traz a sistematização de diferentes iniciativas pedagógicas relacionadas à investigação laboratorial na área técnicoconstrutiva, desenvolvidas tanto em escolas internacionais como nacionais. A partir destes dados foram travadas discussões sobre inovação $X$ reprodução, assim como, caráter exploratório $\mathrm{X}$ instrução básica.

A análise sobre os espaços e práticas experimentais no contexto acadêmico nacional é ampliada no Capítulo 03, correlacionando dados documentais sobre as principais discussões e ações direcionadas às práticas experimentais e infraestrutura na área da Tecnologia da Construção - realizada por entidades nacionais envolvidas com a questão educacional como MEC, CEAU, ABEA, CREA, CAU e instituições de ensino superior - com os dados levantados in loco, a partir das visitas técnicas às 21 escolas públicas de arquitetura localizadas em diferentes regiões do país. As informações coletadas junto a estas escolas permitiram contextualizar a atual configuração dos espaços laboratoriais e práticas acadêmicas, assim como, compreender outras variáveis que influenciam na estruturação da área da Tecnologia da Construção e suas particularidades pedagógicas.

O Capítulo 04 realiza a análise dos dados apresentados no capítulo anterior, a partir da sistematização das informações obtidas junto aos principais atores à frente da área da Tecnologia da Construção das escolas visitadas e também em consulta aos documentos internos dos cursos. Estas considerações estão apresentadas na forma de síntese geral, sendo então construída uma explanação sobre o caso. Ao explicitar a trajetória e a estruturação atual da área da Tecnologia da Construção em diferentes escolas públicas brasileiras foi possível contextualizar os principais desafios enfrentados. 
O trabalho é finalizado com o Capítulo 05, que apresenta o desenvolvimento das respostas às questões inicialmente propostas no trabalho e, ao perpassar por todos os capítulos deste trabalho, possui caráter conclusivo. Por fim, são identificadas as condições essenciais para que estes espaços possam ser implantados e/ou potencializados no contexto acadêmico, com a apresentação de novos questionamentos que podem vir a ser objeto de pesquisas futuras. 

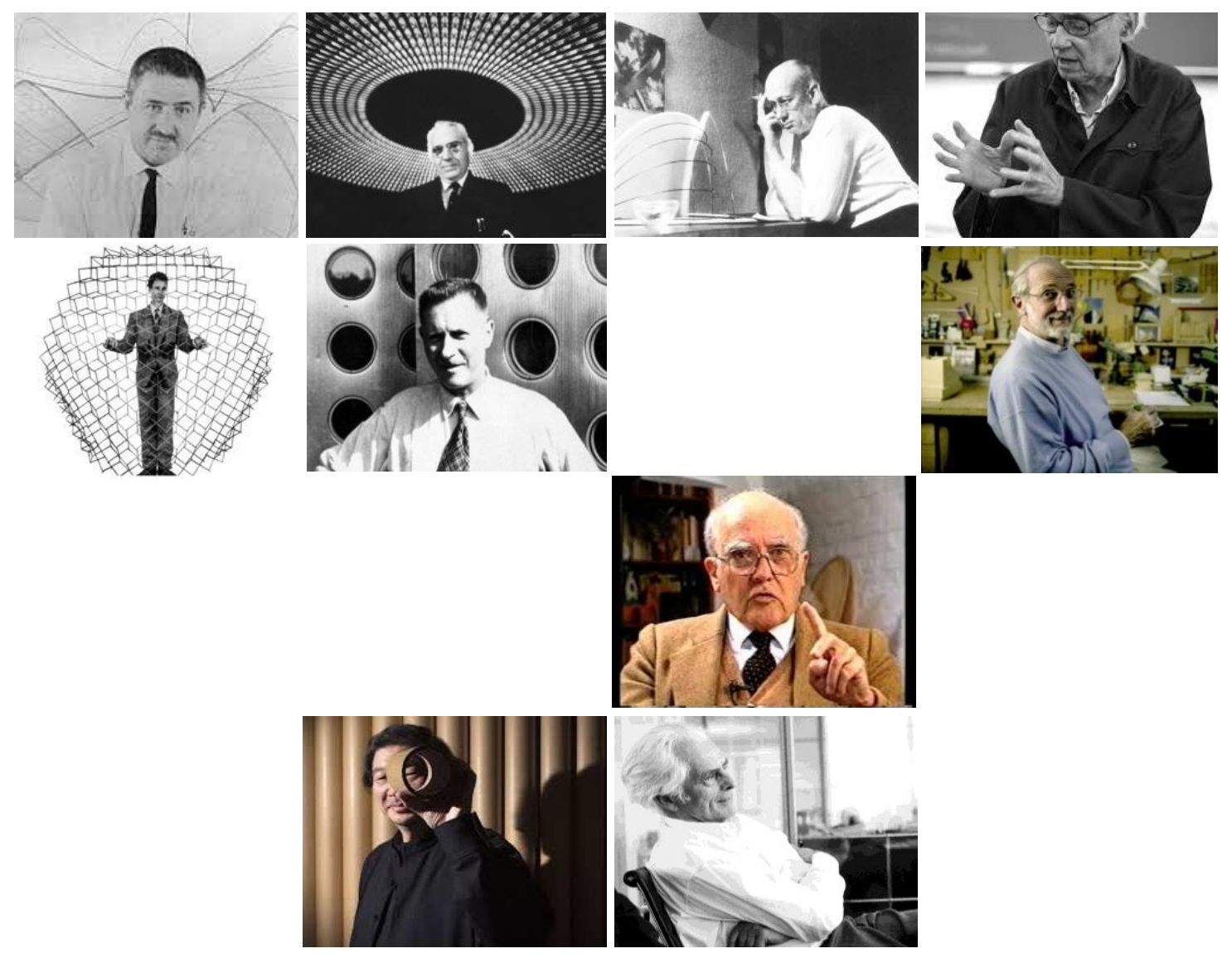

CAPÍTULO 01 A CONCEPÇÃO ARQUITETÔNICA ORIENTADA PELA EXPERIMENTAÇÃO FÍSICA

1.1. CONSIDERAÇÕES SOBRE A DIMENSÃO DA EXPERIMENTAÇÃO NA ARQUITETURA 1.2. A PESQUISA EXPERIMENTAL ASSOCIADA AO PODER DE PRODUÇÃO DA INDÚSTRIA 1.3. A EXPERIMENTAÇÃO CONSTRUTIVA EM RESPOSTA A PROBLEMAS SOCIOECONÔMICOS E AMBIENTAIS 1.4. GENERALISTAS OU ESPECIALISTAS? 


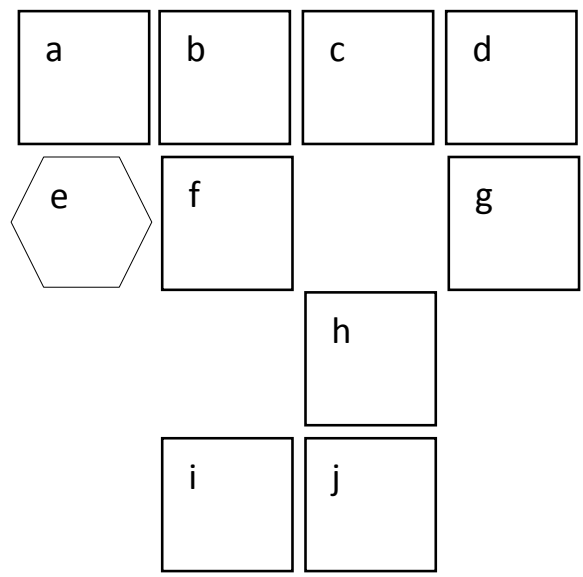

Imagem capa:

a) Arq. Félix Candela. Fonte: Giovannardi (2006)

b) Eng. Pier Luigi Nervi. Fonte: http://www.positanonews.it/articolo/59807/pier-luigi-nervi-I-rsquo-architettura-come-sfida

c) Eng. Eduardo Torroja. Fonte: Perdrix (1999)

d) Arq. João Filgueiras Lima. Fonte: http://www.archdaily.com.br/br/office/joao-filgueiras-lima

e) Arq. Emílio Perez Piñero. Fonte: https://www.pinterest.com/gaiaferraris1/stru/

f) Ind. Jean Prouvè. Fonte: Sulzer, 2009

g) Arq. Renzo Piano. Fonte: http://www.adculture.it/Renzo-Piano

h) Eng. Eládio Dieste. Fonte: http://www.videodownload.cc/youtube/entrevista-a-eladio-dieste

i) Arq. Shigeru Ban. Fonte: http://asiasociety.org/asia-game-changers/shigeru-ban

j) Arq. Frei Otto. Fonte: http://www.architectour.net/architetti/scheda_arc.php?id_arc=3500 
Este capítulo explicita a diversidade de entendimentos e processos metodológicos adotados tanto por arquitetos como por engenheiros que tiveram na experimentação científica o apoio necessário para a realização de suas obras. Observa-se o caráter atemporal deste processo investigativo ao serem analisados exemplos de profissionais que atuaram em diferentes momentos históricos e, consequentemente, com diferentes disponibilidades de tecnologias. Ainda neste capítulo é realizada a análise sobre a pesquisa experimental em associação ao poder de produção da indústria, assim como, sobre o processo experimental/construtivo em resposta a problemas socioeconômicos e ambientais.

\subsection{CONSIDERAÇÕES SOBRE A DIMENSÃO DA EXPERIMENTAÇÃO NA ARQUITETURA}

Sobre a experimentação construtiva, foram poucas as considerações encontradas e sistematizadas que a discutem em associação ao processo projetual arquitetônico. Desta forma, analisar a temática sob a luz de diferentes contextos e momentos históricos torna-se um exercício relevante para que o tema permaneça em pauta, contribuindo para que novos entendimentos sobre metodologias projetuais ligadas aos aspectos que envolvem a materialidade sejam realizadas em um cenário caracterizado por constantes mudanças tecnológicas.

Para melhor compreensão sobre o uso da experimentação, é importante estabelecer parâmetros que diferenciem metodologias projetuais que seguem a lógica construtiva em relação àquelas que se apoiam à lógica experimental. Neste trabalho é defendido como lógica construtiva quando, em um projeto, os aspectos relativos à materialidade são solucionados com base em dados já validados e amplamente divulgados. E, por mais que sejam realizadas releituras das soluções construtivas a partir de novas aplicações, a pesquisa experimental torna-se, nestes casos, desnecessária ao longo do processo. Soma-se a este entendimento, que o conceito de lógica construtiva seja o conjunto de conhecimentos mínimos esperados (envolvendo materiais, técnicas e estruturas) para que o projetista possa atuar de forma responsável ao longo de sua vida profissional sendo, geralmente, adquiridos ao longo da sua formação acadêmica e aperfeiçoados durante sua atuação profissional.

Em relação à metodologia projetual apoiada à lógica experimental/científica - tema deste trabalho - é requerida ao longo de um projeto sem precedentes, quando a ciência ou os procedimentos usuais não são suficientes para gerar a confiança necessária para o início da construção. Nestes casos, os projetistas são inspirados com frequência a realizar estudos 
experimentais específicos, geralmente envolvendo maquetes físicas e até mesmo protótipos para ampliar a ciência da engenharia existente. $\mathrm{O}$ objetivo destas pesquisas, segundo Addis (2009) não seria desenvolver um método de projeto universal, mas sim, compreender uma situação particular a resolver um problema específico.

Ainda segundo este autor, embora tenha sido a partir da década de 1920 que os testes com maquetes em escala tenham sido desenvolvidos por inúmeros centros de pesquisa, inclusive universidades, os testes tornaram-se um método comprovado na comunidade de pesquisa da engenharia por volta da década de 1950, quando os projetistas deixaram de analisar os materiais como artesãos e passaram a fazê-los como cientistas. Diante desta disponibilidade de recursos, quando o problema construtivo não podia ser esclarecido com base na experiência, os projetistas recorriam à experimentação física juntamente com a análise teórica. Esta associação de meios é defendida por Pippard (1947), ao relatar ser fundamental para o amadurecimento das ideias e aperfeiçoamento do projeto, que os dados fornecidos pelas ferramentas físicas sejam tratados e interpretados por quem as desenvolve sob a luz dos dados teóricos, principalmente, quando o desenho não fornece a dimensão real do problema a ser enfrentado, justificando a importância dos protótipos serem adotados nas etapas iniciais de desenvolvimento, porque elucidam a teoria e o processo investigativo tornase parte integral do projeto. Embora, normalmente, exista a tendência de subestimar as potencialidades que estas ferramentas oferecem na simplificação e encurtamento do tempo de desenvolvimento de projeto e novos produtos.

A experimentação com materiais e técnicas construtivas na arquitetura pode ser considerado, segundo Hoyet $(2007)^{15}$, como um processo diferenciado e insere-se no processo de concepção geral do projeto arquitetônico, fazendo o intercâmbio entre concepção e materialização. A partir deste entendimento, não deve ser estudado à parte da concepção projetual; o material, por exemplo, adquire suas qualidades arquitetônicas porque está envolvido no projeto, portanto, a experimentação está associada ao conjunto arquitetônico. A necessidade da experimentação não está entre os procedimentos tradicionais do arquiteto, mas ocorre em condições especiais e com caráter retroalimentador, em que o projetista tem participação direta neste processo em conjunto com os diferentes atores envolvidos, evidenciando a importância da dinâmica coletiva. A

\footnotetext{
${ }^{15}$ Em Hoyet (2007), a autora traz contribuições pertinentes para esta discussão, ao analisar em sua pesquisa de doutorado 'Conception de la matérialisation en architecture : l'expérimentation comme facteur d'innovation industrielle', diferentes métodos de trabalho adotados por profissionais contemporâneos e a influência do material construtivo nas decisões projetuais, orientados ou não pela experimentação. Tem como principal foco compreender o processo de aplicação da experimentação no contexto profissional francês, assim como, a articulação dos atores envolvidos: cliente, profissional, indústria e pesquisadores de centros de pesquisa.
} 
produção do protótipo, segundo Rollet (2007), pode facilitar a reflexão técnica ainda na fase conceitual, neste caso, a materialidade perpassa as diversas etapas da concepção arquitetônica, reforçando o diálogo entre matéria e desenho, a mão e o pensamento, permitindo correções, adaptações, o que seria impossível por meio de outros procedimentos.

Ao analisar metodologias projetuais que se apoiaram na experimentação construtiva, fica claro que o conjunto de experiências desenvolvidas no período compreendido entre 1930 e 1960, destaca-se pelas inovações realizadas no campo da investigação estrutural devido à maestria com que seus criadores manipulavam os materiais construtivos e pelas extraordinárias formas arquitetônicas criadas.

Estas inovações alcançadas não se restringem ao produto, mas estendem-se ao processo projetual e construtivo desenvolvidos, sendo recorrente entre os projetistas a adoção do processo intuitivo por meio da experimentação construtiva. Em Nervi (1951;1965), o engenheiro declara-se partidário fervoroso do processo experimental das estruturas, porque ele ajuda a transpor as fronteiras próprias dos processos analíticos e a investigar com seguridade os casos difíceis ou impossíveis de serem expressados em equações. Para o engenheiro, um dos aspectos mais fecundos e promissores da experimentação seria a possibilidade de confrontar diretamente os dados obtidos pelos modelos com os dados teórico-matemáticos, defendendo a seguinte fórmula: 'mais princípios e menos teoria, porque os princípios possuem caráter universal e permanente, $o$ segundo são pontuais e limitados'.

Algumas de suas inovações, como a técnica do ferrocimento, foi possível pela sua vasta experiência construtiva, permitindo-lhe o desenvolvimento de encaixes e interconectores que refletem a indissociabilidade entre técnica e projeto. Em Nervi (1951), o autor considera que uma de suas primeiras e mais importantes aplicações experimentais em estruturas complexas de grandes dimensões foi realizada no laboratório de Ensaios e Modelos da Politécnica de Milão, para o estudo de hangares, cujo desenvolvimento durou três meses, (Figura 05).
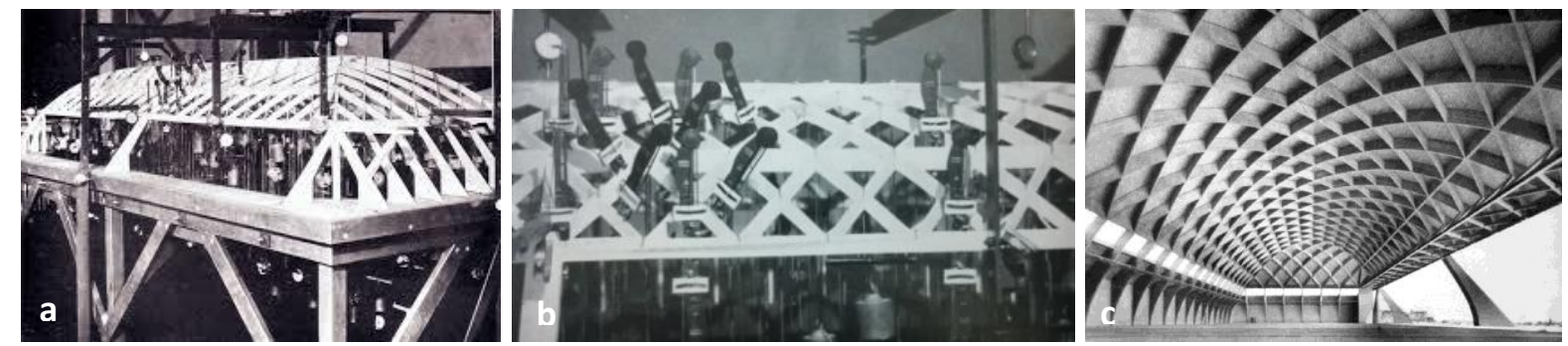

Figura 05: Sequencia de fotos do processo de pesquisa da estrutura do Hangar para aeronaves, Orvieto, Itália, 1936 - a) e b) Maquete usada no Laboratório Politécnico de Milão para medir as deformações e calcular os esforços da casca nervurada por meio de extensômetros. c) Projeto construído do Hangar para aeronaves.

Fonte: Nervi, 1965. 
O engenheiro relata algumas questões importantes sobre o processo investigativo e que devem ser analisadas por serem consideradas grandes inconvenientes da metodologia experimental, como o processo exaustivo e oneroso de preparação e análise dos modelos. Esta questão torna-se importante ao reconhecer que na maioria dos casos, é mais prático e conveniente - porém menos exato - recorrer à apreciação teórica. Naquele momento, considerava que a construção de modelos deveria restringir-se às construções de reconhecida importância técnica e arquitetônica, sendo imprescindível para todos os problemas que escapassem à capacidade resolutiva da Ciência das Construções.

Além disso, complementa esta questão problemática ao reconhecer a dificuldade destas experiências serem sustentadas, sendo necessária a preparação de um considerável número de técnicos e operadores habilitados para o acompanhamento contínuo do processo, esta pode ser considerada uma das condicionantes fundamentais para o bom funcionamento de um laboratório em qualquer campo da investigação experimental ${ }^{16}$.

Assim como Nervi, Eduardo Torroja durante sua carreira apoiou-se no processo intuitivo experimental para aperfeiçoar os estudos de construções de base cimentícia, trazendo grandes avanços no desenvolvimento das cascas de concreto armado. Em alguns de seus projetos de grande complexidade, como o Hipódromo de Madri (Figura 06) e a cobertura do Ginásio de Frontón Recoletos, também em Madri, Torroja foi inicialmente conduzido a compreender o funcionamento da estrutura em termos qualitativos, iniciando seus estudos por meio de maquetes de papelão, passando posteriormente, aos protótipos em escala real, correlacionando estes dados com cálculos matemáticos a fim de assegurar a confiabilidade de sua execução. Para Perdrix (1999), na mente científica de Torroja cada material determina as formas fundamentais da estrutura, esse processo implica volumes e proporções, induz a métodos de análises específicos, impõe processos construtivos e influencia no comportamento da estrutura ao longo do tempo. Em seu livro Razón e ser de los tipos structurales, Torroja defende que antes da concepção da estrutura é imprescindível o conhecimento profundo sobre as propriedades intrínsecas dos materiais. Para ele, a técnica da construção não progrediria se não fossem desenvolvidos novos materiais, ou se não houvesse a melhoria das propriedades dos existentes, justificando que na Arte da Construção há sempre um fundo essencialmente científico.

\footnotetext{
${ }^{16}$ Condicionante para o estabelecimento de parcerias, como a academia. Dado a ser considerado no Capítulo 02, quando a abordagem experimental é analisada estritamente no contexto acadêmico.
} 

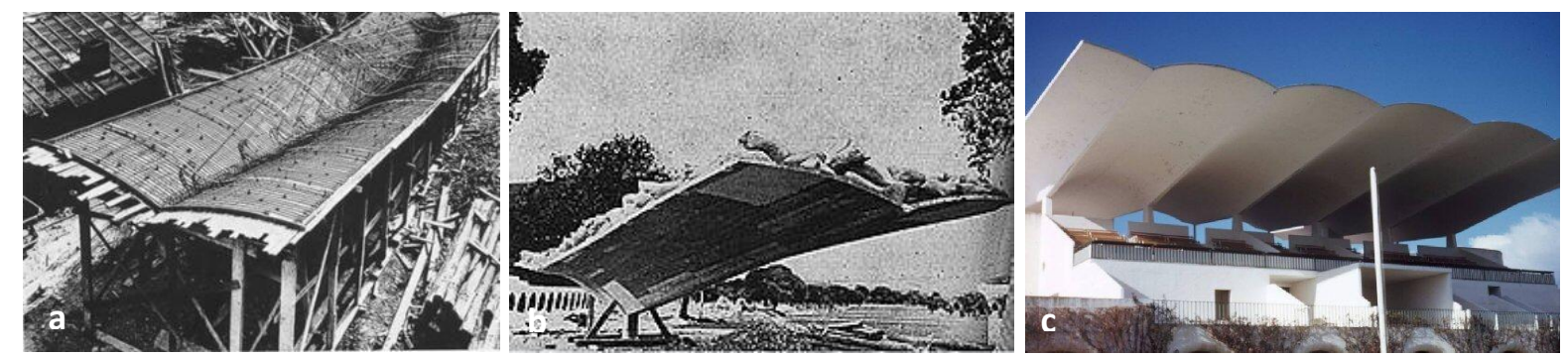

Figura 06: Sequencia de fotos sobre o desenvolvimento projetual por meio de protótipos do Hipódromo de Madri, 1935 - a) Protótipo da cobertura, evidenciando a armadura de aço. b) Processo experimental com prova de carga com sacos de areia. c) Projeto do Hipódromo de Madri.

Fonte: Addis, 2009.

O engenheiro uruguaio Eládio Dieste, diferentemente de Torroja e Nervi, explorou outras possibilidades materiais e construtivas ao desenvolver a técnica da cerâmica armada, mas aproxima-se destes projetistas pela ousadia que alcançou em suas inovações e, assim como eles, destaca-se pela adoção de processos intuitivos e pela paciente tarefa da comprovação experimental. Segundo Dieste (1987), o principal desafio tecnológico que representa o uso da cerâmica armada parte de um trabalho exploratório sobre a capacidade geométrica e geradora das abóbadas até se chegar a uma continuidade estrutural (Figura 07 e Figura 08).

Ao provar a potencialidade desta técnica, Dieste entra em contradição com um preceito de Torroja que, em seu livro de 1958 , defendia a ideia de que a técnica da construção não progrediria se não fossem desenvolvidos novos materiais ou se não houvesse a melhoria das propriedades dos existentes. Mas ao analisar Dieste, o mesmo alcança progressos da mesma dimensão ao propor técnicas de manipulação ainda inexploradas, sem alterar as propriedades do material construtivo. Segundo o engenheiro uruguaio, para que a arquitetura possa ser realmente construída, os materiais não devem ser usados sem um profundo respeito à sua essência e, consequentemente, às suas possibilidades. Sobre esta questão discorre:

$Y$ un edificio no puede ser profundo como arte sin fidelidad seria y sutil a las leyes de la materia; sólo la reverencia que esa fidelidad supone, podrá hacer a nuestras obras graves, perdurables, dignas compañeras de nuestro discurrir contemplativo. DIESTE (1999 p.47)

Outro diferencial em seu trabalho foi encontrar aspectos passíveis de racionalização tanto ao longo do processo de concepção como também na execução das obras sem, no entanto, abrir mão dos valores qualitativos. Mas esta racionalização de meios não era guiada somente pelos aspectos econômicos, e sim pela sensibilidade sobre o contexto onde atuava, equalizando estas questões por meio dos avanços técnicos e formais que alcançou. 

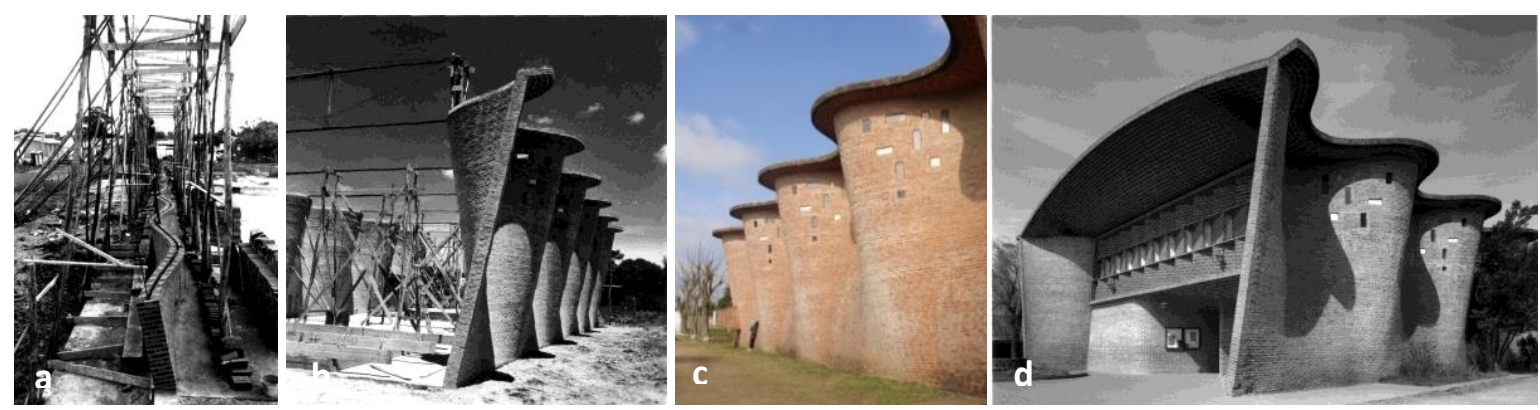

Figura 07: Sequencia de fotos Igreja de Atlantida/ Uruguai - a) Execução das paredes: geratrizes retas reproduzidas por fios-guia fixos em gabaritos. b) Detalhe de execução da abóbada: viga de borda previamente construída. c) e d) Vista externa das paredes em forma de conóides da Igreja de Atlântida.

Fonte: Carvalho, 2004.
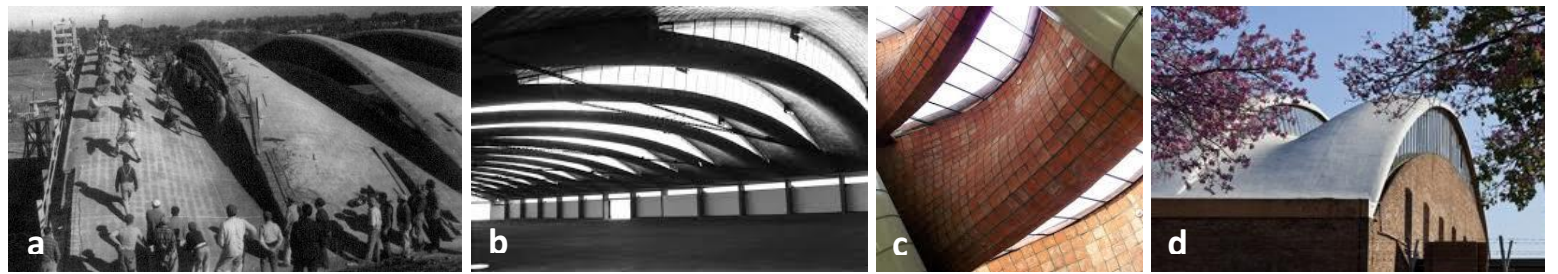

Figura 08: Sequencia de fotos galpão portuário em Montevidéu - Abóbada gaussiana ou de curvatura dupla. a) Prova de carga em abóbada: o engenheiro Dieste encontra-se em pé no meio do vão longitudinal da abóbada e os operários estão dirigindo-se aos lugares pré- definidos. b) e c) Vistas internas e d) Vista externa.

Fonte: Carvalho, 2004.

Impulsionado pelas condicionantes contextuais e técnicas, Dieste encontra-se solitário neste universo dos grandes projetistas adeptos do processo experimental. A falta de conhecimento de seus pares em relação às técnicas por ele desenvolvidas é comprovada pelo pouco crédito depositado a este material construtivo, cujas referências ainda restringiam-se às construções da antiguidade. Félix Candela, por exemplo, no prólogo delicado ao livro de Frei Otto em 1965, defende que as membranas seriam o material do futuro, pela relação peso X vão e realiza o seguinte comentário sobre o material cerâmico:

[...] En las grandes bóvedas y cúpulas de la antiguedad, construídas com materiales de poca eficácia constructiva (piedra y ladrillo), era muy desfavorable la relación entre la resistência y el peso próprio. [...] Con o enpleo de materiales más eficaces fue possible ir reduciendo el espesor de las estructuras de las cubiertas, hasta que el hombre ha logrado superar las estructuras de la natureza con las modernas cáscaras de hormigón armado, que poseen mayor esbeltez que la mayoria de las cáscaras naturales.'(Prólogo de ROLAND (1965), p. V)

Considerando que Dieste e Candela atuaram no mesmo período, suas citações revelam a tendência dos projetistas da época em associar o futuro da Ciência da Construção à descoberta de novos materiais, assim como o fez Torroja. Mas, embora Félix Candela também tenha sido grande estudioso dos materiais cimentícios, principalmente das cascas sinclásticas 
e anticlásticas, foi grande adepto dos processos investigativos com caráter empírico, não aderindo ao cientificismo acadêmico de Nervi e Torroja, o que Ihe rendeu diversas críticas ${ }^{17}$.

Ainda sobre o processo adotado pelo projetista, em Candela (1962), observa-se que, inicialmente, o mesmo procurava imitar os 'inovadores' mestres da História da Arquitetura, convencendo-se de que o caminho mais adequado para a capacitação no desenho e na construção de cascas de concreto armado seria a experimentação direta, mediante a construção de modelos, baseando-se no conhecimento das imutáveis Leis da Natureza (Estática, Mecânica e Resistência dos Materiais).

Ao considerar que a autoaprendizagem seria um processo mais simples e imediato - pois tinha pressa em aprender - durante o processo de construção de modelos em escala natural, o projetista atuou como arquiteto, engenheiro e construtor, sem apoio de nenhum outro profissional. De acordo com Cassinelo (2010), foi neste processo autodidata que construiu sua primeira casca experimental chamada 'Bóveda Ctesiphon' de San Bartolo de Naucalpan, no México (Figura 09), cuja geometria correspondia a um arco funicular de diretriz catenária. Posteriormente, a cada nova variação de geometria, valia-se da construção de cascas experimentais para comprovar seu funcionamento estrutural e compreender as formas de otimização de cada processo construtivo. Também em caráter experimental, construiu uma lâmina com geometria conóide na Fábrica de Fernández em San Bartolo no México (1950) e o protótipo de "Paraguas", em Las Aduanas, também no México (1953).
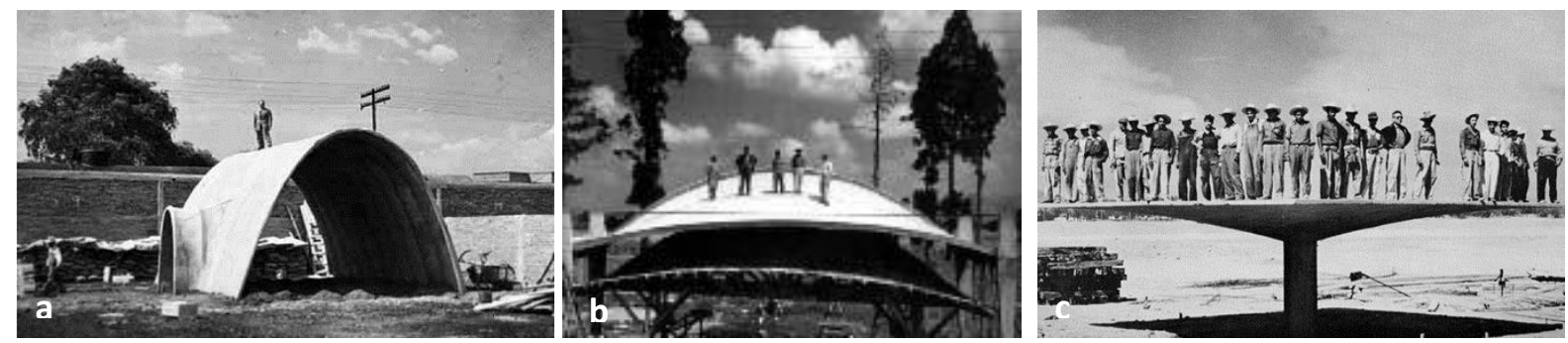

Figura 09: Protótipos experimentais desenvolvidos por Felix Candela no México. a) Bóveda Ctesiphon en San Bartolo, 1949. b) Conoide en la Fábrica de Fernández, 1950. c) Paraguas experimental, en Las Aduanas, 1953. Fonte: Cassinello et.al. 2010.

Embora seus maiores esforços tenham se direcionado ao estudo das cascas cimentícias, Candela buscou aperfeiçoar suas criações em direção à economia e leveza. Segundo Almagro (2013), estas estruturas se destacam no contexto histórico da arquitetura e engenharia desta

\footnotetext{
${ }^{17}$ De acordo com Giovannardi (2006), alguns críticos arquitetos sustentam que Felix Candela foi um magnífico engenheiro estrutural, mas que não se preocupou em terminar suas obras - desprovidas de aberturas e instalações - em que o espaço construído teria uma ocupação sem predeterminação, devido a isso, não caberia dar-lhe o título de arquiteto. Já para alguns críticos engenheiros Felix Candela era um magnífico arquiteto, mas que não sabia calcular suas estruturas - cujos processos utilizados eram questionáveis - sendo então modesta sua importância à engenharia. Para outros arquitetos, ele não se encontra na terra de ninguém, por isso é atacado pelos dois lados, aparentemente inconciliáveis.
} 
época, mas paulatinamente as estruturas laminares de concreto armado, que haviam conseguido cobrir espaços cada vez mais amplos e complexos, dão espaço a novos conceitos de estruturas espaciais formadas por elementos lineares (estruturas em barras). Um exemplo desta mudança pode ser vista na International Association for Shell Structures (IASS), fundada no Instituto de Ciências da Construção Eduardo Torroja, no ano de 1959, e que uma década depois passa a denominar-se International Association for Shell and Spatial Structures.

Estas mudanças podem ser vistas no trabalho do arquiteto espanhol Emilio Perez Piñero, cujas investigações partem destas novas possibilidades estruturais. Considerado um dos mais precoces gênios da concepção estrutural, Perez Piñero teve uma curta carreira devido à sua morte prematura, mas deixou um brilhante e inovador legado sobre as investigações das estruturas reticuladas. $E$, devido ao caráter visionário de suas criações, estas podem ser consideradas como precursoras da arquitetura cinética, cujos mecanismos são muito estudados atualmente.

Segundo Valcárcel (1992), os protótipos que desenvolveu revelam suas complexas investigações a partir de um sofisticado grau de detalhamento, permitindo a reprodução dos movimentos da estrutura real. A Figura 10 traz uma sequencia de imagens do primeiro projeto que Emilio Perez Piñero desenvolveu explorando estes mecanismos dinâmicos a partir da adoção de modelos físicos. Este projeto foi submetido no concurso para estudantes no VI UIA ${ }^{18}$ de 1961 em Londres, recebendo o primeiro lugar pela banca de avaliadores composta por Buckminster Fuller, Ove Arup e Félix Candela. Este primeiro contato com Candela, rendeu-lhe diversas oportunidades de trabalho e futuras parcerias de pesquisa.
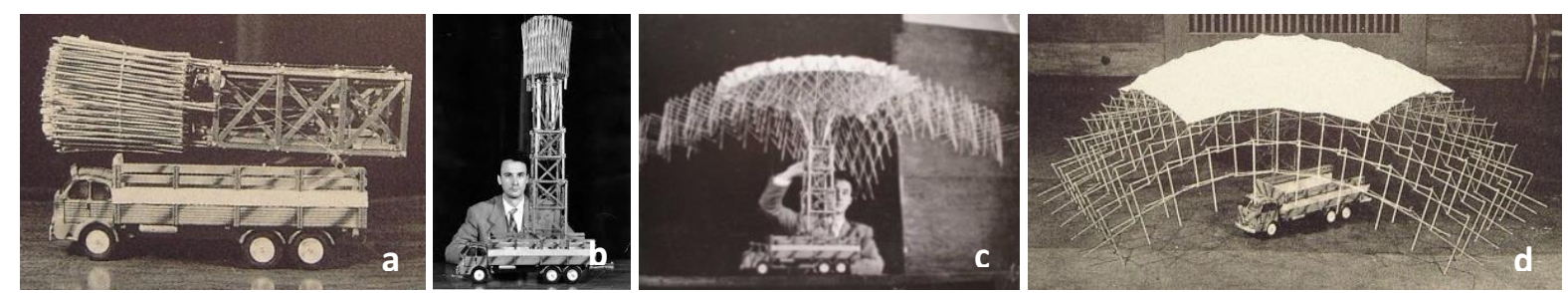

Figura 10: Sequencia de imagens do projeto Teatro Transportável, submetido no VI Congresso UIA. Tema do congresso 'Novas Técnicas e Novos Materiais na Construção', 1961.

Fonte: www.chqs.net/archivos/informes/archivos_1_040310_la +estructura+veloz.pdf

A solução baseava-se em uma estrutura retrátil, passível de ser transportada sem a desmontagem das peças, resolvendo o problema geométrico de articulação das barras de maneira que pudessem girar e se adaptar sem, contudo, dificultar o movimento umas das outras.

A primeira obra real construída por Perez Piñero foi em 1964, com a convocatória do concurso para o Pavilhão Transportável de Exposições em comemoração aos 'XXV Anos de Paz'. Este

\footnotetext{
${ }^{18}$ UIA - Union Internationale des Architectes.
} 



Figura 11: Derivações de conexões nos estudos de Emilio Perez Piñero. a) e b) nó com 3 barras. c) e d) nó com quatro barras.

Fonte: a), b) e d) http://udlapuerta-etsam2010.blogspot.com.br/2010/12/r-referenciasemilio-perz-pinero.html. c) www.chqs.net/archivos/informes/archivos_1_040310_la +estructura+veloz.pdf

De maneira análoga a outros profissionais que defendem o processo intuitivo, Emilio Perez Piñero ao discorrer sobre o dimensionamento das barras, salientava que, salvo algumas exceções, não era possível a aplicação do processo de cálculo e que a adoção de ensaios com modelos em escala era um processo de investigação imprescindível, como forma de contraposição direta com a realidade (Figura 12$)^{19}$.


Figura 12: a, b e c) Sequencia de imagens de protótipos em escala real. d) Estudos por meio de protótipos da cúpula reticulada para o 'Festival da Espanha', 1966.

Fonte: www.chqs.net/archivos/informes/archivos_1_040310_la +estructura+veloz.pdf

\footnotetext{
${ }^{19}$ Embora haja uma reconhecida crítica sobre o estabelecimento de conceituações de classificação dos modelos e protótipos, pela impossibilidade de enquadrar as diferentes possibilidades investigativas dentro de um limitado grupo de tipos, caso fossem considerados os conceitos de classificação de Harris e Sabins (1999), as experiências de Emilio Perez Piñero, Felix Candela e Eládio Dieste podem ser consideradas no campo estrutural como modelos reduzidos. Esta forma investigativa é, sempre que possível, construída segundo as leis da 'Teoria da Semelhança', a qual considera a geometria real como réplica da estrutura original. Mas, para que um modelo possa representar um protótipo, ou para que os resultados obtidos em ensaio com modelos possam ser estendidos aos protótipos, é preciso que, além da semelhança geométrica, os modelos sejam construídos com materiais que apresentem semelhanças físicas em relação aos materiais do protótipo. De acordo com Carneiro (1996) e Cowan (1974), a 'Teoria da Semelhança' foi estudada pioneiramente por Galileu Galilei, que chegou à teoria que quando se comparam dois corpos geometricamente semelhantes, as forças estão entre si como o quadrado da escala geométrica, ao passo que os pesos próprios se relacionam com o cubo dessa escala. Quando se passa de um modelo reduzido ao protótipo, a importância relativa do peso próprio cresce de tal maneira que ao ser atingido um tamanho limite, o protótipo gigante rui pela ação exclusiva de seu peso próprio, ao passo que o pequeno modelo é capaz de suportar cargas adicionais, além do seu peso próprio. De acordo com esta teoria, Galileu adotou a expressão "A Fraqueza dos Gigantes".
} 
Aproximadamente na mesma época em que Piñero desenvolveu suas leves estruturas com barras de aço, Frei Otto inicia suas investigações em seu Institute for Lightweight Structures, em Stuttgart, sobre estruturas tridimensionais, em especial as estruturas tensionadas e com malhas de cabos. Ao longo de 30 anos, continuou a aperfeiçoar os seus métodos para a definição da forma por meio de modelos, tanto para membranas como para coberturas com malhas de cabos valendo-se, posteriormente, dos avanços tecnológicos computacionais, fator que agregou ainda maior sofisticação e precisão em suas experimentações ${ }^{20}$.

Segundo Addis (2009), Otto criou uma nova classe de estruturas que só puderam ser construídas após o desenvolvimento de procedimentos de projeto inteiramente novos que ultrapassaram as limitações inerentes aos métodos de projeto anteriores. Em Roland (1965) e Otto (1973), fica nítido que a utilização de modelos foi imprescindível para o estudo de processos intuitivos ainda inexplorados pela ciência e tecnologia, com o desenvolvimento de processos de projeto e manufatura novos à época (Figura 13 e Figura 14).
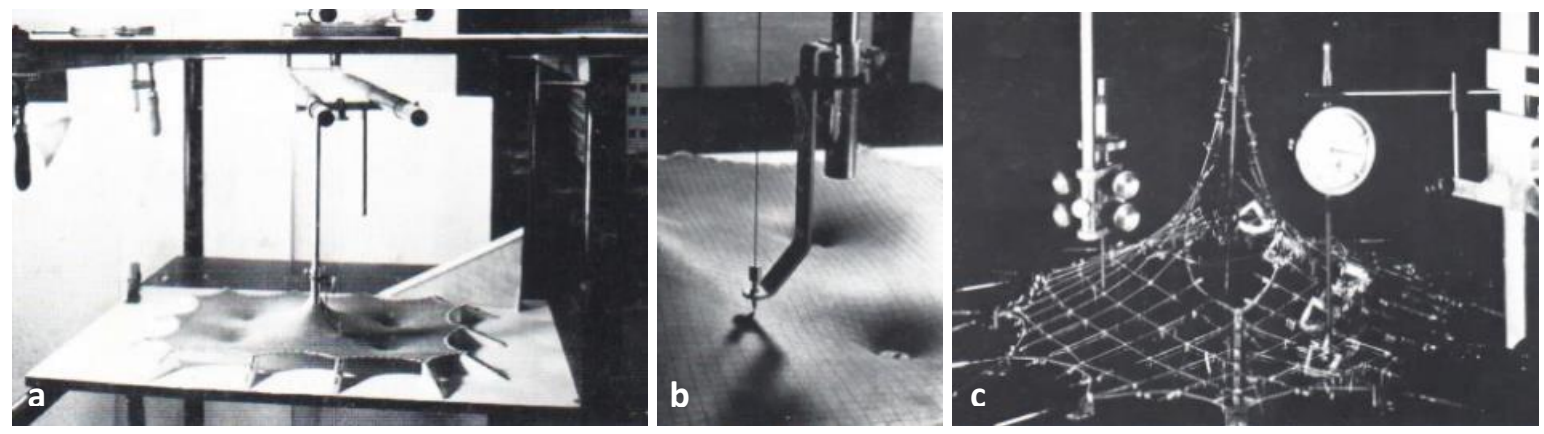

Figura 13: Experimentações por meio de modelos físicos desenvolvidos por Frei Otto. a), b), e c) Imagens dos processos experimentais desenvolvidos no Institute for Lightweight Structures, para o estudo de estruturas retesadas (membranas e malhas de cabos).

Fonte: Drell (1976).


Figura 14: Sequencia de imagens - Projeto Estádio Olímpico de Munique. a) e b) Imagens dos processos experimentais desenvolvidos no Institute for Lightweight Structures, para o projeto do estádio (Olímpico de Munique). c) e d) Estádio de Munique.

Fontes: a) Drell (1976); b) http://www.dn.pt/galerias/fotos/?content_id=4448109\&seccao=Artes. c) concedida por Cláudia Terezinha de Andrade Oliveira.

\footnotetext{
${ }^{20}$ Sobre as novas ferramentas investigativas comenta: ‘O computador pode apenas calcular o que já está conceitualmente dentro dele; nos computadores encontras apenas o que buscas. No entanto, com a experimentação livre, pode-se encontrar o que não foi buscado.'
} 
Embora o projetista tenha se dedicado intensamente ao estudo das estruturas tracionadas, não se limitou ao estudo desta classe tipológica. O principal objetivo de suas investigações era compreender o princípio elementar de transmissão dos esforços aos pontos de apoio com o mínimo gasto de material, iniciando pelo estudo de malhas de cabos e barras de superfície biconvexa, composta em sua maioria por elementos tracionados. Este foi o ponto de partida para outros estudos sobre estruturas mínimas, percebendo que para a resolução de vários problemas construtivos havia a necessidade das estruturas planas trabalharem sob diferentes esforços além da tração. Por este motivo, Frei Otto se preocupou também com os procedimentos de fabricação de estruturas que trabalhassem predominantemente à compressão (Figura 15), por estarem mais intimamente relacionadas com as estruturas tracionadas do que as modernas cascas de concreto desenvolvidas naquela época.

Ao seguir este raciocínio, direciona seus estudos para a compreensão dos mecanismos explorados pelo arquiteto catalão Antoni Gaudì, que ao levar à terceira dimensão o axioma de Robert Hooke, veio influenciar até mesmo os métodos mais tradicionais de construção em alvenaria, afirmando que a forma de um arco estável é aquela de uma catenária invertida. Segundo Miracle (2002), Gaudì em seus estudos de abóbadas, se valia de maquetes físicas compostas de arames e sacos de areia para representar os pesos dos elementos de alvenaria, quando invertida, poderia fornecer uma disposição estável de pilares e abóbadas.
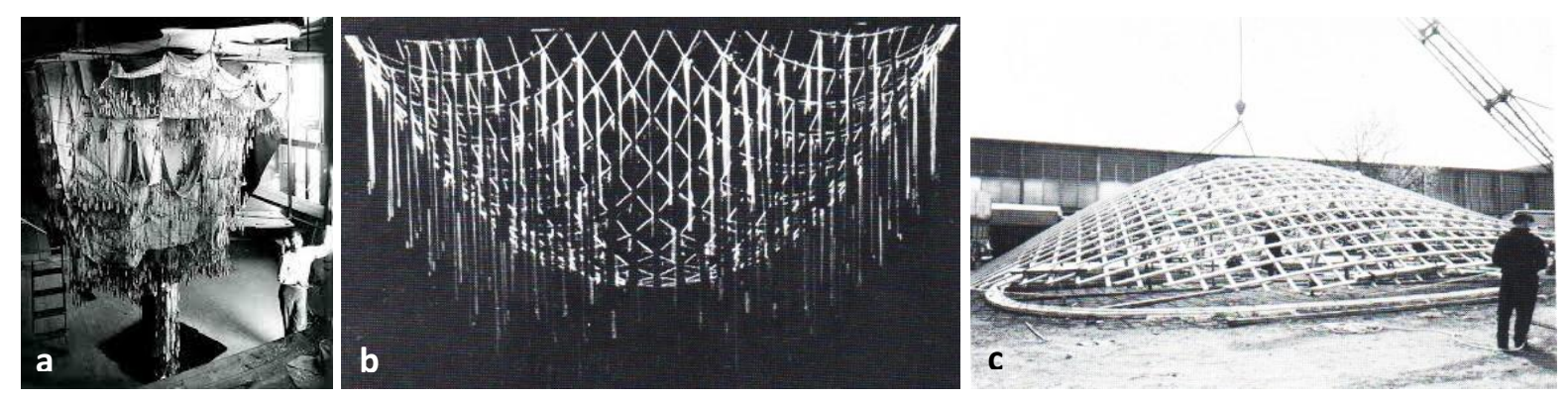

Figura 15: Estudos com malhas de cabos: a) Maquete pendente da Capela da Colonia Guell, Barcelona 1889-1908, arquiteto Antoni Gaudí. b) e c) Estudos de Frei Otto de cúpula com entramados em Deutsche Bauausstellung, 1962.

Fonte: Drell (1976).

Ainda sobre o processo investigativo/experimental, Frei Otto acreditava que a ampliação dos conhecimentos do homem se baseava na abertura de novos caminhos em campos científicos ainda desconhecidos, cujo trabalho científico de investigação deveria se basear no afronto dos 
erros com responsabilidade, na verificação constante da possível aplicação dos resultados e na contínua predisposição à correção, algo somente possível por meio do trabalho experimental ${ }^{21}$.

Segundo Roland (1965), o projetista defendia que quanto mais limitado fosse o campo de ação, tanto melhores e mais maduras seriam as soluções obtidas no campo geral dos conhecimentos e que o homem não cria somente objetos arbitrários, mas também cria problemas cujo significado investiga posteriormente. Para ele, o conhecimento prévio do significado do problema não devia ser uma condição indispensável para seu estudo, pois em um processo de estudo contínuo não existe prioridade alguma entre o problema e sua solução, pois a solução obtida raramente coincide com o problema inicial.

A importância de seu trabalho não está na perfeição do resultado de suas obras, mas sim nos métodos e processos mentais que viabilizaram suas realizações, permanecendo ainda hoje com caráter atemporal um dos princípios que direcionavam suas pesquisas: 'Como resolver um problema construtivo empregando o mínimo de energia construtiva?'

E na busca de respostas, estendeu suas investigações para a compreensão dos princípios físicos presentes na natureza, estudando desde microscópicas estruturas reticulares de algas, as diatomáceas, como também, fez observações em bolhas de sabão para a compreensão das estruturas pneumáticas. No caso das estruturas de cabos e membranas, a equipe de pesquisadores envolvida no Institute for Lightweight Structures ampliou os estudos para a compreensão do processo de confecção das teias de aranhas e, por meio da observação das estruturas arbóreas, foram analisadas a determinação da relação ótima entre número de elementos e suas seções para a otimização de material, de acordo com a Figura 16.
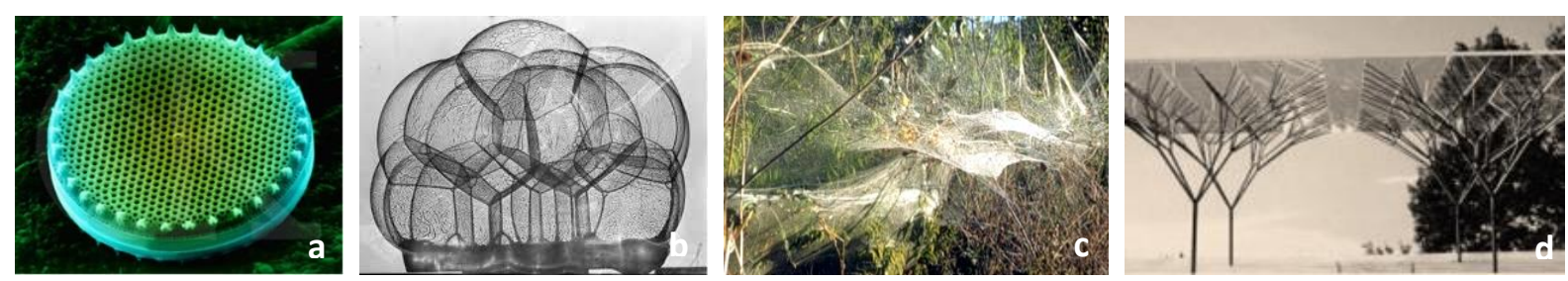

Figura 16: Estudos relativos à interface entre biologia e engenharia. a) Diatomácea. B) Bolhas de sabão. C) Abrigo feito com teias de aranha. D) Projeto baseado em estruturas arbóreas.

Fonte: a) http://people.ufpr.br/ veiga/ficologia/diatomaceas.html. b) http://www.archdaily.com.br/br/tag/pritzker-2015. c) Vasconcelos (2000), d) Roland (1965)

\footnotetext{
${ }^{21}$ Os modelos desenvolvidos por Gaudi e Frei Otto podem ser classificados como modelos indiretos, de acordo com as características definidas por Harris e Sabins (1999). Este método experimental por meio de protótipos reais não apresenta necessariamente semelhança geométrica direta com o protótipo e, atualmente, não são utilizados com muita frequência devido à facilidade de execução dos cálculos em computadores. Mas, em casos excepcionais, em que a forma estrutural é muito complexa e difícil de ser modelada em software, os experimentos com modelos indiretos são ainda utilizados como ferramenta confiável para responder a determinados problemas.
} 
Ao perpassar por diversos processos investigativos envolvendo a materialidade, o arquiteto Renzo Piano desenvolveu uma metodologia particular, algo que o diferencia dos demais profissionais apresentados. Não se destaca propriamente pelo uso de um determinado material ou técnica construtiva ou pelo aprofundamento na compreensão de uma determinada tipologia estrutural; diferencia-se por buscar em suas pesquisas exploratórias não apenas a resolução dos aspectos técnicos mas compreender o valor simbólico e sensorial intrínseco nos materiais e, a cada desafio, busca novos caminhos e possibilidades construtivas, apoiando-se muitas vezes na experimentação.

Ao receber o Prêmio Pritzker em 1998, Piano afirma que pertence a uma geração de pessoas que mantiveram uma abordagem experimental ao longo da sua vida, explorando diversos campos, ignorando fronteiras entre disciplinas, assumindo riscos e cometendo erros. Sobre sua postura quanto à experimentação declara:

"É claro que a sociedade nos impõe restrições e obrigações mas, afinal, quem disse que o arquiteto precisa ser livre para ser considerado bom? É um erro. Acredito que o arquiteto não deva ser totalmente livre. Obrigações e restrições são necessárias. $A$ arquitetura também deve estar sujeita a contradições. Há muitas contradições! Entre a ciência e a natureza. Entre tradição e inovação. Entre liberdade e obrigações e disciplina. Não há escapatória, é necessário aceitar essas contradições [...] e, então, você cresce neste tipo de ambiente, que de um lado você gosta de experimentação, você gosta de pesquisa...mas na Itália você deve ser cego para não gostar do seu passado e tradição...então você passa o resto da sua vida como que preso entre o amor pela tradição e pelo desejo e paixão pela experimentação, pela pesquisa e invenção. Acredito que o passado representa uma grande oportunidade e uma grande fonte de inspiração, é um campo muito seguro, porém, sinto que o futuro é a única direção em que podemos ir, se é que há um lugar para ir [...]".

Em Buchanan (2007), é possível perceber que a metodologia experimental em sua carreira foi praticada antes ainda da construção do emblemático Centro Pompidou (1971-78) em Paris. Nesta primeira fase, Renzo Piano dedica-se, principalmente, ao estudo de estruturas leves e translúcidas e a pesquisa passa a fazer parte de seu processo projetual, com diversas análises sobre as propriedades específicas dos materiais construtivos, buscando novas formas de manipulação para minimizar fragilidades e potencializar qualidades. Posteriormente à construção do Centro Pompidou, firma uma parceria com o engenheiro Peter Rice e, juntos, Piano e Rice embarcam em uma fase experimental intensa, com projetos variados (nem sempre arquitetônicos) que levaram a ampliação de suas preocupações e conhecimentos, muitos deles aplicados em trabalhos subsequentes. Neste momento, sua atenção volta-se também aos aspectos sociais, comunitários 
e, principalmente, nas formas de processo e não apenas na construção, a que tanto já estava habituado.

Piano e seus colaboradores aprenderam muito com a indústria automobilística, geralmente mais avançada do que a indústria da construção civil e, a partir da construção de carros experimentais, Piano e Rice envolveram-se com diversos processos de produção industrial, prototipagem e novos materiais. Estas experiências permitiram que trabalhasse pela primeira vez com o ferro fundido dúctil, plásticos como o policarbonato e colas especiais. Algumas destas tecnologias foram utilizadas mais tarde em projetos como o Menil Collection e o IBM Pavillion (Figura 19).

Neste mesmo período, desenvolveram uma série de programas para uma rede de televisão nacional italiana, com a intenção de mostrar a arquitetura como um produto da invenção tecnológica - utilizando ferramentas, métodos e materiais construtivos, bem como, discutindo sobre a organização social envolvida na obra (Figura 17).
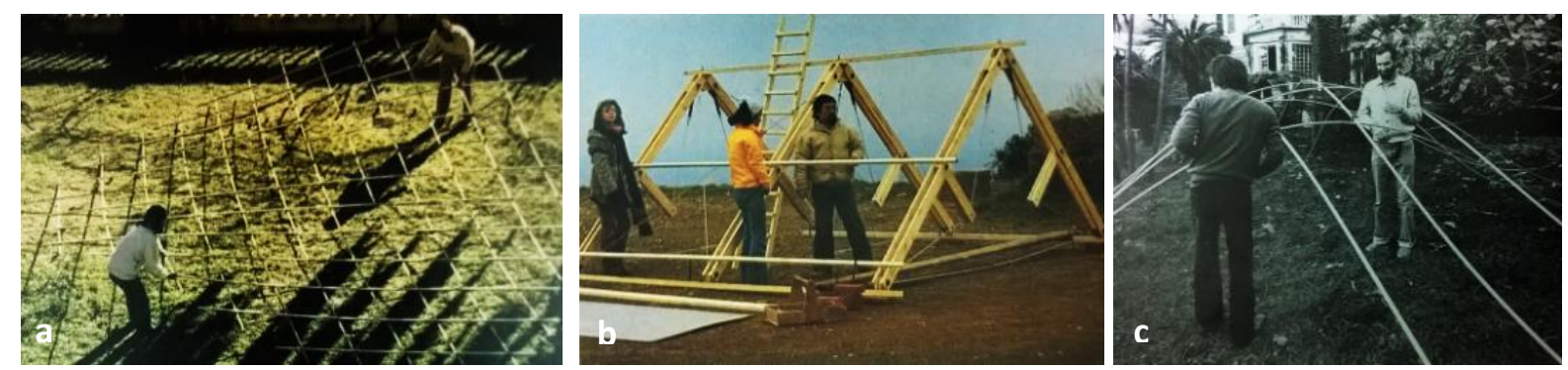

Figura 17: Atividades experimentais realizadas por Renzo Piano antes da criação do escritório Renzo Piano Building Workshop. a) Painéis espaciais em poliéster reforçado: método de montagem. Gênova (1964-65). b, c e d) Processo de montagem de estruturas apresentados no programa de televisão 'The Open Site', com a finalidade de explicar seus princípios construtivos e potencialidades, 1979.

Fonte: Buchanan (2007).

Esta fase multidisciplinar é caracterizada por constantes pesquisas e investigações construtivas, podendo ser considerada como a base de suas futuras experiências no RPBW - Renzo Piano Building Workshop ${ }^{22}$. De acordo com Vincent (2007), os modelos físicos continuam a fazer parte do processo projetual do arquiteto e são manipulados de acordo com a etapa investigada. 0 Quadro 04 apresenta as sucessivas operações empregadas no desenvolvimento do objeto de arquitetura, em que o protótipo vai adquirindo diferentes características e funções.

\footnotetext{
${ }^{22}$ Antes da criação do RPBW - Renzo Piano Building Workshop em 1981, Piano teve três outras experiências práticas: Studio Piano (1964-70), Piano \& Rogers (1971-78) e Piano \& Rice Associates (1978-81).
} 
Quadro 04: Etapas de exploração do protótipo no escritório Renzo Piano Building Workshop.

\begin{tabular}{|c|c|c|c|c|}
\hline Fase do Protótipo & $\begin{array}{c}\text { Fabricação do } \\
\text { Protótipo }\end{array}$ & Avaliação/significado & $\begin{array}{c}\text { Desenvolvimento } \\
\text { Projetual }\end{array}$ & Ação de Projeto \\
\hline Maquete (esboço) & Na agência & $\begin{array}{c}\text { Entre projeto global e } \\
\text { estudo de } \\
\text { detalhes/avaliação da } \\
\text { forma }\end{array}$ & $\begin{array}{l}\text { Projeto conceitual (entre } \\
\text { materialidade e } \\
\text { materialização) }\end{array}$ & Divergência \\
\hline Protótipo modelo & $\begin{array}{c}\text { Na agência em condições } \\
\text { especiais }\end{array}$ & $\begin{array}{c}\text { Avaliação estética. A } \\
\text { estética da técnica }\end{array}$ & $\begin{array}{c}\text { Projeto personificado } \\
\text { (materialização) }\end{array}$ & Transformação \\
\hline $\begin{array}{l}\text { Protótipo artesanal ou } \\
\text { de investigação }\end{array}$ & $\begin{array}{c}\text { Por um artesão } \\
\text { especializado ou um } \\
\text { laboratório de pesquisa }\end{array}$ & $\begin{array}{l}\text { Avaliação de uso e dos } \\
\text { fenômenos perceptíveis }\end{array}$ & $\begin{array}{c}\text { Projeto detalhado (de } \\
\text { acordo com a } \\
\text { materialização) }\end{array}$ & $\begin{array}{c}\text { Transformação e } \\
\text { convergência }\end{array}$ \\
\hline \multicolumn{5}{|c|}{ Processo de seleção da empresa } \\
\hline Protótipo final & Pela empresa contratada & $\begin{array}{c}\text { Avaliação dos } \\
\text { comportamentos físicos }\end{array}$ & $\begin{array}{l}\text { Projeto detalhado (pré- } \\
\text { produção) }\end{array}$ & Convergência \\
\hline
\end{tabular}

Fonte: Adaptado pela autora a partir de Hoyet (2007).

Segundo Vincent (2007), na primeira e segunda fase, o modelo e o protótipo simulam os materiais e técnicas de montagem, geralmente executados com materiais simples como papelão e madeira, estes pré-protótipos possibilitam a previsão de informações formais como proporções e espessuras. De maneira mais superficial são estudados aspectos relativos às características dos materiais construtivos. Posteriormente, são executados protótipos adotando materiais reais e com maior precisão técnica. Nesta fase intermediária, o escritório avalia quase toda a execução dos detalhes do objeto investigado em associação a outras questões conceituais como: apropriação cultural, simbólica e sensorial. É nesta fase que o arquiteto e o cliente avaliam a capacidade do objeto investigado integrar todos os valores almejados (ver Figura 18).

O protótipo final desenvolvido pela empresa contratada tem praticamente todas as propriedades do componente final, este é submetido a verificações laboratoriais para averiguação quanto a sua conformidade com as normas técnicas. A análise do processo investigativo revela uma hierarquia nas diferentes fases, sendo verificado que após o problema ter sido colocado, já é possível inserir nos primeiros estudos o uso de modelos.

A etapa do 'detalhe' trata de questões técnicas e de execução, sendo realizada de acordo com o nível de conhecimento técnico do arquiteto em associação com a empresa fabricante. O último refinamento conceitual é avaliado de acordo com as restrições técnicas colocadas pela empresa executora, isto significa que, teoricamente, a maior parte do projeto é feita sem a presença da mesma. Quando atingem a fase do protótipo final, surge novamente a problemática de avaliação do material quanto ao seu desempenho, resistência e durabilidade. Os resultados desta fase são geralmente obtidos em centros laboratoriais e de pesquisa e subsidiam os processos contratuais das seguradoras. 




Figura 18: Uma parede do Ateliê em Vessima, onde modelos e protótipos em escala real são desenvolvidos para estudos, RPBW.

Fonte: Buchanan (2007).

Diferentes projetos desenvolvidos por Renzo Piano foram submetidos a complexas investigações experimentais. Em Buchanan (2007) é possível acompanhar o processo de concepção do projeto da IBM, em que aspectos técnicos e conceituais são investigados de forma indissociada, conforme a Figura 19. No desenvolvimento dos detalhes deste projeto, por exemplo, o arquiteto não procura resolvê-los simplesmente como processo técnico de montagem, mas em uma relação direta entre usuário e edifício, cuja resolução é alcançada ao permitir a sensação tátil do detalhe que está à altura da mão. As investigações experimentais neste projeto foram direcionadas também para a otimização do processo de montagem/desmontagem e transporte, devido ao caráter itinerante da proposta.


Figura 19: Estudos para o projeto IBM Travelling Pavilion, 1982-84.

Fonte: Buchanan (2007).

Nos exemplos apresentados, fica evidente a importância da dimensão construtiva nas obras destes projetistas que, em diversos momentos, viram na experimentação uma forma de serem confrontados com a materialização de suas obras, pois não bastava concebe-las, tiveram que construí-las, como forma de fomentar o processo de desenvolvimento projetual. Em Roland (1965), o autor faz uma consideração pertinente ao relatar que muitas biografias de 
projetistas apenas citam as obras mais emblemáticas destes profissionais, sem narrar com profundidade as dificuldades encontradas no convencimento sobre o potencial de suas ideias. Sobre esta questão, o arquiteto Felix Candela discorre ao longo do prólogo deste livro, que alguns profissionais subestimam o esforço necessário para se criar algo inovador e que o ato criativo resulta de um trabalho contínuo e de muito esforço, fruto de muitos anos de estudo e dedicação no enfrentamento de diferentes problemas, acreditando ser este o único caminho para a consecução da inspiração construtiva.

\subsection{A PESQUISA EXPERIMENTAL ASSOCIADA AO PODER DE PRODUÇÃO DA INDÚSTRIA}

O envolvimento do arquiteto no processo investigativo projetual permite que os resultados obtidos por meio da experimentação sejam utilizados nas tomadas de decisões tanto técnicas como também formais. Embora este não seja um cenário recorrente, determinados problemas arquitetônicos criaram ao longo da história oportunidades de diálogo entre profissionais das mais diversas formações, proporcionando um caráter mais científico ao processo projetual arquitetônico e, consequentemente, abrindo novos campos de atuação junto à indústria, como o fizeram Renzo Piano, Frei Otto, Jean Prouvè e muitos outros. No caso de Frei Otto, o arquiteto contribuiu para que materiais como as membranas poliméricas, aos poucos, encontrassem novas possibilidades de aplicação arquitetônica de acordo com suas propriedades físicas, desenvolvendo projetos com estruturas tensionadas de membranas ${ }^{23}$ e estruturas pneumáticas.

Sobre a diversidade de possibilidades de parceria com o setor industrial, devem ser destacadas as de Jean Prouvè, considerado tanto por Piano (2011) quanto por Rollet (2007), como o profissional que trouxe as evidências mais consistentes no que diz respeito ao papel e importância da experimentação na Arquitetura.

A intervenção de Jean Prouvé aconteceu no século XX com a ascensão da Arquitetura Moderna, quando desenvolveu sistemas inovadores em sua oficina de metal a partir de experimentações com os meios de produção disponíveis na época. Em Prouvè (2005) e Hoyet (2007), percebe-se que essa busca permanente do princípio construtivo em relação às

\footnotetext{
${ }^{23}$ De acordo com Roland (1965), Frei Otto iniciou suas obras experimentais com o apoio de uma empresa de tendas da Europa e, após os primeiros resultados esta parceria passou a ser colaborativa. Trata-se de um exemplo de atuação direta com o setor industrial, que possibilitou a abertura de novos nichos para a inserção de novos materiais até então pouco explorados pela construção civil.
} 
qualidades mecânicas, próprias do material, o levou a uma constante inovação que se converteu em um dos princípios absolutos de sua carreira. Envolveu-se em quase todas as tarefas de sua oficina, com o desenvolvimento das sequências construtivas dos elementos a serem fabricados. E, ao defender a ideia de que 'É necessário que haja uma harmonia entre quem executa e quem concebe', Prouvé assegura a produção do conhecimento híbrido, que Ihe permite atingir fluência no projeto de um assunto técnico em toda a sua complexidade, alcançando uma excepcional consistência cognitiva onde a experimentação arquitetônica e técnica trabalham juntas.

Uma de suas criações mais emblemáticas, a fachada cortina, representa uma invenção construtiva marcada pelos métodos de produção industrial e parte do princípio de que a fachada não tem mais função portante, sendo possível incorporar aos painéis leves e isolantes diversas funções técnicas, adaptáveis a diferentes materiais e tecnologias de acordo com o contexto e disponibilidade de recursos, como pode ser visto na Figura 20. Sobre o componente criado, Prouvè defendia que o mesmo havia sido concebido como um todo e não poderia ser analisado como um elemento isolado, pois estava associado ao conjunto construído, e criticava aqueles que atribuíam a ele a invenção da fachada cortina, pois não condizia com seus conceitos.
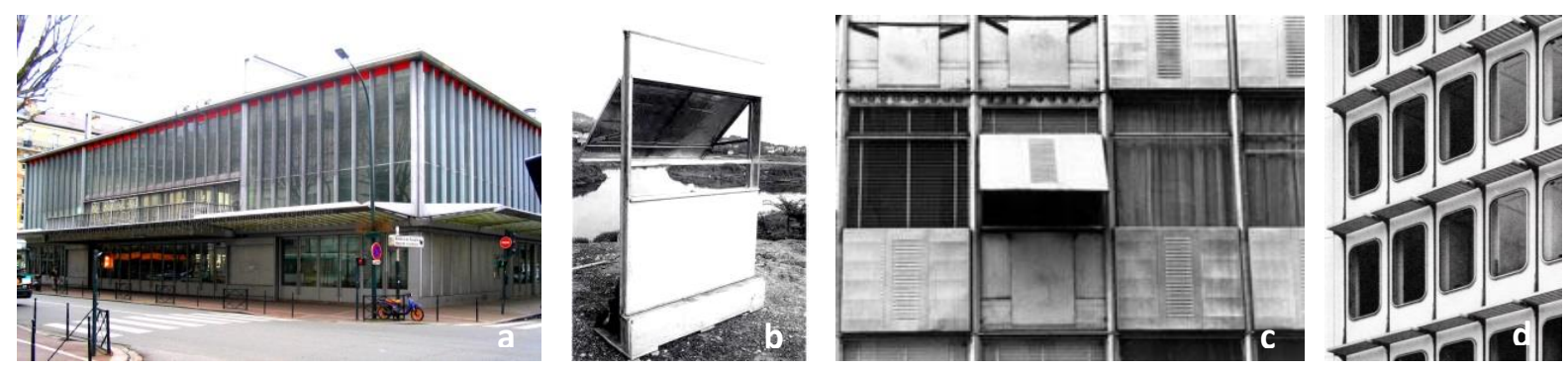

Figura 20: a) Maison du peuple em Clichy. 1935-1939. Fabricação da fachada-cortina por Jean Prouvé. Arquiteto: Marcel Lods. b) Protótipo da fachada-cortina. c) Prédio residencial - Praça Mozart - Paris, 1953-54. Painéis seguindo um complexo sistema de funcionamento: folhas veneziana com caráter projetante e deslizante até a altura do peitoril, permitindo controlar a luminosidade e a ventilação. d) Fachada-cortina com quebra-sol Unesco.

Fonte: Sulzer (2008).

Mesmo diante da diversidade de soluções alcançadas, Prouvè não se considerava um artesão e sim um industrial e, a base do sucesso de sua fábrica foi a pesquisa viabilizada pelos clientes interessados em inovação, consequentemente, em assumir os riscos presentes no processo investigativo. Esta pode ser considerada uma condicionante importante no desenvolvimento e sustentação da metodologia experimental. 
Muitos arquitetos o procuravam em sua oficina acreditando ser este ambiente um local para a verdadeira inspiração arquitetônica pela oportunidade de verem seus traços ganharem a realidade. Sobre isso comenta:

'o jovem arquiteto de hoje passa a maior parte do tempo desenhando coisas que jamais serão feitas. Não acham que isso é mortal para o espírito?' (PROUVÈ, 2005, p. 68)

Devido à centralidade do seu pensamento estar no diálogo com a realidade física por meio do protótipo do projeto, ao perder sua fábrica ficando impossibilitado de realizar suas investigações, chega às seguintes considerações:

'Quando fazia coisas eu mesmo, sabia perfeitamente como as faria. Quando perdi a ferramenta, me vi na mesma situação que os arquitetos. Muito rapidamente compreendi que não era possível fazer nada de bom, porque o processo entre a criação e a execução era ruim. Funcionava mal.' (PROUVÈ, 2005 p. 68).


Figura 21: Sistemas modulares com Estruturas tipo 'Pórtico Central'.

Fonte: Sulzer (2008)

Ao analisar o conjunto de sua obra, é possível perceber que os mesmos conceitos perpassam as diversas escalas, como a adoção de peças com seções descontínuas (Figura 22). Este recurso pode ser compreendido a partir de Prouvè (2005), quando relata seu conhecimento sobre princípios físicos presentes na natureza. Embora este não tenha sido um conceito projetual explicitado constantemente pelo projetista, acabou diferenciando-o dos demais designers da época, até mesmo os da Bauhaus. Segundo ele, o início deste processo deu-se por influência dos membros da Escola de Nancy ${ }^{24}$, que buscavam encontrar a melhor fonte de inspiração, encontrando-a na observação da natureza. Em Prouvè (2005), o autor relembra seu pai que dizia-Ihe: "Está vendo como o espinho está fixado no caule desta rosa?" E ao fazê-lo, abria a palma da mão, percorrendo o contorno com um dedo: "Olhe, é como o polegar se fixa à mão. Tudo aqui é bem feito, tudo aqui é sólido, são formas de igual resistência, e mesmo assim, flexíveis $^{\prime 25}$. Como a Escola de Nancy pode ser considerada sua principal influência, em

\footnotetext{
${ }^{24}$ De acordo com Prouvè (2005), seu pai Victor Prouvè, ajudou a fundar a Escola de Nancy. Os membros desta Escola preconizavam conceitos em estreita relação entre industriais, artistas e artesãos.

${ }^{25}$ Prouvé (2005) p. 12.
} 
diversos projetos que desenhou é observada a materialização destes conceitos: os perfis são de igual resistência, isso quer dizer, mais fortes nos lugares onde são mais solicitados.

Esta questão é reforçada por Grinover (2015), ao relatar em seu trabalho que Prouvè realizou críticas sobre os móveis tubulares da Bauhaus, por não conterem, no desenho das peças, o esforço do material, em que as seções contínuas dissimulavam as tensões e esforços. Enquanto, em seu desenho, a peça continha material condizente com o necessário à sua resistência e a forma adotada explicita estes esforços.
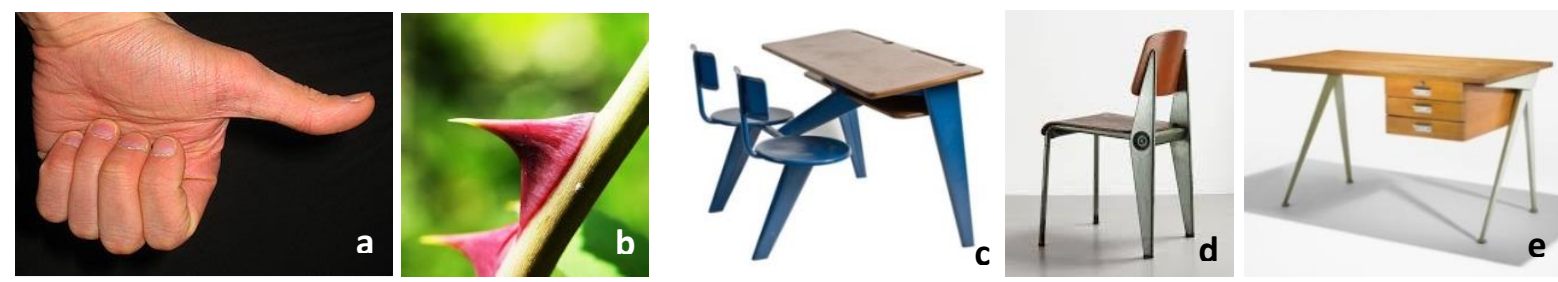

Figura 22: Estudos sobre seções descontínuas: a) e b) Elementos do corpo humano e da natureza. c), d) e e) mobiliário desenvolvido a partir dos conceitos de resistência observados na natureza - com seções descontínuas. Fonte: a)https://pt.wikipedia.org/wiki/Polegar,b) http://mundoeducacao.bol.uol.com.br/curiosidades/espinhoou-espinha.htm, c), d) e e) Sulzer (2008).

A criação de seções com dimensões descontínuas leva em consideração a experimentação técnica e não apenas formal, com a possibilidade de identificar os esforços de acordo com suas solicitações. Mas, para que isso seja realmente possível, devem-se ter os meios para fazêlo e Prouvè os tinha em sua fábrica.

Os ensinamentos de Prouvè influenciaram diversos projetistas de outras gerações, como o arquiteto Renzo Piano, pela consonância que possuíam no modo de interpretar o ofício. E, assim como ele, Piano vivenciou diversas parcerias com o setor industrial, como no desenvolvimento da fachada do edifício IRCAM (Institut de Recherche et Coordination Acoustique/Musique) em Paris (Figura 23), realizada por meio do processo colaborativo entre empresa e escritório na busca de um produto que alcançasse os conceitos almejados no projeto.

Este projeto experimental segundo Buchanan (2005), foi idealizado inicialmente por Renzo Piano como uma fachada capaz de dialogar com o prédio vizinho do século XIX, construído com tijolo cerâmico aparente, sendo a escolha da terracota, primeiramente, de ordem simbólica. No entanto, o princípio construtivo pretendido - o sistema a seco - era incompatível com o sistema tradicional, esta situação deu inicio às investigações para o desenvolvimento de um componente que agregasse todas as variáveis pretendidas.

Neste projeto o processo proposto pelo arquiteto para o desenvolvimento do painel de vedação proporcionou grandes transformações nos sistemas até então adotados pela 
empresa contratada que, segundo Hoyet (2007), se beneficiou com a inovação a partir do impulsionamento das pesquisas internas, motivada também pela potencial oportunidade de comercialização futura do produto desenvolvido.
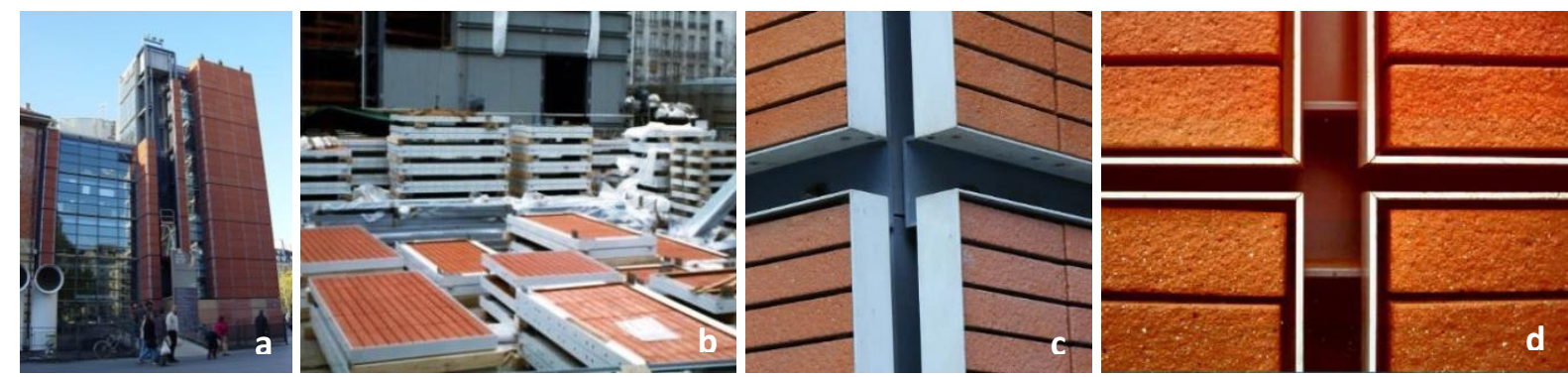

Figura 23: Sequencia de fotos do Edifício IRCAM (Institut de Recherche et Coordination Acoustique/Musique) em Paris. a) Vista externa do edifício. B) armazenagem dos painéis em canteiro de obras. c) e d) Detalhes da interface entre painel metálico e os blocos em terracota.

Fonte: Buchanan (2007).

Ainda sobre o desenvolvimento do projeto IRCAM, em Vincent (2007), é visto que a postura do cliente foi decisiva para a adoção da experimentação ao longo do processo projetual, a partir de sua plena consciência sobre os riscos aos quais poderia estar exposto. Neste caso, o investimento inicial foi equacionado por alguns diferenciais alcançados, como: redução do tempo de montagem, facilidade de manutenção, redução dos custos energéticos e, também, pelo ineditismo técnico. O autor aponta para a existência de dois processos econômicos desenvolvidos em paralelo com o projeto experimental: um relativo à obra arquitetônica e o outro ao desenvolvimento do produto industrial. Cada um destes processos é caracterizado por uma organização composta por diferentes atores que se cruzam em diferentes momentos do desenvolvimento do produto, e o processo experimental pode resultar em uma sinergia positiva em que cada ator se mobiliza, sendo que o arquiteto, como projetista, deve reunir diferentes conhecimentos para atuar nos dois processos.

$\mathrm{Na}$ City International em Lyon (Figura 24), Renzo Piano adota outras variantes do sistema desenvolvido para o edifício IRCAM. Segundo Vincent (2007), neste caso a identidade do produto concebido não se limita a satisfazer a resolução de um problema específico, pois a proposição do projeto da fachada está inserida em um contexto mais amplo de reflexão, que ultrapassa os limites do projeto. O material deveria permitir implementar tecnologias que se adaptassem às condições contemporâneas, atendendo a requisitos de isolamento térmico e acústico. A partir de uma pesquisa em associação direta com o poder de produção da indústria que durou aproximadamente oito meses, foi proposto um revestimento em argila, em que o principal desafio enfrentado foi o desenvolvimento de um produto de maiores dimensões e menor espessura em relação ao convencional. Para responder a este desafio, o arquiteto teve 
que investir em pesquisa na busca de materiais e técnicas de extrusão diferenciadas. Trata-se de uma alternativa contemporânea à fachada em terracota, que integrando técnicas mecanizadas correspondem a novos padrões construtivos.
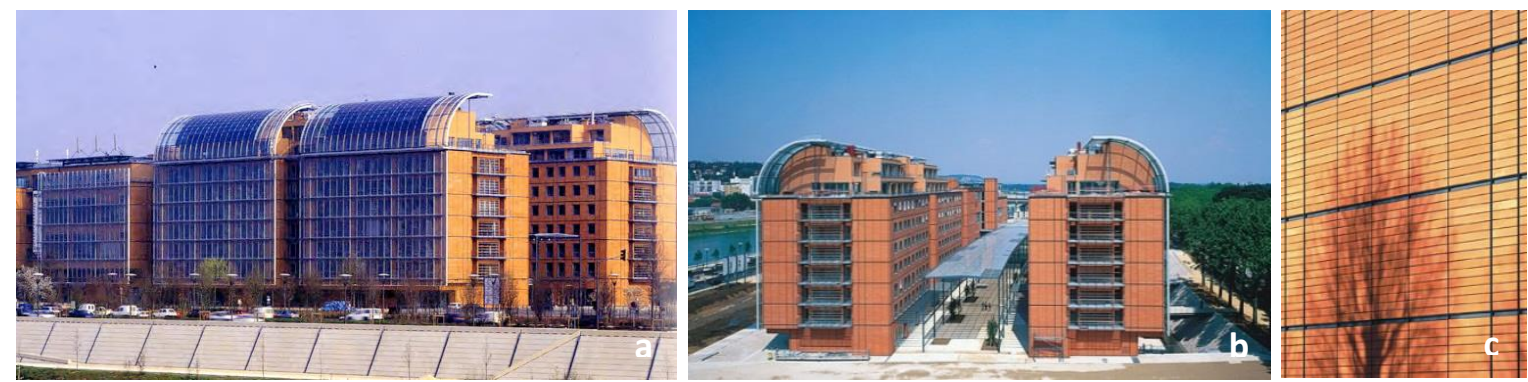

Figura 24: Sequencia de fotos do City International em Lyon, França.

Fonte: Buchanan (2006).

O Quadro 05 revela as etapas de inserção da pesquisa experimental e a utilização dos modelos e protótipos ao longo do desenvolvimento destas duas obras de Renzo Piano, as quais promoveram a disseminação tecnológica do produto desenvolvido a partir do seu aperfeiçoamento.

Quadro 05: Etapas de inserção da pesquisa experimental nos projetos IRCAM (Institut de Recherche et Coordination Acoustique/Musique) em Paris e Citè Internationale em Lyon.

\begin{tabular}{|c|c|c|c|c|c|}
\hline $\begin{array}{c}\text { Tipo de } \\
\text { inovação }\end{array}$ & $\begin{array}{l}\text { Projeto } \\
\text { arquitetural }\end{array}$ & $\begin{array}{l}\text { Ferramenta de } \\
\text { produção }\end{array}$ & $\begin{array}{l}\text { Projeto do } \\
\text { arquiteto } \\
\text { (produto) }\end{array}$ & $\begin{array}{l}\text { Projeto da empresa } \\
\text { (produção) }\end{array}$ & $\begin{array}{l}\text { Tecnologias } \\
\text { solicitadas }\end{array}$ \\
\hline 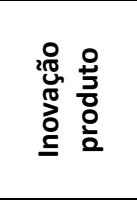 & $\begin{array}{l}\text { IRCAM em } \\
\text { Paris. RPBW }\end{array}$ & $\begin{array}{l}\text { Produção } \\
\text { protótipo }\end{array}$ & $\begin{array}{l}\text { Revestimento em } \\
\text { terracota como } \\
\text { painel a seco de } \\
\text { grandes } \\
\text { dimensões }\end{array}$ & $\begin{array}{c}\text { Adaptação do } \\
\text { conhecimento } \\
\text { existente ao novo } \\
\text { produto } \\
\text { desconhecido }\end{array}$ & $\begin{array}{c}\text { Tecnologia de } \\
\text { extrusão: controle } \\
\text { de fabricação dos } \\
\text { elementos de } \\
\text { grandes dimensões }\end{array}$ \\
\hline  & $\begin{array}{c}\text { Citè } \\
\text { Internationale } \\
\text { em Lyon. Fase } \\
\text { 01. RPBW }\end{array}$ & $\begin{array}{l}\text { Fabricação } \\
\text { provisória }\end{array}$ & $\begin{array}{l}\text { Sistema de } \\
\text { revestimento. } \\
\text { Simplificação do } \\
\text { sistema de } \\
\text { fixação }\end{array}$ & $\begin{array}{l}\text { Foco no produto. } \\
\text { Procedimentos de } \\
\text { certificação }\end{array}$ & $\begin{array}{l}\text { Processo de controle } \\
\text { industrial }\end{array}$ \\
\hline 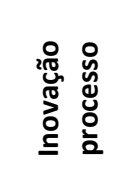 & $\begin{array}{c}\text { Citè } \\
\text { Internationale } \\
\text { em Lyon. Fase } \\
\text { 02. RPBW }\end{array}$ & $\begin{array}{l}\text { Criação de } \\
\text { unidade de } \\
\text { produção } \\
\text { específica }\end{array}$ & $\begin{array}{l}\text { Desenvolvimento } \\
\text { de componentes } \\
\text { (novas formas e } \\
\text { funções) }\end{array}$ & $\begin{array}{c}\text { Modificações no } \\
\text { desenho de acordo } \\
\text { com } \\
\text { aperfeiçoamentos } \\
\text { técnicos }\end{array}$ & $\begin{array}{l}\text { Ferramentas de } \\
\text { Aperfeiçoamento }\end{array}$ \\
\hline 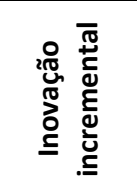 & $\begin{array}{c}\text { Difusão } \\
\text { internacional }\end{array}$ & $\begin{array}{l}\text { Desenvolvimento } \\
\text { de unidade de } \\
\text { produção }\end{array}$ & $\begin{array}{c}\text { Demanda para } \\
\text { fabricações } \\
\text { especiais }\end{array}$ & $\begin{array}{c}\text { Projeto de } \\
\text { inovações } \\
\text { incrementais }\end{array}$ & $\begin{array}{c}\text { Desenvolvimento de } \\
\text { pesquisa } \\
\text { especialmente } \\
\text { simulação do } \\
\text { componente }\end{array}$ \\
\hline
\end{tabular}

Fonte: Adaptado pela autora a partir de Hoyet (2007).

Ao trabalharem com sistemas não convencionais, independentemente do momento histórico, diversos arquitetos foram conduzidos a estender suas investigações para o desenvolvimento de detalhes construtivos específicos, processo que ocorre, geralmente, em estreita relação com o 
setor industrial. Além de Jean Prouvè e Renzo Piano, em Roland (1965), é possível verificar que também Frei Otto desenvolveu diversos processos investigativos neste sentido, principalmente nos casos em que havia a necessidade da criação de novos métodos de ligações de elementos em associação às soluções estruturais tracionadas e aos elementos estruturais flexíveis, em um contexto onde não existiam muitos exemplos no campo da construção ${ }^{26}$.

No caso dos detalhes de construções de grandes vãos com membranas, estas não podiam ser resolvidas com os métodos tradicionais de fabricação. As grandes coberturas e as elevadas tensões de protensão implicavam em esforços até então desconhecidos naquele momento. Desta forma, desenvolveram processos de pesquisa e avaliação de diversos detalhes, iniciando com o que a indústria oferecia naquele momento e evoluindo, posteriormente, para sistemas mais sofisticados e com melhor desempenho. Com isso, surgem lentamente, quase de maneira automática, novos detalhes construtivos, que não são somente perfeitos e econômicos tecnicamente, mas refletem as características do novo método construtivo. A relação da lógica estrutural de cada elemento com a forma não está somente no aspecto geral da obra, mas nas particularidades dos detalhes.
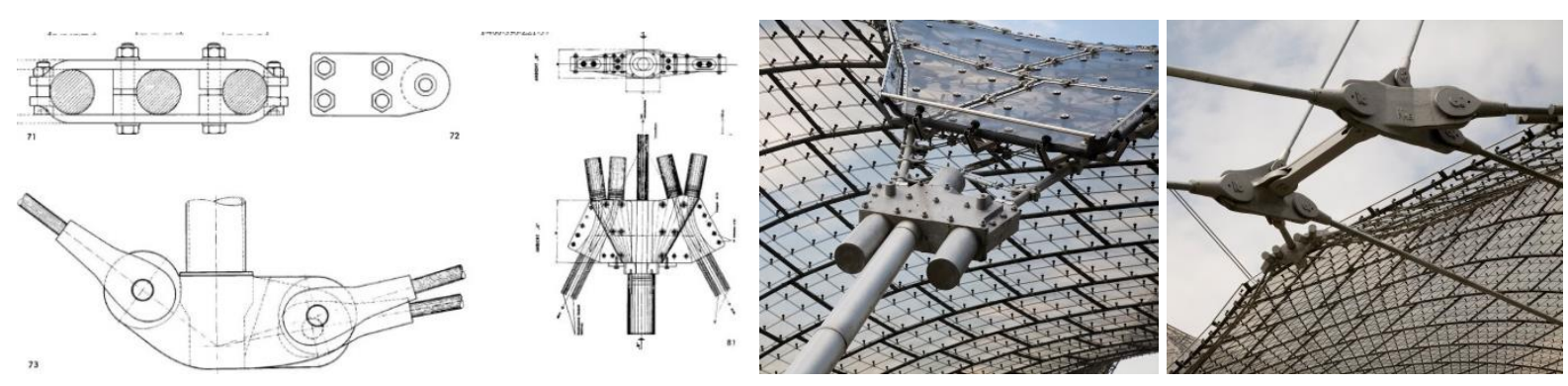

Figura 25 - Detalhes desenvolvidos por Frei Otto para Projeto do Estádio Olímpico de Munique - 72. Fonte: a) https://www.pinterest.com/pin/214484000981022370/. b) e c) https://www.pinterest.com/guikamp/detalhes/

Neste item, fica claro que diversos profissionais ao longo da história trabalharam em associação com o poder de produção da indústria, em que a experimentação construtiva contribuiu para a promoção do espaço de diálogo entre os atores de diferentes campos de atuação. Com o passar dos anos, outros aspectos passaram a ser comtemplados pelos pesquisadores, possibilitando que a tecnologia se abrisse a outras dimensões de análise, como a ambiental e a social, analisadas em associação aos aspectos tecnológicos, formais e econômicos.

\footnotetext{
${ }^{26}$ Diferentemente de outras áreas como a engenharia, que estavam amplamente desenvolvidas, com diversos detalhes para pontes, teleféricos, barcos, aviões, gruas, etc.
} 


\subsection{A EXPERIMENTAÇÃO CONSTRUTIVA EM RESPOSTA A PROBLEMAS AMBIENTAIS E SOCIOECONÔMICOS}

Embora a preocupação pelas questões ambientais tenha iniciado a partir da década de 1960, levou-se algum tempo para que as pesquisas pudessem ser disseminadas nas diferentes áreas do conhecimento. Em relação à construção civil, as pesquisas tiveram maior impulsionamento e visibilidade nas últimas décadas, quando a dimensão ambiental passou a ser discutida em associação a temas como otimização de recursos naturais, cadeia produtiva, ciclo de vida dos materiais e impactos ambientais, gerados tanto no estágio da construção como nas etapas subsequentes, ao longo da utilização da edificação.

De acordo com Addis (2009), alguns setores da indústria se adequaram a estes novos imperativos, mas quando a vida humana não é afetada diretamente a mudança nos materiais da construção civil ocorre de forma mais lenta e menos significativa.

Embora alguns destes materiais nem sempre possam ser utilizados para determinadas finalidades, as pesquisas atuais tem ampliado suas possibilidades de aplicação, como o caso da madeira, a terra-crua, o bambu, o papelão e diversos compósitos. Para isso, estes materiais foram submetidos a pesquisas com tecnologias sofisticadas para que pudessem se adequar a novos usos e melhorar seu desempenho. Além dos materiais vernaculares, as pesquisas também foram direcionadas para potencializar o uso de componentes reaproveitados e materiais reciclados, mas suas aplicações ainda ocupam uma escala modesta (devido a barreiras econômicas, técnicas e culturais), mas com grande potencial de expansão futura.

Estas mudanças tem influenciado muito o papel dos arquitetos ao longo do desenvolvimento do projeto, aumentando a necessidade de seu envolvimento com assuntos técnicos e seu poder de diálogo com outros agentes envolvidos com a construção.

Quando analisados estes novos aspectos em associação ao processo experimental, nota-se que esta metodologia projetual torna-se cada vez mais requerida, pois aspectos relativos às características físicas dos materiais e desempenho de sistemas inovadores dificilmente poderão ser mensurados e analisados em sua integridade por simulações computacionais. Isso não descarta o fato destas ferramentas digitais darem apoio ao processo experimental laboratorial, sendo a associação de meios o cenário ideal para resultados mais consistentes.

É possível verificar a partir de diversos exemplos encontrados que a problemática ambiental dificilmente é trabalhada de forma descolada de outras dimensões, como a socioeconômica, a cultural ou a investigação puramente técnica/formal. Um dos profissionais 
que conseguiu perpassar diversos campos adotando um material comprovadamente de baixo impacto foi Shigeru Ban. O arquiteto japonês com o apoio de pesquisadores e projetistas estruturais desenvolveram diversas pesquisas com o material papelão ${ }^{27}$, ampliando suas possibilidades construtivas para diferentes campos, geralmente por meio de pesquisas com caráter experimental devido ao uso ainda incipiente do material.

Por meio do projeto e detalhes técnicos a equipe conseguiu manter as caraterísticas do material e melhorar suas propriedades mecânicas, desenvolvendo mecanismos para potencializar suas qualidades e minimizar as fragilidades que lhe conferem, muitas vezes, um caráter efêmero. Estes conceitos foram, geralmente, defendidos e aplicados em seus projetos, como o Pavilhão do Japão na Expo Hannover em 2000 (Figura 26), tratando-se da primeira experiência de Shigero Ban com o arquiteto alemão Frei Otto, que participou como consultor deste projeto. Em McQuaid (2008), ambos profissionais relatam como ocorreu o processo de parceria e as dificuldades enfrentadas, tanto de ordem técnica como burocrática, sendo necessárias diversas experimentações para melhor compreensão do projeto e sua validação técnica.

Os estudos formais deste projeto também foram conduzidos por meio de modelos e dependiam diretamente do método construtivo adotado, neste caso, uma trama de tubos de papelão e junções rotativas, de maneira a permitir a elevação da estrutura e sua regulagem após o içamento, este processo construtivo assemelha-se aos estudos que Otto realizou na década de 1960, como pode ser visto na Figura 15 deste trabalho. No projeto do Pavilhão do Japão para a Expo, além dos problemas construtivos encontrados pelos arquitetos, estava a necessidade de equalizar algumas propriedades requeridas, como: aumento de rigidez da estrutura, por um lado, e sua resistência à água e ao fogo, por outro.
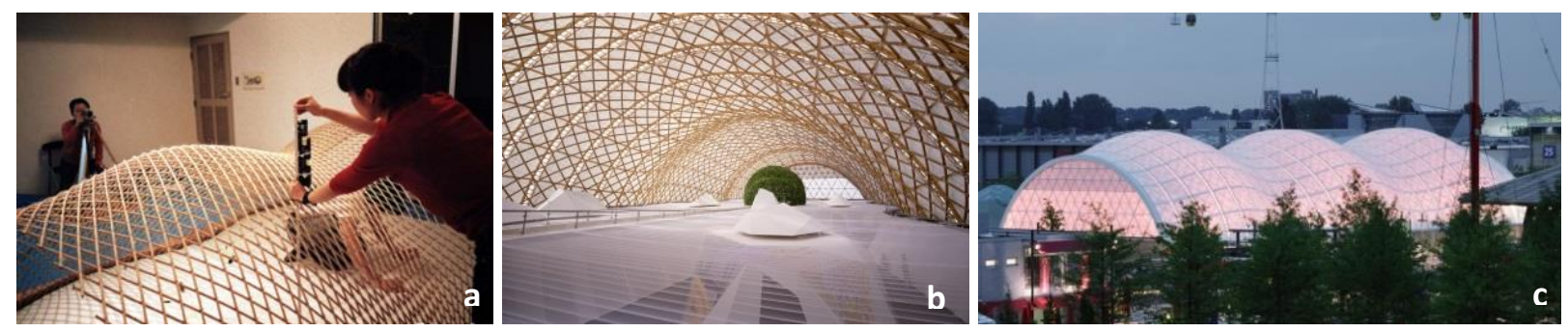

Figura 26: Pavilhão do Japão em Hannover. Oportunidade em que Shigeru Ban trabalhou com Frei Otto. a) Maquetes de estudo da estrutura entramada. b) Vista interna do edifício. c) Vista externa do edifício.

Fonte: McQuaid (2008).

Particularmente, as exigências contextuais e programáticas obrigaram os arquitetos a solicitarem diversas pesquisas diante dos desafios colocados e pela repercussão negativa que

\footnotetext{
${ }^{27}$ O papelão possui diversas qualidades que justificam a ampliação do seu emprego e investimentos contínuos com pesquisa, por se tratar de um material que gera poucos impactos ao longo de sua cadeia produtiva, e pela possibilidade de reaproveitamento e pouca geração de resíduos no processo de montagem e desmontagem.
} 
sua aplicação causou naquele momento, sendo exigido pelas autoridades que os arquitetos dessem ao papelão um tratamento de material convencional. Diante disso, diversos avanços foram alcançados ao longo do processo, desde o desenvolvimento de novas tipologias estruturais até a resolução de novos encaixes. Tanto nesta obra como em outros projetos de grande complexidade realizados por Ban, houve o envolvimento de diversos atores com formação multidisciplinar, pertencentes a Institutos Universitários, Centros de pesquisa e agentes da indústria da construção ${ }^{28}$.

Quanto aos desafios encontrados neste projeto, em McQuaid (2008), o arquiteto alemão comenta que as construções em papel podem apenas ser comparadas às construções têxteis. Este comentário pode ser explicado por ambos profissionais, Otto e Ban, estudarem materiais até então subutilizados no campo da construção, sendo necessária a comprovação por meio de pesquisas sobre o potencial formal e técnico dos mesmos. E, ao conferir-lhes confiabilidade por meio das soluções alcançadas, os arquitetos colocam em questionamento o caráter efêmero destas construções, trata-se de um caminho permeado de dificuldades de diferentes ordens, seja cultural, pela difícil aceitação; econômica, por envolver processos onerosos desde pesquisas até à etapa de manutenção e também dificuldades de ordem técnica, pela limitação de meios disponíveis para sua manipulação.

Ao discutir a questão da efemeridade, Otto (1979) defende que a vida dos edifícios depende, essencialmente, de sua adaptabilidade técnica e humana e não dos materiais de construção, pois edifícios que sobrevivem é porque são necessários ou queridos, portanto adaptáveis, se renovam constantemente, mesmo quando feitos com materiais que perecem. Para ele, o objetivo principal dos futuros trabalhos será fazer surgir novos problemas, neste contexto haverá trabalho suficiente para várias gerações de pessoas que permanecem jovens e adaptáveis.

A manipulação de materiais com caráter efêmero e o interesse por temáticas de cunho social, pode ter sido uma das motivações iniciais que impulsionaram suas carreiras. No caso de Shigeru Ban, paralelamente ao desenvolvimento de obras de grande complexidade construtiva, o arquiteto estende a aplicação dos tubos de papelão para temáticas de caráter emergencial, principalmente, para o desenvolvimento de moradias para a população desabrigada por desastres naturais ou de outra natureza (Figura 27).

\footnotetext{
${ }^{28}$ Dados obtidos em entrevista a arquiteta Mirian Vaccari, que realizou algumas pesquisas com o arquiteto Shigeru Ban na Universidade de Artes e Design de Kyoto, Japão, entre 2013 e 2014. Além desta experiência, também teve a oportunidade de colaborar com o arquiteto em alguns projetos de cunho social na China. Entrevista realizada no dia 13/05/15 em São PauloSP.
} 

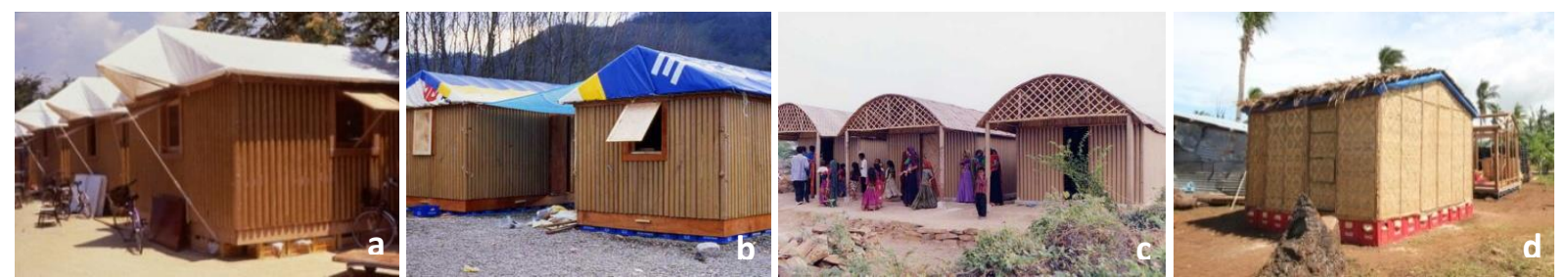

Figura 27: Casas de tubos de papelão - a) Kobe, Japão, 1995. b) Turquia, 2000. c) Bhuj, Índia, 2001. d) Cebu, Filipinas, 2014.

Fonte: a) www.shigerubanarchitects.com. b) e c) McQuaid (2008). d)www.shigerubanarchitects.com.

Os aspectos socioambientais podem ser analisados não apenas sob a dimensão assistencialista, mas outros ganhos sociais podem ser alcançados a partir de um processo construtivo inovador, como o fez Eládio Dieste. Resgatar novamente o engenheiro uruguaio se faz necessário devido às suas contribuições projetuais extrapolarem os limites da inovação puramente técnica e formal. Ao longo de sua carreira teve especial atenção ao contexto de suas intervenções ao considerar em suas inovações a matéria-prima e mão-de-obra local. Para isso, desenvolveu máquinas que se adequassem às suas propostas e respeitassem o operariado envolvido, atentando para questões formais, técnicas, econômicas e de segurança, simultaneamente (Figura 28 e 29).
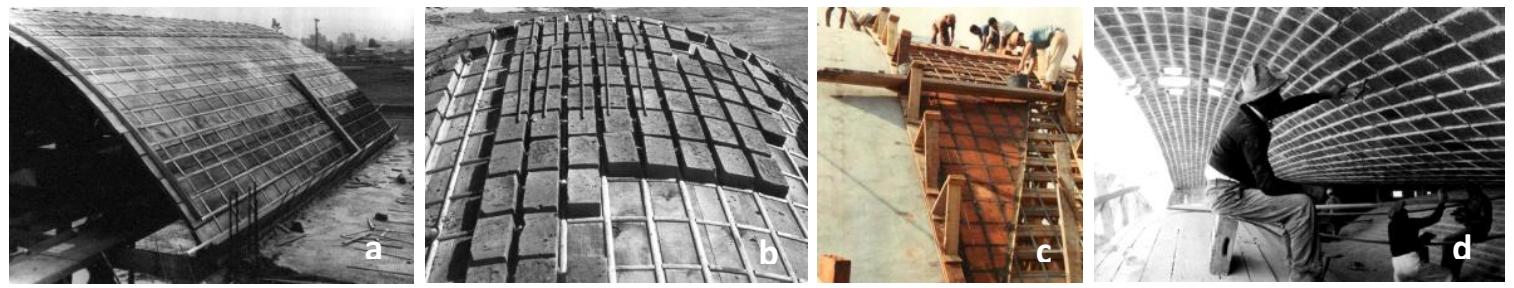

Figura 28: Sequencia de imagens com a execução de uma abóbada elaborada por Eladio Dieste, explicitando as particularidades do processo de otimização do trabalho operário. a) Detalhe do molde quadriculado para execução da abóbada autoportante. b) Preparação das juntas: molde modular com espaçadores e emprego de gabaritos. c) Execução de abóbada: etapas construtivas distintas. d) Limpeza das peças cerâmicas: cuidados no acabamento interno.

Fonte: Carvalho (2004).

Para Dieste, as questões éticas coincidem com as questões práticas, sendo possível verificar no conjunto de sua obra que uma de suas principais particularidades foi não optar pela simplificação do processo ou da função arquitetônica, como forma de se adequar à mãode-obra sem qualificação do contexto local. Dignificava o operário ao lhe dar condições de envolvimento com questões complexas, evitando sincronicamente, o empobrecimento intelectual, artístico e arquitetônico do mesmo. Em suas palavras:

Recuerdo haber asistido con gente del campo, muy humilde, al momento en que se liberó de andamios una estructura muy compleja y audaz; audaz pero serena. No era importante por el tamaño o por el costo, pero se sentía la tensión del esfuerzo que la hizo posible. $Y$ es esto justamente lo que dijo un paisano, que no 
era fácil hacer aquello. La audacia le producía no descofianza, ni sólo sorpresa, sino felicidad; distinguía muy bien la diferencia entre lo que es importante por el tamaño y por el costo, de aquello que nos toca en lo más hondo porque nos expresa sin que se sienta el esfuerzo que lo produjo. (DPA-DIESTE. p. 71)
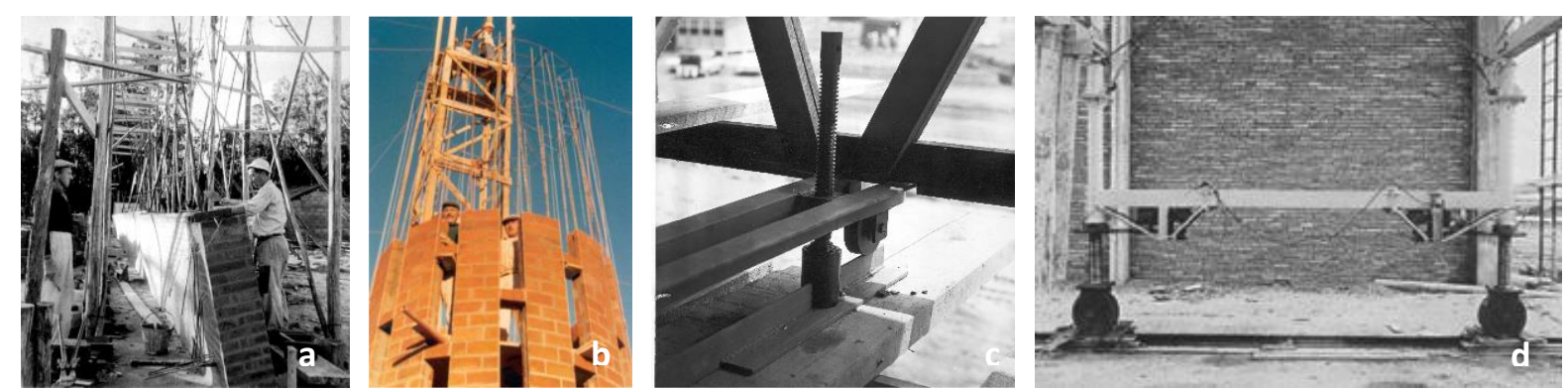

Figura 29: Máquinas e equipamentos desenvolvidos por Eládio Dieste de acordo com as condicionantes contextuais. a) Execução das paredes de Atlantida: retas geratrizes reproduzidas por fios-guia fixos em gabaritos. b) Execução de um tanque de água, no Uruguai: utilização de sistema de reprodução da diretriz superior com gabarito e de fios-guia. c) Molde móvel: detalhe de fixação. d) Sistema motorizado para transporte vertical de fôrmas.

Fonte: a, b e c) Carvalho (2004). d) Dieste (1987).

Em Dieste (1987), o engenheiro afirma que a descoberta de uma série de técnicas com a utilização de um dos mais antigos materiais, o tijolo cerâmico, foi possível por pensar os problemas com independência, descobrindo que se abria um caminho tecnicamente válido e viável, incorporando todos os refinamentos necessários de técnicas mais atualizadas. E, não se trata de um apego reacionário e sentimental às técnicas ditas superadas, mas de não cair em outra atitude ainda mais sentimental, da adoração da riqueza e eficiência mecânica dos países desenvolvidos. Sobre isso, questionava o real valor daquilo que não é obtido por meio da verdadeira dificuldade técnica e com significado artístico, cuja complexidade não deve ser interpretada como uma situação a afrontar o operário e sua integridade física, mas sim como uma oportunidade de dignificá-lo, dando a ele condições para isso.

Ao enquadrar o arquiteto João Filgueiras Lima - Lelé, entre os profissionais que buscaram no processo experimental o apoio para a realização e validação de suas criações, deve-se considerar que o arquiteto foi o único profissional nacional que se dedicou a esta prática com uma profundidade semelhante aos demais aqui abordados, destacando-se no cenário nacional pelo olhar diferenciado sobre o processo projetual. Em depoimento, Lelé ressalta que a cultura brasileira sempre foi muito conservadora em relação à experimentação técnica ou ao investimento em qualificação de mão-de-obra, estabelecendo o lucro imediato como premissa 
de negócio, planejando pouco e, portanto, não fomentando nenhum progresso tecnológico na direção da industrialização aberta ${ }^{29}$.

Quando analisadas as respostas encontradas para problemas socioeconômicos por meio do processo experimental - seja com maior ou menor grau científico - destacam-se algumas soluções cujos detalhes técnicos tiveram uma dimensão muito importante no conjunto da obra implantada. Um destes desafios pode ser visto no uso do sistema de peças pré-moldadas em argamassa armada para a resolução das questões de drenagem e saneamento em lugares propícios ao desabamento, na cidade de Salvador. As peças que compunham a escadaria drenante para o escoamento das águas ou o canal de esgoto podem ser consideradas, de acordo com Pinho (2010), como uma arquitetura verdadeiramente universal, que utiliza a tecnologia da industrialização da construção por meio dos pré-moldados para solucionar um problema bastante específico, atentando para o peso das peças e a forma de transportá-las manualmente em um local pobre e de difícil acesso (Figura 30). Neste caso, há uma associação harmônica entre o alto conhecimento tecnológico com a aplicação quase artesanal.


Figura 30: Intervenções na resolução das questões de drenagem e saneamento por meio da pré-fabricação na cidade de Salvador.

Fonte: a) e b) ELOY, E et al. (2005). c) e d) Imagens concedidas por Cláudia T. de Andrade Oliveira.

Depois desta experiência em Salvador, Lelé deu seguimento ao processo experimental na pequena cidade de Abadiânia - GO, também caracterizada pelo contexto precário, mas com particularidades em relação à cidade de Salvador, seja pela localização geográfica como pela sua distância dos grandes centros urbanos. De acordo com Lima (1984), as experiências realizadas em Abadiânia foram conduzidas de maneira a permitir sua reaplicação em outros contextos, a partir da facilidade que a pré-fabricação promovia na capacitação da mão-deobra não qualificada, (Figura 31).

Para alguns autores, como Pinho (2010), a experiência de Abadiânia é parte de uma fase importante na obra de Lelé, transformando-se em um divisor no que se refere à préfabricação da argamassa armada, iniciada em Salvador com o desenvolvimento de

\footnotetext{
${ }^{29}$ Informações obtidas em: Grinover (2015) e em consulta à entrevista concedida ao arquiteto Adriano Carneiro em 2007, no CTRS de Salvador, publicada em: http://entre-entre.com/?Entrevistald=17. Acesso em 05/10/2016.
} 
equipamentos urbanos para a cidade e depois em Abadiânia, representando a transição até que fosse implantada a Fábrica de Escolas no Rio de Janeiro.
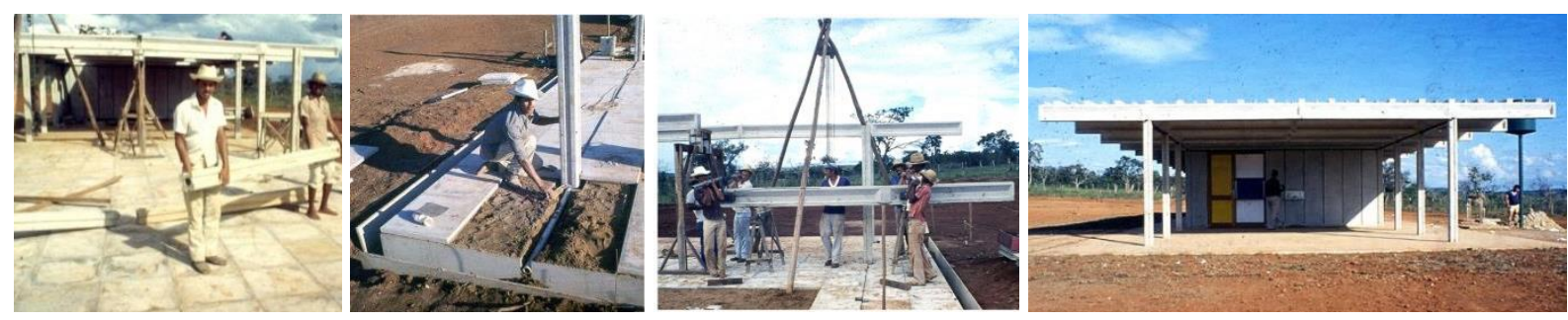

Figura 31: Sequencia de imagens do processo de capacitação de mão de obra ocorrendo simultaneamente ao processo de construção de escolas rurais, no município de Abadiânia, GO.

Fonte: Imagens concedidas por Cláudia T. de Andrade Oliveira.

As experiências de Lelé revelam a difícil tarefa da produção seriada em um ambiente cultural resistente à industrialização e à racionalização da construção. Esta opção pela industrialização e pelo pré-moldado, segundo Risério (2010), passa também por uma perspectiva sociológica, como resposta às grandes carências sociais e culturais de um país continental como o Brasil, as quais Lelé não era insensível:

'Quando nós pensamos no uso da argamassa para construir, pensamos também em uma tecnologia que empregasse gente, porque o desemprego é um dos problemas do Brasil. Não podíamos inventar uma tecnologia industrializada que significasse a perda de empregos na construção civil, que continua a ser o que mantém muitas famílias comendo, sobrevivendo. Tínhamos de inventar uma tecnologia que continuasse a empregar gente'. (LIMA, 2004, p. 113)

Este ponto de vista, embora não seja próxima a de Dieste, que defendia outra postura frente à questão social, revela claramente algumas diferenças contextuais em que ambos profissionais atuaram: próximas economicamente, mas distantes em relação à questão simbólica e cultural, sendo condicionantes importantes no desenvolvimento de cada processo. Diante disso, conclui-se que o contexto é decisivo no processo investigativo ${ }^{30}$.

De acordo com Risselada (2010), para Lelé é necessário que o processo de concepção, concretização e execução seja conduzido tanto quanto possível sob o mesmo denominador, para que haja um mínimo de negociações entre as partes envolvidas na construção e maior cooperação entre os diversos atores, onde a "fábrica", ou local de trabalho, não é apenas um lugar de produção, mas também de pesquisa.

\footnotetext{
${ }^{30}$ Sobre o processo adotado por Eladio Dieste fica a dúvida: A dimensão de suas criações seria mensurada com o mesmo peso em outros contextos? Ou, jamais teria alcançado a sofisticação do processo desenvolvido (em sua plenitude) se não tivesse as condicionantes contextuais?
} 


\subsection{GENERALISTAS OU ESPECIALISTAS?}

Embora os processos de trabalho dos profissionais analisados neste capítulo evidenciem a diversidade de entendimentos sobre as questões relativas à materialidade, estas metodologias empregadas também revelam que a experimentação técnico-construtiva ocupa um papel de destaque na fase conceptiva de seus projetos, momento que a dimensão material inicia seu diálogo com as demais, fazendo referência a uma abordagem intuitiva alimentada pela experiência e criatividade de cada projetista. Os profissionais selecionados tratam a experimentação como uma prática recorrente, mas nem sempre imprescindível, sendo aplicada quando necessário de acordo com o problema investigado.

Pode-se concluir que o principal diferencial que permitiu a estes profissionais terem maior liberdade na condução de seus objetivos foi a adoção de uma postura autodidata e, diante da diversidade de meios técnicos possíveis para a concretização de suas ideias, destaca-se o firmamento de parcerias junto à academia, principalmente quando o objetivo dos projetistas era a sustentação e continuidade das investigações. A discussão sobre pesquisa teórica e aplicada torna-se muito importante na medida em que a pesquisa acadêmica é muitas vezes considerada, por parte dos profissionais, como abstrata e inútil, e a industrial, como sendo enganosa e estreitamente condicionada aos objetivos capitalistas. Muitas entidades de pesquisa, laboratórios industriais, estações experimentais e as universidades precisam de investimentos constantes que viabilizem suas atividades de trabalho, e as condições ideais para que tais parcerias possam ser firmadas é o estabelecimento de acordos pontuais, com contrapartidas claras e justas para o processo de transferência dos resultados alcançados.

Com relação à infraestrutura, além dos equipamentos necessários há a necessidade de um número considerável de técnicos hábeis para o auxílio nos experimentos, de preferência como equipes fixas de trabalho, para uma possível capacitação continuada de acordo com as particularidades de cada ambiente investigativo, seja acadêmico, profissional ou industrial.

Em relação aos meios econômicos, de forma recorrente os projetistas declaram a importância da existência de clientes que depositem confiança no processo experimental, e que estejam cientes sobre possíveis erros e fracassos que o processo está sujeito, de maneira a estabelecer uma postura mais solidária em relação às possíveis cobranças.

Outra questão relevante observada nestes trabalhos analisados é a vinculação entre experimentação e projeto arquitetônico como um todo, em que as questões técnicas e 
formais possam ser estudadas de forma indissociada, algo que dificilmente ocorre quando um componente ou detalhe construtivo é investigado isoladamente, sendo uma prática comum em laboratórios acadêmicos de arquitetura, quando o experimento tem um fim em si mesmo.

Os exemplos históricos também revelam a necessidade de se reinventar constantemente para se adaptar às mudanças que influenciam com maior ou menor intensidade as possibilidades de ações sobre as condições do ambiente construído, embora esta não seja a realidade constatada atualmente, diante da pouca disponibilidade de exemplos contemporâneos. Entretanto, fica cada vez mais evidente que os novos desafios técnicos não podem ser investigados de forma plena e responsável apenas pela simples consultoria técnica, exigindo um profissional com conhecimentos cada vez mais abrangentes sobre os assuntos que envolvem a materialidade, para que não haja um descompasso entre a disponibilidade de meios, por um lado, e de conhecimento profissional, por outro.

Em Engel (1967), o autor já fazia sinalizações sobre os novos desafios que o arquiteto enfrentaria na contemporaneidade, como a discrepância entre a extensão dos conhecimentos exigidos e a limitação individual do profissional, diante da multiplicidade de fatores e particularidades envolvidos na construção. Uma saída para enfrentar esta contradição seria a aquisição de um sólido conhecimento de cada uma das diferentes ciências que contribuem para a materialização do projeto. O autor ainda reforça esta questão, ao colocar que o necessário é o conhecimento que torna o profissional capaz de interpretar criativamente os fatos científicos e tirar deles as ideias para o seu projeto, esta postura pode decidir sobre o sucesso ou fracasso de solidificar a influência do arquiteto com relação aos profissionais que atuam diante dos avanços de seu tempo.

Diante disso, pode-se concluir que a existência dos dois perfis profissionais são igualmente importantes: o especialista e o generalista. A existência do primeiro é imprescindível para o avanço da ciência, já o segundo, teoricamente possui a capacidade de integrar as variáveis que devem ser atendidas no projeto. Mas, ao analisar os conceitos pregados por Heino Engel e outros autores, há questões que seriam discutíveis atualmente, ao pensar até que ponto se conseguirá sustentar o perfil profissional com conhecimento generalista, diante da impossibilidade cada vez maior de adquirir os conhecimentos gerais disponíveis.

Outras mudanças são indicadas por Addis (2009), ao colocar que a colaboração dos engenheiros de edificações se tornará ainda mais decisiva no futuro, à medida que arquitetos, empreendedores, políticos e a sociedade exigirem edificações com desempenho cada vez mais 
complexo. As edificações terão de incorporar muitas características de projeto que otimizem a utilização de recursos naturais, como energias de fontes eólicas, solar e geotérmica e também sistemas de reuso da água. Além disso, terão que indicar meios de maior racionalização de materiais, com menor produção de resíduos e maior atenção ao ciclo de vida dos materiais e possibilidade de reciclá-los. Para enfrentar estes novos desafios, engenheiros e arquitetos terão que trabalhar de modo cada vez mais sincronizado em projetos complexos e com novos métodos de construção.

Em interface a este assunto, o próximo capítulo foi desenvolvido na intenção de compreender a diversidade de práticas experimentais técnico-construtiva nas escolas de arquitetura, e as particularidades deste processo quando desenvolvido no contexto acadêmico, seja promovendo inovação ou reprodução. Também são retomadas as análises sobre alguns dos profissionais aqui selecionados que, embora com posturas autodidatas e motivadas pela afinidade à temática tecnológica e não pela influência acadêmica, muitos deles discutem a questão da formação profissional ao incentivar e valorizar o processo de experimentação no ensino. 




CAPÍTULO 02 OS PROCESSOS EXPERIMENTAIS NO CONTEXTO ACADÊMICO: O DIÁLOGO ENTRE O PROJETO E A MATERIALIDADE

2.1. A EXPERIMENTAÇÃo COMO PRÁTICA PEDAGÓGICA

2.2. A RELAÇão ENTRE AS ATIVIDADES PROFISSIONAIS E ACADÊMICAS NO PROCESSO EXPERIMENTAL

2.3. CARACTERIZAÇÃO DOS ESPAÇOS EXPERIMENTAIS E ATIVIDADES ACADÊMICAS 




Imagem capa: Jean Prouvè como professor do Conservatório Nacional de Artes e Ofícios - CNAN. Paris, França. Fonte: Allegret (2001) 
O conteúdo deste capítulo está direcionado à área do ensino e inicia sua abordagem com a análise da experiência da Bauhaus perpassando, posteriormente, por diversos períodos, na busca de informações que possam ampliar a compreensão sobre as particularidades do contexto acadêmico. Alguns profissionais analisados no Capítulo 01 foram retomados, identificando aqueles que tiveram a oportunidade de estender seu trabalho para o contexto acadêmico, procurando detectar, quando possível, o processo de transferência dos conceitos profissionais para o ensino. Estas informações conjuntamente à sistematização de diferentes iniciativas pedagógicas desenvolvidas tanto em escolas internacionais como nacionais permitiram refletir sobre questões relacionadas à inovação $\mathrm{X}$ reprodução, assim como, caráter exploratório $\mathrm{X}$ instrução básica, intrínsecas nas atividades experimentais.

\subsection{A EXPERIMENTAÇÃO COMO PRÁTICA PEDAGÓGICA}

Durante o Período Moderno, os processos experimentais para o estudo da materialidade foram amplamente explorados no campo acadêmico com a aplicação de diferentes metodologias pedagógicas. Em meio às transformações observadas nesta época, chamam à atenção as experiências realizadas na escola da Bauhaus que tinha como premissa formar um profissional com habilidades tanto técnicas como artísticas. No livro de Gropius, Bauhaus: Novarquitetura $^{31}$, o arquiteto fundador discorre sobre como deveria ser a preparação futura de designer, artesão e arquiteto, a fim de descobrir o homem de talento artístico e prepará-lo por meio de um profundo treino artesanal para o trabalho criativo no seio do processo da produção industrial. Neste sentido, eram promovidas oficinas com caráter laboratorial, onde modelos eram cuidadosamente construídos e constantemente aperfeiçoados, com clara integração entre atividades experimentais e projeto.

A estruturação do ensino na Bauhaus revela o valor educacional que foi atribuído aos problemas práticos. Apoiando-se nestes princípios, Gropius defende o trabalho experimental no canteiro e nas oficinas, salientando ter estas práticas a mesma importância para a aquisição de conhecimentos de base que o ensino teórico, argumentando ser este último muitas vezes superestimado nas escolas de arquitetura e que a capacidade criativa dos alunos não estaria prejudicada ao ser dada ênfase em questões técnicas como produtividade e economia de recursos e materiais. O arquiteto reforça esta questão ao relatar que a prancheta e o livro não podem substituir a valiosa experiência na oficina e no canteiro, por

\footnotetext{
${ }^{31}$ GROPIUS, W. Bauhaus: novarquitetura. São Paulo: Perspectiva, 1997.
} 
isso, seria preciso que a experiência estivesse unida à formação desde o início e não fosse acrescentada posteriormente, após o término da formação acadêmica.

A vinculação correta entre formação científica e prática na visão de Gropius seria um problema crucial no sistema de ensino, tratando-se do único meio de educação que interrelaciona os talentos de ensino e invenção:

'Poderá um arquiteto tornar-se mestre na sua profissão sem dispor de qualquer experiência com ferramentas e material e sem o conhecimento que ele adquire no processo da construção?' (GROPIUS, 1997, p. 89)

'O impacto da indústria em nossa profissão é tão forte que a geração mais jovem deveria ser formada em contato íntimo com a indústria de construção $e$ seus laboratórios.' (GROPIUS, 1997, p. 90)

A partir destes conceitos sobre o papel das atividades experimentais no curso de arquitetura e, por entender que o principiante ainda não conhece a relação com o mundo conjunto $^{32}$, foi proposto na Bauhaus que a formação deveria ser iniciada por um Curso Preliminar. Nesta fase, o aluno não deveria se restringir aos meios de expressão como o desenho e a pintura, mas explorar os experimentos tridimensionais, isto é, os elementos do 'construir' por meio de diferentes materiais. Estes exercícios traziam uma visão hipotética de que a partir da observação dos contrastes, por exemplo, entre áspero e liso, duro e mole, o estudante poderia descobrir com o uso de suas mãos, as peculiaridades do material, suas estruturas e texturas, adquirindo também, agilidade técnica para desenvolver sua própria linguagem formal. Terminados estes estudos, estaria apto a empreender composições de sua própria invenção, não tendo ainda estes exercícios o compromisso de desenvolver a habilidade profissional.

Ainda de acordo com o arquiteto, na discussão da reforma das escolas de Belas-Artes ficou sem resposta a questão de se saber se estas oficinas deveriam servir exclusivamente ao ensino (e se possível à experimentação criativa e à pesquisa de base artístico-técnica) ou se seu objetivo deveria consistir também da produção real para um cliente determinado ou para o mercado autônomo; em outras palavras, se devia tratar-se apenas de oficinas de aprendizagem (sob determinadas circunstâncias com caráter de laboratório), ou de oficinas de produção.

Ainda em relação ao Curso Preliminar, deve-se destacar a atuação docente de Lazlo Moholy-Nagy (1923-1928) e de Josef Albers (1925-1933). Como professor do Curso Preliminar,

\footnotetext{
${ }^{32}$ Para Gropius, seria um erro impor ao aluno ideias 'profissionais' ou uma especialização no começo de sua formação.
} 
Moholy promoveu vários exercícios para adestramento tátil e óptico dos sentidos que, segundo Wick (1989), não se tratavam de exercícios para reconhecer ou experimentar o material real; mas sim, de um modo geral, de condicionar a sensação à facticidade do tato, transformando-a em qualidades abstratas e em suas relações. Junto a estes exercícios, eram realizados exercícios de construção tridimensional, representando o segundo ponto principal da 'teoria geral dos elementos', de Moholy. Serviam fundamentalmente à educação do sentimento e do pensamento plásticos em relação à construção, a momentos estáticos e dinâmicos, a equilíbrio e a espaço e eram de importância capital para a prática ulterior em todos os ramos da criação. Tais estudos de 'criação' obedeciam a um duplo objetivo pedagógico: de um lado, deveriam possibilitar aos estudantes, através de suas próprias práticas experimentais, conhecerem as categorias elementares da estética visual, tais como massa e proporção, estática e dinâmica, tensão e contraste (Figura 32) e, de outro, tinham por objetivo transmitir a esses mesmos estudantes uma compreensão básica das características e do comportamento de diferentes materiais (peso específico, elasticidade, resistência, etc.).

Com isto, Moholy chegava já no Curso Preliminar, à zona divisória entre escultura e arquitetura, e ao seguir esta orientação ele contribuiu decisivamente para a mudança que se processou depois de 1923 na compreensão que a Bauhaus tinha de si mesma, e para a mudança de curso operada no instituto em direção a uma integração entre arte e técnica.



Figura 32 - Lazlo Moholy-Nagy: Acessório luminoso (modulador luz-espaço), 1922-1930. Fonte: Wick (1989); b) Souza (2014)

A contribuição de Josef Albers como diretor do Curso Preliminar distingue-se de seus predecessores por não se voltar de forma decisiva ao aspecto criativo-individual, nem ser orientado no sentido do construtivismo, mas buscava, sobretudo, o intenso contato com o material dado. O princípio de seu processo pedagógico pode ser resumido na fórmula "aprender através da experiência". E, para alcançar a formação do homem criativo na Bauhaus, Albers escolheu um princípio pedagógico que concedia uma posição primordial ao 
aspecto criativo, e que ele mesmo resumiu na frase: "Experimentar é melhor que estudar"33. Para ele, a transmissão tradicional de conhecimentos e de habilidades não deixa espaço à criação e inibe a capacidade de inventar:

"Onde se faz algum trabalho de carpintaria, de encadernação, de entalhadura. Também o ato de serrar, de aplainar, e também o de limar e prensar, empapelar e colar são improdutivos. Pois atendem tão somente ao impulso de se manter ocupado, e não às necessidades da criação." (WICK, 1989. p.237)

Albers eliminou de seu Curso Preliminar os resíduos da formação artesanal específica e embasou seu ensino sobre dois alicerces: os exercícios com a matéria e os exercícios com materiais. O objetivo dos exercícios com a matéria era a pesquisa da aparência externa das coisas, o estudo da epiderme (processos de acabamento). No caso dos exercícios com materiais, neles pode-se reconhecer a contribuição maior de Albers para a pedagogia da Bauhaus. Diferentemente dos exercícios com a matéria, cujo objetivo era o reconhecimento sensorial das superfícies dos materiais, os exercícios com os materiais voltavam-se à experimentação das características intrínsecas dos materiais, tais como estabilidade, resistência, consistência, capacidade, entre outras. Estes aspectos possuem relação direta com o espírito da época orientado pela economia que, segundo ele, a forma econômica resulta da função e do material.

O propósito fundamental desses exercícios propedêuticos com materiais era a construção, entendida em um sentido mais amplo que não se refere exclusivamente à arquitetura, mas que é vista como desenvolvimento da capacidade geral do 'pensamento construtivo'. Um exemplo pode ser visto em seus exercícios com o uso do papel, procurando sensibilizar os alunos quanto às propriedades do material, e como o processo de dobradura permitia que um material com características tão frágeis, pudesse se tornar rígido. Trata-se, portanto, de uma metodologia educativa e não de fabricação, cujo princípio apoia-se na economia de materiais e de trabalho e o princípio da economia adquire relevância do ponto de vista estético, mesmo parecendo incompatíveis e de caráter limitador da criatividade. A prova de que as restrições externas em nada afetavam a criatividade, pode ser vista na diversidade de trabalhos desenvolvidos em sua disciplina, de acordo com a Figura $33^{34}$.

\footnotetext{
${ }^{33}$ Wick, p. 236.

${ }^{34} \mathrm{O}$ excesso de abstração incomodava alguns alunos, fazendo surgir em 1930 dentro da Bauhaus, um grupo de estudantes comunistas que, numa carta mimeografada, exigia o fim do Curso Preliminar, sendo os principais alvos da crítica, Albers e Kandinski. A crítica era:

Através do ensino estético da forma e dos exercícios com materiais, o curso preliminar (pretensamente) visa a ensinar a conhecer e a tratar os materiais...Duvidamos que se possa realizar essa tarefa mediante a utilização abstrata, isto é, não
} 

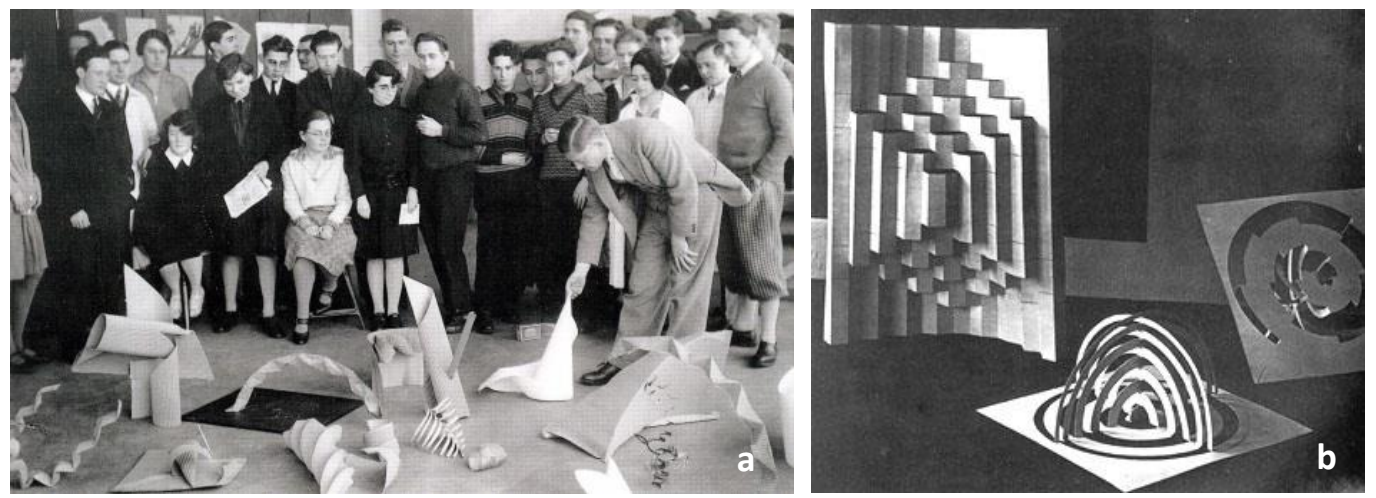

Figura 33 - Exercícios desenvolvidos por Albers com o material papel, com estudos sobre a firmeza e construção sem recortes.

Fonte: a) Droste (2006); b) Wick (1989)

Ao analisar o sequenciamento das atividades do curso oferecido pela Bauhaus, é visto em Gropius (1997), que após o Curso Preliminar os estudantes continuariam necessitando de atividades práticas como aulas de Oficina para adaptarem seus projetos à natureza do material e às técnicas de produção. Nesta fase, o conhecimento da linguagem visual, sua habilidade de construir, desenhar e representar seriam meios imprescindíveis para expressar criativamente as ideias sociais de seu tempo.

Os cursos de Oficinas - conduzidos por mestres artesãos - proporcionaram uma crescente estabilidade na fase inicial da Bauhaus, podendo ser interpretadas como 'núcleos estabilizadores'. Para Wick (1989), um dos méritos dos mestres artesãos seria, portanto, com os conhecimentos que tinham dos materiais e com suas experiências práticas, terem impedido um retrocesso da Bauhaus diante do objetivo em buscar uma mediação entre arte e artesanato, e impedido também que o pensamento da Bauhaus se desviasse em direção a uma academia da elite de vanguarda, transformando-se numa linguagem universal do Instituto'.

Ainda segundo Wick (1989), apesar das declarações de Gropius - no documento de fundação da Bauhaus - representarem um hino em louvor ao artesanato, a hierarquia social da escola, tal como estabelecida nos estatutos, não atribuía aos mestres artesãos qualquer competência decisória. Esta a possuía, em última instância, o diretor, que presidia o assim

funcional, do papelão ondulado, do arame, etc. A confrontação de materiais de diferentes tipos de modo algum demonstra seus valores práticos, mas é algo formal em si... (WICK, 1989. p. 251).

Para Wick (1989), embora os exercícios com materiais pudessem parecer formais, eles se prestavam ao adestramento do pensamento construtivo e da atuação econômica e, de modo algum, seriam exercícios meramente formais. A exigência dos estudantes pelo fim do Curso Preliminar vinha acompanhada da proposta de se criar, em seu lugar, um semestre em oficina, que para alguns críticos teria levado a um diletantismo artesanal. Esta segregação de conteúdos relativos à materialidade: entre o abstrato e o real permanece ainda hoje nas escolas de arquitetura: os aspectos sensoriais como uma disciplina plástica e os aspectos das ciências dos materiais como uma disciplina técnica e ainda hoje estes assuntos são trabalhados de forma dissociada. 
chamado Conselho de Mestres, 'um órgão de assessoria e de decisões no tocante a questões didáticas e de organização'. Neste conselho de mestres só estavam representados com direito a voto os mestres da forma; os mestres artesãos tinham somente uma função consultiva. Esta subordinação dos mestres artesãos aos mestres da forma, que forçosamente viria a gerar tensões, mostra claramente que, na fase inicial, apesar da supervalorização retórica do artesanato, apesar de toda a programação, cujo objetivo era a desmistificação da imagem tradicional do artista, a prioridade ainda recaia sobre o criador autônomo, sobre o artista que defendia exclusivamente o sentido teórico da arte. Não há dúvida que contribuiu para isso, o fato de quase todos os mestres da forma serem personalidades artísticas de indiscutível categoria e marcada individualidade, que em virtude de sua autoridade artística estabeleceram um distanciamento entre si e dos mestres artesãos ${ }^{35}$.

A Bauhaus, portanto, em sua fase inicial estava longe de ser um instituto de formação, no qual se concretizasse a noção da obra de arte total sob 'as asas da arte da construção'. Nesse sentido, faltava nos primeiros anos não apenas um Departamento de Arquitetura, que deveria ser o eixo de rotação da Bauhaus segundo sua ideia inicial, mas também a coordenação entre as diversas oficinas, o que teve por consequência surgirem entre elas diferenças cada vez mais graves, no tocante à estrutura de trabalho e à conformidade com os objetivos ${ }^{36}$.

Mesmo diante destas ausências concretas, havia ideias hipotéticas de como deveriam ser desenvolvidas as atividades na área da construção. De acordo com Gropius (1997), após o Curso Preliminar e o curso de Oficinas, os alunos que quisessem se diplomar arquitetos deveriam cursar uma terceira etapa, onde seria promovida a aproximação com o cotidiano profissional por meio de visitas às construções, fábricas e institutos de pesquisa, de maneira a permitir o maior entendimento sobre a fabricação e o processo de construção, em que deveriam ser obrigatórias as experiências em canteiro de obras reais. No que diz respeito às escolas, sugere que deveriam manter algumas oficinas experimentais vinculadas a coleções de modelos, onde professores e alunos pudessem juntos fazer experiências no tratamento de superfícies de componentes de construção. Para o fundador da Bauhaus, como a parte prática da profissão de arquiteto estaria ligada ao desenvolvimento técnico, os alunos deveriam ter na

\footnotetext{
${ }^{35}$ WICK (1989). p. 40.

${ }^{36}$ A institucionalização do curso de Arquitetura ocorreu apenas em 1927, com a criação do tão sonhado Departamento de Arquitetura.
} 
escola a oportunidade de experimentar e testar como os estudantes de medicina, biologia e química faziam em seus laboratórios ${ }^{37}$.

Neste mesmo período, paralelamente às experiências aplicadas na Bauhaus, outras discussões eram travadas sobre o processo experimental, diante dos avanços alcançados em todas as áreas das ciências. No caso da engenharia, muitos profissionais se valeram destas ferramentas físicas para o melhor entendimento e aperfeiçoamento de suas criações, como também, travaram discussões importantes sobre a adoção da metodologia experimental quando direcionada ao ensino acadêmico. Em interface aos princípios defendidos por Gropius - ao equiparar o curso de arquitetura com outros de caráter mais técnico-científico - Pippard (1947), defende a importância da associação de meios no processo investigativo experimental nos cursos de engenharia, de maneira que o conteúdo teórico ministrado em sala de aula fosse trabalhado juntamente ao processo experimental, possibilitando que os dados fornecidos por estas ferramentas fossem interpretados com o apoio deste recurso.

O autor reforça esta questão ao relatar algumas experiências de Hardy $\operatorname{Cross}^{38}$ no campo acadêmico, ao observar que a maioria dos estudantes de estruturas complexas estavam tão ocupados na busca de inúmeras ferramentas que nunca aprendiam a usá-las. Para Pippard e Cross, a habilidade de projetar objetos complexos seria mensurada na habilidade de visualizar e interpretar o processo experimental em associação com o conteúdo teórico em direção à simplificação do problema. Este caminho leva à formação de um profissional capaz de reinventar continuamente, para adaptar-se as mudanças que influenciam com maior ou menor intensidade as possibilidades de ações sobre o ambiente construído.

O posicionamento de Rapson $(1970)^{39}$ vai ao encontro com os de Cross e Albers, quando direciona críticas ao processo de aquisição de conhecimento por meio de respostas conhecidas, que muitas vezes não deixam espaço para dúvidas, argumenta que quanto mais se adquire informação e conhecimento das soluções previamente bem-sucedidas, aumenta-se o perigo do atrofiamento da imaginação. Diante disso, o processo experimental em associação

\footnotetext{
${ }^{37}$ Até 1927, devido às dificuldades orçamentárias, havia o impedimento de criação do departamento de Arquitetura (o centro de experimentação da construção solicitado por Gropius, em 1923, não havia sido aprovado), o ensino da construção ganhou então a importância que the era devida no plano de ensino da Bauhaus, para logo depois ganhar uma superioridade que colocava em perigo as ideias iniciais de uma escola unificada de arte. WICK, (1989). p.55.

${ }^{38}$ Hardy Cross foi professor de engenharia civil e engenharia estrutural na Universidade de Illinois (1930-1937) e Yale (19371951), criador do famoso método matemático interativo de cálculo de reações estruturais conhecido como método de HardyCross, fundamental para simplificação de cálculos estruturais e adaptado para cálculos de vazões em tubulações malhadas sobre pressão em redes de distribuição de sistemas de abastecimento de água. Disponível em: http://www.brasilescola.com/biografia/hardy-cross.htm. Acesso em 30 ago. de 2013.

${ }^{39}$ RAPSON, R. Prefácio. In: Sistemas de Estructuras, Madrid: Blume, 1970.
} 
à teoria, poderia tornar-se um processo de aquisição de conhecimento capaz de contribuir para ampliar a criatividade do estudante.

$\mathrm{O}$ arquiteto Pascal Rollet, que participou como coordenador e docente no Grands Ateliers de l'lle d'Abeau ${ }^{40}$, também encontra-se entre os profissionais convencidos da necessidade em se promover oportunidades investigativas por meio de protótipos e modelos físicos no contexto acadêmico. Em Hoyet (2007), o arquiteto sugere que as experiências acadêmicas poderiam ser conduzidas por operações reais na escala 1:1, atendendo tanto o interesse dos laboratórios de ensino em que atuam alunos e professores, como também, de arquitetos e industriais.

Sobre a manipulação dos materiais construtivos, em Rollet (2007), o autor defende que por não ser um processo integralmente científico (sensorial e técnico), o processo intuitivo torna-se relevante, e que este seria então um campo de atuação do arquiteto. Mas, ao referirse às atividades de desenvolvimento de novos materiais, sinaliza que determinados especialistas seriam os profissionais mais adequados para a pesquisa científica, devido à necessidade de um profundo conhecimento sobre determinadas questões envolvendo a materialidade. Para ele, o processo experimental realizado no ensino de arquitetura poderia ser direcionado ao desenvolvimento de processos de montagem, técnicas e associações construtivas, levando em consideração diferentes materiais e criando oportunidades de aplicação para alguns deles cujo campo da arquitetura possa não ser habitual ${ }^{41}$. 0 desenvolvimento destas práticas teria também caráter pedagógico, pois encoraja a descoberta do potencial de diferentes materiais, propiciando a aquisição de maior segurança sobre os princípios de desenho, uso dos materiais e análise estrutural.

O reflexo do estudo (ou da falta de estudo) da materialidade em outras áreas do ensino pode ser visto em Tamashiro (2010). Em seu trabalho, o autor é enfático sobre as implicações que a falta de entendimento técnico-construtivo podem trazer ao ensino do desenho técnico arquitetônico, associando a crise no ensino tecnológico à crise no ensino do desenho técnico. A partir destes dois diagnósticos - a do desenho sofrível e do desconhecimento técnico construtivo - propõe uma nova possibilidade de inovação didática no ensino de desenho

\footnotetext{
${ }^{40}$ Grands Ateliers de I'lle d'Abeau, encontra-se perto de Lyon, França. Trata-se de um espaço de uso compartilhado entre diversas escolas francesas de arquitetura, administrado por iniciativa público-privada. Tem como objetivo reunir em um mesmo espaço arquitetos, engenheiros e artistas, para que juntos, possam projetar, desenvolver pesquisas e transferir seus conhecimentos sobre materiais, técnicas de construção e qualidade do ambiente construído. Informações obtidas em: http://www.grenoble.archi.fr/ecole/grands-ateliers-isle-abeau.php. Acesso em: 25 de agosto de 2013.

${ }^{41} \mathrm{O}$ autor ainda complementa esta questão ao reconhecer que, embora os laboratórios acadêmicos de pesquisa concentrem grande quantidade de pessoas competentes e com tempo para a pesquisa, os mesmos sofrem com problemas relacionados à falta de recursos. Diante disso, sugere como solução para este problema o firmamento de parcerias junto ao setor industrial.
} 
técnico arquitetônico, comprovando que a aplicação de exercícios experimentais, com o preparo de aulas que ensinam questões técnicas da construção, bem como sua correta representação gráfica, pode resultar em ganhos em boa parte dos desenhos elaborados pelos alunos.

Neste sentido, tornaram-se recorrentes as discussões envolvendo, por um lado, o estudo da materialidade e, por outro, novas formas de representação do objeto arquitetônico, a partir da inserção de novas ferramentas investigativas ao longo do desenvolvimento projetual. Em Grande (2000), o autor faz uma consideração pertinente sobre a exaltação do poder representacional da tecnologia sobre o da sua aplicação construtiva, que pode levar a construção de sedutores modelos espaciais tridimensionais, mas que se revelam majoritariamente inócuos na possibilidade de se tornarem materializáveis ${ }^{42}$, estas considerações vão ao encontro das preocupações explicitadas em Tamashiro (2010), que atribui parte da deficiência vista em desenho técnico à falta de vivência do alunado com experiências materiais reais ${ }^{43}$.

No trabalho de Bayl-Smith (2011), a autora traz alguns indícios sobre as mudanças no ensino da Tecnologia da Construção em diversas universidades internacionais, priorizando em sua pesquisa as escolas que apresentam integração entre o ensino de Tecnologia da Construção e o Estúdio de Projeto, ao entender ser esta uma oportunidade de expandir o conhecimento sobre construção além das competências tradicionais do currículo acadêmico. Assim como relatado em Grande (2000), a autora faz questionamentos a respeito da inserção de 'novas' tecnologias no processo de fabricação construtiva nos cursos de arquitetura e, se as experiências atualmente exploradas conseguem atingir o grau científico/tecnológico sobre a materialidade construtiva ou permanecem no campo formal/criativo, apresentando uma falsa noção sobre os princípios construtivos reais ${ }^{44}$. A partir desta preocupação, nota-se que o questionamento sobre os rumos do ensino em tecnologia da construção adquire dimensões mais amplas diante do pseudo-entendimento de que novas ferramentas investigativas, como

\footnotetext{
${ }^{42}$ Esta constatação pode ser estendida para o processo de execução de modelos físicos desenvolvidos por meio de novas ferramentas como CNC, impressoras 3D, cortadora a laser, sem o apoio do conhecimento técnico-construtivo dos materiais reais, limitando o aluno ao papel de mero programador e manipulador destes aparatos.

${ }^{43}$ Antes, a problemática era a indagação se a utilização de maquetes e modelos físicos confeccionados com materiais irreais dariam a sensibilidade ao aluno sobre as características físicas e mecânicas dos materiais construtivos. Atualmente, as novas ferramentas de representação, tanto virtual como física, trazem à tona um novo impasse: até que ponto estas ferramentas permitem a aquisição de conhecimentos sobre a materialidade real?

${ }^{44}$ As visitas realizadas pela autora em diferentes instituições de ensino de Arquitetura serão retomadas e discutidas no Item 2.3 deste Capítulo.
} 
impressoras e cortadoras computadorizadas poderão substituir, em sua totalidade, a sensibilidade construtiva adquirida a partir de atividades cognitivas tradicionais.

Uma compilação de trabalhos nacionais com diferentes abordagens sobre o projeto arquitetônico e as metodologias e tecnologias associadas ao seu processo de desenvolvimento são vistos em Kowaltowski et. al. (2011). Este trabalho defende como postura teórica, a associação do fazer arquitetônico à atividade científica e, no que diz respeito à técnica, traz investigações acerca de técnicas e ferramentas disponíveis para a aplicação no processo de projeto, com exemplos de emprego de alguns experimentos em laboratório.

A partir deste trabalho, é possível verificar a necessidade de expandir a discussão de maneira a aproximar a adoção de ferramentas físicas investigativas com a realidade material, ao entender que a avaliação dos aspectos inerentes aos materiais construtivos continua sendo um processo de experimentação mais passível de ser atingido em espaços como o canteiro e laboratórios específicos. As novas ferramentas investigativas, como prototipagem e modelagem virtual, complementam e melhoram os estudos, mas não substituem os dados obtidos por meio de processos próximos à escala real e com materiais reais.

$\mathrm{Na}$ intenção de dar continuidade a esta discussão, o item 2.2 apresenta diferentes experiências acadêmicas desenvolvidas por alguns dos profissionais abordados no Capítulo 01, que tiveram a oportunidade de se envolverem com o processo de formação. A partir deste estudo, é possível compreender como ocorre a aproximação entre seus conceitos profissionais e acadêmicos a partir de suas propostas voltadas ao ensino. E, como seria o papel da experimentação como instrumento pedagógico/metodológico na visão destes profissionais.

\subsection{A RELAÇÃO ENTRE AS ATIVIDADES PROFISSIONAIS E ACADÊMICAS NO PROCESSO EXPERIMENTAL}

O contexto acadêmico foi em diversos momentos uma possibilidade de extensão do trabalho de alguns profissionais. Este período em contato com o ensino reflete nitidamente o quanto acreditavam na valia do processo experimental como instrumento para a inovação construtiva e no avanço da ciência. Embora o contexto acadêmico imponha algumas condicionantes - tanto limitadoras como também facilitadoras do trabalho experimental estas experiências podem ser consideradas como oportunidades de sustentarem os princípios defendidos em suas carreiras profissionais, ampliando o papel da universidade como produtora de conhecimento para a sociedade. 
Sobre a relação entre academia e atuação profissional, em Torroja (1958), o autor faz algumas considerações sobre o processo de aprendizagem, ao relatar que, embora a parte teórico-técnica seja iniciada nas escolas, o processo de especialização, necessária para dominar o tema, ocorre depois da formação. Para ele, sendo ou não principiante, a formação continuada era necessária, pela oportunidade de complementação dos estudos e discussão dos problemas e ainda alertava que a pouca importância dada sobre esta questão poderia induzir a tendências individualistas.

Diante do reconhecimento da insuficiente bagagem adquirida ao longo da formação acadêmica, em Torroja (1958), o engenheiro propõe que fossem criados espaços de intercâmbio entre diferentes profissionais, com trocas de conhecimentos, métodos e tendências, devido à diversidade de contextos econômicos, sociais e tecnológicos. Além disso, defende a preparação de um profissional mais crítico e reflexivo e não apenas proporcionarIhe a aquisição de conhecimento:

[...] y el caso es que en las escuelas hay tanto que aprender que rara vez queda tiempo para pensar. (TORROJA, 1958, p. 1)

Sobre a experimentação física (Figura 34), considera ser esta uma forma eficaz no ensino de melhorar o entendimento dos princípios básicos das estruturas e aguçar o processo da intuição que, em associação ao profundo conhecimento dos materiais construtivos, seria possível alcançar a formação de um profissional mais reflexivo diante do dinamismo tecnológico vivenciado:

El asombroso avance, que en las teorías mecánicas de los elementos sustentantes de las construcciones han producido los siglos XIX y XX, hace menospreciar excesivamente el estudio ontológico de la morfología resistente. Todo proyectista que descuide el conocimiento de sus principios, está expuesto a graves fracasos. (TORROJA, 1958, p. 1)


Figura 34 - Estudos de Eduardo Torroja com modelos de escala reduzida. a) Hospital Cidade Universitária, Madri, 1934. b) Fronton Recoletos, 1935. c) Investigações sobre canais e diques.

Fonte: Torroja (1958). 
Seus princípios vão ao encontro dos defendidos por Nervi (1951), ao relatar que o ensino técnico será muito mais eficiente quando acompanhado de demonstrações experimentais, privilegiando o processo intuitivo e conceitual:

"El alumno que ha visto todo esto con sus propios ojos (y los modernos equipos de laboratorios, sean extensimétricos, sean fotoelásticos, permiten que se realicen esta visión directa de los estadios de coacción de los materiales) puede, mucho más facilmente que a través de la sola enseñanza matematica, hoy unicamente usada, llegar a una clara comprensión del mundo estático-resistente, base indispensable para la invención estructural." (NERVI, 1951, p.22-23)

Em diversas oportunidades o engenheiro discute sobre a dificuldade de se alcançar a síntese entre arte e técnica, agravada ao longo dos anos pelo desenvolvimento técnicocientífico da construção, pela complexidade dos temas e pela formação acelerada, a fim de atender à multiplicação das atividades na área da construção. Em Nervi (1965), sintetiza a essência deste problema em duas partes:

a) Preparação técnico-científica - Fala sobre a insuficiência do desenvolvimento teórico e que o campo entre a teoria e a realidade física não pode ser corretamente resolvido se não passar por um processo intuitivo dos resultados, para que as fórmulas sejam revistas. Para ele, a materialidade não poderá ser alcançada se não uni-la à investigação experimental (Figura 35), a fim de complementar e superar a fase científico-matemática, mas isso não descartaria a importância da aquisição de uma base teórica sólida ao longo da formação;


Figura 35: Estudos realizados por Luigi Nervi com modelos reduzidos. a) Investigações sobre solicitações em coberturas onduladas em ferro cimento. b) Modelo de cobertura em ferro cimento estudada pela Universidade de Tucumán, Laboratório em Milão. c) Investigações em escala real para uma nova Fábrica de tabaco em Bolonha.

Fonte: Nervi (1965)

b) Preparação artística - Ao realizar críticas sobre a falsidade construtiva e funcional vivenciadas em sua época, Nervi sugere que a faculdade deveria orientar para uma verdade funcional, técnica e econômica, acreditando que, na maioria dos casos, este seria o caminho para alcançar o aspecto estético satisfatório. 
Há um consenso entre Torroja, Nervi, Lelé e também Dieste, sobre a necessidade da formação de um profissional mais crítico e reflexivo diante do dinamismo tecnológico vivenciado, sendo fundamental a aquisição de uma base sólida sobre os fundamentos científicos. Em Dieste (1987), o engenheiro uruguaio reforça esta questão ao tratar como um problema a acentuada erudição, relacionada à demasiada preocupação na obtenção de informações sobre o que se está fazendo no mundo, em detrimento do processo de reflexão sobre os fundamentos. Como a maioria de suas obras foram desenvolvidas e condicionadas à realidade contextual, defende que a formação deva dar lugar, predominantemente, às matérias básicas, pois ao pensar cada passo a partir das grandes bases do conhecimento, seria possível alcançar resultados criativos diante de contextos tão diferenciados daqueles que exportam 'alta tecnologia', não cedendo ao encanto das fórmulas finais que podem ser muito sintéticas e elegantes, mas não são fontes verdadeiras do processo criativo.

Assim como o discurso defendido por Dieste tem relação direta com sua atuação profissional - fortemente influenciada pelos aspectos contextuais - o envolvimento de Jean Prouvè com a academia gerou oportunidades de mudança significativa no processo de ensino, ao adaptar e transpor o conhecimento prático acumulado ao longo de sua carreira para suas aulas, atentando para questões sobre a influência do processo construtivo no resultado formal, segundo Prouvè (2005) e Allegret (2001), uma abordagem que até então não era comum nos cursos da área da construção.

Sua experiência acadêmica iniciou em 1957 e durou treze anos. Segundo Allegret (2001), embora a atuação docente no $\mathrm{CNAN}^{45}$ tenha sido curta, esta foi uma oportunidade de transmitir tanto suas experiências práticas, como também, seu conhecimento sobre os sistemas construtivos baseado em processos investigativos envolvendo desde etapas de desenho até o acabamento dos componentes, mas sem recorrer ao cálculo. Naquele período, era rara a abordagem de todas as etapas construtivas no ensino acadêmico, mas já era percebido ser eficaz, motivo que atraia para suas aulas noturnas não apenas os futuros engenheiros, mas outros estudantes do CNAN, assim como, vários profissionais da construção: artesãos, construtores e jovens arquitetos insatisfeitos com o academicismo de sua formação (modelo Belas Artes).

Segundo Prouvè (2005), em paralelo às aulas, eram realizadas atividades práticas de meias jornadas em um local que pouco a pouco se transformou em ateliê. Vale destacar, que os alunos que estavam no trabalho prático visavam, principalmente, o diploma de engenheiro.

\footnotetext{
${ }^{45}$ CNAN - Conservatório Nacional de Artes e Ofícios.
} 


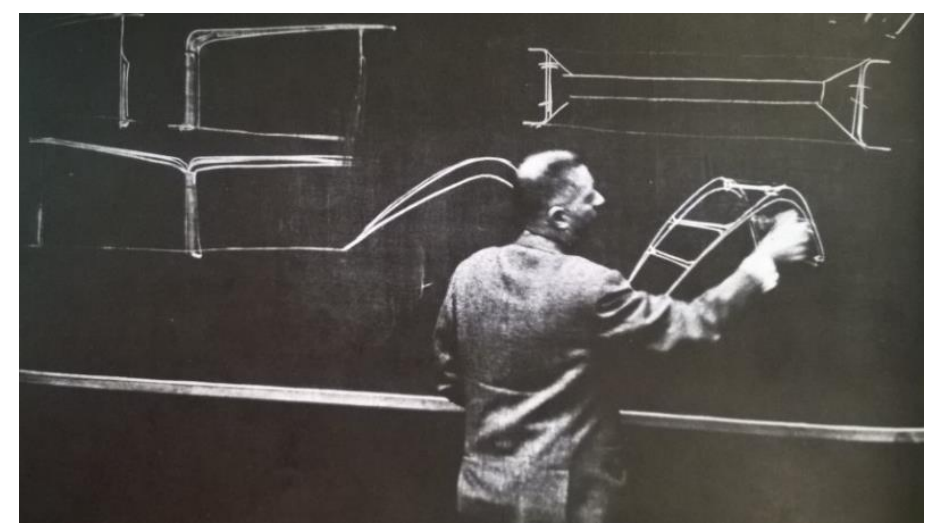

Figura 36 - Jean Prouvè como professor do Conservatório Nacional de Artes e Ofícios - CNAN. Fonte: Allegret (2001)

Atuando em contextos distantes, mas próximos temporalmente, o arquiteto João Filgueiras Lima - Lelé, traz suas primeiras contribuições para o ensino no mesmo período da experiência docente de Jean Prouvè. Dentre as oportunidades surgidas que possibilitaram sua aproximação com a academia, destacam-se: a experiência na UNB em Brasília, a de Abadiânia em Goiás e as realizadas em sua Fábrica na cidade Salvador, Bahia. Estas experiências são distintas entre si devido ao momento histórico/contextual em que foram desenvolvidas e pelas diferentes relações travadas entre Universidade e contexto profissional que, embora as particularidades, em todas elas foram realizados esforços por parte do arquiteto em promover a aproximação dos estudantes com experimentações reais ${ }^{46}$.

Em relação à UNB, ingressou como professor associado a convite de Darcy Ribeiro e Oscar Niemeyer, ficando responsável pela pós-graduação em arquitetura e pelo curso de técnicas e tecnologia da construção. De acordo com Lima (2004), foi estimulado a criar um grande centro de construção industrializada, um centro de Tecnologia que seria usado pela Universidade, esta deveria ser a base de todo o ensino de Arquitetura e Engenharia na Construção Civil, integrando o ensino à produção, com os jovens arquitetos atuando no próprio sistema, seria um espaço laboratorial de pesquisas no campo da construção civil e formação profissional. Embora a fábrica não tenha se concretizado por causa do golpe militar, esta experiência foi de grande relevância na história da pré-fabricação dentro da Universidade.

A segunda experiência que firmou algum vínculo com a academia foi em Abadiânia por volta de 1982. Neste período, lecionou na UCG (Universidade Católica de Goiás), que teve um papel importante como financiadora da experiência, propondo assim como na UNB, que a

\footnotetext{
${ }^{46}$ De acordo com o conteúdo extraído da transcrição da palestra ministrada pelo arquiteto no evento ARQ-FUTURO, em 2011, todas as experiências realizadas junto à academia fracassaram. Talvez isso tenha ocorrido porque neste processo de aproximação entre Academia e experiências reais, o foco principal do arquiteto não era o processo de formação. E, estes dois universos, Academia e Profissional, seguem ritmos e interesses distintos.
} 
universidade estivesse integrada à experiência por meio de uma fábrica com a participação do curso da Engenharia Civil ${ }^{47}$. Segundo Lima (1984), a partir da construção de protótipos experimentais com caráter didático, foi possível demonstrar a viabilidade de se utilizar mãode-obra de baixa qualificação, adotando-se tecnologia avançada e obtendo um produto de alta qualidade, mesmo diante de um contexto precário e complexo.

Esta segunda experiência foi interrompida, sendo anos mais tarde realizada uma terceira tentativa na cidade de Salvador, na Fábrica das Cidades. A intenção era recuperar a ideia de escola integrada à fábrica, destinando uma parte do terreno adquirido a uma escola de pósgraduação e a outra parte à fábrica. Infelizmente, a parte destinada ao ensino de arquitetura com laboratórios de pesquisa integrados à produção nunca foi desenvolvida.

Embora as tentativas frustradas, suas propostas de aproximação com a academia estão diretamente relacionadas com sua metodologia projetual, em que a arquitetura é vista como processo. Para o arquiteto, suas experiências construtivas bem sucedidas no campo profissional tinham grande potencial didático pedagógico, salientando a importância dos jovens arquitetos se envolveram com as experimentações técnico-construtivas. $O$ arquiteto defendia que era preciso dominar o suficiente para dialogar com os especialistas, sendo necessário ao longo da formação dosar a bagagem técnica com a formação artística. Para Lelé, esse aspecto é muito difícil na formação do arquiteto: equilibrar até que ponto se deve aprofundar em determinadas áreas do conhecimento que vão ser necessárias.

A aproximação com a academia como visto em Lelé, pode ter motivações estratégicas diante da necessidade de obter cunho mais científico ao longo do desenvolvimento projetual, assim como, aprofundar conhecimentos por meio da experimentação construtiva. Este cenário é ainda mais evidente ao analisar Frei Otto, pois seu envolvimento com a academia coincide com o momento que passou a tratar a arquitetura sob bases científicas, e isso ocorreu, segundo Drell (1976), quando transferiu seu Laboratório de Estruturas Leves (Institute for Lightweight Structures) para a Universidade de Stuttgart, gesto que evidencia a essência do seu método em aproximar a arquitetura da ciência. Esta pode ser considerada uma estratégia para a obtenção de investimentos contínuos em suas pesquisas e dar maiores chances de materializá-las a partir da oportunidade de aplicação dos resultados em situações reais.

\footnotetext{
${ }^{47}$ Entre as experiências da UNB e Abadiânia, Lelé também se aproximou da área experimental acadêmica por outras vias, ao conhecer o trabalho do engenheiro e professor da EESC-USP Frederico Schiel. A partir daí, com a realização de algumas experiências com Schiel em Brasília em 1972 e, posteriormente, em Salvador em 1979, Lelé alcança um cunho mais científico no aperfeiçoamento da técnica, dando continuidade experimental ao conhecimento adquirido em Abadiânia-GO.
} 
O laboratório sediado na Universidade de Stuttgart foi coordenado por Frei Otto no período compreendido entre 1964 e 1990. Neste local foram desenvolvidos modelos famosos, como o pavilhão alemão na Expo '67', em Montreal, e o Estádio para os Jogos Olímpicos de 1972, em Munique, iniciando suas atividades com apenas seis alunos. Mas, por volta de 1971, este número já havia aumentado para 70 alunos e diversos outros pesquisadores, alguns deles vindos de diferentes partes do mundo, atraídos pelo caráter experimental do laboratório. 0 edifício cuja estrutura principal em forma de tenda explicita as pesquisas lá realizadas foi concebido de maneira a promover uma dinâmica pedagógica particular, a partir de um layout que permitisse que os grupos tivessem maior flexibilidade e pela sua conexão com a área externa, possibilitando a realização de seminários ao ar livre (Figura 37).

Esta organização diferenciada no ensino atraiu para o Instituto uma geração ávida por métodos pedagógicos alternativos, neste caso, a inserção da área laboratorial, sendo que a maior parte das atividades desenvolvidas pelos alunos era direcionada para a confecção de modelos físicos. O processo de construção de modelos conduziu à exploração de recursos diferenciados, desde a medição com equipamentos de grande precisão - o que exigiu intenso trabalho colaborativo com outras áreas do saber - até a adoção de experimentos lúdicos e materiais imprevisíveis como ovos, bolhas e espumas; sendo as pesquisas também direcionadas ao aperfeiçoamento dos dispositivos de medição, necessários para os modelos não convencionais.

Otto incentivava novas formas de interação social, com discussões abertas a grupos de pesquisa interdisciplinares, promovendo a colaboração entre arquitetos, engenheiros, biólogos, antropólogos e historiadores. A insistência de Otto na pesquisa e experimentação como metodologia projetual permanece quase sem paralelo na cultura arquitetônica, mas suas experiências pedagógicas conseguiram acompanhar diversas mudanças que ocorreram no mundo, tanto tecnológicas como comportamentais.


Figura 37: Instituto de Estruturas Leves de Stuttgart. a) Alunos observando um modelo de estudos para o Estádio de Munique, 1969. b) Otto com alguns alunos em um seminário ministrado na área externa do laboratório, 1968. c) Estudos com modelos não convencionais.

Fonte: http://radical-pedagogies.com/search-cases/e14-institute-lightweight-structures-university-stuttgart-ilek/. 
Além dos princípios defendidos pelos profissionais supracitados, outras discussões envolvendo a temática experimental foram travadas no âmbito do ensino. Estas iniciativas pedagógicas, embora não estejam diretamente ligadas ao contexto profissional pelo seu caráter predominantemente acadêmico, podem contribuir para explicitar a diversidade de entendimentos sobre o tema desta pesquisa, como pode ser visto em algumas ações implantadas e analisadas no item 2.3.

\subsection{CARACTERIZAÇÃO DOS ESPAÇOS EXPERIMENTAIS E ATIVIDADES ACADÊMICAS}

Diferentes fontes revelam que o conteúdo abordado no ensino dos cursos de arquitetura tem sofrido transformações em resposta às novas demandas e entendimentos sobre o processo de desenvolvimento projetual. Em relação à área da Tecnologia da Construção, foram observadas diversas discussões envolvendo as práticas experimentais acadêmicas, como o desalinhamento entre as disciplinas de projeto e de construção, com a priorização do produto em relação ao processo ${ }^{48}$. Sobre isso, a pesquisa de Bayl-Smith (2011) sobre o futuro do ensino da Tecnologia da Construção, analisa as metodologias de aprendizagem desenvolvidas por meio de visitas técnicas em diferentes escolas de arquitetura do contexto internacional, observando a existência de problemas comuns e complexos que envolvem o ensino da área técnico-construtiva.

Dentre as dificuldades levantadas pela autora, destaca-se a falta de recursos necessários para o financiamento das práticas experimentais e a influência que as administradoras universitárias exercem no desenvolvimento de determinados setores do ensino, como o laboratorial e os estúdios de projeto, ao regularem a liberação contínua de recursos. Outra problemática seria a falta de intercâmbio entre o campo profissional, o industrial e o

\footnotetext{
${ }^{48}$ O trabalho de Ostwald e Williams (2008), complementa esta observação, ao destacarem que diversas disciplinas básicas da área da Tecnologia da Construção e de Estruturas, estão sendo corroídas pela ascensão de competências genéricas e pela proposição de um currículo fragmentado e com um número elevado de disciplinas, concluindo que esta realidade tem conduzido a falta de clareza sobre as reais competências e responsabilidades do futuro profissional. Dentre as recomendações listadas pelos autores é possível destacar aquelas que possuem maior ligação com a área da Tecnologia da Construção: Recomendação 3 - Clareza e responsabilidade - falta de clareza sobre a educação e as responsabilidades das escolas de arquitetura sobre as práticas arquitetônicas. Recomendação 4 - Currículo superlotado - Os requisitos mínimos curriculares estão se tornando mais extensos e incompatíveis com o tempo e recursos disponíveis. Maior ênfase em competências genéricas e falta de clareza sobre as competências da profissão. Recomendação 6 - Competências genéricas fala sobre o afastamento de competências básicas do currículo (como a Tecnologia da construção e outras áreas de conhecimento técnico) em detrimento de conhecimentos genéricos, levando a perda do foco por proporcionar o desenvolvimento de uma amplitude de conhecimento, mas não a profundidade de conhecimentos específicos e habilidades fundamentais.
} 
acadêmico, de maneira que pudessem ser adequadas e incorporadas às pesquisas dentro de uma estrutura universitária.

O Quadro 06 traz complementações a este assunto, ao realizar uma síntese de diferentes iniciativas de investigações laboratoriais na área técnico-construtivas desenvolvidas atualmente em escolas internacionais. A partir delas, é possível compreender alguns aspectos que caracterizam os espaços utilizados, destacando práticas que agregam maior respaldo científico ao longo do processo de desenvolvimento das atividades, sobressaindo o caráter exploratório em relação à instrução básica.

Quadro 06 - Alguns exemplos de atividades experimentais realizadas em escolas internacionais de arquitetura.

\section{Les Grands Ateliers - Isle D’Abeau - França}

Considerações - $O$ Les Grands Ateliers foi criado em 2002 com a participação de 11 instituições francesas de ensino superior e um centro de pesquisa, com apoio do Ministério da Cultura e Comunicação; o Ministério da Ecologia, Desenvolvimento Sustentável e de Energia e de fabricantes industriais de materiais de construção trata-se de um espaço de uso compartilhado entre várias escolas francesas e administrado pela iniciativa público-privada. O objetivo da criação deste espaço foi possibilitar que artistas, arquitetos e engenheiros se reunissem para o desenvolvimento de módulos de formação, investigação e difusão de conhecimentos e competências relacionados aos materiais e processos construtivos - realizando a fusão entre arquitetura, arte, engenharia, design e indústria - direcionados à inovação tecnológica e pedagógica.
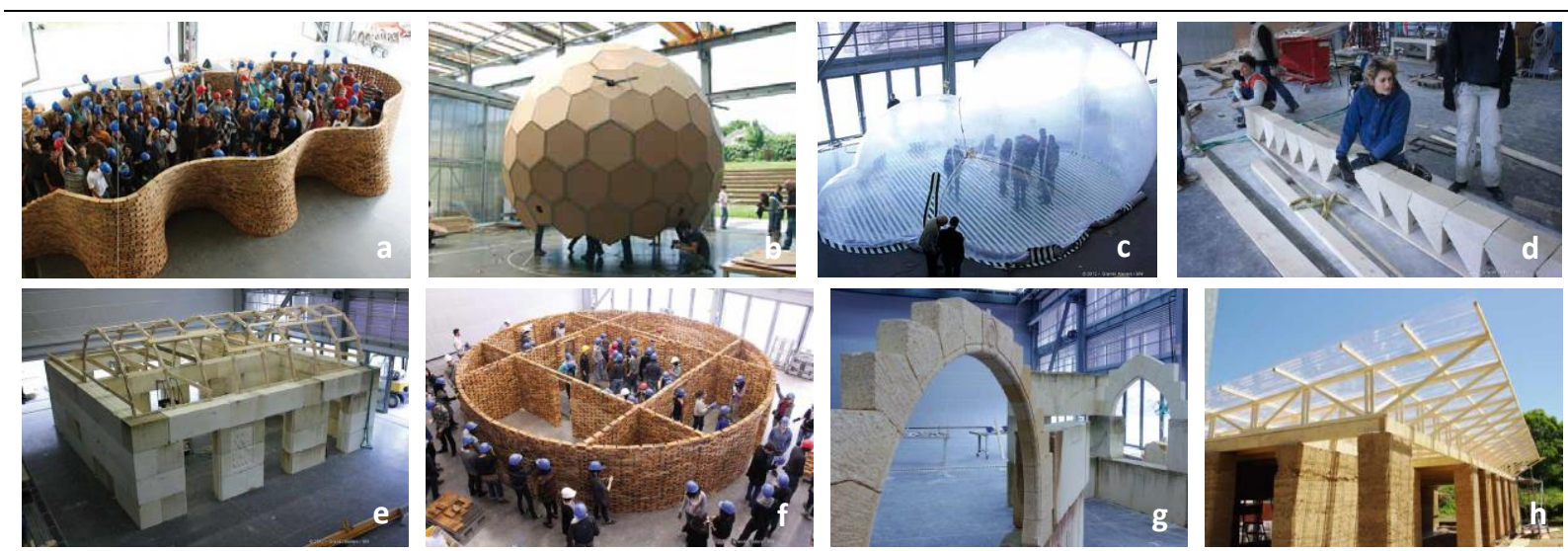

Figura 38: Les Grands Ateliers - Módulos pedagógicos (para manipulação de diferentes materiais: concreto, madeira, pedra, aço, alvenaria e terra) voltados às práticas construtivas. a) e b) Atividades realizadas entre 2008 - 2009. c), d) e) e f) Atividades realizadas entre 2011 - 2012. g) e h) Atividades realizadas entre 2012 - 2013.

Fonte: Disponível em: www.lesgrandsateliers.org.br. Acesso em 08 de agosto de 2013 e 23 de março de 2015.

\section{ETH/Zurich - Suíça}

Considerações - Na escola de Arquitetura D-ARCH na ETH Zurich, o processo exploratório por meio de modelos e protótipos perpassam disciplinas de diferentes áreas. A estrutura departamental está dividida em cadeiras independentes e Institutos de pesquisa com caráter interdisciplinar. No caso do Instituto de Tecnologia em Arquitetura (ITA), são realizadas pesquisas sobre processos construtivos em associação ao projeto arquitetônico. Dentre as nove cadeiras pertencentes ao instituto, sete delas são destinadas às áreas de Estruturas e Tecnologias da Construção e outras duas realizam interface com a área de Fabricação Digital. Verifica-se que a área da Tecnologia é trabalhada em diversas vertentes, como processos e sistemas construtivos, Modelagem estrutural e desenvolvimento de componentes a partir da caracterização física de novos materiais, adotando desde técnicas e materiais tradicionais até a inserção de tecnologias de ponta. As atividades revelam a indissociabilidade entre questões referentes à forma, matéria e aos meios de 
representação, permitindo exercitar o processo criativo entre concepção/construção, alcançando a tangibilidade por meio da experimentação construtiva.
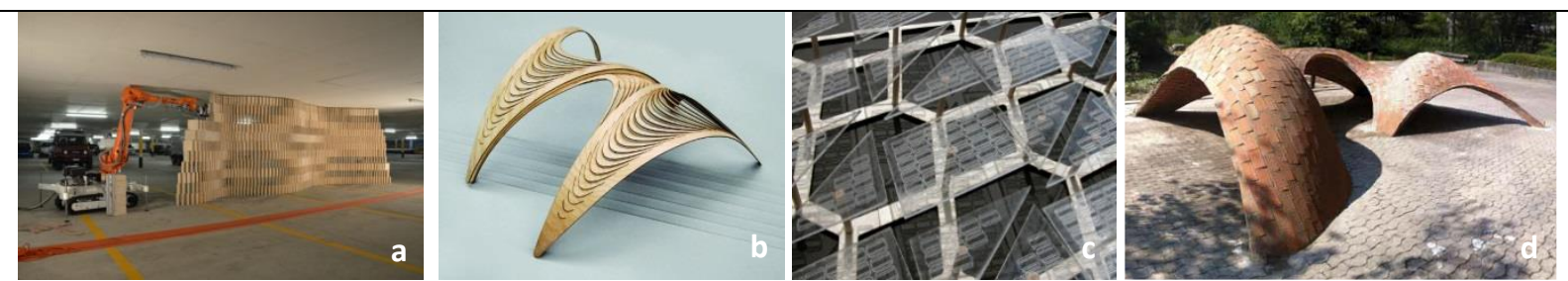

Figura 39: Atividades de pesquisa no ETH/Zurich - ITA - a) Montagem robotizada in loco de 1500 módulos discretizados em madeira. Tese: The Fragile Structure, 2012. b) Projeto de um pavilhão para o campus ETH Science City com base no comportamento de flexão do compensado de madeira, realizado em colaboração com a Architectural Association em Londres. c) Protótipo de um elemento adaptativo para painel solar. d) Protótipo de forma estrutural expressiva alcançada por meio da combinação de técnicas inovadoras (RhinoVAULT) e técnicas históricas de construção (blocos de fina espessura utilizados nas abóbadas catalãs).

Fontes:

- DAVIS, L et al. Innovative funicular tile vaulting: A prototype vault in Switzerland. TheStructuralEngineer. Nov. 2012;

- BAYL-SMITH, M. BuildAbility: the future of construction education. Research Report, May, 2011;

- http://www.ita.arch.ethz.ch. Acesso em 01 de agosto de 2015.

\section{TU Delft - Países Baixos}

Considerações - O curso de arquitetura possui diversos departamentos, dentre eles o AE + T (Engineering Architectural + Tecnology). A partir do entendimento da complexidade de novos campos que se abriram à pesquisa nos últimos anos, como sustentabilidade, eficiência energética, materiais e técnicas de baixo impacto ambiental, etc., um dos objetivos da escola é a promoção de atividades nestas linhas de pesquisa, equalizando criatividade e pesquisas na área da Engenharia.

O curso promovido pelo Buchy Lab (oficina móvel) oferece atividades experimentais em escala 1:1, combinando: Desenho, Técnicas de CAD, Física aplicada às construções, Engenharia de Estruturas e Técnicas de produção industrial. Um dos objetivos divulgados pelo curso é possibilitar que o aluno tenha maior sensibilidade sobre limitações de ordem econômica e humana, criando soluções inovadoras dentro de quadros realistas. Os alunos realizam desde avaliações sobre as características físicas dos materiais construtivos, como também, tem o apoio de instrumentais computacionais para a realização das atividades.


Figura 40: Atividades realizadas pelas equipes do Laboratório Buchy Lab.

Fontes:

- Entrevista realizada em 25 de maio de 2015 (via email), com o pesquisador Jerzy Latka - Doutorando em Desenvolvimento de Produto no Departamento AE + T / Faculdade de Arquitetura/ Universidade de Tecnologia de Delft.

- http://www.buckylab.blogspot.com.br. Acesso em 27 de maio de 2015.

\section{TU Stuttgart - Alemanha}

Considerações - A Faculdade de Arquitetura e Urbanismo é formada por institutos que contemplam diferentes áreas de ensino, dentre os 16 institutos, 06 deles são ou fazem interface à área da Tecnologia da Construção. No caso do Institute of Lightweight Structures and Conceptual Design (ILEK), criado por Frei Otto, pertence à Faculdade de Engenharia Civil e Ambiental da Universidade de Stuttgart. Este laboratório realiza pesquisas associando as áreas de arquitetura com os campos da engenharia, construção e ciência dos materiais. Com uma abordagem altamente interdisciplinar, o instituto se concentra no desenvolvimento de pesquisas sobre vários tipos de tecnologias construtivas: Estruturas para grandes vãos com materiais têxteis, construções com vidros, novas possibilidades construtivas em aço e concreto reforçado e estruturas leves utilizando sistemas adaptativos. O objetivo dos experimentos (em diferentes escalas) é a otimização entre forma e estrutura em relação ao consumo de energia e de recursos, durabilidade e confiabilidade, averiguação do potencial de reciclagem e sustentabilidade ambiental. Devido à abordagem interdisciplinar, este instituto 

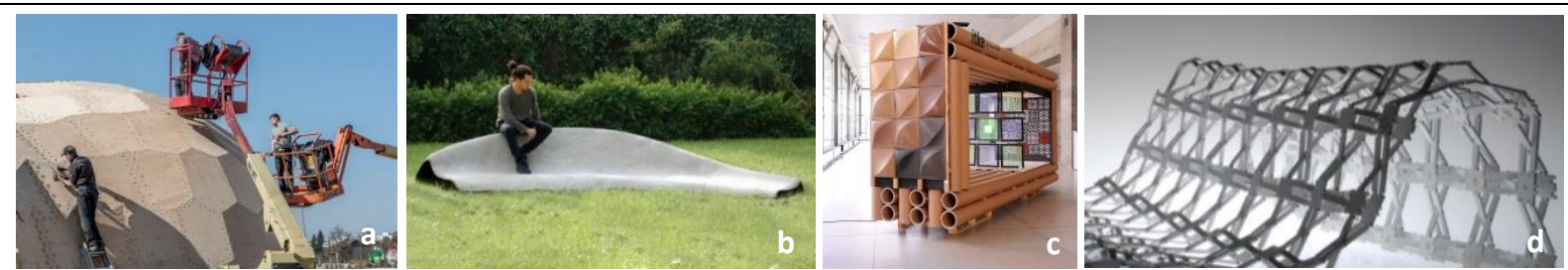

Figura 41: Atividades realizadas em TU Stuttgart. No Institute of Building Structures and Structural Design (ITKE) Faculdade de Arquitetura e Urbanismo - a) Protótipo de uma casca fabricado roboticamente com painéis leves de madeira. b) Protótipo de uma estrutura com forma livre em concreto reforçado. c) Protótipo com resíduos sólidos reciclados - biocompósitos a partir de fibras naturais e resíduos agrícolas recuperados. No Institute of Lightweight Structures and Conceptual Design (ILEK) - Faculdade de Engenharia Civil e Ambiental. d) protótipo de casca fabricada com elementos curtos.

Fonte: http://www.uni-stuttgart.de/home/fakultaeten/index.en.html. Acesso em 01 de agosto de 2015.

\section{Universidade de Kioto - Faculdade de Arte e Design - Japão}

Considerações: De acordo com Vaccari (2015), a presença do arquiteto Shigeru Ban como professor de projeto nesta Faculdade exerceu uma influência direta sobre os alunos, os quais de forma autodidata construíram diversos protótipos adotando os mesmos materiais e sistemas construtivos desenvolvidos pelo arquiteto e sua equipe. Vale destacar que, em diversas ocasiões, as atividades foram realizadas de forma espontânea a partir da iniciativa e interesse dos próprios alunos e não como proposta do curso.
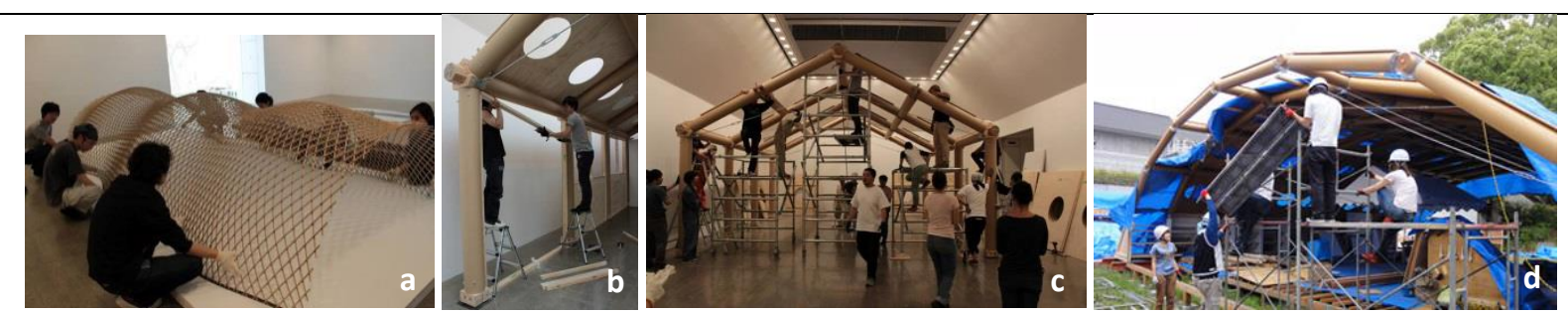

Figura 42: Atividades realizadas em 2013 na Faculdade de Artes e Design da Universidade de Kioto: Práticas a partir da exploração de métodos construtivos adotados pelo arquiteto Shigeru Ban.

Fontes: Imagens concedidas pela arquiteta Mirian Vaccari.

O conjunto de atividades desenvolvidas nestas instituições internacionais permite observar a forte relação existente entre as práticas acadêmicas e as principais discussões que envolvem atualmente a área da tecnologia da construção, como: reaproveitamento de resíduos, inserção de ferramentas computacionais para resolução de formas não convencionais, desenvolvimento de técnicas com materiais de baixo impacto ambiental, atendimento às temáticas emergenciais, manipulação de compósitos e materiais construtivos com maior nível de industrialização e estudos sobre fontes alternativas e renováveis de energia. Todos estes assuntos estão relacionados a temas genéricos como ciclo de vida de materiais, baixo impacto ambiental, cadeia produtiva e eficiência energética, pesquisas que há poucos anos restringiam-se na maior parte delas à pós-graduação e que foram, aos poucos, estendidas à graduação. Os exercícios com modelos físicos e protótipos em escala real revelam preocupação em trabalhar de forma integrada as questões relativas à técnica e à plástica, 
resultando em produtos mais criativos a partir de processos cada vez mais complexos, exigindo discussões simultâneas com equipes multidisciplinares.

A partir das entrevistas realizadas a profissionais que tiveram a oportunidade de participar em algumas das experiências acadêmicas internacionais apresentadas no Quadro $06^{49}$, foi constatada a importância que a área da Tecnologia da Construção e Estruturas ocupa nestes cursos de arquitetura, como algo intrínseco à formação do futuro arquiteto e não com caráter opcional e, também, a importância do envolvimento espontâneo dos alunos (postura autodidata) nas práticas construtivas, que iniciam o curso de forma consciente sobre a dimensão que a área técnica ocupa na profissão e quais as futuras competências profissionais.

Em relação ao contexto nacional, foi possível resgatar algumas iniciativas que contribuíram para a construção de um entendimento sobre a área experimental, influenciando de alguma forma a conformação dos atuais espaços experimentais presentes em várias escolas brasileiras de arquitetura (Quadro 07). A primeira experiência pode ser considerada a implantada na UNB no início da década de 1960, cujos princípios pedagógicos evidenciam a importância dada às práticas técnico-construtivas no processo de formação.

Como já comentado no Item 2.2, embora esta experiência não tenha apresentado vida longa devido às intervenções do regime militar, os conceitos de implantação acabaram repercutindo e influenciando outras experiências no país ${ }^{50}$. Segundo Schlee (2010), o curso de Arquitetura e Urbanismo da UNB entrou em funcionamento em fevereiro de 1962, com sede temporária na Esplanada dos Ministérios e com atividades no canteiro de obras do futuro campus, desde o princípio o seu objeto privilegiado de estudo foi a própria cidade de Brasília e o espaço de treinamento prático a própria Universidade em construção. Neste período, o curso tinha Oscar Niemeyer como coordenador e Ítalo Campofiorito como secretário executivo e o ensino da graduação estava organizado em três linhas complementares: Composição e Planejamento, sob direção de Glauco Campello; Tecnologia, sob direção de João Filgueiras Lima - Lelé e Teoria e História, sob direção de Edgar Graeff. Coube também a Lelé coordenar a pós-graduação, atuando em especial no tronco de técnicas de construção, com ênfase nos estudos sobre industrialização e pré-fabricação.

Assim como o ICA ${ }^{51}$, a graduação era assistida pela pós-graduação, tendo no Ceplan - Centro de Planejamento - uma estrutura peculiar de apoio que, além de

\footnotetext{
${ }^{49}$ Profissionais consultados: Arquiteta Mirian Vaccari - Universidade de Kioto/Japão. Arquiteta Paula Nóia - Le Grands Ateliers - Isle D’Abeau. Arquiteto Jerzy Latka - TU Delft.

${ }^{50}$ Devido à dispersão e migração para outras regiões do país de professores envolvidos no processo de implantação do curso.

${ }^{51}$ ICA - Instituto Central de Artes.
} 
responder pelos projetos do campus, viabilizava na prática a ação dos pósgraduandos. Estamos novamente em face do ensino e sua aplicação; isto é, em face do viés bauhauseano: o corpo teórico que se preocupa com as leis da forma, o conhecimento da natureza e o domínio dos materiais, das técnicas e dos processos produtivos, todos voltados para sua utilização conforme os preceitos éticos do comprometimento social comum. O Ceplan foi responsável à época pelo maior canteiro de pré-moldagem da América Latina. Era, portanto, um campo de experimentação exitosa que objetivava a pré-fabricação da construção no país ${ }^{52}$.

Observa-se que a intenção em aproximar esta proposta da experiência didática bauhauseana revela-se tanto em sua estrutura organizacional - definida em dois níveis de ensino, o universitário e o profissional, com a oferta de oficinas - como também, pela aproximação das atividades práticas com a produção industrial, tratando-se, segundo Almeida (1997), do primeiro exemplo brasileiro oriundo de um plano definido e não da justaposição de cursos pré-existentes.

A arquiteta Mayumi Watanabe ${ }^{53}$ descreve a experiência da UNB como:

"era uma escola em construção, no meio de uma universidade em construção, no meio de uma cidade em construção"

Para Buitoni (2009), há duas particularidades no ensino de arquitetura em Brasília, a primeira refere-se ao destaque que Niemeyer dava à construção, pois para ele, até mesmo o ensino de história deveria estar atrelado à história dos processos construtivos, desta forma, muitas das aulas eram dadas no canteiro de obras da universidade para que os alunos conhecessem todos os métodos construtivos empregados. A segunda seria o destaque dado ao ensino de urbanismo desde o início do curso, para melhor compreensão sobre o contexto de inserção do projeto.

Embora haja indicativos de que a experiência inovadora da UNB pudesse trazer dados consistentes sobre a inserção de atividades experimentais acadêmicas em associação a um contexto real - a construção de Brasília - esta proposta em sua totalidade não se sustentaria no período pós-construção da capital, ou seja, seria necessário o planejamento didático com bases na experimentação a longo prazo, dissociando da imediata demanda da construção da

\footnotetext{
${ }^{52}$ CASTELO, R. A Universidade de Brasília - As lições do passado. Brasília: Palestra proferida, FAU/UnB, 12/04/2010. Apud SCHLEE, A.R.; FICHER, S (2010). p. 2-3.

${ }^{53}$ Mayumi Watanabe, formada na FAUUSP, no início de sua carreira cursou disciplinas na UNB e atuou como docente nesta mesma instituição, trabalhando ao lado do arq. João Filgueira Lima, do eng. Eustáquio de Toledo, e também se envolveu com atividades voltadas à pré-fabricação no Ceplan.

${ }^{54}$ De acordo com Buitoni (2009), esta frase da arquiteta foi encontrada em suas anotações sobre o ensino de arquitetura no Brasil.
} 
capital, mas não foi possível atingir este estágio do planejamento pedagógico devido à instauração do regime militar no Brasil.

Em relação às outras experiências laboratoriais na área da tecnologia da construção desenvolvidas nas demais regiões do país ${ }^{55}$, observa-se que a maior parte delas concentramse na região sudeste, especialmente no estado de São Paulo, tendo início a partir da década de 1970. O Quadro 07, foi desenvolvido principalmente, com base nos dados divulgados nos trabalhos de Lotufo (2014), Lopes (2014), Saramago (2011), Schlee (2010), Leite (2005) e Arantes (2002), sendo consideradas apenas as experiências acadêmicas realizadas de forma sistemática e vinculadas à uma proposta de ensino e não aquelas implantadas de forma isolada ou esporádica como projetos de pesquisa ou extensão, embora haja o reconhecimento sobre a importância e contribuição destas experiências.

Quadro 07 - Histórico de algumas atividades na área experimental construtiva por meio de protótipos em escala, realizadas em escolas brasileiras no período compreendido entre 1962- 2012.

\begin{tabular}{|c|c|c|c|}
\hline Data & $\begin{array}{l}\text { Escolas de } \\
\text { Arquitetura }^{56}\end{array}$ & $\begin{array}{c}\text { Alguns } \\
\text { Profissionais } \\
\text { Envolvidos e } \\
\text { Identificados } \\
\end{array}$ & Considerações \\
\hline $\begin{array}{c}1962- \\
1965\end{array}$ & FAU-UNB & \begin{tabular}{|} 
- João Filgueiras \\
Lima - Lelé \\
(responsável pela \\
área de \\
Tecnologia) \\
- Mayumi \\
Watanabe (co- \\
responsável pela \\
disciplina Física \\
aplicada com Lelé \\
e pelo curso de \\
Edificações com o \\
eng. E- ustáquio \\
de Toledo; \\
- Sérgio de Souza \\
Lima
\end{tabular} & $\begin{array}{l}\text { - Curso estruturado em dois níveis: disciplinas introdutórias e atividades } \\
\text { experimentais/práticas). } \\
\text { - Interface com os conceitos Bauhauseanos. } \\
\text { - Ênfase na importância do ensino sobre processos construtivos nos cursos de } \\
\text { arquitetura e sua integração com outras áreas. } \\
\text { Figura 43: Canteiro de obras de Brasília. a) Construção de Brasília. b) Uma das aulas ao ar } \\
\text { livre. } \\
\text { Fontes: a) e b) UNB: } 50 \text { anos (2012) }\end{array}$ \\
\hline 1970 & $\begin{array}{l}\text { Universidade } \\
\text { Católica de } \\
\text { Santos - FAU } \\
\text { SANTOS }\end{array}$ & \begin{tabular}{|c|} 
- Mayume \\
Watanabe \\
- Sérgio de Souza \\
Lima \\
- Sérgio Ferro \\
- Francisco de
\end{tabular} & $\begin{array}{l}\text { - Experimentações ligadas à Habitação Popular com base nas condições de vida } \\
\text { das classes populares. }\end{array}$ \\
\hline
\end{tabular}

\footnotetext{
${ }^{55}$ Cabe destacar que as experiências selecionadas no Quadro 07 foram aquelas divulgadas por meio de trabalhos científicos, documentos e pesquisas. Levando possivelmente a desconsideração de experiências relevantes em outras regiões do país, as quais foram realizadas, mas não documentadas ou publicadas, cujas fontes não foram encontradas.

${ }^{56}$ Fontes consultadas: FAU-UNB - Buitoni (2009), Castelo (2010), Lima (2004), Schlee e Ficher (2010). FAU SANTOS - Buitoni (2009), Saramago (2011). FAU - SJC - Buitoni (2009), Saramago (2011). FAUUSP - Saramago (2011), Schlee (2010), Canteiro Experimental-10 anos (2008), Ronconi (2002), Arantes (2002), Almeida (1978), Documentos pessoais profa. Cláudia T. De Andrade Oliveira. FAU - Farias Brito - Saramago (2011), Lotufo (2014). FEBASP - Saramago (2011), Lotufo (2014), Lopes (2014). PUCCAMP - Leite (2005), Saramago (2011), Lopes (2014), Lotufo (2014). FAU-SJT - Saramago (2011), Lopes (2014). Unimep - Saramago (2011). PUC-Minas - ABEA Caderno 32. p. 78. IAU-USP - Saramago (2011), Lopes (2014).
} 


\begin{tabular}{|c|c|c|c|}
\hline & & Oliveira & \\
\hline $\begin{array}{c}1971- \\
75\end{array}$ & \begin{tabular}{|c|} 
Instituto de \\
Artes, \\
Arquitetura e \\
Comunicação da \\
Faculdade de \\
Arquitetura \\
Elmano Ferreira \\
Veloso \\
\end{tabular} & $\begin{array}{l}\text { - Mayume } \\
\text { Watanabe } \\
\text { - Siegbert } \\
\text { Zanettini } \\
\text { - Hélio Duarte } \\
\text { - Paulo Bastos }\end{array}$ & $\begin{array}{l}\text { - Apoiada na proposta primeiramente empreendida na UNB, vinculando à } \\
\text { realidade socioeconômica da cidade de São José dos Campos - ateliês } \\
\text { integrados. Nota-se nesta oportunidade que, Mayumi ao resgatar a proposta da } \\
\text { UNB, acreditava que a mesma poderia trazer ações transformadoras em diversos } \\
\text { contextos do país. }\end{array}$ \\
\hline $\begin{array}{c}1975- \\
86\end{array}$ & FAU USP & \begin{tabular}{|c|} 
- Siegbert \\
Zanettini \\
- Rodrigo Lefèvre \\
- Félix Alves de \\
Araújo \\
- Dario \\
Montesano \\
- Eideval Bolanho \\
- Marcos de Souza \\
Dias
\end{tabular} & $\begin{array}{l}\text { - Proposta de curso Integrado a exemplo da implantada em São José dos Campos } \\
\text { - a experiência da FAUUSP procurava aproximar a graduação da periferia, para a } \\
\text { proposição de alternativas de intervenção a partir de tecnologias não } \\
\text { convencionais e apropriáveis pelos moradores. } \\
\text { Figura 44: Exemplo de trabalho realizado no Curso Integrado FAUUSP: produção de tijolo } \\
\text { solo-cimento. } \\
\text { Fonte: Almeida (1978) apud Saramago (2011). }\end{array}$ \\
\hline 1976 & $\begin{array}{c}\text { Faculdade Farias } \\
\text { de Brito de } \\
\text { Guarulhos }\end{array}$ & $\begin{array}{c}\text { - Eduardo Lins de } \\
\text { Melo } \\
\text { - Vítor Lotufo }\end{array}$ & $\begin{array}{l}\text { Figura 45: Práticas construtivas na Universidade Farias Brito. A) Construção de uma } \\
\text { geodésica. b) Publicação sobre as experiências em O Jornal do Arquiteto, 1976. n. 37. } \\
\text { Fonte: Lotufo (2014) }\end{array}$ \\
\hline $\begin{array}{c}1981- \\
86\end{array}$ & $\begin{array}{l}\text { Escola de Belas } \\
\text { Artes de São } \\
\text { Paulo (FEBASP) }\end{array}$ & \begin{tabular}{|c|} 
- Joan Villà \\
(coordenador \\
laboratório de \\
habitação) \\
- Vitor Lotufo \\
- João Marcos de \\
Almeida Lopes \\
- Antonio Bataglia \\
- Yopanan Rebello \\
(estruturas) \\
- Maria Amélia \\
Leite (estruturas) \\
57
\end{tabular} & $\begin{array}{l}\text { - Com apoio dos diversos laboratórios, é criado o primeiro Laboratório de } \\
\text { Habitação (LABHABs) em uma escola de Arquitetura no Brasil. Este espaço } \\
\text { buscava interligar atividades de ensino, pesquisa e extensão voltados à temática } \\
\text { de inclusão social nas cidades e o acesso a habitações adequadas, para isso } \\
\text { experimentava possibilidades construtivas e espaciais a partir do processo } \\
\text { participativo junto às comunidades. } \\
\text { - Segundo Lotufo (2014), houve a reverberação desta experiência para outras } \\
\text { faculdades de arquitetura: o HABTAFAUS (1983-1984) na FAU Santos; o } \\
\text { L'HABTAT desde } 1986 \text { na FAU-PUC de Campinas; o Laboratório de Habitação e } \\
\text { Assentamentos Humanos desde } 1996 \text { na FAUUSP; e o LABHAB-Unicamp (1986- } \\
\text { 1999) no Núcleo de Desenvolvimento de Criatividade da Unicamp. }\end{array}$ \\
\hline
\end{tabular}

\footnotetext{
${ }^{57}$ Em 1982, o arquiteto Joan Villà torna-se coordenador do LABHABs, trazendo consigo uma experiência em cooperativas de arquitetos e trabalhos com comunidades apoiadas pela Igreja Católica. De acordo com Lotufo (2014), em torno do LABHABs se reuniu um grupo de professores de diversas áreas, tornando possível uma atuação mais ampla como: Nabil Bonduki, Yves de Freitas, Antonio Carlos Sant'Anna, Vítor Lotufo, Antonio Sérgio Bergamin, Jorge Caron, Carlos Roberto Monteiro de Andrade, Mário Braga, Mário Biondi, João Marcos de Almeida Lopes, entre outros.
} 


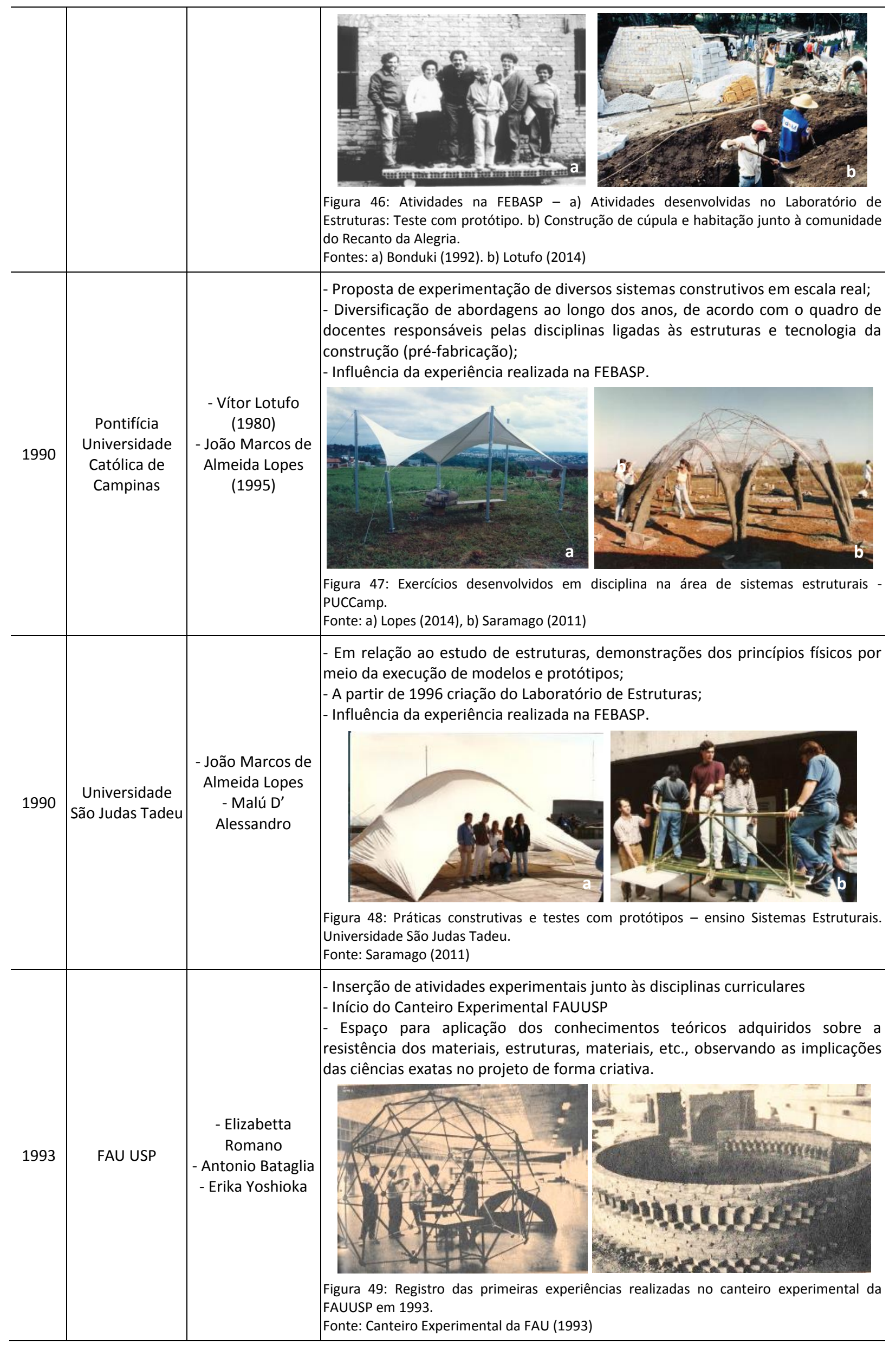




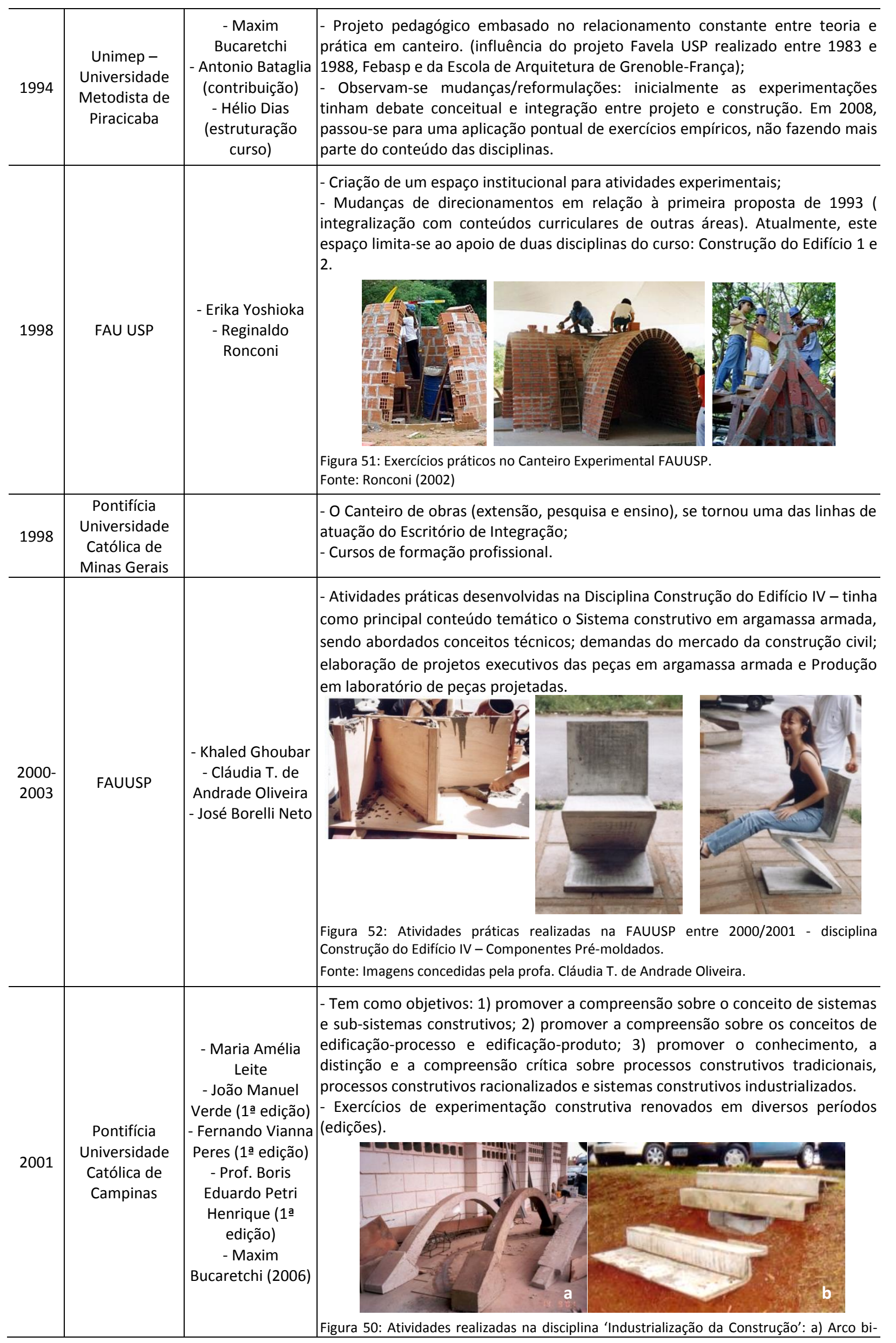




\begin{tabular}{|c|c|c|c|}
\hline & & & $\begin{array}{l}\text { articulado de secção variável. b) Escada drenante } \\
\text { Fonte: Leite (2005) }\end{array}$ \\
\hline 2003 & IAU USP & $\begin{array}{l}\text { - João Marcos de } \\
\text { Almeida Lopes } \\
\text { - Marcelo Suzuki }\end{array}$ & $\begin{array}{l}\text { - Curso de Projeto I-10 ano do Curso de Arquitetura e Urbanismo, } 2003 \text { - atual; } \\
\text { - O primeiro semestre do curso envolve a pesquisa da relação corporal com o } \\
\text { espaço, sem deixar de lado a dimensão material e construtiva que, no caso da } \\
\text { arquitetura, faz a intermediação dessa relação; } \\
\text { - No segundo semestre, a disciplina propõe a apreensão do contexto urbano } \\
\text { local (a cidade de São Carlos) e, a partir de uma sequência de discussões e } \\
\text { exercícios parciais, chega-se à construção de abrigos, pousos ou pavilhões, } \\
\text { instalados e mantidos em alguns pontos da cidade por uma semana. }\end{array}$ \\
\hline 2008 & $\begin{array}{l}\text { Pontifícia } \\
\text { Universidade } \\
\text { Católica de } \\
\text { Minas Gerais }\end{array}$ & - Roberto Santos & $\begin{array}{l}\text { - Reformulação do projeto pedagógico; } \\
\text { - Organização do currículo em dois ciclos: básico (sensibilização dos alunos } \\
\text { quanto aos problemas do edifício e da cidade) e profissionalizante (realizado em } \\
\text { dois tipos de ambientes de ensino-aprendizagem: o ateliê de projeto e os } \\
\text { Laboratórios de Extensão e de Pesquisa). }\end{array}$ \\
\hline 2011 & $\begin{array}{l}\text { Universidade } \\
\text { Federal de } \\
\text { Uberlândia - } \\
\text { UFU }\end{array}$ & - Albenise Laverde & 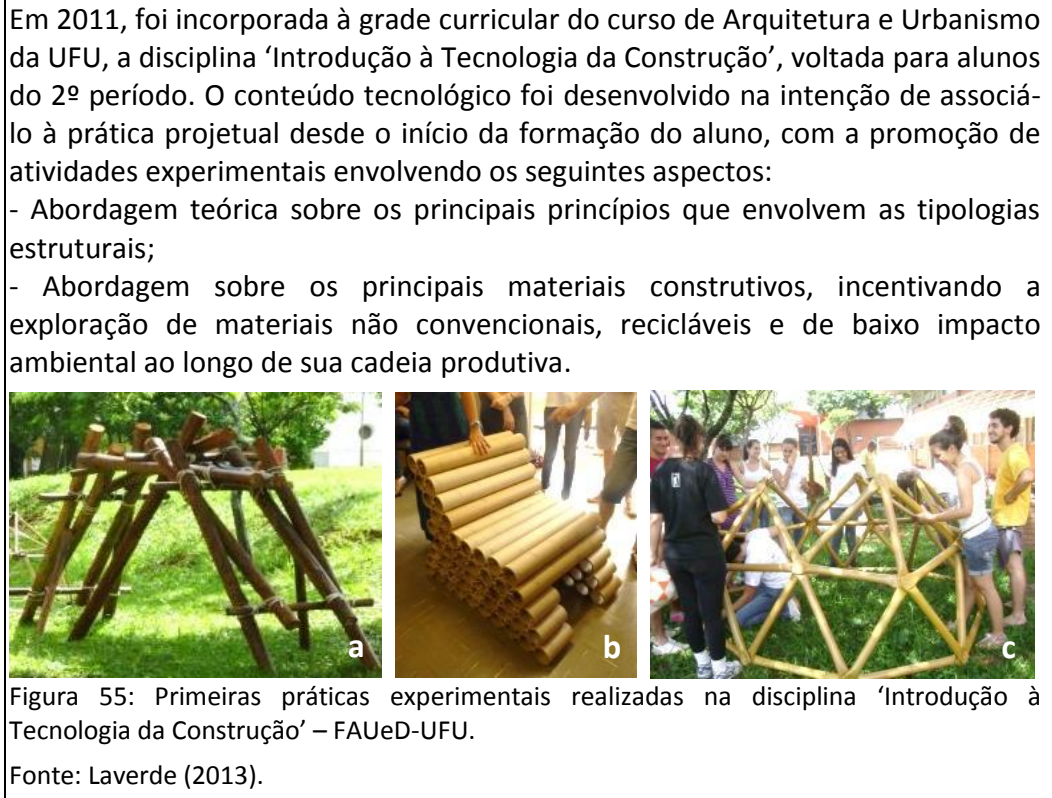 \\
\hline
\end{tabular}


A partir do Quadro 07 é possível verificar o reduzido número de professores envolvidos com as práticas laboratoriais, havendo recorrência de nomes dos atores em diferentes instituições, trata-se da exemplificação do processo de reverberação de experiências e metodologias sobre o desenvolvimento deste tema no Brasil e a influência docente. Este cenário leva a concluir que houve ao longo dos anos, a sustentação de alguns segmentos com interface à área experimental acadêmica, destacando-se aqueles ligados aos movimentos sociais de moradia (projetos extensionistas) e também, o estudo de tipologias estruturais (atividades práticas desenvolvidas prioritariamente em disciplinas de sistemas estruturais). Outro ponto de destaque é que a maioria destas experiências (publicadas) foi desenvolvida em escolas privadas, com algumas exceções (FAUUNB - FAUUSP - IAUUSP - UFU), havendo poucos exemplos publicados até o momento que desenvolvam a experimentação física em associação a diferentes disciplinas. $O$ item 2.4 contribui para reflexões mais aprofundadas que serão realizadas nos próximos capítulos.

\subsection{ENTRE A INVENTIVIDADE E A REPRODUÇÃO}

A experiência pedagógica na Bauhaus pode ser considerada como uma das primeiras iniciativas onde questões sobre tecnologia construtiva, processos industriais e desenvolvimento criativo foram exploradas de forma conjunta no âmbito acadêmico e, dentre as transformações preconizadas por esta escola, a indissociabilidade entre plástica e técnica refletem claramente as transformações vivenciadas na arquitetura daquele momento.

A criação tardia do Departamento de Arquitetura na Bauhaus e sua curta duração impossibilitou a geração de dados consistentes sobre a aplicação dos princípios defendidos por Gropius nesta fase do ensino ${ }^{58}$, que incentivava a área da pesquisa laboratorial e de campo na construção civil na formação dos futuros arquitetos. Este cenário se repetiu na experiência do curso da UNB, considerada uma experiência inovadora no país, cuja interrupção precoce não gerou dados consistentes sobre o novo modelo idealizado que tinha como objetivo promover aos alunos um espaço real para exercitarem o processo criativo em associação às inovações técnicas da época, como a pré-fabricação.

Ainda sobre as primeiras discussões sobre a experimentação no ensino da área da tecnologia, observa-se que foram conduzidas por duas linhas distintas, de um lado, os

\footnotetext{
${ }^{58}$ GROPIUS, W. Bauhaus: novarquitetura. São Paulo: Perspectiva, 1997. p. 89-90.
} 
princípios defendidos por professores engenheiros, a partir de uma visão mais técnicocientífica, em que o processo experimental deveria seguir uma metodologia teórica científica. E, por outro lado, as atividades conduzidas por grupos de professores arquitetos (com algumas exceções), com discussões abrangendo diferentes áreas do saber, defendendo o processo experimental como uma oportunidade para discussão das questões técnicas em associação a políticas públicas, plástica e urbanismo.

Nota-se também, uma relação direta entre metodologia profissional e docente, na medida em que a experiência docente dos profissionais estudados e adeptos do processo experimental refletem claramente a possibilidade de transferência dos processos adotados no contexto profissional para o âmbito acadêmico, desde que hajam as condições essenciais para isso - recursos humanos e técnicos - fazendo com que estas práticas tenham maior cunho científico e se aproximem de demandas reais da sociedade.

Em relação às escolas catalogadas, embora os exemplos internacionais apresentados possam ser considerados diferenciados dentro de um universo mais amplo de escolas, a partir deles é possível verificar o desenvolvimento de pesquisas sobre temas atualizados envolvendo a tecnologia do ambiente construído, e que refletem o estágio vivenciado em relação às tecnologias de seu tempo ou os avanços com técnicas convencionais. Sobre as experiências didáticas realizadas em escolas nacionais, verifica-se indícios de afastamento do contexto industrial e a limitada infraestrutura laboratorial acadêmica, não sendo possível correlacionar as experiências com os avanços técnicos de cada período (com exceção da primeira experiência da UNB).

As experiências levantadas na elaboração do Quadro 07 e os posicionamentos defendidos por Ronconi (2005) e Pisani (2006), sobre o tema canteiro experimental, levam a concluir a existência de uma grande diversidade de entendimentos sobre a real vocação dos espaços de experimentação construtiva inseridos em cursos de arquitetura. Enquanto Ronconi defende tratar-se de um espaço de libertação para o aluno, sem a priorização da investigação técnicoconstrutiva, Pisani e seus colaboradores argumentam que a experimentação deve estar baseada em conhecimentos científicos na área construtiva.

Esta constatação também traz à tona a necessidade de ampliar e compreender melhor o processo de desenvolvimento de atividades desta natureza nas escolas públicas, diante dos poucos exemplos encontrados e da predominância de práticas realizadas em escolas privadas, a fim de investigar se este cenário se deve apenas pela falta de divulgação das experiências 
realizadas ou problemas de diferentes ordens conduziram à construção deste cenário, sendo esta discussão desenvolvida no Capítulo 05 deste trabalho.

Nas iniciativas realizadas pelo CEAU em meados da década de 1990, foi identificado por parte da comissão o fenômeno do 'barateamento dos cursos', devido à falta de infraestrutura adequada para o funcionamento das escolas, incluindo a falta de laboratórios. Os dados levantados in loco e apresentados no Capítulo 03 discutem a situação atual de várias escolas públicas de arquitetura implantadas em diferentes períodos, sinalizando que o tempo de implantação não é garantia da existência de infraestrutura laboratorial, levando à seguinte reflexão: Será que os cursos no Brasil já não foram implantados com o entendimento de que as atividades experimentais seriam dispensáveis, sendo o processo representacional suficiente para a resolução de inovações criativas sobre os problemas que envolvem o Ambiente Construído? 

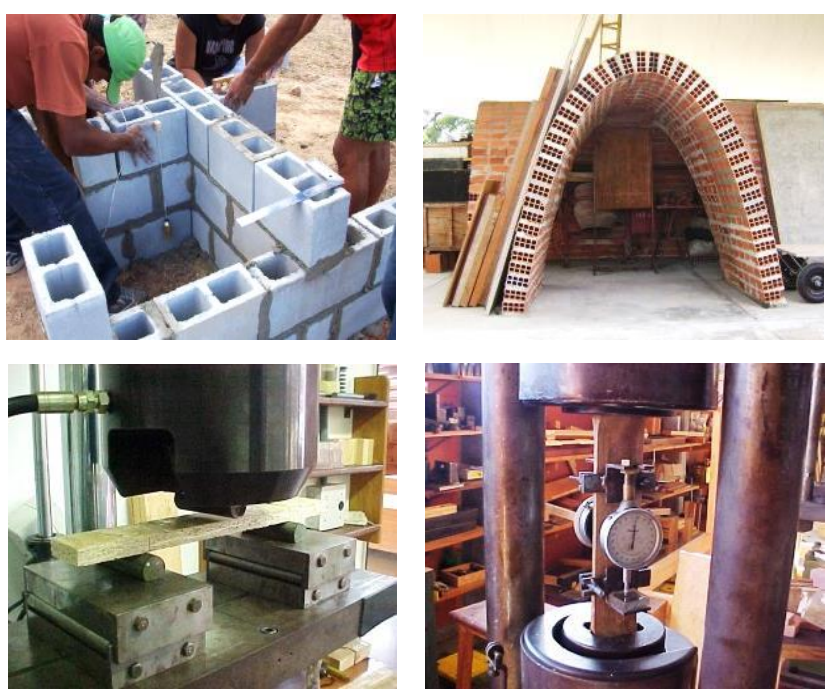

CAPÍTULO 03 OS ESPAÇOS EXPERIMENTAIS E PRÁTICAS TÉCNICOCONSTRUTIVAS DAS ESCOLAS PÚBLICAS DE ARQUITETURA

3.1. O OLHAR DE ENTIDADES NACIONAIS SOBRE A ÁREA TECNOLÓGICA DOS CURSOS DE ARQUITETURA - ENTENDIMENTOS SOBRE A ÁREA EXPERIMENTAL

3.2. CARACTERIZAÇÃO DOS ESPAÇOS EXPERIMENTAIS E DAS PRÁTICAS TÉCNICOCONSTRUTIVAS DAS ESCOLAS VISITADAS

3.2.1. Escolas Visitadas 3.2.2 Quadro Síntese 


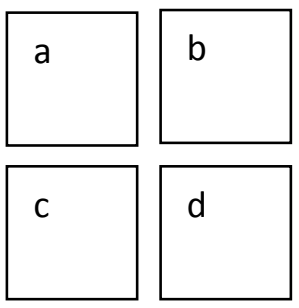

Imagem capa:

a) Curso 'Fundamentos da Construção'. PUC Minas. Fonte: ABEA Caderno 32. p. 78.

b) Canteiro Experimental FAUUSP. Fonte: acervo pessoal

c) Ensaios físicos - Lamem. EESC-USP Fonte: acervo pessoal

d) Ensaios físicos - Lamem. EESC-USP Fonte: acervo pessoal 
Este Capítulo apresenta os dados documentais sobre as principais discussões e ações direcionadas às práticas experimentais e infraestrutura na área da Tecnologia da Construção realizadas por entidades nacionais envolvidas com a questão educacional como MEC, CEAU, ABEA, CREA, CAU e instituições de ensino superior, assim como, os dados levantados in loco, a partir das visitas técnicas às 21 escolas públicas de arquitetura localizadas em diferentes regiões do país. As informações coletadas junto a estas escolas permitiram contextualizar a atual configuração dos espaços laboratoriais e práticas acadêmicas, assim como, compreender outras variáveis que influenciam na estruturação da área da Tecnologia da Construção e suas particularidades pedagógicas.

\subsection{O OLHAR DE ENTIDADES NACIONAIS (MEC, ABEA, CAU E INSTITUIÇÕES DE ENSINO) SOBRE A ÁREA TECNOLÓGICA DOS CURSOS DE ARQUITETURA - entendimentos sobre a área experimental}

Neste item, foram realizadas investigações sobre as principais discussões e ações realizadas por entidades nacionais - algumas delas já extintas - envolvidas com a questão educacional como MEC, CEAU, ABEA, CREA, CAU e instituições de ensino superior, com especial atenção à análise das estratégias e proposições direcionadas às práticas experimentais e melhoria da infraestrutura na área da Tecnologia da Construção dos cursos de Arquitetura e Urbanismo do país. Para que isso fosse possível, foi realizada a triangulação de dados obtidos em fontes documentais como: os Cadernos e Boletins da ABEA, desde sua implantação, em 1973, até o presente momento; decretos e portarias do Governo que, de alguma forma interferiram no ensino e, principalmente, na infraestrutura do curso, com especial atenção à atuação das CEAUs (Comissões de Especialistas em Arquitetura e Urbanismo). Foram também realizadas entrevistas com profissionais do CAU, envolvidos com a questão do Ensino e Formação, na intenção de averiguar os atuais encaminhamentos realizados pelo Conselho sobre este assunto e, por fim, foram analisadas as principais discussões acadêmicas promovidas dentro dos cursos de Arquitetura inseridos nas instituições públicas do país.

A importância da dimensão curricular na evolução do ensino em Arquitetura e Urbanismo derivou segundo Santos (2013), do fato de se constituir num instrumento político capaz de sintetizar documentalmente as demandas profissionais emergentes, e de criar renovadas expectativas de mudança no bojo dos movimentos reivindicatórios. Portanto, o estudo e a 
análise da dimensão curricular podem contribuir, como um fio condutor, para o entendimento do desenvolvimento do ensino de Arquitetura e Urbanismo.

Os primeiros fatos históricos relevantes relacionam-se às reestruturações curriculares direcionadas a oferecer uma formação técnica e artística satisfatórias para o atendimento às demandas da profissão, assim como, a promoção de uma regularização das atribuições do arquiteto, ocorridas a partir do Art. 30 do Decreto $n^{\circ} 23.569$ de 11 de dezembro de 1933, cabendo ao profissional:

1. o estudo, projeto, direção, fiscalização e construção do edifício com todas as suas obras complementares;

2. o estudo, projeto, direção, fiscalização e construção das obras que tenham caráter essencialmente artístico ou monumental;

3. o projeto, direção e fiscalização dos serviços de urbanismo;

4. o projeto, direção e fiscalização das obras de grande decoração arquitetônica;

5. a arquitetura legal, nos assuntos mencionados nas alíneas a e c do mencionado;

6. perícias e arbitramento relativos à matérias de que tratam as alíneas anteriores.

Para Artigas (1977), a arquitetura e o ensino saíram deste processo bem prejudicados, pois não se compreendeu qual o papel do arquiteto neste momento histórico, prevalecendo o conceito de formação que a antiga Academia de Belas Artes havia criado para o arquiteto: uma espécie de técnico menor, um ignorante, alheio às exigências das leis da gravidade e do comportamento das estruturas.

Entre 1933 e início da década de 1960 são travadas discussões e realizadas ações em diversas regiões do país sobre os rumos do ensino do curso de Arquitetura e Urbanismo, e todo o sistema de organização e representação da profissão passaram por um período de reorganização e expansão ${ }^{59}$.

\footnotetext{
59 Para melhor compreensão sobre a dimensão das discussões realizadas neste período em diversas regiões do país, foi organizado de forma sintética a partir de SCHLEE (2010) e da consulta a alguns Projetos Pedagógicos de curso, as ações/rearticulações de maior visibilidade, setorizadas a partir de cada estado: - Rio Grande do Sul: 1939 - o Instituto de Belas Artes de Porto Alegre aprova a criação de um curso técnico de Arquitetura, transformado em curso superior em 1944. Em 1945, é criado o curso de Arquitetura da Escola de Engenharia de Porto Alegre. Em 1947, é aprovado o curso de Urbanismo. Em 1948 é realizada a instalação do IAB/RS e a fusão dos cursos de Arquitetura da Escola de Belas Artes e da Escola de Engenharia de Porto Alegre, originando a futura Faculdade de Arquitetura da Universidade do Rio Grande do Sul. Minas Gerais: Em 1930 o curso de Arquitetura na UMG é criado, quando se fundou a Escola de Arquitetura, trata-se da primeira instituição de ensino de Arquitetura e Urbanismo da América do Sul criada de forma não subordinada a escolas politécnicas ou institutos de belas artes ou filosofia. Em 1943, é instalado o Instituto de Arquitetos do Brasil. - São Paulo: Em 1943 é instalado o Instituto de Arquitetos do Brasil e em 1945 é realizado o I Congresso Brasileiro de Arquitetos. Em 1947, o governo reconheceu a Faculdade de Arquitetura Mackenzie. A FAUUSP foi fundada em 1948, tendo se originado do antigo curso de engenheiro-arquiteto da Escola Politécnica da mesma Universidade. - Pernambuco: Em 1932, o ensino de Arquitetura e Urbanismo começa de forma oficial, com a fundação da Escola de Belas Artes de Pernambuco (Ebap) com reconhecimento como ensino superior em 1945. No ano de 1949 começam movimentos separatistas dentro da Escola de
} 
Embora as discussões sobre os rumos do ensino dos cursos de Arquitetura e Urbanismo tenham sido promovidas em instituições localizadas em diferentes regiões do país, teve grande destaque as propostas da FAUUSP e UNB, devido ao caráter inovador. De acordo com Artigas (1977) e com o Relatório da Comissão de Professores da FAUUSP - elaborado pelos professores Aberlardo de Souza, Hélio Q. Duarte, João Vilanova Artigas e Rino Levi - o curso da FAUUSP foi organizado a partir da adaptação dos currículos da Escola Nacional de Belas Artes e da Escola Politécnica, em que a principal preocupação da comissão seria dar a devida importância à "Composição da Arquitetura", colocando o Atelier em posição de destaque e as demais disciplinas do currículo convergindo para ele: Teoria e Crítica e Tecnologia. Para a comissão, esta estratégia concretizava a hipótese do estabelecimento de uma conexão direta entre a esfera do ensino e da atividade profissional, este pensamento não se restringiu à FAUUSP, pois simultaneamente ao que acontecia nesta escola, os cursos de arquitetura da UMG e da URGS ${ }^{60}$ também direcionavam suas reformas colocando o atelier de projeto em posição de destaque ${ }^{61}$.

Belas Artes, culminando, em 1958, na criação da Faculdade de Arquitetura do Recife. Com a reforma universitária de 1969, a Faculdade de Arquitetura do Recife transforma-se no Departamento de Arquitetura e Urbanismo (DAU). Em 1973, o departamento se muda para o campus - Rio de Janeiro: Em 1826, já como Academia Imperial, inicia-se o ensino regular de Arquitetura, como um dos cursos da Escola Real das Ciências, Artes e Ofícios. A partir de 1890, já na República, as diretrizes do curso foram alteradas dissociando cada vez mais o ensino de Arquitetura das demais da Belas-Artes. A reforma de 1931, introduzida pelo então diretor Arquiteto Lúcio Costa, passou a apresentar uma definida orientação modernista, estas inovações acabaram por provocar em 1945, a separação definitiva do Curso de Arquitetura da Escola de Belas Artes, sendo criada a Faculdade Nacional de Arquitetura (este acontecimento marcou simbolicamente o surgimento dos cursos autônomos na área). Só em 1961, a Faculdade passaria a ocupar seu endereço atual, na Ilha do Fundão, chamando-se, posteriormente, de Faculdade de Arquitetura e Urbanismo. Em Schlee (2010), não é citado o estado da Bahia, mas, de acordo com documentos sobre o histórico do curso da FAUFBA, o curso de Arquitetura foi fundado em 1877 com a Academia de Belas Artes, mas sem reconhecimento nacional. Em 1949, foi realizada sua federalização, com a incorporação da Escola de Belas Artes à universidade. Em 1959, a Faculdade se separa da Escola de Belas Artes e o currículo do curso de arquitetura foi reformulado. Em 1961 a Universidade Federal da Bahia cria o Campus Universitário.

${ }^{60} \mathrm{Em} 28$ de novembro de 1934, foi criada a Universidade de Porto Alegre, integrada incialmente pelas Escola de Engenharia, com os Institutos de Astronomia, Eletrotécnica e Química Industrial; Faculdade de Medicina, com as Escolas de Odontologia e Farmácia; Faculdade de Direito, com sua Escola de Comércio; Faculdade de Agronomia e Veterinária; Faculdade de Filosofia, Ciências e Letras e pelo Instituto de Belas Artes. O terceiro grande momento de transformação dessa Universidade foi em 1947, quando passou a ser denominada Universidade do Rio Grande do Sul, a URGS. Em dezembro de 1950, a Universidade foi federalizada, passando à esfera administrativa da União, passa então a ser denominada de UFRGS - Universidade Federal do Rio Grande do Sul. Dados disponíveis em: http://www.ufrgs.br/ufrgs/a-ufrgs/historico. Acesso em 19/04/2016.

No caso da Universidade de Minas Gerais - UMG foi fundada em 1927, a partir da reunião dos quatro institutos de ensino superior existentes em Belo Horizonte: Direito (criado em 1892), Medicina, Engenharia (criados em 1911), Odontologia e Farmácia (criados, respectivamente, em 1907 e 1911). Permaneceu como instituição estadual até 17 de dezembro de 1949, quando foi federalizada. Nessa época, já haviam sido integradas à Universidade a Escola de Arquitetura (1944) e as Faculdades de Ciências Econômicas e de Filosofia (1948). O nome atual - Universidade Federal de Minas Gerais - UFMG, só foi adotado em $1965 . \quad$ Dados obtidos em: https://www.ufmg.br/proplan_site_antigo/relatorios_anuais/relatorio_anual_2002/historico.htm. Acesso em: 14/10/2016.

${ }^{61}$ De acordo com SANTOS (2001), o movimento por reformas no ensino foi amplificado, com as possibilidades de renovação que o Currículo Mínimo apontava, alcançando na escola de arquitetura da UMG, nos Seminários de Ensino da Faculdade de Arquitetura da URGS e nos Fóruns de ensino da FAUUSP resultados inéditos, sendo simultâneo o discurso relacionado a organizar as escolas em torno do estúdio. 
Os direcionamentos dos encontros então realizados sugeriam a implantação de um currículo comum em nível nacional, construído a partir de uma conceituação da Arquitetura e Urbanismo e do perfil profissional revelado pelo Movimento Moderno, com a possibilidade de estabelecer uma ruptura definitiva com o ensino tradicional herdado das escolas de Engenharia e Belas-Artes, quando analisados de forma isolada. Sobre isso, Graeff relata:

[...] Falo dos memoráveis e quase esquecidos Encontros Nacionais de Arquitetos, Estudantes e professores de Arquitetura, realizados em diversos estados da federação entre meados da década de 1950 e ano histórico de 1962. Este foi, sem nenhuma dúvida possível, o mais alto momento do pensamento brasileiro voltado para a questão da formação profissional do arquiteto. Dele germinou por um lado, a experiência radical que se tentou realizar na Universidade de Brasília, entre 1962 e 1966 e, por outro, resultou no primeiro currículo mínimo para formação de arquitetos. GRAEFF (1983)

As discussões travadas até este momento se restringiam às reformas curriculares, mas as fontes consultadas revelam que foi pouca, ou até inexistente, a discussão sobre a infraestrutura necessária aos cursos para o desenvolvimento das reformas ${ }^{62}$. A proposta curricular que apresenta reformas mais sensíveis na área tecnológica, em que o uso laboratorial e experimental está indissociado da proposta geral de ensino foi desenvolvida na FAUUNB por volta de 1962, ano de sua criação. Esta proposta estruturava o curso em três 'troncos': Teoria, Composição e Tecnologia, havendo uma total integração entre teoria e prática. Sobre sua participação na UNB, João Figueiras Lima - Lelé, comenta:

[...] quando eu fui professor, convocado pelo arquiteto Oscar Niemeyer - que era coordenador do ensino e das obras e eu, secretário executivo da Secretaria de Planejamento - optamos naquela ocasião por iniciar com a industrialização da construção, do pré-fabricado. A nossa ideia era ter uma fábrica de produção dentro da própria universidade, um centro de planejamento, isso trabalhando junto com a Faculdade de Engenharia, e que ela fosse a base de todo o ensino de Arquitetura e Engenharia na construção civil. Esta foi uma ideia muito estimulada por Darcy Ribeiro, que na ocasião foi o fundador da Universidade de Brasília, nosso primeiro reitor. LELE (2011) ${ }^{63}$

\footnotetext{
62 Apenas em 1974, com a criação do CEAU foram realizadas visitas técnicas às escolas do Brasil com elaboração do documento: 'Diagnóstico das condições de ensino e pesquisa em Arquitetura e Urbanismo no Brasil', sendo então realizado um breve comentário crítico sobre a infraestrutura sobre a área da tecnologia existente nas escolas de arquitetura do país, dados presentes nas páginas 103 e 156.

${ }^{63}$ Comentário de João Figueiras Lima - Lelé, ao ministrar uma palestra no evento ArqFuturo de 2011, quando faz um breve histórico sobre as oportunidades que teve ao longo de sua carreira na área do Ensino da Arquitetura. Relata com ênfase, que sempre procurou estender ao ensino os conceitos defendidos no desenvolvimento de suas obras, ao pensar a arquitetura como processo, cujas proposições didáticas estavam totalmente integradas à prática profissional e tecnológica.
} 
As discussões amadurecidas em importantes escolas do país foram interrompidas pelo regime militar, quando houve a prisão de professores e estudantes e a cassação de docentes. Para Graeff (1983), as reformas que revelavam maior vitalidade inovadora entre 1956 e 1962 foram profundamente feridas: UNB, URGS, USP e UMG, exatamente onde o processo de mudança curricular e metodológico se encontrava mais desenvolvido.

A proposta do Currículo Mínimo (CM) de 1962, desenvolvido em conjunto com entidades e instituições de ensino foi substituído pelo Currículo Mínimo de 1969 que, de acordo com Santos (2001), embora mantivesse de maneira geral na Resolução que o instituiu, a relação dos conteúdos constantes do Currículo Mínimo de 1962, a implantação do Currículo Mínimo de 1969 estava centrada em novos parâmetros. As normas não contemplavam o sentido e a profundidade das mudanças alcançadas nos movimentos de reforma do ensino, a partir do entendimento do Currículo Mínimo como o núcleo de matérias considerado o mínimo indispensável para a adequada formação profissional, desdobradas em disciplinas, na forma de matérias básicas e profissionais. As normas, para sua aplicação, denotavam uma visão padronizadora, indiferente às dinâmicas de mudanças de procedimentos didático-pedagógicos em andamento nos cursos, como visto também em Schlee (2010), que complementa esta questão ao relatar que as normas tinham uma visão tecnocrática e padronizada, com o deslocamento do entendimento do currículo como procedimento educativo, com uma visão do todo, para um conjunto de disciplinas.

O Quadro 08 equipara os dois Currículos Mínimos, de 1962 e 1969, para melhor visualização das disciplinas equivalentes.

Quadro 08 - Currículos Mínimos de 1962 e 1969.

\begin{tabular}{|c|c|c|c|}
\hline \multicolumn{2}{|c|}{$\begin{array}{l}\text { Conteúdos mínimos a serem observados na organização } \\
\text { dos cursos de Arquitetura (1962) }\end{array}$} & \multicolumn{2}{|c|}{$\begin{array}{l}\text { Conteúdos mínimos a serem observados na organização } \\
\text { dos cursos de Arquitetura (1969), Resolução CFE n }{ }^{\circ} 3 \text {, de } 23 \\
\text { de junho de } 1969 .\end{array}$} \\
\hline \multirow{15}{*}{ Matérias } & 1. Cálculo & \multirow{6}{*}{$\begin{array}{l}\text { Matérias } \\
\text { Básicas }\end{array}$} & 1. Estética, Hist. das Artes e, especialm., da Arquitet. \\
\hline & 2. Física Aplicada & & 2. Matemática \\
\hline & 3. Resist. dos Materiais e Estabilid. das Construções & & 3. Física \\
\hline & 4. Desenho e Plástica & & 4. Estudos Sociais \\
\hline & 5. Geometria Descritiva & & 5. Desenho e outros meios de expressão \\
\hline & 6. Materiais de Construção & & 6. Plástica \\
\hline & 7. Técnica de Construção & \multirow{9}{*}{$\begin{array}{l}\text { Matérias } \\
\text { Profissionais }\end{array}$} & 1. Teoria da Arquitetura, Arquitetura Brasileira \\
\hline & 8. História da Arquitetura e da Arte & & $\begin{array}{l}\text { 2. Resistencia dos Materiais e Estabilidade das } \\
\text { Construções }\end{array}$ \\
\hline & 9. Teoria da Arquitetura & & $\begin{array}{l}\text { 3. Materiais de Construção, Detalhes e Técnicas da } \\
\text { Construção }\end{array}$ \\
\hline & 10. Estudos Sociais e Econômicos & & 4. Sistemas Estruturais \\
\hline & 11. Sistemas Estruturais & & 5. Instalações e Equipamentos \\
\hline & 12. Legislação, Prática Profissional e Deontologia & & 6. Higiene da Habitação \\
\hline & 13. Evolução Urbana & & 7. Planejamento Arquitetônico \\
\hline & 14. Composição Arquitet., de Interior e de Exteriores & & \\
\hline & 15. Planejamento & & \\
\hline
\end{tabular}

Fonte: Adaptado pela autora a partir de Schlee (2010). 
Ainda segundo Schlee (2010), o distanciamento progressivo da educação escolarizada do arquiteto e urbanista das candentes demandas sociais - com graus variados do ponto de vista teórico-conceitual, da atualização tecnológica e da atuação prática - acabou por tornar rarefeita e episódica a contribuição oferecida pelas escolas às questões sociais, que contam com imediato interesse profissional. Esta situação não vai ao encontro das transformações defendidas pelo governo nesta época, baseadas nos estudos de Rudolph Atcon ${ }^{64}$ e pela Comissão Mista, em que a educação constituía, um "instrumento de aceleração do desenvolvimento", um "instrumento de progresso social", devendo os cursos e currículos serem adaptados às "imposições do desenvolvimento nacional".

Mas, o que se viu a cada nova faculdade de Arquitetura e Urbanismo que iniciava suas atividades ao longo dos 25 anos de vigência do Currículo Mínimo, foi um renovado conflito. Contrapunham-se, de um lado, o desejo de alguns docentes e estudantes, reunidos em torno de um projeto de curso, e, de outro, uma estrutura empresarial, alimentada pela oferta de vagas para um mercado cativo, mais voltado para a produção de diplomas do que para a formação de profissionais com capacidade intelectual e técnica para enfrentar desafios.

O que se observa, é que tanto a proposta do Currículo Mínimo de 1969, como também a proposta do CM de 1962, não contemplam discussões voltadas à infraestrutura técnica e laboratorial na área técnico-construtiva ${ }^{65}$. As poucas experiências acadêmicas inovadoras, na área experimental, foram em sua maioria desenvolvidas na rede privada. De acordo com Santos (2001), esta abertura pelas mantenedoras, foi muitas vezes motivada para atrair alunos e professores interessados em uma experiência educacional diferenciada, mas, na sua maioria, estas propostas não tiveram vida longa, pois não iam ao encontro dos interesses das empresas

\footnotetext{
${ }^{64}$ Professor norte-americano, ao qual segundo Martins (1988), o MEC encomendou em 1966 um estudo sobre o ensino superior, tendo por meta a sua reestruturação. Daí em diante, a influência das experiências norte-americanas seria acentuada e direcionaria a política educacional do regime autoritário. Ainda de acordo com o autor, estas premissas desenvolvimentistas defendidas pelo Estado não foram concretizadas ao longo dos anos, pois os maiores investimentos foram direcionados à infraestrutura do país e não à Educação, há então uma contradição óbvia nas estratégias defendidas por Atcon, pois ao verem a Universidade como estratégica para o desenvolvimento do país e da indústria, os maiores investimentos em pesquisa e ensino deveriam ser direcionados a este setor da sociedade, no entanto, defendem a contenção de gastos e investimentos no ensino público e, ao priorizarem números em detrimento da qualidade do ensino, abrem espaço para que o setor privado assuma a responsabilidade de atender a crescente demanda do Ensino Superior.

${ }^{65}$ Deve ser lembrado, que a experiência da FAU UNB pode ser considerada uma exceção, ao tentar fazer uma conciliação entre atividades projetuais e técnicas por meio da experimentação construtiva, considerada uma proposta muito próxima à implementada na Bauhaus. Mas, por ter sido prematuramente abortada, não foi possível analisar os resultados provenientes desta proposta inovadora frente aos dados gerados pelo modelo centrado no Atelier de projeto, que vigora até hoje na maior parte das escolas brasileiras.
} 
privadas, que era a maximização dos lucros com o ensino, e para manter estas práticas pedagógicas na área experimental há a necessidade de contínuos investimentos ${ }^{66}$.

Embora muitos autores aleguem que o CM de 1969 enrijeceu o ensino brasileiro em relação ao proposto no de 1962 - que permitia maior flexibilidade para que os cursos se ajustassem as particularidades regionais de cada local - em alguns momentos foi questionado se seria correto afirmar com tanta veemência de que o CM de 1969 seja o grande responsável pela inércia vivenciada durante muitos anos no ensino brasileiro, até porque, seria cômodo para muitos cursos se apoiarem em regras e normas ao invés de promoverem discussões que alimentassem experiências diferenciadas. Este questionamento também pode ser analisado sob o ponto de vista de Santos (2001), ao relatar que durante as reuniões que redigiram a Carta de Ouro Preto em 1977, já haviam identificado que a reforma do CM, por si só, não garantiria a melhoria do ensino, mas como indutor de mudanças. Reiterava-se, que somente a mobilização de professores, estudantes e funcionários, articulados por um projetopedagógico, poderia implantar e sustentar de forma permanente o desenvolvimento de novas experimentações no ensino, isso quer dizer, iniciativas intra e inter-departamentais ${ }^{67}$.

De acordo com Gutierrez (2013), diante de uma flagrante diminuição da qualidade do ensino, nesta época, o Ministério da Educação e Cultura foi motivado a instalar as comissões de especialistas e, particularmente para o curso da arquitetura, o CEAU - Comissão de Especialistas em Arquitetura e Urbanismo. Em paralelo, as escolas resolveram juntar forças para fazer frente à problemática que se apresentava, resultando na fundação da ABEA Associação Brasileira de Escolas de Arquitetura - em 23 de novembro de 1973. Assim, o IAB Instituto de Arquitetos do Brasil - passava a atuar especificamente na área profissional e a ABEA e a CEAU na área do ensino, pois a substituição do Currículo Mínimo de 1962,

\footnotetext{
${ }^{66}$ Um fator que talvez tenha contribuído para este cenário, pode estar ligado ao custo financeiro destas atividades para os cursos - inseridos em instituições públicas ou não - além disso, esta exigência seria mais um empecilho para que novos cursos pudessem ser implantados sem a infraestrutura adequada como laboratórios técnicos e canteiros de construção. Outro fator de extrema relevância está relacionado à falta de incentivo advindo da própria classe docente, pelo (des)entendimento sobre o espaço que a área tecnológica deveria ocupar no curso de Arquitetura e, consequentemente, na formação profissional, diante dos constantes embates entre arte e técnica, arquiteto e engenheiro, teoria e prática. Geralmente, esta dualidade não é vista em diversos cursos, cuja área experimental está intrínseca na profissão, sendo considerada uma prática indispensável para a boa formação, como: as engenharias, medicina, odontologia, química, física, biologia, farmácia, entre outros cursos. Outra questão a ser analisada seria o caráter interdisciplinar dos cursos de arquitetura, que na justificativa de evitar a sobreposição de infraestrutura, aproveitam o suporte técnico de outros cursos acadêmicos, principalmente das engenharias. Isso poderia explicar a inexistência de infraestrutura própria em grande parte dos cursos de arquitetura, como também, porque a arquitetura fica a reboque da engenharia ao tratar das áreas técnicas. Este cenário também pode ser justificado pela sustentação do sistema de 'barateamento', visto não somente na rede privada de ensino, mas em cursos das instituições públicas, com o entendimento de que sempre é possível o aproveitamento da infraestrutura alheia, independente se é adequada ou não às particularidades do curso.

${ }^{67}$ Os Capítulos 03 e 04 trazem dados consistentes sobre o distanciamento entre o plano teórico do Projeto Político Pedagógico dos cursos e a realidade encontrada, evidenciando a necessidade de maior reflexão sobre a real influência deste instrumento em implementar mudanças estruturais ou se possui apenas função documental-estrutural.
} 
amplamente discutido por estudantes, professores e profissionais, por outro em 1969, imposto e inadequado, não agradava, assim como o aumento acelerado das matrículas nas instituições privadas.

Quando analisadas as discussões promovidas pela ABEA no período compreendido entre 1973 e 1985, ainda segundo este autor e também em consulta aos Cadernos da Associação publicados neste período, é observado que as preocupações direcionadas à área da tecnologia e utilização de laboratórios em apoio às aulas referem-se somente ao Ensino de Estruturas, pouco ou nada é relatado sobre as demais áreas da Tecnologia da Construção. Os principais assuntos discutidos pela Associação eram: Currículo Mínimo, Carga horária ${ }^{68}$, Atelier de Projeto, Atribuições Profissionais e a inserção de novas disciplinas como: Paisagismo, Conforto Ambiental e Informática, exceto algumas reinvindicações realizadas pela ABEA para que o ensino de tecnologia fosse mais direcionado às particularidades do curso de arquitetura ${ }^{69}$. Sobre isso, os textos encontrados possuem mais caráter reinvindicatório, do que propriamente, um reconhecimento sobre a co-responsabilidade que teria o curso de arquitetura na promoção das melhorias necessárias à área tecnológica. Já em relação ao ensino de Estruturas, as discussões foram conduzidas por professores da engenharia, com pouca participação dos arquitetos. Isto pode ser um indício de que o ensino da área de tecnologia nos cursos de Arquitetura foi prioritariamente conduzido (delegado) pelos (para) professores da engenharia $^{70}$.

Em Schlee (2010), é visto que neste período, dentre as iniciativas promovidas, uma delas era a proposta de trabalho conjunto entre CEAU e ABEA visando a discussão ampla e abrangente sobre o ensino. Com os resultados do extenso levantamento das condições vivenciadas nos cursos de Arquitetura e Urbanismo em funcionamento, o CEAU, neste momento com nova posição, passa a colaborar com a Secretaria de Educação Superior do MEC

\footnotetext{
${ }^{68}$ A primeira recomendação da Carta de Ouro Preto falava que o Currículo Mínimo deveria preservar a unidade na formação profissional, em âmbito nacional, e atender às mais amplas atribuições profissionais. Na sua elaboração, devia ser evitada a tendência à formação de especializações com a defesa da formação generalista. Era preciso abranger matérias das seguintes áreas de conhecimento, com os respectivos porcentuais de carga horária: Planejamento e Projeto, 40\%; Tecnologia e Instrumentação, $20 \%$, e Teoria e História, $20 \%$. Os $20 \%$ restantes ficariam a critério de cada escola. A autora Leite (2005), considera que o primeiro sinal de desprestígio da área tecnológica em relação às demais seria o tempo curricular dedicado, segundo a mesma a partir do Currículo Mínimo de 1969 decresce para 25 a 30\% da carga horária total do curso. Quando comparados os dados da autora com as recomendações da Carta de Ouro Preto, nota-se que o desprestígio é ainda maior em 1977 , quando destinam apenas $20 \%$ do tempo curricular às disciplinas de cunho técnico.

${ }^{69}$ Gutierrez (2013) p. 36.

${ }^{70}$ As considerações feitas pelo professor Siegbert Zanettini sobre a área de tecnologia em 1974, no 'I Encontro de Professores de Estrutura para a Arquitetura', pode ser considerada uma exceção, por ter partido de um arquiteto. O professor apresenta uma publicação sobre o ensino de estrutura voltado aos arquitetos, destacando a necessidade da adequação do conteúdo tecnológico da engenharia para a arquitetura, de maneira mais coerente do que era realizado até então.
} 
na elaboração do Programa Integrado de Melhoria do Ensino de Graduação em Arquitetura (Pimeg-ARQ). A justificativa era que os cursos, em sua maioria, haviam se sensibilizado com a discussão do novo currículo mínimo, cuja proposta estava em processo de encaminhamento no Conselho Federal de Educação (CFE) e sua aprovação abriria, certamente, "uma rara oportunidade de mudanças no sistema de ensino-aprendizagem, por mais conservadoras e rotineiras que muitas delas possam ser". (BRASIL, 1981)

Este Programa visava promover as condições básicas para alcançar quatro objetivos, a saber: 1) apoiar e assessorar o docente, propiciando treinamento em serviço, por meio de cursos (atualização, aperfeiçoamento, especialização, mestrado ou doutorado), seminários, encontros ou outra modalidade equivalente; 2) propiciar um apoio mútuo às diversas escolas da área de Arquitetura por meio do incentivo de permuta de docentes, de produção e intercâmbio de material didático, inclusive material auto instrucionais. 3) estabelecer uma rede funcional de bibliotecas, inicialmente, em âmbito regional, mas com vistas a um sistema nacional de apoio mútuo e; 4) melhorar as condições de instalação e equipamentos da área por meio de uma cooperação que favorecesse diversas instituições da região no uso comum de laboratórios e oficinas.

Ao analisar os cursos de Arquitetura e Urbanismo selecionados para participação no Pimeg-ARQ, e que foram contemplados com recursos, é fácil estabelecer a coincidência com as instituições existentes há mais tempo e com maior tradição na área, estas também eram as que contavam com docentes experientes e com alta capacitação, e, ainda, eram as que possuíam melhor infraestrutura para a oferta educacional em Arquitetura e Urbanismo ${ }^{71}$. Isso significa que as melhores instituições receberam todos os recursos alocados no Programa e, dessa forma, se qualificaram ainda mais para a oferta de seus respectivos cursos, enquanto as que estavam iniciando suas atividades se consolidaram sem qualquer apoio do Programa, inclusive os cursos que iniciavam as suas atividades nas próprias instituições federais. 0 Pimeg-Arq se desenvolveu ao longo dos anos 80. (BRASIL, 1981)

O período de 1990 foi marcado pela extensa expansão do ensino superior no Brasil e pela retomada do processo regulatório pelo Estado. A recomposição das Comissões de Especialistas no âmbito da Secretaria de Ensino Superior (SESU/MEC), possibilitou uma interlocução direta do MEC com as entidades de ensino. No caso da Arquitetura, a comissão de especialistas desempenhou um papel importante ao propor níveis de homogeneidade e

\footnotetext{
${ }^{71}$ As instituições escolhidas e contempladas com os recursos do Pimeg-ARQ foram: UFC, UFPE, UFBA, UNB, PUC/GO, UFMG, UFRJ, USP E UFRGS.
} 
qualidade, este segundo levantamento foi realizado entre fevereiro de 1993 e setembro de $1994^{72}$.

Para Monteiro (2013), o resultado da conjugação de tais esforços culminou na Portaria MEC no 1770/94, que estabelecia as Diretrizes Curriculares nacionais para os cursos de Arquitetura e Urbanismo em substituição ao currículo mínimo de 1969. Essa legislação pode ser considerada como um marco referencial no tocante a profundas mudanças do ensino de Arquitetura e Urbanismo e também por estabelecer padrões de qualidade relativos à infraestrutura necessária aos cursos: laboratórios, acervo bibliográfico mínimo, maquetaria, salas de projeto, etc. O diagnóstico apresentado pela CEAU em 1993 revelava uma situação pouco animadora. Na ocasião, verificou-se que:

"[...] há uma grande diferenciação de realidades com relação a cada uma das regiões, bem como as decorrentes do modelo de estrutura e de sua condição como instituição pública ou privada, mas em geral o quadro é grave, dificultando enormemente o desenvolvimento de pesquisas relevantes $e$ enfraquecendo o ensino."

O autor ainda relata que foi diagnosticado por meio dos dados fornecidos pelas instituições de ensino consultadas pela CEAU que:

"De maneira geral, além das especificidades de cada Curso - cada um tem um quadro de necessidades e reivindicações próprio, há uma inadequação dos espaços atualmente ocupados. Propiciar condições físicas para que a produção discente e docente se realize nas dependências da Universidade é reivindicação geral."

O diagnóstico da CEAU (1996) destaca pela primeira vez e de forma incisiva, a ausência de infraestrutura encontrada nos cursos, reconhecendo que os laboratórios, maquetaria e acervo bibliográfico eram elementos fundamentais para o bom funcionamento dos cursos, "inclusive porque eles são essenciais para criar condições e reforçar a necessidade de pesquisa na graduação".

Em MEIRA (1994), é visto que o cenário encontrado neste segundo processo de avaliação dos cursos é tratado como o "fenômeno do barateamento" e de descaracterização do ensino da arquitetura - que, aparentemente, não precisa de mais do que uma sala com pranchetas (às vezes mesas), alunos, professor e "boas ideias" - levando ao entendimento, por parte das burocracias do ensino superior, de que ele é barato. Para a consultora do CEAU:

"[...] a experimentação passa a ser gráfica, e não construtiva. Suprimem-se os laboratórios, desconsidera-se a biblioteca, extingue-se o acervo bibliográfico e

\footnotetext{
${ }^{72}$ O primeiro levantamento foi realizado pela CEAU de 1974.
} 
iconográfico. A abertura de novos cursos é extremamente facilitada, porque sua implantação se torna "barata" - ainda que a essência da natureza de sua oferta esteja prejudicada".

Ainda sobre este assunto, Leite (2005) relata que nesta segunda avaliação do CEAU, em pelo menos metade dos cursos analisados não havia menção explícita da existência de práticas experimentais como recurso didático. E nos casos onde constava esta referência 'aulas de laboratório', não se verificava a pormenorização da natureza dos espaços pedagógicos, nem tampouco o tipo de atividade desenvolvida. Os programas das disciplinas de Tecnologia, em geral com uma listagem de aulas teórica intercaladas com aulas denominadas 'práticas', destinadas à resolução de exercícios de dedução matemática, levando a entender que o conceito de atividade experimental, quando existia, era bastante restrito, voltado à demonstração e comprovação das teorias científicas transmitidas e não à experimentação e à prospecção, revelando um ensino pouco voltado à problematização como método de aprendizagem.

De acordo com as Diretrizes Curriculares de 1994, passa então a ser exigida a dotação por parte dos cursos das condições infraestruturais e de oferecimento de espaços e equipamentos especializados para as matérias profissionais. Percebe-se que este aspecto aponta ao mesmo tempo para uma concepção de metodologia de ensino de arquitetura e urbanismo baseada na interação entre teoria e prática, com ênfase no caráter experimental do aprendizado. Como também, constitui-se numa estratégia para garantir o suporte para as especificidades da formação na área: ateliers de projeto, maquetaria, laboratórios diversos, etc. É importante registrar que a Portaria no 1.770/94 do Ministro da Educação e Cultura explicita como origem das novas Diretrizes Curriculares as recomendações dos Seminários Regionais e Nacional dos Cursos de Arquitetura e Urbanismo e da Comissão de Especialistas de Ensino de Arquitetura e Urbanismo da Secretaria de Ensino Superior do MEC. A ideia central foi consagrar na estrutura curricular, apoiando-se num recorte temporal (início dos anos 1990), as matérias pertinentes aos conhecimentos que caracterizariam as atribuições e responsabilidades profissionais.

De acordo com Monteiro (2013), diante de tal diagnóstico, a CEAU e a ABEA se uniram novamente para elaboração do documento intitulado Perfis da Área \& Padrões de qualidade expansão, reconhecimento e verificação periódica dos Cursos de Arquitetura e Urbanismo, que foi apresentado ao CNE em 1996. Se a Portaria 1770/94 estabelecia Diretrizes Curriculares a partir do princípio da qualidade do ensino, o documento ia além. O documento Perfis da Área 
\& Padrões de Qualidade estabelecia indicadores e padrões de qualidade para a abertura e funcionamento dos cursos de graduação em Arquitetura e Urbanismo e possibilitavam:

"[...] a análise das características da estrutura curricular proposta para o Curso ou a praticada, o perfil desejável ou existente do corpo docente e as condições de oferta ou de funcionamento da Biblioteca, dos Laboratórios exigidos, e instalações físicas em geral, bem como indicavam a relação professor/aluno a ser respeitada."

De acordo com o referido documento as matérias que integram o conteúdo mínimo e que requerem espaços e equipamentos especializados, tais como tecnologia da construção, sistemas estruturais, conforto ambiental, projeto de arquitetura, de urbanismo e de paisagismo, topografia, informática aplicada à arquitetura e ao urbanismo, têm como condição para a sua oferta a existência de laboratórios, maquetarias, salas de projeto, acervo bibliográfico, além de equipamentos a eles correspondentes.

O documento de 1996 propõe um roteiro das informações a serem fornecidas pelas IES, para a abertura e funcionamento de cursos. Nele, os objetivos do Laboratório de Tecnologia e construção seriam ${ }^{73}$ :

- Permitir a simulação dos mecanismos de sistemas estruturais através de modelos visando identificar e ilustrar o comportamento dos diferentes mecanismos estruturais;

- Da óptica dos sistemas construtivos: identificar as características tipológicas, técnicas, econômicas e do contexto ambiental dos principais sistemas;

- Da óptica dos materiais: a) identificar as características relativas ao desempenho (físico/mecânico, termo-acústico, etc) dos principais materiais; b) apreender as diferentes técnicas de utilização dos diferentes materiais;

- Desempenho e verificação laboratorial de materiais e componentes construtivos especificados no projeto e empregados na obra do edifício e da cidade;

- Experimentação e ensaios relativos a técnicas construtivas e materiais estruturais;

- Características de desempenho e técnicas de utilização dos diferentes materiais;

- Modelos de sistemas construtivos, estruturais e instalações;

\footnotetext{
${ }^{73}$ No roteiro de informações a serem fornecidas pelas IES também era contemplada as Condições de Uso dos Laboratórios, indicando:

- tipificação (características e finalidades); - pessoal especializado para apoio às aulas práticas e ao funcionamento dos laboratórios; - relação dos equipamentos mais importantes e respectivas quantidades; - área de cada laboratório disponível ao curso $\left(\mathrm{m}^{2}\right)$; - capacidade de atendimento ao aluno por turma, considerando a área e os equipamentos disponíveis; - grau de ocupação considerando as aulas práticas (horas de aulas práticas / horas disponíveis para uso); - condições de uso, segurança, higiene e conforto; - horário de funcionamento do laboratório para uso dos alunos. Em relação ao Plano de Manutenção dos Equipamentos, dever-se-ia fornecer as seguintes informações: - existência de contratos de manutenção e/ou existência de estrutura local de manutenção e também, o curso deveria apresentar um Plano de Atualização Tecnológica dos Laboratórios.
} 
- Patologias.

Este mesmo documento também sinaliza uma sugestão sobre a configuração dos laboratórios para atender aos Padrões de Qualidade, no caso do Laboratório de Tecnologia da Construção traz informações questionáveis, ao priorizar atividades com um material construtivo específico em detrimento de outros, ao listar atividades com o concreto armado e $\operatorname{argamassados}^{74}$.

Em 1999, é redigido pela primeira vez por outra comissão de especialistas um documento com a sinalização detalhada sobre como deveriam ser as instalações técnicas do Laboratório de Tecnologia da Construção - englobando o Canteiro Experimental e Maquetaria - discutidas no IX Conabea/XVI Ensea. Os próprios especialistas que redigiram este documento alertavam na época que as configurações sinalizadas não se tratavam de "modelos inquestionáveis", e sim como "parâmetros consistentes de referência" para o processo de avaliação dos cursos, havendo o reconhecimento que a prática laboratorial no ensino de tecnologia da construção é um assunto ainda incipiente nos cursos e que deveria ser discutido em um universo maior, para que seja aprimorada e confrontada com diferentes posições. Nota-se um ponto diferente e amadurecido neste momento em relação às apresentadas em 1996, em Perfis da área \& Padrões de Qualidade, pois enquanto as sugestões do CEAU priorizavam a manipulação do material 'concreto armado', as diretrizes de 1999 (Anexo - Caderno 21 ABEA) propõem que sejam trabalhados pelos laboratórios acadêmicos, além deste material, também as estruturas metálicas, de madeira, alvenaria estrutural e que fossem realizadas experimentações ${ }^{75}$.

De acordo com Monteiro (2013), após um período de rediscussão sobre as Diretrizes Curriculares - adequando-as às exigências decorrentes da base legal expressa nas Diretrizes Curriculares e conteúdos mínimos de 1994 e na nova legislação para o ensino superior, a Lei de Diretrizes e Bases da Educação Nacional (LDB), no 9.394, de 20 de dezembro de 1996 - as contribuições foram então encaminhadas e resultaram na proposta de Resolução das Diretrizes Curriculares para os cursos de Arquitetura e Urbanismo, protocolada no MEC ainda no ano de 1998. Essa proposta de diretrizes curriculares tramitou no Conselho Nacional de Educação (CNE) durante oito anos e, reafirmando o documento de 1994 foi finalmente aprovada no dia 2 de fevereiro de 2006 por meio da Resolução CNE/CES n $n^{\circ}$ 6/2006. BRASIL (2006)

\footnotetext{
${ }^{74} \mathrm{Na}$ íntegra, o documento sugere para os Laboratórios de Tecnologia da Construção: "cujos equipamentos garantam em número e desempenho a verificação laboratorial de materiais e componentes construtivos especificados no projeto $e$ empregados na obra; experimentação e ensaios tais como os relativos a técnicas construtivas; modelos de sistemas construtivos; patologias; equipamentos para rompimento de corpos de prova de concreto e argamassa, ensaio normalizado de agregados miúdos, ensaio não destrutivo do concreto, ensaio de tração. Estão incluídas as instalações e equipamentos prediais e a infraestrutura urbana".

${ }^{75}$ Ver maiores explicações no Quadro 09.
} 
Com a Resolução CNE/CES 2006 que Institui as Diretrizes Curriculares Nacionais do curso de graduação em Arquitetura e Urbanismo, a Portaria 1.770/94 foi substituída. Segundo Maragno (2013), ela estabelece já em seu artigo 2ㅇ que a organização de cursos de graduação em Arquitetura e Urbanismo deverá ser elaborada com "claro estabelecimento de componentes curriculares, os quais abrangerão: projeto pedagógico, descrição de competências, habilidades e perfil desejado para o futuro profissional, conteúdos curriculares, estágio curricular supervisionado, (...)". Ela também estabelece o campo geral de atuação ao determinar que a proposta pedagógica deva assegurar a formação de profissionais generalistas, capazes de compreender e traduzir as necessidades de indivíduos, grupos sociais e comunidade, com relação à concepção, à organização e à construção do espaço interior e exterior, abrangendo o urbanismo, a edificação, o paisagismo, bem como a conservação e a valorização do patrimônio construído, a proteção do equilíbrio do ambiente natural e a utilização racional dos recursos disponíveis.

Além disso, o curso deve ensejar condições para que o futuro arquiteto e urbanista tenha como perfil uma sólida formação de profissional generalista, discurso este já defendido por diversos autores, como Vianna (1989), Zanettini (2002) e Lima (2004), os quais complementam que, além da formação profissional generalista, também dever-se-ia proporcionar ao aluno ferramentas compatíveis com os desafios contemporâneos, no que diz respeito às questões sociais, ambientais, tecnológicas e industriais, atuando como agentes responsáveis pela abertura de novos caminhos a partir da invenção e quebra de paradigmas ${ }^{76}$.

No que se refere à infraestrutura laboratorial, o documento elaborado em 1994 continua a vigorar. O período de oito anos que foram levados para sua aprovação (de 1998 a 2006), sinaliza a necessidade de atualizar os dados publicados de acordo com as significativas mudanças tecnológicas verificadas no setor da construção civil. E, embora esta óbvia constatação, em 2013 o CAU propõe algumas atualizações nas Diretrizes Curriculares encaminhando-as junto ao MEC para análise ${ }^{77}$. Nesta nova proposta, não é mencionada

\footnotetext{
${ }^{76}$ A formação multidisciplinar do arquiteto e o equilíbrio entre o conteúdo teórico e prático foram intensamente discutidos por diversos profissionais brasileiros desde a década de 1950 e revelam desafios comuns aos vivenciados atualmente no ensino de Arquitetura e Urbanismo, principalmente, sobre a dualidade entre arte e técnica, assunto que sempre suscitou opiniões divergentes, como visto no documento O Ensino de Arquitetura, de 1956, quando os professores Mário Wagner Vieira da Cunha, Luís Saia, João Vilanova Artigas e Lina Bo Bardi participaram de um debate sobre as reestruturações necessárias ao curso.

77 Dado obtido em entrevista realizada com o conselheiro do CAU arq. João Carlos Correia, então Conselheiro de Ensino e Formação do CAU-SP. Data da entrevista: 10/04/14.
} 
qualquer atualização no que diz respeito aos laboratórios e espaços experimentais dos cursos de Arquitetura e Urbanismo, permanecendo em vigor o conteúdo do documento de 1994.

Para melhor compreensão, o Quadro 09 traz uma síntese dos principais fatos históricos que, de alguma forma, impactaram em reformas para a área da Tecnologia nos cursos de Arquitetura do país com a identificação das principais ações realizadas por entidades nacionais. Cabe ressaltar, que esta síntese não tem como objetivo detalhar os fatos históricos ocorridos ao longo dos anos, mas apenas situar historicamente em quais momentos a questão da tecnologia construtiva foi pauta de discussões ou sofreu alguma mudança significativa por estes fatos, direta ou indiretamente. Desta forma, foram priorizadas as ações empreendidas pelas entidades, quando demonstram preocupação pela área tecnológica e consciência sobre a importância das atividades experimentais na área técnico-construtiva:

Quadro 09 - Síntese dos principais fatos históricos que contribuíram de alguma forma para reformas e melhorias para a área da Tecnologia da Construção.

Os cursos de arquitetura (inseridos em instituições públicas) cujo início de implantação ocorre anteriormente a 1956 foram: FAU UFRJ; EA UFMG; FA UFRGS; FAU USP; FA UFBA e FAU UFPE. Antes deste período, foram também fundadas as agências do CNPq, em 1950 e da CAPES, em 1951;

\begin{tabular}{|c|c|}
\hline $\begin{array}{l}\text { Data/ } \\
\text { Governo }\end{array}$ & $\begin{array}{c}\text { Principais Ações promovidas pelas Instituições de Ensino; Entidades } \\
\text { Governamentais e Associativas }\end{array}$ \\
\hline $\begin{array}{l}\text { Juscelino } \\
\text { Kubitsche } \\
\text { ck } 1956- \\
1961\end{array}$ & $\begin{array}{l}\text { Ensino : - Impacto da arquitetura modernista brasileira no ensino: influência da construção de Brasília; } \\
\text { - Em } 57 \text { a FAUUSP promove uma reestruturação das linhas mestras do curso, na qual o 'ateliê' passou a ser } \\
\text { chamado de 'espinha dorsal' e foi proposta uma estrutura didático-pedagógica com } 3 \text { departamentos: Projeto, } \\
\text { Tecnologia e História/Estética da Arquitetura; } \\
\text { - Em outras regiões do país também são promovidas discussões sobre reestruturações nos cursos de } \\
\text { arquitetura como UMG e URGS, defendendo conceitos próximos ao da FAUUSP sobre a representatividade dos } \\
\text { ateliers de projeto nos cursos. } \\
\text { Governo: - }\end{array}$ \\
\hline \begin{tabular}{l|l} 
J. Goulart \\
$1961-1964$
\end{tabular} & $\begin{array}{l}\text { Ensino: - A FAUUNB, criada em 1962, teve sua proposta de ensino estruturada em três 'troncos': teoria, } \\
\text { composição e tecnologia (havia uma total integração entre teoria e prática, com foco na arquitetura como } \\
\text { processo) })^{78} \text {. } \\
\text { - Discussões sobre a reforma universitária. Formulação de Diretrizes para o Currículo Mínimo de } 1962 . \\
\text { Governo: - Cursos de arquitetura criados neste governo e inseridos em instituições públicas: UNB (1962); UFPR } \\
\text { (1962/63); UFC (1964); UFPA (1964). }\end{array}$ \\
\hline \multicolumn{2}{|r|}{ 1964-1985 - REGIME MILITAR } \\
\hline $\begin{array}{l}\text { H. Castelo } \\
\text { Branco } \\
1964-1967\end{array}$ & $\begin{array}{l}\text { Ensino: - } \\
\text { Governo: Perseguição e cassação de professores e estudantes universitários. Desestruturação do ensino até } \\
\text { então implantado. }\end{array}$ \\
\hline $\begin{array}{c}\text { Costa e Silva } \\
1967-1969\end{array}$ & $\begin{array}{l}\text { Ensino: - } \\
\text { Governo: - Reforma Universitária e implantação do Currículo Mínimo de } 1969^{79} \text {. De acordo com Leite (2005), }\end{array}$ \\
\hline
\end{tabular}

\footnotetext{
78 De acordo com FICHER e SCHLEE (2010), em fevereiro de 1962 entrou em funcionamento o Curso de Arquitetura e Urbanismo integrado ao Instituto Central de Artes, ICA, então sob direção de Alcides da Rocha Miranda. Com sede temporária na Esplanada dos Ministérios e com atividades no canteiro de obras do futuro campus, desde o princípio o seu objeto privilegiado de estudo foi a própria cidade de Brasília e o espaço de treinamento prático in loco na Universidade em construção. O curso tinha Oscar Niemeyer como coordenador e Ítalo Campofiorito como secretário executivo. O ensino de graduação estava organizado em três linhas complementares: Composição e Planejamento, sob direção de Glauco Campello; Tecnologia, sob direção de João Filgueiras Lima; Teoria e História, sob direção de Edgar Graeff.
} 


\begin{tabular}{|c|c|}
\hline & este documento promove a ampliação da atividade projetual e início do desprestígio dado à área técnica ${ }^{80}$. \\
\hline $\begin{array}{l}\text { Emílio } \\
\text { Médici } \\
\text { 10/1969 a } \\
03 / 1974\end{array}$ & $\begin{array}{l}\text { Ensino: - } \\
\text { Governo: - Pela Portaria Ministerial no } 699 \text { de 1973, foi criada a Comissão de Especialistas no Ensino de } \\
\text { Arquitetura e Urbanismo (CEAU), no Departamento de Assuntos Universitários do Ministério da Educação e } \\
\text { Cultura. Os cursos de arquitetura criados neste governo e inseridos em instituições públicas foram: UFF } \\
\text { (1970); UFPel (1971); UFRN (1973); UFAL (1973); } \\
\text { ABEA: - Criação da ABEA (Associação Brasileira de Escolas de Arquitetura) em 1973; } \\
\text { - Apoio à CEAU para a realização do levantamento sobre a situação do ensino nas escolas nacionais; }\end{array}$ \\
\hline $\begin{array}{l}\text { Ernesto } \\
\text { Geisel } \\
\text { 1974-1979 }\end{array}$ & $\begin{array}{l}\text { Ensino: - Secretaria Geral da União Internacional de Arquitetos (UIA), incumbiu as Faculdades de Arquitetura } \\
\text { e Urbanismo de Brasília e de São Paulo, de organizar um estudo para a UNESCO sobre os Programas de } \\
\text { Ensino de Arquitetura. } \\
\text { - Em } 1974 \text { as deliberações do I Encontro de Professores de Estruturas para Escolas de Arquitetura, } \\
\text { consideraram as peculiaridades intrínsecas do tipo de profissional a ser formado e as especificidades e } \\
\text { comportamento de tipos diversos de estrutura. Entre outras recomendações estavam: a implantação de } \\
\text { laboratórios; abertura da possibilidade de estudo do comportamento estrutural e a viabilidade técnica de } \\
\text { outras estruturas e materiais; } \\
\text { - 1976, mesmas reinvindicações sobre os laboratórios de estruturas. } \\
\text { Governo: - Em 1974, visita pelo CEAU às escolas do Brasil, com elaboração do documento: 'Diagnóstico das } \\
\text { condições de ensino e pesquisa em arquitetura e urbanismo no Brasil'. Este documento traz poucas } \\
\text { discussões sobre a área de tecnologia e da infraestrutura utilizada pelos cursos, sendo apenas destacada a } \\
\text { ausência de padrões de referência e a situação de improviso encontrada nas escolas visitadas }{ }^{81} \text {. Os cursos de } \\
\text { arquitetura criados neste governo e inseridos em instituições públicas: UFPB (1974); UFSC (1977); UEL } \\
\text { (1978); UFES (1978); } \\
\text { ABEA: - }\end{array}$ \\
\hline $\begin{array}{l}\text { João } \\
\text { Figueiredo } \\
1979-1985\end{array}$ & $\begin{array}{l}\text { Ensino: - } \\
\text { Governo: Os cursos de arquitetura criados neste governo e inseridos em instituições públicas: UNESP-Bauru } \\
\text { (1984), EESC-USP (1985); } \\
\text { ABEA: - Entre } 1982 \text { e } 1985 \text { a ABEA deixou de funcionar, de acordo com a falta de documentos desenvolvidos } \\
\text { neste período }{ }^{82} \text {. } \\
\text { - Em } 1982 \text { foi desenvolvida uma Proposta de Currículo Mínimo reencaminhada ao Conselho Federal de } \\
\text { Educação em 1986. De acordo com as ementas propostas para o Setor de Tecnologia da Arquitetura e } \\
\text { Urbanismo, são sugeridos: Práticas de Atelier, Oficina, Laboratório e Canteiro de obras }{ }^{83} \text {. } \\
\text { - Em } 1985 \text { a associação passa por uma reformulação, transformando-se em uma entidade de ensino: } \\
\text { Associação Brasileira de Ensino de Arquitetura e Urbanismo. }\end{array}$ \\
\hline \multicolumn{2}{|r|}{ NOVA REPÚBLICA } \\
\hline \multicolumn{2}{|l|}{$\begin{array}{c}\text { Sarney } \\
1985- \\
1990\end{array}$} \\
\hline \begin{tabular}{c|} 
Collor \\
$03 / 1990-$ \\
$12 / 1992$
\end{tabular} & $\begin{array}{l}\text { Ensino: - } \\
\text { Governo: Os cursos de arquitetura criados neste governo e inseridos em instituições públicas: UFV (1992); UFJF } \\
\text { (1992) } \\
\text { ABEA: - }\end{array}$ \\
\hline Itamar & Ensino: - \\
\hline
\end{tabular}

${ }^{79}$ SANTOS (2001), defende em seu trabalho a hipótese de que a luta pelo estabelecimento de uma concepção própria da educação escolarizada do arquiteto e urbanista, capaz de resgatar e atualizar os fundamentos históricos da profissão e incorporar as experiências modernistas brasileiras, cedeu terreno à luta em torno da ideia de um Currículo Mínimo. E, a busca de novas alternativas ao modelo anterior, centralizado e rígido, foi substituída pela luta pela reformulação deste instrumento formal, que passaria a ser um condão estratégico capaz de complementar a difícil integração das práticas do ofício com o saber escolarizado da universidade e possibilitar a homogeneização da qualificação profissional nos vários pontos do país.

${ }^{80}$ LEITE, M.A.D (2005), p. 48,49 e 50.

${ }^{81}$ No levantamento realizado em 1974 (no início da atuação do CEAU) intitulado: 'Diagnóstico das condições de ensino e pesquisa em arquitetura e urbanismo no Brasil', é comentado que a ausência de laboratórios e serviços auxiliares, na maioria das instituições, é um seguro indicador da tendência de orientação essencialmente teórica em disciplinas que necessitam de experimentação prática, importante para o aprendizado mais adequado. p. 103. O mesmo documento conclui em suas observações que uma visão sadia da Arquitetura não pode deixar de considerar a necessidade dos laboratórios como espaços importantes na complementação dos conhecimentos a serem adquiridos. p. 156.

${ }^{82}$ Gutierrez (2013). p. 20.

${ }^{83}$ Santos (2001), p. 197 


\begin{tabular}{|c|l|c|}
\hline Franco & Governo: - 1994 - o Currículo Mínimo é substituído pelas Diretrizes Curriculares que ficou vigente por 25 anos. \\
$12 / 1992$ & - O último relatório desenvolvido pela CEAU, após um período de interrupção de suas atividades foi publicado \\
em 1994. Os dados divulgados revelam maior reconhecimento da importância dos laboratórios voltados à \\
experimentação construtiva que o anterior de 1973, mas revela um cenário lamentável visto na maioria das \\
escolas brasileiras: a inexistência destes espaços ou quando existentes, muitos foram considerados como \\
'retóricos', pois ou são inadequados ou pertencem a outros cursos, dificultando o acesso pelos alunos da \\
arquitetura. $^{84}$ \\
- Neste período, foi realizada a elaboração de Diretrizes para configuração dos espaços experimentais, visto \\
que foi constatado que estes espaços não respondiam às necessidades do ensino, com verificação de que, a \\
exemplo dos laboratórios de informática, estes também precisam de apoio financeiro, principalmente o \\
canteiro de obras, a maquetaria e materiais de construção. Além disso, foi salientada a necessidade que \\
determinados espaços de trabalho fossem exclusivos para a arquitetura, não sendo possível ter caráter \\
compartilhado.
\end{tabular}

${ }^{84}$ De acordo com o parecer da Comissão de Especialistas: 'A dinâmica do processo de ensino - aprendizagem requer a utilização de múltiplas formas de apropriação do conhecimento, e não se limita à oferta de disciplinas ministradas na sala de aula. Há a necessidade de buscar o conhecimento em sua fonte, com o envolvimento dos alunos nos processos construtivos, verificações laboratoriais, pesquisas bibliográficas, iconográficas e de campo, vivenciando os problemas a serem resolvidos em nível do projeto, e estimulando as atividades de pesquisa e extensão, de forma a garantir o desenvolvimento de metodologias consentâneas com a transformação do conhecimento no campo da construção do edifício e da cidade'. CEAUSESU-MEC - 1996. p. 09 e 10. Para SANTOS (2001), a ausência de laboratórios e serviços auxiliares observada na maioria das instituições é seguro indicador da tendência de orientação essencialmente teórica em disciplinas que necessitam de experimentação prática, importante para o aprendizado mais adequado.

${ }^{85}$ Discussão realizada nos Seminários da Região Nordeste, Norte/Oeste e da Região Sul. É Observado no documento publicado pelo CEAU, o entendimento que a comissão possuía sobre Laboratório de Construção, destacando a indicação de atividades relacionadas ao rompimento de corpos de prova de concreto e análise de componentes de base cimentícia. Não são mencionados outros materiais construtivos como aço, madeira, cerâmicos, derivados e o desenvolvimento de componentes sem função estrutural. Na íntegra, segue as diretrizes deste documento: 'Laboratórios de Tecnologia da Construção', cujos equipamentos garantam em número e desempenho a verificação laboratorial de materiais e componentes construtivos especificados no projeto e empregados na obra; experimentação e ensaios tais como os relativos a técnicas construtivas; modelos de sistemas construtivos; patologias; equipamentos para rompimento de corpos de prova de concreto, ensaios de tração. Estão incluídas as instalações e equipamentos prediais e a infra-estrutura urbana'. No caso da Oficina de Maquetes e Laboratório de Modelos, a percepção dos profissionais que redigiram o documento seria: 'Um espaço equipado de maneira a permitir o trabalho de alunos na experimentação através de maquetes e modelos, auxiliando todas as disciplinas no desenvolvimento dos trabalhos de curso. Número de equipamentos em função do número de usuários. Configuração de equipamentos a critério de cada curso'. Nota-se nas descrições supracitadas sobre os dois laboratórios, que o primeiro possui caráter de laboratório de construção para a engenharia, não estando aberto à experimentação, já o segundo, as oficinas de modelos e maquetaria, possuiriam esta configuração, de acordo com a percepção da comissão que propõe o documento. CEAU-SESU-MEC - 1996. p. 27.

${ }^{86}$ CEAU p. 85 e Portaria 1.770-MEC/1994. Art. 5‥

${ }^{87}$ No contexto brasileiro de Arquitetura e Urbanismo, houve no período, uma forte expansão de cursos por todo o território nacional. Também a informática se popularizou, bem como a utilização de ferramentas digitais nas práticas didáticas. Diante de tal conjuntura, a ABEA considerou que era hora de: "... abrir novamente o debate e mais uma vez acordarmos as bases de qualidade que desejamos para os nossos cursos. Precisamos avaliar a evolução do perfil da nossa área e da natureza de nossa profissão. Precisamos redefinir os requisitos necessários para o funcionamento dos cursos de Arquitetura e Urbanismo e, dessa forma, firmarmos um pacto de qualidade em torno de Padrões de Qualidade que reflitam a realidade nacional e os novos contextos internacionais". 


\begin{tabular}{|c|c|}
\hline & $\begin{array}{l}\text { UFMT (1995); UFU (1996); UNICAMP (1999); UEM (2000); UFRRJ (2000); UFMS (1999/2000); UFT (2000); UFCG } \\
\text { (2002); } \\
\text { ABEA: Em novembro de 1999, com a realização do IX Conabea e XVI Ensea, foi discutido e reunido em Anexo } \\
\text { ao Caderno 21, as configurações preconizadas sobre os laboratórios voltados ao curso de Arquitetura. Pela } \\
\text { primeira vez, é redigido um documento com a sinalização detalhada sobre como deveriam ser as instalações } \\
\text { técnicas do Laboratório de Tecnologia da Construção - englobando o Canteiro Experimental e Maquetaria - na } \\
\text { intenção de ampliar a divulgação entre todos os segmentos interessados no desenvolvimento e na qualidade } \\
\text { da educação de arquitetos. Os próprios especialistas que redigiram este documento alertam que as } \\
\text { configurações propostas não se tratam de "modelos inquestionáveis", e sim como "parâmetros consistentes de } \\
\text { referência" para o processo de avaliação dos cursos, em que os próprios especialistas reconhecem que a } \\
\text { prática laboratorial no ensino de tecnologia da construção é um assunto ainda incipiente nos cursos e que } \\
\text { deveria ser discutido em um universo maior, para que seja aprimorada e confrontada com diferentes } \\
\text { posições }{ }^{88} \text {. As Configurações Preconizadas foram elaboradas por especialistas, no período compreendido entre } \\
\text { 96/97, a pedido da CEAU - SESU/MEC para orientar as IES }{ }^{89} \text {. Um ponto diferenciado observado nas diretrizes } \\
\text { de 1999 em relação às formuladas pelo CEAU sobre as atividades laboratoriais da área construtiva, refere-se } \\
\text { aos tipos de materiais a serem manipulados nestes espaços. Enquanto as sugeridas pela CEAU restringem-se } \\
\text { unicamente a manipulação do material 'concreto armado', as diretrizes de } 1999 \text { (Anexo - Caderno } 21 \text { ABEA) } \\
\text { propõem que sejam trabalhados, além deste material, também as estruturas metálicas, de madeira, alvenaria } \\
\text { estrutural e também sejam realizadas experimentações. }\end{array}$ \\
\hline $\begin{array}{c}\text { Inácio } \\
\text { Lula da } \\
\text { Silva } \\
2003- \\
2011\end{array}$ & 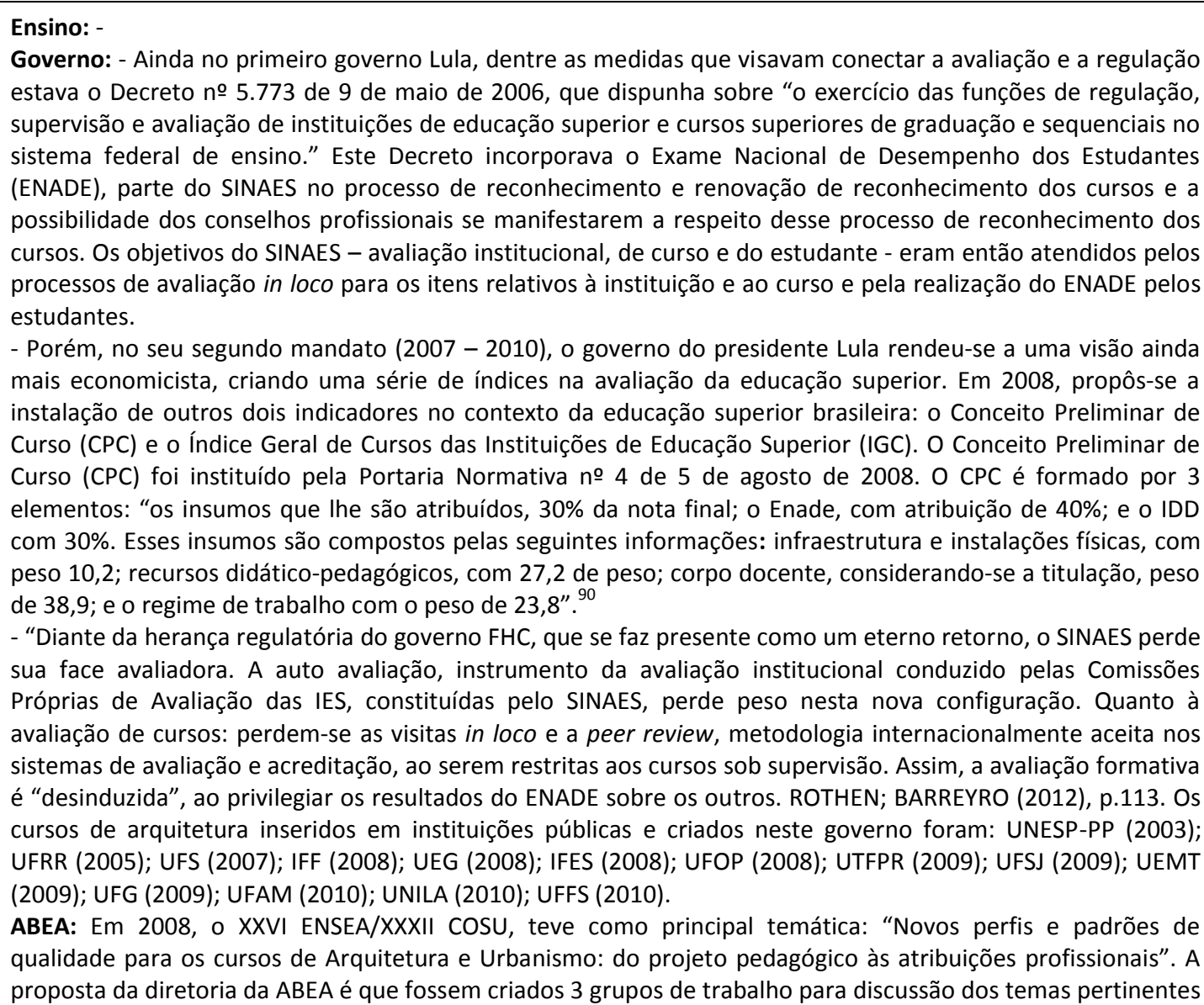 \\
\hline
\end{tabular}

\footnotetext{
${ }^{88}$ Os consultores sobre Tecnologia da Construção e Sistemas Estruturais para a realização deste documento foram os professores: Syllas Grazzia (UFRGS); Érico Weidle (UNB); Anderson Claro (UFSC) e Philip Gunn (USP).

${ }^{89}$ Nota-se que este documento amadurece as diretrizes estabelecidas pela CEAU em 1994, quando o assunto é abordado pela primeira vez com mais profundidade depois de 1973. Pode-se considerar que o Anexo do Caderno 21 da Abea é resultado desta iniciativa. Mas, infelizmente, como pode ser visto nas informações que seguem no Quadro 06, embora estas discussões tenham partido como uma demanda do próprio CEAU-SESU/MEC aos especialistas, estas ficaram restritas neste contexto, não sendo transformadas em normas oficiais pelos dirigentes responsáveis. Estes esforços e iniciativas não se transformaram em ações de lei para a implantação e funcionamento das escolas nacionais, restringindo-se a uma sugestão orientadora oferecida às IES. Embora este assunto tenha sido retomado em 2008, mesmo diante de diversas mutações nas políticas governamentais, até o presente momento ainda vigoram as diretrizes estabelecidas em 1994.

90 É observado, que o Governo atribui um peso menor no item de sua responsabilidade nas instituições públicas: infraestrutura e instalações físicas, e que requerem recursos provenientes, principalmente, de fontes governamentais.
} 


\begin{tabular}{|c|c|}
\hline & $\begin{array}{l}\text { aos Padrões de Qualidade: Grupo } 1 \text { - responsável pelos assuntos relativos aos Recursos Materiais; Grupo } 2 \text { - } \\
\text { responsável pelos assuntos relativos ao corpo docente e Grupo } 3 \text { - responsável pelos assuntos relativos ao } \\
\text { Projeto Pedagógico (ABEA, 2008). A partir daquele momento, a diretoria da ABEA deu início a uma } \\
\text { aproximação junto ao INEP para apresentação do documento acima mencionado e, sua consequente } \\
\text { aprovação junto ao governo federal. Tal iniciativa não logrou êxito. Porém, o documento inicialmente referido } \\
\text { ainda pode ser encontrado e acessado a partir do portal do MEC e, pelo que se sabe, é ainda utilizado pelos } \\
\text { coordenadores de curso para garantia da qualidade de seus cursos. }\end{array}$ \\
\hline $\begin{array}{c}\text { Dilma } \\
\text { Roussef } \\
\text { 2011- } \\
\text { 05/2016 }\end{array}$ & $\begin{array}{l}\text { Ensino: - } \\
\text { Governo: Os cursos de arquitetura inseridos em instituições públicas e criados neste governo foram: UFAP } \\
\text { (2011) } \\
\text { ABEA: - O CAU propõe a revisão da Resolução CNE/CES n }{ }^{\circ} 2 / 2010 \text {, aprovada no XVII CONABEA/2013 e na 30a } \\
\text { Plenária do CAU-BR/2014. É acrescentado no ART } 50 \text { o } \$ 20 \text { que diz: Para atingir os objetivos e desenvolvimento } \\
\text { pleno destas Diretrizes, os cursos de Arquitetura e Urbanismo deverão ser equipados adequadamente com } \\
\text { laboratórios específicos, ateliês ou salas de projetos, instalações para pesquisas estudos avançados, bibliotecas } \\
\text { com acervo adequado e suficiente, e disponibilidade de tecnologias atualizadas para o intercâmbio de } \\
\text { informações } \\
\text { - No } \$ 5 \text {. } \\
\text { sobre os conteúdos: - produção em ateliê, experimentação em laboratórios e canteiros de obras, elaboração } \\
\text { de modelos, utilização de computadores, consulta a bibliotecas e a bancos de dados; }\end{array}$ \\
\hline
\end{tabular}

Os dados sintetizados no Quadro 09 orientaram a coleta de dados durante as visitas técnicas, como também, deram subsídios para o desenvolvimento dos demais ítens deste Capítulo. A compreensão do momento político educacional vivenciado no país na época da implantação de cada escola, possibilita um olhar mais aprofundado sobre o respaldo e apoio que cada curso possuía no momento de sua implantação, aumentando as chances de se obter respostas mais assertivas às perguntas de pesquisa sinalizadas no Capítulo Introdutório.

\subsection{CARACTERIZAÇÃO DOS ESPAÇOS EXPERIMENTAIS E PRÁTICAS TÉCNICO-CONSTRUTIVAS DAS ESCOLAS VISITADAS}

Após duas décadas da realização da primeira avaliação das escolas de arquitetura em 1974, o CEAU conduz uma segunda avaliação dos cursos nacionais de arquitetura por volta de 1994, fornecendo nesta ocasião, dados mais detalhados sobre a infraestrutura das mesmas, com declarações preocupantes sobre as condições encontradas, inclusive as escolas públicas. Sobre esse cenário, chama a atenção uma consideração de Santos (2010), sobre o levantamento do CEAU de 1974, ao relatar que de uma maneira geral, os cursos nas instituições públicas eram os que apresentavam menos deficiências do que a maioria das instituições quanto às instalações. Segundo o autor, em 1994 ocorre uma inversão: observa-se um sucateamento das instalações

\footnotetext{
${ }^{91}$ Deve-se refletir aqui que, embora pareça um avanço em relação à Resolução $\mathrm{n}^{\circ} 2$ de 2010 - pelo fato desta não mencionar a necessidade da existência de laboratórios específicos nos cursos, que propiciariam o desenvolvimento das atividades propostas no Projeto Pedagógico dos cursos (quando propõem prática e teoria) - em nenhum documento é mencionado como deveria ser a configuração dos laboratórios de construção, permanecendo ainda em vigor o documento de 1996: Perfis da Área e Padrões de Qualidade, o qual já apresentava problemas e merecia correções e atualizações. Duas décadas se passaram e nada foi oficialmente amadurecido sobre este aspecto, algo imprescindível diante do momento histórico que vivenciamos, com diversos avanços tecnológicos relacionados à construção civil.
} 
dos cursos sediados nas instituições públicas, decorrentes da falta de manutenção, provavelmente de carência, inadequação ou má distribuição das áreas.

Diferentemente das considerações avaliativas supracitadas, este trabalho tem como principal objetivo compreender a configuração dos espaços laboratoriais das escolas públicas brasileiras, os gargalos enfrentados e o entendimento que os cursos possuem sobre as atividades experimentais e sua importância, evidenciadas por meio da utilização destes espaços nas disciplinas e no desenvolvimento de pesquisas quando existentes.

A análise por categorias (períodos históricos) abre a possibilidade de detectar influências quando existentes - que algumas escolas podem exercer sobre outras ao longo da formação do quadro docente e identificar determinados princípios estruturantes destes espaços e práticas pedagógicas. Na intenção de estabelecer uma análise paritária entre escolas, buscouse organiza-las em períodos históricos delimitados por fatos que condicionaram significativas mudanças na estruturação do ensino de arquitetura no país, de acordo com o Quadro 10.

- Escolas implantadas antes da década de 1960 - Identificando a origem de cada escola a partir de alguns modelos: Escolas de Belas-Artes e Escolas Politécnicas, ou ainda, aquelas que surgiram de forma autônoma a estes modelos (UFBA/UFPE/UFMG/UFRGS/UFRJ/USP);

- Escolas implantadas ao longo da década de 1960 - antes da adoção do Currículo Mínimo de 1969 (UFPR/UNB/UFPA/UFC);

- Escolas implantadas ao longo da década de 1970 -aplicação de regulamentações estabelecidas pelo Currículo Mínimo e pela realização do primeiro levantamento pela Comissão de Especialistas em Arquitetura e Urbanismo - CEAU (UFF/UFPel UEL/UFES/UFPB/UFRN);

- Escolas implantadas ao longo da década de 1980 - fim da ditadura; (IAU-USP ${ }^{92}$ )

- Escolas implantadas ao longo da década de 1990 - realização do segundo levantamento pela Comissão de Especialistas em Arquitetura e Urbanismo - CEAU. (UFMS/UFU/UFV/UNICAMP)

Quadro 10 - Cursos de arquitetura e urbanismo em instituições públicas no país, de acordo com os critérios explicitados no Capítulo Introdutório.

\begin{tabular}{|c|c|c|c|c|c|c|c|c|c|c|c|c|c|c|c|c|c|}
\hline Região Sul & \multicolumn{6}{|c|}{ RS } & \multicolumn{3}{|c|}{ SC } & \multicolumn{8}{|c|}{ PR } \\
\hline $\begin{array}{l}\text { Instituições Públicas que } \\
\text { possuem curso de } \\
\text { Arquitetura }\end{array}$ & \multicolumn{3}{|c|}{ U.SM } & UFPel & \multicolumn{2}{|c|}{ UFRGS } & \multicolumn{2}{|c|}{ UDESC } & U.SC & \multicolumn{2}{|c|}{ UNILA } & \multicolumn{3}{|l|}{ UTFPR } & \multicolumn{2}{|l|}{ UEL } & UFPR \\
\hline Ano de criação do curso & 2010 & 19 & & 1971 & & $8 / 1936$ & 200 & & 1971 & 20 & 10 & 2009 & 200 & & $1978 / 7$ & & $\overline{1962 / 3}$ \\
\hline Região Sudeste & \multicolumn{5}{|c|}{ SP } & \multicolumn{6}{|c|}{ MG } & \multicolumn{4}{|c|}{ RJ } & \multicolumn{2}{|c|}{ ES } \\
\hline $\begin{array}{l}\text { Instituições Públicas que } \\
\text { possuem curso de } \\
\text { Arquitetura }\end{array}$ & $\begin{array}{l}\text { Unesp } \\
\text { P.Prud. }\end{array}$ & Unicamp & $\begin{array}{l}\text { USP/ } \\
\text { SCar }\end{array}$ & Unesp & $\begin{array}{c}\text { USP/ } \\
\text { SP }\end{array}$ & UFSJ & UFOP & UFU & UFV & U.1. & UFMG & IFF & UIRRI & UFF & UFRJ & IFES & UFES \\
\hline Ano de criação do curso & 2003 & 1999 & 1985 & 1984 & 1948 & 2009 & 2008 & 1996 & $\mid 1992$ & 1992 & 1930 & 2008 & 2000 & 1970 & 1826 & 2008 & 1978 \\
\hline
\end{tabular}

\footnotetext{
92 O IAU USP foi criado em 14/12/2010, a partir do desligamento do curso de Arquitetura e Urbanismo da Escola de Engenharia de São Carlos - Universidade de São Paulo - EESC USP.
} 


\begin{tabular}{|c|c|c|c|c|c|c|c|c|c|c|}
\hline \multirow{2}{*}{$\begin{array}{c}\text { Região Centro- } \\
\text { Oeste } \\
\text { Instituições Públicas que } \\
\text { possuem curso de } \\
\text { Arquitetura } \\
\end{array}$} & MS & \multicolumn{3}{|c|}{ MT } & \multicolumn{3}{|c|}{ GO } & \multicolumn{2}{|l|}{ DF } & \multirow{2}{*}{ TO } \\
\hline & \multicolumn{2}{|l|}{ UFMS } & UEMT & U.MTI & \multicolumn{2}{|c|}{ UFG } & UEG & \multicolumn{2}{|l|}{ UNB } & \\
\hline Ano de criação do curso & $1999 / 2000$ & & 2009 & 1995 & \multicolumn{2}{|c|}{2009} & 2008 & \multicolumn{2}{|l|}{1962} & 2000 \\
\hline Região Nordeste & BA & SE & AL & PE & \multicolumn{2}{|c|}{ PB } & RN & $\mathrm{CE}$ & PI & MA \\
\hline $\begin{array}{l}\text { Instituições Públicas que } \\
\text { possuem curso de } \\
\text { Arquitetura }\end{array}$ & UFBA & UFS & UEAL & UFPE & U. U. & UFPB & UFRN & UFC & UEPI & UEMA \\
\hline Ano de criação do curso & 1880 & 2007 & 1974 & 1932 & 2002 & 1974 & 1973 & 1964 & 1993 & 1993 \\
\hline Região Norte & \multicolumn{2}{|l|}{ PA } & AP & \multicolumn{2}{|c|}{ RO } & \multicolumn{2}{|c|}{ AM } & RR & & AC \\
\hline $\begin{array}{l}\text { Instituições Públicas que } \\
\text { possuem curso de } \\
\text { Arquitetura }\end{array}$ & \multicolumn{2}{|l|}{ UFPA } & UFAP & \multicolumn{2}{|c|}{ - } & \multicolumn{2}{|c|}{ UFAM } & UFRR & & - \\
\hline Ano de criação do curso & \multicolumn{2}{|l|}{1964} & $2011 / 12$ & \multicolumn{2}{|r|}{-} & \multicolumn{2}{|c|}{2010} & 2005 & & - \\
\hline
\end{tabular}

Escolas selecionadas para visita técnica

Escolas que atendem ao critério temporal, mas não foram visitadas

Escolas que não atendem ao critério temporal

Uma questão relevante a ser comentada relaciona-se à dificuldade em se chegar a uma zona divisória entre os aspectos relacionados às estruturas, aos materiais e técnicas construtivas, encadeando grande diversidade de conceituações sobre o processo experimental. Esta interface faz com que estes aspectos se atravessem em diversos momentos, dificultando o estabelecimento de limites quando há o interesse em estudá-los isoladamente. A partir desta problemática conceitual, este trabalho não tem a intenção de delimitar, mas de compilar uma maior quantidade de informações sobre a infraestrutura laboratorial acadêmica e as práticas pedagógicas da área da Tecnologia da Construção, procurando identificar a real vocação destes espaços de aprendizagem, e reconhecendo a possibilidade de extrapolar eventualmente para as outras áreas aqui citadas.

\section{Algumas Conceituações sobre os espaços experimentais}

Diante da inexistência - na bibliografia consultada - de conceituações que caracterizassem e, posteriormente, classificassem os tipos de infraestrutura e recursos adotados nas atividades experimentais acadêmicas dos cursos de arquitetura (ex: canteiro experimental, canteiro de obras, laboratório de tecnologia construtiva, de materiais, de processos, de estruturas, marcenaria, etc.), foi analisada a relevância em se delinear ou se definir tais conceitos. Esta ação também foi questionada devido à falta de parâmetros consistentes que atribuam um conceito pré-determinado a um espaço experimental, diante da falta de consenso entre a 
caracterização dos mesmos e as terminologias adotadas para designá-los, visto tanto na bibliografia encontrada como nas entrevistas realizadas.

Esta situação também se estende às práticas didáticas desenvolvidas (fabricação de modelos, protótipos, maquetes e realização de ensaios e simulações), pois os recursos empregados para o estudo da materialidade são diversos, desde aqueles cuja intenção do seu desenvolvimento volta-se ao estudo sensorial como os que envolvem procedimentos científicos, assim como, aqueles que promovem conhecimento instrucional (a partir de dados validados) ou que instigam o desenvolvimento de processos inovadores, apoiando-se em metodologia científica ou empírica. Diante deste cenário foi verificado que, basear-se em alguns autores na intenção de classificar as práticas experimentais a partir de algumas características comuns poderia conduzir a resultados de limitada aplicação, impossibilitando o enquadramento de outras práticas que possam vir a ser desenvolvidas futuramente, que não se encontram entre aquelas observadas no restrito grupo previamente classificado.

A partir destas considerações, este trabalho não busca uma forçosa conceituação sobre os diversos tipos de infraestrutura, recursos e práticas experimentais encontradas, sendo priorizada a descrição dos espaços encontrados e os tipos de atividades desenvolvidas de forma sistemática e contínua, em apoio às disciplinas da área da Tecnologia das Construções. Foram desconsideradas as atividades temporárias vinculadas, especificamente, aos projetos de pesquisa e de extensão, mesmo reconhecendo sua importância acadêmica. Diante disso, julgou-se que a caracterização seria um processo mais relevante do que a classificação, pois faculta a liberdade para diferentes interpretações e evita a consolidação de conceitos classificatórios pessoais e de terceiros, notadamente, os conceitos descritos na restrita bibliografia e, predominantemente, vindos de outras áreas como o Design, não se enquadrando à complexidade e às particularidades das atividades da área da arquitetura ${ }^{93}$.

Segue o Item 3.2.1 com a sistematização de informações obtidas a partir da triangulação de dados provenientes de documentos sobre cada curso (teses, Projetos Pedagógicos, sites institucionais, livros e artigos científicos), das visitas técnicas e também, das entrevistas realizadas.

\subsubsection{ESCOLAS VISITADAS}

\footnotetext{
93 Exceção encontrada nos exemplos publicados por HARRIS; SABNIS (1999) em Structural modeling and experimental techniques, sugerindo uma classificação de modelos didáticos voltados à engenharia e arquitetura.
} 
As visitas técnicas foram realizadas no período compreendido entre novembro de 2013 e novembro de 2016. As informações sobre cada escola foram organizadas em:

a) Breve histórico - baseado no exposto em cada projeto pedagógico de curso e sites institucionais, complementado com outras fontes quando necessário e, de acordo com a bibliografia disponível sobre o assunto;

b) Considerações sobre a estruturação da área da Tecnologia da Construção (TC) - dados sobre a organização das disciplinas por período e área de concentração. Devido ao fato de terem sido encontradas divergências na associação entre disciplinas e áreas, foi considerada neste trabalho uma classificação geral e padronizada, de responsabilidade da pesquisadora e, em alguns casos, não se apresenta de acordo com o exposto nos Projetos Pedagógicos de curso;

c) Quadro Docente da área estudada - devido à impossibilidade de obtenção de dados de todas as escolas visitadas referente à quantificação de docentes em cada área, foi considerada neste item apenas a descrição sobre o curso ao qual pertencem e se as disciplinas da área estudada estão sob a responsabilidade da Arquitetura ou Engenharia Civil;

d) Práticas Didáticas e Infraestrutura laboratorial na área da TC - neste quadro foram consideradas, prioritariamente, as informações obtidas nas visitas e entrevistas realizadas, observando as características da infraestrutura laboratorial e as estratégias pedagógicas utilizadas nas disciplinas da TC. Quando existentes, estas informações foram complementadas com bibliografia específica sobre o ensino da tecnologia de cada escola visitada (vale ressaltar que, ao longo dos anos, poucas escolas documentaram a trajetória da área técnica do seu curso);

e) Pós-Graduação - foram analisadas quais escolas possuem pós-graduação, identificando aquelas que oferecem áreas de concentração ou linhas de pesquisa na área da Tecnologia da Construção, procurando identificar o reflexo destas pesquisas na graduação;

f) Comentários - espaço onde foram realizadas algumas considerações que não se enquadram na organização sugerida, trata-se de constatações feitas pela pesquisadora e que podem apresentar-se de forma diferenciada na abordagem de cada curso. As considerações realizadas pelos docentes entrevistados foram tomadas como referência quando pertinentes ao enquadramento teórico da pesquisa, e apresentam-se pontualmente neste espaço, sendo consideradas, principalmente, ao longo do desenvolvimento do Capítulo 04, quando apresentada a síntese geral dos dados, não sendo possível estabelecer ligação direta entre os entrevistados e os dados fornecidos, de forma a preservar o anonimato dos mesmos.

\subsubsection{ESCOLAS IMPLANTADAS ANTES DA DÉCADA DE 1960}


A visita técnica contemplou todos os cursos criados antes da década de 1960 e inseridos em instituições públicas, são eles: UFRJ (1826), UFBA (1880), UFRGS (1898/1936), UFMG (1930), UFPE (1932), USP-SP (1948). Estes cursos são provenientes, em sua maioria ${ }^{94}$, de dois modelos de ensino: Belas-Artes e Politécnico.

\title{
1- FAU-UFRJ - Faculdade de Arquitetura e Urbanismo da Universidade Federal do Rio de Janeiro $^{95}$
}

\begin{abstract}
a) Breve Histórico ${ }^{96}$
As origens do curso da UFRJ podem ser descritas após a chegada da Família Real ao Brasil, em 1808, quando foi criada a Academia de Artes e Ofícios, a qual começou a funcionar em edifício próprio em 1826, já como Academia Imperial, iniciando-se assim o ensino regular de Arquitetura como um dos cursos da Escola Real das Ciências, Artes e Ofícios, sendo indicado como responsável pelo curso, o arquiteto Grandjean de Montigny.

Para o estudo de Arquitetura os alunos deveriam aprender Desenho Natural e Composições com o arquiteto Grandjean de Montigny, além de frequentar aulas de Ótica e Geometria na Academia Militar. Posteriormente, outros conhecimentos suplementares foram exigidos como Desenho Geométrico, Matemática, Estereotomia, Noções de Composição em Arquitetura. Após a Proclamação da República, com a Reforma Bernardelli, gradativamente outras matérias foram incluídas, dissociando cada vez mais o ensino de Arquitetura das demais Belas-Artes, prenunciando a futura separação.

Até a reforma de 1931 o ensino de Arquitetura foi pouco alterado, um curso com seis anos de duração, com matérias comuns aos demais cursos da Escola de Belas-Artes e cerca de $30 \%$ de matérias específicas ao futuro arquiteto. A reforma de 1931, introduzida pelo então diretor arquiteto Lucio Costa, passou a apresentar uma definida orientação modernista. Em 1937 era criada a Escola Nacional de Arquitetura ${ }^{97}$ e, em 1945 transformava-se na Faculdade Nacional de Arquitetura, com a separação definitiva do Curso de Arquitetura da Escola de Belas Artes. Autônoma, a Faculdade de Arquitetura implementou um novo currículo, incluindo novas cadeiras e ampliou a carga horária das matérias "técnicas". A prática do projeto fortalecida refletia a importância da produção arquitetônica brasileira no cenário internacional. O Urbanismo, cadeira implantada com a reforma de 1931, mais do que uma matéria, transformou-se em um Curso de pós-graduação.

Com edifício próprio, projeto desenvolvido pelo arquiteto Jorge Machado Moreira (Figura 56), em 1961 a Faculdade Nacional de Arquitetura passa a ocupar seu endereço atual, na llha do Fundão, chamando-se, posteriormente, de Faculdade de Arquitetura e Urbanismo da Universidade Federal do Rio de Janeiro ${ }^{98}$.
\end{abstract}

\footnotetext{
${ }^{94}$ Com exceção da UFMG - Universidade Federal de Minas Gerais, em que o curso de Arquitetura foi criado de forma desvinculada de outros cursos. Vale ressaltar que as datas consideradas como de criação do curso, relaciona-se à data de seu reconhecimento, obtidas por meio das publicações consultadas, observando-se que cada escola possui uma trajetória complexa ao longo da consolidação do curso, dificultando a identificação de uma data mais precisa para considerar como de sua criação.

${ }^{95}$ Visita técnica realizada à FAU UFRJ em 11/12/2014, com entrevistas direcionadas ao professor da disciplina Processos Construtivos II e coordenador do Laboratório de Tecnologia da Construção, prof. Marcos Silvoso, e também ao coordenador da Maquetaria e professor de Atelier de Projeto, prof. Andres Passaro.

96 Dados retirados do Projeto Pedagógico do curso, disponível em: http://nova.fau.ufrj.br/uploads/71Projeto\%20Pedag\%C3\%B3gico.pdf. Acesso em: 10/08/15.

${ }^{97}$ A Universidade do Brasil foi criada com a missão de se modelar às instituições universitárias existentes e até mesmo às que futuramente fossem criadas. Além disso, nenhum curso superior poderia existir no país se não tivesse, na UB, o seu modelo de correspondência. Para esta universidade deveriam acorrer também os melhores alunos do país, que nela ingressariam mediante critérios rigorosos de seleção. Ou seja, a Universidade do Brasil nasceu marcada pelo gigantismo, pretensões de unanimidade e profundamente elitista. Todas as suas unidades constituintes tinham, antecedendo o nome, o adjetivo "Nacional", para marcar sua vinculação ao governo federal e às suas políticas de centralização, no contexto do Estado Novo (1937-1945). Dados disponíveis em: http://www.sibi.ufrj.br/Projeto/ufrj_historia.html. Acesso em 14/10/2016.

${ }^{98}$ Em 1965, já no contexto de autoritarismo em que o país vivia, o governo Federal padroniza o nome das instituições universitárias federais e em 20 de agosto é sancionada a Lei № 4.759, que dispunha em seu artigo primeiro que as
} 
Atualmente o curso possui 06 Departamentos:

- Departamento de Tecnologia da Construção - DTC;

- Departamento de Estruturas - DE;

- Departamento de Projeto de Arquitetura - DPA;

- Departamento de Análise e Representação da Forma - DARF;

- Departamento de Teoria e História - DTH;

- Departamento de Urbanismo e Meio Ambiente - DPUR.
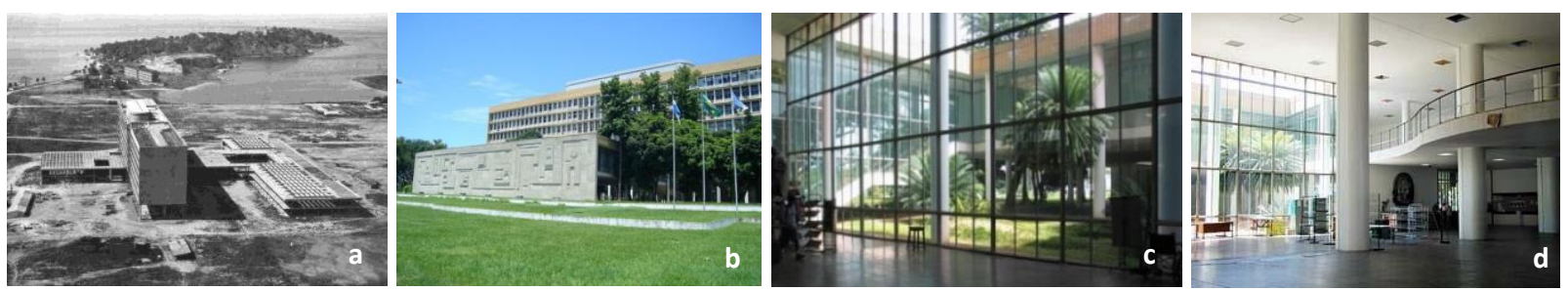

Figura 56: Sequencia de fotos externas e internas do edifício sede do curso de Arquitetura e Urbanismo da UFRJ. Fonte: a) http://arqguia.com/obra/edificio-reitoria-ufrj/?lang=ptbr. b), c) e d) Fotos da autora.

\section{b) Considerações sobre a Estruturação da área da Tecnologia da Construção}

A FAU UFRJ oferece 120 vagas por semestre. O curso é organizado em quatro eixos de conhecimento (Discussão, Concepção, Representação e Construção). A esta ordenação, o novo currículo associou uma estruturação anatômica em três ciclos de estudos que se sucedem com complexidade progressiva, partindo da Fundamentação $\left(1^{\circ}\right.$ ao $4^{\circ}$ períodos), passando pelo Aprofundamento ( $5^{\circ}$ ao $8^{\circ}$ períodos) e chegando à Síntese $\left(9^{\circ}\right.$ e $10^{\circ}$ períodos). Ao final de cada ciclo, são desenvolvidos Trabalhos Integrados - TI 1 e TI 2 - aplicados respectivamente no 4o e 8o períodos, integralizando algumas disciplinas.

As disciplinas do Eixo Construção são atendidas por professores pertencentes ao quadro docente da Faculdade de Arquitetura e Urbanismo e estão distribuídas de acordo com o Quadro 11:

Quadro 11 - Distribuição da Grade Curricular com a carga horária semestral - FAU UFRJ:

\begin{tabular}{|c|c|c|c|c|c|c|c|c|c|}
\hline 10 sem & 20 sem & 30 sem & 4ㅇ sem & 5o sem & 60 sem & 70 sem & 80 sem & 90 sem & 100 sem \\
\hline $\begin{array}{l}\text { Conc. Form. } \\
\text { Arq. I (4C) }\end{array}$ & $\begin{array}{l}\text { Conc. Form. } \\
\text { Arq. II (4C) }\end{array}$ & $\begin{array}{l}\text { Proj. Arq. I } \\
\text { (4C) }\end{array}$ & $\begin{array}{l}\text { Proj. Arq. II } \\
\text { (4C) }\end{array}$ & $\begin{array}{c}\text { Proj.Arq. III } \\
\text { (6C) }\end{array}$ & $\begin{array}{l}\text { Proj. Arq. IV } \\
\text { (4C) }\end{array}$ & $\begin{array}{l}\text { Planej. Urb. } \\
\text { I (2C) }\end{array}$ & $\begin{array}{c}\text { Proj Paisag. } \\
\text { II (2C) }\end{array}$ & TFG I & TFG ॥ \\
\hline $\begin{array}{l}\text { Hist.Arq. } \\
\text { ArtesI (2C) }\end{array}$ & $\begin{array}{l}\text { Hist.Arq. Art . } \\
\text { II (4C) }\end{array}$ & $\begin{array}{l}\text { Anal. F. Urb. } \\
\text { Paisag I (2C) }\end{array}$ & \begin{tabular}{|c|} 
Concep. \\
Estrutural (1C) \\
\end{tabular} & $\begin{array}{l}\text { Hist.Arq. } \\
\text { Art . IV (4C) }\end{array}$ & $\begin{array}{c}\text { Proj. Interior } \\
(4 \mathrm{C})\end{array}$ & $\begin{array}{c}\text { Urb. M. } \\
\text { Amb. (2C) }\end{array}$ & $\begin{array}{l}\text { Conser. } \\
\text { Rest. }(2 \mathrm{C}) \\
\end{array}$ & \begin{tabular}{|c|} 
Etica Ex. \\
Profis. (2C) \\
\end{tabular} & \\
\hline $\begin{array}{l}\text { Hist. T. Urb I } \\
\text { (2C) }\end{array}$ & $\begin{array}{l}\text { Hist. T. Urb II } \\
\text { (4C) }\end{array}$ & $\begin{array}{l}\text { Hist.Arq. Art . } \\
\text { III (4C) }\end{array}$ & \begin{tabular}{|c|} 
Proj. Paisag. I \\
(2C)
\end{tabular} & $\begin{array}{l}\text { Arq. Brasil. I } \\
\text { (2C) }\end{array}$ & $\begin{array}{l}\text { Anal. F. Urb. } \\
\text { Paisag II (2C) }\end{array}$ & $\begin{array}{l}\text { Arq. Brasil. } \\
\text { III (2C) }\end{array}$ & $\begin{array}{l}\text { T. Arq. III } \\
\text { (2C) }\end{array}$ & $\begin{array}{l}\text { Gest. Proc. } \\
\text { Proj (2C) }\end{array}$ & \\
\hline $\begin{array}{c}\text { Desenho Arq. } \\
\text { (3C) }\end{array}$ & E. Sociais (2C) & $\begin{array}{c}\text { Hist. T. Urb III } \\
\text { (4C) }\end{array}$ & T. Arq. I (2C) & $\begin{array}{c}\text { Estrut. } \\
\text { Concr. I (3C) }\end{array}$ & $\begin{array}{l}\text { Plan. Urb. } \\
\text { Regional (2C) }\end{array}$ & $\begin{array}{l}\text { T. Arq. II } \\
\text { (2C) }\end{array}$ & $\begin{array}{l}\text { Tec. Apres. } \\
\text { Proj. (1C) }\end{array}$ & $\begin{array}{l}\text { Orç. Ger. } \\
\text { Obra (3C) }\end{array}$ & \\
\hline $\begin{array}{c}\text { Geom. Desc.I } \\
(4 \mathrm{C})\end{array}$ & $\begin{array}{c}\text { Geom. Desc.II } \\
(4 \mathrm{C})\end{array}$ & $\begin{array}{c}\text { Perspectiva } \\
(2 \mathrm{C})\end{array}$ & $\begin{array}{c}\text { Grafica Digital } \\
(2 \mathrm{C})\end{array}$ & $\begin{array}{c}\text { Conforto II } \\
\text { (3C) }\end{array}$ & $\begin{array}{l}\text { Arq. Brasil. I } \\
\text { (2C) }\end{array}$ & $\begin{array}{l}\text { Saneam. } \\
\text { Urb (2C) }\end{array}$ & $\begin{array}{c}\text { Sist. Estrut. } \\
(5 \mathrm{C})\end{array}$ & Optativas & \\
\hline $\begin{array}{l}\text { Desenho de } \\
\text { Obs. I (4C) }\end{array}$ & $\begin{array}{l}\text { Desenho de } \\
\text { Obs. II (2C) }\end{array}$ & \begin{tabular}{|c|} 
Resist. \\
Materiais (5C)
\end{tabular} & \begin{tabular}{|c|} 
Proc. Const I \\
$(3 \mathrm{C})$ \\
\end{tabular} & \begin{tabular}{|l|}
$\begin{array}{l}\text { Proc. Const } \\
\text { II (4C) }\end{array}$ \\
\end{tabular} & $\begin{array}{l}\text { Hist. Arq. Art } \\
. \mathrm{V}(2 \mathrm{C}) \\
\end{array}$ & $\begin{array}{l}\text { Estrut. Aço } \\
\text { e Mad. (3C) }\end{array}$ & Atelie - & & \\
\hline $\begin{array}{l}\text { Model. Sist. } \\
\text { Estrut. (2C) }\end{array}$ & Isostática (3C) & Conforto I (3C) & $\begin{array}{l}\text { Saneam. } \\
\text { Predial (3C) }\end{array}$ & & \begin{tabular}{|c|} 
Proc. Const III \\
$(3 C)$
\end{tabular} & Optativas & & & \\
\hline & Topogr. (2C) & & Integrado & & $\begin{array}{c}\text { Estrut. Concr. } \\
\text { II (3C) }\end{array}$ & & & & \\
\hline
\end{tabular}

Disciplinas de Projeto

Disciplinas de Representação Gráf. e comp.

Disciplinas de Urbanismo e Meio Ambiente

Disciplinas na área da Tecnologia da Arquitetura

A distribuição das disciplinas consideradas do eixo Construção é realizada desde o 10 até o 9응 período, somando 31,5\% dos créditos destinados às disciplinas obrigatórias (sem considerar Trabalho Final de Graduação - TFG, Ateliê Integrado, Optativas e Estágio), sendo 9\% dos créditos destinados às disciplinas de Tecnologia da Construção (PCl, PCII, PCIII, Gestão de Processo de Projeto e Orçamento e

Universidades e Escolas Técnicas Federais da União seriam qualificadas de "federais", tendo a denominação do respectivo Estado. Assim, a UB é reorganizada e transformada em Universidade Federal do Rio de Janeiro (UFRJ). http://www.sibi.ufrj.br/Projeto/ufrj_historia.html. Acesso em 14/10/2016. 
Gerenciamento de Obra); 14,5\% para Estruturas; 4\% Conforto Ambiental, e 4\% outras (Topografia e Saneamento Predial e Urbano). As disciplinas da Tecnologia da Construção, como Processos

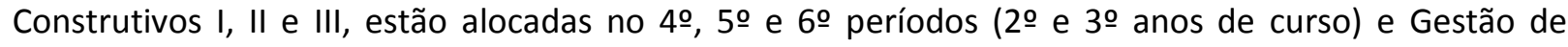
Processo de Projeto e Orçamento e Gerenciamento de Obra no 9o período (5으 ano).

\section{c) Quadro docente}

No período da realização da entrevista, em 11/12/2014, o Departamento da Tecnologia da Construção (DTC) contava com 16 docentes efetivos (02 com formação em engenharia e 14 em arquitetura) e 03 em regime temporário. Todas as disciplinas são ministradas por professores pertencentes ao quadro docente do curso, em que o DTC oferece as disciplinas de Processos Construtivos I, II e III; Saneamento Predial e Urbano; Topografia; Gerenciamento de Obra e Conforto Ambiental.

\section{d) Práticas didáticas e Infraestrutura laboratorial}

Segundo Magalhães (1999) ${ }^{99}$, ao ser construído o prédio na Cidade Universitária na Ilha do Fundão, foi destinado um amplo espaço para o Laboratório de Ensaios de Materiais e, desde sua criação, deu apoio às disciplinas de Materiais de Construção, Estudo do Solo, posteriormente chamadas de Tecnologia da Construção I, II e III, sendo que, atualmente, pode-se identificá-las como Processos Construtivos I, II e III.

Ainda segundo a autora, o Laboratório de Ensaios de Materiais de Construção - LEMC (Figura 57 e 58) está localizado no Bloco $D$ do prédio da Faculdade de Arquitetura e Urbanismo, no andar térreo, sob a responsabilidade administrativa do Departamento de Tecnologia da Construção e ocupa uma área total de $497 \mathrm{~m}^{2}$, constituído por quatro setores. Após a visita técnica realizada em dezembro de 2014, foi possível averiguar modificações em alguns destes setores que a autora identifica como:

- Setor 01 - ocupa uma área de $67 \mathrm{~m} 2$, servindo de acesso e onde ficam localizados os mostruários de materiais de construção para análise dos seguintes aspectos: textura, cor, forma e dimensões. Este espaço permanece ainda com sua função original e apresenta um acervo muito rico e diversificado de amostras materiais.

- Setor 02 - ocupa uma área de $260 \mathrm{~m}^{2}$, onde se localiza o Laboratório de Argamassas e Concretos, voltado à realização de ensaios de caracterização de agregados, aglomerantes, argamassas, concretos, produtos cerâmicos, pedras e barras de aço. As atividades são voltadas para o estudo das propriedades físicas e mecânicas dos materiais citados. A partir de 2010, o laboratório passou por uma reforma e adequações às atuais demandas da área, com aquisição de maquinários para otimização de diversos estudos, climatização e substituição da rede elétrica. Atualmente, este espaço experimental continua com atividades voltadas aos materiais supracitados, com maior atenção ao concreto e argamassas. Anexado a ele, foram identificadas áreas para depósito de materiais e equipamentos, um espaço anteriormente destinado a corredor (de acordo com a planta original do projeto) e que foi acrescentado ao laboratório para apoio às atividades.

- Setor 03 - ocupa uma área de $85 \mathrm{~m}^{2}$, onde segundo a autora, se localiza o Laboratório de Madeiras e Instalações. Hoje, este espaço não possui mais esta função e o material 'madeira' não é estudado como os demais. Uma reforma estava em fase de realização para atendimento às novas demandas, ainda com caráter de laboratório, com intenção de atender também a disciplina de PCIII. Trata-se de um espaço com bancadas e há a possibilidade de aulas serem realizadas juntamente a determinadas experimentações construtivas.

- Setor 04 - Ocupa uma área de $85 \mathrm{~m}^{2}$, serve de sala de professores e de apoio aos alunos. Atualmente, este espaço também estava em reforma direcionada para atender funções administrativas.

\footnotetext{
${ }^{99}$ MAGALHÃES, M.A.A.de A. Tecnologia da Construção e Laboratórios - Ensino e Pesquisa. In: Caderno ABEA n ${ }^{\circ} 21$ - p. $162-$ 165. Londrina, 1999.
} 



\section{Legenda:}

1 - Setor 01 - Mostruário de Materiais

2 - Setor 02 - Laboratório de Materiais

3-Setor 03 - Antigo laboratório de

Madeiras

4-Setor 04 - Escritório

5 - Canteiro Experimental a 
estratégias para viabilizar a obtenção de recursos para as diversas finalidades demandadas, como também, para reforma da infraestrutura laboratorial.
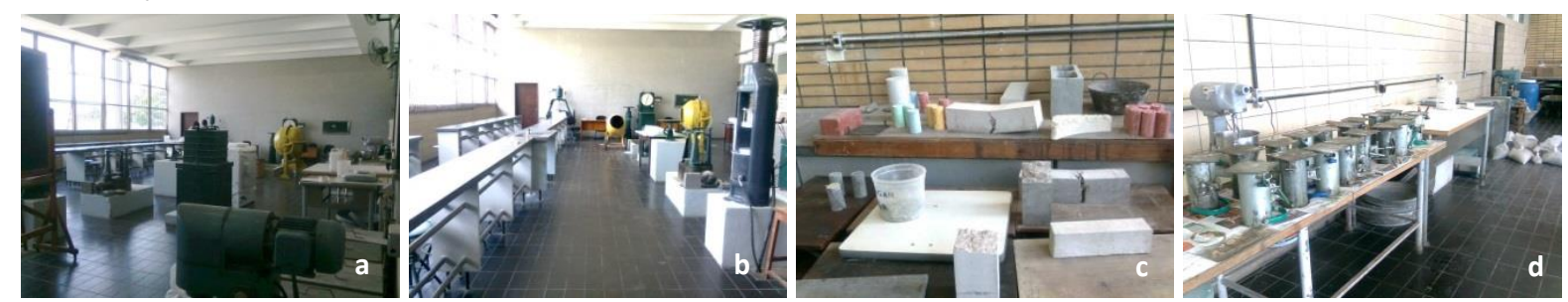

Figura 58 - Sequencia de imagens internas do Laboratório de Materiais da Construção - FAU UFRJ.

Fonte: Fotos da autora.

Além deste espaço laboratorial localizado no prédio da escola de Arquitetura - onde é trabalhada a escala material - há também um espaço externo localizado junto à área próxima ao Laboratório de Materiais, chamado Canteiro Experimental (Figuras 57, 59c e 59d). Este espaço possibilita a realização de atividades em diferentes escalas. Trata-se de uma área delimitada de acordo com o volume de projetos, mas apresenta a possibilidade de expansão, algo já acordado junto à direção da FAU, com maior liberdade para sua utilização.

Esta área externa, ainda em fase de implantação, começou a ser utilizada por volta de 2012, na intenção de desenvolver experimentos com base em metodologia científica, vinculados à disciplina PCII e pesquisas com parcerias junto ao setor industrial.
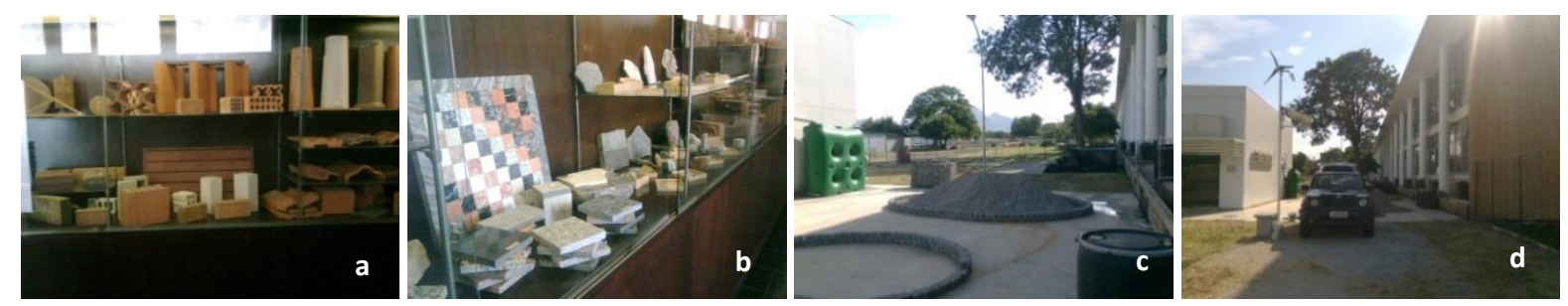

Figura 59 - Sequencia de imagens das áreas de apoio ao Laboratório de Materiais de Construção: a) e b) Mostruário de Materiais. c) e d) Área externa junto ao Laboratório destinada ao Canteiro Experimental.

Fonte: Fotos da autora.

Sobre a conexão entre a área interna e externa, por se tratar de um projeto tombado do arquiteto Jorge Machado Moreira, o edifício não pode sofrer modificações, como a inserção de um acesso direto entre o laboratório idealizado pelo projetista e o canteiro externo (implantado seis décadas mais tarde).

Além do Laboratório de Materiais de Construção e do Canteiro Experimental, o curso também possui uma Maquetaria e Oficina de Cerâmica, esta última de uso compartilhado com o curso de Belas Artes, ambos os espaços localizam-se no 1 o pavimento do mesmo Bloco D. No caso da Maquetaria, o espaço foi reaberto há dois anos, oferecendo a possibilidade de manusear impressoras 3D e máquinas de pequeno porte para confecção de maquetes e protótipos. A maquetaria não apresenta vínculo direto com uma disciplina, e dá suporte a várias disciplinas. O maquinário é utilizado apenas durante o período diurno, mas há a possibilidade de utilização do espaço físico também no período noturno, em atividades específicas, como as etapas de montagem de modelos.

\section{e) Pós graduação ${ }^{101}$ :}

A FAU UFRJ apresenta dois programas de pós-graduação: PROARQ e PROURB. O PROARQ tem sua pesquisa, ensino e produção acadêmica estruturada em função de quatro áreas temáticas de concentração:

- Conforto Ambiental e Eficiência Energética;

- História e Preservação do Patrimônio Cultural;

\footnotetext{
${ }^{101}$ Informações obtidas em: http://www.fau.ufrj.br/. Acesso em: 10/08/2015.
} 


\section{- Racionalização do Projeto e da Construção;}

- Teoria e Projeto.

Em relação ao PROURB duas áreas de concentração são oferecidas:

- Projeto Urbano;

- Teoria e História do Urbanismo.

Dentre as áreas temáticas oferecidas pelo PROARQ, há uma voltada à Tecnologia da Construção Racionalização do Projeto e da Construção - possibilitando que alunos interessados nesta temática tenham a oportunidade de realizar a pós-graduação e, dependendo da especificidade da temática, não tenham que buscar outros cursos com interface à área de formação ou outros locais.

\section{f) Comentários:}

- O curso possui infraestrutura própria para realização de atividades de cunho científico, compatíveis com a complexidade dos conteúdos ministrados. As disciplinas da área da tecnologia são ministradas por professores pertencentes a dois departamentos - Departamentos da Tecnologia da Construção e de Estruturas da FAU UFRJ - possuindo em seu quadro tanto professores arquitetos como engenheiros; - Foram observadas atividades de pesquisa, ensino e extensão vinculadas à área laboratorial;

- Há independência em relação à utilização de infraestrutura pertencente a outros cursos, embora tenham sido identificadas parcerias com outros cursos na participação de editais para obtenção de recursos;

- As atividades realizadas de forma sistemática no laboratório de materiais (ensaios e caracterização de materiais) apresentam-se com caráter mais consolidado e contínuo em relação às realizadas no canteiro experimental, cuja implantação ainda é incipiente;

- As práticas experimentais apresentam grande perspectiva de expansão no curso, mas ainda estão vinculadas à iniciativa docente. Sobre isso, foi verificado nas discussões atualmente realizadas sobre a reformulação do Projeto Pedagógico ${ }^{102}$, que a questão sobre as atividades experimentais na área da tecnologia da construção já se tornou ponto de pauta na discussão entre docentes e discentes do curso.

- Foi observado que a infraestrutura laboratorial é utilizada exclusivamente pelas disciplinas voltadas à Tecnologia da Construção, embora haja o reconhecido incentivo para que as atividades laboratoriais possam ser ampliadas e aprofundadas em associação a outras áreas como Projeto;

- Por se tratar de um edifício do arquiteto Jorge Machado Moreira, determinadas intervenções no edifício não são possíveis, pela concepção do prédio não prever algumas atividades que foram sendo inseridas e ajustadas ao longo do tempo. A impossibilidade de construir um acesso direto entre laboratório de materiais e canteiro experimental dificulta a passagem de materiais e equipamentos, mas não deve ser considerada como uma condicionante para a não utilização do espaço, por haver grande proximidade. Outra situação é a localização da maquetaria, no 1 으 pavimento do mesmo Bloco, que dificulta a montagem e transferência de protótipos confeccionados em escalas maiores.

- A falta de corpo técnico especializado foi considerada um entrave, tanto para que os docentes não tenham que segurar o voluntariado dos alunos, como também, diante de determinadas situações em que os alunos podem ficar expostos a acidentes graves. Além da falta de técnicos, foi sinalizada a necessidade de capacitação continuada destes profissionais, para que haja a possibilidade de se adaptarem à lógica de laboratório e no trato com os alunos.

\section{2- FAUFBA - UFBA - Faculdade de Arquitetura da Universidade Federal da Bahia ${ }^{103}$}

\footnotetext{
102 Discussão realizada após visita técnica e divulgadas em http://nova.fau.ufrj.br/uploads/71-FAU\%20Pesquisa\%20NDE.pdf. Acesso realizado em 18/02/2016.

${ }^{103}$ Dados obtidos em 27 de novembro de 2013, a partir da visita técnica às instalações da FAUFBA e Escola Politécnica com entrevistas direcionadas a alguns professores pertencentes ao Departamento de Tecnologias aplicadas à Arquitetura (profa. Luciana Calixto, profa. Márcia Rebouças Freire, Prof. Edson D'Oliveira Santos Neto) e, também, a alguns professores pertencentes à Escola Politécnica (prof. Jardel Pereira Gonçalves e profa. Cybele Celestino Santiago). Os professores do Departamento de Tecnologias Aplicadas à Arquitetura forneceram dados sobre o curso e sua atual estruturação e os
} 


\begin{abstract}
a) Breve Histórico ${ }^{10}$
A Academia de Belas Artes da Bahia foi fundada em 17 de dezembro de 1877, a partir da iniciativa do pintor espanhol Miguel Navarro y Cañizares, que contou com o apoio do então Presidente da Província da Bahia, Desembargador Henrique Pereira de Lucena, bem como com a colaboração de artistas e estudantes provenientes do Liceu de Artes e Ofícios da Bahia e alguns profissionais liberais, intelectuais e amantes das artes. O curso de Arquitetura foi criado em 1880, no âmbito da Escola de Belas Artes, passando por uma reformulação em 1937, porém, sem reconhecimento nacional. O curso foi federalizado em 1949 a partir da incorporação da Escola de Belas Artes à Universidade. A separação da Escola de Belas Artes ocorreu em 1959, com a criação da Faculdade de Arquitetura, passando a se constituir em uma unidade autônoma, integrante da Universidade Federal da Bahia, com Congregação própria, porém submetida aos Conselhos Superiores da UFBA.

Neste período, o curso de arquitetura foi reformulado tendo como base os conceitos do arquiteto Lúcio Costa e os princípios estabelecidos no Congresso da União Internacional de Arquitetos, realizado em Lisboa no ano de 1959. Em 1961 a Universidade Federal da Bahia cria o Campus Universitário, instalado nos bairros da Federação e de Ondina, ficando a Faculdade de Arquitetura localizada na Federação juntamente com a Escola Politécnica. As obras para a nova sede foram iniciadas em 1965 e, seu projeto foi elaborado por uma comissão composta pelos professores Diógenes Rebouças, Américo Simas e Oscar Caetano Silva ${ }^{105}$ (Figura 60). O ano de 1970 foi marcado pela implantação da Reforma Universitária e as disciplinas do curso foram agrupadas em cinco departamentos ${ }^{106}$ :
\end{abstract}

- Departamento I: Das Geometrias de Representação

- Departamento II: Do Projeto de Arquitetura, Urbanismo e Paisagismo

- Departamento III: Da Teoria e Prática em Planejamento

- Departamento IV: Das Tecnologias Aplicadas à Arquitetura

- Departamento V: Da Evolução da Arquitetura
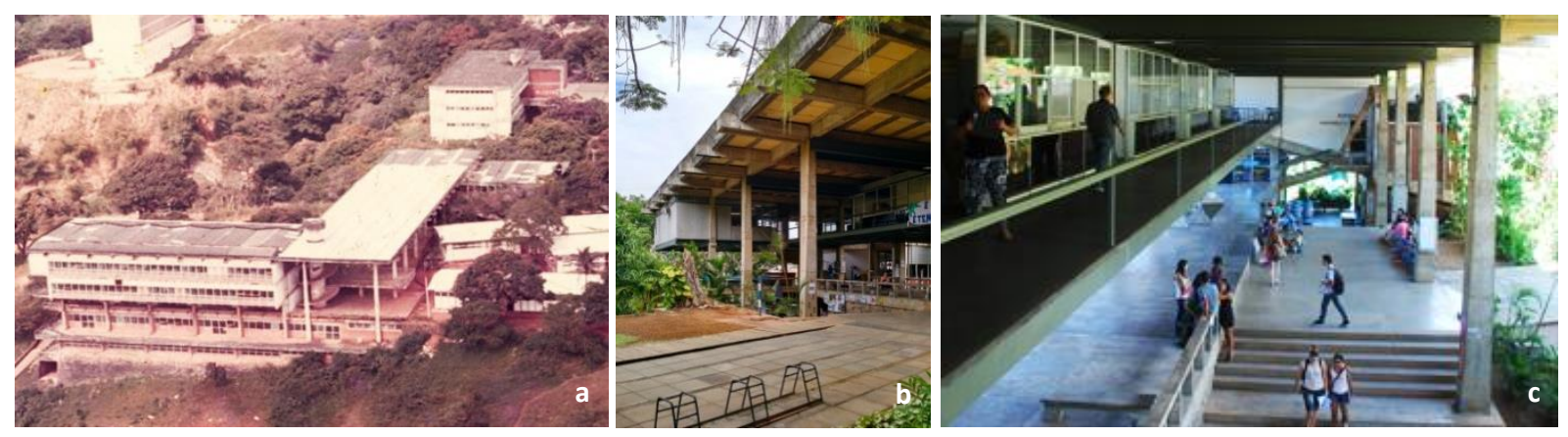

Figura 60 - Imagens do edifício da Faculdade de Arquitetura da UFBA. a) Imagem panorâmica. b) Entrada principal. c) Pátio interno e mezanino.

Fonte: a) e b) http://www.archdaily.com.br/br/758897/classicos-da-arquitetura-faculdade-de-arquitetura-eurbanismo-da-ufba-diogenes-reboucas. c) http://www.cronologiadourbanismo.ufba.br.

\title{
b) Considerações sobre a Estruturação da área de Tecnologia da Construção
}

A FAUFBA oferece 120 vagas (incluindo a reserva de cotas) e apresenta dois cursos de arquitetura, cada um deles com uma estrutura diferenciada: o curso diurno e o curso noturno. $O$ curso noturno foi criado em 2009, portanto, não foi analisado nesta pesquisa por encontrar-se ainda em fase de

professores pertencentes à Escola Politécnica contribuíram com informações sobre as disciplinas de Materiais e Técnicas Construtivas e também, sobre a infraestrutura laboratorial.

${ }^{104}$ Dados obtidos a partir de documentos internos fornecidos pelo curso e no site institucional dos cursos da FAUFBA e EBA: http://www.arquitetura.ufba.br/historico, acesso em: 14/08/14. E http://www.eba130.ufba.br/textos.html, acesso em 01/12/15.

${ }^{105}$ Dados disponíveis em: http://www.forumpatrimonio.com.br/view_full.php?articlelD=214\&modo=1. Acesso em: 01/12/2015.

${ }^{106}$ Sobre isso, na data de realização da visita técnica às instalações do curso (27/11/2013), foi explicitado pelos professores pertencentes à FAUUFBA, que a estruturação do curso em 5 departamentos estava em processo de discussão, havendo a possibilidade futura de reduzir este número para 3 departamentos. 
estruturação. Em relação ao curso diurno, o mesmo emprega um modelo misto na área da tecnologia, devido ao fato das disciplinas serem ministradas tanto por professores engenheiros pertencentes ao quadro docente da Faculdade de Arquitetura (disciplinas de Sistemas Estruturais e Instalações), como também, por professores da Escola Politécnica (disciplinas de Materiais e Técnicas Construtivas I e II).

A disciplina de Materiais Construtivos é oferecida pelo Departamento de Ciência e Tecnologia dos Materiais e as disciplinas de Técnicas Construtivas I e II são ofertadas pelo Departamento de Estrutura e Construção Civil, e estão distribuídas ao longo do curso de acordo com o Quadro 12:

Quadro 12 - Distribuição da Grade Curricular com a carga horária semestral - FA UFBA:

\begin{tabular}{|c|c|c|c|c|c|c|c|c|c|}
\hline 10 sem & 20 sem & 3ㅇ sem & 4 sem & 5o sem & 60 sem & 70 sem & 80 sem & 90 sem & $10 \%$ sem \\
\hline $\begin{array}{l}\text { Atelie I } \\
\text { (12C) }\end{array}$ & $\begin{array}{l}\text { Atelie I } \\
\text { (12C) }\end{array}$ & $\begin{array}{c}\text { Atelie II } \\
\text { (12C) }\end{array}$ & $\begin{array}{c}\text { Atelie II } \\
\text { (12C) }\end{array}$ & $\begin{array}{l}\text { Atelie III } \\
(12 \mathrm{C})\end{array}$ & $\begin{array}{l}\text { Atelie III } \\
\text { (12C) }\end{array}$ & $\begin{array}{c}\text { Atelie } \\
\text { IV (12C) }\end{array}$ & $\begin{array}{c}\text { Atelie IV } \\
\text { (12C) }\end{array}$ & Estagio & TFG \\
\hline $\begin{array}{l}\text { Int.Arq.Urb } \\
\text { (4C) }\end{array}$ & $\begin{array}{c}\text { E. Soc. Amb } \\
(4 C)\end{array}$ & $\begin{array}{l}\text { Hist.Arq. } \\
\text { Cont.(4C) }\end{array}$ & $\begin{array}{l}\text { Hist.Arq. } \\
\text { Urb II (4C) }\end{array}$ & $\begin{array}{l}\text { Hist.Arq. } \\
\text { Bras.(4C) }\end{array}$ & $\begin{array}{c}\text { Tec. Retr. } \\
(4 \mathrm{C})\end{array}$ & $\begin{array}{c}\text { Atelie V } \\
(8 \mathrm{C})\end{array}$ & $\begin{array}{c}\text { Atelie V } \\
(8 C)\end{array}$ & & \\
\hline $\begin{array}{l}\text { Estética } \\
(4 \mathrm{C})\end{array}$ & $\begin{array}{l}\text { Hist.Arq. } \\
\text { Urb.I (4C) }\end{array}$ & $\begin{array}{l}\text { Informat. I } \\
\text { (4C) }\end{array}$ & Ética (2C) & $\begin{array}{c}\text { Informat. II } \\
(4 C)\end{array}$ & $\begin{array}{l}\text { Org.Trab. } \\
\text { (2C) }\end{array}$ & & $\begin{array}{l}\text { H.PI.Urb. } \\
\text { (4C) }\end{array}$ & & \\
\hline $\begin{array}{c}\text { Ex. gráfica } \\
\text { (4C) }\end{array}$ & $\begin{array}{l}\text { Ex. gráfica } \\
(4 C)\end{array}$ & $\begin{array}{c}\text { Mec. Estrut. } \\
(4 \mathrm{C})\end{array}$ & $\begin{array}{l}\text { Int. Sist. Est. } \\
(6 \mathrm{C})\end{array}$ & $\begin{array}{l}\text { Sist. Estr. I } \\
(6 \mathrm{C})\end{array}$ & $\begin{array}{c}\text { Sist. Estr. II } \\
\text { (6C) }\end{array}$ & & & & \\
\hline \multirow[t]{2}{*}{$\begin{array}{c}\text { Matematica } \\
(4 \mathrm{C})\end{array}$} & $\begin{array}{c}\text { Matematica } \\
(4 \mathrm{C})\end{array}$ & $\begin{array}{c}\text { Mat. Constr } \\
\text { (6C) }\end{array}$ & $\begin{array}{c}\text { Tec. Const I } \\
(4 \mathrm{C})\end{array}$ & $\begin{array}{c}\text { Tec. Const II } \\
(4 \mathrm{C})\end{array}$ & $\begin{array}{c}\text { Instalaç. I } \\
(3 \mathrm{C})\end{array}$ & & & & \\
\hline & $\begin{array}{c}\text { Fisica Geral } \\
(6 \mathrm{C})\end{array}$ & $\begin{array}{c}\text { Conforto I + } \\
\text { Lab. (5C) }\end{array}$ & $\begin{array}{l}\text { Conforto II } \\
+ \text { Lab. (5C) }\end{array}$ & $\begin{array}{l}\text { Conforto III } \\
+ \text { Lab. (5C) }\end{array}$ & $\begin{array}{c}\text { Instalaç. II } \\
(3 \mathrm{C})\end{array}$ & & & & \\
\hline
\end{tabular}


anos do curso). Considerando apenas as disciplinas (sem o cômputo da carga horária do ITFG, TFG, optativas e estágio), a área da Tecnologia ocupa aproximadamente $31 \%$ dos créditos direcionados às disciplinas obrigatórias, sendo $6 \%$ dos créditos destinados às disciplinas de Materiais e Técnicas Construtivas; 9,5\% para Estruturas; 6,5\% Conforto Ambiental; 2,5\% para Instalações; 6\% Fundamentação; 0,9\% Outras (Organização do Trabalho).

\section{c) Quadro docente}

Os docentes que pertencem ao Departamento de Tecnologias Aplicadas à Arquitetura possuem especialização nas áreas de Materiais e Técnicas Construtivas, Estruturas, Elétrica, Restauro e Conforto Ambiental, com formação em arquitetura e engenharia.

As disciplinas da área da Tecnologia da Construção são delegadas à Escola Politécnica da UFBA, estando à frente destas disciplinas professores com formação tanto em engenharia como em arquitetura (com especialização na área da Tecnologia).

\section{d) Práticas didáticas e Infraestrutura laboratorial}

Os laboratórios voltados à área da Tecnologia da Construção (Figura 61) pertencem à Escola Politécnica e estão implantados junto ao edifício sede. O curso de Arquitetura possui um Laboratório de Conforto Ambiental e Tecnologia Sustentável em Arquitetura, Urbanismo e Paisagismo - LACAMTEC, mas não desenvolve atividades voltadas às experimentações construtivas.

De acordo com os professores entrevistados, as práticas experimentais são realizadas em laboratórios de uso compartilhado entre as engenharias e a arquitetura e entre a graduação e a pós-graduação. A Escola Politécnica possui vários laboratórios para experimentação física e mecânica para o estudo de diferentes materiais construtivos, estes espaços experimentais são ajustados para dar suporte às atividades práticas das disciplinas do curso de Arquitetura, de acordo com os assuntos abordados.

A disciplina de Materiais Construtivos apresenta em sua proposta didática o oferecimento de práticas laboratoriais, com turmas de no máximo 40 alunos, divididos em grupos de 20 . As atividades são voltadas à caracterização física e mecânica de alguns materiais construtivos e, eventualmente, são realizados ensaios - as estratégias didáticas são realizadas de acordo com a disponibilidade de 
materiais e infraestrutura para os ensaios, quando as atividades experimentais não são possíveis, são realizadas aulas expositivas com amostras de materiais. Estas práticas estão associadas a exercícios de cálculo e aulas teóricas. Quanto à disponibilidade de recursos humanos, há 01 técnico para o acompanhamento dos alunos da arquitetura durante as atividades nesta disciplina.

No que se relaciona às disciplinas de Técnicas Construtivas, no momento da realização da visita técnica, as atividades experimentais eram desenvolvidas na forma de visitas a obras realizadas ao longo do semestre (com equipes divididas entre alunos que estagiam em obra e os que não estagiam), associando as etapas da obra com os conteúdos ministrados em aulas expositivas. As atividades laboratoriais da disciplina de Técnicas Construtivas II estão em fase de planejamento para que sejam implantadas de forma sistematizada, sendo oferecidas atualmente, algumas práticas de execução de protótipos de sistemas construtivos, mas com caráter ainda incipiente. O Laboratório de Estruturas (também destinado às atividades na área da Tecnologia da Construção) possui 01 técnico e, segundo o professor entrevistado, há previsão que no futuro seja um espaço também utilizado pelos alunos da arquitetura.


Figura 61 - Sequencia de imagens do Laboratório de Estruturas (também de Construção) pertencente à Escola Politécnica, com maquinário implantado e em fase de implantação.

Fonte: Imagens cedidas pelo professor Jardel Pereira Gonçalves.

A Figura 62 apresenta a localização dos edifícios pertencentes ao curso de Arquitetura e Escola Politécnica. Cabe ressaltar que o complexo de laboratórios da área da Tecnologia da Construção localiza-se na Escola Politécnica.

Faculdade de Arquitetura

Escola Politécnica



Figura 62 - Implantação dos edifícios pertencentes ao curso de Arquitetura e da Escola Politécnica.

Fonte: http://www.escoladeveraoqa3.ufba.br/Mapa\%20Campus\%20UFBA.pdf. Inserção de informações realizada pela autora.

\section{e) Pós graduação:}


Atualmente, as áreas de concentração e as respectivas linhas de pesquisa oferecidas pelo Programa de Pós-Graduação em Arquitetura são:

Conservação e Restauro

1. Restauração, Conservação e Gestão dos Bens Patrimoniais

2. Ciência e Tecnologia da Conservação e do Restauro

3. Linguagem, Informação e Representação do Espaço

Urbanismo

1. Teoria e Crítica da Arquitetura e do Urbanismo

2. História da Cidade e do Urbanismo

3. Processos Urbanos Contemporâneos

4. Linguagem, Informação e Representação do Espaço

Como não há linhas de pesquisa voltadas, especificamente, à Tecnologia da Construção, os alunos interessados neste tema são absorvidos pelo Programa de Pós-Graduação da Escola Politécnica, isto significa que, quando surge o interesse nesta área específica, os alunos migram para outros cursos. Dentro das áreas de concentração oferecidas, a linha de pesquisa em Ciência e Tecnologia da Conservação e do Restauro, apresenta maior interface à área técnico-construtiva.

\section{f) Comentários:}

- Foram observadas pesquisas voltadas à demanda do contexto local, particularmente, na área de conservação e restauro orientadas às tecnologias sobre durabilidade de materiais e edifícios;

- Os espaços experimentais visitados e pertencentes à Escola Politécnica são frequentados, prioritariamente, por alunos da graduação do curso de Engenharia Civil;

- Não são exploradas práticas didáticas por meio da construção de modelos ou protótipos, mas utilizados outros recursos pedagógicos como a realização de ensaios físicos e mecânicos e visitas a obras;

- Apesar da inexistência de atividades de canteiro de obras, foi manifestada pelos professores a intenção de construírem futuramente um espaço experimental com este caráter, fazendo parceria entre a Faculdade de Arquitetura e a Escola Politécnica para a estimulação destas práticas junto aos alunos;

- A carência de técnicos de laboratório foi considerada como um dos principais gargalos que inviabilizam atividades experimentais de forma contínua na graduação, principalmente, em outros horários das disciplinas, diferentemente da pós-graduação, cujos alunos possuem maior autonomia;

- Foi destacado como um complicador, a falta de proporcionalidade entre a carga horária das disciplinas de Materiais construtivos e Técnicas construtivas, gerando um descompasso no aprofundamento dos conteúdos. A carga horária foi considerada insuficiente para a quantidade de conteúdos para serem abordados.

\section{3- FA - UFRGS - Faculdade de Arquitetura da Universidade Federal do Rio Grande do Sul ${ }^{107}$}

\section{a) Breve Histórico ${ }^{108}$}

\footnotetext{
${ }^{107}$ A visita técnica na FAU UFRGS foi realizada entre os dias 11/04/16 e 13/04/16, com entrevistas direcionadas aos professores responsáveis pelas disciplinas da Tecnologia da Construção no curso de Arquitetura, alguns pertencentes ao curso da Engenharia Civil (profa. Ana Paula Kirchheim e Ana Luiza Raabe Abitante) e pertencente ao curso da Arquitetura e Urbanismo (profa. Luciana Inês Gomes Miron). Também foram realizadas visita ao Laboratório de Ensaios e Modelos Estruturais - LEME e também ao Laboratório de Modelos e Protótipos, sendo a conversa estendida aos técnicos destes espaços.

${ }^{108}$ Os dados sobre o histórico do curso foram obtidos em consulta ao Projeto Pedagógico de Curso e ao trabalho de SALVATORI, E. De la originalidad a la competencia: la enseñanza de arquitectura en la UFRGS, Porto Alegre, Brasil - 1962 a 1994. Tese (Doctorado en Teoría e Historia de la Arquitectura Departamento de Composición Arquitectónica). ETSAB/UPC, Barcelona, 2005.
} 
Em 1896 foi fundada a Escola de Engenharia de Porto Alegre (curso baseado no modelo didático pedagógico da Escola Politécnica de São Paulo), disponibilizando entre os cinco cursos, o de Arquitetura (em 1898), o qual foi extinto em 1908. Em 1936, o Instituto de Belas Artes (baseado, por sua vez, no ensino da École des Beaux-Arts de Paris), que na ocasião era um estabelecimento de ensino privado, inaugurou um curso técnico de Arquitetura, sendo alcançada em 1945, a condição de curso superior. Neste mesmo ano, a Escola de Engenharia já incorporada à Universidade de Porto Alegre, instaura um novo curso de Arquitetura.

Em 1947, o Instituto de Belas Artes passou a fazer parte da Universidade do Rio Grande do Sul (URGS), antiga Universidade de Porto Alegre e, por não haver sentido a manutenção de dois cursos de Arquitetura na mesma Universidade, foi determinada sua fusão e os professores de ambos os cursos passaram a constituir o corpo docente da nova escola (mesmo com orientações didáticas diferenciadas). O processo de fusão foi concluído quando houve a instalação da Faculdade de Arquitetura em edifício próprio em 1952 (Figura 63). O currículo do curso de Arquitetura da UFRGS (federalizada em 1950) teve como referencial o currículo adotado pela Faculdade Nacional de Arquitetura do Rio de Janeiro. Segundo Salvatori (2005), o processo de fusão dos dois cursos foi um processo controverso, porque havia a competição pelo controle hegemônico do campo entre os dois grupos, o "acadêmico" (originário da Escola de Belas Artes) e o "profissional" (originário da Escola de Engenharia).

Ainda de acordo com esta autora, durante vinte anos a Faculdade de Arquitetura da UFRGS foi a única responsável por formar arquitetos no Estado do Rio Grande do Sul. Em 1968 é realizado o seminário de estudos para uma nova estrutura de Ensino" e, em março de 1972, inicia-se a implantação da Reforma Universitária, que extingue as cátedras e as substituem por disciplinas, sendo estas agrupadas por Departamentos e não mais por unidade. A partir desta data o Curso de Arquitetura, antes dirigido pelo Diretor da Faculdade, passa a ser coordenado por uma Comissão de Carreira, que viria a ser denominada mais tarde de Comissão de Graduação. Todas as alterações do Currículo instituído em 1952 até os dias atuais, foram promovidas pelas Comissões de Carreira.

Até o ano de 2005, essa Unidade oferecia apenas o curso de Arquitetura e Urbanismo, a partir de 2006, os cursos de Design de Produto e Design Visual passaram a compartilhar do mesmo espaço físico.

Atualmente, a Faculdade está dividida em três Departamentos:

- Departamento de Arquitetura;

- Departamento de Urbanismo

- Departamento de Design e Expressão Gráfica.
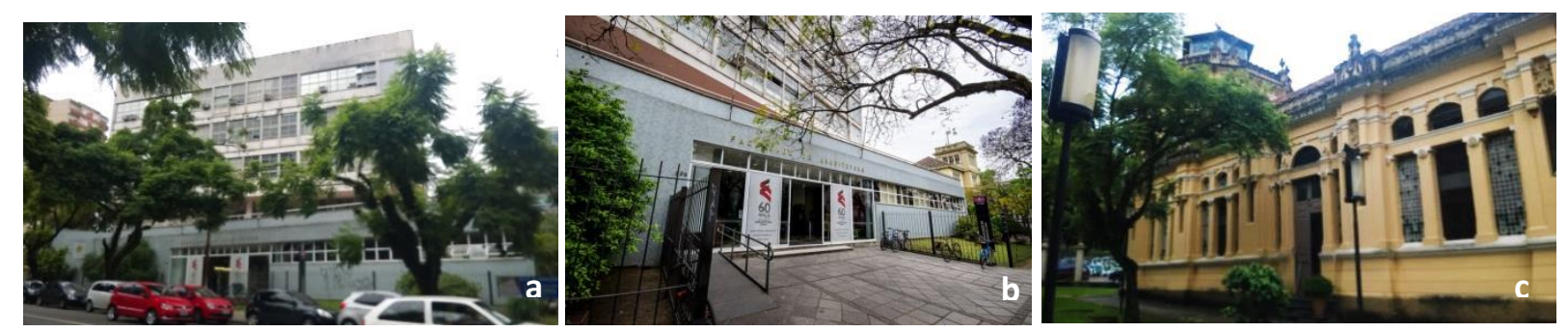

Figura 63 - a) Vista principal do prédio sede do curso de Arquitetura e Urbanismo da UFRGS. b) Entrada principal. c) Entrada do prédio sede do Norie (Núcleo Orientado para a Inovação da Edificação), vinculado ao Departamento de Engenharia Civil da Escola de Engenharia da UFRGS.

Fonte: fotos da autora.

\section{b) Considerações sobre a Estruturação da área de Tecnologia da Construção}

O curso oferece 110 vagas anuais (55/semestre). O Currículo Pleno do Curso de Arquitetura e Urbanismo está estruturado em 10 semestres, com número variável de disciplinas distribuídas ao longo dos períodos, sob competência dos seguintes departamentos: Departamento de Arquitetura, Departamento de Design e Expressão Gráfica, Departamento de Urbanismo, Departamento de Engenharia Civil, Departamento de Engenharia Elétrica, Departamento de Hidromecânica e Hidrologia, Departamento de Engenharia Mecânica, Departamento de Obras Hidráulicas, Departamento de Matemática Pura e Aplicada. 
De acordo com o Quadro 13, na grade curricular atualmente vigente, a distribuição de disciplinas da área da Tecnologia da Arquitetura ocorre entre o 10 e 9o períodos. Em relação às disciplinas da Tecnologia da Construção, são ofertadas entre o 4 e 9o períodos, e envolvem assuntos como: Técnicas da Edificação (Materiais e Técnicas construtivas), Economia e Gestão da Construção e Prática em Obra.

Quadro 13 - Distribuição da Grade Curricular com a carga horária semestral FA UFRGS:

\begin{tabular}{|c|c|c|c|c|c|c|c|c|c|}
\hline 10 sem & 20 sem & 30 sem & 40 sem & 50 sem & 60 sem & 70 sem & 8 sem & 9o sem & $10 \circ$ sem \\
\hline $\begin{array}{l}\text { Introd. proj. } \\
\text { arq. I (10C) }\end{array}$ & $\begin{array}{l}\text { Introd. proj. } \\
\text { arq. II (10C) }\end{array}$ & $\begin{array}{l}\text { Proj. Arq. I } \\
(10 \mathrm{C})\end{array}$ & $\begin{array}{c}\text { Proj. Arq. II } \\
(10 \mathrm{C})\end{array}$ & $\begin{array}{c}\text { Proj. Arq. III } \\
\text { (10C) }\end{array}$ & $\begin{array}{l}\text { Proj. Arq. IV } \\
(10 \mathrm{C})\end{array}$ & $\begin{array}{c}\text { Proj. Arq. V } \\
\text { (10C) }\end{array}$ & $\begin{array}{l}\text { Proj. Arq. } \\
\text { VI (10C) }\end{array}$ & $\begin{array}{l}\text { Proj. Arq. } \\
\text { VII (10C) }\end{array}$ & TFG \\
\hline $\begin{array}{c}\text { Hist. Arq. } \\
\text { Artes I (2C) }\end{array}$ & $\begin{array}{l}\text { Hist. Arq. Art . } \\
\text { II (2C) }\end{array}$ & $\begin{array}{l}\text { Morfologia } \\
\text { urbana }(2 \mathrm{C})\end{array}$ & $\begin{array}{c}\text { Evolução } \\
\text { urbana (6C) }\end{array}$ & $\begin{array}{c}\text { Urbanismo I } \\
(8 \mathrm{C})\end{array}$ & $\begin{array}{c}\text { Urbanismo II } \\
(8 \mathrm{C})\end{array}$ & $\begin{array}{c}\text { Arq. no } \\
\text { Brasil }(4 \mathrm{C})\end{array}$ & $\begin{array}{c}\text { Urbanismo } \\
\text { III (8C) }\end{array}$ & $\begin{array}{c}\text { Urbanismo } \\
\text { IV (8C) }\end{array}$ & \\
\hline $\begin{array}{c}\text { Representaç. I } \\
\text { (4C) }\end{array}$ & $\begin{array}{c}\text { Prat. Sociais } \\
\text { arq. }(2 \mathrm{C})\end{array}$ & $\begin{array}{l}\text { Hist. Arq. Art . } \\
\text { III (2C) }\end{array}$ & \begin{tabular}{|c|} 
Teoria do \\
espaç. urbano \\
(4C)
\end{tabular} & $\begin{array}{l}\text { Infra estrutr } \\
\text { urbana }(2 C)\end{array}$ & $\begin{array}{c}\text { Teoria e estet. } \\
\text { Arq. I (2C) }\end{array}$ & $\begin{array}{c}\text { Tec. } \\
\text { retrospec } \\
(4 \mathrm{C})\end{array}$ & $\begin{array}{c}\text { Planej. } \\
\text { Gest. Urb. } \\
\text { (4C) }\end{array}$ & $\begin{array}{l}\text { Leg. Exerc. } \\
\text { Profis. }(2 \mathrm{C})\end{array}$ & \\
\hline $\begin{array}{c}\text { Representaç. } \\
\text { II (4C) }\end{array}$ & $\begin{array}{l}\text { Representaç. } \\
\text { III (4C) }\end{array}$ & $\begin{array}{c}\text { Representaç. } \\
\text { V (4C) }\end{array}$ & $\begin{array}{c}\text { Instal. Hidrául. } \\
\text { A (2C) }\end{array}$ & $\begin{array}{c}\text { Instal. } \\
\text { Hidrául. B } \\
(2 \mathrm{C})\end{array}$ & $\begin{array}{c}\text { Instal. } \\
\text { eletricas (4C) }\end{array}$ & $\begin{array}{c}\text { Habitab. } \\
\text { edific. II (4C) }\end{array}$ & $\begin{array}{c}\text { Teoria e } \\
\text { estet. Arq. } \\
\text { II }(2 \mathrm{C})\end{array}$ & $\begin{array}{c}\text { Prática em } \\
\text { obra (2C) }\end{array}$ & \\
\hline $\begin{array}{c}\text { Geom. Desc. } \\
(4 C)\end{array}$ & $\begin{array}{l}\text { Representaç. } \\
\text { IV (4C) }\end{array}$ & $\begin{array}{l}\text { Habitab. } \\
\text { edific. I (4C) }\end{array}$ & $\begin{array}{c}\text { Tecnicas } \\
\text { Edificação A } \\
(4 \mathrm{C}) \\
\end{array}$ & \begin{tabular}{|c|} 
Tecnicas \\
Edificação B \\
$(4 \mathrm{C})$ \\
\end{tabular} & $\begin{array}{c}\text { Tecnicas } \\
\text { Edificação C } \\
\text { (4C) }\end{array}$ & \begin{tabular}{|c|} 
Economia e \\
gestão da \\
const $(4 \mathrm{C})$
\end{tabular} & $\begin{array}{c}\text { Prática em } \\
\text { obra }(2 C)\end{array}$ & & \\
\hline \multirow[t]{2}{*}{$\begin{array}{c}\text { Calculo Geom. } \\
\text { analítica }(6 C)\end{array}$} & $\begin{array}{c}\text { Mecânica p/ } \\
\text { arquit. (4C) }\end{array}$ & $\begin{array}{c}\text { Resistencia } \\
\text { materiais (4h) }\end{array}$ & $\begin{array}{l}\text { Analise sist. } \\
\text { estrut. }(4 C)\end{array}$ & \begin{tabular}{|c|} 
Estrut. \\
Concreto A \\
$(4 \mathrm{C})$
\end{tabular} & $\begin{array}{c}\text { Estrut. } \\
\text { Concreto B } \\
\text { (4C) }\end{array}$ & $\begin{array}{c}\text { Estrut. Aço } \\
\text { e madeira } \\
(4 \mathrm{C})\end{array}$ & & & \\
\hline & Topogr. I (4C) & & & & & & & & \\
\hline
\end{tabular}

Disciplinas de Projeto

Disciplinas de Representação Gráfica e comp.

Disciplinas de Urbanismo e Meio Ambiente

Disciplinas na área da Tecnologia da Arquitetura

As disciplinas consideradas da Tecnologia da Arquitetura somam $28 \%$ dos créditos destinados às disciplinas obrigatórias (sem considerar o Trabalho Final de Graduação - TFG, disciplinas optativas e estágio), sendo $7,5 \%$ dos créditos voltados às disciplinas de Tecnologia da Construção (Técnicas da Edificação A, B e C, Economia e Gestão da Construção, Prática em Obra); 9,5\% para Estruturas; 3\% Conforto Ambiental, 3\% Instalações Prediais, 2,5\% Fundamentação e 2,5\% outras (Topografia, e Infraestrutura urbana).

\section{c) Quadro docente}

As disciplinas de Técnicas da Edificação A, B e C são ministradas individualmente por 03 professores com formação em engenharia e pertencentes ao Departamento da Engenharia Civil, com vinculação ao Norie (Núcleo Orientado para a Inovação da Edificação vinculado ao Programa de Pós-Graduação em Engenharia Civil da UFRGS), sendo cada um responsável por uma disciplina. As matérias direcionadas à Gestão da Construção e Práticas em Obra (disciplinas com maior interface à área da Tecnologia da Construção), são ministradas por professores pertencentes ao quadro docente do curso de Arquitetura, em sua maioria arquitetos (apenas 01 engenheiro).

\section{d) Práticas didáticas e Infraestrutura laboratorial}

Em relação à infraestrutura, a FA-UFRGS possui uma Maquetaria e um Laboratório de Modelos e Protótipos amplamente equipado e de uso compartilhado, atendendo tanto o curso de Arquitetura e Urbanismo, como também o Design e a Engenharia Mecânica. Este laboratório não é utilizado diretamente nas disciplinas de Técnicas da Edificação, ministradas por professores pertencentes ao curso de Engenharia Civil. Sobre estas disciplinas, em cada uma delas há a aplicação de estratégias pedagógicas diferenciadas, segundo os professores ministrantes das mesmas.

- No caso da disciplina de Técnicas da Edificação A, as atividades são desenvolvidas compatibilizando aspectos relacionados à segurança e a ampla participação dos alunos, valendo-se de vários recursos didáticos, os quais são renovados ao longo dos anos, a partir de avaliações internas. A disciplina envolve, paralelamente, conteúdos sobre processos executivos e materiais construtivos, sendo o contato com a materialidade desenvolvido por meio do acompanhamento e comparação de 
técnicas construtivas (visitas em obras), de maneira que haja a possibilidade em praticar a análise crítica e reflexiva entre vários elementos e questões: diferentes tipos de estacas, de canteiros, portes de obra, argamassas, construção seca e construção convencional, sistemas artesanais e mecanizados, biocontrução e construção industrializada, etc, onde cada equipe compartilha das análises realizadas.

As aulas teóricas também possuem caráter expositivo, sendo que alguns conteúdos são desenvolvidos na forma de ensaios em laboratórios (LEME - Laboratório de Ensaios e Modelos Estruturais), espaço pertencente ao curso da Engenharia Civil, de uso compartilhado entre arquitetura e engenharia e também entre a graduação e a pós-graduação. Nestas atividades os alunos divididos em grupos, realizam práticas como a análise de argamassas com diferentes materiais e traços, cujas amostras transitam entre as equipes para efeito comparativo e análise crítica. A equipe técnica laboratorial é composta por 01 servidor/engenheiro que realiza a manutenção dos equipamentos; 01 servente/pedreiro terceirizado e 01 técnico contratado/projeto. Os recursos materiais são obtidos por meio de verba institucional, projetos de pesquisa e doações.

- Na disciplina de Técnicas da Edificação B são utilizados, prioritariamente, recursos audiovisuais, não havendo atividades em laboratório. No caso de determinados conteúdos, como dosagem de concreto, são utilizados métodos empíricos em sala de aula, esta estratégia foi justificada pelo entrevistado pela insuficiência de recursos humanos (técnicos de laboratório), para o acompanhamento dos alunos e também pela dificuldade em encontrar agenda livre no laboratório, muito utilizado tanto pela graduação como pela pós-graduação. As aulas teóricas são complementadas com trabalhos a partir de visitas a obras, estabelecendo comparativos entre o conteúdo abordado.

Os conteúdos abordados nas disciplinas de Economia e Gestão da Construção e Práticas em Obra não apresentam necessidade do apoio laboratorial, mas são desenvolvidos em estreita relação com o canteiro de obras.

- Na disciplina de Economia e Gestão da Construção são dadas noções gerais sobre Economia e Gestão na Arquitetura e Construção e sobre Filosofias da Produção. O conteúdo é dividido em 3 blocos, no início são abordadas questões de geração de valor, customização em massa, novas filosofias como a construção enxuta. Em um segundo momento, são abordados assuntos como planejamento, gestão de custos, honorários de arquitetura e, por fim, a gestão da qualidade. Como recursos didáticos são utilizadas aulas expositivas e a realização de trabalhos práticos e aplicação de jogos, para que os alunos possam apreender um pouco da prática de gestão, planejamento e orçamento. Outra estratégia adotada são os trabalhos em grupo, quando realizam uma espécie de consultoria (em uma empresa construtora ou escritório de arquitetura) a partir da aplicação das ferramentas dadas em aula, possibilitando realizar o diagnóstico sobre problemas e possibilidades de melhoria da empresa analisada.

- A disciplina de Práticas em Obra é anual e está direcionada mais à gestão da obra do que necessariamente, às técnicas construtivas. São abordadas questões sobre planejamento, controle de materiais, layout de canteiro e sequenciamento de execução, com palestras sobre segurança no trabalho, normas de desempenho, técnicas de planejamento e tecnologia da informação.

A etapa coletiva também inclui visitas a laboratórios técnicos e a obras, de acordo com a disponibilidade. Na etapa individual (que ocupa a carga horária mais elevada da disciplina), são realizadas visitas técnicas regulares a obras, escolhidas e acompanhadas pelo próprio aluno, mas com supervisão docente realizada continuamente em várias sessões.

\section{e) Pós graduação:}

O Curso de Graduação em Arquitetura e Urbanismo teve a partir de 1970, a criação de Programas de Pós-Graduação: em 1970 é criado o Mestrado em Planejamento Urbano e Regional (PROPUR) e, em 1979, é aberto o Programa de Pesquisa e Pós Graduação em Arquitetura (PROPAR). A partir de 2000 o Doutorado do PROPAR recebe seu credenciamento da CAPES e, a partir de 2004, o PROPUR passa a ter autorização para receber seus primeiros doutorandos. A partir de 2006, passa a funcionar na Faculdade de Arquitetura e Escola de Engenharia o Mestrado conjunto em "Design e Tecnologia".

\footnotetext{
${ }^{109}$ Dados disponíveis em: https://www.ufrgs.br/propar/ e: http://www.ufrgs.br/propur/. Acesso em: 02/04/2016.
} 
PROPUR - Áreas de concentração:

Planejamento e Espaço Urbano e Regional e os Processos Sociais

1- Cidade, cultura e política

2- Planejamento e Espaço Urbano e

Sistemas de Suporte à Decisão em Planejamento e Desenho Urbano

1- Sistemas configuracionais urbanos

2- Percepção e análise do espaço urbano

3- Infra-estrutura e Planejamento Urbano e Ambiental

PROPAR - Áreas de concentração e Linhas de Pesquisa:

Teoria História e Crítica da arquitetura

1 - Arquitetura brasileira e cultura disciplinar

2 - Arquitetura americana e cultura disciplinar

3- Fundamentos teóricos e metodológicos da arquitetura

Projeto de Arquitetura e Urbanismo

1- Habitabilidade da edificação e da urbanização

2- Modelagem da forma urbana e da edificação

3- Princípios e paradigmas de projeto em arquitetura e urbanismo

4- Tipologias arquitetônicas e morfologia urbana

O PROPAR não oferece linhas de pesquisa na área da Tecnologia da Construção, mas, de acordo com os professores entrevistados, a grande parcela dos alunos arquitetos interessados na área da Tecnologia, são absorvidos pelo programa de pós-graduação da Engenharia Civil, geralmente o NORIE Núcleo Orientado para a Inovação da Edificação.

\section{f) Comentários:}

- Foi verificado que existe grande interesse por parte dos arquitetos pela pós-graduação oferecida pelo curso de Engenharia Civil por meio do Núcleo Orientado para a Inovação da Edificação - Norie, que absorve muitos deles;

- Existe uma orientação interna da universidade que o aluno matriculado em disciplinas específicas com atividade de campo já está automaticamente segurado pela universidade, devido à sua exposição;

- Uma particularidade observada no curso é a obrigatoriedade da disciplina de Práticas em Obra, cenário diferente da maioria dos cursos do país que, geralmente, quando ofertam, é em caráter optativo ou incorporadas em algumas disciplinas não de forma sistêmica. Um dos objetivos desta disciplina é procurar dar respaldo aos alunos na condução das visitas em obra, para que possam refletir sobre o impacto da obra no projeto e a necessidade de integrar estas duas questões fragmentadas cada vez mais: obra e o projeto;

- A disciplina de Práticas em Obra possibilita que, tanto alunos como professores, tenham noção abrangente do que está sendo desenvolvido na cidade, a partir do acompanhamento de um grande número de obras com diversas características, desde as mais rudimentares até as que apresentam tecnologias mais avançadas, possibilitando a contextualização do cenário local;

- As entrevistas revelaram que há diferentes formas de interpretação por parte dos docentes, sobre o aproveitamento do conteúdo das disciplinas de Tecnologia da Construção pelos alunos;

- Há o reconhecimento tanto por parte do curso de arquitetura como da engenharia, de que a presença de professores da engenharia nos ateliês de projeto trazem resultados muito positivos ao longo dos atendimentos;

- Os alunos da graduação possuem interesse e se envolvem com pesquisas e atividades da área da tecnologia, independentemente de serem desenvolvidas por professores de outros cursos

- As dificuldades financeiras relacionadas à manutenção das atividades e infraestrutura laboratorial obrigam os pesquisadores a buscarem diferentes fontes para obtenção de recursos, sobrecarregando os mesmos. Estas condicionantes são relevantes para serem consideradas em cursos cujos espaços são de uso compartilhado e as disciplinas da área técnica são delegadas a outros cursos juntamente com esta responsabilidade. 


\title{
4- EA-UFMG - Escola de Arquitetura da Universidade Federal de Minas Gerais ${ }^{110}$
}

\begin{abstract}
a) Breve Histórico ${ }^{11}$
A Escola de Arquitetura de Belo Horizonte nasceu em 1930, a partir da necessidade de formar um número maior de profissionais, cuja ausência se tornava sensível diante das tendências culturais e artísticas do ambiente cultural de Minas Gerais e também das conquistas materiais alcançadas até então. Com o estabelecimento de alguns arquitetos na cidade de Belo Horizonte, por volta de 1924, outros profissionais se agruparam em torno deles, como engenheiros, artistas, advogados e médicos, com o objetivo de organizar uma escola de formação de técnicos da arquitetura e profissionais das artes. De acordo com Figueiredo (1946), outro fato que influenciou os fundadores do novo estabelecimento de ensino foi o resultado de um Congresso Pan-Americano de Arquitetura realizado na época, no qual era recomendada a criação de escolas especiais do ramo das belas artes.

Após reunião realizada no dia 5 de agosto de 1930, foi então fundada a Escola de Arquitetura destinada à formação de engenheiros-arquitetos. Foi a primeira a se organizar no Brasil de forma desvinculada das Escolas de Belas Artes e de Engenharia, sendo a instituição iniciada sem nenhum amparo financeiro além do que Ihe davam seus fundadores. Ainda segundo Figueiredo (1946), os fundadores tiveram a preocupação de formar arquitetos com uma cultura técnica, científica e artística ampla, adotando-se a organização didática da secção de arquitetura da Escola Nacional de Belas Artes, pelo seu reconhecimento perante o Governo da União, sendo as primeiras cadeiras ocupadas por engenheiros, arquitetos, artistas, advogados e médicos.

Transferida para diversas sedes, ora pagas pelos próprios professores, ora cedidas pela Prefeitura da capital, a Escola conquistou o apoio da opinião pública e dos órgãos governamentais, sendo a partir de 1934 autorizado o registro dos diplomas para o exercício da profissão de engenheiro-arquiteto no Estado de Minas Gerais ${ }^{112}$. Em 1944, por intermédio do então prefeito Juscelino Kubitschek de Oliveira, a escola foi incorporada ao Instituto de Belas Artes (ambas, didaticamente autônomas), ocasião em que os encargos financeiros da escola foram assumidos pela prefeitura. Nesta época, a indicação era de que o ensino deveria permanecer correspondente ao da Escola Nacional de Belas Artes, a fim de ultimar a obtenção de seu reconhecimento pelo Governo Federal, ato que ocorreu (logo após 6 meses), em dezembro de $1944^{113}$.

Após este reconhecimento, a Escola de Arquitetura de Belo Horizonte passou a se preparar para ocupar ao lado dos quatro institutos que, até então integravam a Universidade de Minas Gerais (UMG), espaço pleiteado junto ao Conselho Universitário. Após serem baixados os decretos-lei de $n^{\circ} 1749$ e $n^{\circ}$ 1759 e o decreto municipal de $\mathrm{n}^{\circ} 179$ em 1946, concedendo plena autonomia administrativa e financeira à Escola de Arquitetura e desmembrando-a do Instituto de Belas Artes, terminou o período de preparação complementar para a incorporação do estabelecimento à UMG, aprovado pelo
\end{abstract}

\footnotetext{
110 Dados obtidos entre os dias 18 e 19 de outubro de 2016, a partir da visita técnica às instalações da EA UFMG, com entrevistas direcionadas a alguns professores pertencentes ao Departamento de Tecnologia da Arquitetura (profa. Cynara Bremer, prof. Eduardo Cabaleiro Cortizo) e aos professores José Eustáquio Machado de Paiva - professor aposentado do Departamento de Tecnologia da Arquitetura e Urbanismo - e Roberto Eustáaquio dos Santos - professor da área do Departamento de Projeto.

${ }^{111}$ Texto baseado nas seguintes fontes:

- FIGUEIREDO, J. K. de. A Escola de Arquitetura e sua História, 1946.

- Universidade de Minas Gerais. Serviço dos Países S. A. Belo Horizonte, 1965.

- LEMOS, C.B.et al. (org.) Escola de Arquitetura da UFMG: lembranças do passado. Visão do futuro. Belo Horizonte: EA/UFMG, 2010.

${ }^{112} \mathrm{Em}$ 1940, professores, alunos e funcionários foram surpreendidos com a notícia do possível fechamento da Instituição pelo Governo Federal que ainda não a reconhecia. Segundo Lemos et. al. (2010), diante desta ameaça, o então diretor Aníbal de Mattos embarcou para o Rio de Janeiro com o intuito de defender a manutenção da Escola, sendo assegurado pelo então presidente Getúlio Vargas, que em seu governo a escola não seria fechada.

${ }^{113}$ Esta época, segundo Lemos et.al. (2010), coincidiu com o momento em que a arquitetura moderna começa a ganhar espaço na cidade e no país, e as obras do Complexo da Pampulha contribuíram muito para isso e para o clima de crescimento e expansão da Escola.
} 
Conselho Universitário. Em seção realizada em 5 de agosto de 1946 o estabelecimento passou a denominar-se 'Escola de Arquitetura da Universidade de Minas Gerais' e, em dezembro de 1949, ocorreu a federalização da Universidade.

De acordo com Lemos et.al. (2010), com a ajuda de Juscelino Kubitscheck, a Escola ganhou um terreno no bairro dos Funcionários, onde funcionava um antigo Mercado Municipal. Instalando-se provisoriamente nesse local, os professores e alunos se lançaram na empreitada de construir uma sede própria, que começou a surgir no final dos anos 1940 sendo até hoje a atual sede. Para a realização do projeto (Figura 64), foi indicado o arquiteto e professor Shakespeare Gomes, com a participação de Eduardo Mendes Guimarães, formado na escola em 1945. As obras foram concluídas em 1954 e comportavam as instalações necessárias para o funcionamento das atividades da graduação e pósgraduação. Já em 1955, foi apresentado o projeto da primeira expansão, enquanto a Universidade fazia o movimento pela congregação e união de todos os seus centros de ensino superior em um único campus. Entre 1964 e 1967 o edifício da Escola passou pela segunda e última expansão, este projeto previa a construção da ala posterior que abrigaria novas salas de aula e laboratórios em torno do pátio central.

O período compreendido entre 1950 e o início de 1960 marcou um momento de afirmação e consolidação tanto da Escola como também da arquitetura no âmbito nacional. Contudo, com o golpe militar de 1964, a dinâmica da Universidade foi alterada, com a prisão de alunos, cassação de professores e o fechamento do ISSPLA (Instituto Superior de Pesquisas para Planejamento) sob a acusação de subversão, pondo fim a uma importante atividade da Unidade.

Neste período, com a Reforma Universitária, a Escola de Arquitetura também teve que realizar mudanças em seu currículo, motivo de muitas críticas e discussões. Em 1977, conseguiu-se implantar uma nova proposta de curso e, em 1978, as discussões envolviam a questão da mudança da Escola para o Campus da Pampulha, com forte engajamento e apoio dos alunos, culminando em uma greve de 70 dias, cujo cerne das reinvindicações era o Laboratório e a Prestação de Serviços. Como essas reinvindicações não foram atendidas o Laboratório foi fechado. Na década de 1980, chega à Unidade a geração pós-ditadura militar, impulsionando também as atividades acadêmicas voltadas à pesquisa e extensão, sendo a pós-graduação consolidada nos anos de 1990. Em 2007, foi proposto o curso de Design juntamente com a nova graduação em Arquitetura e Urbanismo Noturno, ambas viabilizadas pelo programa REUNI. Atualmente, o curso possui quatro Departamentos (- Análise Crítica e Histórica da Arquitetura e do Urbanismo; - Projetos; - Tecnologia da Arquitetura e do Urbanismo; - Urbanismo) e a discussão acerca da mudança da Escola para o campus da UFMG alcançou expansão, não resultando, entretanto, na sua efetiva transferência para a Cidade Universitária.

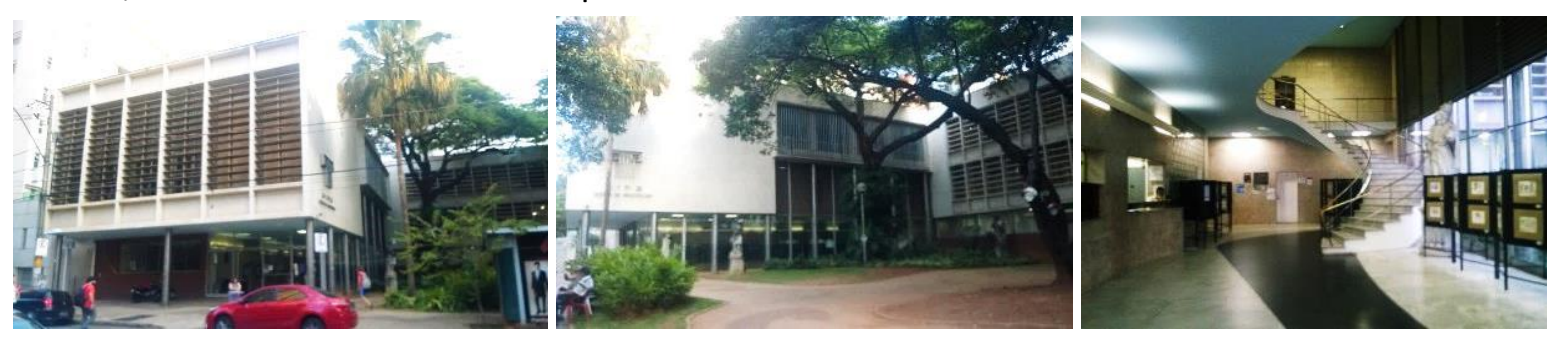

Figura 64 - Escola de Arquitetura da UFMG - a) e b) vistas externas do edifício e praça. c) e d) Vistas internas junto à entrada principal.

Fonte: fotos da autora.

\section{b) Considerações sobre a Estruturação da área da Tecnologia da Construção}

O curso oferece 150 vagas anuais. De acordo com o Projeto Político Pedagógico de Curso, as novas Diretrizes para os Currículos de Graduação da UFMG passaram a exigir que a estrutura dos mesmos contemplasse um núcleo de Formação Específica, uma Formação Complementar e um conjunto de Atividades Livres.

A nova versão curricular possibilita uma flexibilização vertical com dois percursos curriculares, ou seja, um primeiro percurso que inclui uma carga horária para formação complementar com 150 horas, para formação livre com 45 horas e para optativas do núcleo específico com 120 horas. E um segundo percurso, que inclui uma carga horária para formação livre com 45 horas e para optativas com 270 horas. 
Uma das estratégias adotadas ao longo da organização do curso foi destinar maior carga horária semestral nos períodos iniciais, por meio da concentração de disciplinas obrigatórias, de forma a possibilitar ao aluno maior tempo disponível nos últimos períodos para a realização de atividades complementares. Outra estratégia adotada foi a distribuição da carga de atividades optativas, formação complementar e formação livre a partir do meio do curso, de forma a possibilitar ao aluno maior maturidade para as escolhas pessoais e definição de trajetórias próprias.

As disciplinas do eixo de tecnologia estão organizadas em várias linhas: a de Sistemas Estruturais e a de Instalações Prediais e Infraestrutura Urbana, estão sob a responsabilidade de departamentos da Escola de Engenharia da UFMG; a linha de Materiais e Técnicas Construtivas e a de Conforto Ambiental, sob a responsabilidade do Departamento de Tecnologia da Arquitetura e do Urbanismo (TAU).

Em relação à área da Tecnologia da Arquitetura, de acordo com o Quadro 14, a mesma ocupa cerca de $31 \%$ dos créditos destinados às disciplinas obrigatórias do curso, e estão distribuídas entre o 10 e o 8o períodos. As disciplinas da área da Tecnologia das Construções, são oferecidas no 2으, 3ㅇ e 70 períodos, com um intervalo de 3 semestres entre Materiais e Técnicas II e Tecnologia da Construção. Ainda sobre as disciplinas da área da Tecnologia da Construção, as mesmas ocupam cerca de $7 \%$ dos créditos totais e as demais disciplinas ocupam a seguinte proporção de créditos: Sistemas Estruturais 11,5\%; Conforto Ambiental 5\%; Instalações Prediais 3,5\% e Outras (Topografia e Cartografia e Saneamento e Estudos Ambientais) 4\%.

Quadro 14 - Distribuição da Grade Curricular com a carga horária semestral - EA UFMG:

\begin{tabular}{|c|c|c|c|c|c|c|c|c|c|}
\hline 10 sem & 20 sem & 3o sem & 40 sem & 5o sem & 60 sem & 70 sem & 80 sem & 90 sem & $10 \%$ sem \\
\hline $\begin{array}{c}\text { Fund. projeto } \\
\text { de Arq. Urb. I } \\
\text { (11C) }\end{array}$ & $\begin{array}{c}\text { Fund. proj. de } \\
\text { Arq. e Urb. II } \\
\text { (11C) }\end{array}$ & $\begin{array}{l}\text { Carga de Proj. } \\
\text { de Arq. } \\
\text { Optativo (8C) }\end{array}$ & $\begin{array}{l}\text { Carga de Proj. } \\
\text { de Arq. } \\
\text { Optativo (8C) }\end{array}$ & \begin{tabular}{|c} 
Carga de \\
Proj. de Arq. \\
Optat. (4C)
\end{tabular} & $\begin{array}{l}\text { Carga de Proj. } \\
\text { de Arq. } \\
\text { Optativo (4C) }\end{array}$ & \begin{tabular}{|c|} 
Projeto \\
integr. arq. \\
urb. $(8 \mathrm{C})$ \\
\end{tabular} & $\begin{array}{l}\text { Carga de } \\
\text { Proj. Arq. } \\
\text { Optat. ( } 8 \mathrm{C})\end{array}$ & $\begin{array}{l}\text { Carga de } \\
\text { Proj. Arq. } \\
\text { Optat. (4C) }\end{array}$ & TFG \\
\hline $\begin{array}{c}\text { Introd. ao urb. } \\
\text { (3C) }\end{array}$ & $\begin{array}{l}\text { Hist. Arte, Arq. } \\
\text { cid. renasc. } \\
\text { Barroco (4C) }\end{array}$ & $\begin{array}{l}\text { Urbanismo I } \\
(4 C)\end{array}$ & $\begin{array}{l}\text { Urbanismo II } \\
\qquad(4 C)\end{array}$ & $\begin{array}{c}\text { Projeto } \\
\text { Urbano (4C) }\end{array}$ & $\begin{array}{c}\text { Planejamento } \\
\text { Urbano (4C) }\end{array}$ & $\begin{array}{c}\text { Paisagem e } \\
\text { Amb. }(3 C)\end{array}$ & $\begin{array}{l}\text { Planejam. } \\
\text { Regional } \\
\text { (3C) }\end{array}$ & Introd. TFG & \\
\hline $\begin{array}{l}\text { Hist. Arte, } \\
\text { Arq. cid. Ant. } \\
\text { medieval (4C) }\end{array}$ & $\begin{array}{c}\text { Materiais e } \\
\text { Tecn. de } \\
\text { Const. I (4C) }\end{array}$ & $\begin{array}{c}\text { Hist. Arte, } \\
\text { arq.cid.neocl. } \\
\text { funcional. (4C) }\end{array}$ & $\begin{array}{l}\text { Teoria e Arqu. } \\
\text { Contemp. }(4 C)\end{array}$ & $\begin{array}{c}\text { Teoria } \\
\text { Urbana }(4 \mathrm{C})\end{array}$ & $\begin{array}{c}\text { Arquitetura e } \\
\text { Cultura bras. } \\
(4 \mathrm{C})\end{array}$ & $\begin{array}{l}\text { Patrimonio } \\
\text { Cultural }(3 C)\end{array}$ & $\begin{array}{l}\text { Orç. Planej. } \\
\text { admin. de } \\
\text { obras ( } 2 \mathrm{C})\end{array}$ & $\begin{array}{c}\text { Projeto } \\
\text { Paisag. (3C) }\end{array}$ & \\
\hline $\begin{array}{c}\text { Estudos soc.: } \\
\text { espaço e } \\
\text { socied. (4C) }\end{array}$ & $\begin{array}{c}\text { Resistência } \\
\text { dos Materiais } \\
(4 \mathrm{C})\end{array}$ & \begin{tabular}{|c|} 
Conforto \\
term. Climatiz. \\
Amb. (3C)
\end{tabular} & $\begin{array}{c}\text { Iluminação } \\
\text { natural artific. } \\
\text { amb. (3C) }\end{array}$ & $\begin{array}{c}\text { Saneam. e } \\
\text { estudos } \\
\text { amb. (4C) }\end{array}$ & $\begin{array}{c}\text { Técnicas } \\
\text { Retrosp. (3C) }\end{array}$ & \begin{tabular}{|c|} 
Tecnol. da \\
construção \\
$(3 C)$
\end{tabular} & $\begin{array}{l}\text { Formaça } \\
\text { complem. }\end{array}$ & $\begin{array}{c}\text { Semin. } \\
\text { Legisl. prat. } \\
\text { Profiss. (2C) }\end{array}$ & \\
\hline \multirow[t]{4}{*}{$\begin{array}{l}\text { Introd. aos } \\
\text { sist. estrut. } \\
(2 \mathrm{C})\end{array}$} & $\begin{array}{c}\text { Cartografia e } \\
\text { Topografia } \\
(4 \mathrm{C})\end{array}$ & $\begin{array}{c}\text { Materiais e } \\
\text { Tecn. de } \\
\text { Constr. II (4C) }\end{array}$ & $\begin{array}{l}\text { Instal. prediais } \\
\text { elet. e de } \\
\text { comunic. (4C) }\end{array}$ & $\begin{array}{l}\text { Instal. Pred. } \\
\text { Hidro-sanit. } \\
(3 C)\end{array}$ & $\begin{array}{c}\text { Acústica de } \\
\text { ambientes } \\
\text { (3C) }\end{array}$ & Formacá̃o & Optativas & complem. & \\
\hline & & $\begin{array}{c}\text { Análise } \\
\text { Estrutural (4C) }\end{array}$ & $\begin{array}{l}\text { Estruturas de } \\
\text { Concreto }(4 \mathrm{C})\end{array}$ & $\begin{array}{c}\text { Estruturas } \\
\text { de Madeira } \\
(2 \mathrm{C})\end{array}$ & $\begin{array}{c}\text { Sist. } \\
\text { Estrut.aplic. a } \\
\text { arquit. (4C) }\end{array}$ & Optativas & & Optativas & \\
\hline & & & & $\begin{array}{c}\text { Estruturas } \\
\text { de Aço ( } 2 \mathrm{C})\end{array}$ & Supervisio. & & & & \\
\hline & & & & Optativas & Formaç่อ & & & & \\
\hline
\end{tabular}

Disciplinas de Projeto

Disciplinas de Representação Gráfica e comp.
Disciplinas de Urbanismo e Meio Ambiente

Disciplinas na área da Tecnologia da Arquitetura
Disciplinas de Historia e Teoria

\section{c) Quadro docente}

As disciplinas do eixo Tecnologia da Construção são integralmente assumidas pelo Departamento de Tecnologia da Arquitetura, diferentemente das de Sistemas Estruturais e Instalações, as quais são delegadas aos Departamentos pertencentes às Engenharias, portanto, seguem o modelo misto. Foi observado que os professores da área da Tecnologia da Construção do curso diurno não ministram no curso noturno e vice-versa, com a aplicação de metodologias e conteúdos diferentes em cada turno. Todos os professores ministrantes das disciplinas da área estudada (Tecnologia da Construção) possuem formação em Engenharia Civil, com exceção de algumas optativas da área, as quais também são conduzidas por docentes com formação em Arquitetura e Urbanismo. 


\section{d) Práticas didáticas e Infraestrutura laboratorial}

O Departamento de Tecnologia da Arquitetura foi criado no ano de 1992, visando dar suporte técnico às atividades desenvolvidas na área de planejamento e projeto, tendo posteriormente incorporado à área de Design. Os professores vinculados ao Departamento exercem suas atividades nas linhas de design, conforto térmico, acústico e luminoso, tecnologia da construção e materiais e técnicas construtivas. Sob sua coordenação estão quatro laboratórios: o Laboratório de Pesquisa e Tecnologia em Construção Civil - LPT, o Laboratório de Conforto Ambiental e Eficiência Energética no Ambiente Construído - LABCON-UFMG, o Laboratório de Estudos Integrados em Arquitetura e Design, LADE e o Laboratório Virtual do Grupo de Pesquisa GRAFT da UFMG - LavGRAFT ${ }^{114}$.

\section{- Trajetória histórica da área laboratorial técnico-construtiva ${ }^{115}$}

Em Figueiredo (1946), é possível identificar o primeiro professor a ocupar a cadeira de Materiais de Construção, Terrenos e Fundações, o professor Martim Francisco Ribeiro de Andrada, principal responsável por equipar o primeiro laboratório na área da Tecnologia dos Materiais ${ }^{116}$. Até 1964 a Escola teve um conjunto bem estruturado de laboratórios na área da Tecnologia: Materiais de Construção - que não incluía a área de Técnicas Construtivas - Topografia e Conforto Ambiental (na época era entendido como condicionamento de ar). Com a implantação do Regime Militar, a escola foi invadida. Naquele momento, o 40 andar da Escola funcionava como um Instituto de Pesquisas, tendo em seu quadro de atores tanto professores como funcionários que atuavam como pesquisadores e, além disso, havia uma gráfica, a qual permitiu que entre as décadas de 1950 e 1960 a Escola realizasse um grande número de pesquisas e publicações. Com a invasão do exército, grande parte do Laboratório de Materiais foi destruída e, posteriormente, veio a Reforma no ensino ${ }^{117}$ (Figura 65). Ainda de acordo com o professor entrevistado, o que o exército não conseguiu fazer a Reforma Universitária de 1969 o fez, em termos de destruição das condições de ensino: uma universidade criada nos moldes franceses, de repente, teve que funcionar nos moldes americanos. Com a Reforma, a redepartamentalização foi implantada, este cenário criou condições para que um grupo dominante assumisse o poder, com isso, este grupo passa a rechaçar a área da Tecnologia, sendo os professores desta área despachados, involuntariamente, para os Departamentos da Escola de Engenharia, tanto arquitetos como engenheiros da área tecnológica ${ }^{118}$.

Os laboratórios e a gráfica foram arrasados e a Escola ficou desfalcada de figuras representativas na área da Tecnologia. O professor Martim Francisco Ribeiro de Andrada e outros poucos foram lotados no Departamento de Análise Crítica e Histórica - a área de Materiais, Orçamento e Prática, Planejamento financeiro, passou a pertencer a este departamento, com um pequeno grupo à sua frente.

\footnotetext{
${ }^{114}$ Dados obtidos em: http://www.arq.ufmg.br/site/v2/index.php/departamentos/tecnologia-da-arquitetura-e-do-urbanismo. Acesso em: 14 de outubro de 2016.

${ }^{115}$ As informações aqui descritas foram fornecidas em entrevista pelo professor José Eustáquio Machado de Paiva - professor aposentado do Departamento de Tecnologia da Arquitetura e Urbanismo - EA UFMG - realizada em 19 de outubro de 2016. Estes dados sobre o histórico foram complementados com informações fornecidas pelos professores Cynara Bremer e Eduardo Cabaleiro Cortizo.

${ }^{116}$ Os relatos sobre os primórdios da área de Materiais de Construção revelam que esta área não era muito apreciada pelos alunos, julgando o conteúdo da disciplina ser maçante, pois não viam a aplicabilidade e a relação direta com aquilo que eles, alunos e professores, reconheciam como arquitetura, que é Arquitetura enquanto Projeto. Portanto, não seria necessário aquele conteúdo.

${ }^{117}$ Depois da invasão militar em 1964, o Laboratório de Materiais foi 'desapropriado', restando apenas uma máquina de ensaios alemã, o resto foi levado, pois julgavam que aquele laboratório concorria com os laboratórios da Escola de Engenharia.

${ }^{118}$ Concluindo, esta foi a chance de reestruturar como também de se verem livres de desafetos, pois na realidade, já existia o espírito separatista e a reforma foi somente a oportunidade almejada por um grupo de professores para a separação entre a área técnica e o projeto.
} 




Figura 65 - Máquina de ensaios alemã - Único equipamento deixado pelos militares no Laboratório de Materiais após ocupação por volta de 1964. Encontra-se sem uso e é mantida até hoje nas dependências da Escola.

Fonte: foto da autora.

Em um segundo momento, a única instalação existente denominada Laboratório de Tecnologia, era uma grande sala com uma coleção de amostras e de catálogos voltados para especificação de materiais de construção civil. Esta pode ser considerada a segunda fase do laboratório. Na década de 1980, foi iniciado, por parte de alguns professores, um movimento para reforçar o valor da tecnologia no ensino dentro da Escola de Arquitetura, alguns professores de Projeto se recusavam, enquanto outros se abriam ao diálogo ${ }^{119}$. Esse movimento de revalorização da tecnologia foi promovido pelos professores José Eustáquio, Martim e Élcio, na tentativa de se montar um laboratório, o qual, atualmente não existe mais. Foi relatado que a responsabilidade em se manter vivo o laboratório não foi sustentada e passada adiante por outros colegas de trabalho da área da Tecnologia da Construção, sendo destruído aos poucos. O embate de entendimentos sobre a configuração da área laboratorial no curso é evidenciada a partir da transferência desta responsabilidade a outros atores, não havendo continuidade do trabalho e sim um processo de desqualificação da estrutura existente sem, contudo, conhecê-la. Surgiram então novas proposições, levando este espaço a ser transformado em depósito ${ }^{120}$.

Atualmente, a partir da iniciativa de alguns professores que ingressaram nos últimos anos (a partir de 2010), está sendo realizado o esforço de tentar reverter esta situação. Outro espaço, localizado no 10 piso, foi cedido e destinado para a implantação de um novo Laboratório de Materiais. O mesmo se encontra em fase de reforma e alguns equipamentos patrimoniados estão em fase de transferência do curso da Engenharia Civil, processo este, viabilizado por um dos professores que ingressou nestes últimos $\operatorname{anos}^{121}$ (Figura 66). Estes novos equipamentos também serão utilizados pelo curso de Design, para ensaios em móveis, sendo o laboratório provavelmente voltado a ensaios não destrutivos, também devido às limitações do espaço físico concedido, pelo fato da localização no 1으 pavimento, não permitindo que equipamentos de grande porte sejam implantados no local devido à sobrecarga (ex.: máquina universal de ensaios) ${ }^{122}$.

\footnotetext{
119 Ainda de acordo com relatos, houve casos em que, professores de Projeto chegaram a advertir alunos, principalmente, quando estes se interessavam pela área técnica. Pois, na década de 1960 e uma parte de 1970, a rejeição à área da Tecnologia e também da Construção era tão grande sendo uma prática corrente os alunos serem, voluntariamente, reprovados em matérias de natureza tecnológica, pois a reprovação já era premeditada e almejada, com isso, ele se tornava 'maior' perante os 'outros'.

${ }^{120}$ Este espaço laboratorial comentado foi redividido em 2007 e liberado para uso entre 2007 e 2008 . Segundo relato, chegou um momento que o laboratório passou a ser chamado de LPT - Laboratório de Pesquisas Tecnológicas (denominação reconhecida até o presente momento) e virou um laboratório virtual, pois os alunos não ocupavam mais o laboratório, eles optavam pelo acesso aos catálogos digitais on line, fato que contribuiu para a obsolescência das instalações culminando na transformação do laboratório em depósito.

${ }^{121}$ Professor que anteriormente compunha o quadro docente do curso da Engenharia Civil.

122 O local a ser ocupado não coincide com o indicado no projeto original para esta finalidade, sendo realizado o processo de troca (do térreo para o 1ㅇandar), pois o primeiro laboratório não possuía iluminação e ventilação naturais, sendo considerado
} 

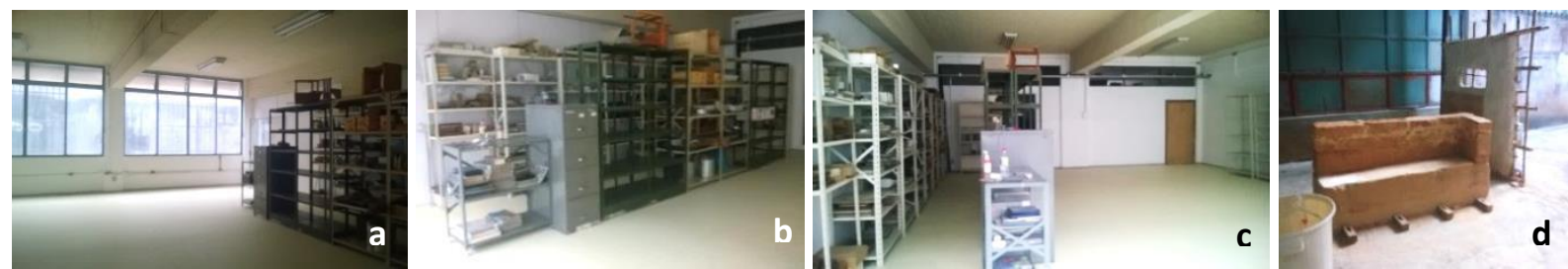

Figura 66 - Atual Laboratório de Materiais em fase de implantação - EA UFMG. a), b) e c) Imagens do novo local onde será implantado o Laboratório de Materiais, encontrando-se em fase de reforma. d) atividades envolvendo algumas técnicas construtivas em terra crua, e realizadas em outras disciplinas.

Fonte: fotos da autora

\section{As disciplinas}

Embora com propostas pedagógicas diferenciadas, ambos os cursos Noturno e Diurno promovem a formação de arquitetos e urbanistas. No caso da Tecnologia da Construção, os professores ministrantes de disciplinas desta área são diferentes em cada turno. A carga horária nesta área é bem maior no período diurno, com uma disciplina semestral de $45 \mathrm{~h}$ e duas semestrais de $60 \mathrm{~h}$, enquanto que no curso noturno são oferecidos vários módulos de 15h cada (com duração de 1 mês - 4 encontros semanais de $4 \mathrm{~h}$ ). Os cursos tem a mesma duração de 5 anos, com Carga Horária total idêntica, mas com um número de disciplinas maior no noturno, as quais apresentam maior fragmentação e não possuem pré-requisitos.

Atualmente, ambos os cursos apresentam-se em fase de discussão, a fim de se chegar a um ponto de equilíbrio e proximidade entre os dois turnos, entre flexibilidade e engessamento, diante de assuntos que naturalmente possuem a necessidade de continuidade (com relação direta entre maturidade intelectual e conteúdo) e também, pela impossibilidade da realização de determinadas práticas pedagógicas no período noturno, como visitas em obras e atividades experimentais, sendo o sábado destinado às atividades de outras disciplinas como as Oficinas. Devido ao curso noturno ter iniciado suas atividades em 2009, estando ainda em fase de experimentação e sua estratégia pedagógica em fase de avaliação, este curso não será abordado neste trabalho, sendo apenas analisado o curso Diurno.

Sobre as disciplinas da área da Tecnologia da Construção, o conteúdo referente a materiais e técnicas era abordado de forma separada, atualmente, ambos os assuntos são estudados na mesma disciplina, tanto propriedades físicas e mecânicas dos materiais como seu processo de aplicação em obra.

- Em Materiais e Técnicas I, há diversificação nas estratégias pedagógicas, são realizadas constantes visitas em obras (em diferentes fases da construção), fábricas e em obras em uso (assuntos como perícia e patologias), todas com acompanhamento docente. A disciplina também envolve aulas teóricas com apoio de vídeos para visualização de processos técnico-construtivos e o conteúdo, aborda tanto materiais comumente empregados nas construções, como também, técnicas de construção em várias etapas. Assuntos referentes a materiais e técnicas inovadoras, geralmente, são diluídos ao longo das aulas de acordo com o tema, não havendo uma disciplina ou aula específica sobre isso.

Além das aulas, são oferecidas oportunidades aos alunos na participação de projetos extensionistas - via Fundação da própria universidade - alguns deles envolvendo a área de perícia técnica em obra, possibilitando que os alunos vejam o que está sendo realizado no mercado. Foi relatado que estas atividades promovem um diferencial às aulas, pois contribuem para que os alunos tenham uma visão mais crítica e reflexiva sobre o conteúdo abordado.

- A disciplina de Materiais e Técnicas II, assim como a anterior, faz uma abordagem sobre estes dois assuntos simultaneamente: propriedades dos materiais e sua aplicabilidade. Atualmente, é a única disciplina que adota entre suas estratégias pedagógicas as atividades laboratoriais, com a realização de ensaios, sendo a infraestrutura utilizada pertencente aos laboratórios do curso da Engenharia Civil e estão localizadas no Campus da Pampulha (distante em torno de 10 a $13 \mathrm{~km}$ da sede do curso de Arquitetura).

inadequado para atividades desta natureza. Foi relatado que o novo local de implantação do laboratório funcionava como restaurante do curso de Arquitetura, sendo posteriormente, desativado e virado depósito. 
Sobre a abordagem de temáticas diferenciadas, foi comentado que no período noturno, devido ao forte viés com o tema sustentabilidade e urbanismo, são oferecidas disciplinas específicas, como a chamada 'Tecnologia do Ambiente Construído' - oferecida em regime obrigatório pelo Departamento de Tecnologia - onde são abordados conteúdos como Pegada Ecológica, Ciclo de Vida, cálculo de Energia Incorporada nos materiais, etc. Embora esta disciplina seja oferecida no período noturno, alunos do diurno também podem cursá-la como optativa, caso haja vagas.

\section{e) Pós graduação: ${ }^{123}$}

O Programa de Pós-graduação da Escola de Arquitetura da Universidade de Minas Gerais está dividida em: NPGAU - Programa de Pós-Graduação em Arquitetura e Urbanismo e MACPS - Mestrado em Ambiente Construído e Patrimônio Sustentável.

O NPGAU foi criado em 1994, com pós-graduação stricto sensu - nível Mestrado, em 2009 foi implantado o Doutorado. De acordo com os dados divulgados pelo próprio Programa, historicamente, o NPGAU é herdeiro do Núcleo de Assessoramento à Pesquisa, criado em 1959 pelo Prof. Sylvio de Vasconcellos e depois denominado Instituto Superior de Pesquisas para o Planejamento (ISSPLA). Com o golpe militar de 1964, o Instituto foi fechado e o professor Sylvio de Vasconcellos compelido a deixar o país. Esse episódio fez com que a pesquisa na Escola de Arquitetura da UFMG ficasse, por um longo período, reduzida a ações e esforços individuais, sem o devido respaldo institucional. A criação do NPGAU representou a rearticulação institucional das atividades de pesquisa na Escola de Arquitetura após a redemocratização do país. Este Programa possui como Área de Concentração:

\section{- Teoria, Produção e Experiência do espaço}

E como Linhas de Pesquisa:

1- Planejamento e dinâmicas sócio-territoriais

2- Produção, projeto e experiência do espaço:

3- Teoria e História da Arquitetura e do Urbanismo e suas relações com outras artes e ciências Em relação ao MACPS, atualmente o Programa passou a ser denominado PACPS, por oferecer a partir de 2017, nível Doutorado. Tem como Área de Concentração:

- Bens Culturais, Tecnologia e Território.

E Linhas de Pesquisa:

1- Conservação de bens culturais

2- Gestão do Patrimônio no Ambiente Construído

3- Tecnologia do Ambiente Construído

O Departamento de Tecnologia da Arquitetura e do Urbanismo está inserido no atual PACPS, e oferece a possibilidade de pesquisas na área da Tecnologia da Construção, a partir da linha de pesquisa em 'Tecnologia do Ambiente Construído'. Este Departamento também oferece o 'Curso de Especialização em Sistemas Tecnológicos e Sustentabilidade Aplicados ao Ambiente Construído', aberto a profissionais que atuem (ou desejem atuar) na área da construção civil e que queiram se atualizar nos temas de inovação e sustentabilidade.

\section{f) Comentários:}

- Foi observada pouca integração na proposta pedagógica entre os cursos diurno e noturno, tanto em relação às disciplinas e atividades serem conduzidas por diferentes docentes em cada turno, como também, pelo período noturno apresentar limitações quanto à utilização de laboratórios e na realização de visitas técnicas;

- A criação da EA UFMG desvinculada dos modelos de ensino Belas Artes e Politécnico (embora tenha, reconhecidamente, seguido o modelo carioca da Escola Nacional), contribui para reflexão sobre o fato desta particularidade não ter influenciado, consideravelmente, no estabelecimento de estratégias inovadoras. De acordo com os relatos e evidências encontradas, a trajetória da área da Tecnologia foi

\footnotetext{
${ }^{123}$ Informações disponíveis em: http://pq.arq.ufmg.br/npgau/ e também em: http://www.arq.ufmg.br/macps/. Acesso em: 14 de outubro de 2016.
} 
permeada de dificuldades para sua sustentação e sobrevivência, exigindo dos professores desta área muito esforço, diante de entendimentos que a mesma deveria ser extinta do curso, principalmente após a invasão militar, a qual desestruturou tanto a infraestrutura desta escola como também de outras escolas pelo país;

- No texto de 2010 há uma crítica sobre o aumento da CH de disciplinas da área de exatas depois da Reforma curricular, mas a crítica parece ter sido fundamentada apenas no aumento do número maior de disciplinas, que antes da reforma eram anuais e atualmente são oferecidas semestralmente. A crítica poderia ter sido verificada quanto à sua validade se houvesse meios de analisar a Carga Horária e não o número de disciplinas;

- Foi relatado que, atualmente, está havendo maior dificuldade para a realização de visitas em obra, devido a três motivos: - Novas exigências em relação a questões de segurança em obra, sendo exigidos EPIs (cada aluno compra o seu kit composto por capacete e botas; os alunos deixam de visitar canteiros quando as condições locais também exigem, além de capacete e botas, o uso de óculos de proteção) e número restrito de alunos em cada visita. - Diminuição de obras sendo construídas, cenário provocado pela crise no setor da Construção Civil, havendo menor número de exemplos disponíveis para serem visitados. - Inexistência de seguro, pois a instituição oferece apenas seguro para deslocamento e não para a finalidade de visitas técnicas e atividades laboratoriais;

- Embora não seja oferecido estágio em obra a todos os alunos, os mesmos possuem diferentes possibilidades de participarem de projetos extensionistas em obra, dando a oportunidade de verem o que está sendo realizado no mercado naquele momento. Há relatos de que estas experiências tem dado resultados positivos e refletem diretamente no aproveitamento das aulas para aqueles que participam destes projetos;

- Em relação ao oferecimento de atividades de laboratório na disciplina de Materiais e Técnicas II, foi comentado que os alunos gostam muito destas práticas pedagógicas quando oferecidas. Sendo a infraestrutura utilizada pertencente ao curso da Engenharia Civil, e sua viabilização facilitada pelo fato do professor ministrante ter pertencido, anteriormente, ao quadro docente deste curso e realizado diversas pesquisas laboratoriais neste curso;

- Atualmente, o curso de Arquitetura e Urbanismo está estruturando um laboratório da área da Tecnologia da Construção, a partir da inserção de novos professores interessados e experientes em pesquisas desta natureza e não por iniciativa intrínseca, como intenção do próprio curso, como visto em seu Projeto Político Pedagógico;

- Foi observado o vivenciamento de um impasse quanto ao atual processo de montagem do novo Laboratório de Tecnologia, devido à pretendida mudança do curso de Arquitetura - cuja sede ainda permanece no centro da cidade - para o Campus da Pampulha. Esta situação não favorece a realização de grandes investimentos na infraestrutura física do atual prédio pois, provavelmente, será possível construir no Campus da Pampulha além do novo edifício, um novo laboratório para esta finalidade e também, ampliar a utilização compartilhada da infraestrutura do curso da Engenharia Civil. Esta mudança também é vista como positiva por promover maior interação dos alunos com os demais, de outros cursos, criando maior espírito universitário;

- Foi possível perceber diferentes pontos de vista em relação ao que seria uma infraestrutura laboratorial ideal para a arquitetura: de um lado, a defesa do laboratório voltado a ensaios e, do outro, o laboratório voltado à especificação de materiais e técnicas.

\section{5- CAU - UFPE - Curso de Arquitetura e Urbanismo da Universidade Federal de Pernambuco ${ }^{124}$}

\footnotetext{
${ }^{124}$ Dados obtidos entre os dias 15 e 17/06/2016, em visita técnica à Faculdade de Arquitetura e Urbanismo da Universidade Federal de Pernambuco, com entrevistas direcionadas aos professores que ministram ou já ministraram disciplinas da cadeia de Tectônica: prof. Me. Sérgio Bittencourt, profa. Dra. Maria Luíza de Freitas e prof. Dr. Roberto A. Dantas Araújo, com visita às instalações existentes.
} 


\section{a) Breve Histórico ${ }^{125}$}

Em 1932, o ensino de Arquitetura e Urbanismo começa de forma oficial com a fundação da Escola de Belas Artes de Pernambuco (EBAP), uma organização particular. O curso ministrado na EBAP é reconhecido como superior em 1945, com a possibilidade de expedir diploma válido em todo Brasil e oferecer os cursos de Arquitetura, com duração de seis anos; de Pintura, Escultura e Gravura, com duração de quatro anos; e Cursos Livres de várias disciplinas. Porém, no ano de 1949 começam os movimentos separatistas dentro da Escola de Belas Artes com o objetivo de criar uma faculdade de arquitetura autônoma. Essa separação se concretizou em abril de 1958, mas o funcionamento efetivo da Faculdade de Arquitetura do Recife teve início em 1959, quando se instalou no Seminário de Olinda, por um curto período de tempo, sendo transferinda para um edifício próprio em 1960.

Com a reforma universitária de 1969, a Faculdade de Arquitetura passou a ser o Departamento de Arquitetura e Urbanismo (DAU) pertencente à UFPE. Em 1973, o Departamento se muda para o campus, funcionando no Instituto de Cursos Básicos, sendo transferido definitivamente para o Centro de Artes e Comunicação (CAC) em 1976 (Figura 67).

Já tendo passado por 16 estruturas curriculares (em 1933, 1955, 1958, 1960, 1961, 1963, 1965, 1967, 1968, 1969; 1970, 1972, 1978, 10 semestre de 1986, 20 semestre de 1986 e 1995), outro ajuste se fez necessário. $\mathrm{O}$ atual Projeto Político Pedagógico consolida os trabalhos realizados pelo Colegiado do Curso de Arquitetura e Urbanismo, entre maio de 2001 e junho de 2010.
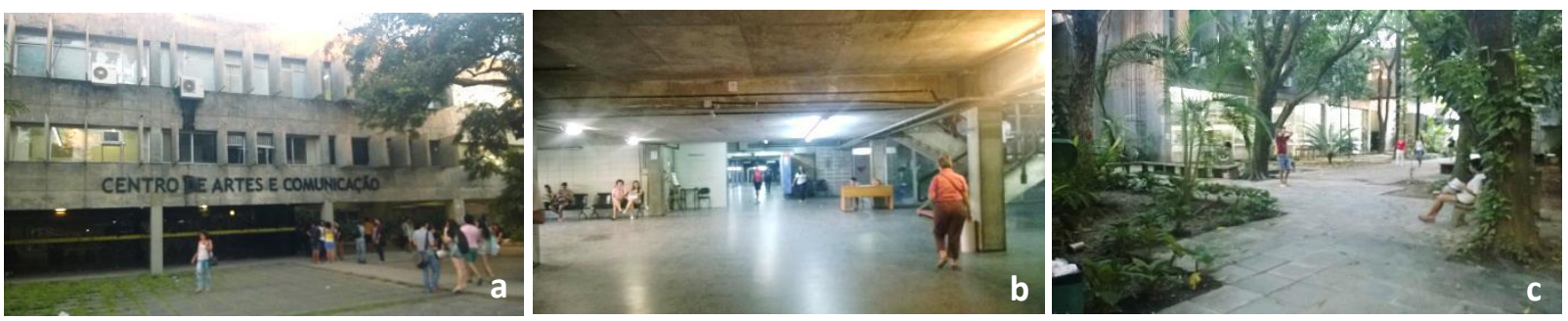

Figura 67 - Imagens do Centro de Artes e Comunicação - CAC - dentre os cursos sediados neste edifício está o curso de Arquitetura e Urbanismo. a) Entrada principal. b) Saguão coberto para circulação entre os diferentes blocos. c) Pátio interno.

Fonte: Fotos da autora.

\section{b) Considerações sobre a Estruturação da área da Tecnologia da Construção}

Atualmente, o CAU oferece 100 vagas por ano voltadas à graduação, divididas em dois ingressos semestrais. De acordo com o PPP de curso de 2010, a estrutura geral se organiza em três blocos de formação. Estes blocos de formação atendem a uma estrutura de organização em torno dos níveis de aquisição de conhecimento e habilidades a serem alcançados, tendo início pelo bloco Capo, seguido pelo Segno, e culminando no Coda, quando se confere a habilitação profissional. Essa última fase deve representar a síntese dos conhecimentos e habilidades adquiridas pelo aluno ${ }^{126}$. De acordo com a Figura 68, o curso tem eixos estruturadores nos temas: 1) Requalificação; 2) Renovação; 3) Urbanização; 4) Conservação. Em função dos Temas, são propostas: 1) Matérias de Integração (vermelhas); 2) Matérias de Instrumentais (azuis); 3) Matérias conceituais (verdes). Do mesmo modo, aproximando-se do Núcleo Temático estão os Conteúdos Obrigatórios de Integração (vermelho); e

\footnotetext{
125 Dados obtidos a partir do Projeto Político Pedagógico de curso de 2010 e também, por meio do endereço eletrônico: https://www.ufpe.br/cac/index.php?option=com_content\&view=article\&id=206\&ltemid=190. Acesso em: 02/06/2016.

${ }^{126}$ De acordo com o Projeto Político Pedagógico de curso de 2010, nestas fases há outros detalhes complementares: Capo Esta primeira fase tem por objetivo oferecer ao aluno recém-ingressado no curso os instrumentos fundamentais para conhecer seu objeto de estudo. O tema central do bloco é a requalificação, ou seja, as ações propositivas fundamentadas na atualização do ambiente construído às demandas contemporâneas. Segno - É organizado em blocos de formação, definidos de acordo com o nível de habilitação e responsabilidade estabelecido pela natureza e integração entre os diversos problemas de Arquitetura e Urbanismo. Esse bloco contempla a parte central da formação do aluno e observa os temas de renovação, urbanização e conservação. Coda - É composto pelo Estágio Curricular e do Trabalho de Curso (TC) entendido como componente curricular de preparação da monografia e, portanto, não se caracteriza como disciplina. Tem por objetivo conferir, através de procedimentos e avaliação estabelecidos pelas Diretrizes Curriculares, o grau de arquiteto e urbanista. Cada uma delas são disciplinas curtas de 15h, dada em 3 dias seguidos, geralmente na 1a semana do semestre letivo.
} 
sucessivamente: os conteúdos obrigatórios instrumentais e conceituais (laranja); conteúdos seletivos instrumentais e conceituais (amarelo). Todas as disciplinas devem estar focadas nestes temas.

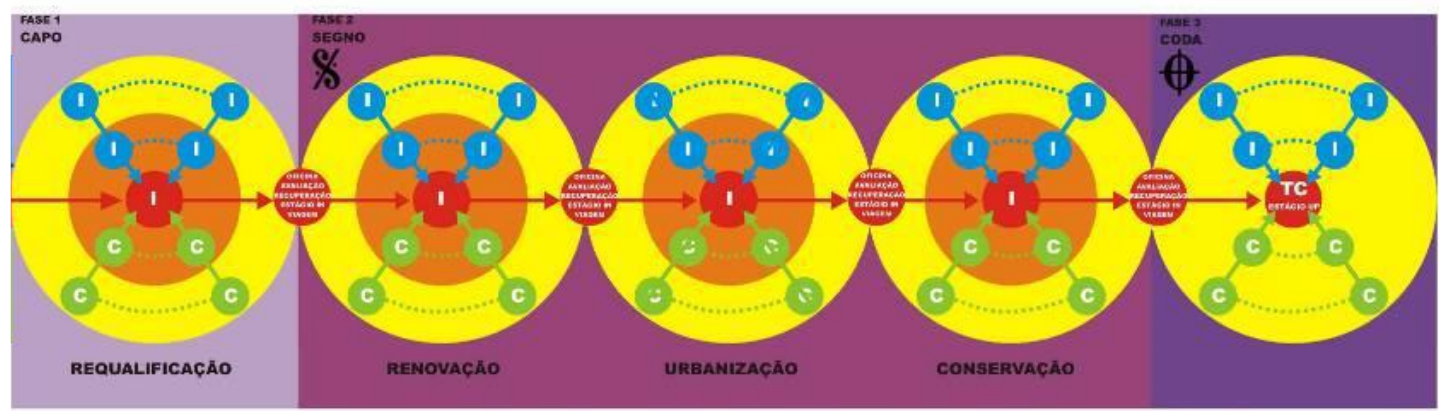

EIXO ESTRUTURADOR DO CURSO = PROJETO DE ARQUITETURA, URBANISMO E PAISAGISMO.

LEGENDA:

II = MATÉRIAS DE INTEGRAÇÃO = MATÉRIAS INSTRUMENTAIS C $=$ MATERIAS CONCEITUAIS

= CONTEÚDOS OBRIGATÓRIOS DE INTEGRAÇĀO - CONTEUDOS OBRIGATORIOS INSTRUMENTAIS E CONCEITUAIS = CONTEÚDOS ELETIVOS INSTRUMENTAIS E CONCEITUAIS

Figura 68 - Estrutura Pedagógica do CAU/UFPE: Fases anuais de formação e linhas de atuação.

Fonte: Projeto Político Pedagógico de Curso - 2010.

Esta estrutura geral proposta para o currículo também se repete a cada semestre letivo, dividido nas três fases, Capo, Segno e Coda, cada uma delas formada por conteúdos e práticas pedagógicas adequadas às fases de formação do aluno. A Capo introduz o conteúdo a ser tratado no semestre letivo em formato de simpósio. As matérias do semestre são reunidas de forma apropriadas e ministradas em formato de disciplinas eixo, satélite e optativas. O Coda encerra o semestre letivo com a apresentação e discussão da produção do curso e é composta por atividades, tais como simpósio, exposição de trabalhos e oficinas.

Deve-se ressaltar que a Capo das fases Segno e Coda se resumem à reunião entre os docentes e discentes do período, em evento solene de abertura do semestre letivo, quando serão discutidas as práticas pedagógicas que serão desenvolvidas no semestre em questão.

Quadro 15 - Distribuição da Grade Curricular com a carga horária semestral - FAU UFPE:

\begin{tabular}{|c|c|c|c|c|c|c|c|c|c|}
\hline 10 sem & 20 sem & 3ㅇ sem & 40 sem & 5o sem & 60 sem & 70 sem & 8 sem & 9o sem & $10 \circ$ sem \\
\hline $\begin{array}{c}\text { Proj. Arq., } \\
\text { Urb., Paisag. } 1 \\
\text { (3C) }\end{array}$ & $\begin{array}{l}\text { Proj. Arq. , } \\
\text { Urb. } \\
\text { Paisag. } 2 \text { (3C) }\end{array}$ & $\begin{array}{c}\text { Proj. Arq., } \\
\text { Urb., Paisag. } 3 \\
\text { (3C) }\end{array}$ & $\begin{array}{c}\text { Proj. Arq., } \\
\text { Urb., Paisag. } 4 \\
\text { (3C) }\end{array}$ & \begin{tabular}{|c|} 
Proj. Arq, \\
Urb, Paisag. \\
$5(3 C)$ \\
\end{tabular} & \begin{tabular}{|c|} 
Proj. \\
Arq.,Urb., \\
Paisag. $6(3 \mathrm{C})$ \\
\end{tabular} & $\begin{array}{c}\text { Proj. Arq, } \\
\text { Urb, Paisag. } \\
7(3 C)\end{array}$ & \begin{tabular}{|c|} 
Proj. Arq, \\
Ur, Paisag. \\
$8(3 C)$ \\
\end{tabular} & $\begin{array}{c}\text { Trabalho de } \\
\text { curso } 1\end{array}$ & $\begin{array}{l}\text { Trabalho } \\
\text { de curso } 2\end{array}$ \\
\hline $\begin{array}{c}\text { Capo arq., } \\
\text { Urb. e paisag. } \\
1(1 \mathrm{C})\end{array}$ & $\begin{array}{c}\text { Segno } \\
\text { Arq., urb. } \\
\text { Paisag. } 2 \text { (1C) }\end{array}$ & $\begin{array}{c}\text { Capo arq., } \\
\text { Urb. e paisag. } \\
2(1 \mathrm{C})\end{array}$ & $\begin{array}{c}\text { Segno } \\
\text { Arq., urb. } \\
\text { Paisag. } 4 \text { (1C) }\end{array}$ & $\begin{array}{l}\text { Capo arq., } \\
\text { Urb. e } \\
\text { paisag. } 3 \\
(1 \mathrm{C})\end{array}$ & $\begin{array}{c}\text { Segno } \\
\text { Arq., urb. } \\
\text { Paisag. } 6(1 \mathrm{C})\end{array}$ & $\begin{array}{l}\text { Capo arq., } \\
\text { Urb. e } \\
\text { paisag. } 4 \\
\text { (1C) }\end{array}$ & $\begin{array}{l}\text { Segno } \\
\text { Arq., urb. } \\
\text { Paisag. } 8 \\
\text { (1C) }\end{array}$ & $\begin{array}{l}\text { Capo arq., } \\
\text { Urb. e } \\
\text { paisag. } 5 \\
\text { (1C) }\end{array}$ & $\begin{array}{l}\text { Segno } \\
\text { Arq., urb. } \\
\text { Pais. } 10 \\
\text { (1C) }\end{array}$ \\
\hline $\begin{array}{c}\text { Segno } \\
\text { Arq.,Urb. e } \\
\text { Paisag. } 1(1 \mathrm{C})\end{array}$ & $\begin{array}{c}\text { Coda Arq., urb. } \\
\text { Paisag. } 2(1 \mathrm{C})\end{array}$ & $\begin{array}{l}\text { Segno Arq., } \\
\text { urb. } \\
\text { Paisag. } 3 \text { (1C) }\end{array}$ & $\begin{array}{c}\text { Coda Arq., } \\
\text { urb. } \\
\text { Paisag. } 4(1 \mathrm{C})\end{array}$ & $\begin{array}{c}\text { Segno Arq., } \\
\text { urb. Pa. } 5 \\
\text { (1C) }\end{array}$ & $\begin{array}{c}\text { Coda Arq., } \\
\text { urb. } \\
\text { Paisag. } 6(1 \mathrm{C})\end{array}$ & $\begin{array}{c}\text { Segno Arq., } \\
\text { urb. Pa. } 7 \\
\text { (1C) }\end{array}$ & $\begin{array}{c}\text { Coda Ar, } \\
\text { Urb Pa. } 8 \\
\text { (1C) }\end{array}$ & $\begin{array}{c}\text { Segno Arq., } \\
\text { urb. Pa.9 } \\
\text { (1C) }\end{array}$ & \\
\hline $\begin{array}{c}\text { Coda Arq., } \\
\text { Urb. e paisag. } \\
1(1 \mathrm{C})\end{array}$ & $\begin{array}{c}\text { Planej. Urb. } \\
\text { Regional } 1(1 \mathrm{C})\end{array}$ & $\begin{array}{c}\text { Coda } \\
\text { Arq., urb. } \\
\text { Paisag. } 3(1 \mathrm{C})\end{array}$ & $\begin{array}{c}\text { Planej. Urb. } \\
\text { Regional } 2 \text { (1C) }\end{array}$ & $\begin{array}{l}\text { Coda Arq. } \\
\text { urb.Paisag. } 5 \\
\text { (1C) }\end{array}$ & $\begin{array}{l}\text { Planej. Urb. } \\
\text { Regional } 3 \\
\text { (1C) }\end{array}$ & $\begin{array}{c}\text { Coda } \\
\text { Arq., urb. } \\
\text { Paisag. } 7(1 \mathrm{C})\end{array}$ & $\begin{array}{c}\text { Planej. Urb. } \\
\text { Regional } 4 \\
\text { (1C) }\end{array}$ & $\begin{array}{c}\text { Coda } \\
\text { Arq., urb. } \\
\text { Paisag. } 9 \\
\text { (1C) }\end{array}$ & \\
\hline $\begin{array}{l}\text { Estudos socio- } \\
\text { econ. amb. } 1 \\
\text { (1C) }\end{array}$ & $\begin{array}{c}\text { História } \\
\text { Arq., urb. } \\
\text { Paisag. } 2 \text { (1C) }\end{array}$ & $\begin{array}{l}\text { Estudos socio- } \\
\text { econ. amb. } 2 \\
\text { (1C) }\end{array}$ & $\begin{array}{c}\text { História } \\
\text { Arq., urb. } \\
\text { Paisag. } 4 \text { (2C) }\end{array}$ & $\begin{array}{c}\text { Estudos } \\
\text { socio- econ. } \\
\text { amb. } 3(1 \mathrm{C})\end{array}$ & $\begin{array}{c}\text { História } \\
\text { Arq., urb. } \\
\text { Paisag. } 6 \text { (1C) }\end{array}$ & $\begin{array}{c}\text { Estudos } \\
\text { socio- econ. } \\
\text { amb. } 3(1 \mathrm{C})\end{array}$ & $\begin{array}{c}\text { Hist.Arq., } \\
\text { urb.Paisag. } \\
8(2 \mathrm{C})\end{array}$ & Curtagio & \\
\hline $\begin{array}{c}\text { Arquitetura } \\
\text { Analítica (1C) }\end{array}$ & $\begin{array}{l}\text { Teoria da } \\
\text { Arq., Urb. } \\
\text { Paisag. } 2 \text { (1C) }\end{array}$ & $\begin{array}{c}\text { Métodos } \\
\text { Técn. Pesq. } \\
\text { Arq., urb. } \\
\text { paisag. } 2 \text { (1C) }\end{array}$ & $\begin{array}{c}\text { Teoria da } \\
\text { Arq., Urb. } \\
\text { Paisag. } 4 \text { (1C) }\end{array}$ & $\begin{array}{l}\text { Mét.Técn. } \\
\text { Pesq.Arq., } \\
\text { urb. paisag. } \\
3(1 \mathrm{C})\end{array}$ & $\begin{array}{c}\text { Teoria da } \\
\text { Arq., Urb. } \\
\text { Paisag. } 6 \text { (1C) }\end{array}$ & $\begin{array}{l}\text { Mét.Técn. } \\
\text { Pesq.Arq., } \\
\text { urb. paisag. } \\
4(1 \mathrm{C}) \\
\end{array}$ & $\begin{array}{c}\text { Historia } \\
\text { Artes plast. } \\
(2 \mathrm{C})\end{array}$ & & \\
\hline $\begin{array}{c}\text { Met. Técn. } \\
\text { pesquisa } \\
\text { Arq., urb. } \\
\text { paisag. } 1 \text { (1C) }\end{array}$ & $\begin{array}{c}\text { Geometria } \\
\text { Gráfica } 3 d 2 \\
(1 \mathrm{~d})\end{array}$ & $\begin{array}{c}\text { História } \\
\text { Arq., urb. } \\
\text { Paisag. } 3 \text { (1C) }\end{array}$ & $\begin{array}{c}\text { Cadastro } \\
\text { Multifinalitár. } \\
\text { (1C) }\end{array}$ & $\begin{array}{l}\text { História } \\
\text { Arq., urb. } \\
\text { Paisag. } 5 \\
\text { (2C) }\end{array}$ & $\begin{array}{l}\text { Empreended. } \\
(2 \mathrm{C})\end{array}$ & $\begin{array}{l}\text { História } \\
\text { Arq., urb. } \\
\text { Paisag. } 7 \\
\text { (2C) }\end{array}$ & $\begin{array}{c}\text { Teoria da } \\
\text { Arq., Urb. } \\
\text { Paisag. } 8 \\
\text { (1C) }\end{array}$ & & \\
\hline História & Conforto & Teoria da & Ergonomia & Teoria da & Acessibilidade & Teoria da & Estetica & & \\
\hline
\end{tabular}




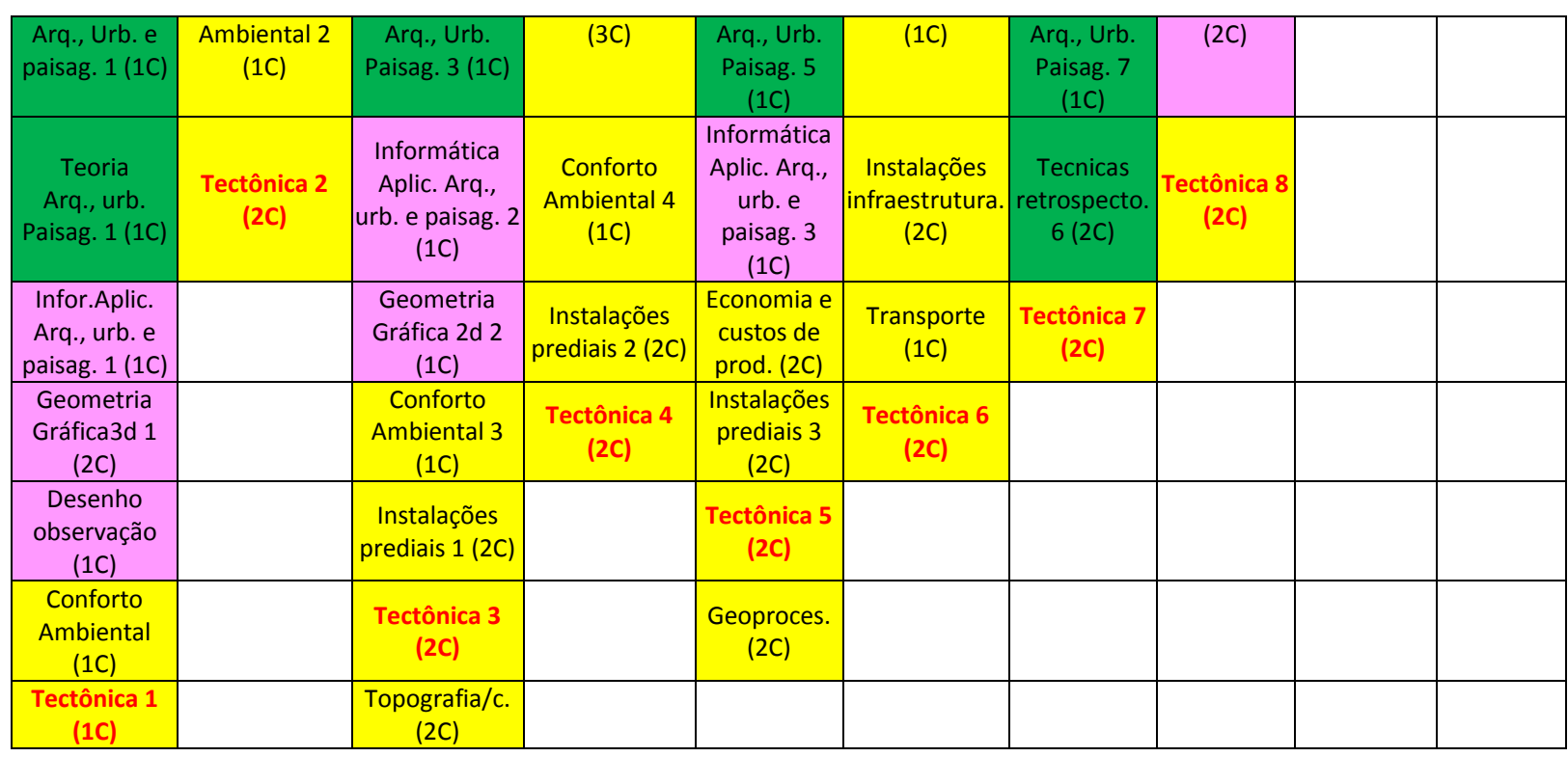

Disciplinas de Projeto

Disciplinas de Representação Gráfica e comp.

Disciplinas de Urbanismo e Meio Ambiente

Disciplinas na área da Tecnologia da Arquitetura

Sobre algumas disciplinas da área da Tecnologia, foi observada a fusão entre as disciplinas de Sistemas estruturais e Tecnologia da Construção (materiais e técnicas construtivas) a partir da última reformulação pedagógica quando estas disciplinas passaram a ser intituladas de Tectônica, da I à VIII.

De acordo com os dados divulgados no PPP, os créditos obtidos em cada disciplina não correspondem diretamente à Carga Horária (C.H.) destinada às disciplinas - seguindo um modelo diferenciado no processo de cálculo, sendo assim, há disciplinas que possuem maior C.H., mas recebem um número menor em créditos. Por exemplo, quando analisado o número de créditos obtidos com as disciplinas da cadeia da Tectônica, chega-se ao valor de $11 \%$ dos créditos totais das disciplinas obrigatórias (sem computar o Estágio Supervisionado, Optativas e o Trabalho de Curso 1 e 2), quando analisada a carga horária destinada a estas disciplinas, as mesmas ocupam $9 \%$ da C.H. total. Já no caso das disciplinas de Projeto Arquitetônico, Urbanístico e Paisagístico, recebem 15,5\% dos créditos mas estas disciplinas ocupam 23,5 da C.H. total, o inverso da cadeia de Tectônica. Este sistema dificulta adotar a sistematização padrão utilizado nas demais escolas, assim como, mensurar o espaço da área da Tecnologia da Construção devido a sua fusão com a cadeia de Sistemas Estruturais e pela rotatividade de conteúdos.

\section{c) Quadro docente}

O quadro docente é formado por professores dos Departamentos de Arquitetura e Urbanismo, Engenharia Civil, Cartografia, Expressão Gráfica e Teoria da Arte e Ciência da Informação. Em relação às disciplinas da área da Tecnologia da Arquitetura, são ministradas tanto por professores arquitetos como engenheiros, e as da cadeia da Tectônica, da I à VIII, são quase integralmente ministradas por professores arquitetos pertencentes ao Departamento de Arquitetura e Urbanismo. Há a colaboração de apenas 01 professor do Departamento da Engenharia Civil em alguns semestres.

\section{d) Práticas didáticas e Infraestrutura laboratorial}

Antes da reformulação promovida pelo Projeto Político Pedagógico (PPP) de 2010, as disciplinas da área da Tecnologia da Arquitetura (com exceção de Instalações prediais) eram ministradas pelo curso 
da Engenharia Civil. A partir do novo PPP foi implantada uma nova proposta para as disciplinas da área de Tecnologia da Construção e Sistemas Estruturais, ao fundi-las nas disciplinas chamadas Tectônica ${ }^{127}$.

Nesta reestruturação foram criadas oito disciplinas oferecidas entre o 10 e o 8 o períodos, com indicação que fossem ministradas por professores arquitetos e pertencentes ao quadro docente do Departamento da Arquitetura, resumidamente, esta proposta contemplava:

- Tectônica I - Conceituação dos fenômenos físicos que atuam nos sistemas estruturais;

- Tectônica II - Análise dos sistemas estruturais básicos, de acordo com a geometria e dos materiais de construção;

- Tectônica III - Associação de sistemas estruturais básicos - edificações horizontais;

- Tectônica IV - Associação de sistemas estruturais básicos - edificações verticais;

- Tectônica V - A lógica e a estética da pré-fabricação - edificações;

- Tectônica VI - A lógica e a estética da pré-fabricação - equipamentos e mobiliário urbano;

- Tectônica VII - Recuperação de edificações históricas - novas edificações em sítios históricas;

- Tectônica VIII - Recuperação de edificações históricas - novas edificações em sítios históricas;

Atualmente, vigora uma nova organização dos conteúdos, motivada pela identificação que a abordagem inicialmente proposta era voltada, predominantemente, para a área de estruturas em detrimento aos conteúdos relativos a materiais e técnicas construtivas, desta forma, a nova organização de conteúdos e estratégias pedagógicas informadas na data da visita técnica são:

- Tectônica I - Introdutória - comportamento das estruturas e esforços básicos;

- Tectônica II - Sistemas estruturais - tipologias estruturais, esforços e tensões a que cada um deles é submetido (arco, cabo, casca, placa, etc.). Nesta disciplina os alunos confeccionam vários modelos, de acordo com os tipologias e esforços físicos estudados;

- Tectônica III - Alvenaria - estrutural, não estrutural, armada e também sistemas horizontais, verticais e cobertas. Eventualmente, são confeccionados elementos de blocos com diferentes materiais, como adobe e solo-cimento;

- Tectônica IV - Concreto - Devido a rotatividade de professores nesta disciplina, não foi possível identificar precisamente as práticas pedagógicas aplicadas, sendo sinalizada a realização de eventuais visitas a obras e ao laboratório de materiais pertencente ao curso da Engenharia Civil, para acompanhamento visual de amostragens e ensaios;

- Tectônica V - Construções Metálicas - aulas teóricas associadas à prática, explorando os sistemas construtivos em associação ao projeto arquitetônico (não são abordadas questões sobre dimensionamento e cálculo), com exercícios de projeto chegando à fase de detalhamento;

- Tectônica VI - Argamassa armada e Sistema steel frame - este assunto tem sido abordado, recorrentemente, com o apoio de atividades práticas, como a confecção de placas (de pequenas dimensões) ou, eventualmente, protótipos na forma de mobiliário urbano, com a participação dos alunos. Ao longo dos anos, outras estratégias foram adotadas, como visitas técnicas a empresas de pré-fabricados;

- Tectônica VII - Madeira - o material é abordado de forma a dar respaldo à próxima disciplina na área do restauro. Ainda em Tectônica 7 são confeccionados diversos modelos de tesoura em madeira e estudados assuntos referentes a técnicas diferenciadas como a MLC (madeira laminada colada);

- Tectônica VIII - Restauro - princípios de intervenção em sítios, materiais construtivos tradicionais (cal, areia, terra, etc.), prospecção tradicional e por instrumentos, recuperação de elementos e estruturas históricas. Como estratégia pedagógica são realizadas aulas teóricas e trabalhos a partir de visitas em obra tanto em grupo como em equipe.

\footnotetext{
127 De acordo com relatos, esta proposta foi uma tentativa de incorporar os dados estruturais e tecnológicos dentro das decisões de projeto, conceituação de projeto e não esperar que os alunos raciocinem dentro das cadeiras de cálculo, por ser uma instância à posteriori, possibilitando o exercício da concepção estrutural e formal. O termo Tectônica foi uma tentativa de usar um termo que estudasse a questão da estrutura, do material e do canteiro e que o princípio construtivo ficasse mais claro no processo de concepção do projeto. Fonte: Dados obtidos em entrevista realizada no dia 18/07/2016 à profa. Anália M. Marinho de C. Amorim - profa. da Escola das Cidades e na FAUUSP - uma das responsáveis pela proposta de reestruturação das disciplinas de Tecnologia e na proposição do termo Tectônica.
} 
Em relação aos espaços laboratoriais, as aulas da cadeia da Tectônica são ministradas em um local chamado Laboratório e Canteiro de Tectônica. Trata-se de um espaço adaptado, concebido inicialmente para atender aos Ateliers de Plástica - neste local eram realizados exercícios compositivos em argila, maquetes volumétricas, dentre outros - estas disciplinas foram retiradas após ser implantado o currículo novo. Trata-se de um espaço de $14 \times 14 \mathrm{~m}$, provido de bancadas junto à parede, cubas com pontos de água e depósito, sendo atualmente dividido em duas salas de 7x14m, interligadas uma à outra mas sem acesso direto à área externa. Nestes espaços são ministradas tanto aulas teóricas como a execução de modelos reduzidos e elementos de pequeno porte (placas em argamassa armada, por exemplo).

Para a realização de atividades em escalas maiores há a possibilidade de utilização de um espaço externo, atrás do prédio onde ocorrem as aulas de Tectônica, cuja cobertura é um beiral prolongado, trata-se de um espaço improvisado e não formalizado como canteiro, mas que apresenta condições de uso para esta finalidade, quando disponível pela administração. Embora próxima, a infraestrutura laboratorial do curso de Engenharia Civil não é utilizada nestas disciplinas, com raras exceções realizadas por meio de alguma iniciativa docente, mas com caráter de visita técnica. Não há o auxílio de técnicos nestas atividades, ficando a cargo do docente a total condução destas práticas junto com os alunos.
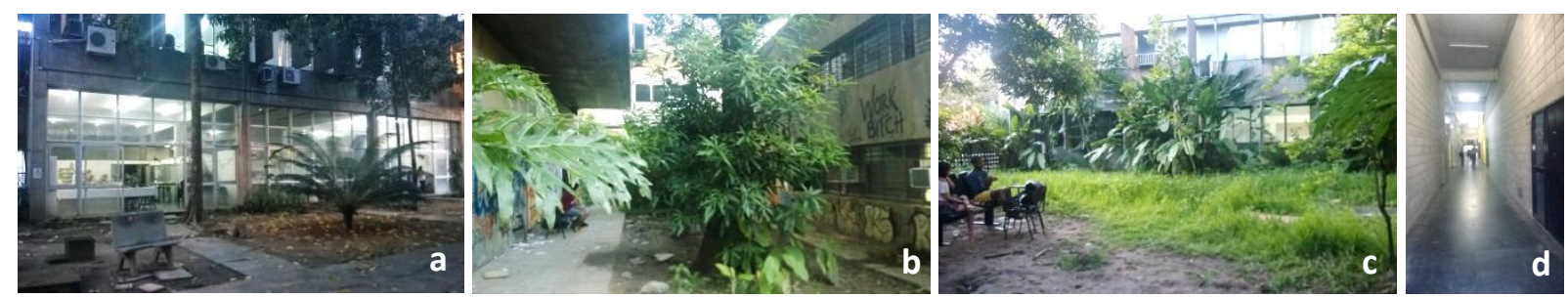

Figura 69 - Imagens de algumas áreas possíveis de uso para a realização de atividades práticas. a) Marcenaria, hoje utilizada pelo curso de Design. b) Beiral junto ao edifício onde ocorrem as disciplinas de Tectônica e utilizado eventualmente como canteiro experimental. c) Espaço externo junto ao Canteiro Experimental. d) Acesso ao espaço utilizado nas aulas de Tectônica chamado 'Laboratório e Canteiro de Tectônica'.

Fonte: fotos da autora.

\section{e) Pós graduação: ${ }^{128}$}

O primeiro curso de pós-graduação do Departamento foi o Mestrado em 'Desenvolvimento Urbano e Regional (MDU)', que começou a funcionar no ano de 1974, enquanto o Doutorado foi implantado em 1998. Atualmente, o MDU oferece três linhas de pesquisa:

1 - Planejamento e Gestão Urbana;

2 - Projeto da Cidade e do Edifício;

3 - Conservação Integrada.

Abordam de modo integrado os dois campos disciplinares: Arquitetura e Urbanismo e Planejamento e Gestão, constituindo-se a principal característica do MDU/UFPE. A interdisciplinaridade constitui-se, portanto, em um diferencial do MDU/UFPE. Os docentes não estão inseridos exclusivamente em uma linha de pesquisa e os alunos podem cursar as disciplinas oferecidas pelas três linhas de pesquisa, construindo seus percursos, de modo a melhor compreender o seu objeto de pesquisa.

Não foi observado o oferecimento de linhas de pesquisa voltadas à Tecnologia da Construção ou com interface à área técnica, portanto, alunos interessados devem procurar outros cursos ou programas de pós-graduação.

\section{f) Comentários:}

${ }^{128}$ Dados disponíveis em: https://www.ufpe.br/mdu/. Acesso em 02/06/2016. 
- Há o reconhecimento no Projeto Político Pedagógico sobre a importância da área laboratorial técnicoconstrutiva e sua ausência no curso, sendo diversas propostas reestruturantes encaminhadas neste sentido, mas ainda encontram-se no plano abstrato do discurso pedagógico;

- Algumas disciplinas eletivas oferecidas possuem em sua abordagem um viés técnico sobre os materiais e processos executivos, como a de 'Detalhamento Arquitetônico', complementando o processo de aprendizagem sobre a materialidade, mas não utiliza atividades experimentais como processo metodológico;

- Foi observado que ainda há entre professores algumas dúvidas e diferentes interpretações sobre o que seria a Tectônica, de como deveria ser ensinada e o que ensinar (após a reestruturação, as disciplinas passaram por contínuas adaptações de conteúdos e rotatividade de professores). Inicialmente, foi dada maior ênfase ao conteúdo sobre os sistemas estruturais e depois, a partir do entendimento de que a materialização da arquitetura também deveria abordar proporcionalmente outras questões, passou-se a dar um espaço maior aos materiais e técnicas construtivas. Atualmente, percebe-se a dificuldade pedagógica em abordar, simultaneamente, os conteúdos referentes a estruturas, materiais e técnicas construtivas, tratando-se de uma experiência isolada de transformação, mas que requer melhor avaliação;

- Devido ao espaço utilizado pelas disciplinas de Tectônica ser um local adaptado para esta finalidade, foram observadas algumas dificuldades em sua utilização, como o transporte de materiais, pela inexistência de acesso direto à área externa. Em relação ao espaço externo identificado como canteiro, não está disponível aos professores de forma efetiva (local muitas vezes utilizado como depósito) dificultando o planejamento para a implantação sistemática de práticas laboratoriais em diferentes escalas;

- Não foram observadas parcerias com o curso de Engenharia Civil para o uso compartilhado de infraestrutura, com a justificativa de que os laboratórios deste curso teriam cunho muito científico e que sua configuração não atenderia às práticas voltadas ao curso da Arquitetura;

- Foi observado bastante esforço por parte dos docentes para que, ao longo dos anos, fossem realizadas atividades práticas, as quais foram em sua maioria executadas com recursos vindos dos próprios docentes envolvidos e complementados com recursos dos alunos. A dificuldade financeira juntamente à falta de técnicos, espaço físico, apoio administrativo e baixa carga horária têm causado alguns impasses internos sobre a sustentação dessas atividades.

\section{6- FAUUSP - USP - Faculdade de Arquitetura e Urbanismo da Universidade de São Paulo ${ }^{129}$}

\section{a) Breve Histórico ${ }^{130}$}

De acordo com o Projeto Político Pedagógico de curso, de 2013, a Faculdade de Arquitetura e Urbanismo da Universidade de São Paulo foi fundada em 1948, em meio ao movimento de criação de escolas autônomas de arquitetura no Brasil no período pós-guerra, sendo constituída a partir do antigo curso de graduação de engenheiros-arquitetos da Escola Politécnica da USP. A matriz politécnica, todavia, conviveu ao longo de toda a primeira década de existência da FAUUSP com o modelo pedagógico das Belas Artes, tratava-se de uma combinação entre formação científica e aplicação técnica com disciplinas tradicionais.

Em 1962 foi promovida uma reforma de ensino pelo primeiro diretor não politécnico da FAUUSP, professor Lourival Gomes Machado, da Faculdade de Filosofia, Ciências e Letras da USP. Em um período de expansão do curso, com o aumento do número de vagas, as modificações então introduzidas visavam flexibilizar a estrutura curricular herdada da Politécnica e estabelecer

\footnotetext{
${ }^{129}$ Entrevistas direcionadas aos coordenadores do LAME (Laboratório de Modelos e Ensaios), prof. Artur Rozestraten e do Canteiro Experimental, prof. Reginaldo Ronconi (este, também professor das disciplinas de Construção do Edifício I e II), ambas realizadas no dia 30/06/2016. Outras entrevistas foram realizadas junto aos principais professores das disciplinas de Construção do Edifício III e IV, profa Fabiana Oliveira, no dia 10/06/2016 e profa. Cláudia de Andrade Oliveira no dia 09/09/2016.

130 Síntese do histórico publicado no PPP do curso de 2013. Disponível em: http://www.cg.fau.usp.br/Documentos/02__projeto_politico_pedagogico-ppp_out_revisado_fev_2014_.pdf. Acesso em: 05/08/2016.
} 
metodologias de ensino mais integradas. O compromisso prático e político do projeto com as questões nacionais propunha deslocar o caráter teórico, fragmentário ou excessivamente formalista do ensino em direção às novas coordenadas sociais, técnicas e espaciais, e mesmo territoriais do processo de modernização. Na reforma curricular deste período, destacaram-se docentes como João Batista Vilanova Artigas, Carlos Milan, Lourival Gomes Machado, dentre outros, estabelecendo-se os fundamentos da estrutura de ensino que, posteriormente, viria a formar os três atuais departamentos da FAU: Projeto História da Arquitetura e Estética do Projeto e Tecnologia da Arquitetura.

No período compreendido entre 1950 e 1969, o curso de graduação funcionou no edifício "Vila Penteado", doado à Universidade de São Paulo no final da década de 1930. A partir de 1971, este local passou a abrigar os trabalhos preparativos para fundação do curso de pós-graduação, fato que ocorreu em 1972. Em 1969 o curso de graduação passou a funcionar na Cidade Universitária, ainda neste período, em 1968, confirmou-se a divisão da escola em departamentos e as reestruturações realizadas dirigiam-se em grande medida às estabelecidas pela Reforma Universitária nacional.

Com a inauguração do novo edifício da FAUUSP na Cidade Universitária (Figura 70) - projeto do arquiteto e professor João Batista Vilanova Artigas - o curso não apenas passou a receber um maior número de alunos, como também passou a ter visibilidade a nova moldura institucional e a estrutura curricular reformada ${ }^{131}$. Neste período, assim como ocorreu em outros cursos pelo país, a FAUUSP também sofreu frente às ações do regime militar, com a interrupção de projetos institucionais e a cassação de docentes e discentes.

Com o passar dos anos, à medida que a pesquisa e a pós-graduação foram se consolidando, difundiram-se modelos de formação alternativos e uma nova geração de professores pesquisadores emergiu no interior da escola, promovendo constantes renovações influenciadas por outros campos disciplinares. Diversos laboratórios de pesquisa se estruturaram a partir da década de 1990, aproximando pesquisas e experiências até então desenvolvidas individualmente, estabelecendo grupos de projetos e pesquisadores.

Segundo o PPP de curso, a criação do curso de Design, em 2006, foi um processo de enorme relevância para o curso de Arquitetura e Urbanismo, que não abriu mão de sua formação abrangente em prol de um caminho de especializações e sim reiterou sua vocação humanista.

Os atuais Departamentos ${ }^{132}$ foram ao longo dos anos agregando outras áreas correlatas. São eles:

- Departamento de Projeto (AUP);

- Departamento de História da Arquitetura e Estética do Projeto (AUH);

- Departamento de Tecnologia (AUT).


Figura 70 - Imagens externas e interna FAUUSP.

Fonte: fotos da autora

\footnotetext{
${ }^{131}$ Foram encontrados relatos deste período em um dos documentos referente à construção do prédio da FAUUSP na cidade Universitária, em que o diretor em exercício naquele momento argumenta junto ao Exmo. Reitor diversas questões que estava levando, na opinião dele, a um retrocesso e a degenerescência do curso devido, dentre várias questões apontadas: 'não atinge as suas melhores finalidades porque se desvia a todo momento do campo da construção para o campo da Arte e de outras culturas ou semi-culturas paralelas'. Fonte: Of.GD/442 - PMAC/rhps, item e, p. 9. 1966. O conteúdo da carta enviada ao Exmo. Reitor, sugere que um dos motivos na inclinação do curso para a área das artes seria a infraestrutura física, solicitando por meio deste documento a liberação de verba para que o edifício fosse construído o mais rápido possível.

${ }^{132}$ De acordo com o documento Of. GD/720 - A - RMGP/rhps, de 1968, os Departamentos existentes à época da mudança do curso para a Cidade Universitária eram 04: Departamento de Projeto, Departamento de Ciências, Departamento de Construção e Departamento de História.
} 


\section{b) Considerações sobre a Estruturação da área da Tecnologia da Construção}

O número de vagas oferecidas na FAU se manteve desde 1970 em 150 alunos por ano e a maior parte das disciplinas são oferecidas pelos três departamentos que constituem o curso: Projeto, História e Tecnologia, contando também com a colaboração de outros departamentos como o da Engenharia de Estruturas e Fundações (PEF), da Engenharia dos Transportes (PTR), da Engenharia da Construção Civil (PCC) e da Engenharia Hidráulica e Sanitária (PHA), todos estes, pertencentes à Escola Politécnica (EP), e também, a participação do Departamento de Matemática (MAT) pertencente ao Instituto de Matemática e Estatística (IME).

No Quadro 16, a grade curricular está colocada como uma proposta sugerida institucionalmente para a integralização do curso de Arquitetura e Urbanismo em 10 semestres.

Quadro 16 - Distribuição da Grade Curricular com a carga horária semestral - FAU USP:

\begin{tabular}{|c|c|c|c|c|c|c|c|c|c|}
\hline 10 sem & 20 sem & 3 sem & 4 sem & 50 sem & 6 sem & 70 sem & 8 sem & 90 sem & $10 \%$ sem \\
\hline $\begin{array}{l}\text { Fundam. } \\
\text { Proj. (16C) }\end{array}$ & $\begin{array}{l}\text { Arquitetura } \\
\text { Paisag. (9C) }\end{array}$ & $\begin{array}{l}\text { Arq. Proj. I } \\
\text { (9C) }\end{array}$ & $\begin{array}{l}\text { Arq. Proj. II } \\
\text { (9C) }\end{array}$ & $\begin{array}{l}\text { Arq. Proj. III } \\
\text { (9C) }\end{array}$ & $\begin{array}{l}\text { Arq. Proj. IV } \\
(9 \mathrm{C})\end{array}$ & $\begin{array}{c}\text { Projeto } \\
\text { Paisag. (5C) }\end{array}$ & $\begin{array}{c}\text { Mecân. } \\
\text { solos (4C) }\end{array}$ & TFG & TFG \\
\hline $\begin{array}{l}\text { Hist. Teor } \\
\text { arq. I (4C) }\end{array}$ & $\begin{array}{l}\text { Planej. Urb: } \\
\text { Introd. (9C) }\end{array}$ & $\begin{array}{l}\text { Planej. Urb: } \\
\text { Estrut. (9C) }\end{array}$ & $\begin{array}{l}\text { Design do } \\
\text { objeto }(9 C)\end{array}$ & $\begin{array}{c}\text { Arquit . e } \\
\text { indust. (9C) }\end{array}$ & $\begin{array}{l}\text { Proj. visual } \\
\text { amb. }(4 C)\end{array}$ & $\begin{array}{c}\text { Des. urb } \\
\text { proj cidade } \\
(9 \mathrm{C})\end{array}$ & $\begin{array}{c}\text { Estrutura } \\
\text { Arq IV (4C) }\end{array}$ & & \\
\hline $\begin{array}{l}\text { Hist. Arte I } \\
\text { (4C) }\end{array}$ & $\begin{array}{c}\text { Fund. soc. arq } \\
\text { e urb I (4C) }\end{array}$ & $\begin{array}{l}\text { Fund. soc. } \\
\text { arq urb II } \\
\text { (4C) }\end{array}$ & $\begin{array}{c}\text { Projeto } \\
\text { visual gráfico } \\
(4 \mathrm{C})\end{array}$ & $\begin{array}{l}\text { Planej. } \\
\text { Paisagem } \\
(5 \mathrm{C})\end{array}$ & $\begin{array}{l}\text { Org. urbana } \\
\text { e planej. }(9 C)\end{array}$ & $\begin{array}{l}\text { Hist. Teor } \\
\text { arq. IV (4C) }\end{array}$ & & & \\
\hline $\begin{array}{c}\text { Geom. aplic } \\
\text { prod. }(2 \mathrm{C})\end{array}$ & $\begin{array}{l}\text { Hist. Teor } \\
\text { arq. II (4C) }\end{array}$ & $\begin{array}{l}\text { Hist. Teor } \\
\text { arq. III (4C) }\end{array}$ & $\begin{array}{l}\text { Estudo de } \\
\text { urb. I (4C) }\end{array}$ & $\begin{array}{l}\text { Estudo de } \\
\text { urb. II (4C) }\end{array}$ & $\begin{array}{c}\text { Hist. urb. } \\
\text { contemp. 4C) }\end{array}$ & $\begin{array}{l}\text { Projeto de } \\
\text { custos (4C) }\end{array}$ & & & \\
\hline $\begin{array}{l}\text { Geometria } \\
\text { descr. }(2 C)\end{array}$ & $\begin{array}{c}\text { Introd Arte e } \\
\text { Arq II (2C) }\end{array}$ & $\begin{array}{l}\text { Ling. Visual } \\
\text { Amb. (5C) }\end{array}$ & $\begin{array}{l}\text { Hist. Arte II } \\
\text { (2C) }\end{array}$ & $\begin{array}{l}\text { Sist. de Infor. } \\
\text { Esp. Urb. 6C) }\end{array}$ & $\begin{array}{l}\text { Infraest. Urb. } \\
\mathrm{M} . \text { Amb (4C) }\end{array}$ & $\begin{array}{l}\text { Desemp. } \\
\text { Amb. Arq } \\
\text { urb }(5 \mathrm{C})\end{array}$ & & & \\
\hline $\begin{array}{c}\text { Homem Arq } \\
\text { Urb }(3 C)\end{array}$ & $\begin{array}{c}\text { Desenho arq. } \\
(2 \mathrm{C})\end{array}$ & $\begin{array}{c}\text { Comput. } \\
\text { grafica }(4 \mathrm{C})\end{array}$ & $\begin{array}{l}\text { Hist. Design } \\
\text { II (2C) }\end{array}$ & $\begin{array}{c}\text { Tec. retrosp. } \\
(4 \mathrm{C})\end{array}$ & $\begin{array}{c}\text { Desemp. } \\
\text { Acústico }(3 \mathrm{C})\end{array}$ & $\begin{array}{c}\text { Estrutura } \\
\text { Arq III (4C) }\end{array}$ & & & \\
\hline \multirow[t]{4}{*}{$\begin{array}{c}\text { Construção } \\
\text { do Edif. I (4C) }\end{array}$} & $\begin{array}{l}\text { Linguagem } \\
\text { visual graf. } \\
\text { (5C) }\end{array}$ & $\begin{array}{l}\text { Instal } \\
\text { Hidrául I } \\
(4 \mathrm{C})\end{array}$ & $\begin{array}{l}\text { Luz, Arq e } \\
\text { Urb (4C) }\end{array}$ & $\begin{array}{l}\text { Estatística } \\
\text { aplic. }(2 \mathrm{C})\end{array}$ & $\begin{array}{c}\text { Desemp. } \\
\text { Térmico }(3 C)\end{array}$ & $\begin{array}{l}\text { Estagio } \\
\text { supery. }\end{array}$ & & & \\
\hline & $\begin{array}{l}\text { Sol, Arq e } \\
\text { Urb. (3C) }\end{array}$ & $\begin{array}{l}\text { Construção } \\
\text { Edif. III (4C) }\end{array}$ & $\begin{array}{l}\text { Construção } \\
\text { Edif. IV (4C) }\end{array}$ & $\begin{array}{l}\text { Construção } \\
\text { Edif. V (2C) }\end{array}$ & $\begin{array}{c}\text { Estrutura Arq } \\
\text { II (4C) }\end{array}$ & & & & \\
\hline & $\begin{array}{l}\text { Construção } \\
\text { Edif. II (4C) }\end{array}$ & Cálculo (6C) & & $\begin{array}{c}\text { Estrutura Arq } \\
I(4 C)\end{array}$ & & & & & \\
\hline & $\begin{array}{c}\text { Topografia } \\
\text { (4C) }\end{array}$ & & & & & & & & \\
\hline
\end{tabular}

Disciplinas de Projeto

Disciplinas de Representação Gráf. e comp.
Disciplinas de Urbanismo e Meio Ambiente Disciplinas na área da Tecnologia da Arquitetura

O conjunto de disciplinas intituladas Construção do Edifício I, II, III, IV e V são iniciadas no 10 período e se estendem até o 5ㅇ período (1으 ao 3ㅇao an de curso), sendo também oferecida outra disciplina da área da Tecnologia da construção, 'Projeto de Custos', oferecida no 70 período (40 ano). A área da Tecnologia da Arquitetura ocupa $28,5 \%$ dos créditos destinados às disciplinas obrigatórias (não sendo considerada no cômputo a carga horária destinada ao TFG, Optativas e Estágio supervisionado). Desse total de $28,5 \%$ de créditos, $7,5 \%$ são destinados às disciplinas da área da Tecnologia da Construção (a disciplina de Construção do Edifício $\mathrm{V}$ contempla conteúdos referentes à área de Instalações Prediais); 5,5\% para Estruturas; 7\% Conforto Ambiental; 1,5\% para Instalações; 3\% Fundamentação; 4\% Outras consideradas da área (Topografia, Mecânica dos Solos e Infraestrutura Urbana e Meio Ambiente).

Deve-se considerar que o conteúdo relativo à disciplina Construção do Edifício V, envolve conteúdos referentes à área de Instalações Prediais e a análise supracitada foi realizada a partir do nome das disciplinas, algo a ser considerado em outras pesquisas.

\section{c) Quadro docente}


As disciplinas da área da Tecnologia da Construção são ministradas integralmente por professores pertencentes ao quadro docente do curso de Arquitetura e Urbanismo, tanto com formação em Engenharia Civil como também, em Arquitetura e Urbanismo. O conjunto de disciplinas de Sistemas Estruturais, Cálculo, Topografia, Mecânica dos Solos e Instalações Hidráulicas, são delegadas à Escola Politécnica e ao Instituto de Matemática e Estatística.

\section{d) Práticas didáticas e Infraestrutura laboratorial}

Institucionalmente, o Departamento de Tecnologia é responsável por três laboratórios: o LABAUT Laboratório de Conforto Ambiental e Eficiência Energética, criado em 2001, o LabSus - Laboratório de Sustentabilidade, criado em 2011 e o LCC - Laboratório de Culturas Construtivas, criado em 2012.

Ao longo do tempo, a infraestrutura e as práticas laboratoriais passaram por reestruturações a partir de diferentes motivações, sendo importante ser observada a trajetória histórica dos principais laboratórios da FAU que dão apoio às atividades experimentais da área técnico-construtiva: Laboratório de Modelos e Ensaios - LAME e Canteiro Experimental, ambos ligados diretamente à Diretoria - também caracterizados como seções técnicas de apoio - atendendo as atividades de ensino, pesquisa, cultura e extensão desenvolvidas pelos diferentes departamentos.

\section{- Laboratório de Modelos e Ensaios (LAME) - Trajetória histórica}

De acordo com dados divulgados pelo próprio curso $^{133}$, as primeiras atividades práticas foram desenvolvidas ainda na Vila Penteado, na Oficina de Maquetes, abrigada no Porão da FAU Maranhão, então sob a responsabilidade de José Zanine Caldas ${ }^{134}$.

O processo experimental acadêmico foi ampliado no momento em que esta primeira Oficina foi transferida para o primeiro subsolo do edifício Vilanova Artigas na Cidade Universitária, passando a ser denominada como Laboratório de Modelos e Ensaios (LAME), sob a coordenação do prof. Caetano Fraccaroli (Figura 71). Neste período a área laboratorial do curso tomou novas vertentes ao ampliar as possibilidades de investigação técnica e material, sendo possível verificar a influência dos princípios bauhauseanos nos conceitos que regiam o laboratório.


Figura 71: Instalações do LAME - Edifício Vilanova Artigas. a) Imagens das primeiras instalações do LAME quando inaugurado na Cidade Universitária na década de 1970. b) Planta FAUUSP cota -1,10 e -3,00. Localização do primeiro Laboratório de Modelos e Protótipos - LAME, no edifício da Cidade Universitária.

Fonte: a) Acervo Biblioteca FAU. b) Revista Acrópole, n. 377. Ano 32, 1970.

O espaço físico do LAME foi inicialmente previsto como uma área única, com máquinas e materiais necessários para o trabalho com diferentes materiais como a madeira, cerâmica, porcelana, metais não ferrosos e polímeros, uma tecnologia bastante moderna para a época. A montagem do setor de ensaios iniciou-se em 1977, com um plano de pesquisa financiado pela FAPESP, orientado pelo professor doutor Aluízio Fontana Margarido. Tal pesquisa previa a instalação de vários equipamentos

\footnotetext{
133 Dados históricos constituídos a partir de relato do Prof. Dr. Júlio Roberto Katinsky, disponível em: http://www.fau.usp.br/fau/secoes/lame/ breve_historico.html. Acesso em: 02/06/2016.

${ }^{134}$ Arquiteto autodidata, profundo conhecedor de madeiras e marcenaria, designer de móveis, além de excepcional maquetista.
} 
especializados para extensometria elétrica, valendo-se de instrumentos para medição e registro de esforços em estruturas para ensaios com modelos reduzidos. Conseguiu-se então, montar na Universidade de São Paulo um laboratório de modelos e ensaios equiparado na época ao das melhores escolas do mundo, atendendo as "necessidades de aperfeiçoamento tecnológico que a Universidade deveria responder em relação ao país."

O LAME também prestou serviços de extensão e atendeu a outras unidades da USP, mantendo contato com organizações como o IPT (Instituto de Pesquisas Tecnológicas) e o Centro de Tecnologia Promon (organização sem fins lucrativos, fundada pela Promon Engenharia S.A.). Mas, para Fraccaroli então coordenador do LAME - essa capacidade foi subtilizada academicamente, ao afirmar no relatório de atividades de 1977, que "as disciplinas (...) que fazem mais uso do LAME, o fazem muito aquém do que este pode oferecer em termos criativos e qualitativos"135. Com a morte de Fraccaroli em 1987, o LAME passou por períodos difíceis devido ao complexo processo de manutenção do espaço, como reposição de materiais e equipamentos, sem investimentos para acompanhar o necessário processo de modernização.

Com o passar dos anos, com o crescimento dos trabalhos acadêmicos, houve a necessidade de ampliar os espaços de apoio didático e, para atender a esta demanda, foi construído o edifício conhecido como "Anexo" - projeto do arquiteto Giancarlo Gasperini - cuja obra foi inaugurada em 1997 (não em sua íntegra), sendo então o Laboratório de Modelos e Ensaios transferido para o espaço que hoje ocupa, ao lado do edifício Vilanova Artigas.

Com a área laboratorial/experimental passando a acontecer fora do edifício principal (tanto o LAME como o LPG - Laboratório de Produção gráfica - e o Laboratório Fotográfico foram transferidos para o edifício 'Anexo') surgiram questionamentos sobre a mudança da dinâmica de uso já enraizada nestes espaços, sendo ao longo do tempo, estabelecida uma nova interatividade, para que os alunos se aproximassem do edifício 'Anexo', projetado exclusivamente para a função de laboratório.

Atualmente, o LAME apresenta-se caracterizado como um laboratório didático, regido por um Conselho. Esta comissão assessora a Direção e tem um papel muito relevante nos processos decisórios sobre demandas específicas, no sentido de preservar a natureza didática deste espaço, atendendo as atividades de ensino, pesquisa e extensão, cuja manutenção se dá integralmente por meio de verba institucional da própria FAU.

No LAME, os alunos tem permissão para manipular algumas máquinas, enquanto outras são de acesso restrito aos técnicos ou de acesso supervisionado. Foi observada a presença de sinalizações com indicativo sobre as restrições de uso e os equipamentos de proteção individual - EPIs - necessários para serem utilizados em cada máquina. A capacitação informal dos alunos tem funcionado bem (de acordo com a cultura de acesso), embora encontre dificuldades com a redução do quadro técnico sem a devida reposição. Atualmente, o laboratório conta com 6 técnicos (incluídos neste número 1 de manutenção de máquinas e 1 na área administrativo/compras).

Há indicativos de que, com a criação do Canteiro Experimental, atividades específicas ligadas a ensaios com materiais, passaram a ter uma presença apenas complementar no LAME, quando antes eram realizadas integralmente neste espaço, a partir do entendimento que a escala ligada ao edifício estaria direcionada ao canteiro e a do objeto, ao LAME. Esta delimitação foi naturalmente sendo criada associada à condição espacial. De acordo com as Figuras 72 e 73, o LAME apresenta as seguintes setorizações espaciais:

135 Informações obtidas em: http://www6.fau.usp.br/atelier/Caetano_Fraccaroli_arte_reflexao_ensino.pdf. Acesso em: 02/06/2016. 


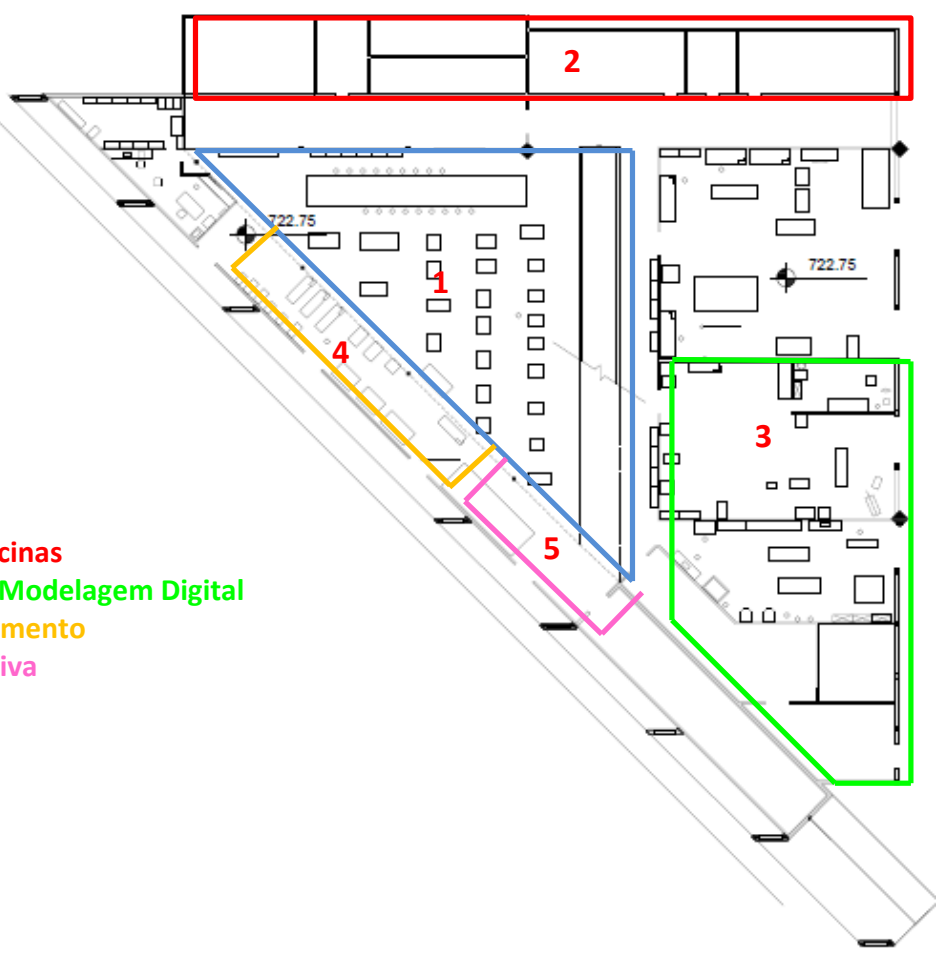

Figura 72 - Planta do LAME no Edifício ANEXO.

Fonte: imagem concedida pelo GEEF - FAUUSP, modificado pela autora (setorização de áreas).
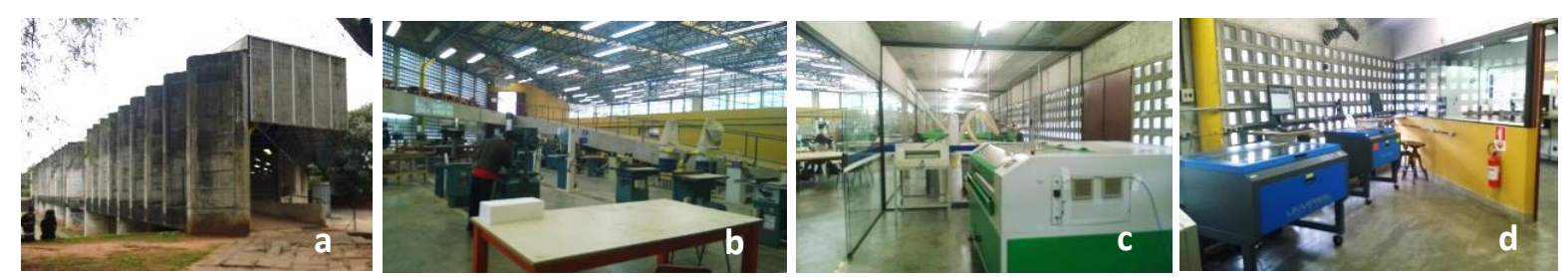

Figura 73 - Edifício ANEXO: a) Vista externa da entrada principal ao edifício. b), c) e d) Vista interna de alguns dos equipamentos disponíveis para as atividades de experimentação.

Fonte: fotos da autora

\section{- Canteiro Experimental Antonio Bataglia - Trajetória histórica}

Por volta de 1989, foram iniciadas as primeiras discussões sobre a implantação de um espaço de experimentações construtivas na FAUUSP, que permitisse o contato direto com os materiais e técnicas de construção, chamado 'Canteiro Experimental'. Neste período foi cedido pela Prefeitura da Cidade Universitária um terreno para a instalação deste espaço mas, devido às dificuldades impostas pela distância deste local ao edifício sede do curso, novas negociações foram realizadas e, em 1993, as atividades do Canteiro Experimental foram iniciadas sob a cobertura lateral do edifício 'Anexo' (em processo de construção, sendo a área destinada à segunda fase de implantação deste edifício), sob a orientação dos professores Antonio Bataglia, Elisabetta Romano e Erica Yoshioka, com apoio de vários alunos (Figura 74$)^{136}$.

\footnotetext{
${ }^{136}$ As primeiras ideias sobre a implantação do Canteiro Experimental na FAU vieram de um aluno, chamado Eduardo de Oliveira Vianna, o qual encontrou força junto à professora Elisabetta Romano, que deu então prosseguimento aos trâmites para sua viabilização junto à coordenação e direção do curso. Com apoio institucional e também dos professores Antonio Bataglia, Elisabetta Romano e Erika Yoshioka, as atividades de canteiro foram iniciadas na disciplina introdutória 'Tecnologia da Construção I', que ofertava aulas igualmente divididas em teóricas e práticas. Fonte: Informações verbais obtidas a partir da entrevista realizada à professora Elisabetta Romano em 21 de junho de 2016.
} 
Segundo documentos de registro sobre a implantação Preliminar do Canteiro Experimental ${ }^{137}$, este novo espaço de trabalho deveria abrigar atividades didáticas e de pesquisa com o mesmo objetivo: fazer, experimentar e avaliar objetos, sistemas e ambientes arquitetônicos, no que se refere às suas características físicas, funcionais e de conforto ambiental, enfocando principalmente, o processo de utilização na obra e o desempenho dos materiais ao longo do tempo, promovendo não somente a inserção de disciplinas da área da Tecnologia da Construção, mas também, de Desenho Industrial, Projeto e outras interessadas ${ }^{138}$.


Figura 74 - Sequencia de fotos das primeiras experiências realizadas no período de implantação do Canteiro Experimental.

Fonte: Canteiro Experimental da FAU: registro preliminar de uma experiência - 2o semestre de 1993. FAUUSP, 1994.

A partir de 1997, este espaço ganha novas instalações, um lugar definitivo para a realização de atividades práticas próximas ao LAME (uma área de aproximadamente $3000 \mathrm{~m}^{2}$ ), caracterizado pela adoção de uma cobertura tensionada para proteção durante a execução das atividades ${ }^{139}$. Com a mudança de coordenação, novas estratégias metodológicas foram implementadas, de acordo com a bagagem e entendimentos dos novos atores à frente da coordenação deste espaço. As atividades passaram a ter então, um viés de discussão sobre experiências de mutirão, gestão e projetos habitacionais e, neste contexto pedagógico, as atividades foram conduzidas com base em uma plataforma metodológica que promovesse o processo de autonomia e emancipação do estudante ${ }^{140}$.

Atualmente, este espaço oferece apoio a três disciplinas do curso de Arquitetura e Urbanismo duas obrigatórias (Construção do Edifício 1 e 2) e uma optativa (Técnicas Alternativas da Construção) e as atividades são voltadas, prioritariamente, ao ensino da graduação. As atividades de pesquisa, extensão e a pós-graduação no canteiro experimental ainda não estão consolidadas. De acordo com o professor entrevistado, as práticas de canteiro restringem-se à manipulação de 4 ou 5 materiais mais comuns (cimento, pedra, areia, blocos de concreto, cerâmico), e esta escolha está condicionada aos custos e facilidade de aquisição, realizada com recursos advindos integralmente da Instituição. 0 espaço coberto com a estrutura tensionada não é fechado lateralmente e seu vão livre abriga duas bancadas fixas de concreto com pontos de água e algumas máquinas, equipamentos e materiais de construção, além disso, diversos protótipos construídos pelos alunos permanecem neste espaço, sendo

\footnotetext{
${ }^{137}$ No período de implantação deste espaço foram divulgados dois Cadernos de Registro: Canteiro Experimental da FAU: registro preliminar de uma experiência - 20 semestre de 1993. FAUUSP, 1994. E também o Documento Preliminar sobre o Canteiro Experimental da FAUUSP. Faculdade de Arquitetura e Urbanismo da Universidade de São Paulo. São Paulo, 1993.

${ }^{138}$ As atividades do Canteiro Experimental tiveram influências advindas de diversas fontes. Em relação à profa. Elisabetta Romano - entrevistada neste trabalho - 10 anos antes da implantação desta experiência na FAUUSP, em 1984, ela teve a oportunidade de participar em Grenoble, França, por um período de aproximadamente 1 ano, das atividades desenvolvidas no Laboratório Craterre, juntamente com o pesquisador francês Patrice Doat. Além desta experiência, outras práticas também foram consideradas como importantes e, de alguma forma, contribuíram para a delimitação de uma proposta para o Canteiro Experimental da FAUUSP, tendo inicialmente como referência teórica o arquiteto Sérgio Ferro. Trata-se de um exemplo, dentre a somatória de experiências e referências vindas de todos os professores envolvidos. Fonte: Informações verbais obtidas a partir da entrevista realizada à professora Elisabetta Romano em 21 de junho de 2016.

${ }^{139}$ A idealização da tipologia na forma de uma tenda ocorreu ainda na fase inicial do Canteiro e, de acordo com a professora entrevistada, não seria correto atribuir um autor a esta ideia, já que a mesma foi discutida em conjunto. Na segunda fase (falecimento do prof. Antonio Bataglia; afastamento da professora Elisabetta Romano do Canteiro; permanência da profa. Erika Yoshioka e contratação do prof. Reginaldo Ronconi), a partir da obtenção de recursos, muitas das ideias anteriormente idealizadas foram colocadas em prática, como a construção do espaço na forma de tenda, sendo o projeto executivo realizado pelo prof. Reginaldo Ronconi. Fonte: Ibid.

${ }^{140}$ Dados fornecidos a partir da entrevista direcionada ao prof. Reginaldo Ronconi em 30 de junho de 2016.
} 
alguns demolidos para dar lugar a outras atividades nos semestres subsequentes (Figura 75). A área destinada ao canteiro de $3000 \mathrm{~m}^{2}$, abriga - além do edifício principal - alguns contêineres para depósito de materiais e ferramentas, sendo um dos protótipos direcionado ao funcionamento do LCC (Laboratório de Culturas Construtivas) ${ }^{141}$. No início da implantação do Canteiro Experimental, este espaço contava com o apoio de 02 técnicos, atualmente, há a presença de apenas 01 técnico para auxiliar as atividades das disciplinas que contam com aproximadamente 160 alunos.


Figura 75: Imagens do Canteiro Experimental da FAUUSP - a) Vista externa. b) e c) Vistas internas evidenciando a dinâmica das atividades realizadas.

Fonte: Fotos da autora - a) e b) março/2009; c) e d) junho/2016.

Em relação às disciplinas obrigatórias voltadas à Tecnologia da Construção, apenas Construção do Edifício 1 e 2 (1 ano do curso) utilizam da infraestrutura oferecida pelo Canteiro Experimental.

De acordo com os dados relatados, a principal abordagem destas disciplinas está em trazer o estudante para o processo de construção de solução, desta forma, as disciplinas do 10 ano foram adaptadas de maneira a preparar para as atividades no canteiro, dando maior enfoque a assuntos referentes aos fenômenos estruturais em relação aos materiais e às técnicas construtivas. Em Construção do Edifício 1, além das aulas teóricas em sala de aula, é realizado um exercício considerado como um ensaio de ruptura (não sendo adotadas metodologias científicas, tratando-se de uma atividade voltada à observação de alguns fenômenos já estudados), trabalhado na escala do modelo reduzido. Este exercício é realizado há mais de 15 anos e nele são discutidas questões relacionadas ao processo de ruptura do objeto. Em um primeiro momento trabalham na escala do modelo e depois, no 20 semestre, na disciplina de Construção do Edifício 2, na escala natural de objeto e componentes construtivos utilizando alvenaria e argamassa, principalmente. Embora a gama de materiais trabalhados em canteiro nesta disciplina seja mais restrito, em sala de aula o repertório é ampliado por meio das aulas teóricas. A partir do 20 semestre, os alunos passam a ter uma base maior sobre processos construtivos, embora a intenção desta disciplina não seja necessariamente esse, segundo o entrevistado. Nesta fase o aluno é motivado a concretizar algo, e a partir de um problema tenta-se equacionar com uma técnica a sua execução com os materiais disponíveis em canteiro. $O$ entendimento é que a técnica seja incluída, naturalmente, no arcabouço de soluções dentro do universo da construção. Estas questões são trabalhadas no canteiro, pois os responsáveis pela disciplina acreditam que esta é a melhor forma de retenção do conhecimento, a vivência do problema.

Em Construção do Edifício 3, são abordados diversos assuntos como: Requisitos e Normas de Desempenho, Canteiro de obras (organização, terrapleno e implantação da obra) e Sistemas construtivos (estruturas, vedos e coberturas) tradicionais e industrializados com diferentes materiais. A disciplina não envolve, necessariamente, a caraterização física dos materiais, mas sua aplicabilidade em sistemas construtivos, com fins estruturais ou não. A abordagem do conteúdo é prioritariamente teórica, sendo as práticas no Canteiro Experimental não viabilizadas por diferentes motivos:

- número muito elevado de alunos (média de 160 por disciplina obrigatória) não sendo adotados, geralmente, o processo de divisão de turmas, com a presença de 3 a 4 professores ministrantes na mesma sala de aula ao longo do semestre;

\footnotetext{
${ }^{141} \mathrm{Na}$ intenção de fazer com que o Canteiro Experimental amparasse pesquisa da pós-graduação, mas sem que isso promovesse sua descaracterização foi implantado o LCC (Laboratório de Culturas Construtivas), como um local que pudesse abrigar pesquisas mantendo esta proximidade e que possibilitasse a canalização de recursos vindos de outras fontes, como a pesquisa, de natureza diferenciada às atividades voltadas ao ensino. Atualmente, ambos os espaços são sustentados com verba institucional, mas há a possibilidade do LCC captar recursos por meio de pesquisas. Fonte: Ibid.
} 
- a impossibilidade da divisão das turmas inviabiliza a adoção de metodologias científicas (indicadas para turmas em torno de 15 a 20 alunos), o que promoveria maior segurança durante a realização destas atividades e o aprendizado de forma mais aprofundada.

Embora não sejam realizadas atividades laboratoriais em Construção do Edifício 3, os alunos tem contato com uma atividade profissional, ao escolherem um canteiro de obras real (a obra pode se encontrar na fase da estrutura, vedação ou acabamento) para visitarem em grupo, acompanhando alguns processos construtivos e correlacionando-os com os aspectos teóricos abordados em sala de aula. É o momento em que o aluno passa a enxergar o canteiro de obras sob aspectos reais, sendo analisadas questões sobre a organização do canteiro, a segurança no trabalho e o gerenciamento dos resíduos na obra, atentando se estas questões fazem parte de um planejamento sistêmico.

No caso de Construção do Edifício 4, outros conteúdos são agregados, dando amparo aos já vistos em Construção do Edifício 3, como: esquadrias, revestimentos, pintura, impermeabilização e pavimentação interna e externa. De acordo com as novas Diretrizes Curriculares estabelecidas pelo MEC, alguns assuntos a serem ministrados, foram recentemente inseridos nesta disciplina como APO Avaliação Pós-Ocupação e Proteção passiva contra incêndio. Além do conteúdo teórico, nesta disciplina é proposto um exercício para ser desenvolvido ao longo do período onde os alunos, divididos em grupos, analisam quatro elementos (revestimento de piso, parede, esquadria e proteção contra incêndio) a partir da visita em edifícios em uso, buscando referências para amparar as análises

Em relação à inserção de conteúdos não tradicionais, as disciplinas de Construção do Edifício 3 e 4 , conseguem abordar alguns assuntos como Requisitos e Normas de Desempenho, Avaliação Pósocupação, Gestão de resíduos e determinados tópicos sobre sustentabilidade, os quais são, geralmente, diluídos dentro dos demais assuntos, não apresentando-se como um conteúdo particular das disciplinas.

\section{e) Pós graduação: ${ }^{142}$}

A década de 1970 foi marcada pela afirmação da pesquisa e da pós-graduação na FAUUSP. Em 1972, o curso de Mestrado e pouco depois, em 1980, o de Doutorado, instituídos na perspectiva compreensiva das "Estruturas Ambientais Urbanas". Até o ano de 1998, o doutorado oferecido pelo PPG FAUUSP permaneceu como o único do Brasil.

À medida que a pesquisa e a pós-graduação se consolidaram ao longo dos anos de 1980, difundiram-se também modelos de formação alternativos, pois uma nova geração de professores pesquisadores emergiu no interior da escola, renovando várias ferramentas teóricas a partir de outros campos disciplinares.

O Programa de Pós-Graduação conta, atualmente, com oito áreas de concentração:

\section{- Tecnologia da Arquitetura}

- História e Fundamentos da Arquitetura e Urbanismo

- Design e Arquitetura

- Paisagem e Ambiente

- Projeto, Espaço e Cultura

- Habitat

- Projeto da Arquitetura

- Planejamento Urbano e Regional

A área de concentração em Tecnologia da Arquitetura apresenta as seguintes Linhas de Pesquisa:

1- Processo de produção da Arquitetura e do Urbanismo/Representações

\section{2- Tecnologia da Construção}

\section{3- Conforto Ambiental, Eficiência Energética e Ergonomia}

Há, portanto, a possibilidade tanto em nível de Mestrado como Doutorado de serem realizadas pesquisas na área da Tecnologia da Construção, embora os projetos ainda sejam desenvolvidos com base teórica ou com base na análise em obras ou edifícios, sem envolver experimentações com materiais ou sistemas construtivos pela ausência de infraestrutura laboratorial específica.

\footnotetext{
${ }^{142}$ Dados obtidos em: http://fau.usp.br/cursos/pos/index.html. Acesso em: 05/08/2016.
} 


\section{f) Comentários:}

- Foi observado que o curso possui um histórico relacionado à inserção dos espaços experimentais nas atividades acadêmicas, a partir do entendimento que o próprio curso tinha de sua importância e não a partir de exemplos e modelos externos. Trata-se, portanto, de uma trajetória particular o fato destes espaços terem sido idealizados de acordo com o cenário local. (embora, indiretamente, tenha recebido influências de outros locais, de acordo com as experiências dos docentes envolvidos);

- Ao analisar os documentos de implantação do Canteiro experimental da FAUUSP e contrapor estes dados com sua atual configuração, percebe-se que ao longo do tempo houve algumas mudanças de direcionamentos: nos primórdios do Canteiro Experimental havia o entendimento da necessidade da promoção de um espaço interdepartamental, assim como havia o reconhecimento da dificuldade de implementação desta intenção, condicionada à revisão e otimização do currículo da FAUUSP. Ao longo de aproximadamente 20 anos de existência do Canteiro Experimental apenas duas disciplinas obrigatórias voltadas à Construção do Edifício se utilizam deste espaço de $3000 \mathrm{~m}^{2}$, sendo que, atualmente, as pesquisas realizadas, tanto pela graduação como pela pós-graduação, ainda são, quantitativamente, inexpressivas dadas as dimensões e infraestrutura do canteiro experimental. Este cenário revela a necessidade de promover o melhor aproveitamento deste espaço para que sua permanência e sustentação sejam justificadas, a partir da otimização e compartilhamento da infraestrutura existente, para que um número maior de professores e disciplinas possam usufruir de forma mais democrática, atendendo também um dos objetivos iniciais do Canteiro: a intra e interdepartamentalidade;

- Sobre a sustentação financeira do Canteiro Experimental, foi evidenciada nos relatórios iniciais a necessidade da parceria junto a instituições, entidades e indústrias. Atualmente, este espaço é mantido integralmente com verba institucional, restringindo a manipulação de materiais diversificados de maneira contínua;

- Foi relatada a falta de visibilidade do Canteiro Experimental dentro do próprio curso; muitos professores não sabem da existência do mesmo e como poderiam utilizá-lo. Este fato pode, em alguns momentos, gerar traços de fragilidade na sustentação deste espaço dentro do curso devido à incompreensão sobre sua importância. Além disso, a demanda contínua de recursos gera uma relação de desgaste para os docentes envolvidos em sua coordenação;

- Em relação ao LAME, a consolidação de uma comissão com chefia rotativa, permitiu tanto reeducar os técnicos para sua função, como também, não abrir espaço para distorções no uso do laboratório (a desconstrução e reorganização ocorreu entre 2011 e 2016), sendo o papel deste conselho de natureza política e administrativa. As restrições de demandas que não tinham caráter experimental e didático julgadas por esta comissão, contribuiu para promover o reconhecimento dos técnicos como educadores e o seu papel dentro do laboratório;

- Embora a existência de dois distintos espaços voltados às experimentações e práticas construtivas, foi sinalizada a identificação de outra demanda a ser atendida nesta área, um local para montagens arquitetônicas e, por serem pesquisas cujo processo de avaliação ocorre por períodos prolongados, há a necessidade de local próprio para o processo de análise técnica, sendo que os espaços atuais não conseguem apoiar projetos desta natureza. Para isso, há a necessidade do planejamento de uma estratégia mais coletiva, entre os professores das disciplinas, conselho do LAME, Canteiro Experimental e Diretoria da FAU, para suprir a necessidade espacial que talvez o edifício Anexo e a lona do Canteiro não atendam na configuração vigente;

- A infraestrutura laboratorial existente é estruturada para atender a graduação e não direcionada à realização de experimentos como ensaios físicos e mecânicos com materiais e sistemas construtivos. No caso da pós-graduação, as linhas de pesquisa em Tecnologia da Construção geralmente desenvolvem seus projetos com base teórica ou por meio da análise de obras e edifícios, devido à inexistência de um laboratório voltado às práticas laboratoriais específicas.

- O reduzido número de professores da área da Tecnologia da Construção pode ser considerado como uma das condicionantes para que as turmas (de aproximadamente 160 alunos) não sejam divididas; 
este cenário também dificulta a implementação de atividades práticas nas disciplinas que, segundo alguns professores, deveria respeitar a relação numérica aluno/professor adequada, sendo considerada didaticamente inaceitável, improdutiva e insegura a participação de um número elevado de alunos em atividades laboratoriais e experimentais;

- Há o reconhecimento de que as visitas em obras deveriam ter o acompanhamento dos professores, pois a percepção entre discente e docente é diferenciada. Mas, devido ao elevado número de alunos e pelo fato das construtoras receberem um número limitado de visitantes, não há a possibilidade desta prática ser realizada de outra forma a não ser a divisão em grupos. Somente em Construção do Edifício 3 e 4 os alunos visitam um canteiro de obras real e tudo que envolve a construção de uma forma sistêmica. Quando as visitas em obras fazem parte do plano de curso o seguro é definido pela própria Universidade;

- Sobre as disciplinas de Construção do Edifício, foi sinalizado que pelo fato das disciplinas serem dadas no início do curso, há muitos conceitos teóricos importantes que ainda não foram abordados, principalmente, sobre Sistemas Estruturais, cujo conteúdo é iniciado apenas no 5o período. Como a proposta das disciplinas de Construção do Edifício 3 e 4 requerem que o aluno já tenha conhecimento de determinados conceitos sobre estruturas e também materiais e sistemas construtivos, foi relatado que há carência destes conhecimentos. Este cenário sobrecarrega as disciplinas de Construção do Edifício 3 e 4 por forçá-las a abordarem, além dos conteúdos relacionados à Tecnologia da Construção, também os conteúdos básicos de pré-dimensionamento e solos (Mecânica dos Solos é oferecida somente no 8ㅇ período), levando os professores a sacrificarem determinados conteúdos sobre Tecnologia da Construção que deveriam ser abordados com maior cuidado, para que os alunos não corram o risco de construírem seus projetos sob uma base muito incipiente e frágil;

- Embora não haja diálogo entre as disciplinas da cadeia da construção (exceções: entre as disciplinas de Construção do Edifício 1 e 2 e entre as disciplinas de Construção do Edifício 3 e 4) e as demais oferecidas, observa-se que há exemplos de interação entre os departamentos, principalmente, por meio de algumas disciplinas optativas.

\subsubsection{ESCOLAS IMPLANTADAS NA DÉCADA DE 1960}

Este período foi marcado por discussões de grande abrangência nacional sobre os rumos do ensino de arquitetura no país e, também, por ser o período de implantação da ditadura militar com a instalação do Currículo Mínimo nas escolas a partir de 1969. A visita técnica contemplou todas as escolas criadas neste período e que estão inseridas em instituições públicas como: UNB (1962); UFPR (1962/63); UFC (1964) e UFPA (1964).

\section{7- FAU - UNB - Faculdade de Arquitetura e Urbanismo da Universidade de Brasília}

\section{a) Breve Histórico ${ }^{143}$}

\footnotetext{
${ }^{143}$ Fontes consultadas:

- Projeto Político Pedagógico de curso;

- Plano Orientador da Universidade de Brasília, Editora Universidade de Brasília, 1962;

- UNB 50 ANOS: história contada: a história da Universidade de Brasília contada por seus personagens: reportagens, depoimentos, entrevistas. Brasília: Editora Universidade de Brasília, 2012;

- SCHLEE, A. R. et al., Registro Arquitetônico da Universidade de Brasília. Brasília: Editora Universidade de Brasília, 2014.

- VULCÃO, M.G.V. A construção do discurso de criação do 'Curso-Tronco' de Arquitetura e Urbanismo da Universidade de Brasília (1962-1963). Dissertação (Mestrado em Arte) - Universidade de Brasília, Brasília, 2008.

- PEREIRA, M. A. Ensino de Arte e Arquitetura. Revista Acrópole, n 369/370. Ano 31. 1970.
} 
De acordo com o Plano Orientador de 1962, a estrutura da Universidade de Brasília era composta por Institutos Centrais (Matemática, Física, Química, Biologia, Geo-Ciências, Biologia, Ciências Humanas, Letras e Artes), Faculdades e Órgãos Complementares. Neste documento é sinalizada a intenção de inauguração em um prazo de dois anos, ou seja em 1964, dos prédios que abrigariam o conjunto dos Institutos citados e os serviços auxiliares. Este tempo também deveria ser suficiente para preparação do quadro docente, aquisição de equipamentos didáticos e de pesquisa e a organização dos serviços de biblioteca.

Ao considerar a possibilidade de atraso na inauguração dos cursos de nível superior na Capital Federal, o Conselho Diretor da Fundação Universidade de Brasília, deliberou instituir, já em 1962, uma série de cursos, organizados em regime transitório e que seriam, mais tarde, absorvidos pelos Institutos Centrais e pelas Faculdades, à medida que estas e aqueles entrassem em funcionamento. A escolha dos cursos foi precedida do estudo de viabilidade no atendimento a diversas questões: recrutamento do pessoal docente com a necessária qualificação e o atendimento às exigências em relação aos equipamentos de ensino e de pesquisa para cada tipo de informação. Considerando estes critérios, verificou-se a possibilidade de oferecer três cursos-tronco, com bom padrão de ensino: 1) Direito, Administração e Economia; 2) Arquitetura e Urbanismo; 3) Letras Brasileiras.

A proposta previa que os cursos seriam ministrados com programa comum de dois anos, ao fim dos quais o aluno faria a opção definitiva da carreira que desejasse, dentro do campo anteriormente escolhido. Ao fim de dois anos, o aluno aprovado poderia ingressar na segunda fase, a profissionalizante, quando passavam a receber o treinamento especializado na Faculdade de Arquitetura e Urbanismo e no seu órgão complementar, o Centro de Planejamento Regional (CEPLAN). Por fim, já com o título profissional, poderiam ainda desenvolver estudos de pós-graduação. Os mestrandos eram admitidos como instrutores e colaboravam com o ensino de graduação.

Segundo Schlee (2010), o curso de Arquitetura e Urbanismo na UNB entrou em funcionamento em fevereiro de 1962, com sede temporária na Esplanada dos Ministérios e com atividades no canteiro de obras do futuro campus, desde o princípio o seu objeto privilegiado de estudo foi a própria cidade de Brasília e o espaço de treinamento prático a própria Universidade em construção. Neste período, o curso tinha Oscar Niemeyer como coordenador e Ítalo Campofiorito como secretário executivo e o ensino da graduação estava organizado em três linhas complementares: Composição e Planejamento, sob direção de Glauco Campello; Tecnologia, sob direção de João Filgueiras Lima - Lelé e Teoria e História, sob direção de Edgar Graeff.

O Golpe de 1964, entretanto, veio interromper a experiência de uma nova Universidade, sepultando o projeto imaginado por Anísio Teixeira e Darcy Ribeiro. De acordo com o Projeto Político Pedagógico de curso, em decorrência da sequência de atos violentos, demissões, perseguições e da péssima qualidade de ensino que se estabeleceram, os estudantes da FAU optaram por fechar o Curso de Arquitetura e Urbanismo. A reabertura só ocorreu em outubro de 1968, quando se estabeleceu uma nova geração de professores. No mesmo ano, foi realizado o Seminário de Revisão e Consolidação dos Planos de Ensino do ICA-FAU e, a partir de 1969, foram ministrados os novos planos de curso. A estrutura curricular, que permitiu a reestruturação da unidade não respondia ao Currículo Mínimo de 1969, de maneira que uma série de alterações modificaram a estrutura didático-pedagógica originalmente estabelecida.

Em 1975, foi aprovado o Projeto do Curso de Graduação em Arquitetura e Urbanismo do Instituto de Artes e Arquitetura da UnB. O Projeto de 1975 considerou a seguinte organização administrativo-departamental:

- Departamento de Arquitetura;

- Departamento de Urbanismo.

Ainda segundo o PPP de curso, a estrutura curricular do Projeto Pedagógico de 1975 foi considerada satisfatória até 1989, quando passou a vigorar um novo desenho curricular que finalmente respondia às exigências do Currículo Mínimo do Conselho Federal de Educação de 1969. No entanto, o Currículo de Graduação de 1989 foi aprovado sem um novo projeto pedagógico. Como consequência, a FAU sentiu necessidade de aprofundar a questão, acompanhando o processo de discussão nacional sobre o ensino de Arquitetura e Urbanismo, que se desdobrou na realização do Seminário Nacional da Área de Arquitetura e Urbanismo (CEAU) em Brasília (1994) e na aprovação das Diretrizes Curriculares e Conteúdos Mínimos (Portaria no 1770-MEC/1994). Em dezembro de 1995, foi aprovado o projeto de 
Reorganização Acadêmica e Administrativa da Faculdade de Arquitetura e Urbanismo da UnB que, entre outras medidas, modificou profundamente a estrutura administrativa da unidade e reestruturou os mestrados da FAU. A estrutura proposta considerou a tradição de discussão de ensino, pesquisa e extensão por meio de colegiados setoriais de disciplinas refletidas nos cursos de graduação e pósgraduação, e criou três departamentos específicos:

- Departamento de Projeto e de Expressão e Representação em Arquitetura e Urbanismo;

- Departamento de Tecnologia em Arquitetura e Urbanismo;

- Departamento de Teoria e História em Arquitetura e Urbanismo.

Aproveitando as contínuas discussões nacionais sobre os rumos do ensino de Arquitetura e Urbanismo, a FAU aprovou a Atualização Curricular do Curso de Arquitetura e Urbanismo em 2003, antecipando-se a aprovação final das Diretrizes Curriculares Nacionais (Resolução no 6-MEC/2006). Por fim, em 2005 foi realizada a Avaliação Interna do Curso de Arquitetura e Urbanismo, bem como a Pesquisa de Egressos Formados de 1993 a 2002, documentos que impulsionaram o início formal dos trabalhos de elaboração do Projeto Político Pedagógico da Faculdade de Arquitetura e Urbanismo da UnB (2007-2009). Desde então ocorreram três seminários de avaliação e proposição, o que permitiu a montagem da proposta de criação do Curso Noturno e avaliação do Curso Diurno de Graduação em Arquitetura e Urbanismo.

Atualmente, FAU é gerenciadora de um curso ministrado por três departamentos:

- Departamento d Projeto, Expressão e Representação;

- Departamento de Tecnologia

- Departamento de Teoria e História
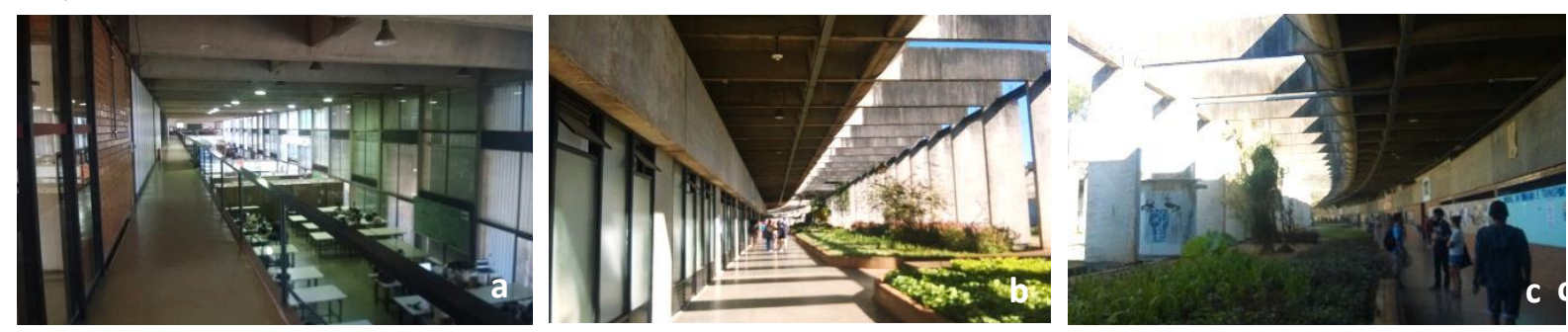

Figura 76 - Instalações físicas utilizadas pela FAUUNB no prédio do ICC - Instituto Central de Ciências: a) vista interna dos ateliers a partir do mezanino. b) e c) áreas de circulação e acesso à FAU e outros cursos sediados no Instituto.

Fonte: Imagens da autora

\section{b) Considerações sobre a Estruturação da área de Tecnologia da Construção}

O curso da FAU UNB oferece anualmente 80 vagas no período diurno (40 vagas semestrais) e, a partir da adesão ao programa REUNE, passou também a oferecer 60 vagas anuais no período noturno, somando 140 vagas/ano. Devido ao curso noturno ter sido criado em 2010, não atendendo ao critério temporal deste trabalho, não foi considerado na pesquisa, sendo somente analisado o curso diurno.

Atualmente, as disciplinas são ministradas quase integralmente pelo quadro docente pertencente a FAU, com exceção das disciplinas de Materiais de Construção e Topografia, delegadas ao curso de Engenharia Civil.

Quadro 17 - Distribuição da Grade Curricular com a carga horária semestral - FAU UNB:

\begin{tabular}{|c|c|c|c|c|c|c|c|c|c|}
\hline 10 sem & 20 sem & 30 sem & 40 sem & 5o sem & 60 sem & 70 sem & 8 sem & 9o sem & $10 \%$ sem \\
\hline $\begin{array}{l}\text { Projeto arq. I } \\
\text { (8C) }\end{array}$ & $\begin{array}{c}\text { Projeto arq. } \\
\text { lingu. Exp. (8C) }\end{array}$ & $\begin{array}{c}\text { Projeto arq. } \\
\text { habitação (8C) }\end{array}$ & \begin{tabular}{|c|}
$\begin{array}{c}\text { Projeto arq. } \\
\text { grandes vãos } \\
(8 \mathrm{C})\end{array}$ \\
\end{tabular} & \begin{tabular}{|c|} 
Projeto arq. \\
edif. altura \\
(8C)
\end{tabular} & \begin{tabular}{|c|} 
Projeto arq. \\
func. Compl. \\
$(8 \mathrm{C})$
\end{tabular} & $\begin{array}{l}\text { Projeto } \\
\text { urbanis. } 1 \\
(8 \mathrm{C})\end{array}$ & $\begin{array}{c}\text { Projeto } \\
\text { urbanis. } 2 \\
(8 \mathrm{C})\end{array}$ & Introd. TFG & TFG \\
\hline $\begin{array}{c}\text { Introduç. arq. } \\
\text { urb. (4C) }\end{array}$ & $\begin{array}{c}\text { Hist. arq. arte } \\
1(4 C)\end{array}$ & $\begin{array}{c}\text { Hist. arq. arte } \\
2(4 C)\end{array}$ & $\begin{array}{l}\text { Arq. urb. soc. } \\
\text { Indust. (4C) }\end{array}$ & $\begin{array}{l}\text { Arq. urb. } \\
\text { col. Império } \\
\text { (4C) }\end{array}$ & \begin{tabular}{|c|} 
Projeto arq. \\
proj. paisag. 1 \\
(8C)
\end{tabular} & $\begin{array}{l}\text { Arq. urb. } \\
\text { atualidade } \\
\text { (4C) }\end{array}$ & $\begin{array}{l}\text { Técnicas } \\
\text { retrosp. } \\
\text { (8C) }\end{array}$ & $\begin{array}{c}\text { Ensaio } \\
\text { teórico (4C) }\end{array}$ & \\
\hline $\begin{array}{l}\text { Desenho e } \\
\text { plast. } 1 \text { (4C) }\end{array}$ & $\begin{array}{l}\text { Mod. Trid. } \\
\text { Digital arq. } \\
\text { (4C) }\end{array}$ & $\begin{array}{l}\text { Desenho e } \\
\text { plast. } 2 \text { (4C) }\end{array}$ & $\begin{array}{l}\text { Conforto amb. } \\
\text { luminoso (2C) }\end{array}$ & $\begin{array}{l}\text { Instal. E } \\
\text { equip. (4C) }\end{array}$ & $\begin{array}{l}\text { Arq. urb. } \\
\text { Brasil cont. } \\
\text { (4C) }\end{array}$ & $\begin{array}{c}\text { Planej. } \\
\text { Urbano (4C) }\end{array}$ & $\begin{array}{l}\text { Estagio } \\
\text { superv. } \\
\text { obra }\end{array}$ & & \\
\hline $\begin{array}{l}\text { Desenho arq. } \\
\text { (4C) }\end{array}$ & $\begin{array}{l}\text { Est. amb. } \\
\text { Bioclimatico } \\
\text { (2C) }\end{array}$ & $\begin{array}{l}\text { Mod. Inf. } \\
\text { Constr. BIM } \\
\text { (2C) }\end{array}$ & $\begin{array}{l}\text { Conforto } \\
\text { sonoro }(2 \mathrm{C})\end{array}$ & $\begin{array}{c}\text { Materiais } \\
\text { de construç. } \\
(6 \mathrm{C})\end{array}$ & $\begin{array}{l}\text { Infra estrut. } \\
\text { urbana }(2 C)\end{array}$ & $\begin{array}{l}\text { Estética } \\
\text { hist. arte } \\
\text { (4C) }\end{array}$ & & & \\
\hline
\end{tabular}




\begin{tabular}{|c|c|c|c|c|c|c|c|c|}
\hline $\begin{array}{c}\text { Geometria } \\
\text { construt. (4C) }\end{array}$ & $\begin{array}{c}\text { Topografia } \\
\text { (4C) }\end{array}$ & $\begin{array}{c}\text { Conforto } \\
\text { term. Amb. } \\
\text { (4C) }\end{array}$ & $\begin{array}{c}\text { Sist. Estrut. } \\
\text { aço (4C) }\end{array}$ & $\begin{array}{c}\text { Sist. Estrut. } \\
\text { madeira } \\
\text { (4C) }\end{array}$ & $\begin{array}{c}\text { Técnicas de } \\
\text { construç. (4C) }\end{array}$ & $\begin{array}{c}\text { Estagio } \\
\text { superv. } \\
\text { Proj. }\end{array}$ & & \\
\hline $\begin{array}{c}\text { Introd. Tec. } \\
\text { arq. urb. (4C) }\end{array}$ & $\begin{array}{c}\text { Sist. Estrut. } \\
\text { Arq. (8C) }\end{array}$ & $\begin{array}{c}\text { Sist. Estrut. } \\
\text { Concr. Arm. } \\
\text { (8C) }\end{array}$ & & & & \\
\hline
\end{tabular}

De acordo com o Quadro 17, as disciplinas da área da Tecnologia da Construção são ministradas no 1으, 5o e 6o períodos do curso (1으 e 3 o anos), com um intervalo de 3 semestres entre a disciplina introdutória e a seguinte, de Materiais de Construção. A área da Tecnologia da Arquitetura ocupa 29\% dos créditos destinados às disciplinas obrigatórias (sem considerar os Estágios supervisionados em projeto e obra, Introdução ao TFG e TFG), sendo $7 \%$ dos créditos direcionados às disciplinas da área da Tecnologia da Construção, 12\% Sistemas Estruturais, 5\% Conforto Ambiental, 2\% Instalações Prediais e 3\% Outras (Topografia e Infraestrutura Urbana).

\section{c) Quadro docente}

As disciplinas da área da Tecnologia da Construção são ministradas tanto por professores pertencentes ao quadro docente do curso de Engenharia Civil (formação em engenharia civil) como também por professores do Departamento de Tecnologia da FAU UNB (com formação em arquitetura e engenharia civil). Apenas as disciplinas de Materiais de Construção e Topografia são ministradas por professores não pertencentes ao quadro docente da FAU, sendo as demais assumidas pelo próprio curso: cadeia das disciplinas de Estruturas, Conforto, Instalações Prediais e Infraestrutura urbana.

\section{d) Práticas didáticas e Infraestrutura laboratorial}

\section{- Considerações históricas sobre a área laboratorial}

O processo de implantação do curso da FAU UNB se desenvolveu sob bases muito particulares, cuja proposta pedagógica é indissociável de um contexto mais amplo: uma universidade em construção, inserida em uma cidade em construção. Em 1962, sob a coordenação de Oscar Niemeyer, o Centro de Estudos e Planejamento Arquitetônico e Urbanístico - Ceplan ${ }^{144}$, hoje chamado de Centro de Planejamento Oscar Niemeyer, seria encarregado do planejamento do crescimento físico da nova universidade. O curso de Arquitetura e Urbanismo na UNB teve como objeto privilegiado de estudo a própria cidade de Brasília e o espaço de treinamento prático a própria Universidade em construção.

Com o conteúdo estruturado em três "troncos": Teoria, Composição e Tecnologia, o curso era dividido em dois momentos de formação: o Curso Base de dois anos e o Curso profissionalizante de três anos e, em ambos os momentos, o aluno tinha uma estrutura peculiar de apoio ligada à prática experimental. No curso fundamental havia o contato com o trabalho realizado em diversas oficinas (ver Figura 77), sob o viés bauhauseano e, posteriormente, juntando atividade profissional e didática.
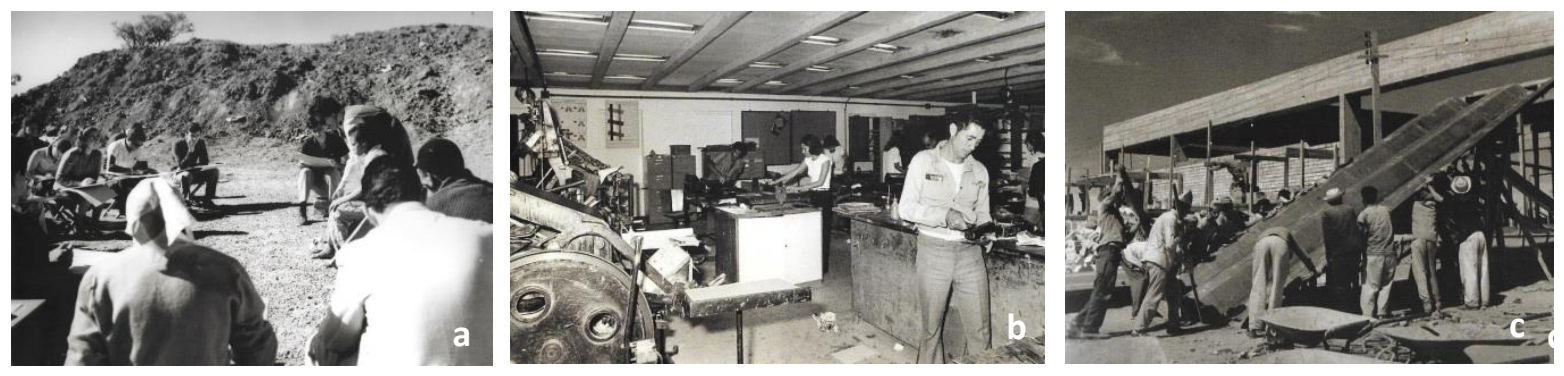

Figura 77 - Imagens do início da implantação da UNB e do curso de Arquitetura e Urbanismo. a) Aula no exterior, em contato com a natureza e o ambiente arquitetônico. b) Oficinas e convivência aluno/professor: além do limite da sala de aula. c) Início das obras na UNB.

Fonte: UNB: 50 anos (2012).

\footnotetext{
${ }^{144}$ Durante a ditadura o Ceplan tinha outro nome: Laboratório Experimental em Arquitetura e Urbanismo - LEAU.
} 


\section{- Cenário Atual}

A Faculdade de Arquitetura e Urbanismo está sediada no ICC - Instituto Central de Ciências - e possui laboratórios em diferentes áreas do ensino, os da Tecnologia da Arquitetura são: Laboratório de Conforto Ambiental e Eficiência Energética - LACAM; o Laboratório de Tecnologia da Construção LABCON - e o Laboratório de Modelos Reduzidos/Maquetaria.

O LABCON é um laboratório cuja implantação ainda é recente, voltado apenas à atividade de pesquisa e extensão com um determinado material, os blocos de solo, não se apresentando configurado como laboratório para atendimento ao ensino e manipulação de diferentes materiais construtivos.

O Laboratório de Modelos Reduzidos/Maquetaria (Figura 78) é composto por um espaço destinado a atelier, (de uso compartilhado com diferentes disciplinas) e que está interligado à Sala de Máquinas, voltadas ao beneficiamento da madeira e processamento de peças para confecção de maquetes, este espaço tem como apoio um depósito de materiais e ferramentas.

Em ambos os laboratórios não há a presença de técnicos, onde o professor é tanto o coordenador do espaço como também responsável por todo o processo que envolve as práticas experimentais, contando eventualmente, com a contribuição dos alunos.

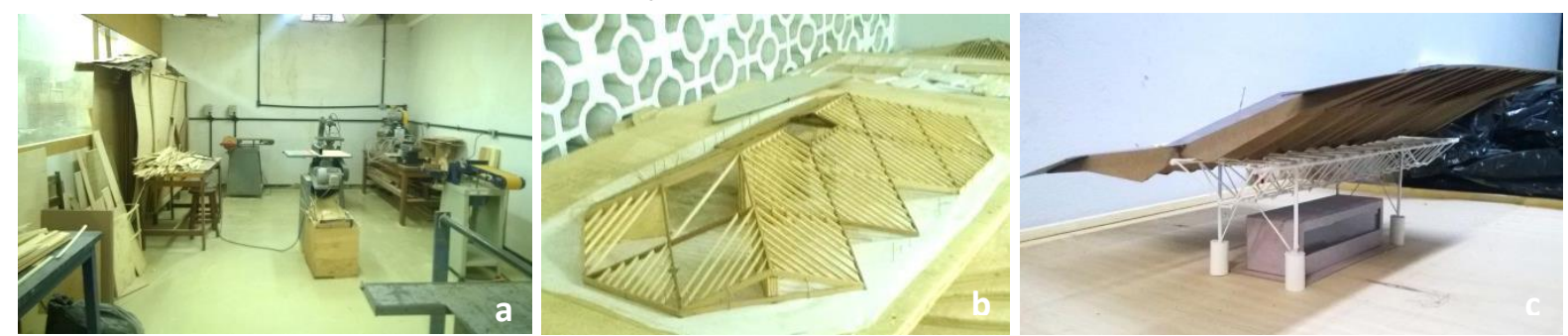

Figura 78 - Laboratório de Modelos Reduzidos. a) Sala de Máquinas interligado ao espaço de Atelier. b) e c) Maquetes de diferentes sistemas construtivos estudados na disciplina optativa: Oficina de Maquetes.

Fonte: fotos da autora

Sobre as disciplinas da área da Tecnologia da Construção, a FAU assume tanto a disciplina de Introdução à Tecnologia da Arquitetura como também de Técnicas de Construção e Estágio em Obra (arquitetos e engenheiros), já a disciplina de Materiais de construção, é assumida pelo curso de Engenharia Civil sendo ministrada por professores engenheiros.

- Em Introdução a Tecnologia da Arquitetura e Urbanismo, há rotatividade de professores que a ministram e, com isso, diferentes estratégias pedagógicas são aplicadas, mas sempre com o mesmo objetivo: fornecer ao aluno iniciante uma visão global sobre concepção estrutural, materiais e sistemas construtivos, ampliando o vocabulário técnico sobre estas questões e a relação da materialidade com o projeto arquitetônico. Esta disciplina também tem como objetivo, introduzir os alunos para as demais disciplinas de Sistemas estruturais (quando são realizadas outras abordagens como o cálculo) e a integração vertical com Projeto arquitetônico I.

Quanto às práticas didáticas, não são trabalhados na disciplina procedimentos baseados em cálculo matemático, priorizando o processo intuitivo experimental por meio de modelos elaborados em computador e reproduzidos, posteriormente, em modelos físicos reduzidos. Neste processo os alunos concebem, constroem e manipulam um projeto, envolvendo todo o processo executivo. Pela ausência de laboratório na área da Tecnologia da Construção, a abordagem sobre materiais e técnicas construtivas é realizada por meio de visitas a obras. A construção de protótipos em outra escala, além da reduzida, é uma prática realizada de forma esporádica, não sendo utilizados espaços formalizados para esta função.

- A disciplina de Materiais de Construção sempre foi ministrada pelo curso de Engenharia Civil e está dividida em duas disciplinas: voltada a aulas teóricas (4C) e voltada à aula experimental em laboratório (2C). Nas aulas experimentais são realizados ensaios sobre as propriedades físicas e mecânicas dos materiais, com a utilização da infraestrutura laboratorial da FT (Faculdade de Tecnologia). Neste laboratório os alunos realizam os experimentos baseados nas normas técnicas e 
com o acompanhamento de técnicos (que manipulam as máquinas), voltados prioritariamente, a análise de materiais de base cimentícia como argamassas e concreto.

- Em Técnicas de Construção, o conteúdo é amplo, e refere-se às diferentes etapas da materialização das edificações e as interações entre a obra e o projeto arquitetônico. Devido ao aluno já ter visto toda a cadeia de estruturas, eles não trabalham com protótipos e sim com procedimentos construtivos. A disciplina é dividida em Módulos: no Módulo I, são apresentadas as principais técnicas de construção utilizadas no país, com discussão crítica e exercícios desenvolvidos a partir de problemas específicos da construção, desde a parte documental de implantação até acabamentos e processo de degradação. No Módulo II, são realizadas visitas em obra, com discussão crítica fundamentada nas práticas observadas e no conteúdo teórico. O Módulo III, é trabalhado com base no projeto arquitetônico, onde os alunos elaboram caderno de detalhamento, manual construtivo e detalhes construtivos. Conteúdos relacionados a sustentabilidade como ciclo de vida, cadeia produtiva, logística reversa e baixo impacto ambiental são abordados ao longo da disciplina, com a apresentação de terminologias, sem aprofundamento no assunto.

- O Estágio Supervisionado em Obra, segundo os relatos, passou a ser uma disciplina bem estruturada e com resultados muito positivos. Trata-se de uma atividade realizada junto a obra(s) nas empresas públicas ou privadas, com participação efetiva do aluno nesta experiência profissional colaborando com a realização de trabalhos executados, sob a responsabilidade de profissionais legalmente habilitados. Nesta oportunidade o aluno consegue relacionar o conteúdo das disciplinas e a viabilidade de aplicação no contexto real, com o acompanhamento sistemático do professor responsável pela disciplina e a elaboração de relatórios. Não foi relatada a existência de seguro para a realização desta atividade didática.

\section{e) Pós graduação ${ }^{145}$ :}

A pós-graduação stricto sensu da FAU-UnB data de 1962, sendo desenvolvida, em nível de mestrado, em concomitância com a criação da Universidade de Brasília, sendo o primeiro na área de Arquitetura e Urbanismo no país. O curso foi encerrado em 1965, devido a crise política iniciada em 1964 sendo as atividades retomadas a partir de 1976, no quadro do $2^{\circ}$ Plano Nacional de Desenvolvimento ( $2^{\circ}$ PND), com a criação do Mestrado em Planejamento Urbano, cujo objetivo principal era atender as demandas por capacitação de recursos humanos no campo das políticas públicas e do desenvolvimento das cidades, contando com apoio do então Conselho Nacional de Política Urbana da Secretaria de Planejamento (CNPU/SEPLAN). Em 1986, a partir do Mestrado em Planejamento Urbano, foi criado o Mestrado em Desenho Urbano, voltado para o estudo da configuração físico-espacial das cidades. O Doutorado vinculado ao programa foi aprovado em 2002.

Atualmente, as áreas de concentração oferecidas são:

THC - Teoria, história e crítica.

TAS - Tecnologia, ambiente e sustentabilidade.

PP - Projeto e planejamento.

E as linhas de pesquisa seguidas da sigla da área de concentração onde está inserida:

1. História e Teoria da Arquitetura (THC):

2. História e Teoria da Cidade e do Urbanismo (THC):

3. Patrimônio e Preservação (THC):

4. Estética, Hermenêutica e Semiótica (THC):

5. Estruturas e Arquitetura (TAS):

6. Sustentabilidade, Qualidade e Eficiência do ambiente construído (TAS):

7. Técnicas e processos de produção do ambiente construído (TAS):

8. Projeto e Planejamento Edilício (PP):

9. Projeto e Planejamento Urbano e Regional (PP):

O curso apresenta a possibilidade de realizar pesquisas na área da Tecnologia da Construção, tanto em nível de mestrado como doutorado.

\footnotetext{
${ }^{145}$ Dados disponíveis em: http://www.ppgfau.unb.br/institucional/historico-da-ppg-fau. Acesso em: 27/09/2016.
} 


\section{f) Comentários:}

- Disciplinas inseridas em diferentes áreas de concentração possuem caráter de integração com a área da tecnologia: Técnicas Retrospectivas, Ateliers de projeto (como Grandes Vãos), Optativas na área de Representação (como Oficina de Maquete);

- Foi considerado positivo o diálogo com outros centros e a interatividade com outros profissionais (como ocorre com a parceria com o curso da Engenharia Civil ao assumirem a cadeira de Materiais de Construção), e que este cenário deveria expandir pois, atualmente, a maioria das disciplinas são oferecidas pelo próprio curso, deixando o aluno da FAU desconectado com outros centros e cursos, diferentemente da primeira proposta pedagógica do curso, que promovia a interdisciplinaridade departamental por meio da realização de 2 anos em disciplinas básicas e genéricas (cursadas com alunos de diferentes áreas) e 3 anos de disciplinas profissionalizantes, considerada por diversos entrevistados como uma proposta muito positiva;

- Uma questão que está em processo de discussão seria o reposicionamento das disciplinas de Materiais e Técnicas de Construção, hoje alocadas no 50 e 60 períodos. A intenção seria trazê-las para o início do curso, pois na proposta em vigor, os alunos cursam diversos Ateliers de Projeto com pouco conhecimento acerca dos materiais e técnicas construtivas, dificultando que o conhecimento destas disciplinas seja refletido no Projeto do Edifício. Esta distância existente entre a disciplina de Introdução à Tecnologia da Arquitetura e Materiais e Técnicas de Construção está sendo minimizada gradualmente, nas disciplinas de Projeto, Conforto Ambiental, Estruturas e outras que abordam aspectos ligados à materialidade;

- Há uma sinalização de que, atualmente, a disciplina de Materiais de Construção possui uma abordagem muito direcionada a um determinado material construtivo, como o concreto, havendo discussões para que a abordagem seja ampliada para os demais materiais construtivos, assim como ocorre em outros momentos do curso como a cadeia de disciplinas de Estruturas;

- Embora o curso não tenha Infraestrutura laboratorial voltada para o ensino na área da Tecnologia da Construção, outras estratégias pedagógicas são adotadas nas disciplinas de forma a atingir todos os alunos, como a confecção de modelos reduzidos, as visitas técnicas e o Estágio obrigatório em obra. Além disso, são oferecidas aos alunos interessados na área, oportunidades pontuais para a ampliação do conhecimento técnico, como as disciplinas Seletivas Obrigatórias e os Projetos de Pesquisa (IC) e Extensão na área da construção;

- A implantação de um Laboratório de Construção/Canteiro Experimental (nome ainda não definido), já foi pauta de discussão em vários momentos do curso, com a elaboração de diversas propostas para a construção deste espaço. Nestas discussões chegaram a conseguir um terreno, o qual já está delimitado para que, futuramente, seja construído e o curso não conte somente com o apoio do laboratório da FT (Faculdade de Tecnologia);

- A falta de técnicos não apenas nos laboratórios da FAU como também na FT, foi levantada como uma condicionante dificultadora para a ampliação e sustentação das atividades experimentais nas disciplinas obrigatórias. Este problema também se estende ao curso noturno, pela dificuldade na obtenção de técnicos para atenderem os alunos neste período. A infraestrutura da engenharia é apenas utilizada para a realização da disciplina de Materiais de Construção - práticas experimentais mas não em outros momentos do curso.

\section{8- CAU - UFPR - Curso de Arquitetura e Urbanismo da Universidade Federal do Paraná ${ }^{146}$}

\footnotetext{
146 Dados obtidos a partir da visita técnica realizada em 11/06/2014, às instalações do CAU UFPR, com entrevistas direcionadas ao coordenador de curso, prof. Paulo Chiesa e também a um dos professores pertencentes à área da Tecnologia, prof. Carlos Alberto Adão (embora seja professor de disciplinas da área de Estruturas, o professor contribuiu com informações sobre a estruturação da área técnica do curso).
} 


\section{a) Breve Histórico ${ }^{147}$}

O Curso de Arquitetura e Urbanismo da Universidade Federal do Paraná (CAU-UFPR) foi criado em 1962, a partir de gestões iniciadas por uma comissão especial de professores da Escola de Engenharia do Paraná. O primeiro grupo de alunos foi formado por terceiranistas do curso de Engenharia Civil que deram continuidade aos estudos cursando cadeiras relativas ao ensino da Arquitetura e Urbanismo, graduando-se em arquitetura em março de 1965.

Antes da formatura da primeira turma de arquitetos do CAU, atuavam na área engenheiros civis e arquitetos formados em outros Estados. A consolidação do curso foi favorecida por fatores como o surto de crescimento econômico do Estado, a urbanização acelerada da capital a partir de 1950 e a disseminação do ideário modernista no território nacional.

Na primeira fase, a Escola de Engenharia da UFPR constituiu uma comissão especial de professores com os engenheiros Rubens Meister, Ralph Leitner e Samuel Chamecki que encomenda ao arq. Lúcio Costa uma proposta de currículo, que não chega a ser implantada. Com a colaboração de dois jovens professores de Belo Horizonte, os arquitetos José Marcos Loureiro Prado e Armando Strambi, é formulada a estrutura e organização curricular do novo curso.

O corpo docente pioneiro é formado por profissionais oriundos de duas escolas: a carioca e a paulista, responsáveis pela vanguarda da arquitetura moderna na época. Porém, deve-se também registrar a presença de profissionais oriundos do Rio Grande do Sul e do Paraná - esses últimos, também formados no Rio de Janeiro e São Paulo.

A direção do curso de arquitetura coube à Escola de Engenharia, e apenas em 1965 foram constituídos os Departamentos de Composição e de Teoria e História da Arquitetura e contratados arquitetos para cumprir as funções docentes e administrativas referentes a essas áreas. As disciplinas da área de tecnologia eram de responsabilidade do Departamento de Técnicas Construtivas existente no Curso de Engenharia. Outros departamentos da UFPR colaboravam ministrando as disciplinas de áreas complementares à formação do arquiteto, tais como: desenho, topografia, sociologia, economia, estatística, etc.

Com a reforma universitária de 1969 é criado o Setor de Tecnologia da UFPR, a antiga Escola de Engenharia transforma-se em Curso de Engenharia, com várias modalidades organizadas em departamentos e o CAU fica subordinado à direção do Setor de Tecnologia. Em 1972 é criado o Colegiado do Curso de Arquitetura e Urbanismo para coordenar o conjunto de disciplinas ministradas pelos demais departamentos no CAU. Em 1973 é criado o Departamento de Arquitetura e Urbanismo (DAU) a partir da fusão dos Departamentos de Composição e Teoria e História.

A publicação da portaria no 1.770/94 do MEC, estabelecendo o novo currículo mínimo para a área de Arquitetura e Urbanismo cria as condições para que uma comissão de professores e estudantes apresentasse uma proposta de reestruturação curricular profunda do curso. Uma vez aprovado o novo currículo, foi iniciada a sua implantação no ano letivo de 1996.

No currículo pleno de 1996 foi mantido o que para o curso se considerava ser a principal qualidade do CAU: o ensino e a prática do projeto, afirmando o ateliê de projeto como a espinha dorsal do processo de formação do arquiteto. Atualmente, esta ênfase no projeto pode ser visualizada na estruturação do currículo e do quadro docente.

\section{b) Considerações sobre a Estruturação da área de Tecnologia da Construção}

Após a adesão no Programa REUNI o CAU passou a oferecer 60 vagas semestrais. E, após 53 anos de existência ainda é reconhecido pela ênfase nas atividades de ensino de arquitetura e urbanismo dirigido ao Ateliê de Projeto. O currículo está dividido em 04 áreas do conhecimento: Projeto, Urbanismo, Teoria/História e Tecnologia.

O conteúdo está distribuído em Núcleo de Conhecimentos de Fundamentação, Núcleo de Conhecimentos Profissionais e o Trabalho Final de Curso. As disciplinas apresentam a seguinte distribuição:

\footnotetext{
${ }^{147}$ Informações obtidas a partir da proposta preliminar do Projeto Político Pedagógico do Curso, reformulado em 2013.
} 
Quadro 18 - Distribuição da Grade Curricular com a carga horária semestral - CAU UFPR:

\begin{tabular}{|c|c|c|c|c|c|c|c|c|c|}
\hline 10 sem & 20 sem & 3ㅇ sem & 4\% sem & 5ㅇ sem & 60 sem & 70 sem & 80 sem & 9ㅇ sem & $10 \%$ sem \\
\hline $\begin{array}{l}\text { Fund. da Arq. } \\
\qquad \text { I (2C) }\end{array}$ & $\begin{array}{l}\text { Fundam. do } \\
\text { Paisag. (2C) }\end{array}$ & \begin{tabular}{|c|} 
Arquitetura I \\
$(8 \mathrm{C})$
\end{tabular} & $\begin{array}{l}\text { Ateliê de Arq e } \\
\text { Paisag. I (8C) }\end{array}$ & $\begin{array}{c}\text { Arquitetura } \\
\text { II (8C) }\end{array}$ & \begin{tabular}{|l} 
Ateliê de Arq \\
Paisag. II (8C)
\end{tabular} & $\begin{array}{c}\text { Arquitetura } \\
\text { III (8C) }\end{array}$ & $\begin{array}{c}\text { Arquitetura } \\
\text { IV (8C) }\end{array}$ & $\begin{array}{c}\text { Arquitetura } \\
\mathrm{V}(4 \mathrm{C})\end{array}$ & TFG II \\
\hline $\begin{array}{l}\text { T. e Hist. da } \\
\text { Arq. I (3C) }\end{array}$ & $\begin{array}{c}\text { Fund. da Arq. } \\
\text { II (2C) }\end{array}$ & $\begin{array}{c}\text { Paisagismo I } \\
\text { (3C) }\end{array}$ & $\begin{array}{c}\text { Cidade e Meio } \\
\text { Amb. II (2C) }\end{array}$ & $\begin{array}{c}\text { Paisagismo } \\
\text { II (3C) }\end{array}$ & $\begin{array}{c}\text { Est. Urb. e } \\
\text { Regio. II (2C) } \\
\end{array}$ & $\begin{array}{l}\text { Planj. Urb. } \\
\text { Reg. I (5C) } \\
\end{array}$ & \begin{tabular}{c|} 
Arq. \\
Interior 4C) \\
\end{tabular} & \begin{tabular}{|c|} 
Desenho \\
Urb. VI (3C)
\end{tabular} & \\
\hline $\begin{array}{l}\text { Estudos da } \\
\text { Forma I (6C) }\end{array}$ & $\begin{array}{l}\text { T. e Hist. da } \\
\text { Arq. II (3C) }\end{array}$ & $\begin{array}{c}\text { Cidade e Meio } \\
\text { Amb. I (2C) }\end{array}$ & $\begin{array}{l}\text { História da } \\
\text { Arte II (2C) }\end{array}$ & $\begin{array}{c}\text { Est. Urb. e } \\
\text { Regio. I (2C) }\end{array}$ & \begin{tabular}{|c|} 
Desenho \\
Urbano I (3C)
\end{tabular} & \begin{tabular}{|c|} 
Desenho \\
Urb. II (3C)
\end{tabular} & $\begin{array}{l}\text { Planj. Urb. } \\
\text { Reg. II (5C) }\end{array}$ & Orient. & \\
\hline $\begin{array}{c}\text { Desenho Arq. } \\
\text { I (6C) }\end{array}$ & $\begin{array}{l}\text { Estudos da } \\
\text { Forma II }(6 C)\end{array}$ & $\begin{array}{l}\text { História da } \\
\text { Arte I (2C) }\end{array}$ & $\begin{array}{l}\text { T. e Hist. da } \\
\text { Arq. IV (3C) }\end{array}$ & $\begin{array}{c}\text { Hist. da Cid. } \\
\text { I (2C) }\end{array}$ & \begin{tabular}{|c} 
Hist. da Cid. I \\
(2C)
\end{tabular} & \begin{tabular}{|l} 
Patr. Tec. \\
Retr. I (2C)
\end{tabular} & $\begin{array}{c}\text { Desenho } \\
\text { Urb. III (3C) }\end{array}$ & & \\
\hline $\begin{array}{l}\text { Inform. na } \\
\text { Arq. (3C) }\end{array}$ & $\begin{array}{c}\text { Desenho Arq. } \\
\text { II (6C) }\end{array}$ & $\begin{array}{l}\text { T. e Hist. da } \\
\text { Arq. III (3C) }\end{array}$ & $\begin{array}{c}\text { Amb. Const. II } \\
\text { (3C) }\end{array}$ & $\begin{array}{l}\text { Arq. Brasil. I } \\
\text { (3C) }\end{array}$ & $\begin{array}{l}\text { Arq. Brasil. I } \\
\text { (3C) }\end{array}$ & $\begin{array}{l}\text { Saneam. } \\
\text { Urb II (2C) }\end{array}$ & $\begin{array}{l}\text { Patr. Tec. } \\
\text { Retr. II (2C) }\end{array}$ & & \\
\hline $\begin{array}{c}\text { Expressão } \\
\text { Gráfica I (4C) }\end{array}$ & $\begin{array}{c}\text { Modelag. } \\
\text { Comput. (3C) }\end{array}$ & \begin{tabular}{|c|} 
Amb. Const. I \\
(3C)
\end{tabular} & $\begin{array}{l}\text { Construção } \\
\text { Civil II (2C) } \\
\end{array}$ & $\begin{array}{c}\text { Amb. Const. } \\
\text { III (2C) }\end{array}$ & \begin{tabular}{|c} 
Saneam. \\
Urbano I (2C)
\end{tabular} & & & & \\
\hline $\begin{array}{l}\text { Materiais de } \\
\text { Constr. I (2C) }\end{array}$ & $\begin{array}{c}\text { Expressão } \\
\text { Gráfica II (4C) } \\
\end{array}$ & $\begin{array}{c}\text { Construção } \\
\text { Civil I (2C) }\end{array}$ & \begin{tabular}{|c|} 
Sistemas \\
Estrut. II (2C) \\
\end{tabular} & $\begin{array}{c}\text { Instal. Pred. } \\
\text { I (2C) }\end{array}$ & \begin{tabular}{|c} 
Amb. Const. \\
IV (2C) \\
\end{tabular} & & & & \\
\hline Estática (3C) & $\begin{array}{l}\text { Materiais de } \\
\text { Constr. II (2C) }\end{array}$ & $\begin{array}{c}\text { Sistemas } \\
\text { Estrut. I (2C) }\end{array}$ & & $\begin{array}{c}\text { Estrut. } \\
\text { Concr. (4C) }\end{array}$ & $\begin{array}{l}\text { Instal. Pred. } \\
\text { II (2C) }\end{array}$ & & & & \\
\hline $\begin{array}{c}\text { Topografia B-I } \\
\text { (3C) }\end{array}$ & $\begin{array}{c}\text { Resistencia } \\
\text { dos Mat. (3C) }\end{array}$ & & & Estag. Sup. & \begin{tabular}{|l} 
Estrut. Metal \\
Madeir. (4C) \\
\end{tabular} & & & & \\
\hline & $\begin{array}{c}\text { Topografia B-II } \\
\text { (3C) }\end{array}$ & & & & & & & & \\
\hline
\end{tabular}

Disciplinas de Projeto

Disciplinas de Representação Gráfica e comp.
Disciplinas de Urbanismo e Meio Ambiente

Disciplinas na área da Tecnologia da Arquitetura

Disciplinas de Historia e Teoria * A setorização de algumas disciplinas de acordo com determinadas áreas de concentração não consta na proposta do Projeto
Pedagógico do curso consultada, sendo a organização apresentada uma versão adaptada pela autora.

$\mathrm{Na}$ intenção de estabelecer o processo classificatório geral para todas escolas, foi considerada a distribuição mais tradicional e recorrentemente utilizadas. A partir disso, foram realizadas algumas modifiçções em dados constantes no PPC, descritas visualizadas no Quadro 18, são elas: a disciplina de Topografia foi considerada como sendo da área da Tecnologia e as disciplinas da área de Paisagem e Paisagismo agrupadas no Item: Disciplinas de Urbanismo e Meio Ambiente. No caso das disciplinas da área de Representação, estas foram dissociadas de Projeto e organizadas em um grupo próprio: Disciplinas de Representação Gráfica e Computacional.

As disciplinas da área da Tecnologia ocupam $23 \%$ dos créditos destinados às disciplinas obrigatórias (no cômputo não foram considerados os créditos destinados ao Estágio supervisionado, Orientação, Optativas e Trabalho Final de Graduação - TFG). A partir do Quadro 15, é observado que as disciplinas de Tecnologia são ministradas entre o 1ㅇ e o 8 o períodos e que as disciplinas da Tecnologia da Construção (Materiais de Construção e Construção Civil) são ministradas nos dois primeiros anos (do 10 ao 4 o períodos), ocupando $4 \%$ dos créditos gerais. As disciplinas de estruturas ocupam $8 \%$, seguidas de Ambiente Construído (conteúdo de Conforto Ambiental) com 4,5\%, Instalações prediais com 2\% e Outras (Topografia e Saneamento Urbano) com 4,5\%.

\section{c) Quadro docente}

De acordo com os dados publicados pelo site oficial do $\mathrm{CAU}^{148}, 61 \%$ do corpo docente do curso é composto por professores contratados em regime de Dedicação Exclusiva, 11\% em regime de 40 horas semanais e $28 \%$ em regime de 20 horas semanais.

No momento da visita técnica, a área da Tecnologia da Arquitetura contava com 03 docentes: 01 docente DE na área do Ambiente Construído (Conforto Ambiental), 01 professor 40h na área de Sistemas Estruturais e 01 professor 20h (substituto) na área da Tecnologia da Construção (Materiais de Construção e Construção Civil), as disciplinas de instalações prediais são ofertadas pelo Departamento de Hidráulica e Saneamento urbano e as disciplinas de Topografia pelo Departamento de Geomática.

\footnotetext{
${ }^{148}$ Disponível em: www.cau.ufpr.br. Acesso em 18/02/2016.
} 
A incorporação da área da Tecnologia ocorreu em 1982, com a entrada de professores engenheiros no curso, antes deste período (durante quase 20 anos), as aulas ocorriam integralmente na engenharia.

\section{d) Práticas didáticas e Infraestrutura laboratorial}

O CAU conta com seis laboratórios de apoio às atividades de ensino, pesquisa e extensão e 02 técnicos.

Quanto ao Laboratório de Tecnologia das Construções para apoio às aulas das áreas de Tecnologia e Projeto, a nova proposta do Projeto Político Pedagógico do curso/2013, reconhece sua inexistência e que o mesmo representa uma enorme condicionante ao desenvolvimento do raciocínio tecnológico e inovador da área. Atualmente, esta questão está sendo resolvida (em caso de necessidade) através do compartilhamento de infraestrutura existentes em outros cursos do Setor da Tecnologia. Foi declarada neste mesmo documento a intenção do curso, em médio prazo, em construir um laboratório nesta área para o CAU, para evitar a divisão de espaços e agendas sobrecarregadas dos laboratórios pertencentes a outros cursos.

De acordo com o Projeto Pedagógico do curso, as ementas publicadas sobre as disciplinas da área da Tecnologia da Construção são consideradas como teóricas, classificando as disciplinas de Materiais de Construção I e II como do Núcleo de conhecimentos de Fundamentação e as de Construção Civil I e II como do Núcleo de conhecimentos Profissionalizantes.

Segundo este documento, a disciplina Materiais de Construção I, faz uma Introdução sobre os principais materiais utilizados na construção civil e, em Materiais de Construção II, os assuntos referem-se à aplicação, produtos e às propriedades dos materiais de construção. Entre as disciplinas do Núcleo Profissionalizante, a de Construção Civil I aborda a Indústria da construção civil como: Etapas e organização de obras e sistemas e processos construtivos. Em Construção Civil II envolve conteúdos sobre a Tecnologia dos processos construtivos e Normas de segurança do trabalho.


Figura 79: Implantação de atividades de caráter experimental- CAU/UFPR. a) Possível local de implantação do futuro canteiro experimental. b) e c) Atividades realizadas em 2015, inexistentes no período da visita técnica em 2014.

Fonte: Disponível em: http://www.cau.ufpr.br/portal/canteiro-experimental/. Acesso em 22/02/2016.

\section{e) Pós graduação:}

O curso não apresenta pós-graduação stricto sensu, oferece apenas os seguintes cursos de especialização:

- Geoprocessamento

- Cidade, meio ambiente e políticas públicas.

\section{f) Comentários:}

- No Projeto Político Pedagógico do curso, é reconhecida a importância de laboratórios próprios da área da Tecnologia da Construção para o ensino. Como a área da Tecnologia da Construção está em fase de reformulação, a implantação de espaços experimentais, provavelmente, poderá fazer parte das ações reestruturantes futuras do curso;

- Embora seja um curso criado dentro da escola de engenharia, a área da tecnologia apresenta reduzido número de docentes. Este cenário aliado ao regime de trabalho (com apenas 01 professor com dedicação exclusiva e nenhum professor efetivo na área da Tecnologia da Construção) dificulta a presença constante de professores no departamento para realização de atividades de pesquisa e de obtenção de recursos para a área técnica; 
- A utilização de laboratórios para a realização de atividades práticas da área da tecnologia da construção ocorre, eventualmente, em outros departamentos como da engenharia mecânica e civil;

- O estágio em obra, antes ofertado em regime obrigatório, passou a ser opcional;

- No trabalho de Vidigal $(2010)^{149}$, é relatado que um dos problemas envolvendo as disciplinas de tecnologia do curso relaciona-se ao distanciamento entre as disciplinas das áreas teóricas $e$ tecnológicas e o ensino de projeto, sendo apontada como uma lacuna histórica do ensino de tecnologia dos cursos analisados neste trabalho.

\section{9- DAU - UFC - Departamento de Arquitetura e Urbanismo da Universidade Federal do Ceará $^{150}$}

a) Breve Histórico ${ }^{151}$

A Escola de Arquitetura da Universidade Federal do Ceará foi criada em 05 de outubro de 1964. As atividades letivas do correspondente Curso de Graduação em Arquitetura foram realizadas no início do ano letivo de 1965, oferecendo vinte vagas de acesso em uma única entrada anual.

Em 1968, com a implantação da Reforma Universitária e consequente reestruturação da UFC (Decreto № 62.279), a Escola de Arquitetura foi transformada em Faculdade de Artes e Arquitetura, figurando entre as unidades que compunham o recém-criado Centro de Humanidades. Constituída de um único departamento, o Departamento de Projetos de Edificações e Urbanismo, teve nessa época os cursos de Arte Dramática e Canto Coral - cursos de formação de nível médio - anexados à sua estrutura.

Em 1973, após nova reformulação estrutural da UFC, a Faculdade de Artes e Arquitetura deu lugar ao Departamento de Arquitetura e Urbanismo (DAU-UFC) e ao Curso de Arquitetura e Urbanismo (CAU-UFC), e foram integrados ao Centro de Tecnologia, situação que se mantém até os dias atuais.

O curso foi instituído de forma autônoma, desvinculado da clássica ligação a escolas de Engenharia ou de Belas Artes, inspirando-se na pioneira escola de arquitetura da UNB para montar a sua primeira organização curricular. Optou pelo regime semestral com oferta de disciplinas pelo sistema de créditos antes da Reforma Universitária, com a participação de outras unidades acadêmicas na regência de matérias das outras áreas do conhecimento. Com a Reforma Universitária de 1977, o Curso de Arquitetura e Urbanismo passou a receber 40 alunos, em consequência da implantação do regime semestral para todos os demais cursos, adotado por recomendação do MEC.

Em 1982, uma nova reestruturação da UFC (Provimento no3/CONSUNI, de 10/09/1982), estabelece um novo conceito para as coordenações de curso de graduação, agora definidas como "órgão básico da administração escolar, tendo por função o planejamento, o acompanhamento, o controle e a avaliação das atividades de ensino do respectivo curso". A partir desta reestruturação, foram criadas as Unidades Curriculares, sendo estas constituídas pelo agrupamento de disciplinas afins, congregando professores que a elas se vinculam. Foram criadas cinco Unidades Curriculares: percepção e representação da forma; projeto arquitetônico; projeto urbanístico e paisagismo; história da arte e da arquitetura; e tecnologia.

Em janeiro de 1997, foi aprovado um novo currículo pelo Colegiado do DAU-UFC, a partir de um longo trabalho iniciado em outubro de 1995, com a abertura das atividades referentes à fixação das Diretrizes Curriculares, e o conteúdo mínimo de graduação em Arquitetura e Urbanismo a partir da Portaria no 1.770, de 21/12/1994, do Ministério da Educação e Desporto. Desde este momento, o

\footnotetext{
${ }^{149}$ VIDIGAL, E. J. O ensino de projeto arquitetônico. Um estudo sobre as práticas didáticas no curso de Arquitetura e Urbanismo na Universidade Federal do Paraná. Tese (Doutorado) FAUUSP, 2010. O autor deste trabalho é também professor de Projeto do CAU-UFPR.

${ }^{150}$ As informações sobre o curso foram obtidas por meio de visita técnica realizada às instalações físicas do Curso de Arquitetura e Urbanismo da UFC entre os dias 23 e 24/06/2016. A partir das tentativas de articulações realizadas junto aos professores ministrantes das disciplinas de Tecnologia da Construção e Coordenação, foi possível entrevistar apenas o professor coordenador de curso prof. Francisco Ricardo Cavalcanti Fernandes.

151 Informações retiradas do Projeto Político Pedagógico do curso, disponível em: http://www.ufc.br/ensino/cursos-degraduacao/183-arquitetura-e-urbanismo-fortaleza. Acesso realizado em: 28/05/2016.
} 
currículo sofreu diversos ajustes ao longo dos anos como parte do seu processo de revisão, observando as novas Diretrizes Curriculares Nacionais. A última atualização do Projeto Pedagógico do curso foi implantada em 2011 e vigora ainda hoje.
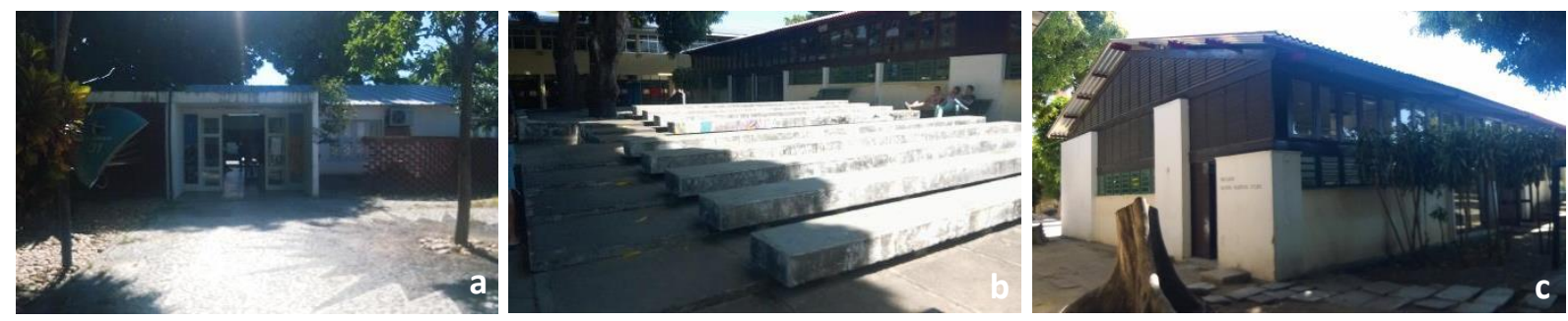

Figura 80: Imagens das instalações físicas do curso de Arquitetura e Urbanismo - UFC - a) Entrada principal ao Departamento de Arquitetura e Urbanismo. b) Pátio Interno. c) Edifício da Pós-Graduação.

Fonte: Fotos da autora.

\section{b) Considerações sobre a Estruturação da área da Tecnologia da Construção}

Até o ano de 2008 o curso oferecia 40 vagas anuais, após este período, com a adesão no Programa REUNI, o CAU-UFC passou a oferecer 64 vagas semestrais (1 semestre de 2009). O currículo está estruturado em eixos curriculares: percepção e representação; teoria e história da arquitetura e do urbanismo; projeto arquitetônico; projeto urbanístico; tecnologia e inter-áreas.

As disciplinas são ofertadas em sua maioria pelo Departamento de Arquitetura e Urbanismo, com exceção das disciplinas da área de Estruturas, ministradas por professores pertencentes ao quadro docente do Departamento de Engenharia Estrutural e Construção Civil, e as disciplinas de Topografia e Geometria, ofertadas pelo Departamento de Transportes.

De acordo com o Quadro 19, a distribuição das disciplinas consideradas da área da Tecnologia da Arquitetura é realizada entre o 20 e 60 períodos, somando aproximadamente $19 \%$ dos créditos destinados às disciplinas obrigatórias (sem considerar os Trabalhos de curso I e II e Estágio Supervisionado), sendo 3,7\% dos créditos destinados às disciplinas de Sistemas e Materiais de Construção I e II; 5,5\% para Estruturas; 3,7\% Conforto Ambiental; 3,7\% Instalações Prediais e 2\% outras (Topografia). As disciplinas da Tecnologia da Construção como Sistemas e Materiais de Construção I e II, estão alocadas no 3 ㅇ e 4 o períodos ( 2 ㅇ ano do curso).

Quadro 19 - Distribuição da Grade Curricular com a carga horária semestral - DAU UFC:

\begin{tabular}{|c|c|c|c|c|c|c|c|c|c|}
\hline 10 sem & 20 sem & 3ㅇ sem & 40 sem & 5ㅇ sem & 60 sem & 70 sem & 80 sem & 90 sem & $10 \%$ sem \\
\hline $\begin{array}{l}\text { Introdução à } \\
\text { Arq e Urb (6C) }\end{array}$ & $\begin{array}{c}\text { Planejamento } \\
\text { da paisagem } \\
(4 \mathrm{C})\end{array}$ & $\begin{array}{c}\text { Projeto } \\
\text { Arquitet. I (8C) }\end{array}$ & $\begin{array}{l}\text { Projeto } \\
\text { Arquitet. II } \\
\text { (8C) }\end{array}$ & \begin{tabular}{|c|} 
Projeto \\
Arquitet. III \\
$(8 \mathrm{C})$
\end{tabular} & $\begin{array}{c}\text { Projeto } \\
\text { Arquitet. IV } \\
\text { (8C) }\end{array}$ & \begin{tabular}{|c|} 
Projeto \\
Arquitet. $\mathrm{V}$ \\
$(8 \mathrm{C})$
\end{tabular} & $\begin{array}{c}\text { Projeto } \\
\text { Arquitet. VI } \\
\text { (8C) }\end{array}$ & $\begin{array}{c}\text { Trabalho de } \\
\text { curso I }\end{array}$ & $\begin{array}{l}\text { Trabalho } \\
\text { de curso II }\end{array}$ \\
\hline $\begin{array}{l}\text { História da } \\
\text { arte }(4 C)\end{array}$ & $\begin{array}{c}\text { Historia da Arq } \\
\text { e Urb I (4C) }\end{array}$ & $\begin{array}{c}\text { Planej. Urbano } \\
\text { e regional I } \\
\text { (4C) }\end{array}$ & $\begin{array}{l}\text { Proj. } \\
\text { arquitetura } \\
\text { paisagistica } \\
\text { (6C) }\end{array}$ & $\begin{array}{c}\text { Projeto } \\
\text { urbanístico I } \\
(6 \mathrm{C})\end{array}$ & $\begin{array}{c}\text { Projeto } \\
\text { urbanístico II } \\
(6 \mathrm{C})\end{array}$ & $\begin{array}{c}\text { Projeto } \\
\text { urbanístico } \\
\text { III (6C) }\end{array}$ & $\begin{array}{c}\text { Projeto } \\
\text { urbanístico } \\
\text { IV (6C) }\end{array}$ & $\begin{array}{l}\text { Ateliê de } \\
\text { trabalho de } \\
\text { curso I }(2 \mathrm{C})\end{array}$ & $\begin{array}{c}\text { Ateliê de } \\
\text { trabalho } \\
\text { de curso II } \\
(2 \mathrm{C}) \\
\end{array}$ \\
\hline $\begin{array}{c}\text { Elementos de } \\
\text { program. } \\
\text { visual (4C) }\end{array}$ & $\begin{array}{c}\text { Desenho } \\
\text { arquitetônico } \\
(6 \mathrm{C})\end{array}$ & $\begin{array}{l}\text { Historia da } \\
\text { Arq e Urb II } \\
\text { (4C) }\end{array}$ & $\begin{array}{c}\text { Planej. Urbano } \\
\text { e regional II } \\
(4 \mathrm{C})\end{array}$ & $\begin{array}{c}\text { Hist. da Arq } \\
\text { e Urb do } \\
\text { Brasil II (4C) }\end{array}$ & $\begin{array}{l}\text { Historia da } \\
\text { Arq e Urb III } \\
(4 C)\end{array}$ & $\begin{array}{c}\text { Legislação } \\
\text { urbana e } \\
\text { region. }(4 C)\end{array}$ & $\begin{array}{l}\text { Patrimonio } \\
\text { cult. Edific. } \\
(4 \mathrm{C})\end{array}$ & \begin{tabular}{|c|} 
Pratica \\
profissional \\
$(4 \mathrm{~h})$
\end{tabular} & \\
\hline $\begin{array}{l}\text { Espaço e } \\
\text { forma I (6C) }\end{array}$ & $\begin{array}{l}\text { Espaço e } \\
\text { forma II (6C) }\end{array}$ & $\begin{array}{l}\text { Des. Arquitet. } \\
\text { Aux. } \\
\text { computador } \\
(4 C)\end{array}$ & $\begin{array}{l}\text { Hist. da Arq e } \\
\text { Urb do Brasil I } \\
(4 \mathrm{C})\end{array}$ & $\begin{array}{l}\text { Condicion. } \\
\text { Ambiental I } \\
(4 \mathrm{C})\end{array}$ & $\begin{array}{l}\text { Condicion. } \\
\text { Ambiental II } \\
(4 C)\end{array}$ & $\begin{array}{l}\text { Historia da } \\
\text { Arq e Urb IV } \\
(4 C)\end{array}$ & $\begin{array}{l}\text { Estagio } \\
\text { supervis. }\end{array}$ & & \\
\hline $\begin{array}{l}\text { Desenho de } \\
\text { observaç. (4C) }\end{array}$ & \begin{tabular}{|l|} 
Resistencia e \\
Estabilidades \\
das estruturas \\
I (4C) \\
\end{tabular} & $\begin{array}{l}\text { Sistemas e } \\
\text { materiais de } \\
\text { const. I (4C) }\end{array}$ & $\begin{array}{l}\text { Sistemas e } \\
\text { materiais de } \\
\text { const. II (4C) }\end{array}$ & $\begin{array}{l}\text { Instal. E } \\
\text { equip. na } \\
\text { edif. I (4C) }\end{array}$ & $\begin{array}{l}\text { Instal. E } \\
\text { equip. na edif. } \\
\text { II (4C) }\end{array}$ & & & & \\
\hline $\begin{array}{l}\text { Geometria } \\
\text { descritiva (4C) }\end{array}$ & $\begin{array}{l}\text { Topografia } \\
(4 C)\end{array}$ & \begin{tabular}{|l|} 
Sistemas \\
estruturais I \\
$(4 \mathrm{C})$
\end{tabular} & $\begin{array}{l}\text { Sistemas } \\
\text { estruturais II } \\
(4 C)\end{array}$ & & & & & & \\
\hline
\end{tabular}

Disciplinas de Projeto

Disciplinas de Representação Gráfica e comp.
Disciplinas de Urbanismo e Meio Ambiente Disciplinas na área da Tecnologia da Arquitetura
Disciplinas de Historia e Teoria 


\section{c) Quadro docente}

A partir da entrevista realizada, foi possível averiguar que as disciplinas da área da Tecnologia da Construção já foram ministradas por professores pertencentes ao curso da Engenharia Civil, mas, atualmente, o próprio curso da Arquitetura e Urbanismo assume estas disciplinas (a partir do ano 2000). Não foi possível identificar os principais atores responsáveis por esta área no curso, pela rotatividade de docentes que assumem as disciplinas, tanto efetivos como substitutos ou de outros cursos (Design), como visto no cenário atual.

Em relação à área da Tecnologia da Arquitetura, há a parceria com outros departamentos, como o Departamento de Engenharia Estrutural e Construção Civil, na área de Estruturas e o Departamento de Transportes, ao oferecer as disciplinas de Topografia e Geometria Descritiva.

\section{d) Práticas didáticas e Infraestrutura laboratorial}

O curso apresenta alguns laboratórios básicos de apoio às atividades de ensino, pesquisa e extensão na área de Computação Gráfica e Conforto Ambiental, mas não foi possível identificar por meio da consulta ao PPP de curso e na entrevista realizada a existência de técnicos nestes locais.

Quanto aos espaços de apoio às disciplinas da área da Tecnologia da Construção, foi relatada sua inexistência, sendo considerada a possibilidade de usar de forma compartilhada a infraestrutura do curso da Engenharia Civil, embora haja indicação de que a mesma não é utilizada pelo curso de Arquitetura e Urbanismo. Foi relatado que o curso reconhece a importância, assim como, a inexistência destes locais de apoio às disciplinas e pesquisa e, que a área da Tecnologia da Construção apresenta-se como uma das menos valorizadas no curso, tanto pela falta de professores como de infraestrutura específica na área.

Em relação às disciplinas da área da Tecnologia da Construção, o PPP de curso apresenta o conteúdo das ementas dividido em: etapas da construção: Fundações (diretas, indiretas, arrimos, contenções, etc.), Estruturas (concreto moldado in loco, concreto pré-moldado, aço, madeira, etc.), Vedações (alvenarias, painéis, pré-fabricados, esquadrias, etc.) e Coberturas (estruturas de coberta, telhas, impermeabilização, etc.), desenvolvido na disciplina de Sistemas e Materiais de Construção I. E o conteúdo referente a Acabamentos da obra (pedras, revestimentos cerâmicos, pavimentações, madeiras, vidros, forros, elementos de serralharia, plásticos, pinturas, etc.) em Sistemas e Materiais de Construção II.

\section{e) Pós graduação: ${ }^{15}$}

O Curso de Arquitetura e Urbanismo da UFC possui Programa de Pós-graduação e sua proposta conceitual relaciona-se às questões do Planejamento Urbano, da Urbanização, da Teoria e História da Arquitetura e Urbanismo, assim como do Design.

Tem como área de Concentração a 'Produção do Espaço Urbano e Arquitetônico', e como linhas de pesquisa:

1 - Planejamento Urbano e Design da Informação;

2 - Teoria e História da Arquitetura, do Urbanismo e da Urbanização

Não foram observadas linhas de pesquisa na área da Tecnologia da Arquitetura.

\section{f) Comentários:}

- O curso, ao assumir as disciplinas da área da Tecnologia da Construção (a partir do ano 2000) não possuía infraestrutura laboratorial, corroborando para que a abordagem seja, predominantemente, teórica nestas disciplinas. Embora a infraestrutura da engenharia tenha sido considerada como de uso compartilhado, a partir do momento que as disciplinas de Sistemas e Materiais de Construção I e II passam a ser ofertadas pelo curso de Arquitetura, há maior dificuldade na utilização dos equipamentos, além disso, foi relatado que a infraestrutura pertencente ao curso da Engenharia Civil está estruturada para atender as atividades de ensino e pesquisa deste curso;

\footnotetext{
${ }^{152}$ Informações obtidas em: http://ppgaud.arquitetura.ufc.br/. Acesso em 29/05/2016.
} 
- Foi relatado que algumas disciplinas da área de Projeto contribuem para complementar alguns assuntos da área técnica, suprindo em diversos momentos, algumas carências relacionadas à materialidade;

- Há o reconhecimento de que o setor da Tecnologia apresenta-se como o mais fragilizado do curso, tanto em relação a pouca oferta de disciplinas, como também, à falta de docentes e infraestrutura na área. Atualmente, o setor da Tecnologia possui 4 professores efetivos, não sendo identificados profissionais na área estudada. A falta de atores representativos promove alta rotatividade de docentes nestas disciplinas, dificultando a continuidade das ações para fortalecimento da área;

- Embora o reduzido número de professores pertencentes ao setor da Tecnologia, foi relatado ser este número suficiente para a demanda atual, sendo que a baixa carga horária voltada à Tecnologia da Arquitetura pode ser uma condicionante que dificulte justificar a contratação de novos professores.

\title{
10- FAU-UFPA - Faculdade de Arquitetura e Urbanismo da Universidade Federal do Pará ${ }^{153}$
}

\begin{abstract}
a) Breve Histórico ${ }^{154}$
O Curso de Arquitetura da Universidade Federal do Pará foi criado em 1964, a partir da demanda de engenheiros locais que atuavam como projetistas, sendo destinadas a estes profissionais duas turmas de adaptação, com duração de três anos ${ }^{155}$. O Curso iniciou suas atividades no chamado 'Chalé de Ferro' (Figura 81a) que hoje pertence à Faculdade de Arquitetura e Urbanismo, por doação do Prof. Euler dos Santos Arruda. Posteriormente, as atividades do curso foram transferidas para o Setor Básico do Campus Universitário (Bloco A), sendo transferido para o bairro de São Braz, e em 1979, conduzido novamente ao Campus, tendo sua parte administrativa sediada no Laboratório de Mecânica dos solos e as aulas nos Pavilhões A, B, C e D do Setor Profissional. Em 1981, o Departamento de Arquitetura e a Coordenação do Colegiado do Curso transferiram-se para o prédio cujo projeto executivo foi concebido pelo arquiteto Armando Diogo Couceiro Filho, permanecendo neste local até os dias atuais (Figura 81b, 81c).

Segundo Miranda (2015), na criação do curso, com o objetivo de compor o quadro docente foram convidados profissionais locais assim como, de outras regiões do país, como Rio Grande do Sul e Rio de Janeiro; alguns deles se estabeleceram definitivamente no estado e outros retornaram à sua terra natal. Alguns recém-egressos passaram a fazer parte do quadro docente juntamente com os professores que permaneceram na região.

Ainda segundo a autora, o curso da UFPA apresentou quatro currículos plenos, o de 1964, baseado no Currículo Mínimo de 1962; as reformulações promovidas na grade curricular em 1971, com base no Currículo Mínimo de 1969; as alterações de 1977, com aumento de C.H. e a inserção das disciplinas de Conforto Ambiental como obrigatórias e as reestruturações 1991, consideradas as mais significativas no currículo do curso, com a incorporação do sistema de blocos e novos conteúdos. Neste período a denominação da sub-unidade de Departamento de Arquitetura passa a ser Departamento de Arquitetura e Urbanismo (proposta de 1977, aprovada após 15 anos).
\end{abstract}

\footnotetext{
153 Informações obtidas em visita técnica realizada entre os dias 31/08/2016 e 02/09/2016 com Visita técnica realizada entre os dias 31/08/2016 e 03/09/2016, com entrevistas direcionadas à 04 professores: Dr. Márcio Santos Barata (atual responsável pela área da Tecnologia da Construção e ministrante de algumas disciplinas desta área), Dr. Fabiano Homobono Paes de Andrade (diretor, forneceu informações sobre a estruturação do curso), Dra. Cybelle Salvador Miranda (forneceu detalhes sobre o histórico de implantação do curso) e profa. Dra. Elcione Maria Lobato de Moraes (da área da Tecnologia da Arquitetura, forneceu informações sobre as atuais reformulações do Projeto Pedagógico e quais delas impactariam na área técnica).

${ }^{154}$ Dados obtidos a partir de: Miranda, C. S. et. al. Uma formação em curso. Esboços da graduação em Arquitetura e

Urbanismo da UFPA. Belém, UFPA, 2015 e no endereço:

http://www.itec.ufpa.br/index.php?option=com_content\&view=article\&id=292\&ltemid=109. Acesso em 26/09/2016.

155 Período marcado pela tendência nacional de valorização do papel do arquiteto e do urbanista em face da política desenvolvimentista iniciada por Juscelino Kubitschek e continuada pelos governos militares. A partir de Miranda (2015), é possível verificar que a criação do curso de arquitetura da UFPA teve forte influência dos engenheiros civis que exerciam as atividades de projeto na região, ao verem-se impedidos de participar de projetos de determinada envergadura, voltada aos arquitetos. Diante destas restrições, estes profissionais incentivaram a criação do curso de Arquitetura na UFPA, sendo que inicialmente, o curso ofereceu etapas de adaptação em paralelo ao curso normal, absorvendo muitos engenheiros interessados, os quais se tornaram engenheiros e arquitetos após cursar esta etapa de adaptação.
} 
A partir de 1996, foram realizadas adaptações curriculares para a adequação às novas Diretrizes obrigatórias com o objetivo de se estabelecer os padrões mínimos de qualidade, consolidando as modificações que já vinham em andamento desde 1991. Este currículo de curso, de 1 de abril de 1991 (Resolução $\mathrm{N}^{\circ}$ 1919), atualmente ainda se mantém como orientador dos programas das disciplinas, estando o novo Projeto Político Pedagógico de curso em processo de discussão.
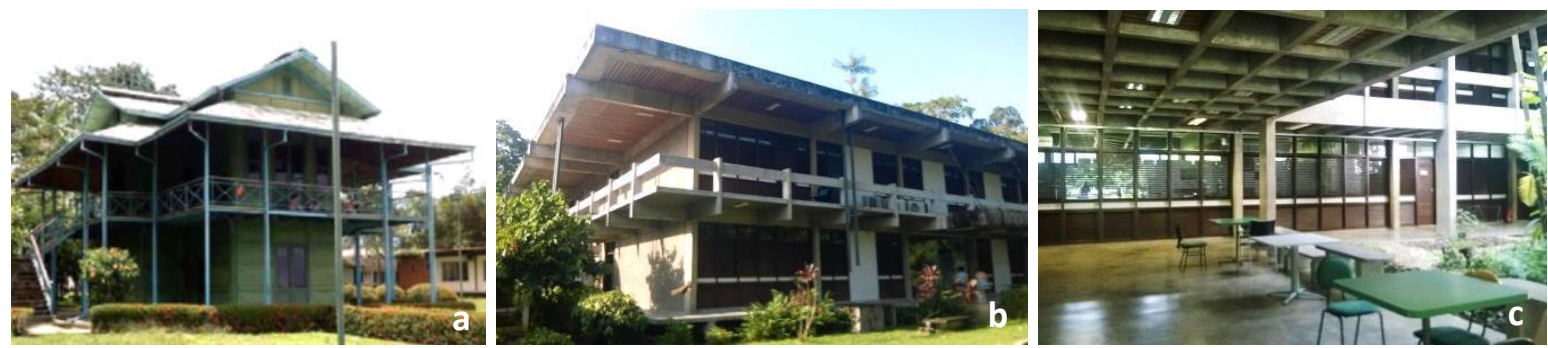

Figura 81 - Edifícios sede do curso de Arquitetura e Urbanismo. a) Chalé de Ferro - local onde o curso iniciou suas atividades. b) e c) Vista externa e interna, respectivamente. Edifício de 1981, construído para sediar o curso de Arquitetura, localizado no Campus Universitário -sede atual.

Fonte: a) Miranda (2015); b) e c) fotos da autora.

\section{b) Considerações sobre a Estruturação da área da Tecnologia da Construção}

O curso de Arquitetura e Urbanismo está inserido administrativamente no Instituto de Tecnologia da Universidade Federal do Pará e oferece 60 vagas anuais, divididas em dois turnos: matutino e vespertino. Atualmente, as disciplinas da área da Tecnologia da Arquitetura são ofertadas tanto pela própria Faculdade como pelo curso de Engenharia Civil. Observa-se a partir do Quadro 20 que as disciplinas intituladas como Tecnologia das Construções englobam os conteúdos da área de Sistemas Estruturais e Tecnologia das Construções (materiais e técnicas construtivas).

De modo geral, as disciplinas da área da Tecnologia da Arquitetura ocupam $24 \%$ dos créditos totais (sem considerar no cômputo Estágio Supervisionado, Optativas, ITFG e TFG) das disciplinas obrigatórias e estão distribuídas entre o 10 e o 9 o períodos. As disciplinas de Tecnologia das Construções estão alocadas entre 0 1ํ e o 60 períodos e contribuem com $11 \%$ dos créditos (conteúdo de sistemas estruturais e tecnologia das construções), as de Conforto Ambiental ocupam 5\% dos créditos, Instalações Prediais 3\% e Outras (Estatística, Topografia e Noções de Economia) 5\%.

Quadro 20 - Distribuição da Grade Curricular com a carga horária semestral - FAU UFPA:

\begin{tabular}{|c|c|c|c|c|c|c|c|c|c|}
\hline 10 sem & 20 sem & 3ㅇ sem & 40 sem & 5ㅇ sem & 60 sem & 7ㅇ sem & 80 sem & 90 sem & $10 \%$ sem \\
\hline Projeto I (4C) & Projeto II (8C) & Projeto III (8C) & Projeto IV (8C) & $\begin{array}{c}\text { Projeto V } \\
(8 \mathrm{C})\end{array}$ & $\begin{array}{c}\text { Projeto VI } \\
(8 \mathrm{C})\end{array}$ & $\begin{array}{c}\text { Projeto VII } \\
(8 \mathrm{C}) \\
\end{array}$ & $\begin{array}{c}\begin{array}{c}\text { Projeto VIII } \\
(8 \mathrm{C})\end{array} \\
\end{array}$ & $\begin{array}{c}\text { Projeto IX } \\
(8 C) \\
\end{array}$ & TFG \\
\hline $\begin{array}{l}\text { Teo. e Hist. } \\
\text { Arq. Urb I (2C) }\end{array}$ & $\begin{array}{l}\text { Teo. e Hist. da } \\
\text { Arq. Urb II(2C) }\end{array}$ & $\begin{array}{l}\text { Teo. e Hist. da } \\
\text { Arq. Urb } \\
\text { III(2C) }\end{array}$ & $\begin{array}{c}\text { Teo. e Hist. da } \\
\text { Arq. Urb } \\
\text { IV(4C) }\end{array}$ & $\begin{array}{l}\text { Teor. anal. } \\
\text { regio. Urb. I } \\
(2 \mathrm{C})\end{array}$ & $\begin{array}{c}\text { Teor. analise } \\
\text { regional } \\
\text { urbana II (4C) }\end{array}$ & $\begin{array}{c}\text { Planejamen. } \\
\text { Urbano I } \\
(6 C)\end{array}$ & $\begin{array}{c}\text { Planejamen } \\
\text {. Urbano II } \\
(4 \mathrm{C})\end{array}$ & Introd. TFG & $\begin{array}{l}\text { Legislação } \\
\text { aplic. (4C) }\end{array}$ \\
\hline $\begin{array}{l}\text { Represent. } \\
\text { Expres. I (6C) }\end{array}$ & $\begin{array}{c}\text { Inicia. Conhec. } \\
\text { Cientif. (2C) }\end{array}$ & $\begin{array}{c}\text { Metodol. Tec. } \\
\text { de pesquisa } \\
(6 \mathrm{C})\end{array}$ & $\begin{array}{c}\text { Psicologia } \\
\text { aplic. Arq. (2C) }\end{array}$ & $\begin{array}{c}\text { Teo. e Hist. } \\
\text { da Arq. Urb } \\
\text { V (4C) }\end{array}$ & $\begin{array}{c}\text { Sociologia } \\
\text { geral e } \\
\text { urbana (4C) }\end{array}$ & $\begin{array}{c}\text { Preserv. } \\
\text { patrimon. } \\
\text { Histor. (2C) }\end{array}$ & $\begin{array}{c}\text { Paisagismo } \\
(6 \mathrm{C})\end{array}$ & $\begin{array}{c}\text { Instalaç. } \\
\text { Prediais e } \\
\text { urb. II (4C) }\end{array}$ & $\begin{array}{l}\text { Estagio } \\
\text { supervis. }\end{array}$ \\
\hline $\begin{array}{c}\text { Geo. desenho } \\
\text { Tecn. I (4C) }\end{array}$ & \begin{tabular}{|c|} 
Represent. \\
Expres. II (6C)
\end{tabular} & $\begin{array}{c}\text { Represent. } \\
\text { Expres. III (6C) }\end{array}$ & $\begin{array}{c}\text { Represent. } \\
\text { Expres. IV (6C) }\end{array}$ & $\begin{array}{c}\text { Estetica das } \\
\text { artes plast. } \\
(4 \mathrm{C}) \\
\end{array}$ & $\begin{array}{c}\text { Teo. e Hist. da } \\
\text { Arq. Urb VI } \\
(4 \mathrm{C})\end{array}$ & $\begin{array}{c}\text { Noções de } \\
\text { economia } \\
(4 C)\end{array}$ & $\begin{array}{l}\text { Instalaç. } \\
\text { Prediais e } \\
\text { urb. I (4C) }\end{array}$ & & \\
\hline $\begin{array}{c}\text { Inform. Aplic. } \\
\text { Arq I (4C) }\end{array}$ & $\begin{array}{c}\text { Geo. desenho } \\
\text { Tecn. II (4C) }\end{array}$ & $\begin{array}{c}\text { Geo. desenho } \\
\text { Tecn. III (4C) }\end{array}$ & $\begin{array}{c}\text { Geo. desenho } \\
\text { Tecn. IV (4C) }\end{array}$ & $\begin{array}{c}\text { Represent. } \\
\text { Expres. V } \\
(6 \mathrm{C}) \\
\end{array}$ & $\begin{array}{c}\text { Conforto } \\
\text { ambiental II } \\
(4 \mathrm{C})\end{array}$ & \begin{tabular}{|c} 
Conforto \\
ambiental III \\
$(4 \mathrm{C})$
\end{tabular} & & & \\
\hline \multirow[t]{2}{*}{$\begin{array}{c}\text { Tecnol. } \\
\text { Constr. I (6C) }\end{array}$} & $\begin{array}{c}\text { Inform. Aplic. } \\
\text { Arq II (4C) }\end{array}$ & $\begin{array}{c}\text { Tecnol. } \\
\text { Constr. III (4C) }\end{array}$ & $\begin{array}{c}\text { Tecnol. } \\
\text { Constr. IV (6C) }\end{array}$ & $\begin{array}{c}\text { Conforto } \\
\text { ambiental I } \\
(4 \mathrm{C})\end{array}$ & $\begin{array}{l}\text { Tecnol. } \\
\text { Constr. VI } \\
\text { (4C) }\end{array}$ & $\begin{array}{l}\text { Estatística } \\
\qquad(4 \mathrm{C})\end{array}$ & & & \\
\hline & $\begin{array}{c}\text { Tecnol. } \\
\text { Constr. II (4C) }\end{array}$ & & & $\begin{array}{c}\text { Tecnol. } \\
\text { Constr. V } \\
(4 \mathrm{C})\end{array}$ & $\begin{array}{c}\text { Topografia I } \\
(4 C)\end{array}$ & & & & \\
\hline
\end{tabular}

Disciplinas de Projeto

Disciplinas de Representação Gráfica e comp.
Disciplinas de Urbanismo e Meio Ambiente Disciplinas na área da Tecnologia da Arquitetura
Disciplinas de Historia e Teoria Dis

\section{(1)}


Obs.: Devido a escola atualmente adotar o Currículo de Curso de 10 de abril de 1991, não foi possível compreender com precisão o processo de cálculo dos créditos e as alterações ocorridas pontualmente sobre a questão, sendo considerado neste trabalho o processo de cálculo convencional 15h.a= $1 \mathrm{C}$, de acordo com as informações obtidas sobre a carga horária das disciplinas, sendo os dados apresentados interpretados pela pesquisadora.

\section{c) Quadro docente}

As disciplinas da área da Tecnologia da Construção são ministradas pelo sistema misto, por professores pertencentes ao quadro docente do curso de Arquitetura e Urbanismo com formação em Engenharia Civil (1/3 das disciplinas) e por professores do curso da Engenharia Civil com formação em Arquitetura e Engenharia Civil (2/3 das disciplinas). Esta distribuição ocorre desde 2013, quando foi contratado para compor o quadro docente do curso o primeiro professor com formação na área, na intenção de dar apoio à Pós-graduação na linha de pesquisa em Tecnologias Construtivas, Conservação e Restauro. Antes desta data, as disciplinas da área estudada eram integralmente ministradas pelos docentes pertencentes ao curso da Engenharia Civil.

\section{d) Práticas didáticas e Infraestrutura laboratorial}

Como já exposto, a partir de 2013, as disciplinas da área da Tecnologia das Construções são assumidas tanto por professores do curso de Arquitetura como também pelo curso da Engenharia Civil. Embora seja adotado o sistema de fusão entre as disciplinas de sistemas estruturais e tecnologia das construções, os conteúdos das ementas adotam a divisão tradicional, cujos conteúdos e estratégias pedagógicas (aquelas que foram possíveis de identificar) são ${ }^{156}$ :

- Tecnologia das Construções (TEC) I e II - ministrada por professor da Engenharia Civil com formação em engenharia - conteúdo de fundamentação sobre os sistemas estruturais e processos de cálculo, assim como resistência dos materiais.

- Tecnologia das Construções (TEC) III e IV - ministradas por professor pertencente ao curso da Arquitetura e Urbanismo com formação em engenharia civil - Em TEC III, o conteúdo permanece ainda em Sistemas Estruturais, abordando os seguintes assuntos: concepção estrutural, pré-dimensionamento e sistemas estruturais em associação aos materiais construtivos (principalmente o concreto e o aço). 0 conteúdo é trabalhado em cima do projeto arquitetônico, desde a concepção até o lançamento da estrutura no projeto, considerando o dimensionamento e espaçamento dos elementos estruturais. Ainda nesta disciplina, é realizada uma visita em obra, para visualização da estrutura e a técnica de execução. Em TEC IV, a abordagem refere-se aos materiais construtivos: normas de desempenho, propriedades e aplicações em sistemas construtivos, ampliando a gama de materiais em relação à TEC III, quando são estudados apenas o concreto e o aço. Nesta disciplina, além das aulas teóricas também é realizada uma visita técnica em obra ao longo do semestre com turmas de 30 alunos. Embora seja um processo ainda incipiente, nestas disciplinas há a integração entre a graduação e a pós-graduação por meio do estágio docente, havendo a oportunidade de alguns mestrandos divulgarem no âmbito da graduação suas pesquisas em andamento. Em projetos de Iniciação Científica há o envolvimento pontual de alunos em pesquisas na área de materiais não convencionais.

- Tecnologia das Construções (TEC) V e VI - são ministradas por professor pertencente ao quadro da Engenharia Civil mas com formação em Arquitetura e Urbanismo. Em TEC $V$ são abordados os procedimentos construtivos e em TEC VI, o conteúdo refere-se a Orçamentos.

Sobre a infraestrutura laboratorial, o curso de Arquitetura e Urbanismo foi se estruturando ao longo do tempo de acordo com os perfis dos professores e suas áreas de atuação (especialização), sendo os laboratórios mais voltados à pesquisa e extensão e não ao ensino. O curso não apresenta espaços experimentais na área da Tecnologia da construção, sendo considerada como de uso compartilhado a infraestrutura da Engenharia Civil (utilizada eventualmente na graduação em aulas

\footnotetext{
${ }^{156}$ De acordo com os dados levantados nas entrevistas, a fusão entre as disciplinas foi realizada devido ao curso seguir as seguintes vertentes: Projeto, Tecnologia e História. Diante disso, houve a necessidade de se criar uma sistemática para a área da Edificação, passando as disciplinas a compor um eixo único: com o cálculo, materiais, estruturas, etc. Teoricamente havia a intenção de todas as áreas estarem interligadas ao Projeto.
} 
sobre o material concreto), e na pós-graduação a infraestrutura compartilhada se estende para as demais engenharias quando há necessidade da realização de determinados experimentos.

\section{e) Pós graduação ${ }^{157}$ :}

O Programa de Pós-Graduação em Arquitetura e Urbanismo, da Universidade Federal do Pará (PPGAU/UFPA), foi criado 2010, em nível de mestrado acadêmico. Trata-se do primeiro Programa de Pós Graduação Stricto Sensu em Arquitetura e Urbanismo do norte do Brasil, sendo considerada uma região com demanda histórica por qualificação, uma vez que o primeiro curso de graduação em arquitetura foi criado na UFPA em 1964. Os docentes arquitetos e urbanistas titulados em nível de mestrado e/ou doutorado alcançaram a qualificação em outras regiões e mesmo em outros países, ou localmente, em outras áreas de conhecimento.

O PPGAU/UFPA tem como área de concentração: "Análise e concepção do espaço construído na Amazônia" e duas linhas de pesquisa:

1- Linha: Arquitetura, desenho da cidade e desempenho ambiental;

2- Linha: Tecnologias construtivas, conservação e restauro;

Segundo os dados divulgados pelo próprio PPGAU/UFPA, o programa tem como missão alterar o quadro atual da região, desprovido de capacitação a nível stricto sensu em Arquitetura e Urbanismo, envolvendo a intersecção das Tecnologias com os conhecimentos das Humanidades, refletidas nas linhas de pesquisa do programa e na composição multidisciplinar do seu quadro docente, com pesquisas direcionadas a produção do espaço amazônico construído.

Atualmente, não há linhas de pesquisa específicas em Tecnologia da Construção. Caso haja o interesse por esta área em nível de doutorado, há a possibilidade da realização da especialização no Programa de Pós-Graduação em Engenharia de Recursos Naturais da Amazônia oferecida pelo Instituto de Tecnologia da UFPA (PRODERNA - ITEC/UFPA), com caráter multidisciplinar. O Programa tem a seguinte área de concentração: Uso e Transformação de Recursos Naturais. E linhas de pesquisa:

1- Engenharia de Processos

2- Meio Ambiente e Energia

3- Modelagem e Simulação de Processos

\section{f) Comentários:}

- Atualmente, vigora o Currículo de 1991, sendo que o novo Projeto Político Pedagógico (PPP) de curso encontra-se em fase de discussão. Diante disso, ao longo dos anos, as ementas das disciplinas foram flexibilizadas e, embora a grade curricular permaneça inalterada, o conteúdo e a bibliografia vão sendo atualizados pelos professores responsáveis;

- Embora haja a fusão entre as disciplinas de Tecnologia das Construções e Sistemas Estruturais, os conteúdos seguem a organização tradicional, de forma segregada, a sequência apresenta-se apenas no título das disciplinas. A área encontra-se em fase de discussão no novo PPP de curso, para que haja melhor conexão entre as disciplinas técnicas e equilíbrio dos conteúdos (entre Sistemas Estruturais e Tecnologia das Construções). A carga horária não foi considerada baixa por parte dos professores, havendo a previsão de que no novo PPP de curso ela seja diminuída;

- Não há perspectivas no curso para a implantação de um laboratório na área da Tecnologia da Construção, devido à falta de recursos humanos, financeiros e espaço físico. As aulas são essencialmente teóricas (sem atividades experimentais), mas caso haja a necessidade do uso da infraestrutura laboratorial há a possibilidade do uso compartilhado com o curso da Engenharia Civil. Na pós-graduação a utilização laboratorial já ocorre de forma mais efetiva, não apenas da Engenharia Civil, mas qualquer laboratório do Instituto de Tecnologia quando há necessidade de ensaios específicos.

- A reformulação do PPP procura não condicioná-lo a falta de recursos para que as proposições sejam alcançáveis. Diante disso, o novo projeto está sendo delineado de acordo com a realidade local,

157 Dados obtidos em: http://ppgau.propesp.ufpa.br/index.php/br/programa/apresentacao, e também no endereço: http://proderna.propesp.ufpa.br/index.php/br/. Acesso em 25/09/2016. 
sanando eventuais demandas (laboratórios) a partir do estabelecimento de parcerias com outros cursos, como a Engenharia Civil;

- O conteúdo das disciplinas de Tecnologia das Construções reflete muito o contexto local e a formação dos alunos ocorre de acordo com o que é praticado na região, o material madeira, por exemplo, não é estudado no curso como o Aço e o Concreto, sendo justificado que o uso da madeira na região não é grande pelas restrições legais e ambientais atualmente vivenciadas, aliado à falta de conhecimento técnico para beneficiamento do material em relação às outras regiões do país. Os assuntos relativos a pré-moldados e pré-fabricados também não são abordados, por não serem técnicas comumente utilizadas, com a presença de casos esporádicos na região;

- Algumas disciplinas de Atelier de Projeto complementam os conhecimentos da área da tecnologia, a fim de suprir eventuais deficiências encontradas relacionadas ao tema trabalhado;

- A Instituição oferece seguro aos alunos, para isso, é necessário que o professor comunique com antecedência aos órgãos competentes sobre suas atividades de campo. A burocracia envolvida neste processo foi considerada um empecilho para que seja oferecido um maior número de visitas técnicas ao longo do semestre;

- A aproximação dos alunos da graduação às pesquisas em desenvolvimento na pós-graduação ocorre de forma pontual por meio da Iniciação Científica ou por meio do estágio docente, onde mestrandos ministram aulas expositivas na graduação sob a supervisão de professores, apresentando suas pesquisas em andamento;

- A contratação do primeiro professor da área da Tecnologia da Construção pela FAU trouxe resultados positivos ao curso, como a facilidade de diálogo com o curso da Engenharia Civil. Apesar deste cenário, a área da Tecnologia da Construção não apresenta um grupo que a represente no curso, estando este professor vinculado atualmente à área de Patrimônio, tendo sido contratado com o objetivo de dar suporte às pesquisas atualmente realizadas nesta área.

\subsubsection{ESCOLAS IMPLANTADAS NA DÉCADA DE 1970}

Este é período marcado pela aplicação de regulamentações estabelecidas pelo Currículo Mínimo no fim da década anterior, em 1969. Outra ação realizada pelo Governo foi a criação da primeira Comissão de Especialistas em Arquitetura e Urbanismo, que trouxe resultados importantes pela realização do primeiro levantamento sobre a situação das escolas de arquitetura implantadas no país. Neste trabalho, as visitas técnicas contemplaram as seguintes escolas criadas neste período e que estão inseridas em instituições públicas: UFF (1970); UFPel (1971); UFRN (1973); UFPB (1974); UEL (1978) e UFES (1978).

\section{1- EAU - UFF - Escola de Arquitetura e Urbanismo da Universidade Federal Fluminense ${ }^{158}$}

\section{a) Breve Histórico ${ }^{159}$}

O curso de Arquitetura e Urbanismo da UFF teve sua proposta inicial em 1968, embora seu currículo pleno só tenha sido aprovado em 1970 através da portaria número 492 (Portaria de Reconhecimento MEC: Dec. $n^{\circ} 79.129$ de 17/01/77). A proposta encaminhada ao Centro Tecnológico por um grupo de

\footnotetext{
${ }^{158}$ Dados obtidos a partir da visita técnica realizada em 12/12/2014, às instalações do EAU-UFF, com entrevistas direcionadas à vice coordenadora de curso de Arquitetura e Urbanismo, profa. Dra. Cristina Lontra Nacif e também, ao professor Me. Francisco José Varejão Marinho, pertencente ao curso da Engenharia Civil.

${ }^{159}$ Informações disponíveis em: http://www.eau.uff.br/sobre-a-eau-uff/
} 
profissionais vinculados ao Instituto de Arquitetos do Brasil (IAB), refletia o anseio e as discussões quanto à formação dos arquitetos atuantes na área de Niterói.

Com a criação da Escola de Arquitetura e Urbanismo houve a separação do Departamento de Arquitetura e Urbanismo (antigo TAU), da Escola de Engenharia. Posteriormente, este departamento único veio a se ramificar em dois: o Departamento de Arquitetura (TAR) e o Departamento de Urbanismo (TUR).

O conjunto dos prédios que caracteriza o espaço desta escola foi originalmente construído para abrigar as instalações de uma firma inglesa que trabalhava com um sistema de comunicação através de cabos submarinos de telégrafos; a Western Telegraph (Figura 82). No início de outubro do ano de 1991 foi lido um decreto que tomba a nível municipal o conjunto Casarão-Chalé e preserva a volumetria do entorno.

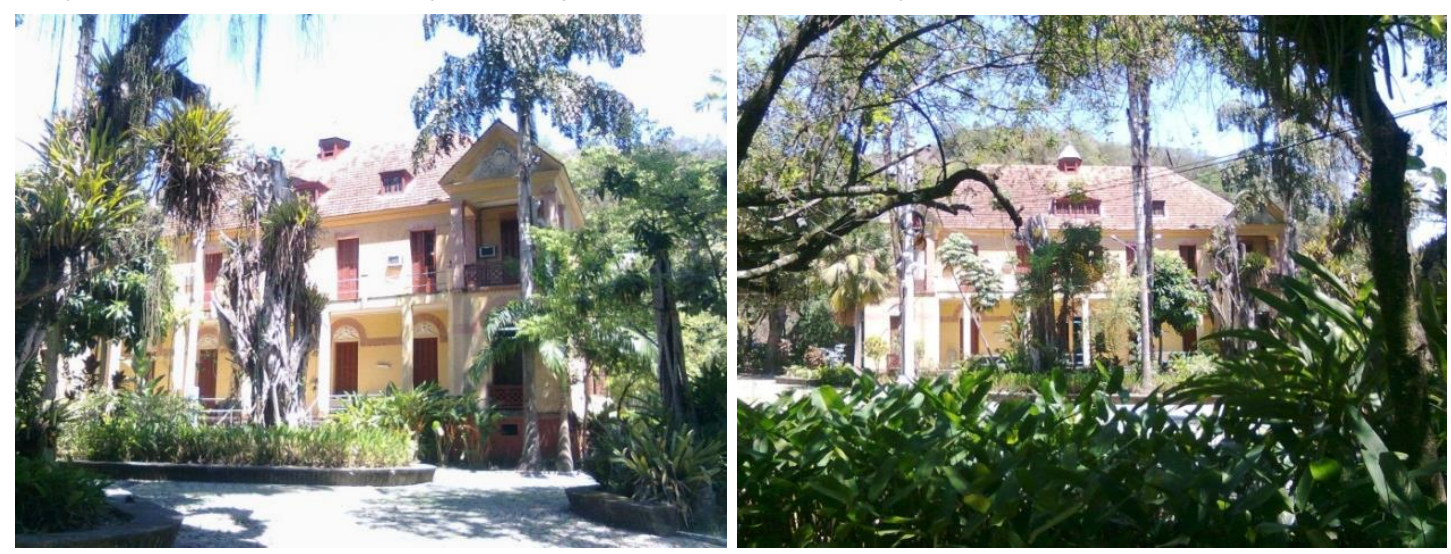

Figura 82: Edifício onde está instalado o curso de Arquitetura e Urbanismo da UFF.

Fonte: Fotos da autora.

\section{b) Considerações sobre a Estruturação da área de Tecnologia da Construção}

O EAU-UFF oferece 74 vagas anuais (37/semestre). Na proposta de ensino do curso há o envolvimento de diferentes departamentos da Universidade Federal Fluminense: Departamento de Arquitetura, Departamento de Urbanismo, Departamento de Engenharia Civil, Departamento de Desenho Técnico, Departamento de Artes, Departamento de Topografia, configurando uma estrutura multidepartamental, com o compartilhamento de equipamentos, laboratórios e bibliotecas.

De acordo com seu PPP, o curso foi organizado de forma que o 10 período oferte disciplinas de fundamentação associadas à diversidade das funções da Arquitetura e do Urbanismo. Os demais períodos tem a intenção de promover a integração entre as diversas disciplinas, considerando a complexidade gradual de seus conteúdos e suas inter-relações tanto verticalmente como na sequencialidade horizontal. Há a proposta de dois momentos de integração temática no curso, mais precisamente no quinto e oitavos períodos quando uma temática comum é abordada em seus diferentes aspectos pelas disciplinas integrantes do período. As integrações temáticas são períodos em que uma disciplina de projeto conta com o apoio direto de outras disciplinas trabalhando sobre uma temática comum. O 9o e 10 períodos são considerados como de Síntese na forma do ITFG e TFG.

De acordo com o Quadro 21, as disciplinas de Tecnologia da Arquitetura estão distribuídas entre o 10 e 8 o períodos, e ocupam $30 \%$ dos créditos das disciplinas obrigatórias (sem considerar os créditos destinados ao TFG, optativas e estágio). As disciplinas da Tecnologia da Construção (Materiais e Técnicas, Sistemas Construtivos I e II e Planejamento e Gestão em Arquitetura e Urbanismo) ocupam 7\% dos créditos; Sistemas Estruturais 11,5\%; Instalações Prediais 3,5\%; Conforto Ambiental 3\% e Outras (Topografia e Infraestrutura urbana) $5 \%$ dos créditos.

As disciplinas da Tecnologia da Construção são ofertadas no 3ํ, 4으, 6으 e 8o períodos (2으, 3으 e 4으 anos de curso).

Quadro 21 - Distribuição da Grade Curricular com a carga horária semestral - EAU UFF: 


\begin{tabular}{|c|c|c|c|c|c|c|c|c|c|}
\hline 10 sem & 20 sem & 3ㅇ sem & 4ㅇs sem & 5 sem & 60 sem & 70 sem & 8 sem & 90 sem & 10 sem \\
\hline $\begin{array}{l}\text { Est. da forma } \\
\text { e espaço ( } 4 h)\end{array}$ & $\begin{array}{c}\text { Projeto de arq } \\
\mathrm{I}(6 \mathrm{~h})\end{array}$ & $\begin{array}{c}\text { Projeto de arq } \\
\text { II (6h) }\end{array}$ & $\begin{array}{c}\text { Projeto de arq } \\
\text { III (6h) }\end{array}$ & $\begin{array}{l}\text { Projeto de } \\
\text { arq IV (6h) }\end{array}$ & $\begin{array}{c}\text { Projeto de arq } \\
\mathrm{V}(6 \mathrm{~h}))\end{array}$ & $\begin{array}{l}\text { Projeto de } \\
\text { arq VI (6h) }\end{array}$ & $\begin{array}{l}\text { Projeto de } \\
\text { arq VII (6h) }\end{array}$ & $\begin{array}{c}\text { Introdução } \\
\text { ao TFG (3h) }\end{array}$ & TFG \\
\hline $\begin{array}{c}\text { Est. Sociais } \\
\text { ambient. (3h) }\end{array}$ & $\begin{array}{c}\text { Anal. Express. } \\
\text { Urban. (5h) }\end{array}$ & $\begin{array}{l}\text { Teor. histor. } \\
\text { urban.I ( } 4 \mathrm{~h})\end{array}$ & $\begin{array}{l}\text { Teor. Paisag. e } \\
\text { Paisagis. (3h) }\end{array}$ & $\begin{array}{c}\text { Projeto } \\
\text { Paisag. (6h) }\end{array}$ & $\begin{array}{c}\text { Proj. Urbanis. } \\
\text { I (6h) }\end{array}$ & $\begin{array}{c}\text { Proj. } \\
\text { Urbanis. II } \\
\text { (6h) }\end{array}$ & $\begin{array}{c}\text { Proj. } \\
\text { Urbanis. III } \\
\text { (6h) }\end{array}$ & Sstag & \\
\hline $\begin{array}{l}\text { Arq. Urb. e } \\
\text { socied. (4h) }\end{array}$ & $\begin{array}{l}\text { Teor. e hist. da } \\
\text { arq. I (4h) }\end{array}$ & $\begin{array}{c}\text { Teor. e hist. da } \\
\text { arq. II (4h) }\end{array}$ & $\begin{array}{l}\text { Teor. histor. } \\
\text { urban.II (4h) }\end{array}$ & $\begin{array}{c}\text { Mét. de } \\
\text { pesqu. (3h) }\end{array}$ & $\begin{array}{c}\text { Teor. da } \\
\text { habitaç. (3h) }\end{array}$ & $\begin{array}{c}\text { Teor. histor. } \\
\text { urban.III } \\
(4 \mathrm{~h})\end{array}$ & $\begin{array}{l}\text { Planej. Urb. } \\
\text { region. (6h) }\end{array}$ & & \\
\hline $\begin{array}{l}\text { Conc. fund. } \\
\text { Hist. arte (4h) }\end{array}$ & $\begin{array}{l}\text { Est. do espaç. } \\
\text { form. arq. (3h) }\end{array}$ & $\begin{array}{c}\text { Gráfica digital } \\
(4 \mathrm{~h})\end{array}$ & $\begin{array}{c}\text { Teor. e hist. da } \\
\text { arq. III (4h) }\end{array}$ & $\begin{array}{c}\text { Conforto } \\
\text { amb II (3h) }\end{array}$ & $\begin{array}{l}\text { Princ. Conserv } \\
\text { bens cult }(3 \mathrm{~h})\end{array}$ & $\begin{array}{l}\text { Viagem de } \\
\text { estud.I (4h) }\end{array}$ & $\begin{array}{c}\text { Viagem de } \\
\text { estud.II } \\
\text { (4h) }\end{array}$ & & \\
\hline $\begin{array}{c}\text { Expressão } \\
\text { grafica (4h) }\end{array}$ & $\begin{array}{l}\text { Represent. } \\
\text { Gráfica I (4h) }\end{array}$ & $\begin{array}{c}\text { Represent. } \\
\text { Gráfica II (4h) }\end{array}$ & $\begin{array}{c}\text { Topografia } \\
\text { (4h) }\end{array}$ & $\begin{array}{c}\text { Instal. Pred. } \\
\text { I (4h) }\end{array}$ & $\begin{array}{c}\text { Infraestrutura } \\
\text { urb. (4h) }\end{array}$ & $\begin{array}{l}\text { Mecân. } \\
\text { Solos e } \\
\text { fund. (4h) }\end{array}$ & $\begin{array}{c}\text { Planej. } \\
\text { Gest. Arq. } \\
\text { urb (4h) }\end{array}$ & & \\
\hline $\begin{array}{l}\text { Sist. Geom. } \\
\text { represen. (4h) }\end{array}$ & $\begin{array}{c}\begin{array}{c}\text { Conforto amb I } \\
(4 \mathrm{~h})\end{array} \\
\end{array}$ & \begin{tabular}{|c|} 
Sist. Construt. \\
Arquit.I $(4 \mathrm{~h})$
\end{tabular} & $\begin{array}{c}\text { Materiais e } \\
\text { técnicas ( } 5 \mathrm{~h})\end{array}$ & $\begin{array}{c}\text { Instal. Pred. } \\
\text { II (4h) } \\
\end{array}$ & \begin{tabular}{|c} 
Sist. Construt. \\
Arquit.II (3h) \\
\end{tabular} & & $\begin{array}{l}\text { Trabalho } \\
\text { Integrado }\end{array}$ & & \\
\hline \multirow[t]{2}{*}{$\begin{array}{c}\text { Fundamentos } \\
\text { model. Sist. } \\
\text { estrut. (6h) }\end{array}$} & $\begin{array}{c}\text { Sist. } \\
\text { isostaticos }(4 h)\end{array}$ & $\begin{array}{c}\text { Resist. dos } \\
\text { materiais (4h) }\end{array}$ & $\begin{array}{c}\text { Tipolog. } \\
\text { Estrutur. (4h) }\end{array}$ & $\begin{array}{c}\text { Projeto } \\
\text { Estrut. I (4h) }\end{array}$ & $\begin{array}{c}\text { Projeto } \\
\text { Estrut. II (4h) }\end{array}$ & & & & \\
\hline & & & & $\begin{array}{l}\text { Trabailho } \\
\text { Integrado }\end{array}$ & & & & & \\
\hline
\end{tabular}

Disciplinas de Projeto

Disciplinas de Representação Gráfica e comp.
Disciplinas de Urbanismo e Meio Ambiente Disciplinas na área da Tecnologia da Arquitetura

\section{c) Quadro docente}

De acordo com os dados fornecidos na entrevista, o EAU-UFF possui 49 docentes, 29 pertencentes ao Departamento de Arquitetura e 20 docentes do Departamento de Urbanismo, não apresentando em seu quadro docente, profissionais com formação na área da engenharia. As disciplinas de Materiais e Técnicas e Sistemas construtivos I e II, são ministradas por professores pertencentes ao curso de Engenharia Civil, não sendo possível identificar quais são, atualmente, os atores representativos das disciplinas estudadas.

\section{d) Práticas didáticas e Infraestrutura laboratorial}

A escola possui dois laboratórios: de informática e expressão. Na área da Tecnologia da construção a infraestrutura utilizada é de uso compartilhado e pertence ao curso da Engenharia Civil, como o Laboratório de Materiais (Figura 80). De acordo com os professores entrevistados, esta infraestrutura não é utilizada de forma sistemática pelos alunos da arquitetura, apenas eventualmente pela disciplina de Materiais construtivos que oferece, aproximadamente, duas aulas laboratoriais. Trata-se de um laboratório que atende tanto a graduação como a pós-graduação e foi configurado para a realização de atividades experimentais voltadas ao curso da engenharia, predominando práticas com materiais cimentícios, com pesquisas também na área de compósitos. Quanto aos recursos humanos, o laboratório apresenta 02 técnicos.

Atualmente, não são oferecidas atividades práticas nas disciplinas estudadas, entretanto, esta questão tem sido ponto de pauta nas discussões sobre a reformulação curricular. Foram relatadas a ocorrência de algumas iniciativas isoladas, decorrentes da iniciativa pessoal de alguns alunos interessados, que trazem à escola algum conhecimento adquirido fora do contexto acadêmico, ex.: cursos em construções vernaculares com terra e bambu. Neste sentido, segundo a professora entrevistada, a reivindicação para a existência tanto do espaço como de atividades práticas tem partido dos próprios alunos, para que sua formação não fique restrita aos estágios e às visitas técnicas, algo que tem motivado iniciativas neste sentido por parte da coordenação do curso, mas apresenta-se ainda em fase de discussão ${ }^{160}$.

\footnotetext{
${ }^{160}$ Após a entrevista realizada em 12/12/2014, quando foram relatadas pela professora entrevistada as intenção do curso em implantar um canteiro experimental, algumas iniciativas sobre estas questões tomaram novas dimensões junto à UFF, como visto em: http://www.uff.br/?q=noticias/23-02-2015/cultura-indigena-viva-na-uff. Acesso em: 25/02/2016.
} 



Figura 83: Imagens internas do Laboratório de Materiais pertencente ao curso da Engenharia Civil.

Fonte: Fotos da autora.

\section{e) Pós graduação:}

O Programa de Pós-Graduação em Arquitetura e Urbanismo - PPGAU da Universidade Federal Fluminense foi criado 2002, oferecendo inicialmente o curso de Mestrado e, em 2012, foi aprovado o curso de Doutorado. O PPGAU oferece três linhas de pesquisa:

1- Projeto, Planejamento e Gestão da Arquitetura e da Cidade;

2- Cultura e História da Arquitetura, da Cidade e do Urbanismo;

3- Espaço Construído, Sustentabilidade e Ambiente

Não foi identificada, atualmente, a oferta de linhas de pesquisa na área da Tecnologia da Construção.

\section{f) Comentários:}

- O curso está em fase de reestruturação, como a criação de um Núcleo Estruturante, que reúne professores de diversas áreas, estando em processo de discussão a possibilidade da criação de um Departamento de Tecnologia no curso;

- As atividades práticas são realizadas em caráter eventual, sendo relatado que há por parte dos alunos, reinvindicações para a implantação de um canteiro experimental no curso;

- Não foram identificados atores representativos da área da Tecnologia da Construção, sendo comentado que em relação a esta área estudada, a mesma está sendo trabalhada de forma tangencial à área de Conforto Ambiental, não tendo conseguido ainda o espaço necessário;

- Embora tenha sido considerado como positivo o sistema colaborativo com outros Departamentos como a Engenharia Civil e a Belas Artes - há o reconhecimento da dificuldade no atendimento às particularidades de cada curso, assim como, a promoção da integralização entre os conteúdos ministrados. Essa dificuldades estão associadas, por exemplo, à continua redução de recursos para a contratação de técnicos e auxiliares para apoio às atividades de ensino e pesquisa nos próprios laboratórios do curso de Engenharia Civil;

- Há o reconhecimento da necessidade de revalorização da área da Tecnologia da Construção, considerada como secundarizada no curso e, que este processo, teria o apoio e adesão dos alunos, bastando oferecer atividades e pesquisas na área.

\section{2- FAURB - UFPel - Faculdade de Arquitetura e Urbanismo da Universidade Federal de Pelotas $^{161}$}

\section{a) Breve Histórico ${ }^{162}$}

\footnotetext{
${ }^{161}$ Cruzamento de informações coletadas a partir do Projeto Político Pedagógico e também a partir da visita técnica ao curso entre os dias 14 e 15 de abril de 2016, com entrevistas direcionadas aos professores: profa. Dra. Margarete Regina Freitas Gonçalves e ao prof. Dr. Sérgio Lund Azevedo.

162 Dados sintetizados a partir do histórico do curso publicado em: http://faurb.ufpel.edu.br/. Acesso realizado em: 27 de março de 2016.
} 
O Curso de Arquitetura e Urbanismo foi criado logo após a fundação da Universidade Federal de Pelotas, com os primeiros estudos para sua implantação realizados por volta de 1970. Na época havia somente dois cursos de Arquitetura e Urbanismo na Região Sul do País - em Porto Alegre e Curitiba. A partir da Portaria $n^{\circ} 215$, de 24 de novembro de 1971, a Reitoria da UFPEL criava e implantava o Curso de Arquitetura no Instituto de Artes, o qual iniciou suas atividades em 1972, oferecendo 35 vagas. A maior parte dos arquitetos que ajudaram a fundar o curso era de Porto Alegre.

As primeiras turmas foram matriculadas nas disciplinas do ciclo básico disponíveis na Universidade (disciplinas dos departamentos de Artes Visuais, Estudos de Artes Letras e Comunicação, do Instituto de Artes, e dos departamentos de Física, Matemática e Desenho do Instituto de Física e Matemática) que correspondiam às matérias básicas do Currículo Mínimo de Arquitetura e Urbanismo (Resolução CFE no 3 , de 25 de junho de 1969). No segundo semestre de 1973 foi criado o Departamento de Arquitetura vinculado ao Instituto de Artes e, no ano seguinte, o Colegiado do Curso de Arquitetura, responsável pela definição e oferta das disciplinas profissionalizantes específicas da formação do Arquiteto.

A partir de 1975, o Colegiado de Curso define o primeiro currículo integral a ser implantado, reduzindo o número de disciplinas básicas e direcionando o conteúdo para atender as necessidades específicas de formação do Curso. No ciclo profissionalizante eram propostas as disciplinas das áreas de Tecnologia da Construção, Projeto e de Teoria e História da Arquitetura. As disciplinas da área de Tecnologia da Construção foram implantadas no Departamento de Engenharia Rural da Faculdade de Agronomia Eliseu Maciel, pela inexistência das demais engenharias na Instituição, como a Engenharia Civil (curso criado apenas em 2009). As áreas de Projeto Arquitetônico e Urbanístico e de Teoria e História da Arquitetura e do Urbanismo foram assumidas pelo Departamento de Arquitetura, localizado naquela ocasião no antigo Instituto de Letras e Artes e as disciplinas de Desenho, Matemática e Física pelo Instituto de Física e Matemática.

Nos primeiros anos de funcionamento o curso foi marcado por sucessivas mudanças na programação das disciplinas, relacionada também com a oferta de professores arquitetos e urbanistas. Em 1978 foi implantado o quarto currículo do curso de Arquitetura, consolidando a estrutura curricular que vinha se constituindo desde sua implantação. No entanto, esta relativa estabilidade não decorria da implantação de um projeto de ensino previamente delineado, resultou de mudanças parciais adaptando no que foi possível o ensino de Arquitetura e Urbanismo às condições prévias da Universidade.

No ano de 1983, o curso adquire autonomia administrativa ao desvincular-se do Departamento de Arquitetura e o colegiado de Curso do então Instituto de Letras e Artes, passando a constituir uma unidade de ensino vinculada a Reitoria. Em 1985 o Departamento de Arquitetura foi desdobrado nos Departamentos de Arquitetura e Urbanismo - DAURB, e de Tecnologia da Construção - DTC, vinculados ao Curso de Arquitetura e Urbanismo. O Departamento de Tecnologia da Construção reuniu os professores da área que antes estavam lotados no Departamento de Engenharia Rural. Em 1987 o Curso de Arquitetura e Urbanismo foi transformado na Faculdade de Arquitetura e Urbanismo.

Atualmente, permanecem ativos os mesmos departamentos: Departamento de Arquitetura e Urbanismo e o Departamento de Tecnologia da Construção.

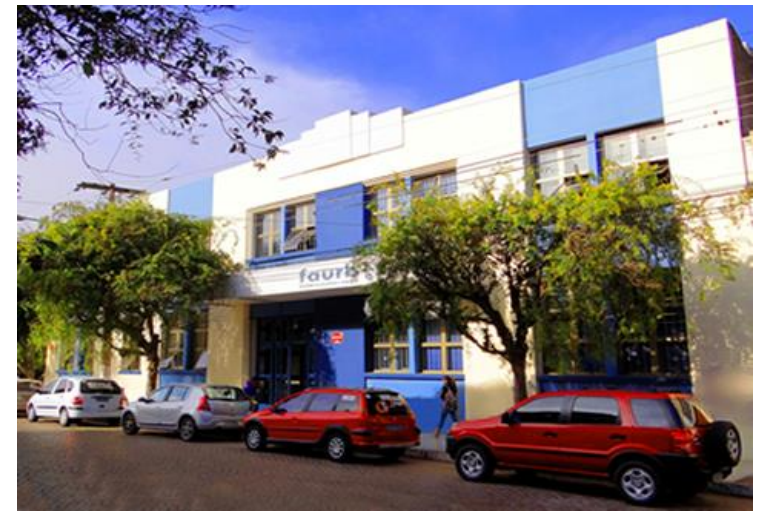

Figura 84 - Edifício sede do curso da Faculdade de Arquitetura e Urbanismo da UFPel.

Fonte: Adriana Portella. Obtida em: http://prograu.ufpel.edu.br/index.php/br/ufpel_faurb. 


\section{b) Considerações sobre a Estruturação da área de Tecnologia da Construção}

Os Departamentos da Faculdade de Arquitetura e Urbanismo foram criados em função das necessidades do ensino e são responsáveis pela oferta das disciplinas do núcleo de Formação Específica. Além desses departamentos, o Departamento de Engenharia Rural, da Faculdade de Agronomia Eliseu Maciel também oferece disciplinas.

Embora a reformulação da grade curricular esteja em fase de discussão, neste trabalho foi considerada a proposta em vigor no momento da visita técnica.

0 curso oferece 60 vagas anuais distribuídas em dois ingressos semestrais com 30 vagas/semestre. De acordo com o Quadro 22, as disciplinas de Tecnologia estão distribuídas entre o 20 e o 9o períodos, ocupando $30 \%$ dos créditos em disciplinas obrigatórias (não considerando no cômputo o Trabalho Final de Graduação - TFG, Viagens de Estudo e Estágio). As disciplinas da Tecnologia da Construção (Materiais e Técnicas da Construção I, II e III, Patologia das Construções e Gerenciamento das Construções) ocupam 8,5\% dos créditos, Sistemas Estruturais 11\%; Instalações Prediais 2,5\%; Conforto Ambiental 4,5\% e outras (Topografia, Prevenção contra Incêndio e Sustentabilidade do Ambiente Construído) 3,5\% dos créditos.

As disciplinas de Materiais e Técnicas da Construção I, II e III são ofertadas, respectivamente, no 3으, 4은 e 50 períodos, Patologias das Construções no 60 período e Gerenciamento das Construções no 70 períodos ( $2{ }^{\circ}, 3^{\circ}$ e 4 으on do curso).

Quadro 22 - Distribuição da Grade Curricular com a carga horária semestral - FAURB UFPel:

\begin{tabular}{|c|c|c|c|c|c|c|c|c|c|}
\hline $10 \mathrm{sem}$ & 20 sem & 30 sem & 40 sem & 50 sem & 60 sem & 70 sem & 80 sem & 9o sem & $10 \circ$ sem \\
\hline $\begin{array}{c}\text { Fund. Pratica } \\
\text { Projeto (8h) }\end{array}$ & $\begin{array}{c}\text { Projeto Arq. I } \\
(8 \mathrm{~h})\end{array}$ & $\begin{array}{c}\text { Projeto Arq. II } \\
\text { (8h) }\end{array}$ & $\begin{array}{c}\text { Projeto Arq. III } \\
\text { (8h) }\end{array}$ & $\begin{array}{l}\text { Projeto Arq. } \\
\text { IV (8h) }\end{array}$ & $\begin{array}{l}\text { Proj. Arq. Urb } \\
\text { (8h) }\end{array}$ & $\begin{array}{c}\text { Projeto Urb. } \\
(8 \mathrm{~h})\end{array}$ & $\begin{array}{l}\text { Tec.retrosp } \\
\text {. Proj. Arq. } \\
\text { Urb. (8h) }\end{array}$ & $\mid \begin{array}{c}\text { Planej. Urb. } \\
\text { (8h) }\end{array}$ & TFG \\
\hline $\begin{array}{l}\text { Hist. Artes } \\
\text { (2h) }\end{array}$ & $\begin{array}{l}\text { Teor. Hist. Arq. } \\
\text { Urb. P. II (2h) }\end{array}$ & $\begin{array}{l}\text { Est. Sociais e } \\
\text { Econom. (2h) }\end{array}$ & $\begin{array}{l}\text { Proj. Paisag. } \\
\text { (4h) }\end{array}$ & $\begin{array}{l}\text { Arq. Interior } \\
(4 \mathrm{~h})\end{array}$ & $\begin{array}{c}\text { Teoria do Urb. } \\
\text { II (2h) }\end{array}$ & $\begin{array}{l}\text { Infraest. } \\
\text { Urb. (2h) }\end{array}$ & $\begin{array}{l}\text { Teor. Hist. } \\
\text { Conser. } \\
\text { Rest. (2h) }\end{array}$ & \begin{tabular}{|c|} 
Planej \\
region. (4h)
\end{tabular} & \\
\hline $\begin{array}{l}\text { Teor. Hist. Arq. } \\
\text { Urb. P. I (4h) }\end{array}$ & $\begin{array}{l}\text { Desenho Tec. } \\
\text { Arq. II (4h) }\end{array}$ & $\begin{array}{l}\text { Teor.Hist. Arq. } \\
\text { Urb. P. III ( } 2 \text { h) }\end{array}$ & $\begin{array}{l}\text { Teor. Hist. Arq. } \\
\text { Urb. P. IV(4h) }\end{array}$ & $\begin{array}{l}\text { Teoria do } \\
\text { Urb. I (3h) }\end{array}$ & $\begin{array}{l}\text { Teor. Hist. } \\
\text { Arq. Urb. P.VI } \\
\text { (2h) }\end{array}$ & $\begin{array}{l}\text { Conf. Amb. } \\
\text { Acust. (2h) }\end{array}$ & $\begin{array}{l}\text { Estetica } \\
(2 \mathrm{~h})\end{array}$ & $\begin{array}{l}\text { Legisl. prat. } \\
\text { Profiss. (2h) }\end{array}$ & \\
\hline $\begin{array}{c}\text { Desenho Tec. } \\
\text { Arq. I (4h) }\end{array}$ & $\begin{array}{l}\text { Expr. Repres. } \\
\text { Grafica II (4h) }\end{array}$ & $\begin{array}{l}\text { Expr. Repres. } \\
\text { Grafica III (4h) }\end{array}$ & $\begin{array}{l}\text { Inform. aplic. } \\
\text { Proj.Arq.II (2h) }\end{array}$ & $\begin{array}{l}\text { Teor. Hist. } \\
\text { Arq. Urb. P. } \\
\text { V (4h) }\end{array}$ & $\begin{array}{c}\text { Sistemas } \\
\text { Estrut. IV (4h) }\end{array}$ & $\begin{array}{c}\text { Sistemas } \\
\text { Estrut.V (4h) }\end{array}$ & $\begin{array}{l}\text { Conf. Amb. } \\
\text { Cond. } \\
\text { Term. (2h) }\end{array}$ & \begin{tabular}{|c|} 
Seminário \\
Diplom. \\
$(2 \mathrm{~h})$
\end{tabular} & \\
\hline $\begin{array}{l}\text { Expr. Repres. } \\
\text { Grafica I (4h) }\end{array}$ & $\begin{array}{l}\text { Geom. Graf. } \\
\text { Digital III (4h) }\end{array}$ & $\begin{array}{l}\text { Inform. aplic. } \\
\text { Proj.Arq. I (3h) }\end{array}$ & $\begin{array}{l}\text { Iluminação } \\
\text { Arq. (2h) }\end{array}$ & $\begin{array}{l}\text { Instalações } \\
\text { Hidro. (3h) }\end{array}$ & $\begin{array}{c}\text { Patologia das } \\
\text { constr. (4h) }\end{array}$ & $\begin{array}{c}\text { Gerenc. } \\
\text { Const. (4h) }\end{array}$ & $\begin{array}{l}\text { Prev. C. } \\
\text { Incendio } \\
\text { (2h) }\end{array}$ & \begin{tabular}{|c|} 
Sustent. \\
Amb.Const. \\
(2h)
\end{tabular} & \\
\hline $\begin{array}{l}\text { Geom. Graf. } \\
\text { Digital I (3h) }\end{array}$ & $\begin{array}{l}\text { Geom. Graf. } \\
\text { Digital IV (4h) }\end{array}$ & $\begin{array}{c}\text { Topografia } \\
\text { (4h) }\end{array}$ & $\begin{array}{l}\text { Instalações } \\
\text { elétricas (3h) }\end{array}$ & $\begin{array}{c}\text { Sistemas } \\
\text { Estrut. III } \\
\text { (4h) }\end{array}$ & Estagio Obrig. & & $\begin{array}{c}\text { Sistemas } \\
\text { Estrut.VI } \\
(4 \mathrm{~h})\end{array}$ & $\begin{array}{c}\text { Sistemas } \\
\text { Estrut.VII } \\
\text { (2h) }\end{array}$ & \\
\hline \multirow[t]{3}{*}{$\begin{array}{l}\text { Geom. Graf. } \\
\text { Digital II (4h) }\end{array}$} & $\begin{array}{c}\text { Arq. Bioclimat. } \\
(4 \mathrm{~h})\end{array}$ & $\begin{array}{l}\text { Sistemas } \\
\text { Estrut. I (3h) }\end{array}$ & $\begin{array}{c}\text { Sistemas } \\
\text { Estrut. II (4h) }\end{array}$ & $\begin{array}{c}\text { Mat. Tec. da } \\
\text { Construç.III } \\
\text { (4h) }\end{array}$ & & & & & \\
\hline & Viagens de & $\begin{array}{l}\text { Mat. Tec. da } \\
\text { Construç.I } \\
(4 \mathrm{~h})\end{array}$ & $\begin{array}{l}\text { Mat. Tec. da } \\
\text { Construç.II } \\
(4 \mathrm{~h})\end{array}$ & & & & & & \\
\hline & Viagens de & & & & & & & & \\
\hline
\end{tabular}

Disciplinas de Projeto

Disciplinas de Representação Gráfica e comp.
Disciplinas de Urbanismo e Meio Ambiente

Disciplinas na área da Tecnologia da Arquitetura
Disciplinas de Historia e Teoria

\section{c) Quadro docente}

No Departamento de Arquitetura e Urbanismo (DAURB) estão lotados apenas professores arquitetos e no Departamento de Tecnologia da Construção (DTC), tanto professores com formação nas áreas de Arquitetura e Urbanismo como em Engenharia Civil. Até pouco tempo, as disciplinas da área estudada eram ministradas, integralmente, por professores engenheiros. Atualmente, professores com formação em arquitetura também passaram a colaborar na área da Tecnologia da Construção. 


\section{d) Práticas didáticas e Infraestrutura laboratorial}

A área da tecnologia da construção sempre foi conduzida pelo curso de arquitetura devido à inexistência do curso de Engenharia Civil na UFPel (criado em 2009), no momento de sua criação (1971) e primeiras décadas de existência, impossibilitando o habitual apoio infraestrutural/técnico deste curso. Ao longo das primeiras décadas de funcionamento do curso, as engenharias não foram implantadas, com exceção da Engenharia agrícola. Apenas em 2006 foi então criada a Engenharia Industrial madeireira e, anos depois, os demais cursos do Centro de Engenharias, este cenário influenciou na criação do Departamento de Tecnologia da Construção na Faculdade de Arquitetura, mas sem infraestrutura laboratorial nesta área.

Atualmente, o curso possui o Laboratório de Conforto e Eficiência Energética e também o Laboratório de Urbanismo. Quanto ao Laboratório de Materiais, de acordo com uma das entrevistas realizadas, houve diversas tentativas iniciais para a criação deste espaço junto ao curso de Arquitetura (entre 1980 e 1995), experiências marcadas pela utilização de pequenos espaços, que apresentavam mostruários de materiais e contavam com a colaboração de um técnico e um auxiliar. Ao longo dos anos, estes locais foram constantemente reivindicados pelo curso e, devido a uma conjuntura de condicionantes não conseguiram ser sustentados, não existindo mais nos dias atuais. Pode-se considerar que, uma das dificuldades encontradas foi a falta do curso de Engenharia Civil que, além de poder vir a dar apoio na sustentação desta infraestrutura, descentralizaria de um único docente o excesso de atribuições, como coordenação e condução de atividades deste cunho, aliado a isso, de acordo com os dados obtidos, a realização de atividades laboratoriais não seria algo imprescindível.

Atualmente, as estratégias didáticas para a realização de atividades práticas em algumas disciplinas, como a de Materiais e Técnicas da Construção II, direciona-se a visitas técnicas em obras, indústrias e fábricas da construção civil, algumas delas em associação à disciplina de Materiais e Técnicas da Construção III, o laboratório passou a ser então externo (visitas aos locais citados), sendo nesta disciplina abordados conteúdos referentes aos materiais construtivos e técnicas de aplicação

Esta simultaneidade de abordagens (materiais e técnicas) também é aplicada na disciplina de Materiais e Tecnologia da Construção I, quando é realizada uma introdução sobre os materiais e técnicas de construção, fundações e solos e, também, materiais produzidos em canteiro de obras, como as argamassas e o concreto (sem a aplicação de procedimentos de cálculo). Esta disciplina, assim como Patologia das Construções, não se utiliza de processos experimentais e visitas técnicas, tendo caráter predominantemente teórico.

\section{e) Pós graduação:}

O Programa de Pós-Graduação em Arquitetura e Urbanismo da Universidade Federal de Pelotas foi credenciado pela CAPES em 2007 e iniciou suas atividades em Agosto de 2008, apresenta duas Áreas de Concentração em nível de Mestrado:

Arquitetura, Patrimônio e Sistemas urbanos. Tendo como linhas de pesquisa:

1- Gráfica Digital Aplicada a Prática Projetual

2- História da Arquitetura e da Cidade

3- Percepção e Avaliação do Ambiente pelo Usuário

4- Sistemas Configuracionais Urbanos

5- Teoria, História e Crítica da Arquitetura e Urbanismo

Qualidade e Tecnologia do Ambiente Construído. Tendo como linhas de pesquisa:

1- Conforto e Sustentabilidade do Ambiente Construído

2- Gestão, Produção e Conservação do Ambiente Construído

Em relação às áreas de concentração apresentadas, 'Qualidade e Tecnologia do Ambiente Construído' apresenta a possibilidade no desenvolvimento de pesquisas com interface à área da Tecnologia da Construção.

\section{f) Comentários:}


- Há discussões recentes no curso para a proposição de uma disciplina Introdutória no 20 semestre, voltada à área de tecnologia, para que os alunos tenham uma visão geral dos sistemas construtivos antes de entrarem em assuntos específicos;

- Foram observados entendimentos diferenciados entre professores sobre a pertinência da adoção de atividades laboratoriais em auxílio às disciplinas da área da Tecnologia da Construção;

- A proximidade docente com as pesquisas da pós-graduação (desenvolvidas nas engenharias) possibilita que alguns assuntos e resultados de pesquisas em andamento sejam abordados (ainda que em caráter informativo) nas disciplinas da graduação;

- Algumas disciplinas possuem relação direta com a formação docente. Ex.: oferecimento da disciplina de Patologias das Construções para a graduação (foi relatado ser o primeiro curso nacional a oferecer esta disciplina na graduação, sendo habitual apenas na pós-graduação, embora tenha tornado-se obrigatória há, aproximadamente, 02 anos).

- Como ponto a ser melhorado, foi comentado ser interessante ao longo do processo de formação a presença de professores da área da Tecnologia nos Ateliês de Projeto. Esta possibilidade daria maiores chances de determinados assuntos técnicos serem trabalhados de forma mais abrangente, como a relação entre a materialidade e o projeto executivo;

- Foi também exposto, que assuntos que não envolvem o processo de representação, geralmente, não suscitam o interesse dos alunos e, que devido a este fato, os alunos procuram, preferencialmente, professores de estruturas para auxiliá-los nas disciplinas de projeto em relação aos de materiais e técnicas, devido a necessidade da representação dos elementos estruturais;

- O histórico do curso revela as dificuldades encontradas na área da Tecnologia, que ao longo do processo de sua implantação não pôde contar com o tradicional apoio laboratorial do curso da Engenharia Civil ao longo do processo de implantação (funcionando quase 4 décadas mais tarde).

\section{3- CAU - UFRN - Curso de Arquitetura e Urbanismo da Universidade Federal do Rio Grande do Norte N63 $^{163}$}

\section{a) Breve Histórico ${ }^{164}$}

O curso da UFRN foi criado a partir da Resolução CONSUNI-58/73 de 13 de agosto 1973, tendo se desmembrado do Curso de Engenharia em maio de 1977, quando passou a fazer parte do Centro de Tecnologia ${ }^{165}$. A primeira turma de alunos ingressou em 1974 e se formou no final de 1978, após este período, em 1979, o curso foi reconhecido pelo MEC. De acordo com o Projeto Pedagógico do curso, o primeiro currículo do CAU baseou-se nos currículos dos cursos da Universidade de Brasília (UNB) e da Universidade Federal do Ceará (UFC), refletindo o momento de seu surgimento pois: (i) submetia os estudantes a uma carga de tecnologia elevada; (ii) era composto por muitas disciplinas isoladas, oferecidas por vários departamentos da universidade; (iii) impunha um saber compartimentado e pouco direcionado para a área de atuação profissional.

Percebe-se que a partir de 1976/77, a história do curso é construída por meio de esforços e iniciativas para ajustes, apoiando-se também em documentos regulatórios divulgados pelo MEC. Uma das primeiras ações realizadas no curso visava o agrupamento dos períodos por blocos, tomando a definição de enfoques como base da organização curricular. Embora o currículo tenha sido objeto de

\footnotetext{
${ }^{163}$ Dados obtidos em visita técnica ao curso de Arquitetura e Urbanismo da UFRN entre os dias 13 e 14/06/2016, com entrevistas direcionadas aos professores: Dra. Edna Pinto Moura e Dr. José Jefferson de Sousa.

${ }^{164}$ As informações referentes ao Histórico do curso foram obtidas no Projeto Pedagógico vigente no período da visita técnica.

165 Mais precisamente em 1973, o Centro de Tecnologia surge como uma sobreposição à Escola de Engenharia, devido à reformulação estrutural que ocorreu no ensino universitário no Brasil nesse período. Com a nova estrutura, o Centro abrangeu os cursos de Engenharia Civil, Engenharia Elétrica, Engenharia Química, Engenharia Mecânica, Arquitetura e Urbanismo e de tecnólogos em Indústria Têxtil, Administração Rural e Cooperativismo, que tinham a duração de três anos. Dados obtidos em: http://www.ct.ufrn.br/sobre/. Acesso em 20/05/2016.
} 
algumas alterações após 1981, ele manteve-se praticamente o mesmo até 1987 . Dentre as críticas realizadas estava o excesso de disciplinas de conteúdo técnico sem relação direta com a formação profissional do arquiteto e urbanista; a desvinculação dos diversos conhecimentos entre si e a não aglutinação das disciplinas afins em torno de áreas de conhecimento.

Durante 1987 e 1988 ocorreram inúmeras discussões que terminaram por impulsionar o surgimento de um currículo diferenciado, chamado A-3. Foram definidas então, 05 áreas de conhecimento (Representação gráfica, Projeto de arquitetura, Estudos urbanos, Teoria/História e Tecnologia) em torno das quais foram organizadas as linhas de estudo e pesquisa bem como as disciplinas. Ainda segundo informações contidas no PPP de curso, a principal mudança curricular ocorreu, porém, através da adoção do princípio de 'integração' de conteúdos e produtos acadêmicos, que norteava todas as atividades, o qual também definiu o período como unidade mínima de integração. O currículo A-3 foi implantado em 1990 e representou um significativo salto qualitativo para o curso, resultando na melhoria da qualidade dos trabalhos desenvolvidos pelos alunos e formação profissional.

As reformas curriculares continuaram nos anos seguintes, motivadas por discussões internas e também pela Portaria $n^{\circ} 1770 / 1994$, do MEC. De modo geral, o PPP atual mantém os avanços obtidos nas últimas reformulações curriculares, em especial a que produziu o currículo seguinte, o chamado A4. Novos ajustes e alterações continuaram a ser realizados ao longo dos anos, em especial no que se refere à obrigatoriedade de atividades que não se encaixam na categoria de disciplinas, assim como da exigência do estágio curricular supervisionado. O último processo de reformulação iniciou em 2000, resultando em uma nova proposta de currículo, o A-5, cujas informações fomentaram o desenvolvimento dos próximos itens.

Atualmente, o curso de Arquitetura e Urbanismo é oferecido pelo Departamento de Arquitetura e permanece como parte integrante do Centro de Tecnologia da UFPB.


Figura 85 - Edifício pertencente ao curso de Arquitetura e Urbanismo da UFRN. a) e b) Entrada principal. c) Vista do edifício a partir da área considerada como Canteiro experimental.

Fonte: fotos da autora.

\section{b) Considerações sobre a Estruturação da área da Tecnologia da Construção}

As áreas de estudo em que se estrutura o Curso são: Representação e Linguagem, Projeto, Planejamento e Projeto Urbano e Regional, História e Teoria da Arquitetura e do Urbanismo e Tecnologia.

A Área da Tecnologia subsidia, de forma gradual e integrada, as demais áreas do Curso, visando o equilíbrio entre o projeto e a execução. Os conteúdos de cada período obedecem a uma sequência lógica e complementar, intensificando sua complexidade a cada semestre, procurando integrar as diversas disciplinas e atividades complementares (quando pertinentes) segundo um enfoque temático que norteia o aprendizado. São eles:

\begin{tabular}{|c|c|c|c|c|c|c|c|c|c|}
\hline $\begin{array}{c}10 \\
\text { Semestre }\end{array}$ & $\begin{array}{c}20 \\
\text { Semestre }\end{array}$ & $\begin{array}{c}\text { 3o } \\
\text { Semestre }\end{array}$ & $\begin{array}{c}40 \\
\text { Semestre }\end{array}$ & $\begin{array}{c}\text { 5o } \\
\text { Semestre }\end{array}$ & $\begin{array}{c}\text { 60 } \\
\text { Semestre }\end{array}$ & $\begin{array}{c}\text { 70 } \\
\text { Semestre }\end{array}$ & $\begin{array}{c}80 \\
\text { Semestre }\end{array}$ & $\begin{array}{c}90 \\
\text { Semestre }\end{array}$ & $\begin{array}{c}10 \circ \\
\text { Semestre }\end{array}$ \\
\hline $\begin{array}{c}\text { Forma e } \\
\text { representação }\end{array}$ & $\begin{array}{c}\text { Espaço e } \\
\text { sociedade }\end{array}$ & $\begin{array}{c}\text { Projeto e } \\
\text { tecnologia }\end{array}$ & $\begin{array}{c}\text { Meio } \\
\text { ambiente }\end{array}$ & $\begin{array}{l}\text { Ambiente } \\
\text { construído }\end{array}$ & $\begin{array}{c}\text { Verticalização } \\
\text { e paisagem }\end{array}$ & $\begin{array}{c}\text { Patrimônio } \\
\text { histórico }\end{array}$ & $\begin{array}{c}\text { Complexida } \\
\text { de }\end{array}$ & $\begin{array}{c}\text { Demandas } \\
\text { sociais }\end{array}$ & $\mathrm{TP}$ \\
\hline
\end{tabular}

Quadro 23 - Distribuição da Grade Curricular com a carga horária semestral - CAU UFRN: 


\begin{tabular}{|c|c|c|c|c|c|c|c|c|c|}
\hline 19 sem & 20 sem & 3ㅇ sem & 4ㅇ sem & 50 sem & 60 sem & 70 sem & 8ㅇ sem & 9o sem & 10 sem \\
\hline $\begin{array}{c}\text { Espaço e } \\
\text { forma } 01(4 C)\end{array}$ & $\begin{array}{c}\text { Espaço e } \\
\text { forma } 02(4 C)\end{array}$ & $\begin{array}{c}\text { Projeto Arq. } \\
01(4 C)\end{array}$ & $\begin{array}{l}\text { Projeto Arq. } \\
02(5 \mathrm{C})\end{array}$ & $\begin{array}{c}\text { Projeto Arq. } \\
03(5 C)\end{array}$ & $\begin{array}{l}\text { Projeto Arq. } \\
04(6 C)\end{array}$ & $\begin{array}{c}\text { Projeto Arq. } \\
05(6 C)\end{array}$ & $\begin{array}{c}\text { Projeto } \\
\text { Arq. } 06(8 \mathrm{C})\end{array}$ & $\begin{array}{c}\text { Ateliê } \\
\text { integrado } \\
\text { de Arq. } \\
(12 \mathrm{C})\end{array}$ & TFG \\
\hline $\begin{array}{l}\text { Introdução à } \\
\text { Arq e Urb (3C) }\end{array}$ & $\begin{array}{c}\text { Estética e hist. } \\
\text { das artes } 02 \\
(4 \mathrm{C})\end{array}$ & $\begin{array}{c}\text { Planej. Urb e } \\
\text { Region. } 01 \\
\text { (3C) }\end{array}$ & $\begin{array}{c}\text { Psicologia } \\
\text { amb. } 01(3 C)\end{array}$ & $\begin{array}{c}\text { Planej. Da } \\
\text { paisag. } 01 \\
(3 \mathrm{C})\end{array}$ & $\begin{array}{c}\text { Planej. da } \\
\text { paisag. } 02 \\
(3 \mathrm{C})\end{array}$ & $\begin{array}{c}\text { Planej. da } \\
\text { paisag. } 03 \\
(3 C)\end{array}$ & $\begin{array}{c}\text { Planej. Urb } \\
\text { e Region. } \\
06(8 C)\end{array}$ & $\begin{array}{c}\text { Introdução } \\
\text { ao TFG }\end{array}$ & \\
\hline \begin{tabular}{|c|} 
Estética e \\
hist. das artes \\
$01(6 \mathrm{C})$ \\
\end{tabular} & $\begin{array}{c}\text { Fundam. } \\
\text { sociais da Arq. } \\
\text { Urb. (3C) }\end{array}$ & $\begin{array}{c}\text { Hist. e teoria } \\
\text { da Arq } 01(6 C)\end{array}$ & $\begin{array}{c}\text { Planej. Urb e } \\
\text { Region. } 02 \\
\text { (3C) }\end{array}$ & $\begin{array}{c}\text { Planej. Urb } \\
\text { e Region. } 03 \\
(5 \mathrm{C})\end{array}$ & $\begin{array}{c}\text { Planej. Urb e } \\
\text { Region. } 04 \\
(5 \mathrm{C})\end{array}$ & $\begin{array}{c}\text { Planej. Urb } \\
\text { e Region. } 05 \\
(6 C)\end{array}$ & $\begin{array}{c}\text { Prática } \\
\text { profissio. } \\
\text { (4C) } \\
\end{array}$ & & \\
\hline $\begin{array}{c}\text { Métodos e } \\
\text { técnicas (3C) }\end{array}$ & $\begin{array}{c}\text { Geometria } \\
\text { gráfica } 02(6 C)\end{array}$ & $\begin{array}{c}\text { Comunicação } \\
\text { visual }(4 C)\end{array}$ & $\begin{array}{c}\text { Hist. e teoria } \\
\text { da Arq } 02(4 C)\end{array}$ & $\begin{array}{c}\text { Hist. e } \\
\text { teoria da } \\
\text { Arq } 03(4 \mathrm{C})\end{array}$ & $\begin{array}{l}\text { Hist. e teoria } \\
\text { da Arq } 04(4 C)\end{array}$ & $\begin{array}{l}\text { Preserv. e } \\
\text { tec. } \\
\text { retrospec. } \\
\text { (3C) }\end{array}$ & $\begin{array}{c}\text { Tecnologia } \\
\text { das } \\
\text { Construç. } \\
03(3 C)\end{array}$ & & \\
\hline $\begin{array}{c}\text { Geometria } \\
\text { gráfica } 01 \\
(6 \mathrm{C})\end{array}$ & $\begin{array}{l}\text { Desenho de } \\
\text { arq. } 02(4 C)\end{array}$ & \begin{tabular}{|c|} 
Tecnologia \\
das Construç. \\
$02(4 \mathrm{C})$ \\
\end{tabular} & \begin{tabular}{|c|}
$\begin{array}{c}\text { Desenho } \\
\text { aux./comp. } 01 \\
\text { (4C) }\end{array}$ \\
\end{tabular} & \begin{tabular}{|c} 
Desenho \\
aux./comp. \\
$02(4 \mathrm{C})$
\end{tabular} & $\begin{array}{c}\text { Conforto } \\
\text { ambiental } 02 \\
(3 \mathrm{C})\end{array}$ & \begin{tabular}{|c} 
Detalhes de \\
repres. Graf. \\
$(4 \mathrm{C})$
\end{tabular} & & & \\
\hline $\begin{array}{l}\text { Desenho de } \\
\text { arq. } 01(4 C)\end{array}$ & $\begin{array}{c}\text { Desenho } \\
\text { artist. } 02(3 C)\end{array}$ & \begin{tabular}{|c|} 
Fundam. das \\
estruturas 01 \\
$(4 \mathrm{C})$
\end{tabular} & $\begin{array}{c}\text { Fundam. } \\
\text { ambientais } \\
(3 C)\end{array}$ & $\begin{array}{c}\text { Conforto } \\
\text { ambiental } \\
01(3 C) \\
\end{array}$ & $\begin{array}{c}\text { Instalações } 02 \\
(4 C)\end{array}$ & $\begin{array}{c}\text { Conforto } \\
\text { ambiental } \\
03(3 \mathrm{C}) \\
\end{array}$ & & & \\
\hline $\begin{array}{c}\text { Desenho } \\
\text { artist. } 01(3 \mathrm{C})\end{array}$ & \begin{tabular}{|c|} 
Tecnologia das \\
Construç. 01 \\
$(4 \mathrm{C})$
\end{tabular} & $\begin{array}{l}\text { Topografia } \\
\text { (4C) }\end{array}$ & $\begin{array}{c}\text { Instalações } 01 \\
\text { (4C) }\end{array}$ & $\begin{array}{c}\text { Estruturas } \\
01(4 \mathrm{C})\end{array}$ & $\begin{array}{c}\text { Estruturas } 02 \\
(4 \mathrm{C})\end{array}$ & & & & \\
\hline $\begin{array}{c}\text { Estatística } \\
\text { aplicada (3C) }\end{array}$ & & & $\begin{array}{c}\text { Fundam. das } \\
\text { estruturas } 02 \\
\text { (4C) }\end{array}$ & & & & & & \\
\hline
\end{tabular}

Disciplinas de Projeto

Disciplinas de Representação Gráfica e comp.

Disciplinas de Urbanismo e Meio Ambiente Disciplinas na área da Tecnologia da Arquitetura

De acordo com o Quadro 23, as disciplinas da área da Tecnologia da Arquitetura, estão distribuídas entre o 1 ㅇ e o 8 o períodos, sendo que as disciplinas de Tecnologia das Construções 1,2 e 3, encontramse no 20 , 3ㅇ e 8 o períodos, respectivamente, observando-se um intervalo entre as duas últimas de 4 semestres. A área da Tecnologia da Arquitetura soma $23 \%$ dos créditos totais destinados às disciplinas obrigatórias (não sendo considerado no cômputo Introdução ao Trabalho Final de Graduação e Trabalho de Graduação), sendo $5 \%$ dos créditos voltados à área da Tecnologia da Construção, 7\% Sistemas Estruturais, 5\% Conforto Ambiental, 3\% Instalações Prediais, 1\% Fundamentação e 2\% em outras disciplinas da área (Topografia).

\section{c) Quadro docente}

Nos primeiros anos do CAU muitas disciplinas técnicas eram oferecidas por outros departamentos. No entanto, devido às suas necessidades metodológicas específicas e à integração horizontal e vertical dos conteúdos ministrados no seu currículo, elas foram gradativamente incorporadas, de modo que, hoje, são oferecidas pelo DARQ, com exceção de Estatística e Topografia. Os professores que compõem o quadro docente na área da Tecnologia são tanto engenheiros ( 02 engenheiros civis e 01 engenheiro mecânico) como arquitetos. Em relação às disciplinas de Tecnologia das Construções 1, 2 e 3 são ministradas integralmente por professores com formação em Arquitetura e Urbanismo.

\section{d) Práticas didáticas e Infraestrutura laboratorial}

Segundo o PPP (2006), o Laboratório de Maquetes e Protótipos possui poucos equipamentos e materiais de consumo disponíveis. Já os últimos laboratórios criados (Ambientação e Arquitetura de Interiores, e Sistemas Estruturais e Construtivos), cuja existência é exigida pelas Diretrizes Curriculares do MEC, foram implantados com grande dificuldade, carecendo totalmente de equipamentos para o seu funcionamento. 
Em relação ao Laboratório de Sistemas Estruturais e Construtivos (LabSec), no momento da visita técnica o mesmo localizava-se junto ao edifício principal, caracterizado por duas salas amplas e fechadas. Este espaço não se configura como um laboratório de experimentação construtiva, mas abriga mostruário de materiais, maquetes e modelos (provenientes em sua maioria de atividades em disciplinas da área de Sistemas Estruturais) e, também, funciona como sala dos professores da área da Tecnologia da Arquitetura. Esta readequação de uso foi ocasionada pela contratação de novos docentes, assim como, a partir da construção de um Canteiro Experimental, o qual foi idealizado para que tanto disciplinas da área da tecnologia como também de projeto se utilizassem deste espaço para a realização de atividades, embora, segundo relatos, não conseguiram implementar este objetivo interdisciplinar, sendo este espaço mais utilizado pelas disciplinas da área da tecnologia.

O Canteiro Experimental está localizado próximo ao edifício principal, havendo a possibilidade de acesso direto a este espaço. É caracterizado por uma edificação de pequeno porte em alvenaria e área livre, com o apoio de baias para depósito de materiais de construção. Atualmente, encontra-se semiutilizado - diferentemente do início de sua construção - transformando-se em depósito de equipamentos e materiais, não necessariamente ligados à pesquisa ou atividades vinculadas às disciplinas técnicas. De acordo com os relatos, a falta de investimento para sua utilização de forma contínua relaciona-se à provável construção de um novo edifício para o curso de Arquitetura e Urbanismo no local do atual canteiro, o que promoverá sua demolição futura, desestimulando então investimentos para sua utilização. Em relação à verba para sustentação das atividades, foi relatado que não há recursos institucionais para esta finalidade e, as práticas já realizadas foram financiadas por meio de doações de empresas e recursos complementados pelos próprios alunos. O local não possui técnico(s) para auxílio nas atividades.



Figura 86 - Área destinada ao atual Canteiro Experimental. a) e b) Edícula em alvenaria, atualmente não utilizada como laboratório. c) Área livre entre edifício principal e edícula. d) Baias descobertas para depósito de materiais de construção.

Fonte: fotos da autora.

Em relação ao conteúdo da área da Tecnologia da Construção, o mesmo é ministrado na forma de 3 disciplinas, extrapolando alguns assuntos para a área de Sistemas Estruturais, que também aborda em alguns momentos, assuntos relativos aos sistemas construtivos, mas sem haver sobreposição de conteúdos.

Na disciplina de Tecnologia da Construção 01 são trabalhados os materiais básicos, como classificação e propriedades dos materiais. Os assuntos referentes à caracterização e aplicabilidade são ministrados simultaneamente, limitando-se a apenas alguns materiais convencionais. Sobre as práticas pedagógicas utilizadas nesta disciplina, além das aulas expositivas, são realizadas algumas visitas em obra e desenvolvidos experimentos básicos com concreto e argamassa. Não há a aplicação regular de práticas experimentais, sendo relatado que em alguns períodos foram confeccionados elementos isolados como blocos e cobogós, mas não protótipos em escalas maiores, como a 1:1, por não possuírem ainda estrutura física adequada. Segundo o professor entrevistado, não há a necessidade da implantação de infraestrutura laboratorial voltada à avaliação mecânica (ex.: rompimentos de corpos de prova) pela sua existência no curso da Engenharia Civil. E, devido à proximidade entre o edifício principal do curso de Arquitetura e a infraestrutura laboratorial pertencente à Engenharia Civil, há a possibilidade de uso compartilhado, embora não seja utilizado nesta disciplina.

A partir de Tecnologia das Construções 02, os alunos passam a ter contato com questões relacionadas ao canteiro de obras e acabamentos. A dinâmica da disciplina passa a envolver visitas a lojas de materiais de construção (divididos em turmas) e os alunos fazem acompanhamento de 3 obras ao longo do semestre: uma em fase de fundação, uma em fase de alvenaria e outra em fase de acabamento. 
Estas visitas de acompanhamento ocorrem em diferentes obras em período quinzenal, com o desenvolvimento de relatórios e, a cada 20 dias, aproximadamente, é realizada uma visita coletiva com a orientação do professor em uma destas obras, desta forma, é possível estabelecer a troca de informações. Esta estratégia tem possibilitado o contato direto dos alunos com a construção, os sistemas construtivos e os profissionais envolvidos na obra, como projetistas, calculistas e construtores.

Em relação à Tecnologia das Construções 3, a disciplina aborda assuntos referentes a planejamento, gestão e orçamento. Este conteúdo é conduzido não apenas em função do que é abordado nas disciplinas anteriores de Tecnologia das Construções, mas também do conteúdo de Instalações e Estruturas.

\section{e) Pós graduação ${ }^{166}$}

O Programa de Pós-Graduação em Arquitetura e Urbanismo - PPGAU da UFRN teve início em março de 1998, com o Curso de Especialização 'Estudos do Habitat com Ênfase na Questão Ambiental' aprovado e financiado pela Coordenação de Aperfeiçoamento de Pessoal de Nível Superior - CAPES, através do Projeto Nordeste.

O Mestrado foi implantado a partir de 1999, sendo as Linhas de Pesquisa iniciais do PPGAU resultantes das investigações e da produção intelectual de seus docentes. Em 2003, o Programa deu início a um processo interno de avaliação e de re-estruturação, resultando no re-ordenamento das Áreas de Concentração e Linhas de Pesquisa e das disciplinas até então oferecidas. Ao longo deste processo, a proposta do Programa para o nível de Doutorado foi encaminhada às instâncias competentes, sendo aprovado pela CAPES em agosto de 2006. As atuais Áreas de Concentração e Linhas de Pesquisa são:

- Urbanização, Projetos e Políticas físico-territoriais

1. Estruturação e gestão do território

2. Política e projeto da habitação social

3. História da arquitetura, do urbanismo e do território

- Projeto, Morfologia e Tecnologia do Ambiente Construído

1. Projeto de Arquitetura

2. Morfologia, Usos e Percepção do Ambiente

3. Tecnologia e Conforto no Ambiente Construído - investiga edificações e espaços urbanos quanto a: planejamento, projeto bioclimático e impacto ambiental; sistemas construtivos; princípios de controle ambiental e eficiência energética; métodos de avaliação de desempenho térmico, acústico, luminoso, de durabilidade e segurança contra incêndio.

Em relação à área de Tecnologia da Construção, o curso oferece na Linha de Pesquisa 'Tecnologia e Conforto no Ambiente Construído', a possibilidade de serem desenvolvidas pesquisas na área da Tecnologia da Construção, em determinados temas específicos.

\section{f) Comentários:}

- As atuais discussões reestruturantes - embora ainda não tivessem em vigor na data da visita técnica acompanham alguns movimentos já vistos em outras escolas nacionais como: enxugamento de carga horária (inclusive da área técnica); retirada de algumas disciplinas de fundamentação como Estatística; criação do Atelier Integrado e diminuição de Pré-requisitos entre disciplinas;

- O envolvimento de vários professores do curso de Arquitetura e Urbanismo em cargos administrativos no Centro Tecnológico pode ser considerado como um diferencial positivo na interlocução de demandas e apoio institucional;

- Foi observada a promoção da integralização entre as disciplinas semestrais, na intenção de aproximação entre as disciplinas de Tecnologia e Projeto;

- Algumas disciplinas de Sistemas Estruturais extrapolam seu conteúdo, ao contemplarem assuntos geralmente pertencentes às disciplinas de sistemas construtivos. Este fato contribui para que, o

\footnotetext{
${ }^{166}$ Informações obtidas em: http://www.posgraduacao.ufrn.br//ppgau. Acesso em: 27 de maio de 2016.
} 
intervalo de 02 anos existentes entre as disciplinas de Tecnologia das Construções 2 e 3, não prejudique a continuidade de aprendizado, a partir do momento que outras disciplinas como Estruturas e Instalações prediais abordam alguns conteúdos relativos aos sistemas construtivos, desta forma, em vários semestres intermediários os alunos continuam tendo contato com a área da Tecnologia da Construção;

- Foi relatado como um momento positivo quando as disciplinas de Sistemas Estruturais eram iniciadas anteriormente à Tecnologia das Construções 1, por proporcionar maior embasamento aos alunos. Embora o atual reposicionamento tenha ocorrido em função do equacionamento da carga horária e não, necessariamente, em função de uma estratégia articuladora da área técnica;

- O envolvimento de alunos cotistas provenientes dos Institutos Federais (cursos de Edificações, Tecnologia das Construções), foi considerado como diferencial nas disciplinas da área da Tecnologia das Construções, por trazerem consigo um bom embasamento da área técnica. Estes alunos são alocados de forma estratégica entre as equipes, como cabeças, como tutores. Os resultados alcançados têm sido considerados muito bons, contribuindo para a elevação do nível dos trabalhos, refletindo não somente nas disciplinas da Tecnologia das Construções como também em Projeto. Trata-se de uma situação particular desta escola, em que estes alunos cotistas são provenientes em sua maioria dos Institutos Federais.

- Foi observado que o oferecimento de disciplinas optativas pela pós-graduação cria uma situação que favorece a integração entre pós-graduação e graduação;

- Os professores pertencentes à área da Tecnologia da Construção possuem perfis diversificados com formação em Engenharia Civil, Engenharia Mecânica, Engenharia Estrutural e Arquitetura, com diferentes especializações. Embora a positiva heterogeneidade, foi relatado que este cenário dificulta a possibilidade de substituição de algum professor que tenha que vir a se afastar e também, por apresentarem um quadro docente reduzido. Embora o reconhecimento por parte da escola sobre a importância da área da Tecnologia, esta foi considerada como a área mais frágil do curso;

- Na UFRN o aluno possui seguro em atividades práticas, desta forma, quando as visitas em obra fazem parte da proposta pedagógica da disciplina, o aluno vai para a obra já com seguro (é preciso realizar com antecedência esta solicitação junto aos órgãos encarregados da Instituição). Esta possibilidade tem promovido o contato direto dos alunos com a construção, os sistemas construtivos e os profissionais envolvidos com a obra. De acordo com o professor entrevistado os alunos gostam e aproveitam muito estas experiências práticas;

- A falta de uma linha regular de oferta de recursos (financeiros e humanos) para a operacionalização e manutenção das instalações do canteiro experimental, aliada ao fato da provável construção de um novo edifício para o curso no local onde o canteiro está localizado, têm dificultado a continuidade das atividades e a permanência de atores neste espaço;

- O compartilhamento de infraestrutura com o curso de Engenharia civil ocorre em algumas disciplinas de Sistemas Estruturais. No caso das disciplinas da área da Tecnologia das Construções esta situação não ocorre, promovida também pelo fato destas disciplinas serem ministradas integralmente pelo próprio Departamento de Arquitetura;

- Um gargalo identificado pelos professores entrevistados seria a falta de um espaço físico adequado para armazenamento de materiais didáticos e que também possibilitasse a montagem de alguns sistemas construtivos, segundo eles, estes recursos contribuiriam para que as aulas tivessem maior rendimento.

\section{4- DAU - UFPB - Departamento de Arquitetura e Urbanismo da Universidade Federal da Paraíba ${ }^{167}$}

\footnotetext{
167 Informações obtidas entre os dias 20 e 21/06/2016, em visita técnica ao curso de Arquitetura e Urbanismo da Universidade Federal da Paraíba. Entrevistas realizadas junto aos professores: Dr. Aluisio Braz de Melo e Dra. Elisabetta Romano.
} 


\section{a) Breve Histórico ${ }^{168}$}

De acordo com o Projeto Pedagógico, o curso de Arquitetura e Urbanismo da UFPB foi criado em dezembro de 1974 como apêndice do Curso de Engenharia Civil do Centro de Tecnologia da UFPB, iniciando suas atividades no primeiro semestre letivo de 1975. Foram implantados nesse mesmo ano, a Coordenação do Curso e o Departamento de Arquitetura, este devendo também atender às demandas de outros cursos do Centro de Tecnologia relativas à área de expressão e representação gráfica.

A partir de 1976, iniciou-se a primeira reformulação curricular do curso, com o objetivo de criar um curso de arquitetura independente, eliminando o seu caráter de apêndice do Curso de Engenharia Civil, assim como o enxergavam. Foi então iniciada, em 1977, uma nova estrutura curricular, que atendia ao Currículo Mínimo aprovado pelo Conselho Federal de Educação em 1969. A nova proposta ampliava a duração do curso e se baseava em três eixos de conhecimento: a) projeto e representação gráfica, b) teoria e história da arquitetura e c) tecnologia. As principais mudanças propostas visavam atender às especificidades da formação do arquiteto, diferenciando-a da formação do engenheiro, e também, de contemplar as necessidades a respeito da intervenção na cidade. Com as instalações físicas específicas em construção, o quadro de professores consolidado e um extenso currículo de atividades realizadas, o curso foi reconhecido em abril de 1979.

Ainda segundo o PPP de curso, o período correspondente aos anos de 1980 a 1986 foi marcado por crises internas, levando a uma nova reformulação curricular: a reforma de 1987-1994. Assim, embrionariamente, foi iniciada a instalação de laboratórios ligados à informática e vídeo. Da mesma forma, foram implantados o Atelier de Artes Aplicadas, o Centro de Documentação e Informação e o Ambiente Especial de Estudos para os alunos. Foram também ampliadas as atividades da Oficina de Maquete, reestruturada a utilização da Oficina de Fotografia e iniciadas as atividades do Laboratório Integrado de Projetos, que a partir de agosto de 1992 foi substituído pelo Laboratório do Espaço Urbano e Construído. A partir das novas Diretrizes Curriculares publicadas na Portaria 1770/1994, foi apresentada uma nova proposta de reformulação do Projeto Pedagógico do curso, sendo que outras discussões reestruturantes foram travadas entre 2005 e 2010.

A concepção atual do Projeto Pedagógico do curso de Arquitetura e Urbanismo da UFPB tem como fundamentos normativos a Resolução № 2, de 17 de junho de 2010 da Câmara de Educação Superior do Conselho Nacional de Educação - MEC e na Resolução no 07/2010 do CONSEPE da UFPB.

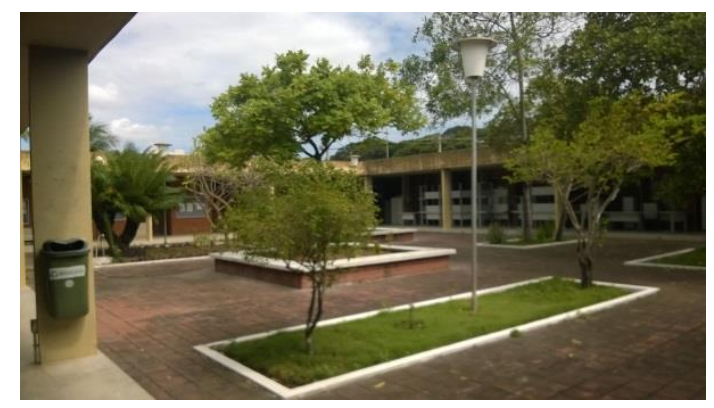

Figura 87 - Vista da Coordenação do Curso de Arquitetura e Urbanismo a partir do pátio central.

Fonte: foto da autora.

\section{b) Considerações sobre a Estruturação da área da Tecnologia da Construção}

O curso oferece 35 vagas semestrais e sua organização curricular - estruturada em núcleos Introdutório e Fundamental e no Trabalho de Curso - constitui-se em três eixos: Teoria e História da Arquitetura e do Urbanismo, Tecnologia da Arquitetura e do Urbanismo e Projeto e Representação Gráfica. Os Conteúdos Complementares apresentam-se como obrigatórios (Metodologia do Trabalho Cientifico e Pesquisa aplicada à Arquitetura e Urbanismo), optativos e flexíveis e são oferecidos entre o 4ㅇ e 9o períodos, evitando sua concentração no fim do curso.

\footnotetext{
${ }^{168}$ Dados obtidos por meio da consulta ao Projeto Pedagógico de Curso/2012, em vigor no momento da visita técnica.
} 
A maior parte das disciplinas da área da Tecnologia da Arquitetura é ministrada por docentes pertencentes ao quadro docente do próprio Departamento de Arquitetura e Urbanismo (DAU), com exceção das disciplinas de Sistemas Estruturais II e III e Fundamentos de Topografia, as quais ficam a cargo do Departamento de Engenharia Civil e Ambiental (DECA) e a disciplina de Ergonomia, que fica à cargo do Departamento de Engenharia de Produção (DEP).

As disciplinas da área da Tecnologia da Arquitetura estão distribuídas entre o 10 e o 70 períodos, de acordo com o Quadro 24, e as disciplinas de Tecnologia das Construções I e II, encontram-se no 40 e 70 períodos, respectivamente, com um intervalo de 2 semestres entre as mesmas. A área da Tecnologia da Arquitetura apresenta $19 \%$ dos créditos totais destinados às disciplinas obrigatórias (não sendo considerado neste cômputo o Trabalho Final de Graduação I e II, os Conteúdos Complementares e o Estágio supervisionado), sendo $4 \%$ dos créditos destinados à área da Tecnologia da Construção (embora a disciplina da Tecnologia da Construção II, contemple conteúdos referentes a Instalações Prediais), 7\% Sistemas Estruturais, 6\% Conforto Ambiental e 2,5\% em outras disciplinas da área (Fundamentos de Topografia e Ergonomia). Cabe ressaltar que o conteúdo relativo às Instalações Prediais, é dado dentro da disciplina de Tecnologia das Construções II, dificultando uma análise mais coerente na divisão de conteúdos a partir do nome das disciplinas.

Quadro 24 - Distribuição da Grade Curricular com a carga horária semestral - DAU UFPB:

\begin{tabular}{|c|c|c|c|c|c|c|c|c|c|}
\hline 10 sem & 20 sem & 30 sem & 40 sem & 5o sem & 60 sem & 70 sem & 80 sem & 9o sem & $10 \%$ sem \\
\hline $\begin{array}{c}\text { Noções de } \\
\text { arq. urb. (3C) }\end{array}$ & $\begin{array}{l}\text { Introdução ao } \\
\text { proj. arq (4C) }\end{array}$ & $\begin{array}{c}\text { Projeto de } \\
\text { Edificaç. I (6C) }\end{array}$ & $\begin{array}{c}\text { Projeto de } \\
\text { edificaç. II (6C) }\end{array}$ & $\begin{array}{l}\text { Projeto de } \\
\text { edificaç. III } \\
(6 C)\end{array}$ & $\begin{array}{l}\text { Projeto de } \\
\text { edificaç. IV } \\
\text { (6C) }\end{array}$ & $\begin{array}{l}\text { Projeto de } \\
\text { edificaç. V } \\
\text { (6C) }\end{array}$ & $\begin{array}{c}\text { Projeto de } \\
\text { edificaç. VI } \\
\text { (6C) }\end{array}$ & TFG I & TFG ॥ \\
\hline $\begin{array}{c}\text { Elementos da } \\
\text { Arte e Arq } \\
\text { (4C) }\end{array}$ & $\begin{array}{c}\text { Historia da arq } \\
\text { e urb I (4C) }\end{array}$ & $\begin{array}{l}\text { Urbanismo I } \\
\text { (6C) }\end{array}$ & $\begin{array}{c}\text { Desenho } \\
\text { Urbano I (6C) }\end{array}$ & $\begin{array}{c}\text { Desenho } \\
\text { Urbano II } \\
\text { (6C) }\end{array}$ & $\begin{array}{c}\text { Desenho } \\
\text { Urbano III } \\
(6 \mathrm{C})\end{array}$ & $\begin{array}{c}\text { Urbanismo } \\
\text { II (4C) }\end{array}$ & $\begin{array}{l}\text { Deontologi } \\
\text { a profissio. } \\
(2 \mathrm{C})\end{array}$ & $\begin{array}{c}\text { Conteudos } \\
\text { complemen } \\
\operatorname{tar}(2 \mathrm{C})\end{array}$ & \\
\hline $\begin{array}{l}\text { Metodologia } \\
\text { do trab. cient } \\
\text { (2C) }\end{array}$ & \begin{tabular}{|c|} 
Pesquisa \\
aplicada Arq e \\
urb (2C)
\end{tabular} & $\begin{array}{c}\text { Historia da arq } \\
\text { e urb II (4C) }\end{array}$ & $\begin{array}{c}\text { Sociologia } \\
\text { urbana }(3 C)\end{array}$ & $\begin{array}{c}\text { Fundam. } \\
\text { intervenç. a. } \\
\text { histor. (6C) }\end{array}$ & $\begin{array}{l}\text { Historia da } \\
\text { Arq e Urb } \\
\text { Brasil II (4C) }\end{array}$ & $\begin{array}{l}\text { Historia da } \\
\text { arq e urb IV } \\
(4 \mathrm{C})\end{array}$ & $\begin{array}{c}\text { Conteudos } \\
\text { compleme } \\
\text { ntar }(2 \mathrm{C})\end{array}$ & & \\
\hline $\begin{array}{c}\text { Oficina de } \\
\text { plástica I (6C) }\end{array}$ & $\begin{array}{c}\text { Oficina de } \\
\text { plástica II }(6 C)\end{array}$ & $\begin{array}{c}\text { Perspectiva } \\
(6 C)\end{array}$ & $\begin{array}{l}\text { Historia da } \\
\text { Arq e Urb } \\
\text { Brasil I (4C) }\end{array}$ & $\begin{array}{c}\text { Historia da } \\
\text { arq e urb III } \\
(4 \mathrm{C})\end{array}$ & $\begin{array}{c}\text { Conteudos } \\
\text { complementa } \\
\text { r (2C) } \\
\end{array}$ & $\begin{array}{c}\text { Conteudos } \\
\text { complemen } \\
\operatorname{tar}(2 \mathrm{C})\end{array}$ & Supervis. II & & \\
\hline $\begin{array}{c}\text { Introdução ao } \\
\text { desenho arq } \\
\text { (4C) }\end{array}$ & $\begin{array}{c}\text { Oficina de } \\
\text { Desenho II } \\
\text { (6C) }\end{array}$ & $\begin{array}{c}\text { Conforto } \\
\text { Ambiental I } \\
\text { (4C) }\end{array}$ & \begin{tabular}{|c|} 
Conteudos \\
complementar \\
(2C)
\end{tabular} & \begin{tabular}{|c|} 
Conteudos \\
complemen \\
$\operatorname{tar}(2 \mathrm{C})$
\end{tabular} & \begin{tabular}{|c|} 
Conforto \\
ambiental III \\
(3C)
\end{tabular} & $\begin{array}{c}\text { Tecnologia } \\
\text { construções } \\
\text { II (4C) }\end{array}$ & & & \\
\hline $\begin{array}{c}\text { Geometria } \\
\text { descritiva }(3 \mathrm{C})\end{array}$ & $\begin{array}{c}\text { Desenho de } \\
\text { Arq. (6C) }\end{array}$ & $\begin{array}{c}\text { Sistemas } \\
\text { Estruturais II } \\
\text { (6C) }\end{array}$ & $\begin{array}{c}\text { Tecnologia } \\
\text { das construç. I } \\
(4 \mathrm{C})\end{array}$ & \begin{tabular}{|c} 
Conforto \\
ambiental II \\
(4C)
\end{tabular} & \begin{tabular}{|c|} 
Sistemas \\
Estruturais III \\
$(4 \mathrm{C})$
\end{tabular} & & & & \\
\hline $\begin{array}{l}\text { Oficina de } \\
\text { Desenho I } \\
(6 \mathrm{C})\end{array}$ & $\begin{array}{c}\text { Ergonomia } \\
(2 \mathrm{C})\end{array}$ & & $\begin{array}{c}\text { Fundamentos } \\
\text { topografia } \\
\text { (3C) }\end{array}$ & & Supervis. I & & & & \\
\hline $\begin{array}{c}\text { Sistemas } \\
\text { Estruturais I } \\
(4 \mathrm{C})\end{array}$ & & & & & & & & & \\
\hline
\end{tabular}

Disciplinas de Projeto

Disciplinas de Representação Gráfica e comp.
Disciplinas de Urbanismo e Meio Ambiente

Disciplinas na área da Tecnologia da Arquitetura
Disciplinas de Historia e Teoria

\section{c) Quadro docente \\ De acordo com a entrevista realizada, as disciplinas da área da Tecnologia da Construção foram ministradas por vários anos por docentes pertencentes ao curso da Engenharia Civil. Atualmente, estas disciplinas são oferecidas pelo próprio curso de Arquitetura e Urbanismo, e todos docentes com formação em Arquitetura e Urbanismo. Em relação à área da Tecnologia da Arquitetura, a parceria com outros departamentos (DECA e DEP) permanece em relação ao oferecimento das disciplinas de Sistemas Estruturais II e III e, também, Ergonomia e Fundamentos de Topografia.}

\section{d) Práticas didáticas e Infraestrutura laboratorial}


Dentre os laboratórios que o curso possui com interface à na área da Tecnologia da Arquitetura, podem ser citados os Laboratório de Conforto Ambiental, de Acessibilidade e de Modelos e Protótipos. No caso da infraestrutura laboratorial na área da Tecnologia da Construção, o Laboratório LABEME (Laboratório de Ensaio de Materiais e Estruturas), apresenta-se como de uso compartilhado e está vinculado institucionalmente ao Departamento de Engenharia Civil e Ambiental (DECA) do Centro de Tecnologia (CT) da UFPB. Desde 2008 este laboratório apoia a linha de pesquisa em 'Tecnologias e Materiais da Arquitetura', que está inserida na área de concentração Tecnologia da Arquitetura e Urbanismo do Programa de Pós Graduação - PPGAU, por meio da atuação e credenciamento de um dos professores do Departamento da Arquitetura e Urbanismo, o único profissional do quadro docente da A\&U que desenvolve pesquisas na área de Materiais e Técnicas Construtivas e se utiliza da infraestrutura laboratorial oferecida por este laboratório.

No LABEME (Figura 88) são realizados ensaios de caracterização e controle de qualidade de materiais utilizados em concretos e argamassa, ensaios de blocos cerâmicos e de concreto e também são realizadas pesquisas experimentais nas áreas de materiais da construção civil e de estruturas. Além disso, são realizadas consultorias especializadas nestas duas áreas. O LABEME é um espaço de uso compartilhado e está disponível para ser utilizado tanto pela graduação como pela pós-graduação do curso de Arquitetura, mas atualmente, em relação ao curso de Arquitetura seu uso é mais intenso na pós-graduação, com o envolvimento de alguns alunos da graduação em pesquisas de Iniciação Científica. A partir das entrevistas não foi observada a utilização deste espaço laboratorial nas disciplinas da Tecnologia da Construção do curso de Arquitetura. Trata-se de um espaço estruturado e voltado para a realização de atividades do curso ao qual está institucionalmente vinculado, a Engenharia Civil. $O$ laboratório possui 05 técnicos e 02 auxiliares ${ }^{169}$ para apoiarem as atividades dos cursos da Engenharia Civil e também da Arquitetura ou outros cursos que, eventualmente, necessitem realizar alguma atividade específica, atendendo tanto o nível da graduação como da pós-graduação.


Figura 88 - Laboratório de Ensaio de Materiais e Estruturas - LABEME. a) e b) Imagens internas, com atividades de ensaios físicos e mecânicos. c) e d) Utilização da área externa para o desenvolvimento de protótipos de avaliação de sistemas construtivos.

Fonte: Fotos da autora.

Diferentemente das disciplinas de Ateliê de Projeto, onde o nível de complexidade avança ao longo do curso, as disciplinas da área da Tecnologia da Construção não seguem a mesma estratégia. Há um intervalo de 2 semestres entre as disciplinas de Tecnologia das Construções I e II, estruturadas de forma independente quanto aos assuntos abordados.

De acordo com o Plano de Curso, na disciplina Tecnologia das Construções $1^{170}$, são abordados conteúdos sobre processos e materiais construtivos, assim como, práticas inovadoras e alternativas, com visitas a obras em suas diferentes fases. Não há evidências da utilização de infraestrutura laboratorial pertencente ao curso da Engenharia Civil nesta disciplina.

A disciplina de Tecnologia das Construções II ainda está em fase de experimentação e o seu conteúdo não está associado aos materiais e técnicas construtivas, mas sim a Instalações Prediais, Infraestrutura urbana e Orçamento, assuntos estes que não possuem disciplinas próprias. As estratégias pedagógicas envolvem desde aulas expositivas como também orientação de projeto. Os conteúdos que envolvem o tema Orçamentos são desenvolvidos na forma de exercícios e pesquisas

\footnotetext{
${ }^{169}$ Dados quantitativos fornecidos verbalmente ao longo da entrevista, não sendo realizada a aferição por meio de outras fontes, estando sujeito a eventual ajuste.

${ }^{170}$ Dados divulgados no PPC, por não ter sido possível entrevistar o professor responsável.
} 
aplicáveis em projeto, instigando o senso crítico dos alunos a partir de situações comparativas de resoluções, na busca de uma decisão projetual coerente, buscando-se aprofundar algum aspecto e, posteriormente, fazer o intercâmbio entre alunos de informações ao longo das apresentações individuais dos resultados.

No caso do conteúdo referente a Instalações, o projeto também se apresenta como plataforma para discussões diferenciadas, como a interferência que pode haver entre projetos complementares e o arquitetônico e a influência de vários aspectos técnicos estudados sobre as decisões projetuais. Os exercícios sobre este assunto são realizados em grupo, com apresentações individuais, não havendo atividades laboratoriais. Na Pós-Graduação em A\&U (em uma das linhas de pesquisa), há maior envolvimento com pesquisas laboratoriais, tanto com materiais como o desenvolvimento de técnicas construtivas. Sobre o resultado destas pesquisas, algumas delas são discutidas no âmbito da graduação, quando possível e de forma pontual, principalmente quando os assuntos estão relacionados a tecnologias alternativas e inovadoras (ex.: adoção de resíduos e materiais reciclados na construção civil). Mas, por não ser um assunto programático do Plano de curso, não há o compromisso desta abordagem, ocorrendo eventualmente e quando possível, na tentativa de interar os alunos do que está sendo desenvolvido na pós-graduação, criando conexões com pesquisas atualmente desenvolvidas no laboratório.

\section{e) Pós graduação ${ }^{171}$ :}

O Programa de Pós graduação em Arquitetura e Urbanismo foi criado em 2008, com o oferecimento do Mestrado. A partir de 2014, com a aprovação por parte da CAPES do curso de Doutorado, o PPGAU/UFPB passou por uma reestruturação das suas áreas de concentração e linhas de pesquisa, em que o Mestrado Acadêmico e o Doutorado em Arquitetura e Urbanismo passou a abrigar uma única Área de Concentração denominada Arquitetura e Cidade: Processo e Produto, evitando divisões em áreas específicas de conhecimento para que o objeto (arquitetônico e urbanístico) fosse tratado enquanto parte constitutiva de um processo complexo de concepção, materialização e apropriação. As linhas de pesquisa oferecida atualmente são:

1 - Produção e apropriação do edifício e da cidade;

2 - Projeto do edifício e da cidade;

\section{3 - Qualidade do ambiente construído.}

A Linha 3 de pesquisa é a que apresenta interface à área da Tecnologia da Construção, cujo objetivo é a avaliação e análise do ambiente construído, com particular ênfase na qualidade de projeto e nas questões de conforto (térmico, lumínico, acústico e ergonômico), mobilidade, acessibilidade e tecnologia e materiais construtivos.

\section{f) Comentários:}

- A grade atual contempla as últimas reestruturações na área técnica, como a criação de duas novas disciplinas: uma de Sistemas Estruturais e outra de Conforto Ambiental, criadas devido a carga horária na área técnica ter sido ainda menor, provavelmente, pelo entendimento da necessidade de dissociar ao longo do tempo a formação do arquiteto em relação à do engenheiro (como visto no histórico do PPC);

- Há evidências de que uma das estratégias para a distribuição das disciplinas de tecnologia centralizase nos Ateliês de Projeto, na intenção de que o aluno articule os conteúdos por meio do desenvolvimento projetual. A articulação vertical observada não está presente horizontalmente entre as disciplinas da área da Tecnologia da Construção;

- Devido aos conteúdos serem independentes entre as disciplinas de Tecnologia das Construções I e II, não foi considerado como problemático o intervalo de dois semestres entre elas. O conteúdo tido como pré-requisito em Tecnologia das Construções II está mais associado a Ateliê de Projeto (Edificações de múltiplos pavimentos) pela sua interface aos conteúdos de Sistemas Prediais. Há, portanto, integração

\footnotetext{
${ }^{171}$ Informações disponíveis em http://www.ufpb.br/pos/ppgau. Acesso em 04/06/2016.
} 
pelo fato do exercício proposto em Tecnologia das Construções II ser o mesmo desenvolvido em Ateliê de Projeto, dando aos alunos a possibilidade de questionarem suas decisões projetuais;

- O envolvimento de professores com a pós-graduação cria a possibilidade de conexões entre as disciplinas da graduação e algumas pesquisas em desenvolvimento, principalmente, envolvendo temáticas relativas a aproveitamento de resíduos, materiais de baixo impacto ambiental e eficiência térmica de materiais e componentes;

- Foi relatado que há grande interesse por parte dos alunos de arquitetura por pesquisas na área de materiais, tanto em Iniciação Científica como também na Pós-Graduação;

- A despeito do empenho e esforço por parte dos docentes envolvidos com as disciplinas de tecnologia das construções, a estrutura burocrática e reguladora da instituição, características próprias das instituições universitárias públicas, dificulta, e até mesmo inviabiliza, a curto prazo, melhorias no ensino. Como exemplos destacam-se: a descontinuidade de conteúdos e práticas didáticas em razão da grande rotatividade de professores nas disciplinas da área e a impossibilidade de ampliação e manutenção da infraestrutura e das instalações laboratoriais pela falta de recursos financeiros e falta de apoio operacional;

- Devido ao oferecimento de apenas duas disciplinas na área da Tecnologia da Construção, sendo uma delas responsável pelo conteúdo de Instalações Prediais, há uma sobrecarga de conteúdos em ambas as disciplinas, dificultando a introdução de atividades como visitas em obra, devido a esta prática demandar mais tempo.

\section{5- CAU - UFES - Curso de Arquitetura e Urbanismo da Universidade Federal do Espírito Santo ${ }^{172}$}



Figura 89 - Centro de Artes - CAR. Imagens do complexo de edifícios utilizados pelo curso da Arquitetura e Urbanismo. Fonte: Fotos da autora

\footnotetext{
172 Dados obtidos a partir da visita técnica realizada entre os dias 06 e 08/06/2016, com entrevistas aos docentes da área da Tecnologia da Construção: Profa. Maristela Gomes da Silva, Profa. Geilma Lima Vieira e Profa. Karla Wingler Rebelo e visita às instalações físicas desta mesma área utilizadas pelo curso da Arquitetura e Urbanismo da UFES. Também foi realizada visita ao Laboratório de Planejamento e Projetos (LPP) com entrevista à professora Cristina Alvarez Engel. Outras informações complementares foram obtidas em: http://lpp.ufes.br/o-laboratorio. Acesso em: 28/07/2016.

${ }^{173}$ Informações presentes no Projeto Político Pedagógico de curso de 2009, em vigor na data da visita técnica.
} 


\section{b) Considerações sobre a Estruturação da área da Tecnologia da Construção}

O curso oferece 60 vagas anuais e as disciplinas do curso de Arquitetura são oferecidas pelos departamentos pertencentes ao Centro de Artes, assim como, pelo Centro Tecnológico ${ }^{174}$, o Centro de Ciências Jurídicas e Econômicas e também, pelo Centro de Ciências Exatas, totalizando, na estrutura curricular vigente, 46 disciplinas obrigatórias e 31 disciplinas optativas distribuídas por 11 departamentos.

Segundo o Projeto Pedagógico do curso, o curso é desenvolvido em três cenários principais: o auditório, o atelier e o laboratório; e os conteúdos se agrupam em três grandes áreas: teoria, projeto e tecnologia.

Em relação à área da Tecnologia da Arquitetura, segundo o Quadro 25, a mesma ocupa cerca de $30,5 \%$ dos créditos destinados às disciplinas obrigatórias do curso, e estão distribuídas entre o 1 으 e o 70 períodos. No caso das disciplinas da área da Tecnologia das Construções, estão alocadas entre o 40 e o 70 períodos e são oferecidas em todos os semestres deste intervalo. Ainda sobre as disciplinas da área da Tecnologia das Construções, as mesmas ocupam cerca de $8 \%$ dos créditos gerais e as demais disciplinas como Sistemas Estruturais também ocupam 8\%, as de Conforto Ambiental 5,5\%, Instalações Prediais 4\%, Fundamentação 2,5\% e Outras (Tecnologia e Recursos Naturais) 2,5\%.

Quadro 25 - Distribuição da Grade Curricular com a carga horária semestral - CAU UFES:

\begin{tabular}{|c|c|c|c|c|c|c|c|c|c|}
\hline 10 sem & 20 sem & 30 sem & 40 sem & 5o sem & 60 sem & 70 sem & 8ㅇ sem & 90 sem & $10 \div$ sem \\
\hline $\begin{array}{l}\text { Introdução à } \\
\text { arquit. (4C) }\end{array}$ & $\begin{array}{c}\text { Projeto arquit. } \\
01(4 \mathrm{C}) \\
\end{array}$ & \begin{tabular}{|c|} 
Projeto arquit. \\
$02(4 C)$ \\
\end{tabular} & \begin{tabular}{|c|} 
Projeto arquit. \\
$03(4 \mathrm{C})$ \\
\end{tabular} & $\begin{array}{c}\text { Projeto arq. } \\
04(4 C)\end{array}$ & $\begin{array}{c}\text { Projeto } \\
\text { arquit. } 05(4 \mathrm{C})\end{array}$ & $\begin{array}{c}\text { Projeto arq. } \\
06(4 \mathrm{C})\end{array}$ & $\begin{array}{l}\text { Estética e } \\
\text { arqu. (4C) }\end{array}$ & TFG I & TFG II \\
\hline $\begin{array}{l}\text { Introdução às } \\
\text { Ciênc. Soc. } \\
\text { (4C) }\end{array}$ & $\begin{array}{c}\text { Estética e hist. } \\
\text { das artes II } \\
\text { (4C) }\end{array}$ & $\begin{array}{c}\text { Teoria e hist. } \\
\text { da arq. e urb. I } \\
\text { (4C) }\end{array}$ & $\begin{array}{l}\text { Teoria e hist. } \\
\text { da arq. e urb. } \\
\text { II (4C) }\end{array}$ & $\begin{array}{c}\text { Paisagismo I } \\
(2 \mathrm{C})\end{array}$ & $\begin{array}{c}\text { Urbanismo II } \\
\qquad(4 \mathrm{C})\end{array}$ & $\begin{array}{l}\text { Urbanismo } \\
\text { III (4C) }\end{array}$ & Optativa & & \\
\hline $\begin{array}{c}\text { Estética e } \\
\text { hist. das artes } \\
\text { I (4C) }\end{array}$ & $\begin{array}{c}\text { Plástica } \\
\text { tridimens. I } \\
(2 \mathrm{C})\end{array}$ & $\begin{array}{c}\text { Sociologia } \\
\text { urbana }(4 C)\end{array}$ & $\begin{array}{c}\text { Geometria } \\
\text { gráfica III (4C) }\end{array}$ & $\begin{array}{c}\text { Urbanismo I } \\
(4 \mathrm{C})\end{array}$ & $\begin{array}{c}\text { Arquitetura } \\
\text { no Brasil (4C) }\end{array}$ & \begin{tabular}{|c|} 
Patrimônio \\
histórico \\
$(3 \mathrm{C})$
\end{tabular} & Optativa & & \\
\hline $\begin{array}{l}\text { Geometria } \\
\text { gráfica I (4C) }\end{array}$ & $\begin{array}{c}\text { Desenho } \\
\text { arquitetura(2C } \\
\text { ) }\end{array}$ & \begin{tabular}{|c|} 
Computação \\
gráfica arquit. \\
(1C)
\end{tabular} & $\begin{array}{c}\text { Instalações } \\
\text { técnicas I (3C) }\end{array}$ & $\begin{array}{c}\text { Teoria e } \\
\text { hist. da arq. } \\
\text { urb. III (4C) }\end{array}$ & $\begin{array}{c}\text { Instalações } \\
\text { técnicas II } \\
(3 C)\end{array}$ & \begin{tabular}{|c|} 
Tecnologia e \\
recursos \\
natur. $(4 \mathrm{C})$
\end{tabular} & & & \\
\hline $\begin{array}{l}\text { Composição } \\
\text { bidimens. } \\
(2 \mathrm{C})\end{array}$ & $\begin{array}{c}\text { Desenho } \\
\text { artístico II (2C) }\end{array}$ & $\begin{array}{c}\text { Geometria } \\
\text { gráfica II (4C) }\end{array}$ & $\begin{array}{c}\text { Tecnologia } \\
\text { das construç. I } \\
\text { (3C) }\end{array}$ & $\begin{array}{c}\text { Tecnologia } \\
\text { das constr.II } \\
(3 \mathrm{C})\end{array}$ & \begin{tabular}{|c|} 
Tecnologia \\
das constr.III \\
(3C)
\end{tabular} & \begin{tabular}{|c|} 
Tecnologia \\
das const.IV \\
$(3 \mathrm{C})$
\end{tabular} & & & \\
\hline $\begin{array}{c}\text { Desenho } \\
\text { artístico I (2C) }\end{array}$ & $\begin{array}{c}\text { Conforto } \\
\text { Ambiental I } \\
(4 \mathrm{C})\end{array}$ & $\begin{array}{c}\text { Conforto } \\
\text { Ambiental II } \\
(4 \mathrm{C})\end{array}$ & $\begin{array}{c}\text { Sistemas } \\
\text { estruturais II } \\
\text { (3C) }\end{array}$ & $\begin{array}{c}\text { Sistemas } \\
\text { estruturais } \\
\text { III }(3 C)\end{array}$ & & & & & \\
\hline $\begin{array}{c}\text { Matemática I } \\
(4 \mathrm{C})\end{array}$ & $\begin{array}{l}\text { Introdução à } \\
\text { estática ( } 3 C)\end{array}$ & $\begin{array}{c}\text { Sistemas } \\
\text { estruturais I } \\
(3 \mathrm{C})\end{array}$ & & & & & & & \\
\hline
\end{tabular}

Disciplinas de Projeto

Disciplinas de Representação Gráfica e comp.
Disciplinas de Urbanismo e Meio Ambiente

Disciplinas na área da Tecnologia da Arquitetura
Disciplinas de Historia e Teoria

\section{c) Quadro docente}

Desde a criação do curso, as disciplinas da área da Tecnologia da Construção são oferecidas integralmente pelo Departamento da Engenharia Civil, localizado no Centro Tecnológico. As quatro disciplinas: Tecnologia das Construções I, II, III e IV, são ministradas por professores com formação em engenharia civil, valendo destacar que o curso de Arquitetura e Urbanismo não possui professores com perfil específico nesta área estudada, mas há alguns núcleos e laboratórios de pesquisa que

\footnotetext{
${ }^{174}$ A história do Centro Tecnológico da Ufes começou com a criação da Escola Politécnica do Espírito Santo (EPES) em 1951. Neste período, a escola era mantida pelo Governo do Estado e o ensino era totalmente gratuito, isento de quaisquer tipos de taxas ou mensalidades. Em 1953, a EPES passou a funcionar em sua sede própria em Maruípe, onde permaneceu até 1975, quando mudou para o Campus Universitário "Alaor Queiroz de Araújo", em Goiabeiras. Com a Reforma Universitária de 1971, as antigas faculdades e escolas foram extintas, surgindo em seu lugar a estrutura de Centros de Ensino com seus respectivos departamentos. Em 3 de Junho de 1971 a Escola Politécnica foi transformada no Centro Tecnológico da Ufes, com um novo modelo de estrutura acadêmica e de funcionamento, a partir da concentração das áreas de conhecimento. Em 1972, o Conselho Universitário decidiu que o Centro Tecnológico seria composto por cinco departamentos: "Estruturas e Edificações", "Hidráulica e Saneamento", "Transportes", "Engenharia Mecânica e Elétrica" e "Engenharia Industrial". Informações obtidas em: http://www.ct.ufes.br/ct-adm-historico-criacao-do-ct. Acesso em: 28/07/2016.
} 
desenvolvem trabalhos multidisciplinares com interface entre a área de Projeto e Tecnologia como o Laboratório de Planejamento e Projetos (LPP).

\section{d) Práticas didáticas e Infraestrutura laboratorial}

O curso oferece diferentes oportunidades de participação em experiências práticas e profissionais de âmbito acadêmico, que ocorrem em laboratórios de projeto, planejamento e de pesquisa, três deles ligados ao Departamento de Arquitetura e Urbanismo: Laboratório de Planejamento e Projetos (LPP), Núcleo de Arquitetura e Urbanismo (NAU) e Grupo de Pesquisa Conexão (VIX), assim como o Grupo de Pesquisas Teóricas em Arte e Arquitetura, interdepartamental do Centro de Artes.

Conforme relatado, este conjunto de laboratórios e núcleos em diferentes áreas oferece a possibilidade de realizar algumas compensações advindas de eventuais deficiências do ensino formal. Esta formação complementar por meio de núcleos e laboratórios gera certa flexibilidade para que os alunos optem pelas áreas de maior afinidade.

Dentre os laboratórios pertencentes ao curso de Arquitetura, o que apresenta maior interface a área técnica construtiva é o Laboratório de Planejamento e Projetos - LPP (Figura 90c). Este espaço possui caráter multidisciplinar (envolvendo alunos da geografia, desenho industrial, engenharia, dentre outros) e desenvolve, principalmente, pesquisas e projetos baseados nos conceitos da sustentabilidade do ambiente natural e construído, concentrando suas atividades nas seguintes áreas: indicadores de sustentabilidade, métodos de avaliação de sustentabilidade (edifício e cidade), desenvolvimento de tecnologias para edificações em áreas inóspitas (Antártica e ilhas oceânicas), projetos em áreas de interesse ambiental, pesquisas em conforto ambiental (térmico, luminoso e acústico), entre outros ${ }^{175}$. O LPP tem parceria com outros espaços laboratoriais pertencentes a diferentes departamentos: engenharias, estatística, entre outros.

Em relação à área da Tecnologia da Construção, a infraestrutura laboratorial encontra-se no Centro Tecnológico e pertence ao Departamento da Engenharia Civil, tendo como principal laboratório de uso compartilhado o LEMAC - Laboratório de Ensaios de Materiais de Construção (Figura 90a, 90b). De acordo com os professores entrevistados, outros laboratórios localizados em diferentes departamentos e centros, quando necessário, também dão apoio às disciplinas e pesquisas da área da Tecnologia da Construção, como o Laboratório de Mecânica dos Solos e de Geologia. Sobre as disciplinas desta área, cada uma delas segue uma estruturação e a aplicação de estratégias pedagógicas particulares. Atualmente, o LEMAC, possui 01 técnicos e 03 profissionais auxiliares. Tratase de um laboratório de uso compartilhado entre graduação e pós-graduação e é utilizado, prioritariamente, pelo curso da Engenharia Civil e também, pelos cursos para os quais o departamento oferece disciplinas, como o caso da Arquitetura. Em relação à sustentação financeira das atividades laboratoriais, o LEMAC possui diferentes fontes: doações, verba institucional e prestação de serviços.

De acordo com a entrevista realizada, na disciplina de Tecnologia das Construções I (TEC I) são abordados, prioritariamente, os materiais de construção, sendo utilizado o método da Aprendizagem com Base em Problemas (ABP), em que a problemática direciona-se à especificação de materiais com adequado desempenho dentro do contexto da sustentabilidade. $E$, a partir deste forte viés (a sustentabilidade), são pensadas as edificações, materiais e diretrizes de projeto. Além destas questões também são trabalhados na disciplina assuntos referentes à deterioração, desempenho e propriedades de materiais e suas especificações.

Como estratégias pedagógicas, a disciplina envolve desde aulas teóricas e laboratoriais, como também, atividades de pesquisa e exercícios aplicados. As aulas teóricas são dadas em conjunto, enquanto as aulas laboratoriais dadas em grupos de até 15 alunos, sendo desenvolvidas não no sentido de controle de qualidade, mas para que os alunos consigam associar o conteúdo teórico das aulas com o que eles estão visualizando em laboratório, compreendendo como funcionam os critérios de desempenho e sua normalização a partir de métodos de ensaio. Nas aulas são propostos exercícios que são desenvolvidos ao longo do semestre (1 exercício - envolvendo questionamentos sobre os

\footnotetext{
${ }^{175}$ Informações baseadas na entrevista realizada à coordenadora do laboratório e complementadas a partir da consulta em: http://lpp.ufes.br/o-laboratorio. Acesso em: 29/07/2016.
} 
materiais vistos em aula; 2o exercício - conteúdo sobre desempenho e propriedades e 3 o exercício tendências e especificação de materiais). O conjunto de informações fomentará o desenvolvimento do 40 exercício, cujo objetivo é a apreensão sobre a especificação de materiais, tendo como plataforma a análise do projeto da disciplina de Projeto Arquitetônico, desenvolvido na disciplina anterior.

As atividades laboratoriais são expositivas e realizadas por técnicos auxiliares com acompanhamento direto da professora responsável. Os alunos observam e tomam nota, realizam cálculos e fazem aferição dos resultados. Sobre alguns assuntos específicos, como concreto e argamassas, os alunos chegam a moldar corpos de prova, mas mesmo nestes casos, não possuem permissão para a manipulação de máquinas de mistura e ensaios.

No caso da disciplina de Tecnologia das Construções II (TEC II), o conteúdo não está relacionado à Tecnologia das Construções e sim ao macro tema Solos, dividido em três tópicos: Geologia, Mecânica dos Solos e Fundações. Para abordagem deste conteúdo são realizadas aulas teóricas, laboratoriais e atividades práticas em sala de aula relacionadas à interpretação de dados e cálculo para dimensionamento de fundações.

Algumas aulas práticas são realizadas em locais específicos como no Museu do curso de Oceanografia, devido ao acervo de amostras de rochas e minerais. A turma é dividida em torno de 4 a 5 grupos e realizam o processo de identificação dos materiais estudados. Em relação ao tema Solos, os alunos também são levados ao laboratório (Laboratório de Mecânica dos Solos e de Geologia pertencente à Engenharia Civil) para realizarem alguns experimentos, nestas práticas eles conseguem associar os termos técnicos com as atividades laboratoriais e aprendem visualizando os fenômenos. Normalmente, as aulas laboratoriais são divididas em 02 aulas de rochas e 02 aulas de solos. No caso de Fundações as aulas foram divididas em tópicos: análise geotécnica; aspectos construtivos sobre os tipos de fundações e o desenvolvimento de um anteprojeto de fundação desenvolvido em sala de aula. No laboratório de Solos há 01 técnico contratado e bolsistas, assim como, alunos de pós-graduação para auxiliarem nas aulas.

Em Tecnologia das Construções III (TEC III), são abordados assuntos referentes à execução de obras, como compatibilização de projetos, técnicas executivas (desde a fundação até o acabamento final), com a aplicação do conhecimento adquirido em TEC I e TEC II. Em relação às práticas pedagógicas, a disciplina envolve aulas expositivas, visitas a canteiros de obra (turmas de 15 a 20 alunos, de acordo com a obra visitada) e relatórios técnicos, mas não são realizadas atividades laboratoriais.

Uma estratégia atualmente colocada em prática nas aulas teóricas foi a integralização dos alunos do curso de Arquitetura e de Engenharia Civil, ao constatar as diferentes abordagens aplicadas em cada curso. $O$ processo de interação segue duas abordagens: uma de técnicas executivas e outra de elaboração de projetos. Embora os resultados sejam ainda recentes, há uma sinalização dos próprios alunos de que a experiência foi positiva, principalmente, para os alunos da Engenharia, pois a interação facilitou o processo de análise de questões projetuais em que os alunos da Arquitetura possuem mais facilidade, como os detalhes, tanto de projeto como de execução. A disciplina está dividida em três partes: 1a - exposição dos assuntos; a 2a - obtenção de subsídios para desenvolver e executar o projeto e a 3 a - com a formação dos grupos para discussão e elaboração do projeto e maquete eletrônica e física.


Figura 90 - Sequencia de fotos da área laboratorial ligada à Tecnologia da Construção e utilizada pelos alunos do curso de Arquitetura e Urbanismo da UFES. a) e b) LEMAC - Laboratório de Ensaios de Materiais de Construção: realização de ensaios pelo técnico no momento da aula laboratorial; sala de aula com mostruário de materiais, respectivamente. c) Vista interna do LPP - Laboratório de Planejamento e Projetos.

Fonte: Fotos da autora. 


\section{e) Pós graduação: ${ }^{176}$}

O Programa de Pós-Graduação em Arquitetura e Urbanismo da UFES (PPGAU) foi criado em 2007 e está vinculado ao Centro de Artes da mesma Instituição. Trata-se do único programa de pós-graduação Stricto Senso em Arquitetura e Urbanismo do Espírito Santo, oferecendo apenas o Mestrado. Desde 2007 até os dias atuais, o PPGAU/UFES conta com uma única área de concentração, denominada Cidade e impactos no território. Em 2013, a partir de recomendações resultantes de avaliação interna do programa, as linhas de pesquisa e disciplinas do PPGAU/UFES foram reestruturadas e o programa passou a contar com as seguintes linhas de pesquisa:

1 - Processos urbanos e políticas físico-territoriais;

2 - Patrimônio, sustentabilidade e tecnologia.

Em relação à área da Tecnologia da Construção, segundo os professores entrevistados, o Programa de Pós-graduação da Engenharia Civil absorve muitos alunos arquitetos, seja pelo credenciamento de um professor da arquitetura neste programa, como também, pelo interesse na área da Construção Civil. Foi relatado que na pós-graduação o intercâmbio entre os cursos da Arquitetura e Engenharia Civil é bem maior.

A linha de pesquisa oferecida pelo PPGAU com maior interface à área tecnológica construtiva é a de Patrimônio, Sustentabilidade e Tecnologia, devido ao caráter multidisciplinar e, quando há uma conexão com assuntos específicos, são firmadas parcerias com outros laboratórios, de maneira a complementar as pesquisas como: água, estruturas, resíduos, energias renováveis, tanto em Urbanismo como em Arquitetura.

\section{f) Comentários:}

- Em relação à sustentação das atividades laboratoriais, foi relatada a diminuição gradual dos investimentos voltados à área laboratorial, a partir da extinção de diversos programas voltados a manutenção de equipamentos, além disso, as atividades de ensino são mantidas exclusivamente com recursos vindos da União, que também sofreu corte nos últimos anos, levando a contar muitas vezes com doações de empresas. Em relação aos recursos advindos da pesquisa, são de uso restrito para esta finalidade. Outra dificuldade colocada para a realização de atividades laboratoriais refere-se às aposentadorias de técnicos sem a devida reposição (ex.: Há 25 atrás o quadro de técnicos de laboratório era o dobro do atual, e o número de vagas bem menor), sendo que, atualmente, o laboratório conta apenas com auxiliares para a condução das atividades tanto da pós-graduação, como também da graduação, sobrecarregando o laboratório. Este cenário vai em sentido contrário ao aumento do número de vagas de alunos oferecidas e de pesquisas realizadas atualmente;

- Houve uma diminuição da carga horária de disciplinas da área da tecnologia e, em contrapartida, os assuntos a serem abordados foram ampliados. Foi observada que há a abordagem de conteúdos atualizados como ciclo de vida, cadeia produtiva, desempenho de materiais e edificações, mas, para que pudessem ser inseridos, houve a necessidade de sacrificar outros assuntos tradicionais, tornando a disciplina mais compactada diante da diminuição de carga horária;

- Há o entendimento de que a disciplina de materiais deveria ser dada em dois períodos Tecnologia I-A e I-B, com carga horária de $4 \mathrm{~h}$ em cada período, diante do extenso conteúdo programático e sua conformidade às atribuições profissionais. Estas considerações também são realizadas pelos alunos ao reconhecerem a grande quantidade de assuntos para uma única disciplina ${ }^{177}$;

- Foi considerado que, atualmente, não há interação direta entre as disciplinas da área da tecnologia da construção e também destas com as disciplinas de projeto, mas acredita-se que, com a implantação recente do núcleo estruturante, as interações se estabeleçam, resultando em ganhos efetivos no processo de ensino-aprendizagem;

- A falta de simultaneidade na abordagem de conteúdos como materiais e técnicas construtivas (TEC I e TEC III, respectivamente) não foi considerada como uma problemática. Ainda sobre esta questão, a

\footnotetext{
${ }^{176}$ Informações obtidas em: http://www.arquitetura.ufes.br/pos-graduacao/PPGAU/historico. Acesso em 29/07/2016.

${ }^{177}$ Consideração colocada por um dos professores entrevistados.
} 
quebra entre TEC I e TEC III provocada pela disciplina Tecnologia das Construções II (TEC II), cujo conteúdo é voltado à Mecânica dos Solos e Fundações, também não foi considerado como problemático, sendo o conteúdo abordado sem prejuízos associados a esta questão;

- As ementas da área da Tecnologia da Construção foram propostas pelo curso de Engenharia Civil e não pelo curso de Arquitetura e Urbanismo, sendo cada plano de ensino elaborado pelo professor responsável por cada disciplina;

- Não foi observada a criação de uma estratégia geral para o desenvolvimento das disciplinas da área da Tecnologia da Construção;

- Em TEC II, embora o conteúdo seja considerado muito denso (Geologia, Mecânica dos Solos e Fundações) e intenso, foi relatado que os alunos gostam muito das aulas laboratoriais, procurando sempre criar associações entre o conteúdo e sua aplicação na arquitetura por meio de vários exemplos;

- Foi identificado como um dos principais gargalos as deficiências na formação de base dos alunos em relação à área da Matemática, comprometendo o desenvolvimento de algumas disciplinas da área da Tecnologia da Construção;

- As disciplinas, segundo os professores entrevistados, ocorrem em um período adequado, não havendo a necessidade de mudanças neste aspecto.

\section{6- CTU - UEL - Centro de Tecnologia e Urbanismo da Universidade Estadual de Londrina ${ }^{178}$}

\section{a) Breve Histórico}

O curso foi criado em 1979 a partir da Resolução n.o 501, de 21.10.78.

(informações sobre o histórico não encontradas/ com indicativo de serem inexistentes)

\section{b) Considerações sobre a Estruturação da área de Tecnologia da Construção}

O curso oferece 60 vagas anuais e adota o regime misto, com disciplinas ofertadas tanto em regime anual e como também semestral.

De acordo com o Quadro 26, as disciplinas de Tecnologia estão distribuídas entre o 10 e o 8응 períodos, ocupando $34 \%$ dos créditos em disciplinas obrigatórias (não considerando o Trabalho Final de Graduação - TFG, Estágio Supervisionado e Atividades Complementares). As disciplinas da Tecnologia da Construção (Materiais de Construção I e II e também Técnicas Construtivas I, II, III e IV) ocupam 8,5\% dos créditos, Sistemas Estruturais 11\%; Instalações Prediais 2,5\%; Conforto Ambiental 5\%, Fundamentação 2\% e Outras (Topografia, Aerofotogametria e Mecânica dos Solos e Fundações) 5\% dos créditos.

As disciplinas de Materiais e Técnicas da Construção I e II são ofertadas no 10 e 20 períodos (10 ano) e as de Técnicas Construtivas I, II, III e IV, entre o 3 ㅇ e o 60 períodos (2ำ e 3 음 anos de curso).

Quadro 26 - Distribuição da Grade Curricular com a carga horária semestral - CTU UEL:

\begin{tabular}{|c|c|c|c|c|c|c|c|c|c|}
\hline 10 sem & 2ㅇ sem & 3ㅇ sem & 4ㅇs sem & 5ㅇ sem & 6 sem & 70 sem & 8 sem & 90 sem & 10 sem \\
\hline $\begin{array}{c}\text { Introd. Arq e } \\
\text { Urb (4C) }\end{array}$ & $\begin{array}{c}\text { Projeto I A } \\
(4 \mathrm{C})\end{array}$ & $\begin{array}{c}\text { Projeto II A } \\
(6 \mathrm{C})\end{array}$ & $\begin{array}{c}\text { Projeto II A } \\
(6 \mathrm{C})\end{array}$ & $\begin{array}{c}\text { Projeto III A } \\
(6 \mathrm{C})\end{array}$ & $\begin{array}{c}\text { Projeto III A } \\
(6 \mathrm{C})\end{array}$ & $\begin{array}{c}\text { Projeto IV A } \\
(6 \mathrm{C})\end{array}$ & $\begin{array}{c}\text { Projeto IV } \\
\text { A (6C) }\end{array}$ & TFG & TFG \\
\hline $\begin{array}{l}\text { Estética e } \\
\text { Hist. (4C) }\end{array}$ & $\begin{array}{c}\text { Estudos Amb. } \\
\text { Urb. }(4 C)\end{array}$ & $\begin{array}{c}\text { Urbanismo I A } \\
(4 \mathrm{C})\end{array}$ & $\begin{array}{l}\text { Planej. Urb. } \\
\text { régio. I A (4C) }\end{array}$ & $\begin{array}{l}\text { Planej. Urb. } \\
\text { reg. II A (4C) }\end{array}$ & $\begin{array}{l}\text { Planej. Urb. } \\
\text { reg. II A (4C) }\end{array}$ & $\begin{array}{c}\text { Paisagismo } \\
\text { A (4C) }\end{array}$ & $\begin{array}{l}\text { PI. Urb. reg. } \\
\text { III A (4C) }\end{array}$ & $\begin{array}{c}\text { Tecnicas de } \\
\text { pesq. TFGI }\end{array}$ & $\begin{array}{c}\text { Tec. de } \\
\text { pesq. TFGI }\end{array}$ \\
\hline $\begin{array}{l}\text { T. e Hist. Arq } \\
\text { e urb I C (3C) }\end{array}$ & $\begin{array}{c}\text { T. e Hist. Arq e } \\
\text { urb I D (3C) }\end{array}$ & $\begin{array}{c}\text { T. e Hist. Arq e } \\
\text { urb II C (3C) }\end{array}$ & $\begin{array}{c}\text { T. e Hist. Arq e } \\
\text { urb II D (3C) }\end{array}$ & $\begin{array}{c}\text { Urbanismo } \\
\text { II A (4C) }\end{array}$ & $\begin{array}{c}\text { Urbanismo II } \\
\text { A (4C) }\end{array}$ & $\begin{array}{c}\text { Urbanismo } \\
\text { III A (4C) }\end{array}$ & $\begin{array}{c}\text { Urbanismo } \\
\text { III A (4C) }\end{array}$ & $\begin{array}{l}\text { Etica legisl. } \\
\text { Profiss. }(2 \mathrm{C})\end{array}$ & $\begin{array}{l}\text { Estagio" } \\
\text { sup. IV A }\end{array}$ \\
\hline $\begin{array}{c}\text { Desenho Proj. } \\
\text { I (3C) }\end{array}$ & $\begin{array}{c}\text { Desenho Proj. } \\
\text { I (3C) }\end{array}$ & $\begin{array}{c}\text { Desenho Proj. } \\
\text { II (3C) }\end{array}$ & $\begin{array}{c}\text { Desenho Proj. } \\
\text { II (3C) }\end{array}$ & $\begin{array}{l}\text { T. e H. Arq e } \\
\text { urb III C (3C) }\end{array}$ & $\begin{array}{l}\text { T. e Hist. Arq } \\
\text { e urb III D (3C) }\end{array}$ & $\begin{array}{l}\text { T. e H. Arq e } \\
\text { urb IV C (3C) }\end{array}$ & $\begin{array}{l}\text { T. H. Arq ur } \\
\text { IV D (3C) }\end{array}$ & $\begin{array}{l}\text { Estagio } \\
\text { superv. II A }\end{array}$ & \\
\hline $\begin{array}{c}\text { Geometria } \\
\text { Descr. D (5C) }\end{array}$ & $\begin{array}{c}\text { Geometria } \\
\text { Descr. D (5C) }\end{array}$ & $\begin{array}{c}\text { Informática } \\
\text { arq }(3 C)\end{array}$ & $\begin{array}{c}\text { Informática } \\
\operatorname{arq}(3 C)\end{array}$ & $\begin{array}{c}\text { Conforto } \\
\text { Amb. II (4h) }\end{array}$ & $\begin{array}{l}\text { Instalaç pred. } \\
\text { II eletrica (3h) }\end{array}$ & $\begin{array}{c}\text { Avaliaç. pós } \\
\text { ocup. (4C) }\end{array}$ & $\begin{array}{c}\text { Téc. retros. } \\
(4 \mathrm{~h})\end{array}$ & & \\
\hline Cálculo C (2C) & $\begin{array}{l}\text { Represent. } \\
\text { Tridim. (4C) }\end{array}$ & $\begin{array}{c}\text { Aerofotogam. } \\
\text { A (4C) }\end{array}$ & $\begin{array}{c}\text { Conforto Amb. } \\
\text { I (4C) }\end{array}$ & $\begin{array}{l}\text { Instal. pred. } \\
\text { I hidr. (3h) }\end{array}$ & \begin{tabular}{|c|} 
Técnicas \\
Constr. II (3C)
\end{tabular} & $\begin{array}{c}\text { Construç. } \\
\text { Metálic (3C) }\end{array}$ & $\begin{array}{c}\text { Construç. } \\
\text { Madei. (3C) }\end{array}$ & & \\
\hline
\end{tabular}

\footnotetext{
178 Dados obtidos a partir da visita técnica realizada em 10/06/2014, às instalações físicas da área técnico-construtiva utilizadas pelo curso de Arquitetura e Urbanismo, com entrevistas direcionadas aos professores: Jorge Daniel de Melo Moura e Marcos Strass e junto aos técnicos de laboratório.
} 




Disciplinas de Projeto

Disciplinas de Representação Gráfica e comp.

Disciplinas de Urbanismo e Meio Ambiente

Disciplinas na área da Tecnologia da Arquitetura
Disciplinas de Historia e Teoria

\section{c) Quadro docente}

As disciplinas de Materiais I e II são ministradas por professores pertencentes ao curso da Engenharia Civil (arquitetos e engenheiros pertencentes ao quadro docente do curso, mas geralmente, são ministradas por professores engenheiros). As disciplinas de Técnicas construtivas I e II estão sob a responsabilidade do curso de Arquitetura e Urbanismo, sendo ministradas por professores com formação em arquitetura. No caso das disciplinas de Técnicas Construtivas III e IV são ministradas por professores da Engenharia Civil.

\section{d) Práticas didáticas e Infraestrutura laboratorial}

Dos três laboratórios visitados e utilizados pelo curso de Arquitetura e Urbanismo, um deles, o Laboratório de Maquetes/Marcenaria apresenta-se como uma subunidade do Centro de Tecnologia e Urbanismo (CTU), sob a direção do Departamento de Arquitetura e Urbanismo (DAU). O Laboratório de Materiais de Construção é muito frequentado e utilizado pelos professores e alunos do curso de Arquitetura, e no Laboratório de Estruturas, mesmo não sendo frequentemente utilizado pelos alunos da Arquitetura há a possibilidade da realização de práticas experimentais, quando necessário. Os Laboratórios de Materiais de Construção e Estruturas estão sob a direção do curso da Engenharia Civil. Tratam-se de espaços de uso compartilhado entre os cursos de Arquitetura e Engenharia Civil, tanto nos níveis da graduação como da pós-graduação.

O Laboratório de Maquetes/Marcenaria (Figura 91), conta com um espaço físico de $420 \mathrm{~m}^{2}$, subdividido em área para maquinário e ferramentas, local para aulas didáticas e estoque de material. Apresenta como corpo técnico 02 funcionários, sendo um técnico em marcenaria e outro auxiliar para serviços. Um dos objetivos do laboratório é a realização de cursos e apoio no desenvolvimento de atividades de ensino, pesquisa e extensão (graduação e pós graduação). Diversos equipamentos do Laboratório de Maquetes/Marcenaria foram adquiridos com recursos de projetos de pesquisa.
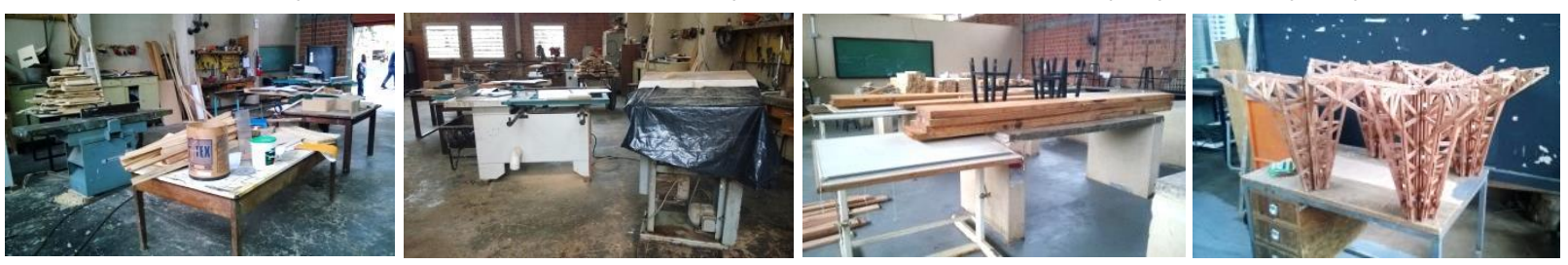

Figura 91 - Sequencia de imagens do Laboratório de Maquetes/Marcenaria - CTU.

Fonte: fotos da autora.

O Laboratório de Materiais de Construção (Figura 92) possui 02 auxiliares para o acompanhamento das atividades e os materiais básicos de consumo (cimento, agregados e blocos) são adquiridos pelo Centro de Tecnologia e Urbanismo, a partir de verba institucional. As atividades experimentais realizadas pelo curso de Arquitetura e vinculadas, principalmente, às disciplinas de Materiais de Construção I e II apresentam-se como: execução de paredes em alvenaria, moldagem de corpos de prova em concreto e argamassa, execução e aplicação de argamassas de revestimento, ensaios de arrancamento ou ensaio de pintura (sobreposições), dentre outras. Este laboratório possui as mesmas dimensões e tipologia construtiva do Laboratório de Maquetes, diferenciando-se apenas na configuração organizacional interna, nos equipamentos e particularidades das atividades, sendo 
possível a manipulação de diferentes materiais, mas está equipado, prioritariamente, para atender as pesquisas com o concreto e argamassas. Possui espaços reservados para maquinários e ensaios específicos, salas de aula, estufa, depósito de materiais e uma extensa área livre para experimentações. Trata-se de um espaço integrado à área externa, onde diversas experimentações também são realizadas fora do ambiente fechado.


Figura 92 - Sequencia de imagens do Laboratório de Materiais de Construção. a) b) e c) Imagens do espaço interno e d) baias para depósito de material localizada na área externa

Fonte: fotos da autora

No Laboratório de Estruturas (Figura 93) há 01 técnico e, dependendo da pesquisa em andamento os laboratórios são utilizados em conjunto: Maquetaria, Materiais de Construção e Estruturas, um exemplo seriam as pesquisas com o material madeira que ocorrem tanto no Laboratório de Maquetes/Marcenaria como também no Laboratório de Estruturas, onde foi instalada uma estufa para secagem de peças de madeira. Segundo o entrevistado, algumas atividades experimentais (madeiras) eram igualmente aplicadas aos alunos da arquitetura e engenharia, mas, devido a concorrência de outras disciplinas do curso de arquitetura, os alunos não tinham disponível o mesmo tempo para conduzir tais atividades que os alunos da engenharia civil, fazendo com que as estratégias didáticas fossem mudadas e se adequassem a esta condição. Isso levou à subtração de algumas atividades para os alunos da arquitetura como a execução de determinados ensaios técnicos. Atualmente, eles apenas observam a realização dos ensaios (arrancamento, flexão, etc), quando antes a proposta didática contemplava a experimentação.

O grupo de pesquisa em Arquitetura é bem atuante e sempre há alunos deste curso envolvidos em projetos de Iniciação Científica no laboratório, independente da implantação do mestrado (ainda incipiente) estes projetos atraem os alunos da graduação.

O Laboratório de Estruturas apresenta as mesmas dimensões e tipologia construtiva dos demais galpões $\left(420 \mathrm{~m}^{2}\right)$.

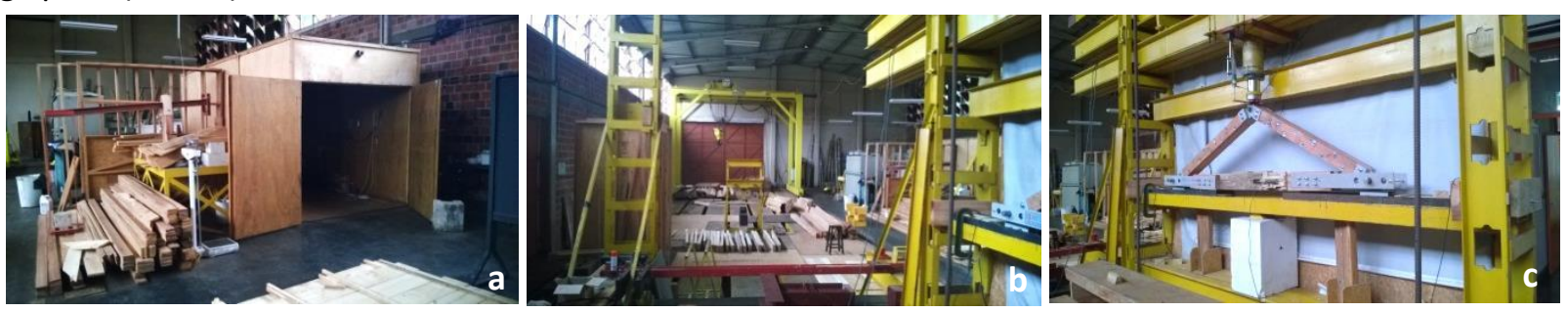

Figura 93 - Imagens do espaço interno do Laboratório de Estruturas. a) estufa implantada no interior do laboratório. b) e c) Ensaios mecânicos realizados em elementos estruturais de madeira, objeto de pesquisa da pós-graduação em Arquitetura.

Fonte: fotos da autora.

Em relação à área externa utilizada em apoio às atividades experimentais (Figura 94), o curso apresenta uma área livre junto aos Laboratórios de Materiais e também à Maquetaria, possibilitando a execução de protótipos com diferentes materiais na escala 1:1 (estas atividades estão vinculadas, prioritariamente, às disciplinas de Sistemas Estruturais em arquitetura e os protótipos habitacionais e ensaios mecânicos pesquisas do curso de Engenharia Civil). Trata-se de um espaço não caracterizado pelo próprio curso como um canteiro experimental, mas há a liberdade de ser utilizado com este propósito, não se tratando de uma área delimitada ou burocraticamente pertencente a um laboratório específico, este caráter de uso faz com que vários protótipos construídos sejam desmontados conforme a necessidade de uso deste espaço. 



Figura 94 - Atividades experimentais na forma de diferentes protótipos. a) Protótipos habitacionais para avaliação de sistemas construtivos e conforto térmico e acústico. b) Ensaios de arrancamento e revestimento. c) Protótipos realizados na disciplina de Sistemas Estruturais.

Fonte: fotos da autora

A disciplina de Materiais de Construção I, ofertada no 1 o ano do curso, discute questões como as propriedades físicas, mecânicas e químicas dos materiais. No 10 semestre são abordados todos os materiais que não estejam dentro do grupo dos de base cimentícia. Já no 2o semestre, o conteúdo é voltado, prioritariamente, para o concreto e as argamassas. Embora a disciplina não contemple os aspectos construtivos, a aplicabilidade dos materiais também é abordada.

De acordo com a entrevista realizada, devido ao fato do Laboratório de Materiais de Construção estar mais bem estruturado para práticas com argamassas e concretos, as atividades realizadas no 1 o semestre estão mais voltadas a visitas em empresas e indústrias, ocorrendo quase alternadamente uma aula teórica e uma visita (em muitas delas são realizados ensaios laboratoriais na própria indústria pelo corpo técnico, para que os alunos possam visualizar). No 20 semestre, em Materiais de Construção II, (materiais de base cimentícia), são realizadas atividades práticas experimentais no Laboratório de Materiais de Construção, geralmente envolvendo dosagem de concreto e argamassa e construção de protótipos em escala real.

Alguns materiais apresentam a possibilidade da realização de ensaios simples, com demonstrações empíricas de funcionamento (comportamento dos materiais com distintas propriedades físicas como densidade, elasticidade, plasticidade, dutilidade). A estratégia pedagógica seria que, mesmo sem o domínio dos métodos de dimensionamento estrutural, a percepção permita que 'empiricamente' sejam tomadas decisões corretas.

Na disciplina de Técnicas Construtivas I (ofertada no 2ㅇan ano do curso), de acordo com sua ementa, são abordadas as etapas do projeto arquitetônico e complementares, desde a preparação do terreno como também as partes da edificação. Também são desenvolvidos assuntos como obras complementares, orçamento, organização administrativa do canteiro, segurança e higiene do trabalho no canteiro de obras. São utilizados programas orçamentários computacionais. Em Técnicas Construtivas II, disciplina do 30 ano do curso, de acordo com o professor entrevistado, são abordados assuntos relacionados à modulação e processos construtivos racionalizados, usando prioritariamente, o material madeira e a alvenaria como elemento estrutural. O tema habitação social é utilizado como plataforma de trabalho, sendo a ementa desenvolvida na intenção de realizar um projeto com estes materiais. As atividades envolvem prioritariamente o projeto, não sendo realizadas atividades em canteiro ou nos laboratórios.

\section{e) Pós graduação:}

O Mestrado em Metodologia de Projeto iniciou suas atividades em 2012, sendo a primeira pósgraduação stricto sensu da área de Arquitetura e Urbanismo do Paraná aprovada pela CAPES, resultado de uma proposta conjunta da Universidade Estadual de Maringá (UEM) e da Universidade Estadual de Londrina (UEL).

O curso é composto por duas linhas de pesquisa:

1- Historiografia e metodologia de organização de dados para o projeto: reflexão sobre a dinâmica da cultura projetual considerando suas dimensões histórica, sócio-cultural, técnica e material, como subsídio para práticas projetuais. 
2- Produção do ambiente construído: avaliação e aplicação de métodos e processos de projeto relacionando questões de desempenho e sustentabilidade

Os assuntos sobre Tecnologia das Construções são contemplados na linha de pesquisa em Produção do Ambiente Construído e os temas trabalhados (no período da visita técnica) aproximam os alunos das atividades laboratoriais, com trabalhos essencialmente experimentais.

\section{f) Comentários:}

- Percebe-se que a inserção de determinados conteúdos na disciplina de Técnicas Construtivas II e as reformulações propostas ao longo dos anos (antes chamada de Industrialização das construções e com outra abordagem) - como o material madeira e a alvenaria estrutural - tem uma relação direta com o perfil docente à frente da disciplina e de suas temáticas de especialização na pós-graduação. Reflexo da trajetória docente na construção da proposta disciplinar;

- A relação entre o curso de Engenharia Civil e Arquitetura é diferenciada, por estarem implantados e permanecerem juntos no mesmo centro: CTU (Centro de Tecnologia e Urbanismo). Esta relação saudável é refletida no uso da infraestrutura laboratorial, no transito dos alunos e na interatividade entre professores na realização das pesquisas;

- Há uma convivência muito interativa entre os cursos da Arquitetura e Urbanismo e Engenharia Civil, vista não somente entre o intercâmbio de professores como também no compartilhamento do espaço e realização das pesquisas na área da tecnologia da construção. Não foi identificada a delimitação de espaços utilizados e burocratização de usos destinados a um ou outro curso;

- O mestrado em Arquitetura (da Engenharia Civil já existia), permite que os trabalhos dos alunos de pósgraduação desenvolvidos nos laboratórios, sejam acompanhados pelos alunos da graduação. Embora o mestrado ainda seja incipiente, há proximidade entre graduandos e pesquisadores de Iniciação Científica;

- A adoção de metodologias pedagógicas apoiadas na construção de protótipos e modelos é uma prática antiga no curso, sendo sinalizado que, apesar do reconhecimento do potencial destas atividades, há dificuldade para que possam ser ampliadas e aplicadas em um número maior de disciplinas, simultaneamente, devido aos custos financeiros envolvidos para aquisição de materiais e contratação de serviços não ofertados pelo CTU, onerando o aluno. Diante disso, outras estratégias são implantadas para que o conteúdo possa ser desenvolvido, como as visitas técnicas a obras e indústrias

- As dificuldades financeiras para aquisição contínua de materiais e manutenção dos laboratórios e equipamentos são recorrentes.

\subsubsection{ESCOLAS IMPLANTADAS NA DÉCADA DE 1980}

O referido período tem como principal fato marcante o fim da Ditadura Militar (19641985), que perdurou por aproximadamente 21 anos. Neste trabalho, diante das poucas escolas de arquitetura inseridas em instituições públicas e criadas na década de 1980 (02 escolas), apenas 01 foi contemplada na visita técnica: IAU-USP (1985).

\section{7- IAU - USP - Instituto de Arquitetura e Urbanismo da Universidade de São Paulo ${ }^{179}$}

\footnotetext{
179 Dados obtidos a partir da visita técnica realizada em 18/12/2015, às instalações do IAU-USP, com entrevistas aos professores Dra. Akemi Ino e Dr. Javier Maraziegos Pablos e também, a técnicos de laboratório e alunos de pós-graduação. Estes dados foram complementados com o Projeto Pedagógico do Curso e o documento de Avaliação Institucional da USP 2010-1014 - Unidade IAU. Disponíveis respectivamente em: http://www.iau.usp.br/graduacao/index.php/agraduacao/projeto-politico- pedagogico e http://www.iau.usp.br/images/documentos/avaliacao_institucional /Avaliacao\%20Institucional\%20USP\%202010 -2014_Unidade-IAU_5\%208\%2015.pdf. Acesso em 25/02/2016.
} 


\section{a) Breve Histórico ${ }^{180}$}

Nos primeiros anos de existência, a Escola de Engenharia de São Carlos - EESC-USP foi regida pelo Regulamento da Escola Politécnica e seu próprio Regulamento entrou em vigor em 1955. No Artigo 23 deste último, encontra-se o que já preconizava a lei de estruturação no tocante ao estabelecimento de Departamentos Científicos, para fins de ensino e pesquisa, dentre eles, o Departamento de Estrutura e Arquitetura, onde a Arquitetura ocupava a cadeira de n. 23. O mesmo documento relata que no final do mandato do primeiro diretor da Escola, foi publicado um documento abrangente sobre as atividades referentes ao período de 1953 a 1967, no qual se constata que a cátedra pertencente à Arquitetura e Planejamento era a de n. 13 pertencente ao Departamento de Estrutura e Arquitetura.

Em 1971 foi criado o curso de mestrado em Industrialização das Construções, junto ao Departamento de Arquitetura e Planejamento da EESC-USP sendo o curso de graduação em Arquitetura implantado posteriormente a ele. Embora já fosse prevista uma Faculdade de Arquitetura, de acordo com a Lei 8488 publicada no Diário Oficial de 17/12/1964, o curso nunca chegou a funcionar neste período junto à EESC-USP, sendo este assunto retomado em 1970 junto à pós-graduação.

A pós-graduação foi criada para dar suporte ao curso de engenharia na área da arquitetura. A primeira proposta para a constituição do Curso em Arquitetura e Urbanismo da EESC data de 1975, sendo o curso aprovado pelo Conselho Universitário em 29/12/1975, mas, por razões internas, o curso foi efetivamente implantado apenas em 1985.

Em 1996, o curso passou por uma reestruturação curricular, a qual promoveu alterações significativas na carga horária das quatro áreas de ensino que estruturam o curso: Tecnologia, Representação e Linguagem, Teoria e História e também Projeto. Em 14/12/2010 o Conselho Universitário aprovou a criação do Instituto de Arquitetura e Urbanismo (IAU) no campus São Carlos, com base no antigo Departamento de Arquitetura e Urbanismo da EESC. O Instituto foi criado para fortalecer a área de ciencias sociais no campus e continuar a formação de um núcleo de humanas no Campus São Carlos. A partir desta data o CAU passou a integrar o IAU, permanecendo o apoio dos distintos Departamentos: Estrutura, Geotecnia, Hidráulica e Saneamento e Transportes - e também de Unidades: Física e Matemática. O curso de Arquitetura e Urbanismo do IAU USP tem como uma de suas definições estruturais significativas o fato de não estar organizado em Departamentos, considerada a dimensão do corpo docente e a convivência de décadas em um único Departamento (o SAP EESC).

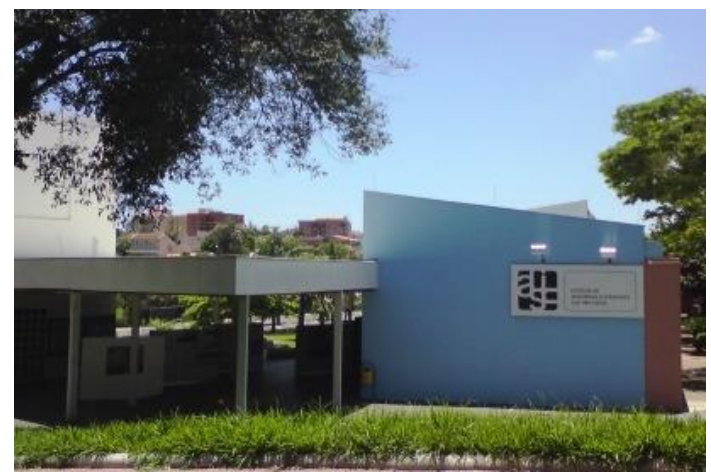

Figura 95 - Vista do edifício sede do curso do IAU USP.

Fonte: http://diariosaocarlos.com.br/site/index.php/universidades/2986-iau-usp.

\footnotetext{
${ }^{180}$ Dados sobre o Histórico do curso obtidos em:

- ALTAFIM, R.A. C. 50 anos da EESC: um olhar no passado visando o futuro. 2a Edição. São Carlos: Escola de Engenharia de São Carlos, 2004.

- CERAVOLO, A.L. Paulo de Camargo e Almeida : arquitetura total na trajetória de um arquiteto brasileiro. Dissertação (Mestrado), Escola de Engenharia de São Carlos. Universidade de São Paulo, 2000.

- KOURY, A.P. Arquitetura Construtiva: proposições para a produção da arquitetura no Brasil (1960-1970). Projeto História, São Paulo, n.34, p. 189-203, jun. 2007. Disponível em: http://revistas.pucsp.br/index.php/revph/article/viewFile/2473/1568. Acesso em: 02/03/2016.

- http://www.iau.usp.br/graduacao/index.php/a-graduacao/projeto-politico-pedagogico. Acesso em 25/02/2016.

- http://www.iau.usp.br/index.php/pos/introducao. Acesso em 25/02/2016.
} 


\section{b) Considerações sobre a Estruturação da área de Tecnologia da Construção}

São oferecidas pelo IAUUSP 45 vagas anuais. De acordo com o PPP do curso, os conteúdos curriculares apresentam-se como campos do conhecimento essenciais e específicos, considerando em cada campo matérias e não ciclos ou disciplinas.

Diferentemente das matérias voltadas às Estruturas, Instalações Prediais, Matemática e Saneamento, as disciplinas de Tecnologia das Construções I-A, I-B e II-A, II-B são ministradas por professores pertencentes ao quadro docente do curso de Arquitetura e Urbanismo. A partir do Quadro 27, é visto que as matérias de caráter técnico são ministradas entre o 10 e 70 períodos, estando as de Tecnologia das Construções concentradas entre o 3 ㅇ e 60 períodos.

Ao considerar somente as matérias ofertadas (não computando os créditos destinados ao TFG I, TFG II, optativas e estágio), aquelas consideradas como técnicas ocupam aproximadamente, 25,5\% dos créditos totais, sendo destinados às matérias de Estruturas 6,5\%, Tecnologia das construções 6,5\%; Conforto ambiental 3,5\%; Instalações 0,65\%; Fundamentação $5 \%$ e Outras consideradas da área (Leituras Topográficas, Mecânica dos Solos e Saneamento) 3,5\%.

Quadro 27 - Distribuição da Grade Curricular com a carga horária semestral - IAU USP:

\begin{tabular}{|c|c|c|c|c|c|c|c|c|c|}
\hline 10 sem & 20 sem & 3 sem & 4\% sem & 5 sem & 60 sem & 70 sem & 8 sem & 90 sem & $10 \%$ sem \\
\hline $\begin{array}{c}\text { Projeto I-A } \\
(10 \mathrm{~h})\end{array}$ & $\begin{array}{c}\text { Projeto I-B } \\
(10 \mathrm{C})\end{array}$ & $\begin{array}{c}\text { Projeto II-A } \\
(10 \mathrm{C})\end{array}$ & $\begin{array}{l}\text { Projeto II-B } \\
(10 \mathrm{C})\end{array}$ & $\begin{array}{c}\text { Projeto III-A } \\
(10 \mathrm{C})\end{array}$ & $\begin{array}{c}\text { Projeto III-B } \\
(10 \mathrm{C})\end{array}$ & $\begin{array}{c}\text { Projeto VI-A } \\
(10 \mathrm{C})\end{array}$ & $\begin{array}{c}\text { Projeto VI- } \\
\mathrm{B}(10 \mathrm{C})\end{array}$ & TFG I & TFG ॥ \\
\hline $\begin{array}{c}\text { Introd. a Teo. } \\
\text { Arte, Arq e } \\
\text { Cidade (10C) }\end{array}$ & $\begin{array}{l}\text { Introd. a Arq e } \\
\text { Urb Mod. (8C) }\end{array}$ & \begin{tabular}{|c|}
$\begin{array}{c}\text { Teor. histor. } \\
\text { Arq. Urb Brasil } \\
\text { I (8C) }\end{array}$ \\
\end{tabular} & $\begin{array}{c}\text { Paisagismo I } \\
\text { (6C) }\end{array}$ & $\begin{array}{c}\text { Teor. histor. } \\
\text { Arq. Urb } \\
\text { Mod. I (8C) } \\
\end{array}$ & $\begin{array}{l}\text { Teor. histor. } \\
\text { Arq. Urb Mod. } \\
\text { II (8C) }\end{array}$ & $\begin{array}{c}\text { Paisagismo } \\
\text { II (6C) }\end{array}$ & ITFG & & supervi \\
\hline Plástica I (5C) & Plástica II (5C) & $\begin{array}{l}\text { Linguagens } \\
\text { visuais I (5C) }\end{array}$ & $\begin{array}{c}\text { Teor. histor. } \\
\text { Arq. Urb Brasil } \\
\text { II (8C) }\end{array}$ & $\begin{array}{l}\text { Estética I } \\
\qquad(5 \mathrm{C})\end{array}$ & Estética II (5C) & $\begin{array}{l}\text { Arq. Urb. } \\
\text { Contemp. I } \\
(8 \mathrm{C})\end{array}$ & $\begin{array}{l}\text { Arq. Urb. } \\
\text { Contemp. II } \\
(8 \mathrm{C})\end{array}$ & & \\
\hline $\begin{array}{c}\text { Desenho de } \\
\text { Arq. I (5C) }\end{array}$ & $\begin{array}{c}\text { Desenho de } \\
\text { Arq. II (5C) }\end{array}$ & $\begin{array}{c}\text { Conforto Amb. } \\
\text { Edificaç. }(5 \mathrm{C})\end{array}$ & $\begin{array}{l}\text { Linguagens } \\
\text { visuais II (5C) }\end{array}$ & \begin{tabular}{|c|} 
Tecnologia \\
construções \\
II-A (5C)
\end{tabular} & $\begin{array}{c}\text { Tecnologia } \\
\text { construções } \\
\text { II-B (5C) }\end{array}$ & $\begin{array}{c}\text { Arq. Urb, } \\
\text { Etica e } \\
\text { Socied (5C) }\end{array}$ & $\begin{array}{c}\text { Lingu.Arq e } \\
\text { Cidad. II } \\
\text { (5C) }\end{array}$ & & \\
\hline $\begin{array}{l}\text { Informática } \\
\text { na arq. I (6C) }\end{array}$ & $\begin{array}{c}\text { Informática na } \\
\text { arq. II (6C) }\end{array}$ & $\begin{array}{c}\text { Instalaç. } \\
\text { Prediais } \\
\text { hid/san (2C) }\end{array}$ & $\begin{array}{c}\text { Conforto Amb. } \\
\text { Edificaç. }(5 \mathrm{C})\end{array}$ & $\begin{array}{c}\text { Sist. Estrut } \\
\text { Concr. I-A } \\
(5 \mathrm{C})\end{array}$ & \begin{tabular}{|c|} 
Sist. Estrut. \\
Aço madeira \\
$(5 \mathrm{C})$
\end{tabular} & $\begin{array}{l}\text { Linguagem } \\
\text { da Arq e } \\
\text { Cidad. I (5C) }\end{array}$ & & & \\
\hline \multirow[t]{3}{*}{$\begin{array}{c}\text { Matemática } \\
\text { arq. I (5C) }\end{array}$} & $\begin{array}{c}\text { Matemática } \\
\text { arq. I (5C) }\end{array}$ & \begin{tabular}{|c|} 
Tecnologia \\
construções I- \\
$\mathrm{A}(\mathrm{5C})$ \\
\end{tabular} & \begin{tabular}{|c|} 
Tecnologia \\
construções I- \\
B (5C) \\
\end{tabular} & \begin{tabular}{|c|} 
Mecânica \\
solos e fund \\
$(4 \mathrm{C})$
\end{tabular} & & $\begin{array}{c}\text { Saneamento } \\
\text { e meio amb } \\
(3 \mathrm{C})\end{array}$ & & & \\
\hline & Física (5C) & $\begin{array}{c}\text { Leituras } \\
\text { topograf. (4C) }\end{array}$ & \begin{tabular}{|c|} 
Sistemas \\
Estruturais I-B \\
$(5 \mathrm{C})$
\end{tabular} & & & & & & \\
\hline & & \begin{tabular}{|c|} 
Sistemas \\
Estruturais I-A \\
$(5 \mathrm{C})$
\end{tabular} & Pesq. Cient & & & & & & \\
\hline
\end{tabular}

Disciplinas de Projeto

Disciplinas de Representação Gráfica e comp.
Disciplinas de Urbanismo e Meio Ambiente

Disciplinas na área da Tecnologia da Arquitetura

OBS.:

- Para os créditos obtidos nas disciplinas foram somados os destinados às aulas e trabalhos, de acordo com os dados publicados na grade curricular do curso.

- Foi observado que a distribuição das disciplinas na grade curricular segue uma orientação diferente de outros cursos com relação às áreas de concentração, ao considerar as disciplinas de Matemática, Conforto Ambiental, Leituras Topográficas e Saneamento, como não pertencentes à área da Tecnologia. Desta forma, a autora realizou modificações na representação destas áreas, de acordo com os demais Quadros já apresentados neste trabalho

\section{c) Quadro docente}

Até meados de 2015 o quadro docente estava composto por 39 docentes, sendo 35 em RDIDP e 03 em RTC (regime de 24 horas semanais), além de 01 professor temporário (regime de 12 horas semanais, sem atividade de pesquisa). Deste grupo, 06 professores são engenheiros, 28 são arquitetos e 05 possuem formação em outras áreas. 
Como o curso não adota o sistema de departamentos, os professores não estão alocados em áreas de concentração específicas, este processo facilita com que transitem em diferentes áreas entre a graduação e a pós-graduação, mas respeitando sua(s) área(s) de conhecimento.

Em relação às disciplinas da Tecnologia das Construções, estas estão sob a responsabilidade de professores pertencentes ao quadro docente do próprio curso, com formação tanto em Engenharia Civil como em Arquitetura e Urbanismo.

\section{d) Práticas didáticas e Infraestrutura laboratorial}

O IAU possui 05 laboratórios, dentre eles, 02 dão suporte às disciplinas da área da Tecnologia da Construção: Laboratório de Construção Civil - LCC (Figura 96 e 97) e o Laboratório de Modelos e Maquetes. Além disso, outros laboratórios pertencentes à EESC também estão à disposição para dar apoio às práticas experimentais, dependendo das particularidades das atividades e dos materiais manipulados.

O LCC possui 04 técnicos especializados e área de $672,95 \mathrm{~m}^{2}$, já o Laboratório de Modelos e Maquetes possui 02 técnicos especializados e inclui a oficina de Maquetes e o Laboratório de Plástica, dispondo de equipamentos para trabalhos em madeira, metal, plástico e cerâmica. Ocupa área de 292,68 $\mathrm{m}^{2}$ e desde 2014 passou a ter uma seção para Prototipagem, Impressão 3D e fresagem. Trata-se de um espaço laboratorial de uso compartilhado, atendendo tanto a graduação como a pós-graduação, mas as atividades e infraestrutura laboratorial estão voltadas, prioritariamente, à pós-graduação, consequentemente, a infraestrutura tem cunho mais científico. Ao longo dos anos, foram acumulados no laboratório um vasto mostruário com diferentes materiais, tanto convencionais como não convencionais, muitos provenientes de pesquisas realizadas na pós-graduação, este cenário faz com que, indiretamente, os graduandos tenham fácil contato com as pesquisas desenvolvidas na pósgraduação, devido ao compartilhamento do espaço físico.

A maquetaria é constituída por máquinas de bancada e estacionárias, as quais possibilitam a confecção tanto de maquetes de escala reduzida como também, de protótipos próximos à escala real.

Os recursos para manutenção dos laboratórios vêm do próprio Instituto - da Universidade de São Paulo, complementados com projetos de pesquisa da pós-graduação e também com trabalhos de assessoria, via fundação de apoio à universidade, cuja participação segue o ritmo do cenário econômico do país, aumentando a procura por parcerias junto à universidade de acordo com a demanda da construção civil.


Figura 96 - Sequencia de imagens do interior do LCC - Laboratório de Construção Civil.

Fonte: fotos da autora.

De acordo com os relatos, na disciplina de Tecnologia das Construções I- A e I-B, são discutidos assuntos relacionados às propriedades físicas e mecânicas dos materiais construtivos. Quanto à realização das atividades experimentais nestas disciplinas, os alunos frequentam o LCC para conhecer os materiais abordados nas aulas teóricas e visualizar determinados ensaios pelo professor responsável, mas as experimentações laboratoriais não são realizadas pelos alunos, tendo estas práticas também caráter expositivo, com periodicidade de aproximadamente 3 aulas de laboratório/semestre. De acordo com o entrevistado, esta estratégia foi condicionada à falta de espaço físico para atendimento dos 45 alunos pelo fato do espaço ser compartilhado com a pós-graduação.

Em contrapartida, os professores aproveitam algumas pesquisas realizadas na pós-graduação, quando são fabricados protótipos de sistemas construtivos convencionais ou não e utilizam para expor estes sistemas diferenciados aos alunos da graduação, possibilitando que discussões mais atualizadas sejam travadas com os mesmos, como ciclo de vida, cadeia produtiva, materiais reciclados e 
aproveitamento de resíduos. Também foi relatado que as novas propostas de reestruturação do curso, no que se refere a área da tecnologia, estão voltadas a produtos e processos de baixo impacto ambiental e gerenciamento do projeto e produto por meio de plataformas - BIM (Building Information Modeling).

Sobre as disciplinas da Tecnologia das Construções II-A e II-B, os conteúdos envolvem principalmente os processos construtivos, havendo o desenvolvimento de atividades experimentais na forma de protótipos próximos à escala real, associando o conteúdo da disciplina com o projeto. Foi relatado que embora os esforços realizados, estas práticas não ocorrem de forma sistemática e constante, por estarem condicionadas à disponibilidade de recursos humanos e econômicos para sua viabilização, não sendo, portanto, uma proposta didática vinculada ao plano geral do curso e sim, à iniciativa docente e de parcerias. Atualmente, estão sendo aplicadas na disciplina estratégias para aproximá-la cada vez mais da atividade de projeto, por meio da proposição de módulos: com aulas teóricas expositivas, desenvolvimento de projeto em interface com o conteúdo e execução de atividades práticas quando possível.

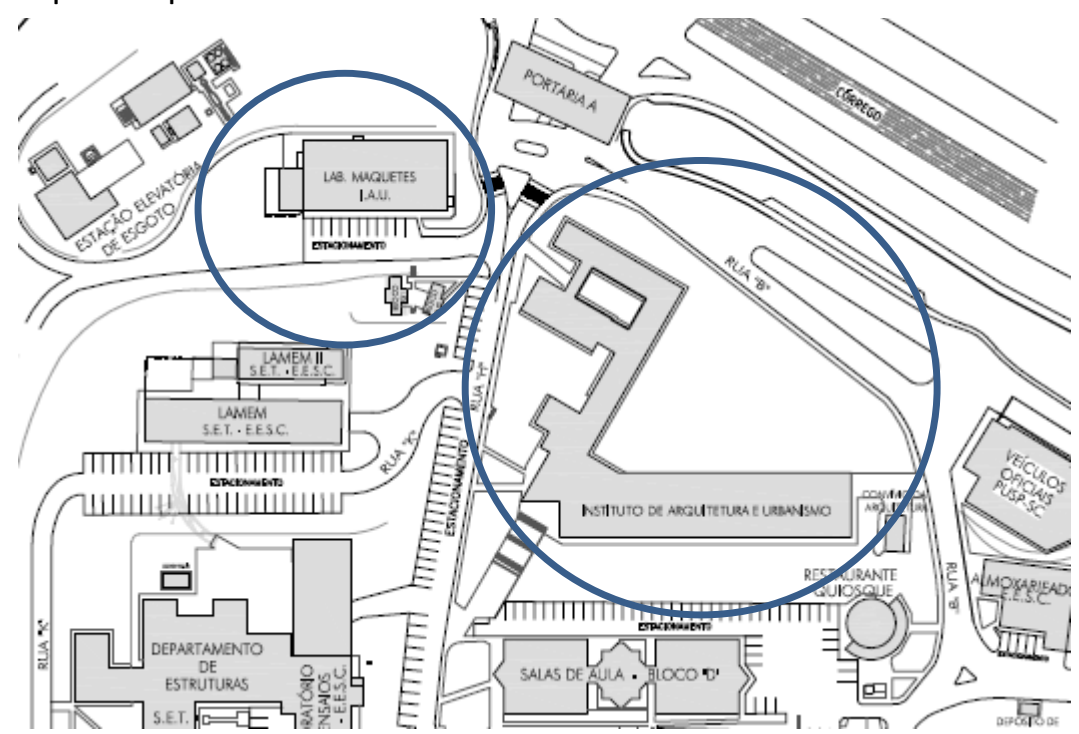

Figura 97 - Parte do mapa geral da EESC-USP com a localização dos edifícios e laboratórios pertencentes ao IAU. Fonte: http://www.puspsc.usp.br/imagens/site_mapa_USP_Area1.pdf. Acesso em: 27/02/2016.

Não há, propriamente, um espaço delimitado voltado às atividades práticas de canteiro e em escalas maiores. Quando realizadas, os alunos se apropriam do espaço externo próximo ao Instituto e laboratórios, de maneira a utilizar a infraestrutura disponível tanto do LCC como de outras unidades parceiras, como as pertencentes ao Lamem (Laboratório de Madeira e Estruturas de Madeira). Atualmente, foi construído um espaço provisório (Figura 98) para abrigar diversos materiais e componentes construtivos executados nas disciplinas e oficinas oferecidas, este espaço coberto foi construído pelos próprios alunos, os quais tiveram a oportunidade de acompanharem o processo executivo e depois de pronto, a possibilidade de ficarem expostos diversos sistemas construtivos.
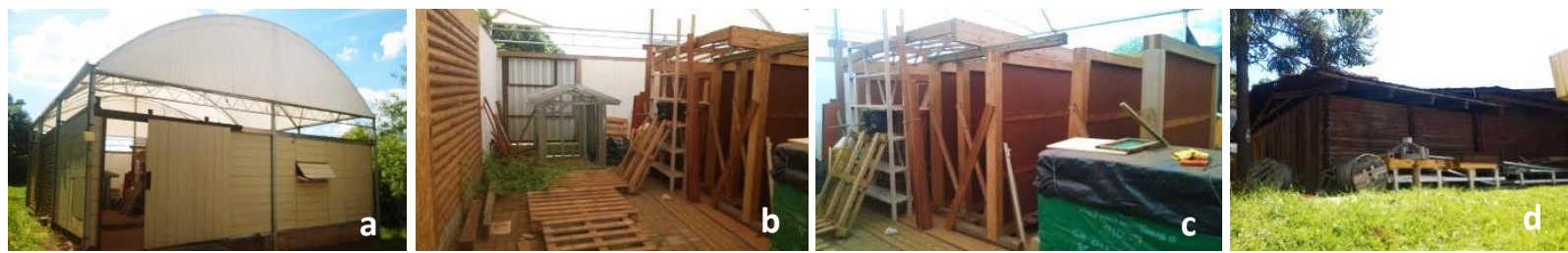

Figura 98 - Espaço provisório/expositivo construído pelos próprios alunos para abrigar materiais, equipamentos e sistemas construtivos. a) Imagem externa da construção. b) e c) Imagens internas do espaço provisório. c) Marcenaria pertencente ao Lamem - Laboratório de Madeira e Estrutura de Madeira, que também dá apoio a diversas atividades do curso de Arquitetura e Urbanismo.

Fonte: fotos da autora.

\section{e) Pós graduação:}


O curso de Mestrado foi criado em 1971, em Industrialização das Construções, por Paulo de Camargo na EESC-USP. Trata-se de um dos primeiros cursos de pós-graduação do país e tem um histórico de origem bem particular em relação a outras escolas de Arquitetura, devido à sua criação ter ocorrido antes da implantação do curso de graduação em Arquitetura e Urbanismo (em 1985).

De acordo com Koury (2007), Paulo de Camargo tratou de organizar uma escola multidisciplinar, com a colaboração de diversos conhecimentos específicos, estabelecendo no plano didático uma linha de produção que partia do desenho industrial e alcançava o planejamento urbano. Essa linha de produção organizava-se para o desenvolvimento da aplicação da técnica da argamassa armada, que estava sendo desenvolvida junto ao Laboratório de Estruturas com a participação dos professores Dante Martinelli, João Bento Hanai e Frederich Schiel. A linha de produção montada por Camargo, então, previa a organização do curso a partir da contribuição de vários especialistas: em desenho industrial (Gastão de Castro Lima), em conforto térmico (Domingos Bataglia), em materiais (Lafael Petroni), em processos industriais (Azael Rangel Camargo e Ricardo Martucci) e em planejamento (Celso Lamparelli). Do aporte desses vários especialistas sob a coordenação de Camargo, seria possível propor a industrialização da argamassa armada e sua aplicação em obras de equipamentos e habitação racionalmente dimensionadas e distribuídas pelo território nacional. Segundo a autora, esta experiência acadêmica pretendeu catalisar a experiência de desenvolvimento das técnicas construtivas desenvolvidas a partir das iniciativas do Estado, de modo mais organizado e efetivo, a exemplo do que havia sido realizado na UnB.

Reestruturado em 1993, passou a contar com duas áreas de concentração: Teoria e História da Arquitetura e do Urbanismo e Arquitetura, Urbanismo e Tecnologia, as quais permanecem até hoje:

- Arquitetura, Urbanismo e Tecnologia, cujas Linhas de Pesquisa são:

1) Desenvolvimento e Avaliação de Produtos, Sistemas e Processos

2) Conforto Ambiental e Eficiência Energética

3) Projeto, Inovação e Sustentabilidade

4) Política, Tecnologia e Produção de Habitação

- Teoria e História da Arquitetura e do Urbanismo, cujas Linhas de Pesquisa são:

1) Arquitetura, Cidade e Paisagem no Brasil e na América Latina

2) Arquitetura e Urbanismo como Disciplinas: Cultura Técnica e Profissional

3) Territórios e Cidades: Transformações, Permanências, Preservação

4) Habitação e Infraestrutura na Cidade e no Território: Produção e Políticas Públicas

5) Cidade, Arte e Cultura

A principal modificação observada entre a criação do Programa em 1971, com a única área 'Industrialização das Construções' e a configuração atual, é a ampliação das linhas de pesquisa, tornando-as mais genéricas, possibilitando que temáticas referentes a diversos materiais e técnicas construtivas contemporâneas sejam contempladas (o foco deixa de ser prioritariamente, a argamassa armada).

\section{f) Comentários:}

- A partir do documento de Avaliação Institucional do Curso (2010-2014), há a intenção de ampliar a atuação da USP/São Carlos para a área de Ciências Humanas e Sociais. A proposta prevê a criação, em médio prazo, de três novos cursos de graduação: Geografia, História e Design, para isso, a transformação do Departamento em Unidade de Ensino e Pesquisa era a condição institucional para a realização desses objetivos estratégicos. A prioridade ao Curso de Geografia está baseada na perspectiva de estabelecer sinergia com áreas e grupos já atuantes no Campus, como Engenharia Ambiental, Engenharia de Transportes, Solos e Geotecnia, oferecendo condições para o desenvolvimento de importante polo multidisciplinar nas áreas de políticas urbanas, regionais e ambientais;

- Embora o LCC (Laboratório de Construção Civil) seja um laboratório muito bem estruturado para as pesquisas, tanto em recursos físicos como também humanos, o compartilhamento de infraestrutura com as pesquisas de pós-graduação dificulta a apropriação deste espaço por parte dos alunos da graduação. Durante as entrevistas não houve comentários sobre adoção de procedimentos que visem 
à racionalização o uso do espaço como, por exemplo, a divisão da turma de 45 alunos em turmas menores de modo a viabilizar o acompanhamento individualizado do aluno, durante as atividades em laboratório. Há dificuldade em estabelecer uma estratégia que equilibre a falta de espaço para a graduação e que mantenha o ponto positivo desta proximidade, como a facilidade dos alunos da graduação terem contato com pesquisas de ponta, estimulando-os a se especializarem na área da Tecnologia da Construção;

- As disciplinas de Projeto I-A e I-B ${ }^{181}$ possuem um histórico de experimentação prática bastante consolidado, formatado para que os alunos possam se aprofundar nos diversos aspectos construtivos envolvidos na produção dos objetos apresentados como resultados finais dos respectivos semestres. Ao longo de todo o primeiro semestre com as dimensões do corpo e suas relações com o espaço, chegando ao final com um exercício aliando construção, mecanismo e corpo, o "aparato vestível". No segundo semestre, a proposta desta disciplina é estudar alguns princípios de projeto a partir da análise da obra de alguns arquitetos paradigmáticos, chegando ao final com a construção de um "pavilhão";

- Apesar da falta de espaço físico no campus, foi relatado que há intenção futura de serem ampliadas as práticas experimentais para os alunos da graduação, condicionada à implantação de infraestrutura mais adequada às atividades de ensino, possibilitando dissocia-las da pós-graduação e não comprometer as pesquisas em andamento

- Há discussões envolvendo a necessidade de maior integração entre disciplinas, em que a tecnologia deveria ser discutida juntamente com as demais disciplinas;

\subsubsection{ESCOLAS IMPLANTADAS NA DÉCADA DE 1990}

Período em que foi realizado o segundo levantamento pela Comissão de Especialistas em Arquitetura e Urbanismo - CEAU, sobre as condições de ensino oferecidas pelas escolas brasileiras. Neste trabalho foram visitadas as seguintes escolas criadas neste período: UFV (1992); UFU (1996); UFMS (1999) e UNICAMP (1999).

\section{8- DAU - UFV - Departamento de Arquitetura e Urbanismo da Universidade Federal de Viçosa $^{182}$}

\footnotetext{
a) Breve Histórico ${ }^{183}$

O Departamento de Arquitetura e Urbanismo (DAU) da Universidade Federal de Viçosa (UFV) foi criado em 1992 e reconhecido pelo MEC em 1997, tendo surgido a partir do desmembramento do setor de arquitetura inserido no curso de Engenharia Civil. Passou a funcionar em sede própria desde agosto de 1996 e está vinculado ao Centro de Ciências Exatas e Tecnológicas.

Segundo dados publicados pela escola, em junho de 1992 (ano de sua criação), o DAU / UFV firmou um convênio com a Technical University of Nova Scotia, universidade canadense, que possibilitou o treinamento e o intercâmbio de professores e alunos, permitiu a criação do curso de Pós-Graduação -

${ }^{181}$ Informações obtidas a partir de LOPES (2014).

182 Dados obtidos a partir da visita técnica realizada entre os dias 20 e 21/10/2016, com visita à infraestrutura laboratorial pertencente ao curso da Engenharia Civil, considerada esta de uso compartilhado com o curso de Arquitetura, também foram entrevistados os seguintes professores: prof. Dr. Leonardo Pedrotti e Délio Porto Fassoni (ambos pertencentes ao curso da Engenharia civil e atuais docentes das disciplinas de Tecnologia da Construção) e o professor Antonio Cleber Tibiriçá (professor engenheiro e pertencente ao quadro docente do curso de Arquitetura).

183 Dados obtidos a partir da consulta ao Projeto Político Pedagógico do curso e divulgados pela escola em: http://www.dau.ufv.br/interna.php?p=historico. Acesso em: 17 de outubro de 2016.
} 
Especialização em Planejamento Municipal - e contribuiu para a aquisição de livros, equipamentos e computadores para o departamento.
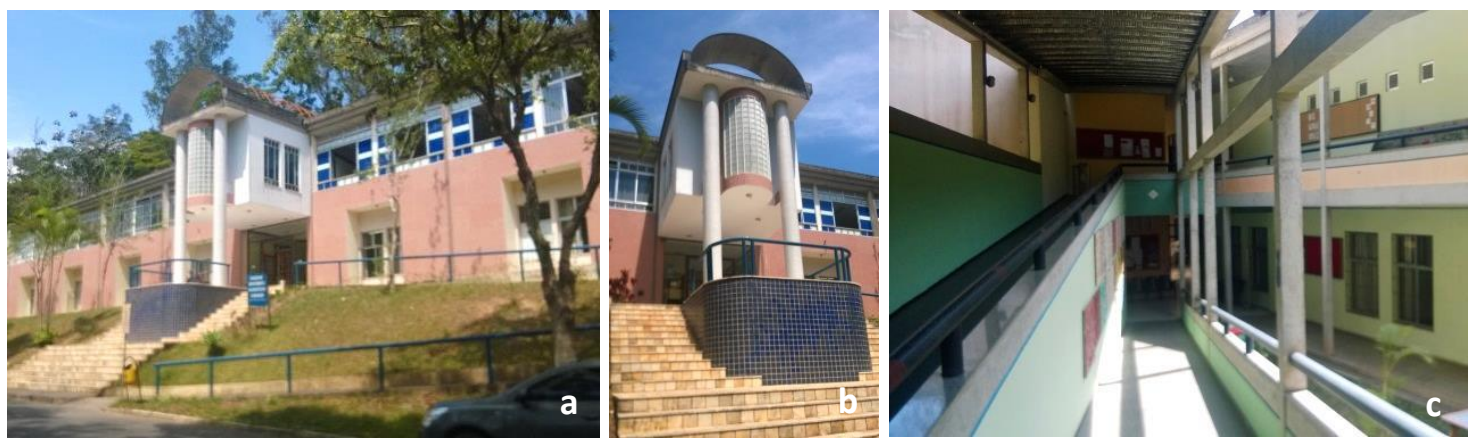

Figura 99 - Imagens do edifício pertencente ao Departamento de Arquitetura e Urbanismo. a) e b) Entrada principal. c) Circulação interna

Fonte: fotos da autora

\section{b) Considerações sobre a Estruturação da área de Tecnologia da Construção}

De acordo com o Projeto Político Pedagógico, o curso de arquitetura ministrado na UFV prevê três áreas de enfoques: arquitetura agroindustrial, planejamento da paisagem e planejamento urbano e rural, cuja proposta visa oferecer uma formação para atuação não apenas em grandes centros urbanos, mas também nas cidades de pequeno e médio porte.

O DAU oferece 40 vagas anuais, sendo o curso desenvolvido em período integral. Além do Departamento de Arquitetura e Urbanismo, o curso conta com a colaboração de professores pertencentes a outros departamentos como os Departamentos de Engenharia Civil (que oferece o maior número de disciplinas ao curso), Engenharia Florestal, Matemática, Economia, entre outros.

As disciplinas da área da Tecnologia da Construção são ministradas por professores engenheiros pertencentes ao Departamento de Engenharia Civil e estão alocadas entre 0 50 e o 70 períodos. 0 Quadro 28 apresenta as disciplinas e seus respectivos créditos, sendo observado que a área da Tecnologia da Arquitetura ocupa $30 \%$ dos créditos totais. Sobre este valor, $5,5 \%$ dos créditos são destinados à área da Tecnologia da Construção, 8\% Sistemas Estruturais, $4 \%$ Conforto Ambiental, 4,5\% Instalações, 4\% Fundamentação e 4\% Outras (Topografia e Compatibilização de Projetos).

Quadro 28 - Distribuição da Grade Curricular com a carga horária semestral - DAU UFV:

\begin{tabular}{|c|c|c|c|c|c|c|c|c|c|}
\hline 10 sem & 20 sem & 3o sem & 40 sem & 5o sem & 60 sem & 70 sem & 80 sem & 9o sem & $10 \%$ sem \\
\hline $\begin{array}{l}\text { Introdução ao } \\
\text { Projeto (4C) }\end{array}$ & Projeto I (8C) & Projeto II (8C) & Projeto III (8C) & $\begin{array}{c}\text { Projeto IV } \\
(8 C)\end{array}$ & Projeto V (8C) & $\begin{array}{l}\text { Projeto VI } \\
\text { (8C) }\end{array}$ & $\begin{array}{l}\text { Projeto VII } \\
(8 \mathrm{C})\end{array}$ & $\begin{array}{c}\text { TFG- } \\
\text { fundament. }\end{array}$ & $\begin{array}{c}\text { TFG- } \\
\text { proposiç. }\end{array}$ \\
\hline $\begin{array}{c}\text { Desenho } \\
\text { Artistico (6C) }\end{array}$ & $\begin{array}{l}\text { Hist. e Teoria } \\
\text { Arq. I (4C) }\end{array}$ & $\begin{array}{l}\text { Hist. e Teoria } \\
\text { Arq. II (4C) }\end{array}$ & $\begin{array}{l}\text { Teoria da } \\
\text { Preserv. (3C) }\end{array}$ & $\begin{array}{l}\text { Teo. Planej. } \\
\text { Urbano (4C) }\end{array}$ & \begin{tabular}{|c} 
Planej. Urb. \\
municipal (4C)
\end{tabular} & $\begin{array}{l}\text { Planej. Urb. } \\
\text { regional } \\
\text { (6C) }\end{array}$ & $\begin{array}{c}\text { Planej. } \\
\text { Paisag. (4C) }\end{array}$ & $\begin{array}{c}\text { Ética e } \\
\text { pratica } \\
\text { prof. (1C) }\end{array}$ & \\
\hline $\begin{array}{l}\text { Represent. } \\
\text { Gráfica I (4C) }\end{array}$ & $\begin{array}{c}\text { Represent. } \\
\text { Gráfica II (4C) }\end{array}$ & $\begin{array}{c}\text { Sistemas CAD } \\
\text { (4C) }\end{array}$ & \begin{tabular}{|c} 
Hist. e Teoria \\
Arq. III (4C)
\end{tabular} & $\begin{array}{l}\text { Hist. e } \\
\text { Teoria Arq. } \\
\text { IV (4C) } \\
\end{array}$ & \begin{tabular}{|c|} 
Praticas de \\
preserv. (4C)
\end{tabular} & $\begin{array}{c}\text { Arq. } \\
\text { brasileira I } \\
\text { (4C) }\end{array}$ & $\begin{array}{c}\text { Gestão } \\
\text { ambiental } \\
\text { (4C) }\end{array}$ & $\begin{array}{l}\text { Estagio. } \\
\text { superv. }\end{array}$ & \\
\hline Plástica I (4C) & Plástica II (4C) & $\begin{array}{l}\text { Comportam. } \\
\text { Ambiental I } \\
\text { (4C) }\end{array}$ & $\begin{array}{c}\text { Perspec. e } \\
\text { sombra (4C) }\end{array}$ & \begin{tabular}{|c|} 
Instalações \\
Prediais (6C)
\end{tabular} & \begin{tabular}{|} 
Hist. e Teoria \\
Arq. V (4C)
\end{tabular} & $\begin{array}{l}\text { Saneamen. } \\
\text { Básico (4C) }\end{array}$ & $\begin{array}{c}\text { Arq. } \\
\text { brasileira II } \\
\text { (4C) }\end{array}$ & $\begin{array}{l}\text { Atividades } \\
\text { complem. }\end{array}$ & \\
\hline $\begin{array}{c}\text { Geometria } \\
\text { Descritiva } \\
(4 \mathrm{C})\end{array}$ & Mecânica (4C) & $\begin{array}{l}\text { Elementos de } \\
\text { Resistência } \\
\text { Materiais (4C) }\end{array}$ & $\begin{array}{l}\text { Comportam. } \\
\text { Ambiental II } \\
(4 \mathrm{C})\end{array}$ & $\begin{array}{c}\text { Materiais } \\
\text { na Arq. (4C) }\end{array}$ & $\begin{array}{l}\text { Construção } \\
\text { Civil I (4C) }\end{array}$ & $\begin{array}{l}\text { Construção } \\
\text { Civil II (4C) }\end{array}$ & $\begin{array}{c}\text { Compatibil } \\
\text { de projetos } \\
\text { (4C) }\end{array}$ & & \\
\hline $\begin{array}{l}\text { Topografia } \\
\text { Básica (4C) }\end{array}$ & $\begin{array}{c}\text { Modelos } \\
\text { Estruturais } \\
(2 \mathrm{C})\end{array}$ & & \begin{tabular}{|l} 
Fundam. das \\
estruturas (4C)
\end{tabular} & \begin{tabular}{|c} 
Sistemas \\
Estruturais I \\
(4C)
\end{tabular} & \begin{tabular}{|c} 
Sistemas \\
Estruturais II \\
$(4 \mathrm{C})$
\end{tabular} & & & & \\
\hline Cálculo I (4C) & & & & & & & & & \\
\hline
\end{tabular}

Disciplinas de Projeto

Disciplinas de Representação Gráfica e comp.
Disciplinas de Urbanismo e Meio Ambiente

Disciplinas na área da Tecnologia da Arquitetura
Disciplinas de Historia e Teoria

\section{c) Quadro docente}


O Departamento de Arquitetura e Urbanismo possui, atualmente, professores com diferentes formações: em Arquitetura e Urbanismo, Engenharia Civil e Artes Plásticas. As disciplinas da área da Tecnologia da Construção estão sob a responsabilidade de professores engenheiros pertencentes ao quadro docente do Departamento da Engenharia Civil.

\section{d) Práticas didáticas e Infraestrutura laboratorial}

O Laboratório de Materiais de Construção Civil (Figura 100) foi montado no início da década de 1980 e funciona no Departamento de Engenharia Civil (DEC) em edifício com aproximadamente $310 \mathrm{~m} 2^{184}$. Atualmente, o laboratório dá suporte aos cursos de graduação em Engenharia Civil e Arquitetura, além de contribuir com os cursos de Agronomia e Zootecnia. O laboratório atende ao ensino, às pesquisas tanto da graduação como da pós-graduação e também trabalhos extensionistas, envolvendo treinamento e ensaios de controle tecnológico de materiais. Os equipamentos vão desde mostruários de materiais a equipamentos para a realização de diferentes ensaios com concreto, argamassas e agregados, materiais metálicos, cerâmicos, rochosos e madeira. Junto ao edifício há espaço destinado às atividades de canteiro de obras e execução de protótipos. Em relação aos recursos humanos, o laboratório conta com a colaboração de 3 laboratoristas de nível médio, com experiência superior a 15 anos e de 3 auxiliares técnicos: 2 pedreiros e 1 marceneiro.

O laboratório possui como anexo algumas salas de aula, onde ocorre a disciplina de 'Materiais para a Arquitetura', cujas práticas pedagógicas tem como apoio os mostruários de materiais e a infraestrutura laboratorial. Esta disciplina sempre foi oferecida pelo curso de Engenharia Civil, e é desenvolvida especificamente para o curso de Arquitetura e Urbanismo. Nela são trabalhados assuntos relacionados às propriedades físicas dos materiais e sua aplicação, com aulas práticas laboratoriais onde os alunos fazem correlações entre os dados dos ensaios físicos e as normas técnicas, na intenção de aguçar o senso crítico dos alunos.

Em relação a estas atividades laboratoriais, os alunos não realizam os ensaios, apenas visualizam os ensaios realizados pelos técnicos e, a partir destes dados coletados, desenvolvem relatórios, cálculos e gráficos. Dentre as atividades práticas realizadas pelos próprios alunos está o assentamento de revestimentos como pastilha, materiais cerâmicos e a aplicação de massa em parede. Além disso, nas aulas sobre solocimento e argamassa, os alunos realizam a prensagem e confecção de blocos. Assuntos relativos aos novos materiais e temáticas como impacto ambiental são abordados de forma pontual e diluídos nos demais conteúdos, mas não de forma específica. A disciplina também promove algumas visitas técnicas em indústrias, onde seja possível ver a fabricação e aplicação de produtos (a região apresenta algumas indústrias fabricantes dos produtos estudados). Estas atividades não são obrigatórias, diferentemente das aulas práticas em laboratório.

- Em relação às disciplinas 'Construção Civil I e II', são tanto oferecidas para o curso da Engenharia Civil como também para a Arquitetura, sendo o mesmo conteúdo abordado para os dois cursos, a partir do pressuposto que ambos profissionais possuem a mesma habilitação para determinadas atividades. As disciplinas abordam a aplicabilidade em obra do repertório adquirido na disciplina anterior, 'Materiais para a Arquitetura'. Em Construção Civil I, são estudadas as etapas de um edifício, desde a implantação, até a cobertura, sem entrar no tema acabamentos. Em Construção Civil II, são trabalhados os tipos de acabamentos e outros assuntos como: custos de construção, segurança no trabalho, orçamento e cronograma de obra. As disciplinas são conduzidas pelo mesmo professor que conta com o apoio didático de vídeos ilustrativos de processos construtivos ao longo das aulas teóricas. Foi relatado que, atualmente, não está sendo possível realizar visitas em obra devido à pouca disponibilidade de obras locais e por questões de segurança, pelo elevado número de alunos. Diante deste cenário, é feita a recomendação aos alunos para que os mesmos realizem estágio em obra, não sendo esta atividade obrigatória.

\footnotetext{
${ }^{184}$ O laboratório tem aproximadamente 30 anos, permanecendo no mesmo local desde que foi criado o curso de Engenharia Civil. De acordo com os relatos, trata-se de um local adaptado, não tendo sido concebido como um laboratório, cuja função inicial era uma garagem, a qual foi fechada e transformada em sala de aula e laboratório.
} 

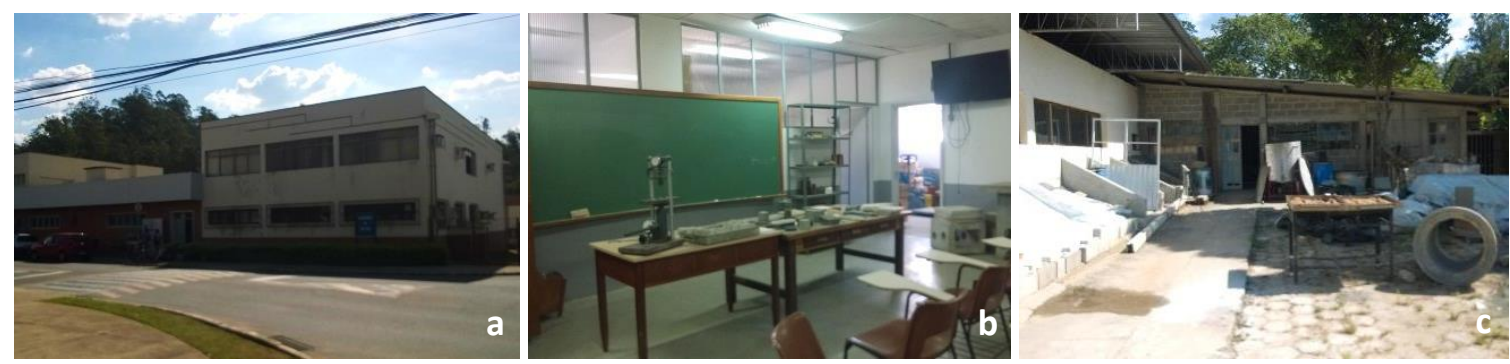

Figura 100 - Laboratório de Materiais de Materiais de Construção Civil: a) Vista da Entrada. b) Sala de aula anexada ao laboratório. c) Área externa junto ao laboratório, voltada para experimentos em escala real.

Fonte: fotos da autora.

\section{e) Pós graduação: ${ }^{185}$}

A Pós-Graduação passou a ser oferecida pelo Departamento de Arquitetura e Urbanismo em 2009, e oferece o nível de Mestrado. Tem como Área de Concentração o tema 'Planejamento e avaliação do espaço construído', que procura abranger o planejamento, o uso e a apropriação do espaço urbano e das edificações, objetos de estudo da Arquitetura e Urbanismo, cujo objetivo é a investigação das relações entre o homem e o ambiente, nas várias escalas territoriais e de poder, tomando-se como referencial empírico as pequenas e médias cidades.

As Linhas de Pesquisa são:

1- Planejamento do Espaço Urbano e Regional

2- Comportamento Ambiental do Espaço Construído - Tecnologia e Conforto

A Linha de Pesquisa 2, oferece a possibilidade na realização de trabalhos voltados à área estudada da Tecnologia da Construção.

\section{f) Comentários:}

- De acordo com os relatos, o Laboratório de Materiais de Construção Civil sempre foi de natureza autossustentável, a partir da prestação de serviços junto a empresas locais via Fundação. Estes recursos são destinados à compra de materiais, equipamentos e manutenção do próprio laboratório, contribuindo significativamente para sua sustentação, chegando a um percentual próximo a $90 \%$ em relação à verba institucional. Desta forma, estes recursos são voltados ao atendimento de demandas mais imediatas, como manutenção e aquisição de materiais utilizados em atividades de ensino;

- Atualmente, o laboratório também está expandindo as atividades para a pesquisa da pós-graduação, sendo ainda recente, de 2007, o oferecimento da área de concentração em Engenharia de Materiais pelo curso de Engenharia Civil, diferentemente de outras áreas de concentração, iniciaram suas atividades a partir de 1991. Trata-se de uma área de concentração ainda em fase de consolidação junto ao curso da Engenharia Civil, cujo laboratório ainda possui caráter extensionista voltado, principalmente, à prestação de serviços e aulas práticas no ensino;

- Segundo o Projeto Político Pedagógico de curso, a cidade de Viçosa - considerada de pequeno porte não oferece muitas oportunidades de estágio em escritórios de profissionais liberais, sendo esta lacuna suprida com estágios em outras áreas diferentes do projeto arquitetônico, como planejamento urbano municipal, design e patrimônio histórico. Esta característica também influencia na oferta de obras para a realização de visitas técnicas e estágio, sendo considerada como um dos gargalos vivenciados por alunos e professores;

- Na intenção de aproximar as disciplinas de projeto e tecnologia, está em discussão a presença de professores da área técnica nos ateliês de projeto, cuja proposta precisa ainda ser compatibilizada com o reduzido número de professores disponíveis na área da Tecnologia da Construção;

- Pode ser considerado como diferencial o oferecimento à graduação da disciplina 'Compatibilização de Projetos', que tem como aporte todas as disciplinas relacionadas à materialidade. Nesta oportunidade,

\footnotetext{
${ }^{185}$ Dados disponíveis em: www.dau.ufv.br/mestrado.au. Com acesso em: 17/10/2016.
} 
os alunos são instigados a vivenciarem um ambiente real de trabalho a partir do trabalho em equipe e pela análise de projetos executivos, procurando identificar não conformidades e inconsistências nos mesmos ao longo do processo de compatibilização;

- Foi relatada a necessidade de serem oferecidos, institucionalmente, cursos de capacitação gerencial e de gestão para diversos servidores que lidam em algum nível com atividades desta natureza, devido a diferentes profissionais ocuparem em algum momento de sua carreira, cargos administrativos e de coordenação, como os laboratórios;

- Em diversos momentos foi sinalizado um grande nível de desmotivação pelas disciplinas técnicas por parte dos alunos, associada em maior ou menor grau às características de cada turma. Diante deste fato, há constantes indagações por parte dos professores da engenharia sobre o conteúdo ideal a ser ministrado aos alunos da arquitetura, de maneira que sejam contempladas as atuais competências técnicas da profissão e que haja o reconhecimento e maior dedicação por parte dos alunos. Por um lado, acreditam que o fato dos cursos não estarem espacialmente próximos e não serem realizadas pesquisas laboratoriais comuns, faz com que haja o isolamento e a pouca interatividade entre os Departamentos, contribuindo para a falta de compreensão sobre as necessidades e dificuldades na proposição de estratégias;

- Foram observadas visões diferenciadas entre professores sobre a utilização do laboratório em apoio às disciplinas da área da Tecnologia da Construção;

- Quando o curso foi criado, a proposta curricular foi realizada em função das possibilidades de oferta de disciplinas e da formação das pessoas que estavam à frente desta questão. Não se trata, portanto, de uma estratégia pedagógica, e sim, de uma matriz construída com determinadas limitações do passado relacionadas à quantidade de pessoas e à disponibilidade destas em ofertar as disciplinas. Embora ainda não esteja em vigor, diversos ajustes estão sendo realizados atualmente, sobre a composição da matriz curricular e seu diálogo com as demais disciplinas, na intenção de promover melhor conexão a partir de um novo reposicionamento entre as mesmas.

\title{
19- FAUeD - UFU - Faculdade de Arquitetura e Urbanismo e Design da Universidade Federal de Uberlândia ${ }^{186}$
}

\begin{abstract}
a) Breve Histórico ${ }^{187}$
O Curso de Arquitetura e Urbanismo da Universidade Federal de Uberlândia, diferentemente da maioria das escolas até então estudadas, foi criado no seio do curso de Decoração desta mesma Universidade, que data de 1972 (com reconhecido em 1977) ${ }^{188}$.

Em 1995, o curso de Arquitetura e Urbanismo foi aprovado pelo antigo Conselho Superior de Ensino e Pesquisa (CONSEP), com implantação realizada em 1996, sendo reconhecido pela Portaria MEC no 1.780/01, após ter passado pelo processo de Avaliação para Reconhecimento de Cursos, que atendeu à Portaria MEC № 1770/94 - Diretrizes Curriculares e Conteúdos Mínimos para Cursos de
\end{abstract}

\footnotetext{
${ }^{186}$ Dados obtidos a partir da visita técnica realizada no dia 29/11/2016, com visita à infraestrutura laboratorial pertencente ao curso da Engenharia Civil, e realização de entrevista ao professor Dr. Antonio Peruzzi (pertencente ao curso da Engenharia civil e principal docente ministrante das disciplinas de Tecnologia da Construção nos últimos anos. Outras informações foram analisadas a partir dos registros realizados pela própria pesquisadora (pertencente ao quadro docente do curso da FAUeD), nos anos em que atuou junto à disciplina de Introdução à Tecnologia da Construção e em pesquisas na área da Tecnologia da Construção no curso de Arquitetura e Urbanismo.

${ }^{187}$ Informações obtidas a partir da consulta dos projetos pedagógicos dos cursos de Arquitetura e Urbanismo e também de Design, disponíveis respectivamente nos seguintes endereços: http://www.faued.ufu.br/node/55 e http://www.faued.ufu.br/node/229. Acesso realizado em: 28/11/2016.

188 O curso de Decoração, criado em 1972, passa pela primeira mudança de nome e currículo em 1984, passando a chamar-se Curso de Decoração - Composição de Interiores. Nessa época, havia uma grande ênfase em disciplinas ligadas tanto à expressão como à criação artística, sendo poucas disciplinas dedicadas ao projeto de interiores. A mudança do nome do Curso de Decoração para Curso de Design de Interiores foi aprovada pelo Conselho Universitário CONSUN em 2006. Atualmente, o curso é chamado de Design, de acordo com as novas resoluções do MEC para a área.
} 
Arquitetura e Urbanismo, bem como à legislação vigente, a Portaria MEC № 640/97 e 641/97, o Decreto 2.026/96.

Dentro da estrutura da Universidade Federal de Uberlândia, o curso de Arquitetura e Urbanismo faz parte da Faculdade de Arquitetura e Urbanismo e Design, sendo o único curso inserido em instituição pública do Triângulo Mineiro e Vale do Paranaíba. No ano de 2000, com a ampla mudança da estrutura da Universidade Federal de Uberlândia, foi criada a Faculdade de Arquitetura e Urbanismo - FAURB, que passou a abrigar os cursos de Decoração e de Arquitetura e Urbanismo, passando a se chamar Faculdade de Arquitetura e Urbanismo e Design - FAUeD, a partir de 2010.

A última reformulação do Projeto Pedagógico de curso e vigente até o momento data de 2010, apresentando-se como resultado de um processo de auto avaliação, considerando também os pressupostos que orientaram o Curso de Arquitetura e Urbanismo no processo de sua implantação em 1996, seu reconhecimento em 2001, até o advento do programa de Reestruturação e Expansão das Universidades Federais (REUNI), implantado a partir de 2009, o qual gerou uma ampliação no número de alunos ingressantes de 25 para 35 vagas, e um aumento significativo do quadro de docentes da Faculdade de Arquitetura, Urbanismo e Design com dedicação exclusiva, que passou de 15 para 26 professores da Unidade. Esse ingresso de docentes com dedicação exclusiva a partir de 2009 e a capacitação de professores em programas de doutorado, consolidou o papel dos Núcleos de Pesquisa e Extensão na orientação, supervisão e coordenação das atividades de ensino, pesquisa e extensão nas suas diversas áreas de atuação.

\section{b) Considerações sobre a Estruturação da área de Tecnologia da Construção}

O curso compartilha do mesmo espaço físico com os cursos de Design e de Artes Plásticas, cujo edifício Bloco I, abriga toda a área administrativa do curso de graduação e pós-graduação em Arquitetura, sala de professores e alguns laboratórios. As salas de aula utilizadas nas disciplinas são, em sua maioria, de uso comum com outros cursos da Instituição, cujas aulas são ministradas fora da sede do curso, em edifícios compostos exclusivamente por salas de aula e auditórios, sendo desprovidos de laboratórios específicos.

O curso oferece 35 vagas anuais e as disciplinas da área da Tecnologia da Arquitetura são ministradas por docentes pertencentes tanto ao quadro docente da FAUeD, como também da Faculdade de Engenharia Civil (FECIV) e a Faculdade de Matemática.

As disciplinas da área da Tecnologia da Arquitetura estão distribuídas entre o 2ํ e o 7ํ períodos, de acordo com o Quadro 29, e as disciplinas da Tecnologia das Construções são oferecidas em todos os semestres entre o 20 e 60 períodos. A área da Tecnologia da Arquitetura apresenta $28 \%$ dos créditos totais destinados às disciplinas obrigatórias (não sendo considerado neste cômputo o Trabalho Final de Graduação - fase Introdutória e Final, Conteúdos Complementares, Optativas e o Estágio Supervisionado), sendo $7 \%$ dos créditos destinados à área da Tecnologia da Construção, 7,5\% a Sistemas Estruturais, 4\% Conforto Ambiental, 3\% Instalações Prediais, 2\% Fundamentação e 4,5\% em Outras disciplinas da área (Topografia e Infraestrutura Urbana).

Quadro 29 - Distribuição da Grade Curricular com a carga horária semestral - FAUeD - UFU:

\begin{tabular}{|c|c|c|c|c|c|c|c|c|c|}
\hline 10 sem & 20 sem & 3ㅇ sem & 40 sem & 5o sem & 60 sem & 70 sem & 8ㅇ sem & 90 sem & 100 sem \\
\hline APII (6C) & API II (6C) & API III (6C) & API IV (6C) & API V (6C) & API VI (6C) & API VII (7C) & API VIII (7C) & ITFG & TFG \\
\hline $\begin{array}{l}\text { Introdução a } \\
\text { estét. proj. } \\
\text { (2C) }\end{array}$ & $\begin{array}{l}\text { Arquit. Urb. e } \\
\text { meio amb. II } \\
\text { (2C) }\end{array}$ & $\begin{array}{l}\text { T. Hist. da arq. } \\
\text { e cidade II ( }(3 C)\end{array}$ & $\begin{array}{l}\text { T. Hist. da arq. } \\
\text { e cidade III } \\
\text { (3C) }\end{array}$ & $\begin{array}{c}\text { Paisagismo I } \\
\text { (3C) }\end{array}$ & $\begin{array}{c}\text { Paisagismo II } \\
\text { (3C) }\end{array}$ & $\begin{array}{l}\text { Planej. Urb. } \\
\text { e regional I } \\
\text { (4C) }\end{array}$ & $\begin{array}{l}\text { Planej. Urb. } \\
\text { e regional II } \\
\text { (4C) }\end{array}$ & Estagio & \\
\hline $\begin{array}{l}\text { Arquit. Urb. e } \\
\text { meio amb. I } \\
\text { (2C) }\end{array}$ & $\begin{array}{l}\text { T. Hist. da arq. } \\
\text { e cidade I ( } 2 C \text { ) }\end{array}$ & \begin{tabular}{|c|} 
Hist. da arq. e \\
cidade no \\
Brasil I (3C) \\
\end{tabular} & \begin{tabular}{|c|} 
Hist. da arq. e \\
cidade no \\
Brasil II (3C) \\
\end{tabular} & \begin{tabular}{|c|} 
T. Critica \\
arq. contem \\
(3C)
\end{tabular} & $\begin{array}{l}\text { T. Critica arq. } \\
\text { contemp. A. } \\
\text { Latina (3C) }\end{array}$ & \begin{tabular}{|c|} 
Tecnicas \\
retrospec. I \\
(3C)
\end{tabular} & $\begin{array}{l}\text { Tecnicas } \\
\text { retrospec. } \\
\text { II (3C) }\end{array}$ & & \\
\hline $\begin{array}{l}\text { Sociologia } \\
\text { urbana }(4 C)\end{array}$ & $\begin{array}{l}\text { Teoria do urb. } \\
\text { I (2C) }\end{array}$ & \begin{tabular}{|l|} 
Urbanização \\
Brasilei. I (2C)
\end{tabular} & \begin{tabular}{|c|} 
Urbanização \\
Brasilei. II (2C)
\end{tabular} & $\begin{array}{l}\text { Analise da } \\
\text { forma (3C) }\end{array}$ & \begin{tabular}{|c|} 
Instalações \\
prediais I (2C)
\end{tabular} & $\begin{array}{l}\text { Infraestrut. } \\
\text { urbana }(2 C)\end{array}$ & $\begin{array}{l}\text { Estagio } \\
\text { supervis. }\end{array}$ & & \\
\hline $\begin{array}{l}\text { História das } \\
\text { cidad. I (2C) }\end{array}$ & $\begin{array}{l}\text { Simulação } \\
\text { Digital (2C) }\end{array}$ & $\begin{array}{c}\text { Teoria do urb. } \\
\text { II (2C) }\end{array}$ & $\begin{array}{c}\text { Teoria do urb. } \\
\text { III (2C) }\end{array}$ & $\begin{array}{l}\text { Instalações } \\
\text { pred. I (4C) }\end{array}$ & $\begin{array}{l}\text { Materiais e } \\
\text { tecn. IV (3C) }\end{array}$ & \begin{tabular}{|c|} 
Eficiência \\
energé. $(2 \mathrm{C})$
\end{tabular} & Optativas & & \\
\hline $\begin{array}{l}\text { Interface } \\
\text { Digital (3C) }\end{array}$ & $\begin{array}{c}\text { Desenho } \\
\text { Arquit. II (4C) }\end{array}$ & $\begin{array}{l}\text { Modelagem } \\
\text { paramétrica } \\
(2 \mathrm{C})\end{array}$ & $\begin{array}{l}\text { Arquitetura e } \\
\text { interativ. (3C) }\end{array}$ & $\begin{array}{l}\text { Materiais e } \\
\text { tecn. III (3C) }\end{array}$ & \begin{tabular}{|c|} 
Estruturas de \\
aço e madeira \\
$(4 \mathrm{C})$
\end{tabular} & & Complem. & & \\
\hline Geometria & Plástica II (3C) & Construções & Construções & Estruturas & & & & & \\
\hline
\end{tabular}




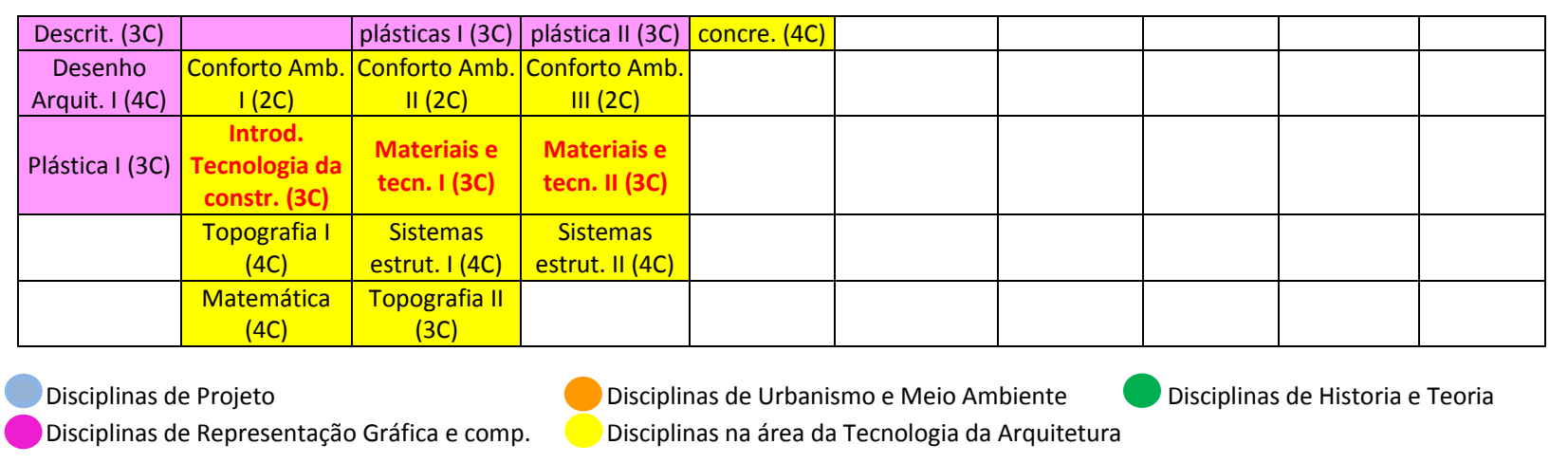

\section{c) Quadro docente}

O quadro docente da Faculdade atende ambos os cursos: Arquitetura e Urbanismo e Design sendo, portanto, composto por professores com formação em arquitetura (19 professores) e design (06 professores). Das 05 disciplinas da área da Tecnologia da Construção 04 delas são delegadas ao curso da Engenharia Civil e ministradas integralmente por engenheiros, enquanto que a disciplina 'Introdução à Tecnologia da Construção' está sob a responsabilidade de professor pertencente ao quadro docente do próprio curso, com formação em Arquitetura e Urbanismo.

\section{d) Práticas didáticas e Infraestrutura laboratorial}

De acordo com Laverde (2012), entre os anos de 2009 e 2010 o curso de Arquitetura e Urbanismo da FAUeD passou por uma reformulação em seu Projeto Político Pedagógico, com a reavaliação das disciplinas de cunho tecnológico, a fim de melhor distribuí-las ao longo do curso e promover a atualização dos conteúdos ministrados. Nesta reavaliação uma das problemáticas levantadas foi a dificuldade de transferência dos conhecimentos adquiridos na área tecnológica para os Ateliers de Projeto, sendo observado o distanciamento entre a atividade projetual e construtiva. Outro ponto observado foi a não valorização, por parte dos alunos, das disciplinas de cunho tecnológico ministradas pelo curso da Engenharia Civil.

$\mathrm{Na}$ intenção de resolver este problema foi proposta a inserção de uma nova disciplina com caráter introdutório, chamada 'Introdução à Tecnologia da Construção', oferecida no 2o período do curso com atividades práticas de canteiro e a realização de oficinas, sendo ministrada por docente pertencente do próprio curso da arquitetura. Esta estratégia foi sugerida para que o aluno tivesse consciência desde o início do curso sobre a importância do conteúdo técnico na profissão e, a partir desta percepção, passasse a cursar as disciplinas da engenharia de forma mais responsável. De acordo com os relatos, este objetivo foi atingido e o desempenho dos alunos melhorou tanto nas disciplinas de tecnologia da construção, como também nas de sistemas estruturais.

Trata-se da primeira disciplina do grupo da Construção e abrange conteúdos básicos sobre sistemas estruturais, materiais e técnicas construtivas. Em relação aos materiais, são abordados tanto os de caráter convencional (sem entrar no conteúdo sobre acabamento e revestimento) como também, alguns não convencionais e/ou reciclados, como a terra crua, o bambu e os tubos de papelão, entre outros, juntamente com suas técnicas de processamento e manipulação.

Ainda segundo Laverde (2012), a escolha destes assuntos ocorreu devido ao fato dos materiais convencionais, como o aço e o concreto serem abordados com maior propriedade nos períodos subsequentes, quando os alunos têm contato com determinados conteúdos com maior profundidade. Além disso, a abordagem dos materiais não convencionais desde o inicio do curso possibilitaria que os alunos não criassem determinados (pré-) conceitos sobre os materiais reciclados e alternativos mas, também, atentassem para a complexidade de sua adoção, algo necessário nos dias atuais devido à preocupação com assuntos relativos ao impacto ambiental da cadeia produtiva de materiais e processos dentro da construção civil e a necessidade de uma postura mais flexível e repertório mais amplo. 
Sobre as estratégias pedagógicas aplicadas nesta disciplina, além das aulas teóricas - que tem como apoio tanto mostruários de materiais como a adoção de modelos reduzidos - são realizados seminários sobre assuntos relativos à interface entre princípios da natureza e engenharia, visitas em obra, palestras e oferecidas em torno de 2 a 3 oficinas, com a construção de protótipos em escala real, envolvendo assuntos sobre tipologias estruturais, materiais e técnicas construtivas (Figura 101).

As demais disciplinas como Materiais e Técnicas Construtivas (MTC) I, II, III e IV, são ministradas entre o 3ㅇ e o 60 semestres por docentes pertencentes ao curso da Engenharia Civil.

As disciplinas de MTC I e MTC II são complementares uma da outra e abordam, sequencialmente, assuntos relacionados tanto a materiais como também técnicas construtivas: materiais cerâmicos, metálicos, pedras, concreto, argamassa, etc. Em MTC I são ministrados assuntos relativos a fundações e, em TCII, estruturas e vedações, sendo os materiais geralmente distribuídos de acordo com os sistemas construtivos.

As estratégias pedagógicas adotadas nestas duas disciplinas são semelhantes e contemplam - além das aulas teóricas - seminários e visitas em obra, geralmente realizadas em grupo e sem o acompanhamento do professor, tratando-se de uma demanda colocada por um dos trabalhos desenvolvidos na disciplina, nestes casos, cada aluno possui seu kit de EPIs (equipamento de proteção individual) adquirido no 1 o ano. A apresentação dos trabalhos relativos às visitas em obra são consideradas oportunidades para complementar e exemplificar os conteúdos teóricos, tratando-se de um espaço onde são retomados e inseridos outros assuntos.

Em relação à inserção de práticas laboratoriais, em MTC I e II são realizadas aulas demonstrativas em laboratório, pertencente ao curso da Engenharia Civil, sendo ao longo deste processo visualizadas a fabricação de concretos e ensaios de rompimento de corpos de prova (geralmente concreto e aço). Nestas atividades os alunos não executam nenhum tipo de objeto ou elemento, como corpos de prova ou placas, apenas visualizam o processo de execução e ensaios, estes são realizados pelos técnicos, de acordo com os relatos, estas disciplinas são predominantemente teóricas.

Em MTC III, os assuntos não estão conectados entre si, cuja ementa traz indicação de abordagem sobre instalações hidrossanitárias, construção seca, vãos, esquadrias e revestimentos. Nesta disciplina não são adotadas atividades laboratoriais e visitas em obra, sendo predominantemente teórica. No caso de MTC IV o conteúdo refere-se à compatibilidade de projetos, orçamento, gerenciamento de obras e aspectos legais. Como estratégia pedagógica é adotada a inserção do projeto com exercícios práticos ao longo de sua análise, quando são realizados exercícios sobre orçamento, análise de viabilidade e compatibilidade de projetos. Nesta disciplina não são adotadas atividades laboratoriais e não são realizadas visitas em obra, sendo estas práticas restritas a MTC I e II.

Em relação à inserção de assuntos relativos aos novos materiais não há uma aula específica sobre isso, mas são realizadas abordagens pontuais, sendo os assuntos diluídos em algumas aulas, de acordo com a temática, principalmente ao longo dos seminários, sendo geralmente estas questões trazidas pelos próprios alunos.

Sobre os espaços experimentais, atualmente a FAUeD possui alguns espaços destinados à função de laboratórios, como o Laboratório de Conforto Ambiental, Laboratório de Tecnologia do Ambiente Construído, Laboratório de Projeto e Laboratório de Computação Gráfica.

O Laboratório de Tecnologia do Ambiente Construído foi implantado em 2009 - com a entrada do primeiro docente na área da Tecnologia da Construção - compartilhando o mesmo espaço físico utilizado pelo Laboratório de Conforto Ambiental, um dos primeiros implantados no curso. Este espaço está caracterizado, principalmente, por abrigar modelos físicos construídos pelos alunos ao longo de disciplinas e também, possui equipamentos utilizados ao longo das atividades práticas - as de pequeno porte e com o envolvimento de poucos alunos são executadas no próprio laboratório.

A partir de 2011, foi realizada uma tentativa voltada à inserção de atividades práticas em escala real construção de protótipos - a partir do início da disciplina 'Introdução à Tecnologia da Construção'. Para que isso fosse possível, foi utilizado um espaço externo junto ao laboratório de Tecnologia do Ambiente Construído, com a função de Canteiro Experimental, mas devido ao fato de não estar formalizado junto à Universidade, a cada atividade prática realizada o docente responsável tem que pedir permissão à Prefeitura do campus para a utilização desta área. O Laboratório do Ambiente Construído, além de dar suporte às atividades de ensino, também apoia atividades de pesquisa e extensão. 

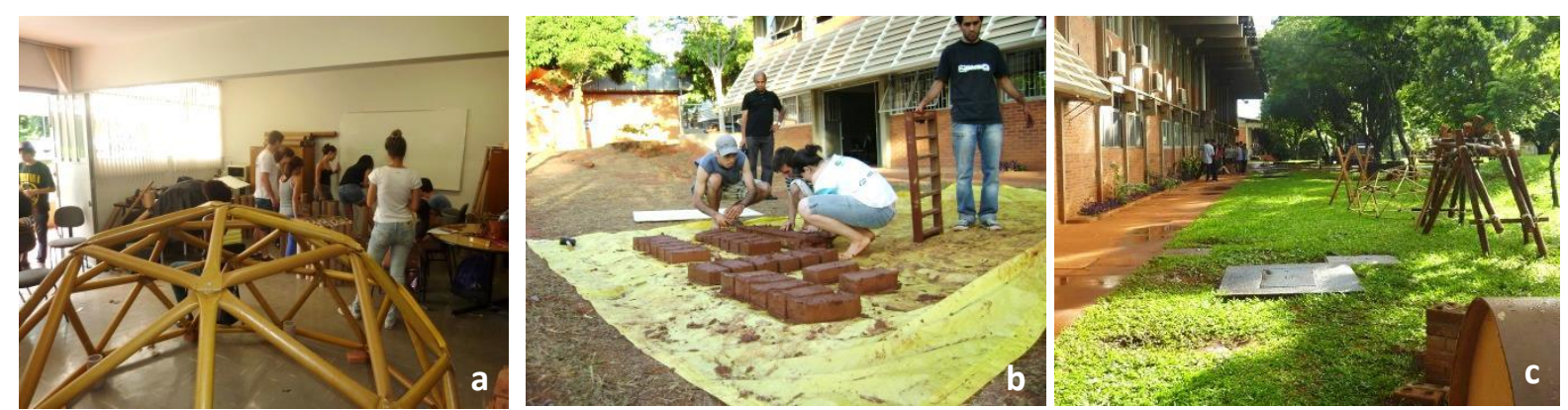

Figura 101 - Laboratório do Ambiente Construído (FAUeD) e área externa. a) Vista interna do Laboratório e de alguns protótipos construídos pelos alunos. b) e c) Área externa utilizada em algumas oficinas realizadas na disciplina 'Introdução à Tecnologia da Construção', trata-se de uma área considerada pelos alunos como canteiro experimental, mas o espaço não possui esta função formalizada.

Fonte: acervo pessoal da autora.

No caso das disciplinas de MTC I e MTCII, a infraestrutura laboratorial pertence ao curso da Engenharia Civil - o Laboratório de Materiais e Técnicas de Construção Civil (Figura 102) - é considerada de uso compartilhado com o curso da Arquitetura. Este espaço está estruturado com maquinários para realização de ensaios e pesquisas com materiais construtivos e é sustentado por meio de verba institucional, complementada com prestação de serviços e projetos de extensão, via Fundação.

Ao longo das atividades laboratoriais as turmas são divididas em torno de 14 alunos, com 2 aulas teóricas e 2 práticas. $\mathrm{O}$ curso da Engenharia Civil possui 2 técnicos, um atuante no Laboratório da Construção Civil e outro no Laboratório de Estruturas, sendo considerado um número suficiente para a demanda atual e o laboratório considerado muito bem equipado em relação a maquinário.

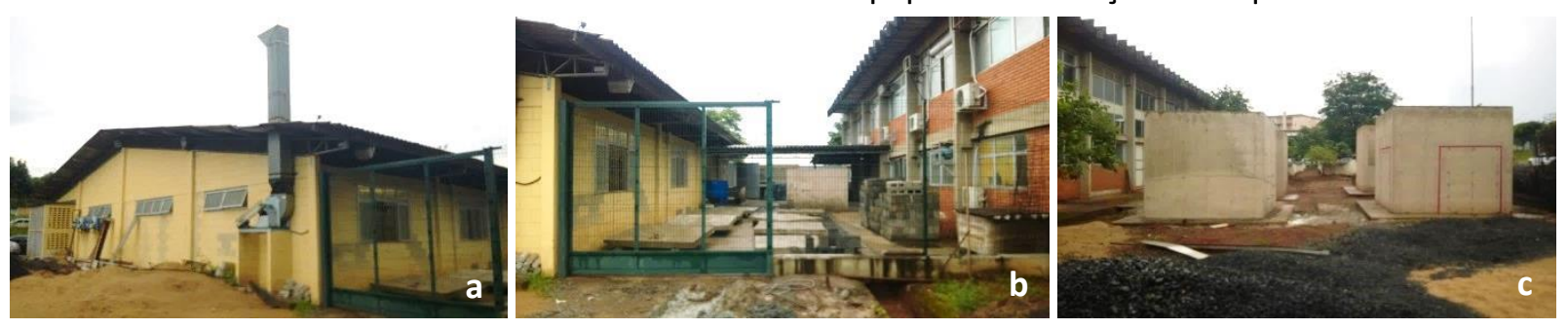

Figura 102 - Laboratório de Materiais e Técnicas de Construção Civil, pertencente à FECIV (Faculdade de Engenharia Civil). a) e b) Vista externa do Laboratório. c) Área externa anexada ao laboratório e destinada para experimentos em escala real pelo curso da Engenharia Civil.

Fonte: acervo pessoal da autora.

\section{e) Pós graduação: ${ }^{18}$}

O Programa de Pós-graduação em Arquitetura e Urbanismo em nível de Mestrado Acadêmico está vinculado à Faculdade de Arquitetura e Urbanismo e Design (FAUeD). Foi aprovado pelo Conselho Superior da UFU em 2011 (Resolução n 05/20011 do CONSUN) e, em 2012, recebeu parecer favorável do Conselho Técnico Consultivo (CTC) da Coordenação de Aperfeiçoamento de Pessoal de Nível Superior (CAPES).

Tem como Área de Concentração 'Projeto, Espaço e Cultura' e como Linhas de Pesquisa:

1- Arquitetura e Cidade

2- Produção do espaço

O Programa não oferece linhas de pesquisa em Tecnologia da Construção, sendo os alunos interessados nesta área absorvidos pelo Programa de Pós-Graduação da Faculdade da Engenharia Civil (FECIV).

\section{f) Comentários:}

\footnotetext{
${ }^{189}$ Informações obtidas em: http://www.ppgau.faued.ufu.br. Acesso em: 28/11/2016.
} 
- Foi relatado ser desafiador para o professor ministrar de forma simultânea conteúdos relativos a materiais e técnicas construtivas, pela dificuldade de se encontrar docentes com este perfil, pois cada profissional se especializa em um destes assuntos. A abordagem simultânea foi uma reinvindicação do curso da arquitetura, mas não segue o que atualmente ocorre no curso da Engenharia Civil, onde as disciplinas de materiais e técnicas construtivas são ministradas separadamente. Esta estruturação segregada foi adotada no inicio da implantação do curso de arquitetura, havendo maior proximidade entre as ementas entre os dois cursos. Esta reestruturação foi realizada a partir de 2011, embora as ementas ainda precisem ser revistas, pois não contemplam o conteúdo sugerido pelo curso da Arquitetura ao longo da reformulação do Projeto Político Pedagógico - a proposta não foi acatada por todos os professores responsáveis.

- Com exceção da disciplina Introdução à Tecnologia da Construção, não foi observada a existência de uma estratégia geral na distribuição dos conteúdos entre as demais disciplinas, havendo um descompasso entre o que está sendo adotado (as ementas antigas - sendo o Plano de Curso considerado um instrumento legal) e o reconhecimento de que a atual proposta não está funcionando bem. A falta de conexão horizontal entre as disciplinas também permanece verticalmente, pela falta de diálogo entre as disciplinas de MTC e as demais, tanto entre as de técnicas e sistemas estruturais como entre as de Ateliers e de técnicas.

- Foi observado um distanciamento entre o conteúdo do Projeto Pedagógico e a realidade enfrentada pelos docentes ministrantes, no que diz respeito à existência de canteiro experimental e recursos para esta finalidade no curso de Arquitetura e Urbanismo, sendo constatado que, as atividades práticas realizadas até então foram fruto da iniciativa docente, algo que dificulta sua sustentação e promove o desgaste dos profissionais envolvidos.

- Embora o curso de engenharia possua infraestrutura laboratorial bem equipada não são realizadas atividades práticas pelos alunos. Foi relatado que, caso a arquitetura usasse o laboratório em outra sistemática como 'mãos na massa', deveria haver mais professores e técnicos para a viabilização e, diante deste cenário o curso de arquitetura é considerado um visitante por frequentar o laboratório apenas duas a três vezes por semestre. Para viabilizar a contratação de mais recursos humanos e a estruturação da área laboratorial, dever-se-ia aumentar a demanda por estes espaços.

- Em relação às visitas em obra, foi declarado que o processo de viabilização das visitas é bastante complexo e burocrático e fica sob total responsabilidade do docente, sem apoio administrativo (tarefas como a identificação da(s) obra(s), a formalização da solicitação de acesso à(s) obra(s), viabilização do transporte, quando necessário). Estas dificuldades têm levado muitos professores a reavaliarem a adoção desta estratégia didática nas disciplinas. Outro ponto levantado, seria a questão do seguro para esta finalidade, sendo relatado que há seguro para viagens técnicas, mas restrita ao transporte; para a realização de atividades laboratoriais e visitas a obras não há seguro.

\section{0- CAU UFMS - Curso de Arquitetura e Urbanismo da Universidade Federal do Mato Grosso do Sul ${ }^{190}$}

\section{a) Breve Histórico ${ }^{191}$}

Com a implantação do Curso de Engenharia Civil pela Universidade Estadual de Mato Grosso (UEMT), na Cidade Universitária de Campo Grande em 1972, criou-se o Centro de Estudos Gerais (CEG) constituído pelos Departamentos de Engenharia, Matemática, Química, Física e Biologia. Com a divisão

\footnotetext{
${ }^{190}$ Informações obtidas a partir da visita técnica realizada entre os dias 05 e 07/11/2015, com entrevistas realizadas com os professores pertencentes ao curso de Arquitetura e Urbanismo: Dra. Andrea Naguissa Yuba e Dr. Gogliardo Maragno e também aos professores pertencentes ao quadro docente do curso de Engenharia Civil, responsáveis pela coordenação do Laboratório de Materiais e Construção Civil e docente das disciplinas de Tecnologia da Construção I e II, respectivamente: Dr. Ana Paula Milani e Me. Michele Giongo.

191 Referencias retiradas do Projeto Pedagógico do curso, disponível em: http://www.4shared.com/office/_oNIc9bhce/ Projeto_Pedagogico_CAU_2014_F.html. Acesso em: 27/02/2016.
} 
do Estado de Mato Grosso e a federalização da antiga UEMT, houve uma reestruturação administrativa da Universidade, criando-se novos centros.

Após a criação do estado de Mato Grosso do Sul em 1979, os arquitetos e urbanistas, reunidos em Assembleia no Instituto de Arquitetos do Brasil - Departamento de MS (IAB-MS), colocaram a necessidade da criação de um curso de Arquitetura e Urbanismo oferecido por instituição pública no Estado, tal anseio se concretizou em 1999, a partir da iniciativa de professores arquitetos e urbanistas e engenheiros civis do Departamento de Estruturas e Construção Civil.

A comissão que elaborou os estudos para a criação do curso era constituída por professores da UFMS e profissionais convidados atuantes na área: engenheiro civil Alcides Higa (presidente); arquiteto e urbanista Jurandir Nogueira (in memorian); arquiteto e urbanista Roberto Hodgson, bacharel em artes visuais Carla Maria de Cápua e pelo arquiteto e urbanista Sérgio Yonamine, então presidente do PLANURB - Instituto Municipal de Planejamento Urbano. Foram consultados internamente todos os chefes de departamento de disciplinas que deveriam ser oferecidas pelo curso, bem como todos os coordenadores de curso da área tecnológica e de artes, e externamente, entre outras entidades, o Sindicato de Arquitetos e Urbanistas do Mato Grosso do Sul, o Instituto de Arquitetos do Brasil, o Conselho Regional de Engenharia, Arquitetura e Agronomia e sua Câmara Especializada de Arquitetura e a ABEA - Associação Brasileira de Ensino de Arquitetura e Urbanismo que esteve sediada em Campo Grande de novembro de 1997 a novembro de 1999.

O curso funcionou, desde a sua criação, no CCET - Centro de Ciências Exatas e Tecnologia vinculado ao Departamento de Estruturas e Construção Civil (DEC), até o ano de 2013. Conforme o relatório da Comissão, o curso ao ser criado se apoiou na estrutura existente no CCET garantindo a inserção do conhecimento técnico e das ciências exatas.

As aulas foram iniciadas com professores já vinculados aos cursos da UFMS, com 40 alunos ingressantes. E, a partir da Resolução n. 21, de 17 de dezembro de 2009, que instituiu a semestralização dos cursos na UFMS, foram realizadas alterações no projeto pedagógico e o número de vagas, originalmente de 40 , com ingresso anual, foi ampliado a partir de 2010 , com o programa REUNI, para 50 vagas, mantendo-se o ingresso anual.

Em 2012, o curso foi instalado em espaço antes utilizado pelas antigas instalações da Biblioteca Central, a qual foi adaptada e reformada para receber o curso de Arquitetura e Urbanismo, funcionando juntamente com a pós-graduação.

\section{b) Considerações sobre a Estruturação da área de Tecnologia da Construção}

O CAU-UFMS oferece 50 vagas anuais e os conteúdos são estruturados em três núcleos, de acordo com as Diretrizes Curriculares Nacionais: 1) Núcleo de Conhecimentos de Fundamentação; 2) Núcleo de Conhecimentos Profissionais e 3) Trabalho de Curso.

A estratégia utilizada ao longo da reformulação do Projeto Pedagógico em 2013, em relação às disciplinas de tecnologia, foi alocá-las no início do curso, com o objetivo de instrumentalizar melhor os alunos para as disciplinas de Projeto e para que não dependessem de outras disciplinas, as instrumentais e conceituais básicas, mas de acordo com o Quadro 30, há uma exceção dentre estas considerações, como o posicionamento da disciplina de Tecnologia das Construções IV no 9o período.

Portanto, as disciplinas de caráter técnico são ministradas entre o 10 e 0 9o períodos. Ao considerar somente as disciplinas obrigatórias (não computando os créditos destinados à Fundamentação do TFG, TFG II e Ateliê Integrado), aquelas consideradas como da área técnica ocupam $23 \%$ dos créditos totais destinados às disciplinas obrigatórias, apresentando as de Estruturas 7\%, Tecnologia das Construções 7\%, Conforto Ambiental 4,5\% e outras consideradas da área (Topografia e Infraestrutura Urbana) 4,5\%.

Quadro 30 - Distribuição da Grade Curricular com a carga horária semestral - CAU - UFMS:

\begin{tabular}{|c|c|c|c|c|c|c|c|c|c|}
\hline 10 sem & 20 sem & 3o sem & 40 sem & 50 sem & 60 sem & 70 sem & 80 sem & 9o sem & 10- sem \\
\hline $\begin{array}{c}\text { Sustent. Arq. } \\
\text { e urb. (2C) }\end{array}$ & $\begin{array}{c}\text { Fundam. de } \\
\text { arquit. (4C) }\end{array}$ & Projeto I (6C) & Projeto II (6C) & $\begin{array}{c}\text { Projeto III } \\
\text { (6C) }\end{array}$ & $\begin{array}{c}\text { Projeto IV } \\
\text { (6C) }\end{array}$ & $\begin{array}{c}\text { Projeto V } \\
\text { (3C) }\end{array}$ & $\begin{array}{c}\text { Projeto VI } \\
\text { (3C) }\end{array}$ & $\begin{array}{c}\text { Projeto VII } \\
\text { (5C) }\end{array}$ & TFG \\
\hline $\begin{array}{c}\text { Est. Sociais na } \\
\text { arq. urb (3C) }\end{array}$ & $\begin{array}{c}\text { Fundam. de } \\
\text { urban. (4C) }\end{array}$ & $\begin{array}{c}\text { Paisagismo I } \\
\text { (4C) }\end{array}$ & $\begin{array}{c}\text { Paisagismo II } \\
\text { (4C) }\end{array}$ & $\begin{array}{c}\text { Paisagismo } \\
\text { III (4C) }\end{array}$ & $\begin{array}{c}\text { Planej. Urba. } \\
\text { IV (4C) }\end{array}$ & $\begin{array}{c}\text { Projeto } \\
\text { urban.I (3C) }\end{array}$ & $\begin{array}{c}\text { Projeto } \\
\text { urb.II (3C) }\end{array}$ & $\begin{array}{c}\text { Planej. Gest } \\
\text { amb. (4C) }\end{array}$ & \\
\hline
\end{tabular}


O Canteiro Experimental tem sua implantação ainda incipiente, com estruturação iniciada em 2015. Embora seja um espaço reconhecido pelo curso, a viabilização da infraestrutura foi realizada predominantemente por iniciativa docente e não como um projeto de curso. A criação do canteiro se deu a partir de um projeto de pesquisa e extensão, possibilitando a construção do edifício sede associado a um determinado material e sistema construtivo de pesquisa - a terra crua (Figura 104b, 104c). O objetivo atual deste espaço direciona-se a estender as atividades vinculadas à pesquisa também para o ensino e tornar este espaço um apoio às disciplinas da área da Tecnologia da Construção (adaptações para atender a 50 alunos), ampliando a aquisição de equipamentos e, com o tempo, possibilitar a manipulação de um maior rol de materiais. Atualmente, as atividades estão vinculadas, principalmente, aos projetos de pesquisa e extensão, mas sem caráter de laboratório. Tem como participantes alunos da graduação como também da pós-graduação em Engenharia civil (Eficiência Energética), mas ainda não possui técnicos para auxílio nas atividades, sendo esta considerada uma outra condicionante para que as atividades possam ser estendidas à graduação.

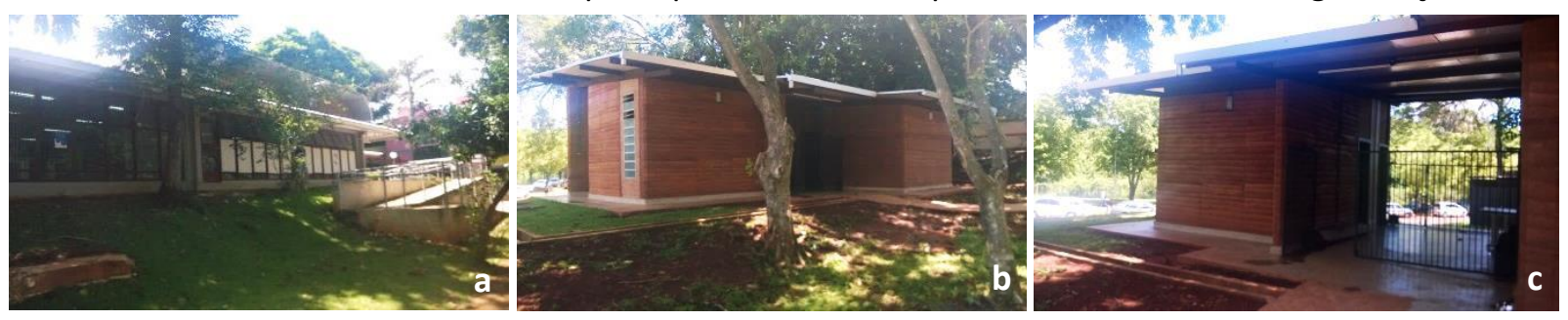

Figura 104: Edifícios pertencentes ao CAU UFMS. a) Imagem do edifício sede do curso de Arquitetura e Urbanismo. b) e c) Imagens externas do Canteiro Experimental, construído em terra crua - taipa de pilão.

Fonte: fotos da autora.

Em relação ao Laboratório de Materiais de Construção Civil (Figura 105), o mesmo pertence ao curso de Engenharia Civil, apresentando-se como de uso compartilhado com curso de Arquitetura e Urbanismo. Possui 01 técnica e 02 auxiliares, atendendo tanto o ensino da graduação como também da pós-graduação, sendo utilizado, prioritariamente, pelos alunos da Engenharia Civil. Os alunos de Iniciação Científica que geralmente frequentam o laboratório também são do curso da Engenharia Civil, em alguns casos pontuais (durante o desenvolvimento de algum projeto de extensão ou de pesquisa) há a participação de alunos do curso da Arquitetura.

Este laboratório não é voltado ao uso exclusivo do ensino, pois a sustentação das atividades não ocorre somente com verba advinda da Instituição, sendo complementada com a prestação de serviços a terceiros. O laboratório está equipado para atender basicamente atividades do curso de Engenharia Civil e, em 2012, foi possível a aquisição de uma máquina universal de ensaios (com recursos internos do CTinfra), dando maior flexibilidade aos pesquisadores para ampliar os ensaios com diferentes materiais. Segundo relato, o laboratório apresenta $50 \%$ de suas atividades ligadas ao ensino, $20 \%$ em pesquisa e $30 \%$ em serviços terceirizados. A prestação de serviços está direcionada, principalmente, a ensaios com o material concreto, sendo ainda incipiente a demanda por ensaios com outros materiais não convencionais, embora esta demanda esteja aumentando gradativamente, a partir da publicação e inicio da vigência da norma de desempenho, em 2013. Atualmente, assuntos referentes aos materiais não convencionais são abordados exclusivamente na pós-graduação, havendo planos para que futuramente seja também ampliado para a graduação.
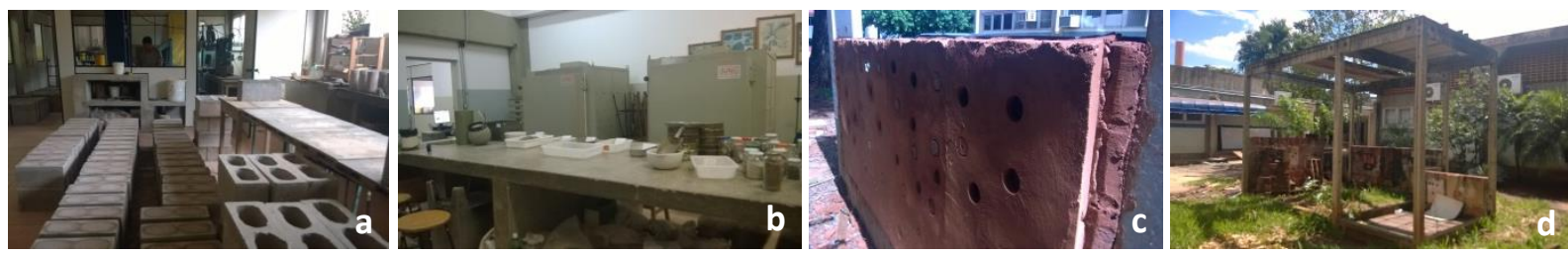

Figura 105: Laboratório de Materiais de Construção Civil. a) e b) Imagens internas. c) e d) protótipos desenvolvidos no espaço externo.

Fonte: fotos da autora 
As disciplinas de Tecnologia da Construção I e $\|^{192}$ abordam assuntos referentes aos materiais construtivos e partes da edificação, sobressaindo as aulas expositivas em relação às práticas experimentais. De acordo com os dados relatados, em algumas aulas pontuais são realizadas visitas ao Laboratório de Materiais de Construção Civil, quando os alunos visualizam a realização de alguns ensaios e o processo de execução de concreto e argamassa pelos técnicos do laboratório, mas não participam diretamente destas práticas. Outros materiais são analisados e visualizados em sala de aula com auxílio de amostras.

De acordo com o novo Projeto Pedagógico do curso, o conteúdo referente aos sistemas construtivos será abordado de forma dissociada de Tecnologia das Construções I e II, na disciplina Tecnologia da Construção IV, sendo que a mesma ainda não foi ministrada por estar alocada no 2o semestre do 4으 ano do curso e a nova grade ainda em fase de implantação. De acordo com os dados, a previsão seria que o conteúdo fosse ministrado com apoio laboratorial futuramente.

\section{e) Pós graduação:}

O curso de Arquitetura e Urbanismo da UFMS oferece um curso de Pós-Graduação Lato Sensu chamado: 'Abordagem Contemporânea na Arquitetura e na Cidade', o qual passou a vigorar em 2014. Trata-se do primeiro curso de pós-graduação gratuita em Arquitetura e Urbanismo no Estado do Mato Grosso do Sul. Em relação às temáticas com interface à área da Tecnologia da Construção, a Faculdade de Engenharias, Arquitetura e Urbanismo e Geografia oferece Mestrado em Engenharia Civil 'Eficiência Energética e Sustentabilidade' - com três áreas de concentração:

- Eficiência Energética;

-Sustentabilidade;

- Energias Renováveis.

Com início em 2012, este curso é dirigido por professores da área de Engenharia Elétrica, Engenharia Civil, Engenharia Ambiental, Arquitetura e Urbanismo e Administração, absorvendo os alunos arquitetos interessados nas áreas oferecidas.

\section{f) Comentários:}

- A prestação de serviços direcionada, principalmente, a ensaios com o material concreto e técnicas convencionais, reflete o contexto local, ainda em fase de desenvolvimento e construção, sendo que a inserção de novas técnicas e materiais tem ocorrido gradualmente;

- Embora haja a existência de alguns espaços para experimentação construtiva, de acordo com os professores entrevistados este processo ainda não está em fase de inserção no curso;

- Embora atualmente os alunos da arquitetura não frequentem regularmente o laboratório de Materiais e Construção Civil, segundo os professores, vários deles já demonstraram interesse em trabalhar no laboratório em áreas inseridas nas disciplinas de Tecnologia das Construções;

- A redução da carga horária das disciplinas da área da Tecnologia da Construção a partir do compartilhamento de espaço com outras disciplinas (fusão entre disciplinas), visto no novo Projeto Pedagógico do curso, poderá acarretar na diminuição das possibilidades de utilização de infraestrutura laboratorial durante as disciplinas. Diante do tempo reduzido para abordagem de um extenso conteúdo, a prioridade será o conteúdo teórico, tratando-se de uma consequência previamente anunciada;

- A inserção de visitas técnicas em obras nas disciplinas da Tecnologia da Construção está condicionada à disponibilidade de obras na cidade, aliada à possibilidade de deslocamento dos 50 alunos para outras cidades e regiões.

\footnotetext{
192 De acordo com o novo Projeto Pedagógico do curso que passou a vigorar em 2015, a disciplina de Tecnologia das Construções II terá seu conteúdo compactado em meio semestre, dando espaço para o compartilhamento do conteúdo de Mecânica dos solos e fundações, cujos conteúdos também serão compactados em meio semestre por terem deixado de existir como disciplinas independentes. Já o conteúdo referente à Tecnologia das Construções III, é direcionado às Instalações elétricas e hidráulicas. Sendo assim, as disciplinas realmente voltadas à Tecnologia das Construções são: TEC I, 1/2 semestre de TEC II e TEC IV.
} 

Campinas $^{193}$

a) Breve Histórico ${ }^{194}$

Vinculada à Unicamp, a Faculdade de Engenharia de Limeira (FEL) foi criada em 1969, na cidade de Limeira (a $50 \mathrm{~km}$ do campus central da UNICAMP em Campinas), oferecendo o curso de Engenharia Civil. A partir da transferência do curso para Campinas, em 1989, a denominação mudou para Faculdade de Engenharia Civil (FEC) e no campus de Limeira passou a funcionar o Centro Superior de Educação Tecnológica (Ceset) ${ }^{195}$. Esta mudança propiciou à Faculdade juntar-se às demais áreas tecnológicas da UNICAMP, sendo considerada bastante benéfica ao estimular a integração de alunos e professores com a comunidade científica e universitária e, também, propiciar a oportunidade para a implantação do curso de graduação em Arquitetura e Urbanismo, assim como os programas de pós-graduação.

O curso de Arquitetura e Urbanismo foi criado em 1999, a partir da iniciativa de professores que atuavam no curso de Engenharia Civil (com a presença de profissionais arquitetos no quadro docente do antigo Departamento de Construção Civil) e viabilizado em um momento em que a Universidade incentivava, por meio de legislação, a criação de novos cursos noturnos, atendendo a uma demanda de cunho social.

Hoje chamada de Faculdade de Engenharia Civil, Arquitetura e Urbanismo, a FEC é uma das seis unidades da área Tecnológica da Unicamp e sua estrutura administrativa é composta por cinco Departamentos:

- Departamentos de Arquitetura e Construção;

- Departamentos de Saneamento e Ambiente;

- Departamentos de Estruturas;

- Departamentos de Recursos Hídricos;

- Departamentos de Geotecnia e Transportes.
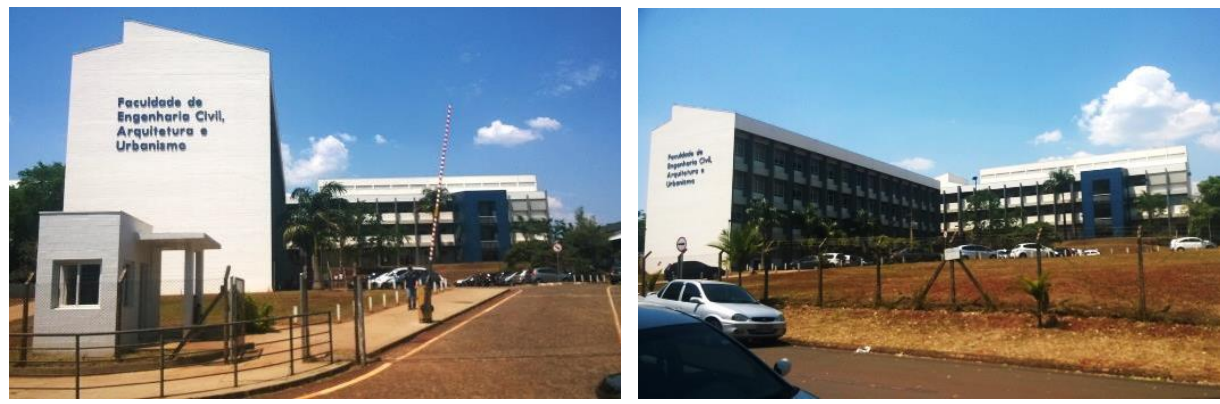

Figura 106: Edifício de uso compartilhado entre o curso de Arquitetura e Urbanismo e Engenharia Civil.

Fonte: fotos da autora.

\section{b) Considerações sobre a Estruturação da área de Tecnologia da Construção}

O curso de A\&U da UNICAMP é oferecido no período noturno, com aulas entre 19 e 23 horas, com exceções feitas a algumas disciplinas eletivas e também àquelas ministradas aos sábados no período da manhã. Há o oferecimento de 30 vagas anuais, sendo o curso desenvolvido a partir de uma estrutura curricular de seis anos.

A formação inter e multidisciplinar é possibilitada, dentre outras maneiras, por meio da interação entre as faculdades e institutos da Unicamp: a Faculdade de Engenharia Civil, Arquitetura e Urbanismo

\footnotetext{
${ }^{193}$ As informações foram obtidas a partir da visita técnica realizada nos dias 15/10/2015 e 21/03/2016, com entrevistas direcionadas ao coordenador do Laboratório de Materiais de Construção prof. Carlos Eduardo Marmorato e à profa. Gladis Camarini, professora do curso de Arquitetura e Urbanismo e pesquisadora na área da Tecnologia da Construção. Ambos os professores, estão vinculados ao Departamento de Arquitetura e Construção. Outros dados foram complementados no dia 03/11/2015 em entrevista ao prof. Paulo Sérgio Scarazzato, professor na FAUUSP e também na Unicamp, que também contribuiu com a pesquisa.

${ }^{194}$ Referencias retiradas do Projeto Pedagógico do curso, disponível em: http://www.fec.unicamp.br/ au/projeto/ projeto_pedagogico_au.pdf. Acesso em: 11/10/2015.

${ }^{195}$ Dados obtidos em: http://www.prg.unicamp.br/index.php/2015-03-23-22-21-20/historico-prg. Acesso realizado em 11/10/2015.
} 
(FEC), o Instituto de Filosofia e Ciências Humanas (IFCH), o Instituto de Artes (IA). A formação promovida nestes institutos é complementada por professores vinculados ao Instituto da Matemática, Estatística e Computação Científica (IMECC). Do total de 72 disciplinas obrigatórias, a FEC é responsável por 51 , o que representa $70,83 \%$ do total de disciplinas.

As disciplinas na área da Tecnologia da Construção são ministradas por professores engenheiros, pertencentes ao Departamento de Arquitetura e Construção e são ministradas entre o 50 e 9o períodos (3ㄴ, 4 e 5o anos), com intervalo de 02 semestres, pois no 60 e 70 períodos não são ministradas disciplinas da área da Tecnologia da Construção.

O Quadro 31 apresenta as disciplinas acompanhadas dos créditos, sendo observado que a área técnica ocupa $23 \%$ do total de créditos destinados às disciplinas obrigatórias (não foram considerados no cômputo a carga horária destinada às disciplinas de Projeto de Graduação I e II), sendo $8 \%$ para Sistemas Estruturais, 5\% Tecnologia da Construção, 3\% Instalações Prediais, 0,8\% Eficiência Energética (o conteúdo de conforto térmico e acústico é ministrado juntamente com Projeto), 2\% Fundamentação e 4\% Outras consideradas da área (Topografia, Estatística da terra e Hidrologia Urbana).

Quadro 31 - Distribuição da Grade Curricular com a carga horária semestral - FEC - UNICAMP:

\begin{tabular}{|c|c|c|c|c|c|c|c|c|c|}
\hline 10 sem & 20 sem & 30 sem & 4ㅇs sem & 5o sem & 60 sem & 70 sem & 8ㅇ sem & 9o sem & 100 sem \\
\hline $\begin{array}{c}\text { T. e proj. I } \\
\text { (6C) }\end{array}$ & $\begin{array}{l}\text { T. e proj. II } \\
(6 \mathrm{C})\end{array}$ & $\begin{array}{c}\text { Projeto III } \\
(6 \mathrm{C})\end{array}$ & $\begin{array}{c}\text { Projeto IV } \\
(6 C)\end{array}$ & $\begin{array}{c}\text { Projeto V } \\
(6 \mathrm{C})\end{array}$ & $\begin{array}{c}\text { Projeto VI } \\
(6 \mathrm{C})\end{array}$ & $\begin{array}{c}\text { Projeto VII } \\
(6 \mathrm{C})\end{array}$ & $\begin{array}{c}\text { Projeto VIII } \\
(6 \mathrm{C})\end{array}$ & $\begin{array}{c}\text { Projeto IX } \\
(6 C)\end{array}$ & $\begin{array}{c}\text { Projeto } X \\
(6 C)\end{array}$ \\
\hline $\begin{array}{l}\text { Fund. teoria } \\
\text { arq. }(2 \mathrm{C})\end{array}$ & $\begin{array}{l}\text { Hist. arq. e } \\
\text { urb. }(4 \mathrm{C})\end{array}$ & $\begin{array}{l}\text { Metodologia } \\
\text { projeto III } \\
\text { (2C) }\end{array}$ & $\begin{array}{l}\text { Metodologia } \\
\text { projeto IV } \\
\text { (2C) }\end{array}$ & $\begin{array}{l}\text { Metod. } \\
\text { Proj. V (2C) }\end{array}$ & $\begin{array}{l}\text { Metod. Proj. } \\
\text { VI (2C) }\end{array}$ & $\begin{array}{l}\text { Metod. } \\
\text { Proj. VII } \\
\text { (2C) }\end{array}$ & $\begin{array}{l}\text { Metod. Proj } \\
\text { VIII (2C) }\end{array}$ & $\begin{array}{c}\text { Metod. } \\
\text { Proj. IX (2C) }\end{array}$ & $\begin{array}{l}\text { Teor. proj. X } \\
\text { (2C) }\end{array}$ \\
\hline $\begin{array}{l}\text { Introd. estat. } \\
\text { cidade (2C) }\end{array}$ & $\begin{array}{l}\text { Desenho II } \\
\text { (4C) }\end{array}$ & $\begin{array}{c}\text { Est. Socioec.I } \\
(4 \mathrm{C})\end{array}$ & $\begin{array}{l}\text { Fundam. Urb. } \\
\text { (4C) }\end{array}$ & $\begin{array}{c}\text { Planej. Urb. } \\
\text { II (6C) }\end{array}$ & $\begin{array}{l}\text { Arq. paisagíst. } \\
\text { I (4C) }\end{array}$ & $\begin{array}{c}\text { Arq. paisag. } \\
\text { II (4C) }\end{array}$ & $\begin{array}{c}\text { Planej. } \\
\text { Paisag. (4C) }\end{array}$ & $\begin{array}{c}\text { Planej. Urb } \\
\text { IV (6C) }\end{array}$ & $\begin{array}{l}\text { T. projeto } X: \\
\text { int }(6 C)\end{array}$ \\
\hline $\begin{array}{c}\text { Geomet. } \\
\text { Aplic. arq (4C) }\end{array}$ & $\begin{array}{l}\text { Física aplic. } \\
\qquad(2 \mathrm{C})\end{array}$ & $\begin{array}{l}\text { Modelos e } \\
\text { maquetes } \\
(4 C)\end{array}$ & $\begin{array}{l}\text { Hist. arq e urb } \\
\text { moder. (4C) }\end{array}$ & $\begin{array}{c}\text { Infor. } \\
\text { Aplic.III (4C) }\end{array}$ & $\begin{array}{c}\text { Planej. Urb III } \\
(6 \mathrm{C})\end{array}$ & $\begin{array}{c}\text { Est. } \\
\text { socioe.II } \\
(4 \mathrm{C})\end{array}$ & $\begin{array}{l}\text { Desenho } \\
\text { Ind. I (4C) }\end{array}$ & $\begin{array}{c}\text { Tec. } \\
\text { Retrosp } \\
(4 \mathrm{C})\end{array}$ & $\begin{array}{l}\text { Arq. suste. } \\
\quad(6 \mathrm{C})\end{array}$ \\
\hline $\begin{array}{c}\text { Desenho I } \\
(4 C)\end{array}$ & $\begin{array}{c}\text { Estruturas I } \\
(4 \mathrm{C})\end{array}$ & $\begin{array}{c}\text { Infor. Aplic.II } \\
\text { (4C) }\end{array}$ & $\begin{array}{l}\text { Desenho III } \\
\text { (4C) }\end{array}$ & $\begin{array}{l}\text { Estruturas } \\
\text { IV (4C) }\end{array}$ & $\begin{array}{l}\text { Hist. arq e urb } \\
\text { contemp (4C) }\end{array}$ & $\begin{array}{l}\text { Est. socioec. } \\
\text { (2C) }\end{array}$ & $\begin{array}{l}\text { Hidrologia } \\
\text { Urb. (2C) }\end{array}$ & $\begin{array}{l}\text { Desenho } \\
\text { Ind.II (4C) }\end{array}$ & $\begin{array}{l}\text { Prat. Proj } \\
\text { urb (4C) }\end{array}$ \\
\hline $\begin{array}{l}\text { Infor. Aplic.I } \\
\text { (2C) }\end{array}$ & $\begin{array}{l}\text { Topografia } \\
\text { (4C) }\end{array}$ & $\begin{array}{l}\text { Estatística } \\
\text { terra }(4 C)\end{array}$ & $\begin{array}{l}\text { Infor. Aplic.III } \\
\text { (4C) }\end{array}$ & $\begin{array}{l}\text { Estruturas } \\
\text { VII (2C) }\end{array}$ & $\begin{array}{c}\text { Estruturas V } \\
\text { (4C) }\end{array}$ & $\begin{array}{c}\text { Efici. Energ. } \\
(2 \mathrm{C})^{*}\end{array}$ & $\begin{array}{l}\text { Sist. Predia. } \\
\text { (4C) }\end{array}$ & \begin{tabular}{|} 
Tec. Amb. \\
Cons IV \\
(6C)
\end{tabular} & $\begin{array}{l}\text { Met. Tec. } \\
\text { Pesq. (6C) }\end{array}$ \\
\hline $\begin{array}{l}\text { Elemen. de } \\
\text { cálculo (4C) }\end{array}$ & & $\begin{array}{c}\text { Estruturas II } \\
(2 \mathrm{C})\end{array}$ & $\begin{array}{c}\text { Estruturas III } \\
(2 \mathrm{C})\end{array}$ & $\begin{array}{c}\text { Tec. Amb. } \\
\text { Constr.I } \\
\text { (4C) }\end{array}$ & & $\begin{array}{l}\text { Hidraulica } \\
\text { (2C) }\end{array}$ & $\begin{array}{c}\text { Sist. } \\
\text { Elétric.(2C) }\end{array}$ & & \\
\hline & & & & & & $\begin{array}{c}\text { Estruturas } \\
\text { VI (4C) }\end{array}$ & \begin{tabular}{|c|} 
Tec.Amb. \\
Const.II \\
(4C)
\end{tabular} & & \\
\hline
\end{tabular}

Disciplinas de Projeto

Disciplinas de Representação Gráfica e comp.
Disciplinas de Urbanismo e Meio Ambiente

Disciplinas na área da Tecnologia da Arquitetura

*Como disciplina independente de Projeto apresenta-se apenas Eficiência Energética, já o conteúdo referente a Conforto térmico e acústico é ministrado em Projeto.

Obs.: Curso noturno e com estrutura curricular distribuída em 6 anos, em que o 11ㅇp período destina-se a: - Metodologia de Projeto XI (2C) e Projeto de Graduação I. O 12ำ período é destinado exclusivamente a Projeto de Graduação II.

\section{c) Quadro docente}

O Departamento de Arquitetura e Construção conta atualmente com professores com formação em Arquitetura e Urbanismo, Engenharia Civil e Física.

Outras Faculdades e Institutos da Unicamp também possuem docentes que ministram algumas disciplinas para o curso, tais como: outros Departamentos da Faculdade de Engenharia Civil, Arquitetura e Urbanismo (FEC), o Instituto de Filosofia e Ciências Humanas (IFCH), o Instituto de Artes (IA), Instituto de Matemática, Estatística e Computação Científica (IMECC).

Em relação às disciplinas da Tecnologia da Construção, estão sob a responsabilidade de professores pertencentes ao quadro docente do Departamento de Arquitetura e Construção, todos eles com formação em Engenharia Civil. 
A Faculdade conta atualmente com diversos laboratórios de ensino e pesquisa, os quais são utilizados tanto pela pós-graduação como pela graduação. Destes, sete estão localizados em quatro prédios destinados exclusivamente a laboratórios da Faculdade e, os demais (de predominância para usos de recursos computacionais), situam-se em edificações compartilhadas com outras ocupações (salas de aula, gabinetes de professores, etc.).

O Laboratório de Materiais de Construção - LMC (Figuras 107 e 108) - está vinculado ao Departamento de Arquitetura e Construção e oferece suporte técnico às disciplinas dos cursos de graduação em Engenharia Civil e Arquitetura e Urbanismo, e também, para as disciplinas do programa de pós-graduação da FEC. Os Laboratórios das áreas de Materiais e de Estruturas compartilham a mesma infraestrutura e espaço físico (LMC), com atividades voltadas para a vertente experimental, em que os alunos realizam desde ensaios com corpos de prova até experimentações em escala real (atividades prioritariamente desenvolvidas pela pós-graduação em Engenharia Civil). Ainda como laboratório didático, possibilita o desenvolvimento de pesquisas de iniciação científica, estendendo a oportunidade aos alunos do Ensino Médio (programas pontuais).
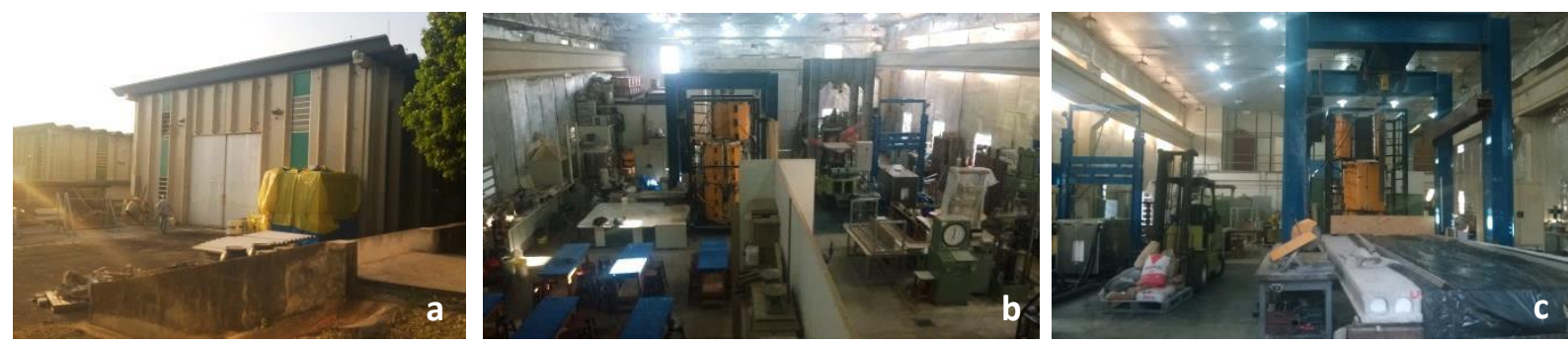

Figura 107 - Laboratório de Materiais de Construção - LMC. a) Vista externa do edifício. b) e c) Vistas internas da infraestrutura.

Fonte: fotos da autora.

Os alunos de Iniciação Científica que utilizam as dependências do LMC são, geralmente, do curso da Engenharia Civil, uma das condicionantes para o menor envolvimento dos alunos da arquitetura está associada ao curso de arquitetura funcionar no período noturno.

Os recursos para manutenção do LMC são provenientes da instituição e complementados por meio de editais internos e também por convênios com empresas e agências externas de pesquisa. Atualmente, este laboratório não desenvolve atividades em conjunto com outros Laboratórios pertencentes ao Departamento de Arquitetura e Construção e que exploram atividades representacionais como os espaços da Maquetaria e Prototipagem.

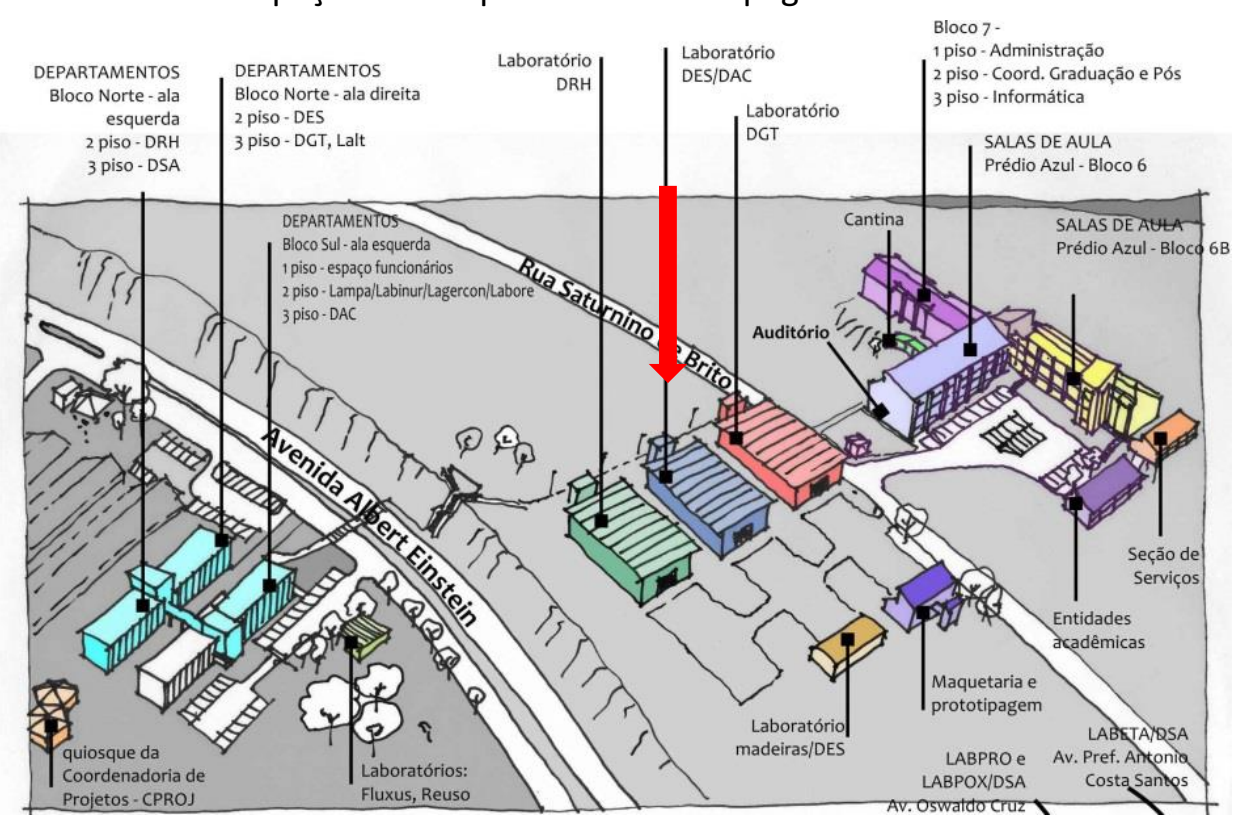

Figura 108 - Mapa esquemático com a localização do Laboratório de Materiais e Construção - LMC.

Figura: Disponível em: http://www.fec.unicamp.br/img/mapa_maior.jpg 
Além do LMC, uma área externa de $17 \times 17 m$ junto ao edifício das salas de aula (Figura 109) está sendo destinada ao futuro Canteiro Experimental, para atender alunos dos cursos de Arquitetura e Urbanismo e Engenharia Civil. Será uma área coberta e terá como apoio um contêiner para armazenamento de equipamentos. Este espaço está sendo desenvolvido na intenção de funcionar de forma independente da infraestrutura de outros departamentos, mas vinculado às coordenações de curso. Embora a discussão ainda seja incipiente e o processo de implantação em fase de desenvolvimento, alguns aspectos de regulamentação estão em fase adiantada de discussão como, destinar este espaço para apoio exclusivo das disciplinas da graduação de acordo com a demanda semestral proposta pelo docente à coordenação, a qual será incumbida da gestão operacional do espaço. No caso da pós-graduação ou pesquisa, há o entendimento de que a infraestrutura laboratorial existente seria mais apropriada para pesquisas de longa duração.

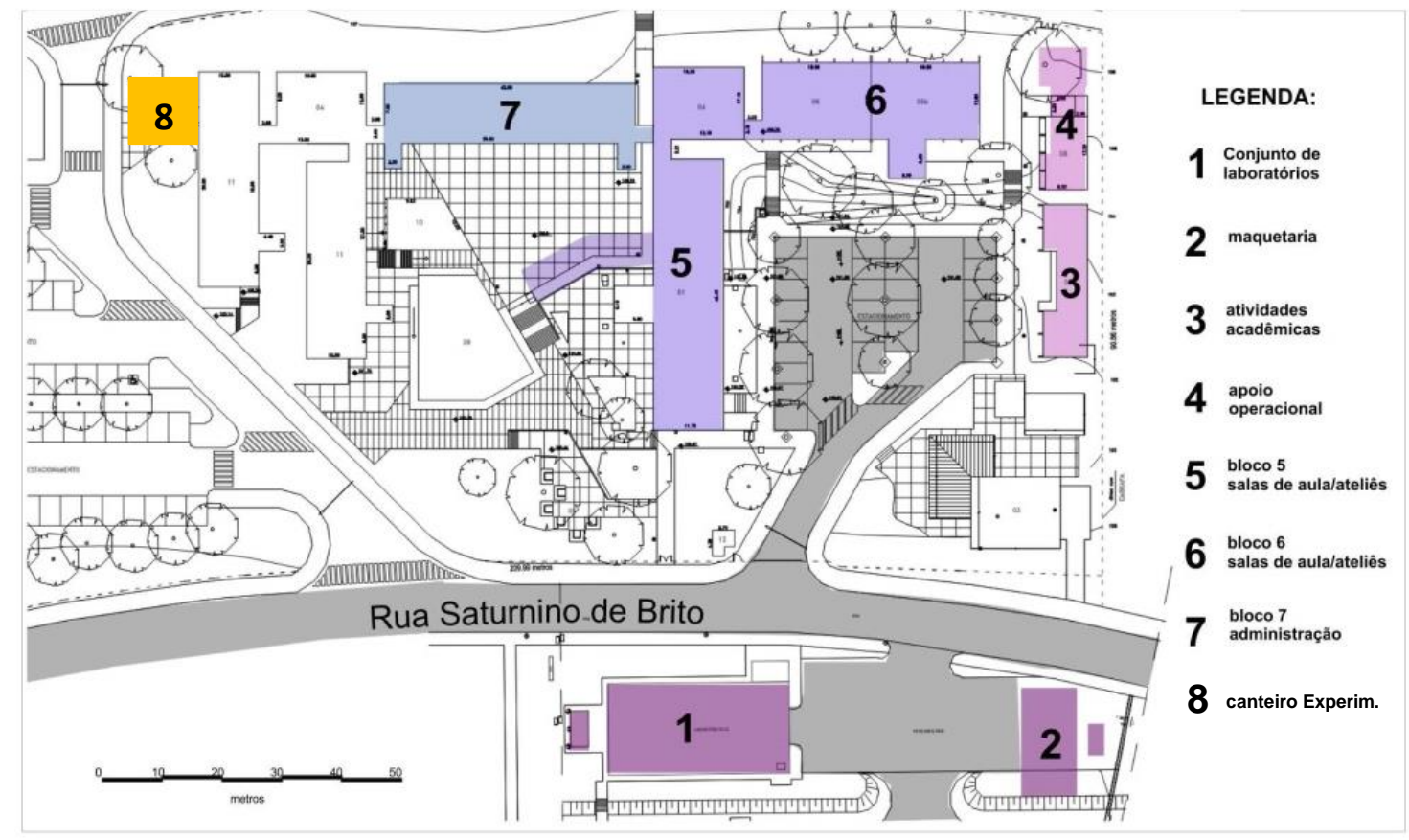

Figura 109 - FEC - Faculdade de Engenharia Civil, Arquitetura e Urbanismo. Plano Diretor - Unicamp. Adaptado pela autora.

Fonte: http://www.fec.unicamp.br/img/FEC-planta.jpg. Acesso em: 16/03/2016.

Nas disciplinas voltadas à Tecnologia da Construção os alunos divididos em turmas (aproximadamente 15 alunos) realizam ensaios utilizando corpos de prova com diferentes materiais como argamassa, concreto, aço, etc. com auxílio dos técnicos de laboratório. Há 06 técnicos para o atendimento dos dois cursos nos níveis da graduação e pós-graduação, 03 deles pertencem ao Departamento de Arquitetura e Construção e 03 ao Departamento de Estruturas, estando em fase de contratação outro técnico com disponibilidade para atuar no período noturno e aos sábados.

\section{e) Pós graduação:}

Além dos cursos de graduação, atualmente a Faculdade possui dois programas de pós-graduação, ambos com mestrado e doutorado: um em Arquitetura, Tecnologia e Cidade, com uma área de concentração; e o de Engenharia Civil, com cinco áreas de concentração.

O Programa de Pós-Graduação em Arquitetura, Tecnologia e Cidade tem sua área de concentração denominada Arquitetura, Tecnologia e Cidade, com três linhas de pesquisa:

1 - Teoria e Metodologia do Projeto e da Cidade;

2 - Conforto Ambiental do Edifício e da Cidade;

3 - Tecnologia e Gestão do Ambiente Construído. 
A linha de pesquisa 3, possui interface à área da Tecnologia da Construção, havendo a possiblidade do desenvolvimento de pesquisas nesta área específica.

\section{f) Comentários:}

- Foi relatado que há incentivo por parte do Departamento para que as atividades propostas procurem aproximar as duas áreas: Arquitetura e Engenharia Civil;

- O espaço do LMC apresenta-se flexível para uso dos alunos tanto da graduação como da pósgraduação, mas os experimentos de grande porte são realizados apenas na pós-graduação ou voltados à prestação de serviços, sendo processos considerados perigosos para alunos da graduação e ensino médio que geralmente frequentam o laboratório, com indicação de que o layout será revisto futuramente;

- Os alunos realizam alguns ensaios (fazem concreto, preparam corpos de prova, peneiram materiais), mas não manipulam as máquinas, apenas os técnicos o fazem. Geralmente, as atividades laboratoriais estão vinculadas ao estudo dos materiais (realização de ensaios) e não ao desenvolvimento de componentes (aplicação em sistemas construtivos);

- O pouco envolvimento dos alunos do curso de Arquitetura em atividades de Iniciação Científica pode estar condicionado ao fato do curso ocorrer no período noturno, inviabilizando a participação dos alunos em alguns tipos de pesquisa. Além disso, a integração entre graduação e pós-graduação é dificultada pelo mesmo motivo;

- Algumas atividades condicionadas à luz diurna são desenvolvidas aos sábados, embora tenha sido relatado que tanto visitas técnicas como estas atividades não tem atingido o rendimento satisfatório, devido a pouca participação dos alunos. Segundo relatos, o curso poderia potencializar ainda mais o nível de excelência com a mudança de período;

- De acordo com os relatos a reivindicação pela implantação de um canteiro experimental partiu dos próprios alunos da graduação do curso de Arquitetura, em contrapartida, o desejo de permanecer com o curso no período noturno também partiu dos alunos. Esta dualidade de posições compromete o desenvolvimento das atividades de caráter técnico-experimental, geralmente indicadas para serem desenvolvidas durante o período diurno;

- Há previsão de que o canteiro experimental tenha caráter efêmero e não permanente, para que possa ser retirado caso haja necessidade futura de ocupação do local para outra finalidade;

\subsubsection{QUADRO SÍNTESE}

Quadro 32 - Quadro Síntese

* Disciplinas que embora estejam intituladas como Tecnologia das Construções, não contemplam necessariamente conteúdos desta área e sim, de outras, como Instalações Prediais, Mecânica dos Solos, Estruturas, etc, geralmente fundidas a partir de diferentes motivos. O número exposto é menor.

** Exceções entre as escolas visitadas, devido a adoção de base de cálculo de créditos diferenciada, não sendo possível estabelecer parâmetros equivalentes ao adotado nas demais escolas.

***Infraestrutura pertencente ao curso de Engenharia civil, mas que apresenta utilização efetiva por parte do curso de Arquitetura e Urbanismo. Não sendo considerados os cursos que burocraticamente/teoricamente adotam o termo 'compartilhado'.

**** Não se deve confundir a fabricação de protótipos com a confecção de elementos (placas, tijolos, etc.) e também exercícios com modelos reduzidos (geralmente na área de sistemas estruturais) com protótipos na escala real do material. 


\begin{tabular}{|c|c|c|c|c|c|c|c|c|c|c|c|c|c|c|c|c|c|c|c|c|c|c|c|}
\hline \multicolumn{3}{|c|}{ INSTITUIÇÕES ONDE CADA ESCOLA ESTÁ INSERIDA } & $\begin{array}{ll}\frac{a}{3} \\
\frac{0}{3}\end{array}$ & 㟧 &  & 獣 & 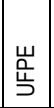 & $\begin{array}{l}\text { 离 } \\
\text { 岁 }\end{array}$ & $\underline{m}$ & 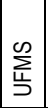 & 랃 & 学 & $\sum_{\mathrm{y}}^{0}$ & 岂 & 荙 & 岁 & 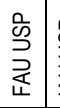 & 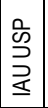 & 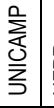 & 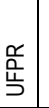 & $\overrightarrow{\mathrm{S}}$ & & 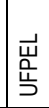 \\
\hline \multicolumn{3}{|c|}{$\begin{array}{c}\text { (número de vagas oferecidas anualmente - cursos diurnos e noturnos } \\
\text { criados antes de 2000) }\end{array}$} & 60 & 64 & 42 & 70 & 100 & 120 & 80 & 50 & 35 & 40 & 150 & 60 & 240 & 74 & 150 & 45 & 30 & 60 & 60 & 110 & 60 \\
\hline \multicolumn{24}{|c|}{ DADOS LEVANTADOS } \\
\hline \multirow{4}{*}{ 1. Histórico do curso } & Escola & a Belas Artes & & & & & & & & & & & & & & & & & & & & & \\
\hline & Escola & a Politécnica & & & & & & & & & & & & & & & & & & & & & \\
\hline & Outros & s cursos & & & & & & & & & & & & & & & & & & & & & \\
\hline & Indepe & endente de cursos existentes & & & & & & & & & & & & & & & & & & & & & \\
\hline \multirow{5}{*}{\begin{tabular}{|l|} 
\\
2 - Modelo atual Adotado \\
escola - reponsabilidade \\
disciplinas da área da \\
Tecnologia da Construção
\end{tabular}} & $\begin{array}{l}\text { Arquite } \\
\text { arquite }\end{array}$ & $\begin{array}{l}\text { etura - disciplinas ministradas por } \\
\text { etos c/ especialização tecnologia }\end{array}$ & & & & & & & & & & & & & & & & & & & & & \\
\hline & $\begin{array}{l}\text { Arquite } \\
\text { arquite }\end{array}$ & $\begin{array}{l}\text { etura - disciplinas ministradas por } \\
\text { etos s/ especialização tecnologia }\end{array}$ & & & & & & & & & & & & & & & & & & & & & \\
\hline & $\begin{array}{l}\text { Arquite } \\
\text { engen }\end{array}$ & $\begin{array}{l}\text { etura - disciplinas ministradas por } \\
\text { heiros }\end{array}$ & & & & & & & & & & & & & & & & & & & & & \\
\hline & $\begin{array}{l}\text { Engen } \\
\text { engen }\end{array}$ & $\begin{array}{l}\text { hharia - disciplinas ministradas por } \\
\text { heiros }\end{array}$ & & & & & & & & & & & & & & & & & & & & & \\
\hline & $\begin{array}{l}\text { Engen } \\
\text { arquite }\end{array}$ & $\begin{array}{l}\text { רharia - disciplinas ministradas por } \\
\text { etos }\end{array}$ & & & & & & & & & & & & & & & & & & & & & \\
\hline \multirow{4}{*}{$\begin{array}{l}3 \text { - Carga Horária das } \\
\text { disciplinas Técnicas X } \\
\text { Tecnologia da Construção }\end{array}$} & $\begin{array}{l}\text { Área d } \\
\text { Geral }\end{array}$ & $\begin{array}{l}\text { da Tecnologia da Arquitetura - C.H. } \\
-(\%)\end{array}$ & 24 & 19 & 23 & 19 & 28 & 31 & 29 & 23 & 28 & 30 & 31 & \begin{tabular}{c|c}
30 \\
, 5
\end{tabular} & \begin{tabular}{c|c}
31 \\
5
\end{tabular} & 30 & \begin{tabular}{|c|c|c|c|c|}
28 & 2 \\
5 & \\
\end{tabular} & \begin{tabular}{c|}
25 \\
5 \\
\end{tabular} & 23 & 23 & 34 & 28 & 30 \\
\hline & Númel & ro de créditos Tecnologia Arquitetura & 60 & 40 & 54 & 38 & 38 & 73 & 58 & 51 & 58 & 64 & 59 & 46 & 52 & 69 & \begin{tabular}{|l|l}
83 & 7 \\
\end{tabular} & 78 & 62 & 50 & 80 & 72 & 69 \\
\hline & Área T & Tecnologia da Construção - C.H. (\%) & ** & 3,7 & 5 & $4^{*}$ & ** & 6 & 7 & $7^{*}$ & 7 & 5,5 & 7 & 8 & 9 & \begin{tabular}{l|l}
7 & 7
\end{tabular} & $7,5^{*} 6$ & 6,5 & 5 & 4 & 8,5 & 7,5 & 8,5 \\
\hline & NúmeI & ro de créditos Tecnologia Construção & ** & 8 & 11 & $8^{*}$ & ** & 14 & 14 & $16^{*}$ & 15 & 12 & 13 & 12 & 15 & \begin{tabular}{|l|l|l|}
16 & 2 \\
\end{tabular} & $22^{*}$ & 20 & 14 & 8 & 20 & 20 & 20 \\
\hline $\begin{array}{l}\text { - Período destinado às } \\
\text { disciplinas na área de TC }\end{array}$ & & & $\begin{array}{l}1 / 2 \\
3 / 4 \\
5 / 6\end{array}$ & $3 / 4$ & $\begin{array}{c}2 / 3 \\
8\end{array}$ & $4 / 7$ & $\begin{array}{l}1 / 2 \\
3 / 4 \\
5 / 6 \\
7 / 8 \\
\end{array}$ & $\begin{array}{c}3 / 4 \\
5\end{array}$ & $\begin{array}{c}1 / 5 \\
6\end{array}$ & $\begin{array}{l}3 / 4 \\
5 / 9\end{array}$ & \begin{tabular}{c|}
$2 / 3$ \\
$4 / 5$ \\
6
\end{tabular} & $\begin{array}{c}5 / 6 \\
7\end{array}$ & $\begin{array}{c}2 / 3 \\
7\end{array}$ & $\begin{array}{l}4 / 5 \\
6 / 7\end{array}$ & $\begin{array}{l}4 / 5 \\
6 / 9 \\
\end{array}$ & $\begin{array}{ll}3 / 4 \\
6 / 8\end{array}$ & \begin{tabular}{l|l}
$1 / 2$ & \\
$3 / 4$ & 3 \\
$5 / 7$ & 5
\end{tabular} & \begin{tabular}{|l|}
$3 / 4$ \\
$5 / 6$
\end{tabular} & $5 / 8 \mid \begin{array}{c}1 \\
9\end{array}$ & $\begin{array}{l}1 / 2 \\
3 / 4\end{array}$ & $\begin{array}{l}1 / 2 \\
3 / 4 \\
5 / 6\end{array}$ & & $\begin{array}{c}3 / 4 \\
5 / 6 \\
7\end{array}$ \\
\hline \multirow{6}{*}{\begin{tabular}{|l|} 
- Caracterização \\
infraestrutura laboratorial \\
na área da TC e utilizada \\
pela Arq. *** no caso de \\
compartilhamento \\
considerado apenas a infra \\
utilizada no Ensino \\
\end{tabular}} & & Canteiro Experimental/ formalizado & & & & & & & & & & & & & & & & & & & & & \\
\hline & $A R O$ & Canteiro Experimental/ não formal. & & & & & & & & & & & & & & & & & & & & & \\
\hline & ARQ & \begin{tabular}{|l|} 
Laboratório Maquetes/ Protótipos \\
\end{tabular} & & & & & & & & & & & & & & & & & & & & & \\
\hline & & Laboratório voltado à ensaios tec. & & & & & & & & & & & & & & & & & & & & & \\
\hline & & Canteiro de obras/experimentação ext. & & & & & & & & & & & & & & & & & & & & & \\
\hline & ERQ & Laboratório Materiais/ ensaios & & & & & & & & & & & & & & & & & & & & & \\
\hline \multirow{4}{*}{\begin{tabular}{|l|}
6 - Recursos humanos - \\
laboratório TC -(Materiais/ \\
Técnicas/ Marcenaria). - \\
Obs.: Informação verbal
\end{tabular}} & & Técnico & & & & & & & & & & & & & 2 & &  & 6 & & & 1 & & \\
\hline & ARQ & Auxiliar & & & & & & & & & & & & & 1 & & & & & & 1 & & \\
\hline & ENG/ & Técnico (somatória técnicos labor.) & & & & 5 & & 2 & & 1 & 2 & 3 & & 1 & & 2 & & & 6 & & 1 & 1 & \\
\hline & ARQ & Auxiliar (considera também terceirizad) & & & & 2 & & & & 2 & & 3 & & 3 & & & & & & & 2 & 2 & \\
\hline \multirow{8}{*}{\begin{tabular}{|l|}
7 - Metodologia \\
pedagógica para \\
abordagem do conteúdo \\
nas disciplinas de \\
Tecnologia da Construção \\
- realizada \\
sistematicamente e não \\
eventualmente
\end{tabular}} & Por me & eio da análise de Projetos & & & & & & & & & & & & & & & & & & & & & \\
\hline & Experi & imentação construtiva - protótipos ${ }^{\star \star \star \star *}$ & & & & & & & & & & & & & & & & & & & & & \\
\hline & Visitas & s à obras & & & & & & & & & & & & & & & & & & & & & \\
\hline & Expos & itiva laboratorial (realizada por técnicos) & & & & & & & & & & & & & & & & & & & & & \\
\hline & Expos & sitiva sala de aula & & & & & & & & & & & & & & & & & & & & & \\
\hline & Realiz & zação de ensaios em laboratório & & & & & & & & & & & & & & & & & & & & & \\
\hline & Aulas & teóricas & & & & & & & & & & & & & & & & & & & & & \\
\hline & Inform & רações insuficientes & & & & & & & & & & & & & & & & & & & & & \\
\hline \multirow{5}{*}{$\begin{array}{l}8 \text { - Caráter das atividades } \\
\text { laboratoriais (quando } \\
\text { existentes) - ensaios/ de } \\
\text { modelos e protótipos para } \\
\text { o ensino do conteúdo de } \\
\text { TC }\end{array}$} & Instruc & cional (ensaios) & & & & & & & & & & & & & & & & & & & & & \\
\hline & Experi & imental (ensaios) & & & & & & & & & & & & & & & & & & & & & \\
\hline & Protóti & ipos - De acordo c/ dados científicos & & & & & & & & & & & & & & & & & & & & & \\
\hline & $\begin{array}{l}\text { Protóti } \\
\text { discus }\end{array}$ & $\begin{array}{l}\text { tipos - Caráter plástico/outras } \\
\text { ssões }\end{array}$ & & & & & & & & & & & & & & & & & & & & & \\
\hline & Não re & ealiza atividades laborat./Eventualmente & & & & & & & & & & & & & & & & & & & & & \\
\hline \multirow{3}{*}{$\begin{array}{l}9 \text { - Projetos pedagógicos } \\
\text { que discutem a temática } \\
\text { laboratorial técnica }\end{array}$} & 0 assi & unto é discutido no PP & & & & & & & & & & & & & & & & & & & & & \\
\hline & 0 assi & unto não é discutido no PP & & & & & & & & & & & & & & & & & & & & & \\
\hline & $\overline{E m ~ f a s}$ & se de discussão (vigora o antigo PP) & & & & & & & & & & & & & & & & & & & & & \\
\hline \multirow{4}{*}{$\begin{array}{l}10 \text { - Existência de cursos } \\
\text { de pós-graduação no } \\
\text { Curso de Arquitetura e } \\
\text { Urbanismo }\end{array}$} & $\begin{array}{l}\text { SIM - } \\
\text { tecnol }\end{array}$ & $\begin{array}{l}\text { oferece linhas de pesquisa na área da } \\
\text { logia da construção - ME e DO }\end{array}$ & & & & & & & & & & & & & & & & & & & & & \\
\hline & $\begin{array}{l}\text { SIM - } \\
\text { tecnol }\end{array}$ & $\begin{array}{l}\text { oferece linhas de pesquisa na área da } \\
\text { logia da construção - apenas ME }\end{array}$ & & & & & & & & & & & & & & & & & & & & & \\
\hline & $\begin{array}{l}\text { SIM - } \\
\text { na áre }\end{array}$ & $\begin{array}{l}\text { mas NÃO oferece linhas de pesquisa } \\
\text { ea da Tecnologia da Construção }\end{array}$ & & & & & & & & & & & & & & & & & & & & & \\
\hline & Apena & as especialização Latu Senso & & & & & & & & & & & & & & & & & & & & & \\
\hline
\end{tabular}




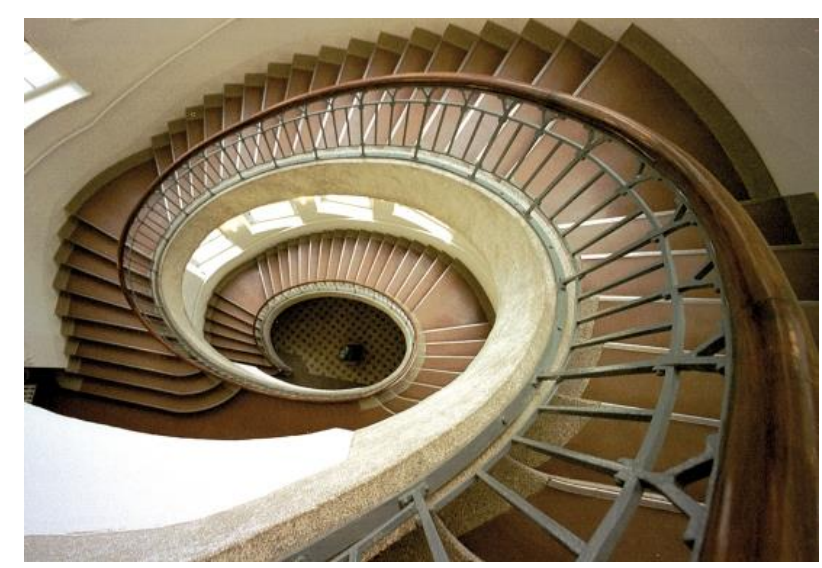

CAPÍTULO 04 ANALISANDO OS DADOS, COMPREENDENDO OS FATOS

4.1. O IMBRICAMENTO DAS PARTICULARIDADES HISTÓRICA, REGIONAL E ESTRUTURAL

4.2. CONFLUÊNCIA DE ENTENDIMENTOS SOBRE A ÁREA EXPERIMENTAL/CONSTRUTIVA ENTRE AS ESCOLAS VISITADAS

4.2.1. Estrutura Curricular e os conteúdos da área da Tecnologia da Construção 4.2.2. Infraestrutura física laboratorial e as práticas pedagógicas 4.2.3. Recursos humanos 


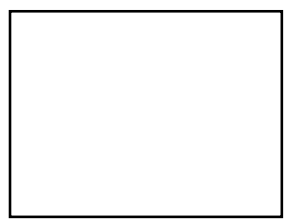

Imagem capa: Bauhaus - Universidade de Weimar - escada interna em espiral Fonte: http://www.germany.travel/pt/cidades-e-cultura/patrimonio-mundial-da-unesco 
Ao explicitar a trajetória e a estruturação atual da área da Tecnologia da Construção em diferentes escolas públicas brasileiras foi possível contextualizar os desafios enfrentados, que não se resumem ao arranjo físico laboratorial, mas a uma dimensão mais ampla, pois abrange aspectos político-educacionais, estruturais e sócio-econômicos. Uma simples abordagem quantitativa não possibilitaria compreender questões de fundo, no que diz respeito à natureza das relações interpessoais e burocráticas que envolvem a temática, difíceis de serem captadas por meio de instrumentos somente descritivos. Como já detalhado no Capítulo Introdutório, o trabalho então partiu para a forma qualitativa, algo somente possível por meio de visitas técnicas in loco e entrevistas direcionadas aos principais atores atuantes na área estudada, somando ao todo 67 profissionais (docentes e técnicos) pertencentes a 21 escolas do país e entidades de classe.

Os dados publicados no Capítulo 03 serão discutidos neste Capítulo em associação às demais informações não divulgadas anteriormente, como um ensaio crítico do todo, sem a divulgação de dados que permitam individualizar os entrevistados, evitando-se associações diretas e análises de efeito comparativo ${ }^{196}$.

\subsection{O IMBRICAMENTO DAS PARTICULARIDADES HISTÓRICA, REGIONAL E ESTRUTURAL}

Dividir as escolas para análise a partir da categoria histórica, possibilitou contrapor diferentes processos de implantação e trajetórias ao longo da estruturação de cada curso, assim como, identificar aspectos comuns intra e inter períodos. De antemão, algo observado ao longo do tratamento dos dados foi a inexistência de uma causa comum que explique a heterogeneidade encontrada em relação ao desenvolvimento da área técnica, com indicativo de que o problema não está diretamente ligado à história de implantação de cada curso e sua associação a um modelo de ensino (Politécnico ou Belas Artes - Gráfico 01) e sim, à história construída ao longo das décadas, diante das oportunidades surgidas e da composição do quadro docente que, consequentemente, direcionaria o curso para uma determinada vertente e daria o tom das prioridades de cada escola ${ }^{197}$.

\footnotetext{
${ }^{196}$ Não será realizada a análise das escolas de forma individual, algo de ordem muito mais complexa e que exigiria estratégias metodológicas complementares às adotadas, não fazendo parte dos objetivos da pesquisa.

197 Muitos autores e profissionais entrevistados alegam ser a origem de implantação e a tradição cultural uma das condicionantes para que as escolas estabelecessem determinado diálogo com os cursos da Engenharia Civil e adotassem alguns modelos para a condução das disciplinas e práticas didáticas na área da Tecnologia da Construção, como: a) delegar as disciplinas para o curso da Engenharia Civil; b) terem em seu quadro docente profissionais engenheiros, os quais assumem as
} 


\section{Levantamento a partir das 21 escolas visitadas}

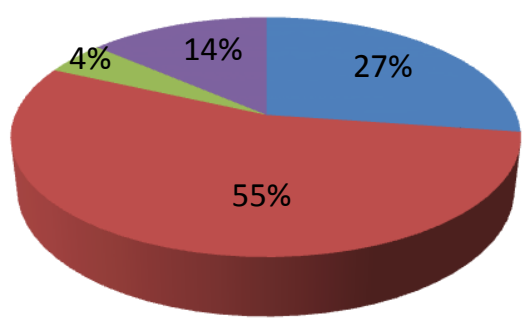

Ensino Belas Artes

Ensino Politécnico

Outros

Independente de cursos existentes

Gráfico 01 - Porcentagem das escolas visitadas (inseridas em Instituições Públicas) de acordo com o histórico de implantação/origem.

Ao analisar cronologicamente estas trajetórias é visto que a busca pela autonomia da formação do arquiteto em relação às antigas Escolas de Engenharia e Belas Artes não ocorreu de maneira automática, ao contrário, a criação dos novos cursos e escolas adaptou-se às condições de cada local, principalmente, naquelas regiões distantes dos centros de formação tradicionais. As ações direcionadas à criação dos primeiros cursos de arquitetura datam do século XIX e foram realizadas em distintas regiões do país, nas capitais dos estados do Rio de Janeiro e Bahia (no seio das Escolas de Belas Artes) e também Rio Grande do Sul e São Paulo (como um curso da Escola Politécnica).

A partir da década de 1930, o ensino de arquitetura toma expansão com a implantação de novos cursos em outras regiões do país, assim como, novas ações, reestruturações e regulamentos redirecionariam os cursos já implantados. Um acontecimento de grande relevância ocorreu em 1931 na Escola Real das Ciências, Artes e Ofícios, quando recebe a primeira reforma com orientação modernista (mesmo não tendo sido aplicada naquele momento). Nesta mesma época, é criado em Belo Horizonte o primeiro curso de arquitetura da América Latina desvinculado do modelo Politécnico e Belas Artes, assim como, começa a funcionar o ensino de Arquitetura e Urbanismo na recém-criada Escola de Belas Artes de Pernambuco. Ainda nesta década o Instituto de Belas Artes de Porto Alegre inaugura seu curso de Arquitetura e, em São Paulo, a Escola Politécnica passa a fazer parte da Universidade de São Paulo, oferecendo dentre seus cursos o de engenheiro-arquiteto. Enquanto isso, o curso

disciplinas da Tecnologia da Construção, c) a área ser conduzida por profissionais arquitetos com formação complementar na área da Tecnologia da Construção e d) disciplinas assumidas por profissionais arquitetos sem especialização na área da Tecnologia. 
de arquitetura da Escola de Belas Artes da Bahia seguia suas atividades, mas ainda sem reconhecimento nacional.

Nas décadas posteriores a este período, são vistos consideráveis avanços expansionistas e estruturantes sobre o ensino, principalmente, em capitais do país com um determinado grau de desenvolvimento urbano. Na intenção de caminharem de forma independente em relação aos cursos de origem, a maior parte destas escolas enfrentou longos e conturbados processos de cunho separatista ou de fusão. Em meados da década de 1940, a Escola Nacional de Arquitetura no Rio de Janeiro passa a Faculdade Nacional de Arquitetura e se separa da Escola de Belas Artes, no mesmo ano, os cursos de arquitetura em funcionamento na Escola de Belas Artes de Pernambuco e no Instituto de Belas Artes em Porto Alegre são reconhecidos como cursos superiores e a Escola de Engenharia da Universidade de Porto Alegre volta a criar um novo curso de arquitetura, que havia funcionado antes por um breve período (1896-1908), enquanto que, ainda no Rio Grande do Sul, o Instituto de Belas Artes também passa a fazer parte da universidade, fato que ocasionou a fusão dos dois cursos. No fim desta década o curso da Escola de Belas Artes da Bahia é federalizado e o curso de engenheiro-arquiteto da Escola Politécnica de São Paulo é desvinculado passando a ter autonomia como curso de Arquitetura e Urbanismo.

Neste período, o contexto desenvolvimentista e o debate modernista já haviam se legitimado no país, havendo um descompasso entre a atividade profissional e o ensino, já que a reforma curricular proposta por Lucio Costa na Escola Nacional de Belas Artes demorou a ser reconhecida e aplicada no contexto acadêmico, fato que ocorreu por volta de 1945 na Escola Nacional de Arquitetura, servindo posteriormente, de modelo curricular para a implantação e reforma de outros cursos pelo país. Diversos autores relatam que os cursos até então criados passam a ter um alinhamento, por força de lei, ao da escola do Rio de Janeiro, como aconteceu com São Paulo e Rio Grande do Sul e antes deles, também com a Escola de Arquitetura de Belo Horizonte, a qual, desde os primórdios de sua criação, já se enquadrava nos moldes definidos pelo Estado durante o governo de Getúlio Vargas, sendo esta uma estratégia para o reconhecimento nacional do curso (antes da implantação do currículo de matriz modernista).

Embora os esforços realizados neste período, é possível encontrar outros pontos de vista, como o de Santos (2002), ao relatar que a defasagem entre produção e ensino somados às características da universidade brasileira - um conglomerado de escolas elitizadas, não 
orientado para a pesquisa - certamente contribuíram para que o arquiteto brasileiro atribuísse maior valor à criação do projeto do que à reflexão sistemática sobre a disciplina arquitetônica. Para o autor, naquele momento, tanto Estado quanto profissionais estavam mais interessados em legitimação do que currículo, e muito menos em forma de organização do sistema educacional em relação à qualidade, concluindo que a sistemática modernista exigia ambiente de interlocução e recursos que a universidade brasileira não dispunha naquele momento.

Quando analisadas as colocações do autor supracitado sob o ponto de vista infraestrutural, é possível se chegar a outras considerações, a partir da análise de outras variáveis como os projetos arquitetônicos das escolas que ganharam suas primeiras sedes. A maior parte delas construiu edifícios próprios e de grande valor arquitetônico, cenário que não se repetiu nos anos seguintes, pelo fato de grande parte dos cursos terem sido sediados em locais compartilhados ou adaptados, sendo encontradas poucas exceções. Ao analisar estes projetos - construídos durante e antes da década de 1960 - a maior parte deles foram concebidos prevendo um espaço para a área laboratorial (alguns deles podem ser visualizados no subitem 3.2.1.1- UFRJ, USP, UFMG, UFRGS e UFBA), geralmente, voltados para atividades de marcenaria, maquetaria ou laboratório de materiais construtivos (ensaios físicos e mecânicos). Este é apenas um dos indícios que não deve ser desconsiderado, e que revela os esforços de vários grupos de atores mobilizados em prol da melhoria do ensino.

Em razão da maturidade alcançada até a década de 1960 e à inexistência de processos regulatórios como a Reforma Universitária de 1969, foram realizados neste período profundos debates sobre o processo de formação em diversas regiões da federação, em especial entre meados da década de 1950 e o ano histórico de 1962, os quais promoveram transformações de ordem estrutural, pedagógica e política. De acordo com Graeff (1995), o currículo mínimo desenvolvido em 1962 vinha abrir oportunidades de mudanças e experiências inovadoras, inclusive no sentido de colocar o ensino em sintonia com as realidades geográficas, sociais e culturais de cada região.

Quando analisada a relação entre modelo de implantação e a configuração da área técnica, das seis escolas criadas antes da década de 1960 e analisadas neste trabalho, três delas foram, ao longo dos anos, se estruturando de maneira a assumirem a área técnicoconstrutiva, não sendo observada a relação direta entre modelo de implantação e configuração laboratorial (pois cada uma originou-se no seio de diferentes modelos), sendo 
mais provável que a caracterização dos espaços voltados à área técnica tenha sido mais influenciada pelo entendimento dos docentes à frente destas atividades do que, necessariamente, pelo modelo de origem, como já comentado no início deste texto. Estas 03 escolas estão localizadas na região sudeste (RJ, SP e MG), sendo as demais escolas implantadas neste período, pertencentes a outras regiões do território nacional (RS e BA), as quais ainda hoje, delegam as disciplinas da área da Tecnologia da Construção para o curso da Engenharia Civil, com exceção de uma que, recentemente, assume as disciplinas de cunho tecnológico, mas sem apresentar infraestrutura laboratorial na área técnica construtiva (PE).

Posteriormente, na década de 1960, outras 04 escolas de arquitetura (inseridas em Instituições públicas) foram criadas em diferentes capitais do país como UNB, UFPR, UFPA e UFC, cidades estas em processo de desenvolvimento. Neste período, há grande intercâmbio de profissionais, destacando-se aqueles formados pelas escolas carioca, paulista, mineira e gaúcha, os quais passam a atuar em outras regiões do país e disseminam o conhecimento adquirido nestes estabelecimentos com propostas de ensino mais consolidadas. Desta forma, as novas escolas criadas tem como apoio as discussões que até então já haviam sido travadas sobre o ensino e, sob bases muito particulares, estes conceitos foram sendo adaptados de acordo com cada contexto. Destaca-se nesse momento, a experiência da FAU UNB, podendo ser considerada a mais inovadora até então, com inspiração bauhauseana e coordenada por profissionais formados em outras regiões do país.

Embora esta proposta didática tenha sido abortada precocemente devido às ações do regime militar, tornou-se outra fonte de referência (além do modelo Politécnico e Belas Artes) para as escolas criadas posteriormente ${ }^{198}$, sendo visto que as propostas para a área técnica em que o uso laboratorial e experimental integra a proposta geral do ensino - nunca foram replicadas em nenhuma outra escola nacional, nem mesmo na UNB este viés foi retomado ao longo das tentativas de reestruturação. Este fato fortalece a hipótese da relação entre experiências práticas e iniciativa docente, cujas propostas somente são viabilizadas de acordo com a influência e poder de decisão que os atores possuem nas reestruturações do ensino de determinada escola.

\footnotetext{
198 Foram encontradas duas escolas que fazem menção a esta referência e, embora esta referência em seus Projetos Pedagógicos, não foram identificados com clareza aspectos que aproximem as propostas destas escolas com a experiência vivenciada na UNB.
} 
O relatório do 'Encontro Nacional de Ensino de Arquitetura', promovido pelo IAB-SP em $1967^{199}$, evidencia a visibilidade nacional da experiência da UNB - considerada como referência de reformulação acadêmica - pelo fato de engajar o ensino superior no processo de desenvolvimento do país e de promover a formação de um cidadão consciente da realidade nacional. Neste mesmo documento é realizada uma crítica à formação tecnicista e empresarial, ao considerar serem aspectos impeditivos da obtenção de uma visão global dos problemas da nação. Ao mesmo tempo, o texto procura incentivar o diálogo com profissionais de outras especialidades diante do reconhecimento que a formação tende a ser cada vez mais complexa, sendo assim, as atribuições do arquiteto, mesmo mantendo sua essência, deveria evoluir e resultar nos seguintes componentes:

- que envolvam conhecimentos que permitam uma visão realista da sociedade e uma atitude prospectiva diante do progresso da humanidade;

- que incluam o domínio do instrumental adequado e atualizado indispensável ao exercício da profissão, através de conhecimentos de materiais, métodos e técnicas que proporcionam a qualificação dos elementos que manipula nos diversos níveis de sua atuação e a identificação dos aspectos que envolvem a contribuição, a coparticipação ou a decisão de outros profissionais.

Outro ponto verificado neste documento é o permanente reconhecimento dos preceitos bauhauseanos como uma referência, ao ser mencionada a experiência de Brasília como exemplo pioneiro e defender a proposição da inserção de disciplinas da área do Design Industrial e Comunicação visual no ensino de arquitetura (aplicada na FAUUSP). Sendo assim, as inovações reestruturantes sugeridas nesta época ainda remetiam, mesmo que tardiamente, aos conceitos modernistas da escola alemã como referência para resolver os problemas prospectivos $^{200}$.

Mas ao cruzar este posicionamento com outras considerações realizadas por Santos (2002), é possível verificar que a dúvida continua pairando sobre o tema mesmo após décadas de discussão, sobre qual seria a responsabilidade técnica do arquiteto e quais pesquisas experimentais por ele poderiam ser conduzidas:

'Mas é fato que a introdução de conteúdos técnicos no ensino de arquitetura intencionava a afirmação da profissão enquanto tal. A legitimação profissional

\footnotetext{
${ }^{199}$ Encontro Nacional de Ensino de Arquitetura - 1967. Revista Acrópole, nov. 1967. Ano XXIX, nº 345, p. 14.

${ }^{200}$ Atualmente, a partir da análise das escolas criadas no período da década de 1960, percebe-se que não foram estruturadas para assumirem a área técnica e, geralmente, não contemplam atividades de cunho experimental tecnológico na formação. A experiência da UNB no período compreendido entre 1962 e, aproximadamente 1965, pode ser considerada uma exceção, pois não foi retomada, mas influenciou, posteriormente e pontualmente, algumas experiências em escolas particulares, devido à migração de profissionais atuantes nesta experiência, levando consigo esta experiência e, alguns deles, conseguiram adaptá-la em outros contextos, como visto no Quadro 07, do Capítulo 02.
} 
baseada na noção de perícia técnica garantia a arquitetos, pelo menos em tese, o mesmo status profissional de engenheiros. Desse modo, no âmbito da organização profissional, os arquitetos assumiram, ou se viram obrigados a assumir o pragmatismo e o espirit de corps típicos de engenheiros, no momento em que é criado o Conselho Federal e os Conselhos Regionais de Engenharia e Arquitetura. Essa associação, no entanto, não leva em conta certas tradições do ofício da arquitetura' (SANTOS, 2002, p. 91).

Estas colocações podem ser interpretadas como o permanente questionamento sobre as atribuições técnicas do arquiteto, pois ao fazer este atrelamento histórico como uma particularidade nacional, sustenta a hipótese que poderia haver outras possibilidades relacionadas à tradição do ofício, mas quais seriam elas?

Em meio às discussões travadas no fim do período de 1960, está o Currículo Mínimo de 1969, criticado por diversos autores ao defenderem que as normas para sua aplicação denotavam uma visão tecnocrática e padronizadora, indiferente às dinâmicas de mudanças de procedimentos didático-pedagógicos em andamento nas escolas de Arquitetura e Urbanismo. O tempo revelou que estas considerações padronizadoras não foram aplicadas em sua íntegra, diante da heterogeneidade vista tanto na configuração dos espaços experimentais das escolas visitadas como nas práticas didáticas empregadas na área da Tecnologia da Construção, pois se assim fosse, as escolas estariam igualmente desenvolvidas e, diante da liberdade concedida a cada uma delas, ao longo dos anos cada curso pôde formular suas propostas e delinear suas prioridades.

Ainda sobre a questão de que o Currículo Mínimo de 1969 enrijeceu o ensino brasileiro em relação ao proposto no de 1962 - que permitia maior flexibilidade para que os cursos se ajustassem as particularidades regionais de cada local - em alguns momentos foi questionado se seria correto afirmar com tanta veemência de que o mesmo fosse o grande responsável pela inércia vivenciada durante muitos anos no ensino brasileiro, até porque, seria cômodo para muitos cursos se apoiarem em regras e normas ao invés de continuarem a promover discussões que alimentassem experiências diferenciadas. Este questionamento também pode ser analisado sob o ponto de vista de Santos (2001), ao relatar que durante as reuniões que redigiram a Carta de Ouro Preto em 1977, já haviam identificado que a reforma do Currículo Mínimo, por si só, não garantiria a melhoria do ensino, mas como indutor de mudanças. Reiterava-se que, somente a mobilização de professores, estudantes e funcionários, articulados por um projeto-pedagógico, poderia implantar e sustentar de forma permanente o 
desenvolvimento de novas experimentações no ensino, isso quer dizer, iniciativas intra e interdepartamentais.

Seguindo cronologicamente os fatos, além do Currículo Mínimo implantado pelo Governo, entidades como ABEA e CEAU foram criadas na década de 1970 e realizaram diversas discussões sobre o ensino a partir de avaliações sistemáticas. As informações produzidas até então, seja pelas escolas com trajetória de várias décadas, assim como, por estas entidades, daria oportunidade para que novos cursos fossem criados sob bases mais sólidas de discussão sobre o ensino. Porém, este cenário que supostamente levaria a implantações com maior respaldo de informações e experiências não acarretou em propostas inovadoras, sendo visto por meio dos históricos analisados trajetórias orientadas, prioritariamente, por meio de resoluções regulamentadoras do ensino e parecidas entre si.

Algo que ocorreu neste período e que pode ser considerado como um fato diferenciado em relação às décadas anteriores foi a interiorização do ensino de arquitetura, a partir da implantação de novos cursos (em instituições públicas) não apenas nas demais capitais do país, mas também em cidades do interior dos Estados, como é o caso de Pelotas e Londrina, respectivamente, UFPel e UEL.

Quando analisado o conjunto de escolas criadas neste período (década de 1970), há um número mais expressivo de implantações realizadas a partir de desmembramentos dos cursos de Engenharia Civil (não todas), sendo que, das seis escolas visitadas, todas elas ainda hoje compartilham da infraestrutura laboratorial pertencente aos cursos da Engenharia Civil, com exceção de uma que, devido ao referido curso ter sido criado tardiamente, não faz uso deste tipo de espaço técnico nas atividades didáticas. Foi constatado que até o fim da década de 1970, um percentual de 55,5\% dos Estados da Federação possuíam cursos de arquitetura inseridos em instituições públicas, equivalendo a 35,5\% das escolas atualmente existentes no país.

As demais escolas foram criadas no período pós-ditadura, sendo a década de 1980 a que apresentou o menor número de cursos implantados em instituições públicas, apenas 02 (dois) em instituições estaduais no interior do estado de São Paulo (USP-São Carlos e UNESP-Bauru). Na década de 1990, o Currículo Mínimo é substituído pelas Diretrizes Curriculares, sendo observada neste período uma expansão significativa na criação de cursos de arquitetura em instituições públicas, chegando a 09 escolas, implantadas tanto nas demais capitais como também em outras cidades do interior dos estados, sendo 03 delas no estado de Minas Gerais. Dentre as escolas do período pós-ditadura e visitadas neste trabalho apenas 01 possui 
infraestrutura laboratorial própria na área da Tecnologia da Construção e as demais compartilham desta infraestrutura com outros cursos. Até o fim da década de $1990,70 \%$ dos estados da federação possuíam cursos de arquitetura inseridos em instituições públicas.

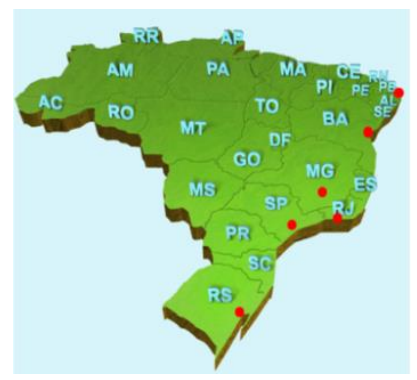

Antes da década de 1960



Durante a década de 1960

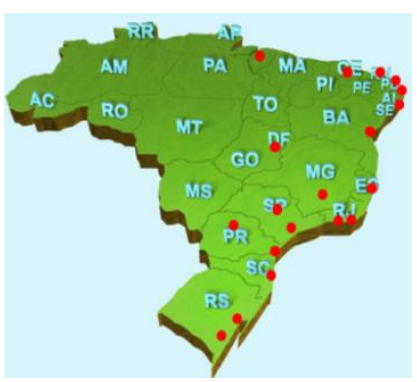

Durante a década de 1970 e 1980



Durante a década de 1990

Figura 110 - Sequencia de imagens indicando cronologicamente as implantações das escolas inseridas em instituições públicas pelo território nacional (visitadas e não visitadas).

Fonte: Adaptação realizada pela autora a partir de http://emec.mec.gov.br/.

Foi possível identificar por meio das visitas técnicas que escolas pertencentes a uma mesma região apresentam diferentes configurações de infraestrutura laboratorial, havendo situações de inexistência ou não utilização, levando a crer que, especificamente sobre o tema estudado neste trabalho, poucas escolas exercem influência regional sobre as outras, com indicativos de pouco intercâmbio e conhecimento sobre a infraestrutura das escolas da mesma região e de outros locais do país.

Embora muitas escolas relatem o alinhamento de seus projetos pedagógicos às Diretrizes Curriculares de 1994, tendo também como apoio outro documento publicado no mesmo período pela comissão do CEAU: Perfis da Área \& Padrões de qualidade - expansão, reconhecimento e verificação periódica dos cursos de Arquitetura e Urbanismo ${ }^{201}$, não foi visto impacto deste documento e mudanças significativas na infraestrutura laboratorial da área técnico-construtiva nas escolas implantadas após este período ou reestruturações infraestruturais nas escolas já implantadas a partir deste respaldo (ver Gráfico 08).

O próximo item traz reflexões relevantes sobre os dados levantados ao longo das visitas técnicas, a partir do compilamento e análise de diferentes informações que envolvem a área da Tecnologia da Construção.

\footnotetext{
${ }^{201}$ O qual trazia informações mais consistentes sobre indicadores e padrões de qualidade para a abertura de novos cursos de graduação, principalmente críticas sobre a inexistência ou inadequação dos espaços experimentais na área da Tecnologia da Construção.
} 


\subsection{CONFLUÊNCIA DE ENTENDIMENTOS SOBRE A ÁREA EXPERIMENTAL CONSTRUTIVA ENTRE AS ESCOLAS VISITADAS}

As reflexões sobre o ensino não tratam, com a devida relevância, da formação docente em áreas específicas como a pedagogia, pois se entende que, instintivamente ou voluntariamente, diversos docentes buscam formação complementar e se dedicam à discussão sobre o assunto seja nas constantes auto avaliações sobre suas práticas, como também na participação dos debates ao longo dos processos reestruturantes. Na legislação vigente também não há instrução específica sobre a formação pedagógica de professores, transferindo essa atribuição à própria formação em nível superior. De acordo com o Artigo 66 da Lei de Diretrizes e Bases da Educação (LDB) a "preparação para o exercício do magistério superior far-se-á em nível de pós-graduação, prioritariamente em programas de mestrado e doutorado", assim como, segundo a Lei № 12.378, de 31 de dezembro de 2010 que regula o exercício da profissão de arquiteto, no seu inciso VIII do Artigo 2o, dentre as atribuições do arquiteto constam: "treinamento, ensino, pesquisa e extensão universitária".

Em relação à liberdade concedida, Trigueiro (1999) realiza considerações polêmicas ao colocar que a cultura organizacional, pautada na autonomia por parte dos docentes e dirigentes acadêmicos, leva as universidades públicas a desenvolverem resistências a quaisquer interferências externas. A referida autonomia está diretamente associada à liberdade de escolha do enfoque disciplinar e curricular e, indiretamente, à escolha do problema de pesquisa, das relações com a comunidade científica e artística que, muitas vezes, produz impactos na forma como são conduzidas as disciplinas e na decisão interna das prioridades acadêmicas e administrativas.

Suas considerações esbarram na nítida dificuldade em se estabelecer limites entre liberdade estrutural-pedagógica e a abordagem do conteúdo mínimo necessário na formação acadêmica e, diante da instituição de competências profissionais comuns em todo o território nacional, surge o seguinte questionamento: poderia haver discrepância na formação técnica a partir da diversificação de estruturações curriculares, infraestrutura física e recursos humanos, quais seriam os limites das adequações contextuais?

Um exemplo sobre a dificuldade em se chegar a uma resposta objetiva sobre esta questão, e que evidencia prós e contras relacionados à liberdade propositiva/metodológica, pode ser vista em dois fatos que ocorreram no mesmo ano de 1962, quando duas escolas de Arquitetura, UNB e USP, instituem o mesmo eixo tronco em suas propostas acadêmicas: 
Projeto, Teoria e Tecnologia, apresentando cada uma delas estratégias diferenciadas para conduzir suas atividades pedagógicas. Na UNB, procurava-se viabilizar os conceitos bauhauseanos e suas práticas dentro do peculiar contexto de Brasília, onde o canteiro ocorria dentro de uma universidade em construção, inserida em uma cidade em construção. Enquanto na FAUUSP, a proposta curricular previa a utilização de uma infraestrutura laboratorial tradicional, que sofreu um dinâmico processo de adaptação ao longo dos anos de acordo com as condições espaciais e humanas disponíveis em cada período. Estes exemplos revelam o resultado da dinâmica aplicada a partir da liberdade dada às escolas, que podem gerar propostas criativas na condução das atividades a partir de variáveis particulares, mesmo seguindo princípios norteadores semelhantes.

Por outro lado, diversas discussões e ações realizadas ao longo dos anos trazem indicativos de que processos regulatórios podem ser considerados como ferramentas úteis na garantia de uma formação básica e homogênea no país, pelo menos no plano teórico. Mas, também, podem vir a dificultar adaptações contextuais, assim como, dificultar discussões mais aprofundadas sobre determinados assuntos, formalizando posicionamentos pontuais e pessoais de atores que, geralmente, estão à frente destas discussões.

Como já sinalizado no início deste Capítulo, os desafios enfrentados na área da Tecnologia da Construção não se resumem ao arranjo físico laboratorial, mas envolvem aspectos políticoeducacionais, estruturais, sócio-econômicos e também questões de fundo, como a natureza das relações interpessoais e burocráticas. Os próximos itens foram desenvolvidos a partir da sistematização das informações obtidas junto aos principais atores à frente da área da Tecnologia da Construção das escolas visitadas; suas considerações estão apresentadas na forma de síntese geral, de modo a gerar um debate (indireto) sobre a questão e de preservar o anonimato dos entrevistados.

\subsubsection{ESTRUTURA CURRICULAR E OS CONTEÚdOS DA ÁREA DA TECNOLOGIA DA CONSTRUÇÃO}

Com relação à grade curricular, foi possível perceber ao longo da pesquisa, que alguns autores e entrevistados não atribuem muita importância à mesma como instrumento promotor de mudanças significativas na área. Mas, a partir da análise de diferentes propostas pelo país, verificou-se que esta questão não deveria ser subestimada, pois evidencia documentalmente algumas particularidades estruturais como: a) o desequilíbrio entre áreas e a relação direta entre grade e composição do quadro docente; b) alocações que revelam a existência ou não de 
estratégias pedagógicas por meio da conexão entre conteúdos e disciplinas; c) liberdade propositiva e indícios da heterogeneidade de formações acadêmicas entre os cursos.

Ainda sobre a estrutura curricular, as primeiras recomendações da Carta de Ouro Preto de 1977, defendem que o Currículo Mínimo deveria preservar a unidade na formação profissional em âmbito nacional e atender às mais amplas atribuições profissionais, para isso, deveria ser evitada a tendência à formação de especializações com a defesa da formação generalista ${ }^{202}$. Como proposta, é sugerido que as matérias abrangessem as seguintes áreas de conhecimento, com os respectivos percentuais de carga horária: Planejamento e Projeto, 40\%; Tecnologia e Instrumentação, 20\% e Teoria e História, 20\%. Os 20\% restantes ficariam a critério de cada escola. Sobre valores destinados à área técnica, a autora Leite (2005), considera que o primeiro sinal de desprestígio da área tecnológica em relação às demais seria o tempo curricular dedicado, identificando que a partir do Currículo Mínimo de 1969 a carga horária destinada às disciplinas de tecnologia decresce para $25 \%$ a $30 \%$ da carga horária total do curso. Quando comparados os dados da autora com as recomendações da Carta de Ouro Preto, nota-se que o desprestígio é ainda maior em 1977, quando sugerem apenas $20 \%$ do tempo curricular às disciplinas de cunho técnico.

Já na década de 1990, a segunda avaliação do CEAU trouxe considerações importantes neste sentido, algumas delas sobre o dramático cenário infraestrutural/técnico das escolas, com a proposição de diretrizes que minimizassem tal problema e orientassem novas demandas a diversificarem suas metodologias acadêmicas como a utilização de laboratórios, não se restringindo apenas a aulas teóricas. Não há menção neste documento sobre a relação entre utilização de infraestrutura laboratorial e carga horária demandada, pois caso esta sugestão fosse aplicada, consequentemente, seria necessário tempo compatível para a aplicação de novos recursos pedagógicos como o laboratorial. Esta questão foi observada ao longo da pesquisa, com indicativo de contínuo declínio, diante da diminuição gradativa da carga horária destinada à área tecnológica e o enxugamento do tempo destinado a estas disciplinas, levando a questionamentos sobre o distanciamento do plano teórico dos Projetos Pedagógicos e Diretrizes Curriculares em relação às proposições acadêmicas colocadas em prática. Provavelmente, contribuiu para este fato, o natural processo de inserção de novas disciplinas na composição da grade curricular ao longo do tempo, dificultando o balizamento

\footnotetext{
${ }^{202}$ Estas intenções permanecem até hoje nas Diretrizes Curriculares e são recorrentes em diversos Projetos Pedagógicos consultados neste trabalho.
} 
entre conteúdos essenciais e aqueles que podem valer-se de outras estratégias para sua abordagem e não, necessariamente, a criação de novas disciplinas.

Em relação aos dados obtidos nas visitas técnicas não foi possível estabelecer paralelos entre estruturação curricular e as categorias históricas a que cada escola pertence, assim como, a seus modelos de origem (Belas Artes ou Politécnico), esta dificuldade se estende também para correlações regionais, já que as discrepâncias entre os cenários encontrados ocorrem também dentro de uma mesma região ou estado.

Quando analisada a carga horária (C.H.) percebe-se que os cursos que destinam maior número de créditos à área da Tecnologia da Construção, não necessariamente destinam maior C.H. para esta área, devido à relação direta entre a C.H de uma área e a C.H geral do curso, sendo que, esta última é díspar entre os cursos (ver Quadro 32). O número de créditos destinados a estas disciplinas varia de 8 a 20 créditos, em que o mínimo não chega à metade do valor máximo encontrado; quanto ao espaço que esta área ocupa no curso varia entre 3,7 a $9 \%$. O cenário é parecido quando analisados os dados referentes à carga horária de toda área da Tecnologia da Arquitetura, ocupando de 19\% a 34\% dos créditos totais das disciplinas obrigatórias, com números que variam de 38 a 83 créditos destinados à área técnica. Os dados indicam que $1 / 3$ das escolas visitadas destinam menos que $25 \%$ de sua carga horária para a área da Tecnologia da Arquitetura (ver os Gráficos 02 a 05 em associação ao Quadro 32).

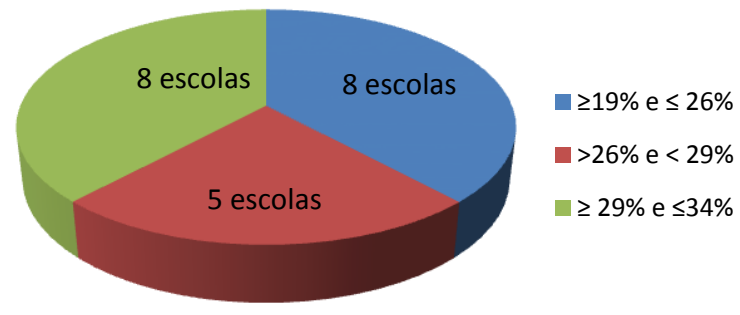

Gráfico 02 - Área ocupada pela Tecnologia da Arquitetura nas grades curriculares

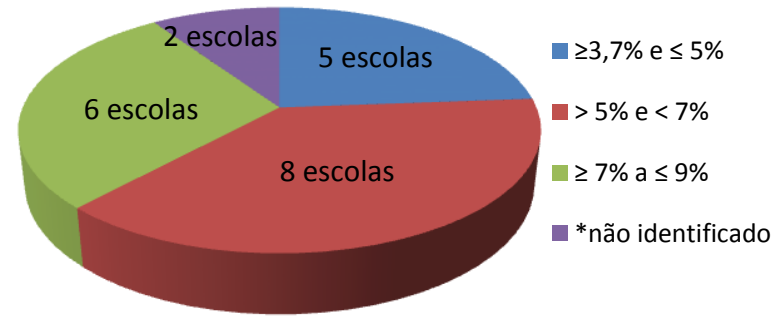

Gráfico 04 - *Área ocupada pela Tecnologia da Construção de acordo com as grades curriculares

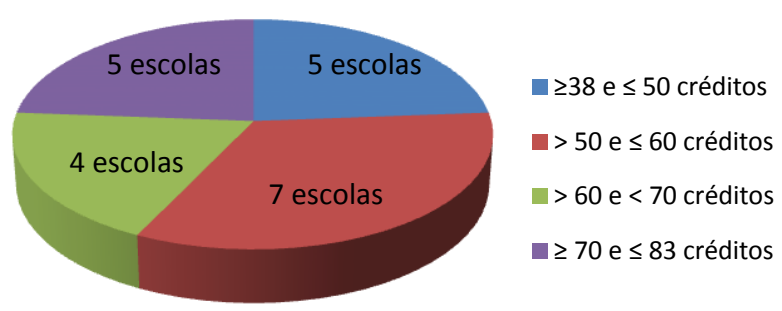

Gráfico 03 - Número de créditos destinados à Área da Tecnologia da Arquitetura

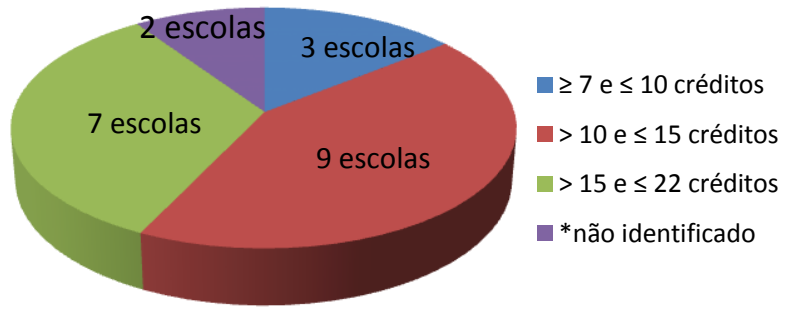

Gráfico 05 - *Número de créditos destinados à área da Tecnologia da Construção

\footnotetext{
* Obs: As escolas que adotam o mecanismo de fusão entre as áreas de Tecnologia da Construção e Sistemas Estruturais estão inclusas no grupo 'não identificado'.
} 
Como já sinalizado, atualmente, vivencia-se a contraditória questão entre a diminuição da C.H. técnica nos cursos e a inserção de atividades experimentais no ensino ${ }^{203}$ que, naturalmente, necessitam de um tempo maior para sua realização. Outro problema gerado com a perda da C.H. e comentado ao longo das entrevistas, relaciona-se à retirada de determinados conteúdos que deveriam ser abordados com maior cuidado, para que os alunos não corram o risco de construírem seus projetos sob bases superficiais e frágeis de conhecimento. Diante da baixa C.H. para abordagem de um extenso e complexo conteúdo, uma estratégia usualmente utilizada em alguns locais tem sido requisitar apoio de outras disciplinas, de maneira a alimentar e incrementar os assuntos referentes à materialidade, principalmente, quando estas demandam um conteúdo que ainda não foi ou não será abordado.

Outra questão observada durante as análises das grades curriculares volta-se às denominações de algumas disciplinas da área da Tecnologia da Construção, no que diz respeito à falta de conexão entre o nome da disciplina e seu conteúdo (diversas disciplinas chamadas de Tecnologia da Construção possuem como conteúdo assuntos ligados a Instalações prediais, Mecânica dos solos, Estruturas, Orçamento, etc.), fato ocasionado muitas vezes pela fusão de matérias para diminuição de C.H., destituindo-as de seus conteúdos específicos. Em outras situações foram encontradas diferentes denominações para o mesmo conteúdo: Materiais de Construção, Técnicas Construtivas, Processos Construtivos, Sistemas Construtivos, Construção Civil, Tecnologia da Construção, Tectônica, etc. Nesse sentido, muitas revisões se dão apenas para demonstrar atualização, cujo resultado volta-se à alteração de nomes de disciplinas e suas cargas horárias sem uma estratégia pedagógica bem definida.

Foi observado que a maior parte das escolas aborda, simultaneamente, conteúdos referentes tanto a área de Materiais Construtivos como Técnicas Construtivas, sendo esta estratégia considerada positiva para facilitar o processo de compreensão dos alunos sobre a aplicabilidade dos conceitos teóricos. Com relação às propostas consideradas diferenciadas, foram encontradas apenas 02 escolas que adotam (intencionalmente) o sistema de fusão entre o conteúdo da área da Tecnologia da Construção e Sistemas Estruturais, mas foi observado que esta fusão restringe-se às intenções e ao nome da disciplina e não na forma de abordagem, pois a estruturação das ementas apresenta-se próxima às tradicionais, cujo conteúdo está dividido entre Tecnologia da Construção e Sistemas Estruturais. Tal situação

\footnotetext{
${ }^{203}$ A análise dos Projetos Políticos Pedagógicos revelaram que $24 \%$ dos cursos (05) discutem a questão da infraestrutura laboratorial em seus projetos, $67 \%$ dos cursos não discutem (13) e $4 \%$ deles (03) estão de alguma forma iniciando esta discussão em outras instâncias.
} 
pode ser explicada diante da dificuldade de contratação de docentes para ministrar os três conteúdos de forma indissociada: Materiais Construtivos, Técnicas Construtivas e Sistemas Estruturais - dentro da complexidade exigida na formação dos futuros profissionais - com riscos de ser oferecida uma abordagem superficial destes conteúdos. Essa abordagem fundamenta-se no pressuposto de que a abordagem deve acompanhar o processo de concepção projetual, quando todos esses assuntos são trabalhados simultaneamente.

As diferentes propostas curriculares e alocações revelam indicativos sobre a liberdade na estruturação curricular dos cursos, a partir de diferentes motivações (nem sempre estratégicas) quando encontrados currículos que iniciam o conteúdo sobre Tecnologia da Construção (Materiais e Técnicas Construtivas) em diferentes períodos, ora no 1으 semestre, ou

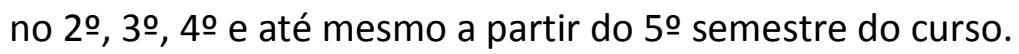

Foram apresentados diferentes pontos de vista sobre o momento ideal para ser iniciada a matéria. Nas escolas onde o ensino inicia no $1^{0}$ ano, foi declarado que os alunos já possuem maturidade para isso (matérias de caráter introdutório), pois chegam muito bem preparados do vestibular, sendo uma estratégia importante para que o aluno tenha uma visão generalista da profissão desde o início da formação, sendo o $2^{\circ}$ ano também indicado como um bom momento para iniciarem o conteúdo. Este posicionamento não foi compartilhado por alguns docentes de escolas que não vivenciam este tipo de experiência, os quais consideram os alunos, até mesmo do 20 ano, imaturos para o conteúdo relativo à Tecnologia da Construção. O ponto consensual relatado foi que, a partir do 5으 período seria tardio para iniciar esta abordagem.

Embora haja exceções, de modo geral, as entrevistas revelaram a ausência de estratégias na condução das disciplinas da Tecnologia da Construção e falta de conexão entre os conteúdos das disciplinas desta área, assim como, a falta do diálogo com as demais disciplinas do curso. Foram observadas recorrentes adequações no conteúdo ministrado das disciplinas, sendo em diversos momentos realizadas de acordo com o entendimento individual do docente envolvido, ou implantadas sem uma definição estratégica. Esta situação muitas vezes ocorre devido à falta de diálogo entre os cursos de Arquitetura e Engenharia (nos casos em que as disciplinas são delegadas) e também dentro do próprio curso de arquitetura (quando as disciplinas são assumidas pelo curso), pela ausência de estruturação clara da área em relação aos objetivos do curso como um todo.

Um exemplo apontado foi a desconexão entre as disciplinas da cadeia da Construção e de Sistemas Estruturais, com relatos sobre o impacto negativo quando o conteúdo referente a 
estruturas é iniciado posteriormente à Tecnologia da Construção, sendo recomendável que os conceitos voltados à Estruturas sejam abordados antes ou simultaneamente. Ainda sobre estas duas áreas, um fator apontado como uma das causas para o desinteresse dos alunos pela área da Tecnologia da Construção em relação à de Sistemas Estruturais, seria a preocupação primordial pelos aspectos ligados ao que é 'graficável', em outros termos, à geometria, devido a grande preocupação pelo pré-dimensionamento e ao impacto das dimensões no desenho. Como os materiais e técnicas construtivas nem sempre são levados em consideração na concepção ou até mesmo representados de acordo com a realidade, estes aspectos são subestimados e pouco explorados nas disciplinas de Projeto, evidenciando a falta de reconhecimento do impacto que as técnicas e materiais construtivos geram na obra construída.

Em outros casos, diante da necessidade em aproximar o conteúdo técnico (Tecnologia da Construção e Sistemas Estruturais) das disciplinas de Projeto, algumas escolas tem realizado experiências na intenção de promover maior integração entre as áreas, segue a compilação das informações obtidas e os resultados da implantação destas estratégias articuladoras ${ }^{204}$ :

1) Atrelamento do conteúdo das disciplinas de Tecnologia à temática semestral de Projeto - Foram identificados alguns problemas desta proposta, um deles relacionado à grande quantidade de assuntos que devem ser contemplados pelo reduzido número de disciplinas da área construtiva e, caso os assuntos forem delimitados com o objetivo de darem o referido respaldo à Projeto, as disciplinas técnicas ficariam ainda mais restritas;

2) Presença de um professor da área da Tecnologia (de Materiais, Técnicas ou de Sistemas Estruturais) nas disciplinas de Projeto - Esta proposta tem sido recorrente em muitos cursos, mas por serem ainda incipientes e a maioria delas estarem no plano intencional, foram apenas apontadas questões conflitantes surgidas até o momento, como a dificuldade na consideração da carga horária dos professores da tecnologia, para que seja evitada a informalidade do antigo formato 'atendimento/assessoria'. Pois os professores da área de tecnologia e, em muitos casos, pertencentes a outros cursos apresentam-se em número reduzido e possuem pouca disponibilidade de tempo para se adequarem à proposta sugerida pelos cursos de arquitetura. Outra questão apontada seria que tal proposição teria melhores resultados quando trabalhada com alunos que estejam cursando os últimos anos, pois a maturidade

\footnotetext{
204 Diversas falas ao longo das entrevistas levam à hipótese de que a atual formação excessivamente acadêmica dos professores de projeto tem dificultado a abordagem técnica nestas disciplinas, levando muitos cursos a buscarem novas estratégias para sanarem esta lacuna.
} 
permitiria aprofundar as discussões, antes disso, o aluno ainda está formando seu repertório sobre os assuntos relativos à materialidade;

3) A implantação dos chamados 'Ateliers Integrados' - Criados na intenção de aproximar as diferentes áreas em torno de um mesmo tema de projeto, sendo este um espaço para a aplicabilidade dos conhecimentos adquiridos. Esta proposta tem sido aderida por muitos cursos, e ganho cada vez mais adeptos, como observado nas novas reformulações de Projetos Pedagógicos e entrevistas realizadas. Para sua implantação deve-se atentar para a C.H. geral do curso e a compatibilização desta proposta com as demais disciplinas;

4) A área da Tecnologia ser integralmente assumida pelos cursos de Arquitetura - Esta proposta tem sido sugerida diante da constante insatisfação por parte dos cursos de Arquitetura sobre a condução da área, defendendo que deveria ser menos próxima da abordagem direcionada aos cursos da Engenharia Civil e mais associadas às disciplinas de Projeto. Foram observadas ações neste sentido realizadas mesmo com a ausência de infraestrutura laboratorial, sendo um indicativo de que, para alguns cursos, as disciplinas podem ser conduzidas sem a realização de práticas experimentais ${ }^{205}$.

Diante das diferentes propostas para a condução da área da Tecnologia da Construção foi identificado um questionamento muito recorrente ao longo das entrevistas e realizado com preocupação pelos professores engenheiros. A questão estaria relacionada ao nível de abordagem dos conteúdos e sua associação às competências técnicas dos futuros profissionais (atualmente ampliada devido à aplicação das Normas de Desempenho), com constantes indagações sobre o conteúdo ideal a ser ministrado aos alunos da arquitetura, de maneira que sejam contempladas as atuais competências técnicas da profissão. Para que isso ocorra, os cursos de Arquitetura deveriam dar o apoio necessário na realização de reestruturações que permitam esta abordagem.

Esta questão vai ao encontro do conflito de entendimentos e de consenso observados ao longo das entrevistas, refletindo a permanente dúvida (de ambas as partes) sobre o que deveria ser abordado e o que explorar como conteúdo e atividade experimental nos cursos de

\footnotetext{
${ }^{205}$ Foi comentada em diversos cursos a intenção de que a área técnica seja ocupada primordialmente por arquitetos e não por engenheiros, a partir do pressuposto de que a linguagem do arquiteto facilitaria os estudantes a compreenderem o conteúdo relativo à materialidade e esta proposta também vem se estendendo às disciplinas de Sistemas Estruturais. Por outro lado, foram diversas as falas que consideram positiva a interatividade dos alunos com profissionais de outros cursos e até mesmo o fato de saírem de suas unidades e estudarem em outros centros, contribuindo para a formação generalista e multidisciplinar, aproximando o aluno do futuro cenário profissional onde é requerido o diálogo com atores de diferentes formações.
} 
arquitetura, associar o conteúdo às futuras competências profissionais ou realizar uma abordagem em associação ao projeto arquitetônico.

Os dados permitem concluir que, dificilmente será possível indicar um modelo ideal, diante de resultados positivos e negativos presentes nas diferentes práticas aplicadas. Esta questão pode ser exemplificada a partir de experiências docentes que, mesmo com a adoção de metodologias pautadas em atividades prioritariamente científicas, conseguiram sucesso ao despertar o interesse e a boa formação dos alunos da arquitetura, situação que leva a questionamentos sobre outros pontos de vista, que consideram esta prática como inapropriada à formação do arquiteto e voltada à formação do engenheiro, sendo sugerido que as atividades fossem mais lúdicas para que esse interesse pudesse ser despertado ou que o conteúdo fosse diretamente aplicável ao projeto, destituindo o aluno da co-responsabilidade em realizar o processo de integração. Permanece, portanto, a constante dúvida se a formação deverá fornecer subsídios diretamente aplicáveis ao projeto ou fazer o aluno, de fato, conhecer na medida da complexidade possível, o que é a produção da edificação real (cuja abordagem muitas vezes é realizada de forma indireta ao processo projetual).

E, diante de propostas tão diversificadas para a área da Tecnologia da Construção, pode-se retomar a pergunta inicialmente introduzida neste texto: como alcançar a homogeneização da qualificação profissional nos vários pontos do país e garantir as mesmas atribuições profissionais de caráter técnico diante de propostas curriculares tão diferenciadas? Como garantir que conteúdos cada vez mais complexos e amplos sejam desenvolvidos dentro de um espaço tão reduzido de tempo? A partir dos dados analisados pode-se descartar alguns caminhos, como a simples adoção de leis e documentos normativos (cuja dinâmica de discussão resulta em revisões e atualizações lentas e descompassadas com o que acontece na sociedade), pois não garantem que será alcançada a formação acadêmica necessária ao atendimento das futuras competências, assim como, o formato normativo não assegura que o conteúdo presente no plano teórico do Projeto Pedagógico seja realmente cumprido pelas escolas.

\section{- A inserção de novos conteúdos}

Sobre a inserção de novas temáticas no nível da graduação como: materiais de baixo impacto ambiental, ciclo de vida, cadeia produtiva, gestão de resíduos e normas de desempenho (as quais ficaram durante muito tempo restritas à pós-graduação), foram expostos ao longo das entrevistas diferentes pontos de vista sobre a possibilidade de 
abordagem destes assuntos. As principais informações foram compiladas e sistematizadas de acordo com a frequência com que foram citadas:

- Foi relatada que a abordagem de conteúdos que incluem processos construtivos diferenciados (autoconstrução, construção ecológica, adoção de resíduos, etc.) tem confundido os alunos. Isto se deve ao fato de que estes assuntos, muitas vezes, não têm base consolidada a partir de princípios científicos, havendo certa incompatibilidade com outros conteúdos abordados em sala de aula, sobre qualidade das construções, requisitos de desempenho, normatização, etc.;

- Diante da disponibilidade cada vez maior de diferentes materiais no mercado, o compromisso do ensino acadêmico seria compreender as técnicas já consolidadas, equilibrando questões como formação atualizada $X$ dados científicos a partir de fontes confiáveis. Sobre isso, foi também colocada a necessidade de uma abordagem cuidadosa na graduação, sendo recomendado que a prioridade seja a aprendizagem consistente dos conceitos básicos que norteiam, também, o entendimento e a aplicação de outras tecnologias inovadoras;

- Muitos entrevistados declararam ser mais indicado que estes assuntos sejam condensados em uma disciplina optativa específica, para que seja possível uma abordagem mais aprofundada diante da complexidade do tema e a lógica que está por trás destes materiais e processos. Atualmente, a abordagem deste assunto é geralmente realizada de maneira informal, estando restrita ao envolvimento do docente com as pesquisas de pósgraduação desenvolvidas nesta linha específica, sendo esta uma condição para que seja possível levar este conteúdo à instância do Ensino. A situação mais comum de envolvimento do aluno de graduação com esta temática seria em projetos de Iniciação Científica e Extensionistas e não no ambiente do Ensino. Portanto, a abordagem destes conceitos está muito vinculada à iniciativa pessoal docente e do seu envolvimento profissional com pesquisas desta natureza;

- Devido ao fato destes temas não serem formatados para abordagem exclusiva em uma disciplina específica, sua inserção tem sido realizada de forma gradativa e diluída aos conteúdos tradicionais. Foi comentado que, para que isso aconteça, alguns assuntos tradicionais são sacrificados diante da baixa carga horária disponível;

- Além dos comentários em sala de aula, outra estratégia comumente colocada em prática para a abordagem destes assuntos seria o desenvolvimento de trabalhos pontuais pelos 
alunos, sendo esta uma forma de colocá-los em contato com o conteúdo e trazer para a sala de aula seus pontos de vista e dúvidas para discussão.

Além da estruturação curricular e delineamento do conteúdo da área da Tecnologia da Construção, outras questões relativas à Infraestrutura laboratorial e práticas metodológicas foram levantadas, estando apresentadas no item 4.2.2.

\subsubsection{INFRAESTRUTURA FÍSICA LABORATORIAL E AS PRÁTICAS ACADÊMICAS}

Como já descrito nos itens anteriores, ao longo das visitas técnicas foram encontrados diferentes cenários quanto à forma de condução das atividades voltadas à Tecnologia da Construção (TC), sendo de grande relevância o aspecto ligado ao modelo adotado pelas escolas visitadas quanto à responsabilidade das disciplinas desta área, havendo influência direta entre este aspecto e as metodologias exploradas, assim como, na utilização e configuração dos espaços experimentais.

O Gráfico 06 refere-se às situações encontradas e sintetizadas a partir do Quadro 32 do Capítulo 03. Estes valores indicam a somatória de modelos, pelo fato de algumas escolas adotarem o modelo misto - quando há várias situações de condução das disciplinas da área da Tecnologia da Construção - enquanto outras adotam um único modelo, indicando então a representatividade de cada modelo.

\section{Modelo atual adotado pelas escolas}

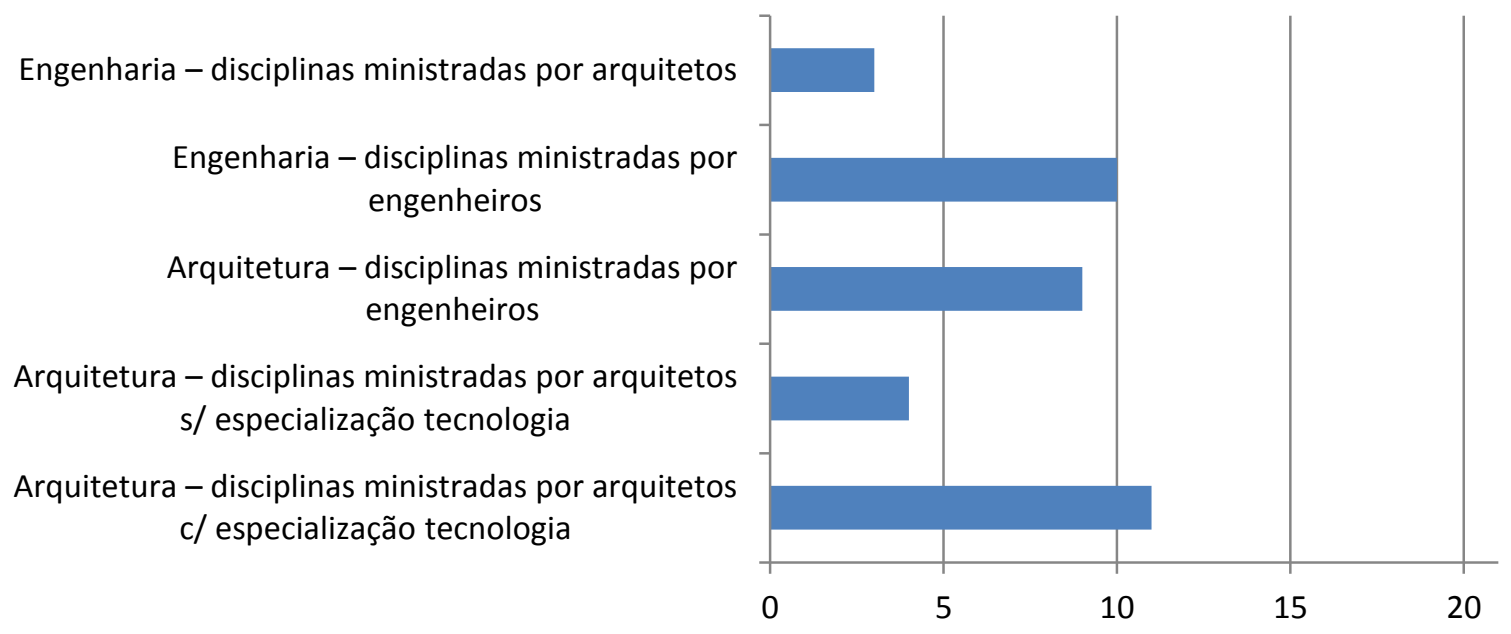

Gráfico 06 - Modelo atual adotado pelas escolas - responsabilidade assumida para a área da Tecnologia da Construção - número de situações encontradas.

Os números mais representativos são os de cursos cujas disciplinas da área da Tecnologia da Construção são ministradas por arquitetos com especialização nesta área, seguidos dos 
cursos em que as disciplinas são conduzidas por engenheiros pertencentes ao quadro docente do curso da Engenharia Civil. Posteriormente, estão os cursos de Arquitetura que possuem engenheiros em seus quadros docentes, sendo os atores responsáveis pela área da Tecnologia da Construção. Estes são, portanto, os três modelos predominantes nas escolas visitadas. De acordo com o Quadro 32, do total de 21 escolas, 12 delas (57\%) adotam o modelo misto, com a adoção de mais de um modelo e, 09 escolas (43\%), um único modelo ${ }^{206}$.

Ao analisar a participação de cada perfil profissional (engenheiros e arquitetos) à frente das disciplinas, independentemente se a área da TC é assumida pelo curso da Engenharia Civil ou da Arquitetura, é possível verificar que, em média, há uma participação equilibrada de cada perfil profissional, $50 \%$ de arquitetos e $50 \%$ de engenheiros.

Os dados levantados dão indicativos de que não há associação direta entre a adoção de um modelo específico e a melhor estruturação da área, pois dentro de cada modelo (disciplinas ministradas por engenheiros ou arquitetos ou então assumidas pelo curso de engenharia ou arquitetura), há situações muito diversificadas, sendo dois outros fatores considerados como mais relevantes na estruturação da área da Tecnologia da Construção:

- Perfil docente - independentemente da formação em arquitetura ou engenharia - algo importante é a afinidade e formação complementar especificamente na área da Tecnologia da Construção, sendo esta uma condicionante para que sejam realizadas pesquisas e investimentos contínuos nesta área, principalmente, as de ordem prática/laboratorial, estejam elas vinculadas ou não à pós-graduação. Além disso, para a abordagem de determinados conteúdos (como Técnicas construtivas e Gestão de obras), ter experiência prática de obra e mercado são considerados aspectos diferenciais;

- Relacionamento intra e inter curso(s) - o fato das disciplinas serem conduzidas por docentes pertencentes a outros cursos não foi visto como um complicador, mas a relação estabelecida entre os cursos pode ser considerada determinante. Sendo verificado que, em cursos onde há uma relação satisfatória entre Arquitetura e Engenharia Civil, a área da TC apresenta-se melhor estruturada e, em muitos casos, são realizadas pesquisas conjuntas. Ainda sobre esta questão, independentemente do modelo adotado, o curso de arquitetura deve dar o apoio necessário assumindo a responsabilidade da área da TC, tanto na proposição

\footnotetext{
${ }^{206}$ Das 09 escolas que adotam um único modelo: em 02 delas as disciplinas são de responsabilidade do curso de Arquitetura e ministradas por arquitetos com especialização em Tecnologia; 01 escola assume as disciplinas, mas estas são ministradas por arquitetos sem especialização na área; outras 02 escolas tem suas disciplinas ministradas por engenheiros pertencentes ao quadro docente da Arquitetura; enquanto 04 escolas delegam integralmente as disciplinas para o curso da Engenharia Civil, sendo estas ministradas por engenheiros.
} 
dos conteúdos como também no delineamento das relações estratégicas desta área junto às demais disciplinas.

Dentre os modelos apresentados, o único que apresentou indícios de fragilidade em relação aos demais e, portanto, quando possível deve ser evitado pelas escolas, seria aquele em que as disciplinas são ministradas por docentes arquitetos sem especialização na área da Tecnologia da Construção. Essa formação docente é requerida diante da amplitude e crescente complexidade dos conteúdos, principalmente, diante dos novos desafios que a área enfrentará futuramente, como a inserção de novas temáticas.

\section{As práticas acadêmicas}

A partir do Gráfico 07 é possível identificar as principais metodologias pedagógicas empregadas na condução das disciplinas de TC nas escolas visitadas (além das aulas teóricas, que são empregadas em $100 \%$ das escolas), destacando-se as Visitas à Obra seguida da utilização de Mostruário de Materiais em sala de aula. Posteriormente, está a Análise de Projetos e, em seguida, a realização de Ensaios Físicos em laboratório, sendo proporcionais os casos em que os ensaios são realizados pelos alunos com aqueles em que o técnico laboratorista é quem os realiza. A adoção de processos experimentais como a Construção de Protótipos físicos ainda é um recurso pouco utilizado pelas escolas visitadas, apresentando um número inexpressivo em relação às demais práticas pedagógicas. As escolas que geralmente oferecem este tipo de atividade possuem infraestrutura laboratorial própria, sendo uma proposição adotada prioritariamente pelos cursos da arquitetura.

Deve-se ressaltar que, geralmente, as metodologias pedagógicas são adotadas de forma diversificada pelas escolas, de acordo com o assunto e os recursos físicos, humanos e econômicos disponíveis. 


\section{Metodologia pedagógica adotada nas diciplinas da área da Tecnologia da Construção}

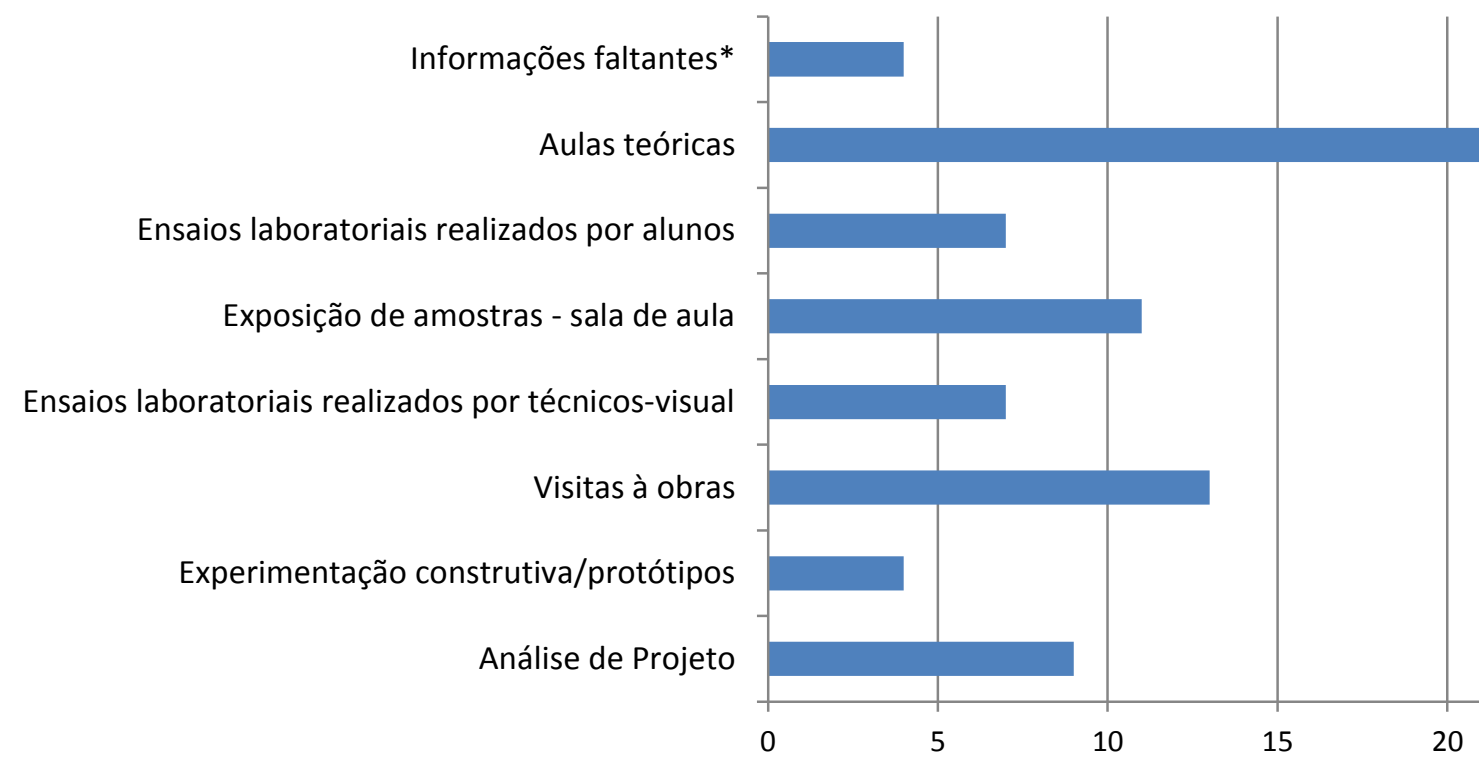

* As informações faltantes referem-se aos casos onde não foi possível obter informações suficientes, geralmente, em escolas onde um dos professores à frente das disciplinas não teve disponibilidade para participar da pesquisa.

Gráfico 07 - Representatividade da metodologia pedagógica utilizada na abordagem do conteúdo das disciplinas de Tecnologia da Construção - oferecida sistematicamente e não eventualmente.

\section{Visitas à obra}

Sobre o vivenciamento do cotidiano da obra, das 21 escolas visitadas apenas 02 delas tem em sua proposta curricular a obrigatoriedade do estágio em obra, sendo relatados consensualmente, os resultados positivos desta iniciativa. Trata-se de uma particularidade diante do cenário presente na maioria dos cursos do país que, geralmente, quando ofertam, é em caráter optativo ou como proposta didática inserida em algumas disciplinas na forma de trabalhos pontuais (62\% dos cursos). Foi possível levantar junto aos docentes entrevistados várias questões que tem interferido, atualmente, na continuidade da adoção desta prática pedagógica junto às disciplinas, como:

a) Diminuição de obras em processo de construção - como o setor da Construção Civil está diretamente ligado ao contexto econômico do país, nos momentos de crise diminui o número de obras disponíveis para serem visitadas. Além disso, nem todas as cidades sedes dos cursos possuem disponibilidade de obras em diferentes fases de construção e em número suficiente para o acesso de todos os alunos; 
b) Exigências quanto à segurança em obra - O acesso ao canteiro de obras junto às construtoras está cada vez mais restrito aos estudantes, principalmente, devido a questões de segurança. Desta forma, recebem um número limitado de visitantes, sendo obrigatória a utilização de EPIs (Equipamentos de Proteção Individual) por parte dos alunos. Além disso, outro complicador para a realização da visita técnica seria a quebra do ritmo da obra, sendo as construtoras obrigadas a adotar outros procedimentos para que seja possível receber os estudantes;

c) Disponibilidade de seguro para visita em obra - A dimensão da responsabilidade docente ao oferecer este tipo de atividade tem sido constantemente questionada pelos professores, diante de alunos que muitas vezes subestimam os perigos aos quais estão expostos, não atentando aos devidos cuidados preconizados em sala de aula e, por ser um local de risco constante, deve haver consciência e clareza quanto aos limites desta responsabilidade. Diante disso, algumas instituições (em número reduzido) oferecem seguro aos alunos em casos de disciplinas em que haja a necessidade do contato laboratorial ou de visitas técnicas. Embora esta possibilidade, a maior parte dos entrevistados relatou a inexistência deste tipo de seguro, sendo mais corriqueiro as instituições oferecerem seguro de viagens técnicas, limitando-se à cobertura de eventuais sinistros durante o deslocamento e não durante a realização das visitas propriamente ditas, ou mesmo das atividades técnicas-laboratoriais. Esta realidade vem desestimulando os docentes para a adoção desta prática pedagógica, devido à falta de apoio institucional em casos de eventuais acidentes;

d) Obras que não adotam procedimentos corretos - Este fato faz com que haja um descompasso entre o conteúdo ministrado em sala de aula e o contexto real, algo que poderia ser corrigido pela presença do docente junto às equipes no momento da visita à obra. No entanto, essa condição é inviável por dois motivos. O primeiro é relativo ao restrito número de alunos que podem, simultaneamente, acessar um canteiro de obras por questões de segurança; portanto, tais visitas são realizadas, geralmente, por grupos pequenos. O segundo motivo decorre do primeiro. Sendo o docente responsável por numerosas turmas de alunos, não há viabilidade de acompanhar todas as equipes compostas por um número restrito de alunos, independentemente do fato das visitas serem realizadas durante o período das aulas ou em horários alternativos. Há o reconhecimento, por parte dos professores, não ser este o cenário ideal, pois, sendo a percepção dos alunos diferente a dos professores, a simbiose e a 
crítica entre o conteúdo da sala e a obra visitada é necessária, especialmente quando essas visitas são realizadas por alunos nos primeiros anos do curso.

\section{Atividades experimentais/laboratoriais}

As visitas técnicas permitiram identificar tanto a existência como a utilização da infraestrutura laboratorial por parte dos cursos de arquitetura, sendo verificado quando o uso compartilhado é uma realidade e não apenas uma formalização para o cumprimento de regulamentações específicas da área.

Foi observado que as configurações dos laboratórios existentes muitas vezes condicionam o tipo de atividade oferecida, e estão diretamente associadas ao perfil docente à frente destas práticas, pois em muitos casos, a infraestrutura laboratorial foi adquirida com recursos provenientes de suas pesquisas. 0 Gráfico 08 expõe os dados referentes aos tipos de espaços encontrados e sua relação com determinado curso (Engenharia Civil ou Arquitetura), dados estes que devem ser analisados de forma conjunta ao Gráfico 09.

\section{Caracterização da infraestrutura laboratorial utilizada pelos cursos de Arquitetura}

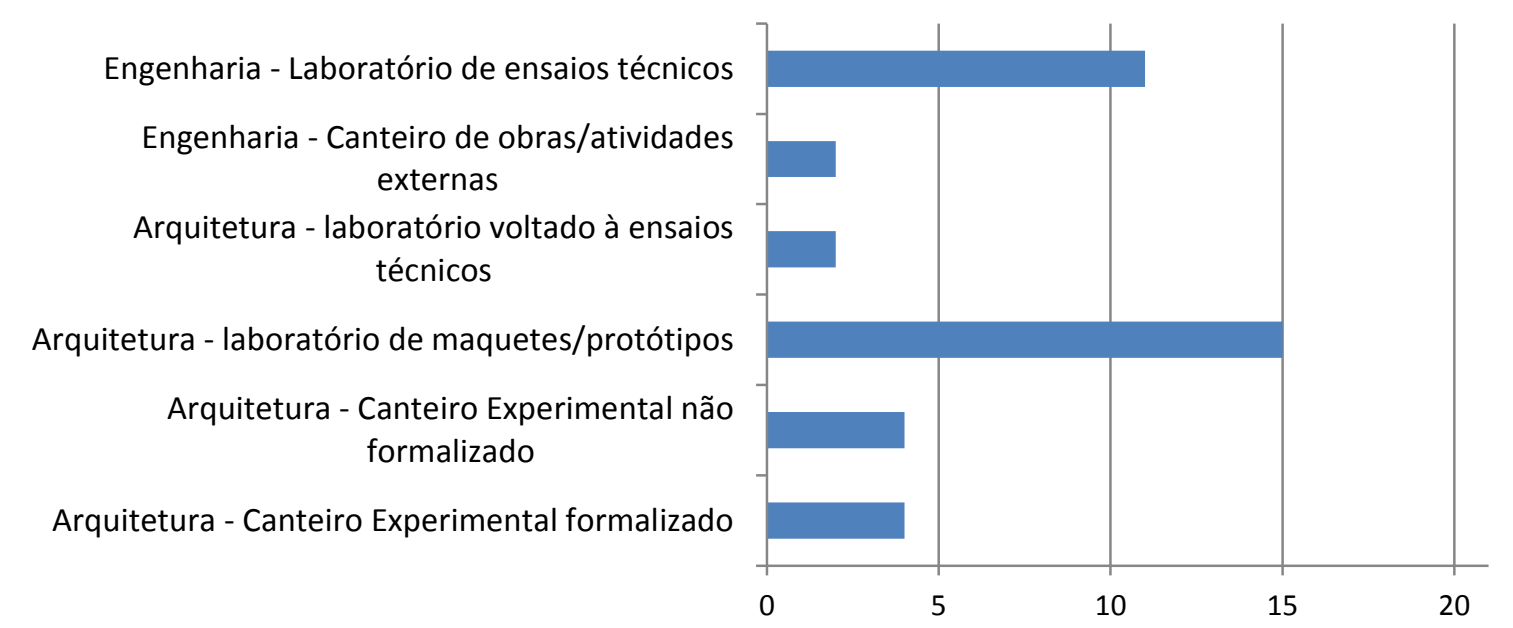

* Em relação à infraestrutura pertencente aos cursos da Engenharia Civil, foram considerados apenas os casos em que realmente ocorre o uso compartilhado e o espaço é utilizado pelo curso da Arquitetura em atividades de Ensino e não pontualmente por alguns alunos de Iniciação Científica ou pesquisas de Extensão.

Gráfico 08 - Existência e caracterização da infraestrutura laboratorial na área da Tecnologia da Construção.

De acordo com os dados expostos no Gráfico 08, os Laboratórios de Maquetes e Protótipos pertencentes aos cursos da Arquitetura aparece com mais expressividade em relação aos demais, embora deva ser considerado neste levantamento que a maior parte deles é, geralmente, pouco utilizada pelas disciplinas da área da Tecnologia da Construção; muitos 
desses laboratórios dão maior suporte às disciplinas da área representacional e de mídias digitais. Ainda de acordo com o Gráfico 08, em segundo lugar aparece a infraestrutura laboratorial pertencente ao curso da Engenharia Civil, como os Laboratórios da Tecnologia da Construção (Materiais e Técnicas construtivas), geralmente voltados a ensaios técnicos e normatizados de caracterização de materiais. Posteriormente, está o uso do Canteiro Experimental $^{207}$ que, em todos os casos analisados é utilizado exclusivamente pelo curso da arquitetura, sendo identificado um número reduzido de escolas que adotam este tipo de recurso. Foi observado proporcionalidade no número de escolas que possuem este espaço formalizado junto ao curso e aquelas que utilizam espaços não formalizados para esta função. O número menos representativo do Gráfico 08 refere-se tanto à utilização de espaços externos pertencentes à Engenharia para a realização de atividades práticas, como também, o de escolas de arquitetura que possuem laboratórios próprios voltados a ensaios físicos de materiais (apenas 02 escolas em relação ao total visitado).

Buscaram-se respostas que explicassem este último cenário, sobre o que levaria um curso de arquitetura a montar uma infraestrutura para o oferecimento de atividades laboratoriais voltadas a ensaios e outros cursos não. Foi observado que estes laboratórios possuem em seu histórico diversas fases, geralmente, condicionadas a presença de docentes com perfil voltado à pesquisa laboratorial, sendo o número de profissionais dedicados à continuidade e melhoria das iniciativas um fator importante para a sustentação destas atividades ao longo do tempo. Outros históricos revelaram que a falta de docentes com este perfil fez com que, em várias escolas, os laboratórios implantados no início do curso ficassem inoperantes (na área de materiais construtivos e ensaios), os quais não foram mais recuperados com o oferecimento de atividades desta natureza.

\footnotetext{
${ }^{207}$ Cabe ressaltar que existem muitas interpretações sobre o que seria um Canteiro Experimental e suas instalações, sendo considerados neste trabalho os espaços destinados para finalidades de montagem de protótipos, geralmente na escala 1:1, desde espaços cobertos de 30 a $300 \mathrm{~m} 2$ e descobertos de $200 \mathrm{~m}^{2}$ a $3000 \mathrm{~m}^{2}$. Neste trabalho procurou-se diferenciar aqueles de uso formalizado daqueles cujo uso não está formalizado junto ao curso. Mesmo somando-se as duas situações, foram identificados poucos exemplos voltados a esta finalidade.
} 


\section{Natureza das atividades laboratoriais}

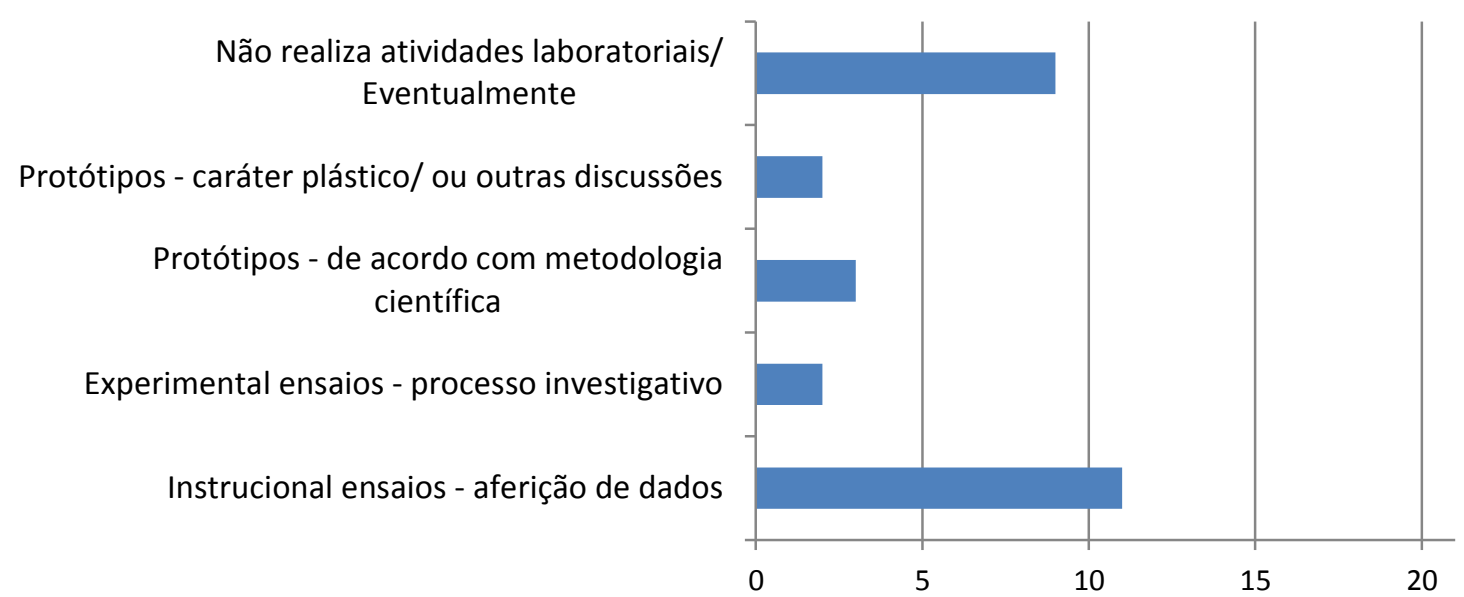

Gráfico 09 - Representatividade das atividades de caráter laboratorial (quando existentes) - utilização de modelos/protótipos ou realização de ensaios para o ensino do conteúdo da área da Tecnologia da Construção.

A partir do Gráfico 09, é possível observar que o número mais expressivo refere-se aos cursos que exploram as atividades laboratoriais na forma de ensaios físicos, sendo geralmente voltados à aferição de dados. Em seguida, estão os cursos que não adotam atividades de cunho experimental em apoio à abordagem do conteúdo da área da Tecnologia da Construção ou, quando adotam, isso é feito de forma eventual e não sistemática ao longo dos semestres. O mesmo gráfico também expõe um número reduzido de exemplos que adotam a execução de protótipos como atividade prática, sendo o número inexpressivo tanto dos casos que se apoiam em metodologia científica para desenvolvê-los como os que não adotam (3 e 2 cursos, respectivamente). A utilização de ensaios físicos como processo investigativo também se apresenta em número reduzido, com apenas 02 escolas que adotam este tipo de metodologia laboratorial, tratando-se, assim como a confecção de protótipos, como experiências isoladas.

Geralmente, as disciplinas (e/ou conteúdos) que mais fazem uso da infraestrutura laboratorial são as voltadas aos Materiais Construtivos, devido a isso, predominam atividades na área de ensaios físicos demonstrativos e não aqueles voltados à experimentação ou à prospecção, sendo identificadas poucas experiências desenvolvidas na área de técnicas e sistemas construtivos, proporcional ao reduzido número de canteiros experimentais ou canteiros de obras.

Sobre as atividades nos 'canteiros experimentais' ${ }^{208}$ - devido ao reduzido número de cursos que adotam este tipo de recurso - as entrevistas permitiram discutir com os atores os tipos de

\footnotetext{
${ }^{208}$ Como já comentado na nota de n. 78, as primeiras ideias sobre a implantação do Canteiro Experimental na FAU vieram a partir da iniciativa discente, o qual encontrou apoio junto a um dos professores, dando prosseguimento aos trâmites para sua viabilização junto à coordenação e direção do curso. 0 termo passou então a ser usado pela primeira vez nesta experiência da
} 
práticas que deveriam ser exploradas nestes espaços (caso existissem). Os resultados revelam diversidade de opiniões, muito mais sobre 'o que não explorar' em relação a possíveis sugestões, com declarações que colocam em dúvida a real vocação destes espaços. Por outro lado, as críticas devem ser estudadas de forma cuidadosa, para que não se transformem em justificativas para a não exploração desta prática pedagógica junto aos cursos, de modo que sejam aperfeiçoadas e não abandonadas. Os tipos de práticas possíveis e as principais considerações realizadas envolvendo cada uma delas foram:

a) Atividades exclusivamente expositivas - geralmente envolvendo um número elevado de alunos em canteiro - neste caso, a execução de atividades por um técnico enquanto os alunos apenas observam sua realização foi considerado como improdutivo e inaceitável por alguns, sendo defendida a divisão de turmas para que haja uma relação numérica satisfatória entre aluno/professor, tornando a experiência mais participativa;

b) Atividades braçais a partir de processos repetitivos - caracterizadas por serviços relacionados a assentamento de tijolos, levantamento de parede, assentamento de revestimentos, etc. Foi defendido que estas atividades não deveriam ser realizadas por não fazerem parte do cotidiano do futuro profissional e também por não oferecerem oportunidades para investigações técnicas e plásticas. Outra questão envolvendo este tipo de experiência refere-se ao grau de dificuldade para sua execução, necessitando de habilidades específicas que outros agentes da construção civil possuem;

c) Atividades voltadas à replicação sem investigações científicas - os questionamentos deste tipo de experiência referem-se à sua pertinência e importância frente aos custos de manutenção destes espaços, sendo difícil justificar sua sustentação institucional, principalmente, quando inseridos em instituições públicas, diante da necessidade de recursos contínuos;

d) Atividades excessivamente lúdicas - por imprimirem pouca seriedade (na sua maioria, apenas de natureza exploratória, cujos resultados são interpretáveis, predominantemente, com base em critérios formais e estéticos) são tratadas muitas vezes como dispensáveis, com poucas possibilidades no estabelecimento de parcerias de pesquisa junto a outras unidades.

A falta de espaços adequados, recursos contínuos e de carga horária compatível com as atividades laboratoriais tem dificultado o desenvolvimento destas práticas no ensino, levando à conclusão que há um distanciamento entre quem propõe e quem executa,

FAUUSP e, ao longo dos anos, outras escolas passaram a adotá-lo no lugar do termo Canteiro de Obras sem, no entanto, haver clareza se esta substituição influenciaria na natureza das atividades. 
portanto, entre o plano teórico do projeto pedagógico e os profissionais diretamente envolvidos. Seguem no próximo texto, considerações referentes aos espaços experimentais acadêmicos que complementam os dados já expostos sobre a natureza das atividades realizadas nestes ambientes investigativos.

\section{A configuração dos espaços experimentais: Laboratórios da área da Tecnologia da Construção e os Canteiros Experimentais}

Uma das condicionantes para que sejam oferecidas atividades de cunho prático laboratorial nos cursos seria a existência de espaços experimentais. Como poucos cursos tiveram a oportunidade de construir edifícios sede, são poucos aqueles que possuem infraestrutura laboratorial e, quando existente, apresenta-se geralmente como locais adaptados, sendo encontradas poucas exceções. Retomando o Gráfico 08, é possível verificar que um número considerável de escolas utiliza infraestrutura compartilhada e pertencente aos cursos da Engenharia Civil, sendo poucos os laboratórios sob a administração do curso da Arquitetura (02 laboratórios dentro do conjunto de 21 escolas) com as mesmas características e voltados às práticas na área da Tecnologia da Construção. No caso dos laboratórios pertencentes à Engenharia Civil foram somente considerados aqueles onde realmente ocorre o processo de compartilhamento por meio de atividades voltadas ao ensino (ao longo das disciplinas) realizadas de forma sistemática e não eventual, sendo contabilizados 11 laboratórios. Portanto, este dado não está relacionado à existência de laboratórios nos cursos de Engenharia Civil, mas sim aqueles frequentados pelos graduandos de arquitetura durante as disciplinas.

Algo que chama a atenção, é que dos 13 laboratórios da área da Tecnologia da Construção utilizados (02 pertencentes ao curso da Arquitetura e 11 deles à Engenharia Civil), 100\% são de uso compartilhado com a pós-graduação e estão estruturados, prioritariamente, para a manipulação de materiais de base cimentícia, como concretos e argamassas, com um número elevado de pesquisas direcionadas ao desenvolvimento de compósitos. Alguns destes laboratórios também realizam pesquisas com outros materiais, como a alvenaria cerâmica, aço, madeira, terra crua, poliméricos, etc., mas em menor número.

Há uma relação direta entre as pesquisas realizadas e a estruturação da infraestrutura laboratorial, o que explica o fato da maior parte dos laboratórios terem condições de oferecer atividades práticas com materiais específicos como os de base cimentícia, já que o maior número de pesquisas envolve este material. O sistema de apoio às Universidades acaba induzindo à configuração do cenário atual: laboratórios muitas vezes estruturados para 
pesquisas individuais, não atendendo à diversidade que o ensino requer. Esta situação tem estreita relação com a ausência de verba institucional para finalidades como manutenção e aquisição de infraestrutura física, sendo disponibilizadas aos pesquisadores outras vias para isso, como a participação em editais, que geralmente estão atrelados a uma pesquisa específica. Como a responsabilidade em estruturar e indicar prioridades fica a cargo do docente participante, os recursos adquiridos devem dar suporte para viabilizar estas pesquisas e, com isso, muitos laboratórios vão tomando determinadas configurações, sendo esta a mesma infraestrutura que, predominantemente, dá apoio às atividades voltadas à graduação. Isso explica o reflexo da pós-graduação nas condições de ensino da graduação, pois o docente e pesquisador é um dos poucos profissionais que cria seu próprio ambiente de trabalho, a partir das oportunidades surgidas. Nos casos em que o profissional não possui vínculo direto com a pós-graduação e pesquisas laboratoriais, há maior dificuldade em oferecer à graduação práticas pedagógicas desta natureza, devido à política de compartilhamento, como os ajustes de agenda de acordo com a disponibilidade de técnicos e equipamentos.

O fato destes espaços darem suporte à pós-graduação e, em muitos casos, serem estruturados com recursos provenientes da pesquisa (não integralmente), faz com que a prioridade de uso seja a pós-graduação, dificultando a apropriação deste espaço por parte dos graduandos. Foi relatada grande dificuldade no estabelecimento de uma estratégia que equilibre a falta de espaço para a graduação e que mantenha o ponto positivo desta proximidade, como a facilidade dos alunos terem contato com pesquisas de ponta, estimulando-os a se especializarem na área da Tecnologia da Construção.

Em relação aos canteiros experimentais, a maior parte deles caracteriza-se como locais adaptados, independentemente de serem formalizados ou não junto ao curso. Os não formalizados caracterizam-se como espaços externos, 'livres' para uso, não apresentando institucionalmente uso exclusivo para esta finalidade. Destituídos de infraestrutura, no período de realização das atividades contam com o apoio de outros laboratórios existentes.

No caso dos espaços formalizados, foram encontradas situações muito diversificadas entre as 04 escolas que apresentam canteiros experimentais com este reconhecimento perante 0 curso, desde espaços cobertos de $30 \mathrm{~m}^{2}$ até $300 \mathrm{~m}^{2}$, devendo ser levado em consideração que o número de alunos atendidos varia proporcionalmente às áreas apresentadas, de 30 a 160 alunos/semestre, sendo encontradas implantações tanto em áreas residuais como também em áreas estratégicas, com atenção ao fato de apenas 01 curso possuir técnico específico para dar 
suporte a estas atividades. Este mesmo curso é o único que apresenta recursos contínuos, (embora esteja enfrentando reduções progressivas), para esta finalidade e provenientes de verba institucional podendo ser tratado, portanto, como uma exceção. Os demais canteiros encontrados se apresentam em fase de consolidação e reconhecimento, mas possuem potencial de crescimento. Já os canteiros não formalizados (04 cursos) e que possuem como apoio a infraestrutura laboratorial pertencente à Engenharia Civil, suas atividades possuem perspectivas de continuidade, mas os que pretendem desenvolver estas práticas de forma isolada nos cursos de arquitetura (principalmente quando o curso não possui infraestrutura que dê suporte a atividades desta natureza), dificilmente terão vida longa, sendo suas atividades, geralmente, caraterizadas como empíricas, sem a possibilidade de avaliações mais aprofundadas.

Embora tenha sido encontrado ao longo das visitas técnicas um número reduzido de canteiros experimentais, pôde-se notar que estes espaços correm o risco de se tornarem espaços subutilizados, pois além dos recursos financeiros necessários para sua manutenção, há também poucos docentes da área envolvidos e dificuldade em sensibilizar profissionais de outras áreas para parcerias conjuntas, ficando as atividades bastante restritas às disciplinas da área da Tecnologia da Construção. Este problema não é novo, pois relatos contidos em documentos de registro sobre o funcionamento de alguns laboratórios já indicavam que espaços como este, já operavam aquém de sua capacidade ${ }^{209}$, devido ao reduzido número de professores que se utilizam do processo experimental em seus estudos.

Ainda sobre os canteiros experimentais, foram compiladas informações (algumas já comentadas neste texto) sobre como poderia ocorrer o apoio interno do curso para que realmente as práticas experimentais nestes espaços possam ser desenvolvidas na graduação, algo que vai além do simples reconhecimento sobre sua importância ou citação no plano teórico do Projeto Pedagógico, estando a inserção destas atividades condicionadas a ações reestruturantes mais profundas do curso, tais como:

a) Facilitar a divisão de turmas de maneira que haja uma relação numérica professor/aluno coerente às práticas laboratoriais, pois o número de alunos envolvidos no ensino em relação à pesquisa e extensão é muito discrepante. Além disso, a coordenação de curso deve disponibilizar carga horária compatível com a realização destas atividades, tratando as disciplinas da área técnica de forma coerente à sua natureza;

\footnotetext{
209 Informações obtidas em: http://www6.fau.usp.br/atelier/Caetano_Fraccaroli_arte_reflexao_ensino.pdf. Acesso em: 02/06/2016.
} 
b) Viabilizar recursos financeiros para criação, operação e manutenção de canteiros experimentais didáticos, já que verbas adquiridas por meio de pesquisas não podem ser direcionadas ao ensino de modo a atender plenamente as exigências curriculares da graduação. Observa-se que, geralmente, os cursos não tomam para si esta responsabilidade, ficando centralizada em um único ou poucos docentes e, diante da incumbência de coordenar, estruturar e manter vivo este espaço sem o apoio necessário, os docentes à frente destes espaços passam por um processo de desgaste e desestímulo. Este cenário compromete a continuidade das atividades e faz com que surjam desigualdades no ambiente de trabalho, já que outras áreas do ensino da graduação não demandam infraestrutura específica e o mesmo volume de recursos para serem desenvolvidas;

c) Evitar a centralização desta responsabilidade em um único docente e, para que isso aconteça, os cursos devem ter um grupo de professores da área técnica, para que haja rotatividade de coordenação dos espaços laboratoriais e a possibilidade de colaboração em pesquisas conjuntas para melhoria da infraestrutura. Ainda sobre esta questão, os cursos devem apoiar as parcerias multidisciplinares com pesquisadores de outras unidades, para que as atividades possam ser desenvolvidas de forma mais aprofundada. Cursos que procuram formar quadros docentes muito homogêneos tendem a comprometer a formação generalista, e também, o diálogo com os diversos atores que futuramente farão parte da vida profissional.

Ainda sobre esta questão, o fato das atividades e espaços laboratoriais estarem condicionados prioritariamente à iniciativa pessoal docente pode dar margens para que estas experiências sejam interrompidas a qualquer momento, seja pela mudança de professor ou pela falta de apoio financeiro contínuo. Esta situação contribui para que as experiências acadêmicas, aos poucos, sejam desvinculadas do caráter científico, em que as atividades predominantemente empíricas pode ser uma resposta à falta de apoio.

Seguem algumas informações sobre o processo de manutenção laboratorial, obtidas a partir das entrevistas juntos aos pesquisadores.

\section{Manutenção laboratorial}

A política de obtenção de recursos voltados à manutenção dos espaços e práticas laboratoriais na área da Tecnologia da Construção possui diferentes vias de acordo com sua finalidade: Ensino, Pesquisa ou Extensão. Pelo fato de poucas escolas de arquitetura possuírem espaços desta natureza, este problema nem sempre é vivenciado por elas, 
predominando os Laboratórios de Modelos e Protótipos ou as antigas Marcenarias/maquetarias.

Foram poucos posicionamentos a favor da implantação de Laboratórios de Materiais nos cursos de arquitetura (diferentemente do Canteiro Experimental, em que a maior parte dos entrevistados julga ser necessário - embora tenha ficado explícita a pouca compreensão sobre o que seria um canteiro experimental), a partir das seguintes justificativas: primeiro, de que a natureza das atividades voltadas à arquitetura não são iguais às voltadas aos cursos de engenharia, portanto, não deveriam contemplar ensaios físicos. $E$, segundo, de que as escolas públicas deveriam conter gastos evitando a sobreposição de infraestrutura, já que a mesma já existe nos cursos da Engenharia Civil, devendo ser utilizada de forma compartilhada, evitando a sustentação de um laboratório de custo elevado.

Como a responsabilidade dos Laboratórios de Tecnologia da Construção, entre as escolas visitadas, geralmente fica a cargo dos cursos de Engenharia Civil, os dados sobre sua sustentação foram obtidos junto a estes cursos e seus coordenadores, sendo relatado que as verbas para a sustentação das atividades voltadas ao ensino (da engenharia civil e da arquitetura) geralmente são provenientes de recursos institucionais, doações e prestações de serviços.

Atividades realizadas exclusivamente com recursos institucionais, ficam restritas à utilização de poucos materiais. Para reverter esta situação, muitos laboratórios prestam serviço a empresas e, com isso, complementam seus recursos. Esta via financiadora segue o ritmo do cenário econômico do país, pois a procura por prestação de serviço ou parcerias junto à universidade aumenta de acordo com a demanda da construção civil, desta forma, não há recursos contínuos provenientes desta fonte.

Os recursos obtidos por meio de editais vinculados às pesquisas de pós-graduação são direcionados exclusivamente para esta finalidade. Como já comentado anteriormente, quando esta via de apoio é adotada, geralmente, a responsabilidade em estruturar e indicar prioridades fica a cargo do docente que participa destes editais e recebe verba para conduzir suas pesquisas.

Sobre o uso compartilhado de infraestrutura, há questões de fundo que desvelam algumas dificuldades no uso conjunto dos espaços físicos, equipamentos e técnicos, pois a responsabilidade na manutenção deste espaço geralmente fica a cargo do curso ao qual o laboratório está vinculado. Foi alegada que a falta de editais específicos para a arquitetura e de recursos vindos diretamente deste curso dificulta o oferecimento de práticas laboratoriais nos 
casos de infraestrutura compartilhada, cuja prioridade será o curso ao qual o laboratório está vinculado, portanto, a Engenharia Civil. Estas considerações são relevantes em cursos cujas disciplinas da área técnica são delegadas a outros cursos, juntamente com esta responsabilidade.

Nestes casos, há contradição nas opiniões encontradas, pois ao mesmo tempo em que é alegada a necessidade de serem evitadas sobreposições de infraestrutura laboratorial, há também reclamações de que o sistema de compartilhamento não funciona, devido ao fato do curso da arquitetura não ter prioridade de uso e por não poder realizar atividades fora do horário de aula. Mas, quando a demanda é inversa (embora esta situação seja uma exceção), com solicitações de uso vindas de outras unidades, a prioridade passa a ser a arquitetura. Há, portanto, uma política na universidade que, de um lado, a universidade repassa para os institutos uma responsabilidade universitária e, por outro lado, ela não tem uma política geral e de integração que não seja aquela em que cada unidade define as suas prioridades, e na prática os cursos privilegiarão suas demandas, ficando os cursos que usam recursos compartilhados na dependência de ações espontâneas e relações interpessoais.

O uso compartilhado, portanto, deve adotar uma política para que realmente possa gerar resultados satisfatórios, com constantes e flexíveis regras de uso para que diferentes disciplinas e pesquisadores possam usufruir deste espaço, assim como, contribuir para sua sustentação, passando pelo sentido de planejamento estratégico e de gestão mais coletiva e igualitária entre cursos e entre a graduação e a pós-graduação.

A escassez ou mesmo a falta de recursos voltados a atividades realizadas de forma sistemática, como ocorre no ensino, limita e direciona a definição do tipo de atividade a ser desenvolvida. E, diante da burocracia envolvida no processo de aquisição de recursos institucionais para a realização de atividades laboratoriais (foram citados períodos entre 06 meses a 2 anos de antecedência para compra de materiais), muitos docentes envolvidos com estas práticas tem utilizado recursos próprios, tanto nas atividades do ensino como também em atividades de pesquisa, devido à sazonalidade no oferecimento de editais.

Este pode ser considerado um dos motivos pelo qual muitos docentes preferem adotar as visitas técnicas em obra ao invés da área laboratorial, embora todas estas práticas tenham e/ou estejam enfrentado problemas para serem implementadas.

\subsubsection{RECURSOS HUMANOS}


Como já sinalizado, a formação do quadro docente possui associação direta com o histórico de cada curso, assim como, suas estruturas organizacionais, as quais se apresentam divididas ou não em departamentos ou então, em outra forma de apoio organizacional como núcleos, comissões, etc., geralmente, a partir de um fator delimitador, como as áreas. A liberdade gerencial e decisória dada às unidades de ensino permitiu que os cursos se estruturassem de acordo com o entendimento dos atores em exercício, os quais foram estabelecendo as prioridades ao longo do tempo e o equilíbrio a ser alcançado quanto ao número e tipos de especialidade dos docentes em direção à formação generalista ${ }^{210}$.

Quanto à Tecnologia da Arquitetura, não foi possível identificar nas escolas visitadas o número preciso de docentes pertencentes a esta área específica, em alguns casos devido à inexistência de departamentos, assim como, pela atuação de alguns docentes no curso nem sempre estar associada com a área na qual se especializou.

Diante desta realidade, outros dados considerados relevantes foram levantados, na intenção de compreender a atuação e influência dos recursos humanos no desenvolvimento desta área específica, sendo constatada a existência de uma carência histórica de professores da área técnica na maioria dos cursos, dificultando a formação de grupos com objetivos e pesquisas comuns. Este aspecto torna-se importante, principalmente, para os cursos que pretendem implantar espaços laboratoriais, cujo custo de sustentação é elevado e há a necessidade de pesquisas constantes e em número que justifique sua existência, motivo pelo qual deveria ser evitado o modelo centralizador desta responsabilidade em um único professor.

O termo 'Canteiro Experimental', por exemplo, em diversos momentos foi citado sem a devida compreensão sobre a conjuntura de aspectos e recursos envolvidos para sua implantação e manutenção, cuja utilização não é garantida a partir de sua citação no Projeto Pedagógico de curso, tratando-se de uma estratégia insuficiente para adoção deste recurso didático. Aliado a isso, a falta de apoio interno do próprio curso de arquitetura, os boicotes e a ausência de ações (re)estruturantes que facilitem o desenvolvimento da área tem provocado

\footnotetext{
${ }^{210} \mathrm{O}$ fato do curso geralmente assumir uma configuração de acordo com o quadro docente disponível foi uma questão constantemente colocada pelos professores ao longo das entrevistas, sendo relatado que muitos cursos estão assumindo uma postura em que a Instituição está ficando em segundo plano em relação às escolhas pessoais e particulares dos professores. Em outras palavras, a influência do perfil do profissional docente prevalece na formação do aluno em detrimento do perfil profissional que deve ser formado naquela escola, então o curso se encaixa na identidade do professor a partir de proposições individuais de conteúdo, tendendo à formação de uma grande 'colcha de retalhos'.
} 
um cenário de desgaste e desestímulo entre os atores envolvidos, predominando experiências laboratoriais vinculadas à iniciativa pessoal do professor ou então com duração limitada.

Há duas instâncias que precisam ser trabalhadas diante das diferentes estruturações encontradas, as que assumem e as que delegam a área técnica a outro curso, portanto, intra e inter cursos.

Com relação à primeira, o curso deve dar o apoio necessário para que estas práticas aconteçam, para isso, todos os atores, independentemente da área que pertençam ou cargo que ocupem, devem compreender a dimensão das variáveis que influenciam na existência das atividades laboratoriais, que vão desde a estrutura curricular até a necessidade de recursos humanos, materiais e financeiros compatíveis para sua implantação.

Sobre o segundo tipo de estruturação, quando os cursos delegam esta responsabilidade, foi observada a falta de diálogo entre os cursos de Arquitetura e Urbanismo e de Engenharia Civil, evidenciada a partir da dificuldade no reconhecimento das responsabilidades e sobre a sistemática laboratorial por parte do curso de arquitetura ${ }^{211}$. Para que seja possível a adequação da infraestrutura laboratorial disponível às necessidades particulares do curso de arquitetura, deve haver diálogo entre os parceiros, a fim de dar o apoio e as informações necessárias ao outro curso sobre as particularidades que devem ser atendidas, de maneira que as atividades não sejam apenas ajustadas a partir do entendimento individual do docente envolvido e, muitas ações, implantadas com ausência de uma definição estratégica.

A partir dos históricos consultados e das estratégias atualmente implementadas foi observado que muitos cursos, cuja origem está associada à formação politécnica, demandaram ao longo dos anos grande esforço em busca de autonomia e uma abordagem pedagógica que acreditavam estar mais próxima e adequada à formação do arquiteto, ampliando assim a contratação de professores de áreas de concentração diferentes da tecnológica. Mas, diante do desequilíbrio consolidado na configuração do quadro docente, onde a área da tecnologia foi excessivamente enxugada ou delegada, as consequências acabaram refletindo não somente nos ateliês de projeto como também em outras disciplinas, como as da área representacional.

\footnotetext{
${ }^{211}$ Há uma crítica recorrente referente às aulas ministradas pelo outro curso, de que do mesmo jeito que os professores engenheiros davam aula na engenharia, também davam aula na arquitetura e de que não ministravam de acordo com os interesses do curso de Arquitetura. Por outro lado, muitos professores engenheiros alegaram que, diante da constante insatisfação, perguntam constantemente aos professores do curso como gostariam que fossem ministradas as disciplinas e qual seria o conteúdo mais adequado à arquitetura. Sobre isso, tanto professores da engenharia como da arquitetura reconhecem que esta resposta geralmente não é fornecida.
} 
Diante da reconhecida deficiência nesta formação e do déficit de profissionais com especialização nesta área, atualmente, alguns cursos estão tentando reequilibrar seus quadros docentes ao oferecerem vagas nesta área específica. E, embora haja um déficit de profissionais arquitetos com especialização na área da tecnologia da construção, observa-se resistência de muitos cursos em aceitarem a contratação de profissionais engenheiros para comporem o seu quadro docente, correndo-se o risco destas vagas serem ocupadas por profissionais sem o perfil adequado na área da Tecnologia da Construção ${ }^{212}$.

Sobre esta questão, o processo contratual docente, em alguns casos, pode vir a comprometer o futuro da área, como nos casos da adoção de amplas ementas nos concursos, que possibilitam a participação de profissionais sem a especialização requerida. Este profissional dificilmente realizará pesquisas na área técnica, que promoveria a captação de recursos e melhoria das condições laboratoriais, cumprindo o papel burocrático em relação ao ensino, mas suas pesquisas geralmente permanecem direcionadas à área com a qual tem maior afinidade. Esse cenário tem feito muitos cursos, indiretamente, perderem as vagas destinadas à Tecnologia, a qual será apenas preenchida por um curto período de tempo até o processo de migração para outra área ser efetivada. Foi declarado que concursos cujo objetivo é a contratação de profissional com perfil de múltiplos conhecimentos ou perfil multifacetado, em alguns momentos até pode dar certo, mas em outros não.

Além dos docentes, os técnicos também tem uma participação efetiva para o desenvolvimento da área da Tecnologia da Construção. Com relação a estes profissionais, o principal gargalo recorrentemente declarado ao longo das visitas foi a carência de técnicos laboratoristas. De acordo com o Quadro 32, este problema é vivenciado tanto pelos cursos da Engenharia Civil como da Arquitetura, sendo mais dramático neste último, ao ser verificado que apenas 04 cursos possuem técnicos para auxílio à área da TC.

No caso dos laboratórios de uso compartilhado e pertencentes aos cursos da Engenharia Civil, embora todos eles possuam profissionais para darem apoio às atividades, dentre técnicos e auxiliares, a escassez de técnicos também é uma realidade, e uma das causas para este cenário refere-se às aposentadorias sem a devida reposição dos quadros de funcionários. Este problema foi agravado ao longo dos anos pelo aumento do número de alunos tanto da

\footnotetext{
${ }^{212}$ Por outro lado, vários cursos declararam ser positivo o diálogo com outros centros e a interatividade com profissionais de diferentes formações (como ocorre com a parceria com o curso da Engenharia Civil ao assumirem as cadeiras da área da Tecnologia da Construção e Sistemas Estruturais), e que este cenário deveria expandir, pois caso assumissem integralmente estas disciplinas, o curso deixaria de se conectar com outros centros e unidades, comprometendo a interdisciplinaridade departamental, e a formação mais próxima ao contexto profissional.
} 
graduação como da pós-graduação, portanto, a relação numérica de técnicos e docentes não tem acompanhado proporcionalmente o aumento da oferta de vagas para alunos, com déficit destes dois profissionais, em especial de técnicos laboratoristas ${ }^{213}$.

Além da falta de técnicos, também foi sinalizada a necessidade de serem oferecidos processos de capacitação continuada a estes profissionais, para que haja a possibilidade de se adaptarem à lógica de laboratório e no trato com os alunos, diante de determinadas situações onde há a exposição a acidentes graves ${ }^{214}$. A questão da capacitação também se estende a outros servidores que ocupam cargos administrativos e de coordenação, pois em algum momento de suas carreiras diferentes profissionais ocuparão cargos desta natureza, sendo considerado de extrema relevância o oferecimento institucional de cursos de capacitação gerencial e de gestão.

Portanto, há um conjunto de ações individuais e coletivas articuladas entre si que colaboram para uma cultura voltada à valorização de determinado eixo, vinculadas às vezes a uma disputa de projeto universitário e de escola de arquitetura, que perpassa desde a estruturação curricular, como à composição dos recursos humanos e físicos.

\section{- A Pós- graduação e a Formação de Recursos Humanos}

A partir das visitas técnicas e da leitura das publicações institucionais, foi possível levantar o número de escolas de Arquitetura que oferecem Pós-graduação com temáticas na área da Tecnologia da Construção. Estas informações foram compiladas e expostas no Gráfico 10:

\footnotetext{
${ }^{213}$ O problema é ainda mais sério em lugares onde há o oferecimento de cursos no período noturno, onde a ausência de técnicos laboratoristas é uma constante, ficando muitas vezes sem o oferecimento de atividades desta natureza, as quais são indicadas para serem realizadas no período diurno.

${ }^{214}$ Algo observado em alguns espaços experimentais refere-se ao desestímulo de técnicos diante de locais desorganizados, assim como aqueles que não estão envolvidos com a pesquisa. $O$ contato constante com diferentes pesquisas constitui-se em oportunidades e contribui para o processo de especialização.
} 


\section{Número de escolas visitadas que possuem Programas de Pós- Graduação}

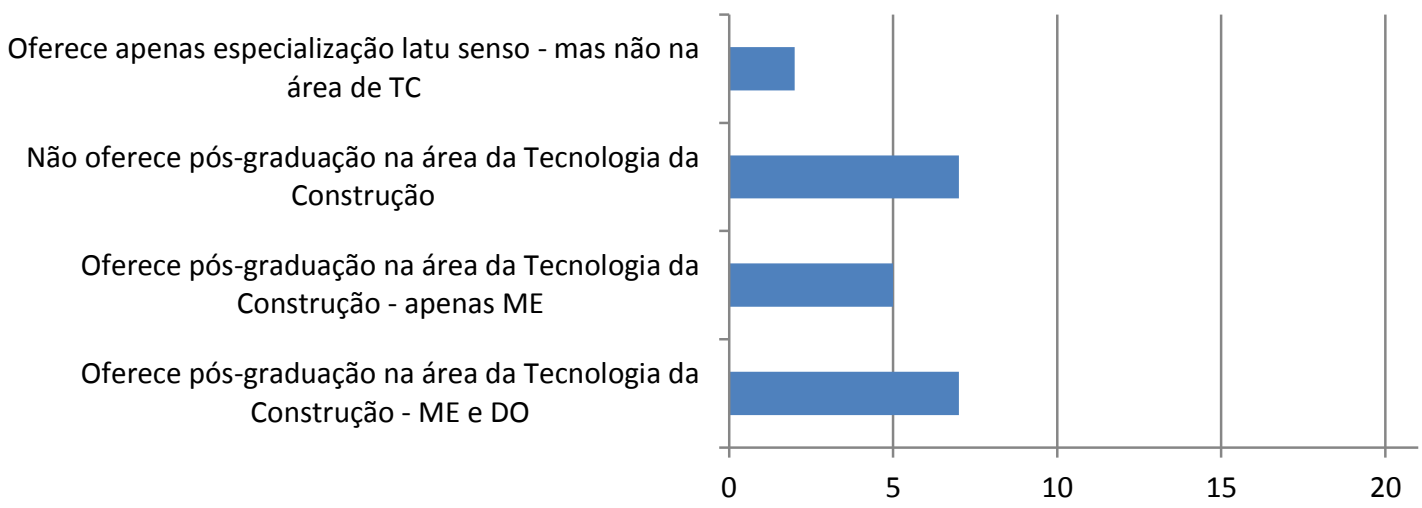

Gráfico 10 - Existência de cursos de Pós-Graduação nos cursos de Arquitetura e Urbanismo visitados.

A partir do Gráfico 10 é possível visualizar o reduzido número de cursos de arquitetura que oferecem Pós-graduação, nível doutorado, na área da Tecnologia da Construção. Dos 07 cursos identificados, 02 deles apresentam linhas de pesquisa ainda incipientes, diferentemente dos outros 05 cursos. Em relação à localização, 04 destes programas (dentre os mais consolidados) estão localizados na região sudeste, sendo um indicativo da centralização e da dificuldade que demais regiões do país possuem para formar seus quadros docentes nesta área específica, cuja alternativa seria cursar a especialização em outras áreas correlatas, oferecidas geralmente pelo curso da Engenharia Civil.

Um questionamento realizado ao longo das entrevistas seria se a pouca oferta de programas estaria associada à falta de demanda, ou se a falta de demanda estaria ligada à pouca oferta e oportunidades. Observa-se que os programas de pós-graduação quando oferecem determinadas linhas de pesquisa na área da Tecnologia da Construção, geralmente possuem em seus quadros entre 01 e 02 docentes, fazendo com que a área esteja centralizada em poucos profissionais, portanto, a escassez de professores na área estudada é um cenário presente tanto na graduação como na pós-graduação.

Devido à área técnica e sua escala trazerem diversos desafios e dificuldades aos docentes como o trabalhoso processo de captação de recursos, e por esta situação estar diretamente vinculada aos sistemas de avaliação docente com base em sua produtividade bibliométrica, os esforços e investimentos realizados tem sido direcionados à pós-graduação diante das pressões por publicações. Isso tem feito com que, gradativamente, os cursos de graduação recebam cada vez menos apoio financeiro. 
Até que um arquiteto não seja capaz de escutar as pessoas e compreendê-las, será simplesmente alguém que cria arquitetura em benefício de sua própria fama e glória pessoal, em vez de se dedicar a fazer a obra que realmente tem que fazer. Um arquiteto deve ser artesão. É evidente que o uso de qualquer ferramenta lhe confere este caráter e, hoje em dia, podemos incluir entre as ferramentas um computador, um modelo experimental ou a matemática. Mas, contudo, segue sendo o artesanato a obra de alguém que não separa a mente do trabalho da mão. Supomos um processo circular que nos leva da ideia a um desenho, do desenho a um experimento, do experimento a uma construção e desta, outra vez, a ideia inicial. Na minha opinião, este ciclo é fundamental para o trabalho criativo. Infelizmente muitos têm aceitado a independência destes passos. 0 trabalho em equipe é essencial para fazermos trabalhos criativos. 0 trabalho coletivo requer a habilidade de escutar e conduzir um diálogo.

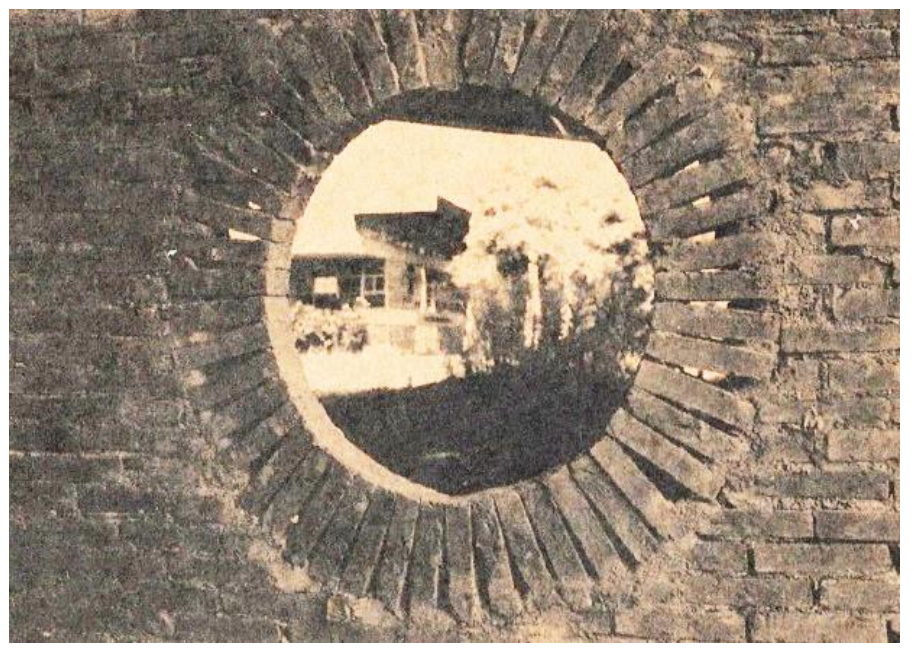

\section{CAPÍTULO 05 CONSIDERAÇÕES FINAIS}

ANÁLISE NACIONAL A PARTIR DAS PARTICULARIDADES LEVANTADAS 


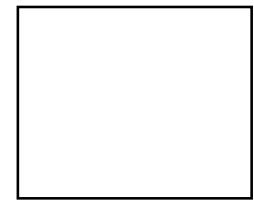

Imagem capa: Primeiro Símbolo do Canteiro Experimental da FAUUSP, proposto pela professora Elisabetta Romano, uma das primeiras coordenadoras deste espaço.

Fonte: Canteiro Experimental, 1993.

Fonte texto: Piano, 1992 apud Grinover, 2015. 


\section{ANÁLISE NACIONAL A PARTIR DAS PARTICULARIDADES LEVANTADAS}

A etapa de cruzamento e análise das informações, apresentada no Capítulo 04, foi desenvolvida a partir da triangulação dos dados de acordo com as fontes de evidência sendo, posteriormente, verificada a convergência destas fontes em direção ao fenômeno de estudo e construída então uma explanação sobre o caso.

Com base nesta explanação as questões inicialmente propostas no trabalho como hipótese, objetivo principal e perguntas de pesquisa foram retomadas e, a partir das particularidades levantadas, obtidas tanto nas fontes documentais como ao longo das visitas aos 21 cursos aproximadamente $64 \%$ do total de escolas - foi construído um panorama nacional sobre o atual cenário da área da Tecnologia da Construção vivenciado pelas escolas públicas de arquitetura.

Em relação à hipótese inicial, o processo de desenvolvimento do trabalho confirmou a escassez de pesquisas e publicações sobre o tema. Tanto as fontes bibliográficas consultadas como os dados levantados junto às escolas visitadas e entrevistas permitiram verificar a ausência de pesquisas nacionais que procuram analisar qualitativamente as práticas e espaços experimentais na área da Tecnologia da Construção. Diante deste cenário, uma das contribuições alcançadas foi a estruturação de uma bibliografia de referência mesmo que, em diversos momentos, não se apresente diretamente ligada ao tema. Isto se deve aos poucos trabalhos disponíveis para consulta, sendo preciso buscar em fontes diversas o apoio necessário para o desenvolvimento da pesquisa. Esta situação, que em um primeiro momento pareceu ser limitadora, mostrou-se favorável para a construção de diferentes pontos de vista em relação àqueles encontrados nas poucas publicações sobre a temática.

Portanto, durante a busca por informações direcionadas à forma clássica de experimentação em canteiros e espaços laboratoriais, foram identificados outros entendimentos sobre a abordagem do conteúdo da área da Tecnologia da Construção e a infraestrutura necessária para seu desenvolvimento, que também podem trazer resultados positivos na formação do aluno, permitindo a reflexão sobre questões técnicas, sociais e ambientais, como visto em experiências promovidas por diversas escolas pelo país. Esta pode ser considerada uma das contribuições do trabalho, a sistematização de uma bibliografia abrangente para um tema pouco estudado no contexto nacional.

Ainda sobre a hipótese proposta, os dados levantados sobre a atual conformação dos espaços experimentais das escolas públicas de arquitetura do país trouxe subsídios relevantes 
para a potencialização das atividades existentes, oferecendo dados consistentes para a viabilização de novas implantações, sem deixar de considerar as diferentes particularidades contextuais. As visitas técnicas e as entrevistas presenciais possibilitaram atualizar as informações sobre o contexto nacional com mais precisão, algo que dificilmente seria possível por meio de outros recursos metodológicos como a aplicação de questionários, preenchimento de formulários, entrevistas à distância, etc. E, diante da diversidade de informações obtidas - muitas delas não previstas inicialmente no trabalho - abriram-se novas vertentes de discussão, contribuindo para que, futuramente, este tema continue a ser estudado.

A partir da hipótese foi delineado como objetivo principal 'compreender o processo de configuração dos espaços experimentais da área da Tecnologia da Construção de acordo com as particularidades advindas dos diferentes contextos do país, das políticas educacionais e das ações dos atores envolvidos, com a sugestão de diretrizes que promovessem implantações com maior respaldo técnico'. O objetivo foi alcançado e os dados obtidos permitiram maior compreensão sobre o contexto nacional. A explanação desta averiguação está detalhada nos Capítulos 03 e 04 deste trabalho.

Como já descrito anteriormente, o objetivo do trabalho também considerava o desenvolvimento de diretrizes voltadas a dar apoio a novas implantações e potencializar práticas já existentes. Contudo, com a análise dos dados, chegou-se ao entendimento que a apresentação das 'condições essenciais' seriam mais adequadas pelo caráter reflexivo e não como algo direcionado à linha normativa com instruções do que deve ser seguido, permitindo que cada escola analise estas questões de acordo com seu contexto e formule estratégias mais criativas e diversificadas, evitando que experiências de maior 'visibilidade' sejam fontes prioritárias de referência.

Embora estas considerações, há o reconhecimento de que, em determinados casos, o delineamento de diretrizes regulatórias podem trazer benefícios, desde que desenvolvidas de forma coletiva, a partir do envolvimento de outros atores. Sobre esta questão, considera-se que o equilíbrio entre liberdade metodológica $X$ regulamentação (flexível e dinâmica) de conteúdos possa ser o caminho mais adequado para se chegar a resultados compatíveis aos diferentes contextos e momentos históricos, por reconhecer que a liberdade permite o desenvolvimento de experiências inovadoras, enquanto a regulamentação permite frear escolas que venham a 
desequilibrar excessivamente determinadas áreas, impedindo a formação generalista e a aquisição dos conhecimentos necessários para o exercício da profissão de forma responsável.

Sendo assim, o trabalho priorizou a formulação das condições essenciais de implantação, ao invés de diretrizes, as quais devem ser delineadas coletivamente e não a partir do entendimento de um único ator ${ }^{215}$. As condições essenciais encontram-se como resposta à quinta pergunta de pesquisa: 'Quais as condições mais favoráveis para que atividades de caráter experimental possam ser desenvolvidas no contexto acadêmico, permitindo o diálogo entre a dimensão expressiva e construtiva?'

Em relação às perguntas de pesquisa, as respostas alcançadas perpassam por todos os capítulos deste trabalho e, pelo caráter conclusivo das mesmas, trazem indicativos de diversos aspectos que influenciam, de alguma forma, a área da Tecnologia da Construção e seus espaços laboratoriais. Além disso, os dados levantados na pesquisa de campo trouxeram novas variáveis à análise do tema, acrescentando às respostas destas perguntas outras informações e elementos essenciais à compreensão do processo de configuração dos espaços experimentais, objeto desta tese.

Seguem as perguntas inicialmente propostas no trabalho, seguidas das respostas alcançadas:

1) 'Como e em que medida os processos exploratórios dos profissionais analisados ao serem transferidos para a área acadêmica, podem contribuir para o estabelecimento de correlações segundo alguns aspectos: metodologia projetual em associação às questões relativas à materialidade, infraestrutura laboratorial necessária, parcerias com o setor industrial e a liberdade de criação e pesquisa no desenvolvimento de processos inovadores?'

A trajetória dos profissionais adeptos da experimentação física e analisados ao longo do Capítulo 01 e do Capítulo 02 sinaliza diversos aspectos passíveis de transferência para o campo acadêmico, visíveis tanto na atuação daqueles que se envolveram em algum momento com a docência, como nos que se dedicaram estritamente ao campo profissional. Estes aspectos não se limitam àqueles sugeridos na pergunta supracitada, sendo assim, a resposta extrapola a estas indicações, sendo identificadas outras informações que podem vir a ser importantes ao longo das pesquisas acadêmicas sobre experimentação construtiva $X$ processo projetual, estas seriam:

a) Recursos materiais e humanos $X$ Parcerias de pesquisa - para viabilizar suas criações, os profissionais pesquisados firmaram parcerias estratégicas com os setores acadêmico e industrial, pela disponibilidade de meios técnicos específicos (materiais e humanos) para a

\footnotetext{
${ }^{215}$ Neste caso, o ator refere-se à própria pesquisadora desta pesquisa.
} 
concretização das suas ideias. Algo necessário, principalmente, quando o objetivo era a sustentação e continuidade das investigações, cuja duração pode se estender por longos períodos. A disponibilidade de recursos humanos capacitados como docentes, pesquisadores e técnicos hábeis para o auxílio nos experimentos, é uma variável importante para o processo projetual/experimental, de preferência como equipes fixas de trabalho, para que haja a capacitação continuada.

Uma condicionante recorrentemente identificada nas trajetórias dos projetistas analisados refere-se à importância em estabelecer parcerias interessadas na pesquisa e inovação e, consequentemente, dispostas a assumirem os riscos presentes no processo investigativo. Esta parceria pode vir da própria indústria na forma de demandas pontuais como também a partir de clientes de outros setores (público ou privado). Como as entidades de pesquisa, laboratórios industriais, estações experimentais e as universidades precisam de investimentos constantes para a viabilização de suas atividades de trabalho, o estabelecimento de parcerias, considerando o poder de produção da indústria, é um dos caminhos para isso, sendo possível que este processo seja saudável, desde que haja as condições ideais para seu firmamento.

b) Colaboração de equipes multidisciplinares - este aspecto é decisivo na trajetória dos projetistas estudados, quando os problemas arquitetônicos enfrentados criaram oportunidades de diálogo com profissionais das mais diversas formações (geralmente especialistas), proporcionando caráter científico ao processo projetual e, consequentemente, possibilitando a abertura de novos campos de atuação junto à indústria. O envolvimento com assuntos técnicos e o diálogo com estes atores contribui para que o arquiteto deixe, aos poucos, o papel de especificador para tornar-se um agente articulador de soluções de problemas de ordem técnica, funcional e plástica, sendo este um dos grandes diferenciais da profissão.

c) Equilibrio entre conhecimentos gerais e específicos - 0 caráter atemporal do processo investigativo é revelado ao serem analisados profissionais atuantes em diferentes momentos históricos, consequentemente, com diferentes disponibilidades de tecnologias. É visto que a necessidade de adequação aos avanços disponíveis em cada período exigem conhecimentos cada vez mais abrangentes sobre as questões que envolvem a materialidade, para que não haja um descompasso entre a disponibilidade de meios (indústria), por um lado, e de conhecimento profissional (formação), por outro. Mas diante da crescente discrepância entre a extensão dos conhecimentos exigidos e a limitação individual, uma estratégia observada nos 
profissionais estudados para enfrentar esta contradição é a necessidade permanente da aquisição de um sólido conhecimento de base das diferentes ciências que envolvem a materialização do projeto (formação generalista), mas, também, a necessidade cada vez maior do apoio dos profissionais especialistas (formação específica) diante da crescente complexidade dos projetos.

d) Discernimento sobre a necessidade da pesquisa experimental - Nos exemplos apresentados fica evidente o impacto da dimensão construtiva nas obras dos projetistas analisados que, em diversos momentos, viram na experimentação uma forma de serem confrontados com a materialização de suas obras, pois não bastava concebê-las, tiveram que construí-las. E, em diversos momentos, reconhecem que a metodologia projetual apoiada na lógica experimental/científica é requerida diante de um projeto sem precedentes, cujo objetivo não seria o desenvolvimento de um método de projeto universal, mas sim, a compreensão de uma situação particular ou um problema específico. E, por se tratar de um processo exaustivo e oneroso, há indicativos que esta metodologia deveria restringir-se às construções de reconhecida importância técnica e arquitetônica, sendo imprescindível a todos os problemas que escapem à atual capacidade resolutiva da Ciência das Construções. À medida que novas soluções vão sendo testadas quanto à sua eficiência, a fronteira do conhecimento avança, assim como a capacidade resolutiva das Ciências das Construções.

e) Associação de meios: processo experimental X análise teórica - A associação de meios é considerada pelos projetistas como um processo fundamental para que os dados fornecidos pelas ferramentas físicas ao longo do processo experimental possam ser tratados e interpretados por quem as desenvolve sob a luz dos fundamentos teóricos. Devido a isso, os protótipos adotados nas etapas iniciais de desenvolvimento contribuem para elucidar a teoria, fazendo com que o processo investigativo torne-se parte integral do projeto; o material, por exemplo, adquire suas qualidades arquitetônicas porque está envolvido no projeto, portanto, a experimentação está associada ao conjunto arquitetônico.

f) Desenvolvimento da pesquisa em diferentes circunstâncias e contextos - os exemplos analisados revelam a possibilidade de explorar a pesquisa experimental em diferentes contextos e circunstâncias, desde os mais limitantes (refletindo no impulsionamento de determinadas inovações alcançadas, como o fez Eládio Dieste, Frei Otto, João Figueiras Lima, entre outros) até aqueles com maior disponibilidade de recursos técnicos. 
g) Reconhecimento sobre a complexidade do processo experimental - o ato criativo dos profissionais estudados resulta de um trabalho contínuo e de muito esforço, fruto de muitos anos de estudo e dedicação no enfrentamento de diferentes problemas. Muitas das inovações apresentadas enfrentaram um caminho permeado de dificuldades para serem viabilizadas, tanto de ordem cultural, pela difícil aceitação; como econômica, por envolver processos onerosos nas pesquisas e na etapa de manutenção e também as dificuldades de ordem técnica, pela limitação de meios disponíveis para sua manipulação. Devido a esta conjuntura de variáveis envolvidas ao longo do desenvolvimento de algo inovador, a maioria dos projetistas analisados se envolveu com pesquisas específicas, limitando-se a estudar um determinado material ou técnica construtiva, ou uma tipologia estrutural em particular, de maneira a darem continuidade nas investigações e atingirem os avanços técnicos desejados ${ }^{216}$.

2) A partir do incipiente desenvolvimento de atividades experimentais nas escolas brasileiras, estas seriam dispensáveis diante de um histórico que não tem por base este método pedagógico?

3) Se este cenário se deve apenas pela falta de divulgações sobre as experiências realizadas ou problemas de diferentes ordens conduziram a esta constatação? $E$ as experiências que adotam predominantemente técnicas de trabalho-intensivas como instrumental pedagógico, podem contribuir para o desenvolvimento de processos mais racionalizados?

Devido às perguntas de $\mathrm{n}^{\circ} 2$ e parcialmente a de $\mathrm{n}^{\circ} 3$ (primeira parte) serem complementares, a resposta a estas duas questões foi desenvolvida conjuntamente. A segunda parte da pergunta de $n^{0} 3$ será respondida na sequência da primeira resposta.

As informações levantadas ao longo do trabalho não permitiram a verificação da afirmação colocada, diante da constatação de que em algumas escolas as atividades experimentais não são incipientes, mas apresentam-se em número reduzido e com pouca representatividade quando comparadas ao conjunto de práticas pedagógicas geralmente aplicadas, como revela o

\footnotetext{
${ }^{216}$ Em Margarido (2011), o entrevistado faz algumas considerações que podem servir para reflexão dos itens e) e g), sobre a exaltação da intuição em detrimento da teoria e do cálculo e também sobre a complexidade do conhecimento técnico. Para ele: [...], deve-se estudar Estrutura com seriedade. Quer dizer, não procurar achar uma maneira de intuir, de simplesmente intuir...porque é muito difícil! Porque a intuição vem com a prática muito grande da profissão. Senão, você queria começar justamente do lado oposto...[...] Bom, eu acho uma coisa, que existe um engano muito grande no arquiteto é ele querer ter a intuição. Eu vou fazer duas comparações: do arquiteto e do engenheiro. Bom, o arquiteto queria um curso que desse a intuição da estrutura sem calcular. Eu posso dizer para você? Todo engenheiro também gostaria de ter! Mas não tem. É a mesma coisa que o arquiteto que começa a trabalhar... Você acha que dá pra dar um curso, durante um ano, para o arquiteto entender todos os aspectos da Arquitetura: paisagismo, comportamento, divisão de espaço, iluminação, acústica, etc.? É possível? Então não tem. Porque se precisa evoluir para entender mais. Uma coisa que é fundamental, que eu sempre falava para os alunos: 'Se vocês forem fazer um serviço particular, forem fazer um projetinho, procurem entender o que vocês estão fazendo'. E não adianta negar alguns conhecimentos que são importantes...[...].
} 
Gráfico 07 apresentado no Capítulo anterior; do total de 21 escolas somente 04 possuem práticas de canteiro oferecidas sistematicamente.

Já os dados do Quadro 07, do Capítulo 02, indicam que a maior parte das experiências publicadas concentra-se na rede privada (com poucas exceções de publicações vindas das universidades públicas - FAUUNB - FAUUSP - IAUUSP - UFU) e são caracterizadas como atividades de curta duração devido a diversos motivos, desde os de ordem política (intervenção militar no período da ditadura) até os de ordem administrativa (falta de estrutura e apoio às atividades experimentais). A mesma fonte traz indicações sobre os principais atores envolvidos com as práticas laboratoriais, sendo observada a recorrência dos nomes em diferentes instituições. Trata-se do processo de reverberação de experiências e metodologias sobre o desenvolvimento deste tema no Brasil e a influência docente ocasionada pelos processos migratórios, sendo estes atores, geralmente, os principais responsáveis pelo processo de divulgação destas experiências.

Ao correlacionar o reduzido número de experiências encontradas com o processo de divulgação, há associação entre as limitações que dificultam a realização de experiências práticas nas escolas brasileiras e a impossibilidade de divulgá-las. Devido ao fato de serem, geralmente, experiências de curta duração muitas delas foram destruídas precocemente, sem deixar vestígios, ou até mesmo foram consideradas de pouca relevância para a documentação e divulgação.

Foi observado que estas experiências, em sua maioria, foram desenvolvidas com distanciamento do setor industrial, com pouca influência de experiências internacionais relevantes, como a promovida pela escola da Bauhaus (com exceção da UNB - período inicial da escola), cujas atividades possuem relação direta com o processo de produção da indústria e de seus laboratórios. A responsabilidade no desenvolvimento de inovações está mais explícita nos projetos de pesquisa e extensão e não na área do ensino.

Diante das dificuldades voltadas tanto à implantação como à sustentação de espaços experimentais/laboratoriais junto às escolas de arquitetura, foi declarada recorrentemente ao longo das visitas técnicas a falta de reconhecimento dos próprios cursos sobre a importância dessas práticas na formação do aluno. Há relação direta entre o cenário relatado e a formação docente, sendo constatado que muitas gerações de profissionais - que hoje atuam nas universidades - foram formadas em ambientes nos quais a experimentação não era adotada como recurso didático. A ausência destas práticas ao longo da formação destes atores pode vir 
a influenciar diversas ações reestruturantes direcionadas a favorecer a implantação destas atividades. Pois, em alguns casos, o fato de não terem feito parte do processo de formação, cria-se o entendimento de que estas práticas são dispensáveis e que a área da tecnologia pode ser desenvolvida sem infraestrutura laboratorial.

Embora não tenha sido observada a adoção destas experiências com a mesma amplitude em relação aos exemplos do contexto internacional, os resultados de sua adoção são reconhecidos e defendidos por aqueles que as praticam (ou praticaram), pela possibilidade de ampliar a compreensão do conteúdo técnico. E, nos casos onde não há condições para a implantação de espaços laboratoriais exclusivos para os cursos, outras estratégias podem ser adotadas na abordagem do conteúdo sobre a materialidade, como a utilização de espaços compartilhados, o estágio supervisionado obrigatório em obra, entre outros. Pois a diversidade de práticas pedagógicas encontradas revela que a conjuntura de estratégias pode levar a resultados satisfatórios pelo caráter complementar, podendo até trazer resultados mais interessantes e menos onerosos em relação aos canteiros experimentais nos quais as práticas não são apoiadas em procedimentos metodológicos claros.

Provavelmente, as ações direcionadas a mudar esta realidade (ausência de experiências práticas) ocorrerão a longo prazo e não por vias exclusivamente normativas, mas pela conscientização dos dirigentes, professores e demais atores intervenientes nos cursos. A avaliação dos cursos realizada em meados da década de 1990 foi um momento importante de autocrítica, de olhar para si e ver como estava a situação nacional, tornando-se posteriormente obrigatória a existência de laboratórios e canteiros na área da Tecnologia da Construção. Mas, ao longo dos anos, o que se constatou em diversas escolas foi a implantação de alguns espaços experimentais desprovidos de infraestrutura mínima para o desenvolvimento de atividades práticas, sendo comum, em algumas escolas, a implantação de espaços com kits de mostruários fornecidos por empresas, apenas para atender uma demanda legal, portanto, a essência pedagógica da experimentação foi pouco explorada ao longo dos $\operatorname{anos}^{217}$.

\footnotetext{
${ }^{217}$ Um trecho de uma declaração do arquiteto Lelé traz reflexões sobre o tipo de atividade a ser explorada no ambiente acadêmico: "O arquiteto é muito responsável porque está abrindo mão, gradualmente, da sua função de construtor. Para $\mathrm{mim}$, o arquiteto é basicamente um construtor. E com isso não quero dizer que ele vai pegar a colher de pedreiro para assentar massa. $O$ arquiteto precisa conceber a construção do seu objeto, que precisa ficar em pé. Deve estar implícito no projeto como se constrói esse objeto. Agora, se o arquiteto está abrindo mão dessa sua prerrogativa básica para se tornar especialista em fazer fachada, fazer desenhos, isso é um problema nosso, profissional. Não adianta discutir sustentabilidade da construção se não queremos trabalhar. Isso é negligência do trabalho. É preciso enfrentar o problema da construção. A universidade deve reforçar a consciência de que o arquiteto é o responsável pela construção".
} 
Diante disso, as evidências revelam que nem mesmo as Diretrizes estabelecidas a partir dos levantamentos realizados pela CEAU - quando se notou o quanto a arquitetura havia se distanciado da área técnica - motivaram na realização de mudanças significativas relacionadas à adoção de práticas experimentais, ficando claro que este assunto deveria ser conduzido de acordo com a complexidade das variáveis envolvidas, que não se resumem à existência de espaço físico que, embora possa levar ao cumprimento de uma exigência legal, em muitos casos não cumpre a sua verdadeira função.

Quando analisada a natureza das atividades encontradas, pode-se retomar a segunda parte da Questão 03: $E$ as experiências que adotam predominantemente técnicas de trabalho-intensivas como instrumental pedagógico, podem contribuir para 0 desenvolvimento de processos mais racionalizados?

As evidências apontam que as atividades nos canteiros experimentais, na sua maioria, são de natureza empírica. Não há tempo hábil ou espaço na grade curricular para o aprofundamento de uma determinada técnica a fim de dominá-la e, posteriormente, tentar racionalizá-la. Este procedimento depende de um conhecimento tácito que o aluno não consegue obter em pouco tempo. Portanto, como as escolas ainda não chegaram nesta etapa de racionalização de processos, não foram encontrados exemplos para serem analisados. Em alguns casos, foram encontrados exemplos pontuais sobre consumo sustentável e utilização de materiais de baixo impacto ambiental, mas sem evidências da adoção de processos racionalizados ao longo desta abordagem.

4) De que forma estes espaços experimentais inseridos nos cursos de Arquitetura podem contribuir para a formação de um profissional mais sensível às questões relativas à materialidade e que participe no desenvolvimento técnico do setor construtivo? Quais os limites e potencialidades da parceria entre indústria e academia na formação do futuro profissional?

A partir das informações obtidas em Trigueiro (1999), foi possível estabelecer conexões entre seus comentários e o campo do ensino da área da tecnologia da arquitetura, ao identificar que Ensino e Prática dão-se as mãos em cumplicidade problemática em pleno desacordo com novas demandas e necessidades advindas, não apenas do meio estudantil, mas de amplos setores da sociedade, que cada vez mais cobram resultados e respostas da universidade para seus problemas mais importantes. O autor ainda considera que no desenvolvimento tecnológico, por um lado, as inovações impulsionam sempre mudanças em 
antigos padrões de produção ou em processos estabelecidos há algum tempo, mas por outro lado, as instituições apresentam grande resistência à mudança, havendo um descompasso entre novas e contínuas demandas da sociedade e as respostas necessárias por parte destas universidades.

A discussão sobre pesquisa teórica e aplicada torna-se muito importante na medida em que a pesquisa acadêmica é muitas vezes considerada, por parte dos profissionais, como abstrata e inútil, e a industrial como sendo enganosa e estreitamente condicionada aos objetivos capitalistas $^{218}$. Foram então identificadas algumas questões que podem vir a potencializar as parcerias entre academia e indústria, assim como, evidenciar algumas dificuldades para que sejam estabelecidas estratégias para superá-las, sendo algumas delas destacadas como potencialidades e outras como limitações:

\section{Potencialidades:}

a) Obtenção de recursos e materiais adicionais - Diante da necessidade de investimentos constantes para a manutenção laboratorial e o oferecimento sistemático de práticas desta natureza, parcerias são necessárias junto a instituições, entidades e indústrias. A partir da diversificação das fontes de obtenção de recursos é possível desvincular estas atividades da dependência integral de verbas institucionais que, por serem escassas, acabam limitando as pesquisas e restringindo a manipulação de materiais diversificados. Uma das condições ideais para que tais parcerias possam ser firmadas com o setor industrial seria o estabelecimento de acordos pontuais, com contrapartidas claras e justas para que o processo de transferência dos resultados seja alcançado de maneira a não comprometer a idoneidade da universidade.

b) Desenvolvimento projetual com base em dados científicos - A partir do maior envolvimento com o processo investigativo projetual são criadas oportunidades de diálogo com profissionais de diferentes formações, geralmente especialistas, proporcionando um caráter mais científico ao processo. O poder de diálogo com estes profissionais e com o setor industrial pode dar respaldo ao arquiteto no desenvolvimento de novos processos de montagem, técnicas e associações construtivas, levando em consideração diferentes materiais

\footnotetext{
${ }^{218}$ Foi também declarado que um dos empecilhos para que sejam desenvolvidas parcerias entre Universidade e Indústria, seria a sustentação de que o papel da Instituição pública seria devolver à sociedade o investimento que ela destina às Instituições na forma de impostos, sem considerar, entretanto, que o setor industrial também contribui com uma parcela expressiva na manutenção das escolas públicas, a partir das mesmas vias de captação de recursos, os impostos. Diante destas considerações ficam evidentes as contradições nos posicionamentos dos declarantes, em que as formas de parceria entre indústria e academia merecem ser tratadas com maior cuidado, de maneira que fique mais claro o papel da indústria como investidora da pesquisa nas Universidades Públicas e as possíveis contrapartidas por parte destas.
} 
e criando possibilidades de aplicação para alguns deles cujo campo da arquitetura possa não ser habitual, consequentemente, abrindo novos campos de atuação ainda inexplorados junto à indústria.

Estas metodologias que incorporam a pesquisa ao longo do processo projetual e que consideram o poder de produção da indústria, quando levadas para o contexto acadêmico criam oportunidades de aproximação com o contexto real de atuação, com base em conceitos mais consistentes.

c) Compartilhamento de risco - Quando há o envolvimento de grandes investimentos na forma de recursos materiais e humanos ao longo de um período prolongado de tempo para investigação, as parcerias são importantes no momento do compartilhamento das responsabilidades e dos riscos presentes no processo experimental.

\section{Limitações}

a) Compatibilização com a burocracia institucional - Em diversos momentos, diante do receio político ou da falta de uma formação sólida são criadas barreiras no processo de parcerias junto à indústria, fazendo com que se percam boas oportunidades para a implantação de uma infraestrutura mais ampla para os alunos. E, diante dos limitados recursos institucionais voltados à implantação e manutenção destes espaços, estas parcerias contribuiriam para evitar o sucateamento da infraestrutura existente.

No que se relaciona à pesquisa, as parcerias com o setor industrial podem ser mais promissoras do que as parcerias com as construtoras, pois enquanto as construtoras estão mais voltadas à situação interna da empresa, à solução de problemas específicos das suas obras e à prestação de serviços, a indústria, devido à metodologia e organização do trabalho, possui maior preocupação com as pesquisas que podem estar direcionadas ao desenvolvimento de novos produtos e bases tecnológicas, gerando pesquisas de ponta e suprindo a infraestrutura necessária.

Quanto ao papel docente neste processo, há questões que precisam ser ainda definidas quanto à sua participação em atividades externas à instituição. Em alguns casos, de acordo com a área de pesquisa, a capacitação e atualização profissional é complementada fora do âmbito acadêmico. Mas, para que isso seja possível, há a necessidade do delineamento de regras claras e objetivas quanto aos processos de parcerias, seja por meio de fundações institucionais (processo utilizado pela maior parte das universidades) ou por outras vias. 
b) Descompasso entre pesquisas acadêmicas e industriais - o desequilíbrio entre estes dois contextos pode estar nas diferenças informacionais dos atores envolvidos, como também nos objetivos da pesquisa acadêmica, que nem sempre atendem às reais necessidades do mercado e da sociedade. Além disso, há diferentes orientações de prazos para o desenvolvimento dos projetos, pois o tempo da indústria nem sempre é o tempo da academia, podendo haver pressão comercial das indústrias parceiras.

\section{5) Quais as condições mais favoráveis para que atividades de caráter experimental possam ser desenvolvidas no contexto acadêmico, permitindo o diálogo entre a dimensão expressiva e construtiva?}

Seguem as condições consideradas essenciais para reflexão ao longo de (re)formulação de estratégias para a área da Tecnologia da Construção e sua infraestrutura.

a) Auto avaliação dos cursos - ao longo das visitas técnicas foi identificada heterogeneidade na disponibilidade de informações referentes ao processo de documentação interna das escolas sobre aspectos históricos e estruturais, presentes tanto nos Projetos Pedagógicos de curso como em outras fontes. Esta questão torna-se relevante diante da natural rotatividade de docentes que há em cada escola, sendo os processos de auto avaliação e documentação uma forma para que novas gerações de professores possam compreender as particularidades daquele contexto e propor estratégias que evitem a replicação de modelos de maior visibilidade ou estritamente vinculados à sua formação, os quais podem vir a ser inadequados em outras circunstâncias. Além disso, as discussões e debates internos a partir do autoconhecimento criam oportunidades promissoras para experiências inovadoras.

b) Apoio do curso - As visitas técnicas permitiram avaliar que os maiores problemas no desenvolvimento das atividades experimentais são colocados pelo próprio curso. $\mathrm{O}$ apoio interno pode ocorrer de diversas formas como: - não delegar a responsabilidade pela estruturação da área da Tecnologia - mesmo quando as disciplinas são de responsabilidade de outro curso; - estabelecer relação numérica aluno/professor adequada às atividades de natureza prática; - disponibilizar carga horária compatível para a realização de atividades laboratoriais; - em relação aos recursos materiais e humanos, facilitar administrativamente que a área se desenvolva sem obstáculos internos.

c) Reconhecimento sobre co-responsabilidades - Todos atores envolvidos no processo educacional tem a co-responsabilidade de criarem pontos de encontro (tridimensionais) entre 
áreas e disciplinas ao longo do processo de integralização, algo que também pode ocorrer fora da plataforma/base dos Ateliers de projeto.

A partir do entendimento de que a responsabilidade da abordagem da materialidade deve ser compartilhada e não restritiva aos professores da Tecnologia, todos se comprometem na ação de interligar os conteúdos, desde professores de diferentes áreas como também o próprio aluno é co-responsável por este processo (o professor pode facilitar o aprendizado, desde que o aluno queira aprender). Caso contrário, as reestruturações serão sempre pontuais e direcionadas às disciplinas técnicas, trata-se de uma visão muito simplória diante dos problemas de fundo que comprometem a formação plena, que vão desde a estrutura curricular até a captação de recursos humanos, físicos e financeiros.

d) Implantação de estratégias coletivas - a infraestrutura universitária - principalmente a laboratorial - quando estruturada por meio da iniciativa docente e sem apoio institucional contínuo, corre o risco de ser implantada de acordo com o julgamento dos atores envolvidos e, geralmente, em estreita relação às suas pesquisas individuais, já que os editais estão atrelados a temas específicos. Este cenário decorre da falta de ações conjuntas entre as diferentes instâncias administrativas levando a implantações sem uma definição estratégica e coletiva.

O fato das atividades e espaços laboratoriais estarem condicionados, prioritariamente, à iniciativa pessoal docente e não de acordo com os interesses do curso, pode favorecer a interrupção destas experiências a qualquer momento, seja pela mudança de professor ou pela falta de apoio financeiro contínuo. Faz parte das estratégias coletivas do curso em apoio à área da Tecnologia da Construção a constituição de grupos de professores da área técnica, para que haja rotatividade de coordenação dos espaços laboratoriais e a possibilidade de colaboração em pesquisas conjuntas.

e) Envolvimento de profissionais de diferentes áreas - devido ao processo experimental envolver a esfera multidisciplinar, a inserção de pesquisadores com perfis diversificados (tanto de outras áreas da arquitetura como de profissionais com outras formações) torna-se muito importante para se alcançar patamares mais avançados, já que determinados conhecimentos necessários para se avançar na pesquisa experimental fogem do campo de competência do arquiteto. Além disso, a formação generalista é favorecida com a promoção do diálogo entre os diversos atores envolvidos no projeto, gerando espaços de interatividade e trabalhos mais aprofundados. 
f) Formação de recursos humanos - A carência histórica de professores da área técnica vista na maioria dos cursos é um aspecto importante para ser analisado, principalmente, nos cursos que pretendem implantar espaços laboratoriais, cujo custo de sustentação é elevado e há a necessidade de pesquisas constantes e em número que justifique sua existência, motivo pelo qual deveria ser evitado o modelo centralizador desta responsabilidade em um ou poucos docentes. Para que as disciplinas sejam conduzidas, prioritariamente, por profissionais com especialização na área técnica e em número suficiente, é necessário que ações efetivas garantam esta formação complementar do professor, a partir do oferecimento de cursos de especialização e atualização em maior número e em diferentes localizações do país.

g) Viabilização de recursos financeiros - o Ensino - geralmente, os recursos destinados às atividades vinculadas ao Ensino são verbas institucionais, não sendo possível que recursos obtidos por meio de projetos de pesquisa e extensão sejam direcionados para esta finalidade.

Quando os cursos não tomam para si a responsabilidade pela área técnica e de suas práticas, centralizando-a em um ou poucos docentes, pode surgir um processo de desgaste e desestímulo, diante da incumbência de coordenar, captar recursos (muitas vezes recursos próprios), estruturar e manter vivo este espaço sem o apoio necessário. Esta situação também contribui para que as experiências acadêmicas, aos poucos, sejam desvinculadas do caráter científico, em que as atividades predominantemente empíricas podem ser uma resposta à falta de apoio interno, pois práticas laboratoriais em complemento ao conteúdo das disciplinas apenas podem ser sustentadas a partir de investimentos contínuos.

Esse cenário compromete a continuidade das atividades e faz com que surjam desigualdades no ambiente de trabalho, já que outras áreas não demandam infraestrutura específica para serem desenvolvidas como a área tecnológica. Devido a isso, a viabilização dos recursos financeiros voltados às atividades de ensino deve ser de responsabilidade compartilhada com o curso, já que há poucas vias disponíveis aos docentes para isso e, também, pelas práticas serem voltadas a um número elevado de alunos, diferentemente da pesquisa e da extensão.

h) Viabilização de recursos financeiros - a Pesquisa e a Extensão - Embora haja vias mais diversificadas para obtenção de recursos para a pesquisa e extensão em relação ao Ensino, ao longo das entrevistas foram feitas considerações pertinentes sobre esta questão. Uma delas relaciona-se à falta de editais - especificamente voltados à arquitetura - para o financiamento de infraestrutura e desenvolvimento da área da Tecnologia da Construção, pois geralmente, 
somente os cursos da Engenharia Civil tem oportunidade de participar de editais desta natureza e, no caso de espaços compartilhados, a prioridade será dos cursos participantes, portanto, das engenharias. Para que esta situação fosse revertida seriam necessárias ações articuladoras empreendidas por entidades como CAU, ABEA e até mesmo o próprio setor da Construção Civil, junto aos órgãos governamentais responsáveis.

Por outro lado, esta questão trouxe outros pontos de vista junto aos entrevistados, considerando que, diante da baixa procura (e poucos pesquisadores) não haveria a necessidade de editais tão específicos para a área da tecnologia da arquitetura, sendo a demanda da engenharia muito maior, desta forma, a oferta está proporcional à demanda. Sobre o fato do curso da Arquitetura estar inserido no grupo das Ciências Sociais Aplicadas, foi relatado que muitos trabalhos submetidos à avaliação passam por pareceristas sem formação na área técnica, diante do fato de haver poucos profissionais em relação às demais áreas, ficando a Tecnologia da Construção descoberta, ou então, pela sua interface à Engenharia muitos profissionais buscam esta área para inserir suas pesquisas, sendo estes processos mais concorridos.

i) Parcerias público-privado - diante das escassas e sazonais oportunidades de obtenção de recursos por meio de editais, as parcerias com o setor privado devem ser incentivadas e regularizadas de maneira que os interesses da pesquisa sejam preservados. Os maiores avanços científicos demandam tempo e recursos, desta forma, tanto a burocracia institucional voltada a gerenciar os recursos como também a sustentação de ideologias políticas pode fazer com que se percam oportunidades de parcerias com a iniciativa privada. Atualmente, diferentes agências de fomento incentivam o firmamento de convênios com empresas como forma de promover a inovação tecnológica e incrementar a contribuição da pesquisa para o desenvolvimento econômico e social, induzindo o aumento do investimento privado em pesquisa tecnológica.

j) Equilíbrio entre Conteúdos essenciais $X$ Competências profissionais - Considerando que o conhecimento generalista não é sinônimo de conhecimento superficial, a excessiva fragmentação curricular pode levar à redução dos conteúdos, sendo alguns deles considerados essenciais e diretamente ligados às futuras competências profissionais. Foi observado que a busca por estratégias baseadas estritamente na intuição construtiva ${ }^{219}$, sem

\footnotetext{
${ }^{219}$ Há uma visão contraditória sobre o conhecimento intuitivo, enquanto alguns profissionais (geralmente arquitetos) defendem que o conhecimento intuitivo precede o científico, outros profissionais julgam que o conhecimento intuitivo é
} 
se valer de outros recursos como o conteúdo teórico-científico, pode conduzir ao conhecimento superficial.

Ao cruzar o conteúdo dos Projetos Político Pedagógicos (PPPs) com as Diretrizes Curriculares Nacionais (Art. 5ㅇ e 6을 observa-se que a maior parte dos PPPs considera o Art. 6으 (Conteúdos Curriculares). No entanto, foi percebido um descompasso entre os Art 60 (Conteúdos Curriculares) e Art 5으 (Competências Curriculares) no que se refere à Tecnologia da Construção, pois para se atingir as competências pressupõe-se haver a experimentação e poucas escolas oferecem estas práticas. Diante disso, deve-se também tomar o cuidado para que, na tentativa de cumprir uma burocracia normativa, as escolas venham a criar espaços que podem se tornar subutilizados e desvinculados da experimentação científica.

\section{OS ESPAÇOS EXPERIMENTAIS DAS ESCOLAS PÚBLICAS DE ARQUITETURA DO BRASIL:}

\section{REALIDADE OU UTOPIA? ?20 $^{220}$}

Para responder à macro pergunta da pesquisa que intitula esta tese, foi levada em consideração a reflexão sobre os dois termos: realidade e utopia.

Em relação à realidade, há uma diferença entre 'relatar' e 'interpretar' os fatos reais, sendo este último correspondente àquilo que se compreende sobre o que se relata, algo que pode levar a muitas interpretações contraditórias. O Capítulo 03 deste trabalho teve a preocupação de relatar a realidade captada no momento das visitas técnicas, para que, com base nestas informações o leitor tivesse condições de realizar novas interpretações diferentes das desenvolvidas pela autora desta tese. Além disso, a realidade é dinâmica e, segundo Andreoli (2006), para apreender seu movimento é necessário compreendê-la historicamente; aquilo que em um momento é aceito como realidade pode deixar de ser. Em outras palavras, o que está aí pode se dissolver diante do vir-a-ser. Isso quer dizer que, embora as constatações realizadas, muitos contextos analisados possuem potencial de transformação.

Com base nestas definições e na 'realidade relatada', chega-se a conclusão que os espaços experimentais na área da Tecnologia da Construção das escolas públicas de arquitetura são quase inexistentes no país e, quanto aos espaços compartilhados (geralmente pertencentes aos cursos de Engenharia Civil), estes têm, aproximadamente, 50\% de representatividade. Portanto, há pouca utilização de infraestrutura laboratorial e de canteiros de obra ao longo da

exercitado e adquirido a partir da aquisição de uma base sólida de conhecimentos científicos e após um longo período de prática projetual.

${ }^{220}$ Esta questão teve como apoio o texto de ANDRIOLI, A. I. Utopia e Realidade. Revista Espaço Acadêmico - $\mathrm{n}^{\circ} 56$. Janeiro, 2006 - Mensal - Ano V. 
abordagem do conteúdo referente à materialidade, sobressaindo as aulas teóricas. Esta realidade referente tanto aos espaços físicos como às práticas pedagógicas é o reflexo da política educacional vigente nas diferentes esferas, influenciando uma conjuntura de questões, desde a estrutura curricular dos cursos até a configuração dos recursos materiais e humanos, sendo muitas vezes insuficientes e incompatíveis com o desenvolvimento de atividades práticas/experimentais - entendidas como recurso ou estratégia pedagógica.

A utopia é uma espécie de jogo entre um real que se rejeita e um ideal que se espera e se deseja, mas que parece inalcançável. Em relação à sua conceituação, a utopia, originalmente designa um "não lugar" ou "lugar nenhum". Ao transpor esta ideia aos espaços experimentais pode-se ponderar que, mesmo não existindo na sua forma ideal, estes locais ainda não encontraram o seu "lugar" ideal, visto tanto na infraestrutura física como na estrutura curricular dos cursos de arquitetura, em que as práticas experimentais poderiam contribuir para a formação frente aos atuais desafios que envolvem a produção do ambiente construído.

Segundo Andrioli (2006), "em tese, a utopia permite uma ligação entre o presente e o futuro, no momento que ela se enraíza no presente em mudança, influenciando-o e sendo influenciada por ele". E, assim como a realidade é influenciada pela maneira como ela é concebida, também a noção de utopia está imbricada nesta mesma dinâmica. A utopia poderia ser entendida não como algo ilusório, e sim como algo "que não é, mas pode vir a ser". Neste sentido, para mudar a realidade, evidentemente, não basta ter uma utopia, é necessário identificar as contradições históricas objetivas que apontam para a possibilidade de superação real.

Portanto, ao considerar as conceituações aqui colocadas, de modo geral, os espaços experimentais não são uma realidade, e sim uma utopia, a partir do entendimento de que utopia não é algo inalcançável e sim algo que pode vir a ser, com potencial de transformação, desde que levadas em consideração a história e a realidade.

Compreender a realidade exige de cada local, de cada escola, um processo de autoconhecimento, que pode levar à obtenção de pistas para experiências criativas e promissoras. E, com o desvencilhamento do habitual caminho da busca de 'exemplos' externos, aumenta-se as chances de serem encontradas soluções para os problemas internos de forma mais assertiva e sustentável.

Os fatores contextuais e históricos e, principalmente, os recursos humanos (à frente destas iniciativas) e o apoio institucional e administrativo (do próprio curso) podem conduzir à 
criação de espaços diversificados de acordo com a vocação local. Isso levaria, naturalmente, a proposições de ensino diferenciadas entre regiões, mesmo seguindo eixos norteadores comuns.

Ao longo do trabalho foi visto que a existência de espaços físicos exclusivos e voltados à realização de atividades práticas torna-se apenas um detalhe diante de outros problemas que diretamente impactam na estruturação da área da Tecnologia da Construção. Embora seja uma infraestrutura desejável, não são imprescindíveis para que a área se desenvolva e o conteúdo possa ser abordado junto aos alunos. Estas considerações vão ao encontro da resposta às perguntas 2 e 3 , ao ser constatado que nos casos onde não há condições para a implantação de espaços laboratoriais exclusivos junto aos cursos, outras estratégias podem ser adotadas na abordagem do conteúdo sobre a materialidade, como a utilização de espaços compartilhados, o estágio obrigatório em obra, entre outras. A diversidade de práticas pedagógicas encontradas revela que a conjuntura de estratégias também pode levar a resultados satisfatórios e complementares, podendo até ser mais interessantes e menos onerosos em relação aos canteiros experimentais que não têm por base métodos científicos.

Diante do complexo entrelaçamento das particularidades inerentes à área da Tecnologia da Construção, os espaços e práticas experimentais demandam grande esforço e dedicação por parte dos atores, consequentemente, envidam maior tempo para condução e sustentação destas atividades, havendo a necessidade da formação continuada para que possam atuar na implantação, operacionalização e manutenção destes espaços de investigação. Desta forma, tanto o curso como seus dirigentes precisam (re)conhecer as especificidades envolvidas e os recursos requeridos, para que os docentes da área técnica possam assumir esta empreitada com o apoio necessário, evitando-se o processo de desgaste e desestímulo.

Estas e as demais questões que esta tese buscou responder não esgotam, mas elucidam o longo caminho a ser percorrido pelos pesquisadores que queiram dar continuidade aos estudos sobre a temática aqui apresentada: os espaços experimentais da área técnicoconstrutiva inseridos nas escolas públicas de arquitetura do país. Desta forma, este trabalho sugere questões para serem analisadas à luz de novos entendimentos, na perspectiva de que o tema permaneça em pauta o tempo necessário.

\section{Novos questionamentos X Perspectivas de continuidade}


- Diante da exaltação do processo intuitivo em relação ao conteúdo teórico-científico, deverse-ia analisar se esta metodologia seria suficiente para abordar o conteúdo da Tecnologia da Construção. E, se este seria um indício da subestimação da complexidade envolvida sobre o conteúdo técnico.

- Como alcançar a homogeneização da qualificação profissional nos vários pontos do país e garantir as mesmas atribuições profissionais de caráter técnico diante de propostas curriculares tão diferenciadas? Quais seriam os limites das adequações contextuais?

- Como garantir que conteúdos cada vez mais amplos e complexos sejam desenvolvidos por meio de proposições curriculares que oferecem carga horária tão reduzida?

- A pouca oferta de Programas de Pós-graduação nos cursos de arquitetura na área da Tecnologia da Construção estaria associada à falta de demanda, ou a falta de demanda estaria ligada a pouca oferta e oportunidades? De que forma o cenário atual tem impactado na formação, reciclagem e aperfeiçoamento dos quadros docentes atuantes na graduação?

- Ao analisar escolas com maior tempo de implantação a ausência de espaços experimentais também é uma realidade. Será que os cursos no Brasil já não foram implantados com o entendimento de que as atividades experimentais seriam dispensáveis, sendo o processo representacional suficiente para a resolução de inovações criativas sobre os problemas que envolvem o Ambiente Construído? 


\section{REFERÊNCIAS BIBLIOGRÁFICAS:}

\section{CAPÍTULO 01}

- ADDIS, B. Edificação: 3000 Anos de Projeto, Engenharia e Construção. Porto Alegre: Boohman, 2009. - AKIPEK, F. Ö., KOZIKOĞLU, N. Prototypes in architectural education: as instruments of integration in the digital era. In: METU JFA 2007/2. (24:2) 169-178.

- ASSOCIAÇÃO BRASILEIRA DE ENSINO DE ARQUITETURA E URBANISMO - ABEA. Síntese e Contribuições do XXVI ENSEA para a discussão dos perfis da área \& padrões de qualidade do curso de Arquitetura e Urbanismo, João Pessoa - PB, 2008.

- ALMEIDA, J. G. A formação do arquiteto e a universidade. In GOUVÊA, L.A.C. et. Al. (orgs). Contribuição ao ensino de arquitetura e urbanismo. Brasília: Instituto Nacional de Estudos e Pesquisas Educacionais, 1999.

- BENEVOLO, L. A arquitetura no novo milênio. São Paulo: Estação Liberdade, 2007.

- BRASIL. MEC. DAU. CEAU. Diagnóstico das condições de ensino e pesquisa em Arquitetura e Urbanismo no Brasil - 1974. Brasília, MEC, 1977.

- BUCHANAN, P. Renzo Piano Building Workshop: Complete Works. V.1. Phaidon Press Limited, New York, 2007. (primeira edição 1993)

- CANDELA, F. Hacia uma nueva filosofia de las estructuras. Buenos Aires: Ediciones, 1962.

- CANTEIRO EXPERIMENTAL: 10 anos da FAU USP. São Paulo, FAUUSP. 2008.

- CARNeIRO, F. L. Análise Dimensional e Teoria da Semelhança e dos Modelos Físicos, 2a Edição, Editora UFRJ, 1996.

- CARVALHO, M.C.R. de. Caracterização da tecnologia construtiva de Eladio Dieste: Contribuições para a inovação do projeto arquitetônico e da construção em alvenaria estrutural. 2004. Tese (Doutorado). Faculdade de Engenharia Civil. Universidade Federal de Santa Catarina. Florianópolis, 2004.

- CASSINELLO, P. et. al. Félix Candela. In memorian (1910-1997). From thin concrete shells to the 21st century's lightweight structures. Informes de la Construcción Vol. 62, 519, 5-26, julio-septiembre 2010.

- CHURTICHAGUA, J. de. La estructura veloz: trayectorias estructurales a propósito de la obra de Emilio Perez Piñero y Felix Candela. Disponível em:

<HTTP: www.chqs.net/archivos/informes/archivos_1_040310_la +estructura+veloz.pdf> Acesso em 06 de julho de 2012.

- COMBA, M.; OLMO, C. Tra pratiche e sperimentazioni: Renzo Piano nela città del lavoro e del rischio progettuale. In: Renzo Piano Building Workshop - Le città visibili/ a cura de Fulvio Irace. Triennale Electa, 2007.

- COSTA, L. Razões da nova arquitetura. In: XAVIER, A. (org). Depoimento de uma geração. São Paulo: Cosac \& Naify, 2003.

- COWAN, H. J. et. al. Models in architecture, Elsevier Publishing Company, New York: 1974

- DIESTE, E. La Estructura Cerámica. Colección Somosur. Colombia: Escala, 1987.

- DPA - DIESTE - Documents de Projectes d'Arquitectura. Publicación del Departament de Projectes Arquitectònics de la Universitat Politècnica de Catalunya (UPC). v. 15. Catalunya, 1999

- DRELL, P. Frei Otto: form and structure. London: Crosby Lookwood Staples, 1976.

- DROSTE, M. Bauhaus. 1919-1933. Reforma e Vanguarda. Tashen, 2006.

- ELOY, E et al. Invenção: Popular e Erudito. Arquitetura e Urbanismo. Edição 141 - Dezembro/2005 
- ENGEL, H. Sistemas de structuras. Madrid: Blume, 1970.

- FICHER, S. Os arquitetos da Poli: ensino e profissão em São Paulo. EdUSP, 2005.

- GEIPEL, F.; MICHELIN, N. LABFAC: Laboratory for Architecture (French Edition), 1998.

- GIOVANNARDI, P. Félix Candela: costruttore di sogni. Borgo San Lorenzo: Studio Giovannardi e Rontini, 2006. Disponível em: http://Inx.costruzioni.net/wp-content/uploads/2009/01/F\%C3\%A9lixCandela-Costruttore-di-sogni.pdf. Acesso em: 06/07/13.

- GONÇALVES, E.M.V. A linguagem da gravidade - Para uma reflexão sobre o ensino da razão e ser dos elementos arquitectónicos estruturais. Trabalho de Síntese. Universidade do Porto, 2005.

- GRAEFF, E. A. Arte e Técnica na formação do arquiteto. São Paulo: Studio Nobel/ Fundação Vilanova Artigas, 1995.

- GRAZZIA, S. et. al. Configuração de laboratórios de tecnologia de construção e de sistemas estruturais. In: IX Conabea: Ética para o III Milênio. Londrina - PR, 1999.

- HARRIS, Harry G.; SABNIS, Gajanan M. Structural modeling and experimental techniques. 2a Ed. CRC Press LLC, Florida:1999.

- HOYET, N. Conception de la matérialisation en architecture : l'expérimentation comme facteur d'innovation industrielle. Doctorat de l'Institut National Polytechnique de Lorraine. Nancy- Universitè, 2007.

- JODIDIO, P. Piano: Renzo Piano Building Workshop - 1966 to today. Hong Kong: Taschen, 2008.

- KIND-BARKAUSKAS, F. et.al. Construire em béton. Conception des bâtiments en béton armé. Presses Polytechniques et Universitaires Romandes. Lausanne, Suisse, 2006.

- KOWALTOVSKI, D. et al. (org.) 0 processo de projeto em arquitetura: da teoria à tecnologia. São Paulo. Oficina de Textos, 2011.

- LES GRANDS ATELIERS ACTIVITÉS 2011 - 2012 - 2013. Disponível em: http://www.lesgrandsateliers.org/TPL_CODE/TPL_MEDIATHEQUEDOC/idThematique/8/4- mediatheque.htm

- LEITE, M.A.D.F.A. A aprendizagem tecnológica do arquiteto. 2005. Tese (Doutorado). Faculdade de Arquitetura e Urbanismo. Universidade de São Paulo. São Paulo, 2005.

O ensino de Tecnologia em Arquitetura e Urbanismo. 1998. Dissertação (Mestrado). Faculdade de Arquitetura e Urbanismo. Universidade de São Paulo. São Paulo, 1998.

- LÉVI-STRAUSS,C. A lógica das classificações totêmicas. In: O Pensamento Selvagem. Campinas, SP: Papirus, 1989.

- LIMA, J. F. Escola Transitória - Modelo Rural. Brasília, MEC/CEDATE, 1984.

O que é ser arquiteto: memórias profissionais de Lelé (João Figueiras Lima); em depoimento à Cynara Menezes. Rio de Janeiro: Record, 2004.

- LINA POR ESCRITO - Textos escolhidos de Lina - 1943 - 1991. Organizado por Silvana Rubino e Marina Grinover, São Paulo: Cosac Naify, 2009.

- LOPES, J. M. A. Tecnologia: arquitetura e urbanismo: escola \& ofício. 1999. Dissertação (Mestrado). Faculdade de Arquitetura e Urbanismo, Escola de Engenharia de São Carlos. Universidade de São Paulo, São Paulo. 1999.

- MARANGONI, R. F. A maquete manual como estímulo à criatividade na formação de arquitetos e urbanistas. 2011. Dissertação (Mestrado). Universidade Estadual de Campinas. Faculdade de Engenharia Civil, Arquitetura e Urbanismo. Campinas, SP, 2011.

- MASCARÓ, L. Tecnologia e Arquitetura. São Paulo, Nobel, 1989.

- MATTAR, F. N. Pesquisa de marketing. São Paulo : Atlas, 1996.

- McQuaid, M. Shigeru Ban. London: Phaidon Press Limited, 2008.

- MILL, C. Projetando com maquetes. Porto Alegre: Bookman, 2007. 
- MIRACLE, D. G. Gaudí. La búsqueda de la forma. Espacio, geometría, estructura y construcción. Lunwerg Editores, 2002.

- MONTEIRO, A. M. R. G. A construção de um novo olhar sobre o ensino de arquitetura e urbanismo no Brasil: os $\mathbf{4 0}$ anos da Associação Brasileira de Ensino de Arquitetura e Urbanismo./ Ana Maria Reis Goes Monteiro, Gogliardo Vieira Maragno, Wilson Ribeiro dos Santos Junior; Ester Judite Bendjouya Gutierrez (org.). - Brasília: ABEA, 2013.

- MORIN, E. Os sete saberes necessários à educação do futuro. 12. ed. São Paulo : Cortez, 2007.

- NATTERER, J. et. al. Construire en Bois. Choisir, Concevoir, Réaliser. 2a Edição. Presses Polytechniques et Universitaire Romandes. Lausanne, Suisse, 2001.

- NERVI, P.L. Lenguage arquitectónico. Buenos Aires. Faculdad de Arquitectura y Urbanismo, 1951.

Construire Correttamente - Caratteristiche e Possibilità dele Strutture Cementizie

Armate. 2a Edizione, Editore Ulrico Hoepli Milano. Milan, 1965.

- OLIVEIRA, T. M. V. Amostragem não Probabilística: Adequação de Situações para uso e Limitações de amostras por Conveniência, Julgamento e Quotas. Administração On Line Prática -Pesquisa Ensino,Vol. 2, $\quad$ n. $3 . \quad$ Jul/ago/set/ 2001. Disponível em: http://www.fecap.br/adm_online/art23/tania2.htm. Acesso em 27/10/14.

- OTTO, F. Tensile Structures. Cambridge. Mass.: MIT Press, 1973.

- OTTO, F. et al. Tecnologia y Arquitectura. Arquitectura Adaptable. Seminário organizado por el Instituto de Estructuras Ligeras. Editorial Gustavo Gili, S.A. Barcelona, 1979.

- PERDRIX, M. C. A. Centenario de Eduardo Torroja - Ciencia, Tecnología y Empresa. Informes de la Construcción, Vol. 51 rt $^{\circ}$ 462, julio/agosto 1999.

- PIANO, R. Renzo Piano - A responsabilidade do arquiteto/ conversas com Renzo Cassigoli. São Paulo: BEI Comunicação, 2011.

Electa, 2007.

Renzo Piano Building Workshop - Le città visibili/ a cura de Fulvio Irace. Triennale

- PINHO, R. Lelé: um arquiteto universal. In: A arquitetura de Lelé: fábrica e invenção / organização Max Risselada e Giancarlo Latorraca. São Paulo : Imprensa Oficial do Estado de São Paulo/Museu da Casa Brasileira, 2010.

- PIPPARD, A. J. S. The Experimental Study Of Structures. London: Edward Arnold \& Co, 1947.

- PROUVÉ, J. Conversaciones com Jean Prouvè./ Armelle Lavalou (ed.). Editorial Gustavo Gili, Barcelona, 2005.

- REBELLO, Y.C.P. Contribuição ao ensino de estruturas nas escolas de arquitetura. 1993. Dissertação (Mestrado). Faculdade de Arquitetura e Urbanismo. Universidade de São Paulo. São Paulo, 1993.

Uma proposta de ensino da concepção estrutural. 1999. Tese (Doutorado). Faculdade de Arquitetura e Urbanismo. Universidade de São Paulo. São Paulo, 1999.

RICHARDSON, R. J. Pesquisa social: métodos e técnicas. São Paulo: Atlas. 1985

- RISÉRIO, A. Um mestre da precisão e da delicadeza estética e social. In: A Arquitetura de Lelé: fábrica e invenção. São Paulo: Imprensa Oficial do Estado de São Paulo: Museu da Casa Brasileira, 2010. p. 3145.

- RISSELADA, M. ; LATORRACA, G. (org). A Arquitetura de Lelé: fábrica e invenção. São Paulo: Imprensa Oficial do Estado de São Paulo: Museu da Casa Brasileira, 2010. 244p.

- ROLAND, C. Frei Otto: Estructuras. Estudios y trabajos sobre la construcción ligera. Editora Gustavo Gili, Barcelona,1965

- ROLLET, P. L'architecture expérimentée à échelle grandeur. [abr. 2006]. Entrevistador: Nadie Hoyet. Grenoble. 
- RONCONI, R L.N. Inserção do canteiro experimental nas faculdades de arquitetura e urbanismo. 2002. Tese (Doutorado). Faculdade de Arquitetura e Urbanismo. Universidade de São Paulo. São Paulo, 2002.

- SARAMAGO, R.C.P. Ensino de estruturas nas escolas de arquitetura do Brasil. 2011. Dissertação (Mestrado). Faculdade de Arquitetura e Urbanismo, Escola de Engenharia de São Carlos. Universidade de São Paulo, São Paulo. 2011.

SELLTIZ, C. e outros. Métodos de pesquisa nas relações sociais. "Tradução de Dante Moreira Leite. São Paulo: EPU. Editora da Universidade de São Paulo, 1975.

- SIMONNET, C.; FRAMPTON, K; CHUPIN,J.P. Projet tectonique. Infolio éditions, French, 2005.

- SIMONNET, C. A dimensão do Detalhe. Arquitetura e Urbanismo. Ago/set. 1990.

- SULZER, Peter. Jean Prouvé, oeuvre complète. 1934 - 1944. Vol. 2. Basel : Birkhäuser Boston Berlin. 2008.

- TAMASHIRO, H. A. Entendimento técnico-construtivo e desenho arquitetônico: uma possibilidade de inovação didática. 2010. Tese (Doutorado). Faculdade de Arquitetura e Urbanismo, Escola de Engenharia de São Carlos. Universidade de São Paulo. 2010.

- Textos sobre o ensino de arquitetura: Mario Wagner Vieira da Cunha, Luís Saia, João Batista Vilanova Artigas, Lina Bo Bardi - Grêmio da Faculdade de Arquitetura e Urbanismo da Universidade de São Paulo. São Paulo, 1956.

- The Pritzker architecture prize, 1998 : presented to Renzo Piano - sponsored by the Hyatt Foundation. Los Angeles, Calif. : Jensen \& Walker, 1999.

- TORROJA, E. Razon y ser de los tipos structurales. Madrid: Instituto Técnico de la Construcción e del Cemento, 1958.

- Trajetória e estado da arte da formação em engenharia, arquitetura e agronomia/ Conselho Federal de Engenharia, Arquitetura e Agronomia. Brasília: Instituto Nacional de Estudos e Pesquisas Educacionais Anísio Teixeira./ Conselho Federal de Engenharia, Arquitetura e Agronomia, 2010.

- VALCARCEL, J. P.; ESCRIG, F. La obra arquitectonica de Emilio Perez Piñero. Boletín Académico. Escola Técnica Superior de Arquitectura da Coruña, 1992, 16: 3-12.

- VASCONCELOS, C. A. de. Estruturas da natureza: um estudo da interface entre biologia e engenharia. Studio Nobel, 2000.

- VIANNA, N.S. Tecnologia e Arquitetura. In: Tecnologia e Arquitetura. São Paulo, Nobel, 1989.

- VINCENT, P. La conception architecturale par l'expérimentation. [set. 2006]. Entrevistador: Nadie Hoyet. Paris.

- WICK, R. A Pedagogia da Bauhaus. São Paulo: Martins Fontes, 1989.

- ZANETTINI, S. Siegbert Zanettini: arquitetura, razão e sensibilidade. São Paulo: Editora da Universidade de São Paulo, 2002.

O Ensino de Projeto na área de edificação. São Paulo, FAUUSP, 1980.

\section{CAPÍTULO 02}

- ADDIS, Bill. Edificação: 3000 Anos de Projeto, Engenharia e Construção. Porto Alegre: Boohman, 2009.

- ALLEGRET, L; VAUDOU, V. Jean Prouvè et Paris. Paris : Editions du Pavillon de l'Arsenal, 2001.

- ALMEIDA, J. G. A. A formação do arquiteto e a universidade. 1997. In.: GOUVÊA, L. A. C. et. Al. (Orgs). Contribuição ao ensino de Arquitetura e Urbanismo. Brasília: Instituto Nacional de Estudos e Pesquisas Educacionais, 1999. P. $101-119$. 
- AKIPEK, F. Ö., KOZIKOĞLU, N. Prototypes in architectural education: as instruments of integration in the digital era. In: METU JFA 2007/2. (24:2) 169-178.

- BAN, S.; Keio University SFC Ban Laboratory. Voluntary Architects Network. Making Architecture, Nurturing people: From Rwanda to Haiti. Tóquio: INAX Publishing, 2010.

- BAYL-SMITH, M. BuildAbility: the future of construction education. Research Report, May, 2011.

- BUCHANAN, P. Renzo Piano Building Workshop: Complete Works. V.1-5. Phaidon Press Limited, New York, 2007.

- BUITONI, C. S. Mayumi Watanabe Souza Lima: a construção do espaço para a educação. 2009. Dissertação (Mestrado). Faculdade de Arquitetura e Urbanismo. Universidade de São Paulo, São Paulo. 2009.

- CANDELA, F. Hacia uma nueva filosofia de las estructuras. Buenos Aires: Ediciones, 1962.

- CANTEIRO EXPERIMENTAL: 10 anos da FAU USP. São Paulo, FAUUSP. 2008.

- COWAN, H. J. et. al. Models in architecture, Elsevier Publishing Company, New York: 1974.

- DAVIS, L. et al. Innovative funicular tile vaulting: A prototype vault in Switzerland. TheStructuralEngineer. Nov. 2012.

- DIESTE, E. La Estructura Cerámica. Colección Somosur. Colombia: Escala, 1987.

- DRELL, P. Frei Otto: form and structure. London: Crosby Lookwood Staples, 1976.

- DROSTE, M. Bauhaus. 1919-1933. Reforma e Vanguarda. Tashen, 2006.

- ENGEL, H. Sistemas de structuras. Madrid: Blume, 1970.

- FICHER, S. Os arquitetos da Poli: ensino e profissão em São Paulo. EdUSP, 2005.

- GONÇALVES, E.M.V. A linguagem da gravidade - Para uma reflexão sobre o ensino da razão e ser dos elementos arquitectónicos estruturais. Trabalho de Síntese. Universidade do Porto, 2005.

- GRAEFF, E. A. Arte e Técnica na formação do arquiteto. São Paulo: Studio Nobel/ Fundação Vilanova Artigas, 1995.

- GRANDE, N. Arquitetura e Tecnologia na crise da Cultura Tectònica. In: A tecnologia na arquitetura contemporânea:Dominique Perrault, Baumschlager \& Eberle, Mansilla + Tuñón, Carrilho da Graça / Michele Cannatà, Fárima Fernandes. Lisboa : Estar Editora, 2000.

- GROPIUS, W. Bauhaus: novarquitetura. São Paulo: Perspectiva. 3ạ edição, 1997.

- HARRIS, Harry G.; SABINS, Gajanan M. Structural modeling and experimental techniques. 2a Ed. CRC Press LLc, Florida:1999.

- HOYET, N. Conception de la matérialisation en architecture : l'expérimentation comme facteur d'innovation industrielle. Doctorat de l'Institut National Polytechnique de Lorraine. Nancy- Universitè, 2007.

- KOWALTOVSKI, D. et al. (org.) 0 processo de projeto em arquitetura: da teoria à tecnologia. São Paulo. Oficina de Textos, 2011.

- LAVERDE, A. A Experimentação física como mediadora entre o pensável e o possível. VI PROJETAR O Projeto como instrumento para a materialização da Arquitetura: ensino, pesquisa e prática. Salvador, 2013.

- LES GRANDS ATELIERS ACTIVITÉS 2011 - 2012 - 2013. Disponível em http://www.lesgrandsateliers.org/TPL_CODE/TPL_MEDIATHEQUEDOC/idThematique/8/4- mediatheque.htm - LEITE, M.A.D.F.A. A aprendizagem tecnológica do arquiteto. 2005. Tese (Doutorado). Faculdade de Arquitetura e Urbanismo. Universidade de São Paulo. São Paulo, 2005.

O ensino de Tecnologia em Arquitetura e Urbanismo. 1998. Dissertação (Mestrado). Faculdade de Arquitetura e Urbanismo. Universidade de São Paulo. São Paulo, 1998.

- LIMA, J. F. Escola Transitória - Modelo Rural. Brasília, MEC/CEDATE, 1984. 
O que é ser arquiteto: memórias profissionais de Lelé (João Figueiras Lima); em depoimento à Cynara Menezes. Rio de Janeiro: Record, 2004.

- LINA POR ESCRITO - Textos escolhidos de Lina - 1943 - 1991. Organizado por Silvana Rubino e Marina Grinover, São Paulo: Cosac Naify, 2009.

- LOPES, J. M. A. Tecnologia: arquitetura e urbanismo: escola \& ofício. 1999. Dissertação (Mestrado). Faculdade de Arquitetura e Urbanismo, Escola de Engenharia de São Carlos. Universidade de São Paulo, São Paulo. 1999.

Quando menos não é mais: tectônica e o ensino tecnológico da Arquitetura e do Urbanismo. III Encontro da Associação Nacional de Pesquisa e Pós-graduação em Arquitetura e Urbanismo arquitetura, cidade e projeto: uma construção coletiva São Paulo, 2014.

- LOTUFO, T. Um novo ensino para uma outra prática. Rural Studio e Canteiro Experimental, contribuições para o ensino de arquitetura no Brasil. Dissertação (Mestrado). Faculdade de Arquitetura e Urbanismo. Universidade de São Paulo. São Paulo, 2014.

- MARANGONI, R. F. A maquete manual como estímulo à criatividade na formação de arquitetos e urbanistas. 2011. Dissertação (Mestrado). Universidade Estadual de Campinas. Faculdade de Engenharia Civil, Arquitetura e Urbanismo. Campinas, SP, 2011.

- MILL, C. Projetando com maquetes. Porto Alegre: Bookman, 2007.

- MORIN, E. Os sete saberes necessários à educação do futuro. 12. ed. São Paulo : Cortez, 2007.

- NERVI, P.L. Lenguage arquitectónico. Buenos Aires. Faculdad de Arquitectura y Urbanismo, 1951.

Construire Correttamente - Caratteristiche e Possibilità dele Strutture Cementizie Armate. 2a Edizione, Editore Ulrico Hoepli Milano. Milan, 1965.

- Ostwald, M.J. and William, A. Understanding Architectural Education in Australasia: An Analysis of Architecture Schools, Programs, Academics and Students. Australian Learning and Teaching Council, Australia, Vol. 1, 2008.

- Ostwald, M.J. and Williams, A. Understanding Architectural Education in Australasia: An Analysis of Architecture Schools, Programs, Academics and Students. Australian Learning and Teaching Council, Vol. 2: Results and Recommendations, 2008.

- OTTO, F. Tensile Structures. Cambridge. Mass.: MIT Press, 1973.

- PIANO, R. Renzo Piano - A responsabilidade do arquiteto/ conversas com Renzo Cassigoli. São Paulo: BEI Comunicação, 2011.

- PIPPARD, A. J. S. The Experimental Study Of Structures. London: Edward Arnold \& Co, 1947.

- PISANI. M.A.J. et. al. Canteiro experimental: prática ou invenção? Aedificandi Revista de Arquitetura e Construção (especial), São Paulo, vl. 1-15.

- PROUVÉ, J. Conversaciones com Jean Prouvè./ Armelle Lavalou (ed.). Editorial Gustavo Gili, Barcelona, 2005.

- RAPSON, R. Prefácio. In: Sistemas de Estructuras, Madrid: Blume, 1970.

- REBELLO, Y.C.P. Contribuição ao ensino de estruturas nas escolas de arquitetura. 1993. Dissertação (Mestrado). Faculdade de Arquitetura e Urbanismo. Universidade de São Paulo. São Paulo, 1993.

Uma proposta de ensino da concepção estrutural. 1999. Tese (Doutorado). Faculdade de Arquitetura e Urbanismo. Universidade de São Paulo. São Paulo, 1999.

- ROLLET, P. L'architecture expérimentée à échelle grandeur. [abr. 2006]. Entrevistador: Nadie Hoyet. Grenoble.

- RONCONI, R L.N. Inserção do canteiro experimental nas faculdades de arquitetura e urbanismo. 2002. Tese (Doutorado). Faculdade de Arquitetura e Urbanismo. Universidade de São Paulo. São Paulo, 2002. 
Canteiro experimental - uma proposta pedagógica para a formação do arquiteto e urbanista. In: Pós : Revista do Programa de Pós-Graduação da Faculdade de Arquitetura e Urbanismo, São Paulo, n.17, p.142-158, jun. 2005.

- SARAMAGO, R.C.P. Ensino de estruturas nas escolas de arquitetura do Brasil. 2011. Dissertação (Mestrado). Faculdade de Arquitetura e Urbanismo, Escola de Engenharia de São Carlos. Universidade de São Paulo, São Paulo. 2011.

- SCHLLE, A. R. (Org.). Trajetória e estado da arte da formação em Engenharia, Arquitetura e Agronomia - Volume X: Arquitetura e Urbanismo. Brasília: INEP/CONFEA. 2010.

- SCHLEE, A. R. et al. Registro Arquitetônico da Universidade de Brasília. Brasília: Editora Universidade de Brasília, 2014.

- SCHLEE, A.R.; FICHER, S. Brasília - Confronto entre a iluminação do passado e a reflexão sobre um presente em evolução constante. ENANPARQ. Arquitetura, Cidade, Paisagem e Território: percursos e prospectivas. Rio de Janeiro, 2010.

- SIMONNET, C.; FRAMPTON, K; CHUPIN,J.P. Projet tectonique. Infolio éditions, French, 2005.

- SOUZA, R. M. de. O Olho e a Mão: Walter Gropius. 2014. Dissertação (Mestrado). Faculdade de Arquitetura e Urbanismo. Universidade de São Paulo, São Paulo. 2014.

- SULZER, Peter. Jean Prouvé, oeuvre complète. 1934 - 1944. Vol. 2. Basel : Birkhäuser Boston Berlin. 2008.

- TAMASHIRO, H. A. Entendimento técnico-construtivo e desenho arquitetônico: uma possibilidade de inovação didática. 2010. Tese (Doutorado). Faculdade de Arquitetura e Urbanismo, Escola de Engenharia de São Carlos. Universidade de São Paulo. 2010.

- Textos sobre o ensino de arquitetura: Mario Wagner Vieira da Cunha, Luís Saia, João Batista Vilanova Artigas, Lina Bo Bardi - Grêmio da Faculdade de Arquitetura e Urbanismo da Universidade de São Paulo. São Paulo, 1956.

- TORROJA, E. Razon y ser de los tipos structurales. Madrid: Instituto Técnico de la Construcción e del Cemento, 1958.

Structures of Eduardo Torroja : an autobiography of engineering accomplishments. New York : Dodge, 1958.

- VACCARI, M. A obra de Shigeru Ban e sua influência na Academia. [mai. 2015]. Entrevistador: Albenise Laverde. São Paulo, SP.

Mito. Maio, 2013.

Shigeru Ban: Arquitetura e Atividades Humanitárias. Acervo pessoal, apresentação:

- VIANNA, N.S. Tecnologia e Arquitetura. In: Tecnologia e Arquitetura. São Paulo, Nobel, 1989.

- WICK, R. A Pedagogia da Bauhaus. São Paulo: Martins Fontes, 1989.

- ZANETTINI, S. Siegbert Zanettini: arquitetura, razão e sensibilidade. São Paulo: Editora da Universidade de São Paulo, 2002.

O Ensino de Projeto na área de edificação. São Paulo, FAUUSP, 1980.

\section{CAPÍTULO 03}

- ALTAFIM, R.A. C. 50 anos da EESC: um olhar no passado visando o futuro. 2a Edição. São Carlos: Escola de Engenharia de São Carlos, 2004.

- ARTIGAS, V. Contribuição para o relatório sobre ensino de Arquitetura e Urbanismo, 1974. In: Sobre a história do ensino de Arquitetura no Brasil. São Paulo: Associação Brasileira de Escolas de Arquitetura, 1977. 
- ASSOCIAÇÃO BRASILEIRA DE ESCOLAS DE ARQUITETURA. Caderno 21. Anais do XVI Encontro Nacional Sobre Ensino de Arquitetura Urbanismo e IX Congresso Nacional da ABEA - Ética para o III Milênio ANEXO: Laboratórios: configurações preconizadas. Londrina - PR, Novembro de 1999.

- ASSOCIAÇÃO BRASILEIRA DE ESCOLAS DE ARQUITETURA. Caderno 32. XXXII COSU - Conselho Superior da ABEA e XXVI Encontro Nacional Sobre Ensino de Arquitetura e Urbanismo - Novos Perfis e Padrões de Qualidade para os Cursos de Arquitetura e Urbanismo: do Projeto Pedagógico às Atribuições Profissionais. João Pessoa - PB, novembro de 2008.

BRASIL. Lei $n^{0} 12.378$, de 31 de dezembro de 2010. Regulamenta o exercício da Arquitetura e Urbanismo; cria o Conselho de Arquitetura e Urbanismo do Brasil - CAU/BR e os Conselhos de Arquitetura e Urbanismo dos Estados e do Distrito Federal - CAUs; e dá outras providencias. Diário Oficial da União, Brasília, DF, 31 dez. 2010.

. Resolução $n^{\circ}$ 6, de 02 de fevereiro de 2006. Institui as Diretrizes Curriculares Nacionais do Curso de Arquitetura e Urbanismo e dá outras providências. Diário Oficial da União, Brasília, DF, 03 fev. 2006. Seção 1.

- BRASIL. Ministério da Educação e Cultura. Secretaria de Ensino Superior. Comissão de Ensino em Arquitetura. Diagnóstico das condições de ensino e pesquisa em Arquitetura e Urbanismo no Brasil 1974. Brasília, MEC, 1977.

. Ministério da Educação e Cultura. Secretaria de Ensino Superior. Programa Integrado de melhoria do ensino de graduação em arquitetura (PIMEG-ARQ). Brasília, 1981.

Ministério da Educação e Cultura. Secretaria de Ensino Superior. Comissão de Ensino em Arquitetura. PERFIS DA ÁREA \& PADRÕES DE QUALIDADE Expansão, Reconhecimento e Verificação Periódica dos Cursos de Arquitetura e Urbanismo, Brasília, 1995.

- Canteiro Experimental da FAU: registro preliminar de uma experiência - 20 semestre de 1993. FAUUSP, 1994.

- CERAVOLO, A.L. Paulo de Camargo e Almeida : arquitetura total na trajetória de um arquiteto brasileiro. Dissertação (Mestrado), Escola de Engenharia de São Carlos. Universidade de São Paulo, 2000.

- Documento Preliminar sobre o Canteiro Experimental da FAUUSP. Faculdade de Arquitetura e Urbanismo da Universidade de São Paulo. São Paulo, 1993.

- FICHER, S.; SCHEELE, A.R. Olhares, Brasília, 2010.

- FIGUEIREDO, J. K. de. A Escola de Arquitetura e sua História, Belo Horizonte, 1946.

- GRAEFF, E. A. Arte e Técnica na formação do arquiteto. São Paulo: Studio Nobel/ Fundação Vilanova Artigas, 1995.

Um balanço crítico das lutas pelo novo currículo mínimo. Revista Projeto 53, 1983.

- GRAZZIA, S. et. al. Configuração de laboratórios de tecnologia de construção e de sistemas estruturais. In: IX Conabea: Ética para o III Milênio. Londrina - PR, 1999.

- GUTIERREZ, E.J.B. A Associação Brasileira de Ensino de Arquitetura e os seus primeiros tempos (19731985). A construção de um novo olhar sobre o ensino de arquitetura e urbanismo no Brasil: os 40 anos da Associação Brasileira de Ensino de Arquitetura e Urbanismo. Brasília: ABEA, 2013.

- KOURY, A.P. Arquitetura Construtiva: proposições para a produção da arquitetura no Brasil (19601970). Projeto História, São Paulo, n.34, p. 189-203, jun. 2007.

- LAVERDE, A. Construção de uma cúpula geodésica com tubos de papelão: uma experiência na Universidade Federal de Uberlândia - UFU/MG. XL Congresso Brasileiro de Educação em Engenharia COBENGE, Belém, PA, 2012.

- LEITE, M.A.D.F.A. A aprendizagem tecnológica do arquiteto. 2005. Tese (Doutorado). Faculdade de Arquitetura e Urbanismo. Universidade de São Paulo. São Paulo, 2005. 
- LEMOS, C.B.et al. (org.) Escola de Arquitetura da UFMG: lembranças do passado. Visão do futuro. Belo Horizonte: EA/UFMG, 2010.

- LIMA, J.F. O que é ser arquiteto: memórias profissionais de Lelé (João Figueiras Lima); em depoimento à Cynara Menezes. Rio de Janeiro: Record, 2004.

- LOPES, J.M.A. Quando Menos não é mais: tectônica e o ensino tecnológico da Arquitetura e Urbanismo. III Enamparq - Encontro da Associação Nacional de Pesquisa e Pós-graduação em Arquitetura e Urbanismo, São Paulo, 2014.

- MAGALHÃES, M.A.A. de A. Tecnologia da Construção e Laboratórios - Ensino e Pesquisa. In: Caderno ABEA no 21 - p. 162-165. Londrina, 1999.

- MARAGNO, G. V. Associação Brasileira de Ensino de Arquitetura e as relações entre o ensino de Arquitetura e Urbanismo e a habilitação profissional no Brasil. In: A construção de um novo olhar sobre o ensino de arquitetura e urbanismo no Brasil: os $\mathbf{4 0}$ anos da Associação Brasileira de Ensino de Arquitetura e Urbanismo. Brasília: ABEA, 2013.

- MARTINS, C.B. O novo ensino superior privado no Brasil (1964-1980). In: Ensino Superior Brasileiro transformações e perspectivas. São Paulo: Editora Brasiliense, 1988.

- MEIRA, M. E. Da forma ao conteúdo. A educação de arquitetos e urbanistas no Brasil . Revista Projeto. São Paulo. Agosto 1994.

- MIRANDA, C. S. et. al. Uma formação em curso. Esboços da graduação em Arquitetura e Urbanismo da UFPA. Belém, UFPA, 2015.

- MONTEIRO, A. M. R. G et. al. A construção de um novo olhar sobre o ensino de arquitetura e urbanismo no Brasil: os $\mathbf{4 0}$ anos da Associação Brasileira de Ensino de Arquitetura e Urbanismo. Brasília: ABEA, 2013.

- MONTEIRO, A. M. R. A atuação da Associação Brasileira de Ensino de Arquitetura na consolidação de um ensino de Arquitetura e Urbanismo de qualidade (2000-2010). In: A construção de um novo olhar sobre o ensino de arquitetura e urbanismo no Brasil: os 40 anos da Associação Brasileira de Ensino de Arquitetura e Urbanismo. Brasília: ABEA, 2013.

- Ofício GD/442 - PMAC/rhps - Universidade de São Paulo - Faculdade de Arquitetura e Urbanismo, São Paulo, 1966.

- Ofício GD/720 - A - RMGP/rhps - Universidade de São Paulo - Faculdade de Arquitetura e Urbanismo, São Paulo, 1968.

- PEREIRA, M. A. Ensino de Arte e Arquitetura. Revista Acrópole, n 369/370. Ano 31. 1970.

- ROTHEN, J.C.; BARREYRO G. B. Avaliação da educação superior no segundo governo Lula: "provão II" ou a reedição de velhas práticas? Educação \& Sociedade, Mar2011, vol. 32, n.114. Disponível em:

$<$ http://www.scielo.br/scielo.php?script=sci_arttext\&pid=S0101-

$73302011000100002 \&$ Ing=en\&nrm=iso>. Acesso em 17 de março de 2012.

- SALVATORI, E. De la originalidad a la competencia: la enseñanza de arquitectura en la UFRGS, Porto Alegre, Brasil - 1962 a 1994. Tese (Doctorado en Teoría e Historia de la Arquitectura Departamento de Composición Arquitectónica). ETSAB/UPC, Barcelona, 2005.

- SANTOS JUNIOR, W. R. dos. A ABEA e a conquista das Diretrizes Curriculares nacionais para os cursos de Arquitetura e Urbanismo em 1994: uma inflexão inovadora no ensino de Arquitetura e Urbanismo no Brasil (1985 - 1994/95). In: A construção de um novo olhar sobre o ensino de arquitetura e urbanismo no Brasil: os 40 anos da Associação Brasileira de Ensino de Arquitetura e Urbanismo. Brasília: ABEA, 2013.

. O currículo mínimo no ensino de arquitetura e urbanismo no Brasil: $1969-1994$. Tese

(Doutorado em Arquitetura) - Faculdade de Arquitetura e Urbanismo, Universidade de São Paulo, São Paulo, 2001. 
SARAMAGO, R.C.P. Ensino de estruturas nas escolas de arquitetura do Brasil. 2011. Dissertação (Mestrado). Faculdade de Arquitetura e Urbanismo, Escola de Engenharia de São Carlos. Universidade de São Paulo, São Paulo. 2011.

- SCHLEE, A. R. et al. Registro Arquitetônico da Universidade de Brasília. Brasília: Editora Universidade de Brasília, 2014.

- Textos sobre o ensino de arquitetura: Mario Wagner Vieira da Cunha, Luís Saia, João Batista Vilanova Artigas, Lina Bo Bardi - Grêmio da Faculdade de Arquitetura e Urbanismo da Universidade de São Paulo. São Paulo, 1956.

- Trajetória e estado da arte da formação em Engenharia, Arquitetura e Agronomia. Conselho Federal de Engenharia, Arquitetura e Agronomia. Brasília: Instituto Nacional de Estudos e Pesquisas Educacionais Anísio Teixeira. Conselho Federal de Engenharia, Arquitetura e Agronomia, 2010.

- SCHLEE A. R. (Org.). Trajetória e estado da arte da formação em Engenharia, Arquitetura e Agronomia - volume X: Arquitetura e Urbanismo. Brasília :INEP/CONFEA. 2010.

- UNIVERSIDADE DE BRASÍLIA. Faculdade de Arquitetura e Urbanismo. Projeto Político Pedagógico de curso, Brasília, 2012.

. Plano orientador da Universidade de Brasília. Brasília: Ed. UnB, 1962.

50 ANOS: história contada: a história da Universidade de Brasília contada por seus personagens: reportagens, depoimentos, entrevistas. Brasília: Editora Universidade de Brasília, 2012;

- UNIVERSIDADE DE MINAS GERAIS. Serviço dos Países S. A. Belo Horizonte, 1965.

- UNIVERSIDADE DE SÃO PAULO. Faculdade de Arquitetura e Urbanismo. União Internacional de Arquitetos - UNESCO. Relatório sobre o ensino de arquitetura no Brasil. Outubro de 1974. In: Associação Brasileira de Escolas de Arquitetura. Sobre o ensino de arquitetura no Brasil. São Paulo: ABEA, 1977.

Paulo, 2013.

Faculdade de Arquitetura e Urbanismo. Projeto Político Pedagógico de curso. São

. Faculdade de Arquitetura e Urbanismo. Departamento de Tecnologia - Relatório de Atividades, 2013.

UNIVERSIDADE DE SÃO PAULO. Instituto de Arquitetura e Urbanismo. Projeto Político Pedagógico de curso, São Carlos, 2013. . Instituto de Arquitetura e Urbanismo. Avaliação Institucional da USP 2010-1014.

- UNIVERSIDADE ESTADUAL DE CAMPINAS. Faculdade de Engenharia, Arquitetura e Urbanismo. Curso de Arquitetura e Urbanismo. Projeto Político Pedagógico de curso - 2011(12).

- UNIVERSIDADE FEDERAL DA BAHIA - Faculdade de Arquitetura - Considerações Gerais sobre o Currículo do Curso - FAUFBA, Salvador, 2001.

. Projeto Político Pedagógico de curso - Resumo. Salvador, 201(?)

- UNIVERSIDADE FEDERAL DA PARAÍBA - Centro de Tecnologia - Curso de Arquitetura e Urbanismo Projeto Político Pedagógico de curso - CAU UFPB, João Pessoa, 2012.

- UNIVERSIDADE FEDERAL DE MATO GROSSO DO SUL - Faculdade de Engenharias, Arquitetura e Urbanismo e Geografia - Curso de Arquitetura e Urbanismo - Projeto Político Pedagógico de curso CAU - UFMS, Campo Grande, 2014.

- UNIVERSIDADE FEDERAL DE MINAS GERAIS. Escola de Arquitetura. Projeto Político Pedagógico de curso - EA UFMG, Belo Horizonte, 2011.

- UNIVERSIDADE FEDERAL DE PERNAMBUCO. Curso de Graduação em Arquitetura e Urbanismo. Projeto Político Pedagógico de curso - CAU UFPE, Recife, 2010.

- UNIVERSIDADE FEDERAL DE UBERLÂNDIA - Faculdade de Arquitetura Urbanismo e Design - Projeto Político Pedagógico de curso - FAUeD UFU, Uberlândia, 2011. 
- UNIVERSIDADE FEDERAL DE VIÇOSA - Centro de Ciências Exatas e Tecnológicas - Curso de Arquitetura e Urbanismo - Projeto Político Pedagógico de curso - CAU UFV, Viçosa, 2012.

- UNIVERSIDADE FEDERAL DO CEARÁ - Centro de Tecnologia - Departamento de Arquitetura e Urbanismo - DAU UFC, Fortaleza, 2011.

- UNIVERSIDADE FEDERAL DO ESPÍRITO SANTO - Curso de Arquitetura e Urbanismo - Projeto Político Pedagógico de curso - CAU UFES, Vitória, 2011.

- UNIVERSIDADE FEDERAL DO PARANÁ - Curso de Arquitetura e Urbanismo. Projeto Político Pedagógico de curso - CAU UFPR, Curitiba, 2013.

- UNIVERSIDADE FEDERAL DO RIO DE JANEIRO - Faculdade de Arquitetura e Urbanismo. Projeto Político Pedagógico de curso - FAUUFRJ, Rio de Janeiro, 2006.

- UNIVERSIDADE FEDERAL DO RIO GRANDE DO NORTE - Centro de Tecnologia - Departamento de Arquitetura. Curso de Arquitetura e Urbanismo - Projeto Político Pedagógico de curso - CAU UFRN, Natal, 2006.

- UNIVERSIDADE FEDERAL DO RIO GRANDE DO SUL - Faculdade de Arquitetura. Projeto Político Pedagógico de curso - FAUFRGS, Porto Alegre, 2012.

- VIANNA, N.S. Tecnologia e Arquitetura. In: Tecnologia e Arquitetura. São Paulo, Nobel, 1989.

- VIDIGAL, E. J. O ensino de projeto arquitetônico. Um estudo sobre as práticas didáticas no curso de Arquitetura e Urbanismo na Universidade Federal do Paraná. Tese (Doutorado) FAUUSP, 2010. 0 autor deste trabalho é também professor de Projeto do CAU-UFPR.

- VULCÃO, M.G.V. A construção do discurso de criação do 'Curso-Tronco' de Arquitetura e Urbanismo da Universidade de Brasília (1962-1963). Dissertação (Mestrado em Arte) - Universidade de Brasília, Brasília, 2008.

- ZANETTINI, S. Aspectos do ensino de arquitetura para arquitetos. In: Encontro de Professores de Estruturas para escolas de Arquitetura, 1, 1974, Anais... São Paulo, FAUUSP.

. Siegbert Zanettini: arquitetura, razão e sensibilidade. São Paulo: Editora da Universidade de São Paulo, 2002.

\section{OUTRAS FONTES CONSULTADAS - CAPÍTULO 03}

- ASSOCIAÇÃO BRASILEIRA DE ESCOLAS DE ARQUITETURA. Brasília, Primeiro Encontro. Boletim no1, jun. 1974. s.p. Acervo da ABEA. . Boletim no2, 1976. Acervo da ABEA. s. p. . Boletim no3, 1976. Acervo da ABEA. s. $p$ . Carta de Ouro Preto. São Paulo: ABEA, 1978. s.p.

. Cadernos 9 e 10 - Anais Seminário Nacional: Critérios para avaliação da Educação do Arquiteto e Urbanista.

- Caderno 11 - Anais Seminário Nacional: Critérios para avaliação da Educação do Arquiteto e Urbanista.

- Caderno 12 - Anais do Seminário Nacional de Pós-Graduação em Arquitetura e Urbanismo - Salvador, setembro de 1994.

. Caderno 14 - Anais do I Seminário Nacional sobre Extensão em Arquitetura e Urbanismo - Salvador, setembro de 1994.

. Caderno 15 - Anais do XII Encontro Nacional sobre o Ensino de Arquitetura e Urbanismo Belém, outubro I novembro de 1995.

Caderno 16 - Anais do Seminário Nacional sobre Pesquisa na Educação do Arquiteto e Urbanista. Cuiabá, junho de 1995. 
. Caderno 19 - VIII Congresso Nacional da ABEA e XIV Encontro Nacional sobre Ensino de Arquitetura. "Implantação dos Currículos e o Trabalho Final de Graduação". Florianópolis, novembro de 1997.

. Caderno 20. Anais do 15을 Encontro Nacional Sobre Ensino de Arquitetura Urbanismo Práticas Pedagógicas em ensino de Arquitetura e Urbanismo. Campo Grande - MS, Novembro de 1998.

Caderno 21. Anais do XVI Encontro Nacional Sobre Ensino de Arquitetura Urbanismo e IX Congresso Nacional da ABEA - Ética para o III Milênio - ANEXO: Laboratórios: configurações preconizadas. Londrina - PR, Novembro de 1999.

. Caderno 22. XI Congresso Nacional da ABEA e XVII Encontro Nacional Sobre Ensino de Arquitetura e Urbanismo - Técnicas Retrospectivas: "Manutenção e Reabilitação da Paisagem Construída". Rio de Janeiro - RJ, novembro de 2001.

Caderno 23. XXIV COSU - Conselho Superior da ABEA e XVIII Encontro Nacional Sobre Ensino de Arquitetura e Urbanismo - Projeto Político Pedagógico. Belo horizonte - MG, junho de 2002.

Caderno 24. XXV COSU - Conselho Superior da ABEA e XIX Encontro Nacional Sobre Ensino de Arquitetura e Urbanismo - Projeto Pedagógico e In(Ex)clusão Social. Natal - RN, novembro de 2002.

- Caderno 26. XXVII COSU - Conselho Superior da ABEA e XXI Encontro Nacional Sobre Ensino de Arquitetura e Urbanismo - Habitação e Mobilidade e seu Ensino. São Paulo - SP, agosto de 2004.

- Caderno 28. XIII Congresso Nacional da ABEA e XXIII Encontro Nacional Sobre Ensino de Arquitetura e Urbanismo - Projetos Políticos Pedagógicos - Novas experiências. V1. Fortaleza - CE, novembro de 2005.

. Caderno 29. XIII Congresso Nacional da ABEA e XXIII Encontro Nacional Sobre Ensino de Arquitetura e Urbanismo - Projetos Políticos Pedagógicos - Novas experiências. v2. Fortaleza - CE, novembro de 2005.

. Caderno 30. XXX COSU - Conselho Superior da ABEA e XXIV Encontro Nacional Sobre Ensino de Arquitetura e Urbanismo - Novas Diretrizes Curriculares. Goiânia - GO, outubro de 2006.

. Caderno 32. XXXII COSU - Conselho Superior da ABEA e XXVI Encontro Nacional Sobre Ensino de Arquitetura e Urbanismo - Novos Perfis e Padrões de Qualidade para os Cursos de Arquitetura e Urbanismo: do Projeto Pedagógico às Atribuições Profissionais. João Pessoa - PE, novembro de 2008.

. Caderno 33. XXXIII COSU - Conselho Superior da ABEA e XXVII Encontro Nacional Sobre Ensino de Arquitetura e Urbanismo - Ensino e atribuição profissional: A Assistência Técnica e a Lei Federal no. 11.888/08 e A Conservação do Patrimônio Cultural e as Técnicas Retrospectivas. São Paulo - SP, maio de 2009.

. Caderno 37. XXXV COSU - Conselho Superior da ABEA e XXXI Encontro Nacional Sobre Ensino de Arquitetura e Urbanismo - Novos cenários para o ensino de arquitetura e urbanismo: Atualizar - Avaliar - Acreditar. São Paulo - SP, novembro de 2012.

. Caderno 38. XVII Congresso Nacional da ABEA e XXXII Encontro Nacional Sobre Ensino de Arquitetura e Urbanismo - Novos cenários para o ensino de arquitetura e urbanismo: Atualizar Avaliar - Acreditar. Goiânia - GO, novembro de 2013.

- FICHER, S. Os arquitetos da Poli: ensino e profissão em São Paulo. EdUSP, 2005.

. A desmoralização do ensino público. Revista da Faculdade de Arquitetura e Urbanismo da Universidade de Brasília, Brasília n. 1, 1998.

- GUNN, P.O. O departamento de Tecnologia e o currículo da FAUUSP. Sinopses Memória FAU/USP. São Paulo, 1993.

O ensino de Tecnologia em Arquitetura e Urbanismo. 1998. Dissertação (Mestrado). Faculdade de Arquitetura e Urbanismo. Universidade de São Paulo. São Paulo, 1998. 
- LINA POR ESCRITO - Textos escolhidos de Lina - 1943 - 1991. Organizado por Silvana Rubino e Marina Grinover, São Paulo: Cosac Naify, 2009.

- MORIN, E. Os sete saberes necessários à educação do futuro. 12. ed. São Paulo : Cortez, 2007.

- ZANETTINI, S. O Ensino de Projeto na área de edificação. São Paulo, FAUUSP, 1980.

\section{CAPÍTULO 04}

- BRASIL. Ministério da Educação e Cultura. Secretaria de Ensino Superior. Comissão de Ensino em Arquitetura. PERFIS DA ÁREA \& PADRÕES DE QUALIDADE Expansão, Reconhecimento e Verificação Periódica dos Cursos de Arquitetura e Urbanismo, Brasília, 1995.

Lei $n^{\circ}$ 12.378, de 31 de dezembro de 2010. Regulamenta o exercício da Arquitetura e Urbanismo; cria o Conselho de Arquitetura e Urbanismo do Brasil - CAU/BR e os Conselhos de Arquitetura e Urbanismo dos Estados e do Distrito Federal - CAUs; e dá outras providencias. Diário Oficial da União, Brasília, DF, 31 dez. 2010.

Lei número 9394, 20 de dezembro de 1996. Lei de Diretrizes e Bases da Educação Nacional. Artigo 66. Brasília, DF. 2005.

- Encontro Nacional de Ensino de Arquitetura - 1967. Revista Acrópole, nov. 1967. Ano XXIX, no 345, p. 14.

- GRAEFF, E. A. Arte e Técnica na formação do arquiteto. São Paulo: Studio Nobel/ Fundação Vilanova Artigas, 1995.

- LEITE, M.A.D.F.A. A aprendizagem tecnológica do arquiteto. 2005. Tese (Doutorado). Faculdade de Arquitetura e Urbanismo. Universidade de São Paulo. São Paulo, 2005.

- SANTOS JUNIOR, W. R. dos. O currículo mínimo no ensino de arquitetura e urbanismo no Brasil: 1969 -1994. Tese (Doutorado em Arquitetura) - Faculdade de Arquitetura e Urbanismo, Universidade de São Paulo, São Paulo, 2001.

- SANTOS, R. E. dos. Atrás das Grades Curriculares - da Fragmentação do currículo de graduação em Arquitetura e Urbanismo no Brasil. 2002. Dissertação (Mestrado). Escola de Arquitetura. Universidade Federal de Minas Gerais. Belo Horizonte, 2002.

- TRIGUEIRO, M. G. S. Universidades públicas: desafios e possibilidades no Brasil contemporâneo. Brasília: Editora Universidade de Brasília, 1999.

\section{CAPÍTULO 05}

- ANDRIOLI, A. I. Utopia e Realidade. Revista Espaço Acadêmico - $n^{\circ}$ 56. Janeiro, 2006 - Mensal - ISSN 1519.6186. Ano V.

- GRINOVER, M. M. Laboratório de Projeto e Construção: prática da arquitetura na obra de Renzo Piano e João Figueiras Lima. 2015. Tese (Doutorado). Faculdade de Arquitetura e Urbanismo. Universidade de São Paulo. São Paulo, 2015.

- MARGARIDO, A. Ensino de estruturas nas escolas de arquitetura do Brasil. [mai. 2009]. Entrevistador: Rita de Cássia Saramago. São Paulo.

- TRIGUEIRO, M. G. S. Universidades públicas: desafios e possibilidades no Brasil contemporâneo. Brasília: Editora Universidade de Brasília, 1999. 


\section{1 - Coleta de Dados - Roteiro Entrevista}

a) Dados Gerais sobre a escola:

b) Descrição sobre a formação docente.

c) Quais as estratégias de estruturação das disciplinas da área tecnológica e seu diálogo com os Ateliers de Projeto, como são desenvolvidas?

d) Quais as práticas (estratégias) pedagógicas exploradas nas disciplinas da Tecnologia da Construção? Projeto, aulas expositivas, laboratoriais, experimentais, visitas à obra, etc?

e) Sobre os espaços e práticas experimentais utilizados nas disciplinas (quando existentes), como poderiam ser caracterizados? A infraestrutura é de uso compartilhado?

\begin{tabular}{|l|l|}
\hline Espaços Experimentais & Características do laboratório e práticas /Recursos técnicos e humanos \\
\hline a) Maquetaria: & \\
\hline b) Laboratório de Materiais/ & \\
Técnicas Construtivas & \\
\hline c) Laboratório de Estruturas & \\
\hline d) Canteiro de & \\
obras/experimental & \\
\hline Obs.: & \\
- Forma de utilização dos laboratórios pelos alunos da arquitetura \\
- Proximidade dos laboratórios aos edifícios ocupados pela arquitetura \\
- Caracterização dos laboratórios \\
- Número de técnicos e perfil (técnicos ou auxiliares) \\
\hline
\end{tabular}

f) Comente sobre a inserção dos novos materiais construtivos e como este tema poderia ser trabalhado na graduação.

g) Como ocorre a manutenção dos laboratórios, os recursos são provenientes de quais fontes? Da Instituição/ verba do departamento/ editais / pesquisa / empresas?

h) Há dificuldades em obter recursos para o desenvolvimento de pesquisas na área de Tecnologia da Arquitetura? Os editais na área da tecnologia são mais voltados às engenharias ou também contemplam o curso de Arquitetura?

i) Qual a opinião dos professores sobre a forma ideal de parceria junto ao setor industrial?

j) O curso possui pós-graduação? Em quais áreas de concentração? Os alunos interessados na área de Tecnologia da Construção são absorvidos pelo programa? (verificar áreas de concentração e linhas de pesquisa)

I) Qual a leitura que o próprio curso faz da área tecnológica, é satisfatória? Atende bem ao curso e ao projeto pedagógico (número de professores; infraestrutura; pesquisas; apoio da direção, coordenação e alunos)? (O olhar do entrevistado sobre a responsabilidade do curso - arquitetura e engenharia - e seus atores frente ao cenário vivenciado).

m) Descrição dos principais gargalos vivenciados no curso e sugestões para a melhoria da área da Tecnologia da Construção. 


\section{TERMO DE CONSENTIMENTO LIVRE E ESCLARECIDO}

Uso de informações fornecidas por meio de entrevista para desenvolvimento de pesquisa de doutorado

Eu, abaixo assinado(a) e identificado(a), autorizo o uso de fotos, imagens, informações e documentos fornecidos por ocasião e em decorrência da entrevista concedida à arquiteta Albenise Laverde, residente à Rua Carlos Petit, 232, apto. 76, CEP 04110000, São Paulo - SP, RG 6728815-7, CPF 02672377901, para a sua pesquisa de doutorado intitulada 'Os espaços experimentais das escolas públicas de Arquitetura do Brasil: realidade ou utopia?', desenvolvida no Programa de Pós Graduação em Arquitetura e Urbanismo da Universidade de São Paulo - FAUUSP, sob a orientação da professora Cláudia Terezinha de Andrade Oliveira, pertencente ao quadro docente da Universidade de São Paulo Faculdade de Arquitetura e Urbanismo - FAUUSP. Declaro ter sido informado(a), verbalmente e por escrito, de forma suficiente a respeito da pesquisa supracitada.

Estou ciente de que os dados fornecidos serão destinados para divulgação científica ao público em geral e/ou para formação de acervo acadêmico/histórico, considerando: a mídia impressa (tese, livros, catálogos, revistas, jornais, entre outros), bem como mídia eletrônica (internet, banco de dados informatizado multimídia, CD ROM, DVD (digital video disc), entre outros), para divulgação científica sem qualquer ônus a Albenise Laverde ou a terceiros, por esta expressamente autorizados, que poderão utilizá-los em todo e qualquer trabalho de natureza sociocultural voltado ao fomento acadêmico e cultural, em todo território nacional e no exterior.

Por esta ser a expressão da minha vontade, autorizo os usos acima descritos sem que nada haja a ser reclamado a título de direitos conexos à imagem, ou a qualquer outro, e assino a presente autorização esclarecendo que o conteúdo e informações prestadas são de responsabilidade exclusiva do entrevistado e não representam a opinião da Instituição e Unidade as quais pertence.

de de

\section{Assinatura}

\begin{tabular}{|l|}
\hline Nome: \\
\hline Endereço: \\
\hline Cidade: \\
\hline RG №: \\
\hline CPF №: \\
\hline Telefone para contato: \\
\hline E-mail: \\
\hline
\end{tabular}

